QL676

.366

1867

**

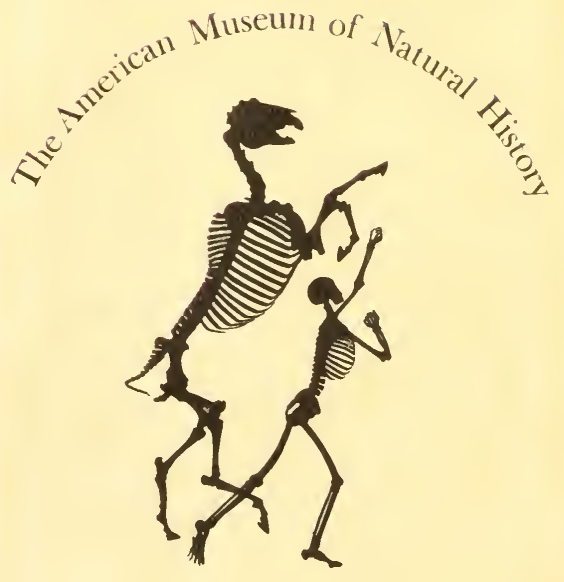

1869

THE LIBRARY 






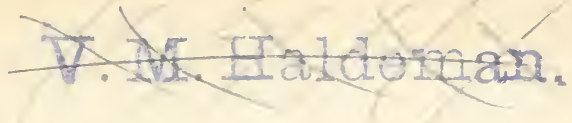

T H E

NATURAL HISTORY OF BIRDS. 



\section{NATURAL HISTORY OF BIRIS:}

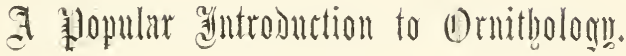

'THOMAS RYMEK JONES, F.R.S.

PROFESSOR OF XATLRAL HISTORY AND COMPARATIVE ANATOMY IN KING'S COLLEGE, LONDON.

PCBLTSHED ENDER THE DIRECTION OF THE COMMITTEE OF GENERAL LITERATLRE AND EDLCATION, APPOINTED BY THE SOCIETY FOH PRONOTING CHRISTIAN KNOWLEDGE.

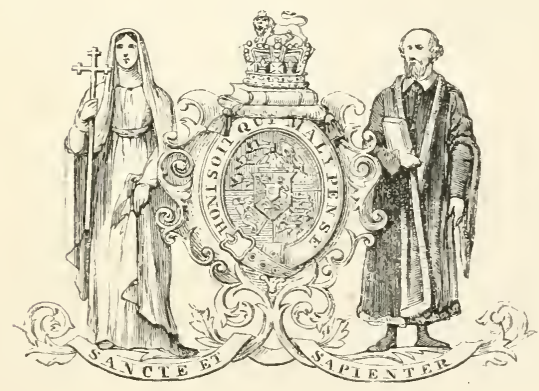

\section{LONDON :}

SOCIETY FOR PRONOTING CHRISTIAN KNOWIEDGE. SOLD AT THE DEPOSITORIES:

77 , GREAT QUEEN STREET, LINCOLN'S.INY FIELDS;

4, ROYAL EXCHANGE; 19, PICCADILLY; AXI BY ALL BUOKSELLEKS. 
WYMAN AND SONS, PRINTERS, GREAT QUEEN STREET, LINCOLN'S-INN FIELDS, LONDON, W.C. 
$\mathrm{T}()$

\section{GEORGE ROBER'T GRAY, F.R.S.,}

TO WHOSE ZEALOUS LABOURS

ORNITHOLOGY IS SO DEEPLY INDEBTED,

THE FOLLOWING

POPULAR INTRODUCTION TO THE NATURAL HISTORY OF

$$
\text { B I R D S }
$$

IS RESPECTFULLY DEDICATED, 



\section{PREFACE.}

THE Society for Promoting Christian Knowledge 1 being naturally desirous of promulgating as extensively as possible sound information relative to the works of Amishty God, issued some time ago a series of "Tabular Views," illustrative of the modern Classification of Animals, containing engraved figures of typical forms, representing the families and sub-families composing the Animal C'reation.

These Tables, arranged by the highest authorities in their respective departments, and illustrated by eminent artists, have however proved insufficient for the purpose intended, inasmuch as the history of the objects represented could only be derived from extraneous sources, sometimes not easily attainable by the general student.

To obviate this deficiency, the Society have resolved upon the publication of a series of volumes, rombining with the portraits of the animals described an account of the zoological character's 
whereby they are distinguished; and also a concise history of their habits and general importance in ('reation.

The present volume, containing the Natural History of Birds, is based npon the Tabular View arranged by George Robert Gray, Esq., F.R.s., Director of the Ornithological department of the British Museum, and is in conformity with the (lassification adopted in om National Collection, to the study of which it will be found a useful guide. 


\section{B I R D S.}

I NTRODUCTION.*

THE feathered tribes, as they are emphatically 1 called, have at all times been favourite objects of study to the naturalist. The beauty of their plumage, the elegance of their forms, the gracefulness of their movements, and above all, the cheerfulness which everrwhere surrounds them, tempt his observation, and impart to the thinking mind no small share of that exuberant happiness expressed by the gaiety of their demeanour and the chorus of their song.

Inhabitants of the air, lightness and activity are the characteristic features of their economy. Some, borne on rapid wing, skim onwards like the meteor's flight, and are by far the swiftest of the animal creation. Some soar aloft, till, lost to human vision, only their voice is heard like music from the sky. Others frequent the woods, making the trees their residence, where, as they hop from spray to spray, they pour forth streams of melody; or gorgeously attired, glancing like fairy visions in the sunny landscape, seem the very gems and ornaments of Nature's lovely dress.

Paces of stronger wing and sterner attributes obtain their food by waging active war on living animals, their destined prey, swooping upon their quarry from afar like falling thunderbolts; or else by night, prowling on muffled wings, invade the dark* See "Animal Creation," page 407. 
ness, and approach stealthily their unsuspecting rictims. By far the greater number of birds, however, have been appointed, in one way or another, to feed on insects that abound on every side, and which, without such check, would, from their undue increase, become serionsly detrimental. Some catch them on the wing. The Swallows and the Swifts, firom early morning till the close of day, ply their untiring pinions in pursuit of such as fly abroad by daylight; and when evening comes, only give ip) the chase to kindred species, that prefer the gloom of twilight or the silence of the night.

Nor do they live on winged insects only ; but in all the stages of their growth, the insect hosts are the appointed food of numerous tribes of birds, adapted by their structure to obtain such prey wherever met with: on the ground, beneath the bark of trees, in every hole and crevice where they lurk, their presence is detected. From the upturned soil, thousands of beaks are ready to pick out the wingless grubs; and prying eyes investigate each leaf of every tree, in search of caterpillars and the hung'ry bands of similar destroyers.

Fed on more dainty fare, the Humming-birds and Soui-mangas, with their slender bills, explore the blossoms of a thousand plants, in search of honied stores, sipping the nectar and the dew from flowerbells beauteous as themselves. Some feed on fiuits, and in the sunny climes find a perpetual autumn, or devour the seeds of grasses, and, masked, approach the harvest-field to share the abundant corn. Terrestrial in their habits, not a few scrape from the ground their vegetable food; while many, raised on stilted legs, wade in the marsh, and probe the oozy soil in search of worms or slugs. Nor are the lakes, the rivers, or the sea without their feathered occupants; legions of water-fowl are everywhere provided. Ducks paddle in the ponds, Swans row their "oary state," reflected on the tranquil bosom of the stream ; multitudes frequent the shore, crowding the rocks, 
or riding on the waves; while far away at sea, upborne on outstretched wings, the Albatrosses sweep along over degrees of longitude, and circle round the globe itself, in the unbounded freedom of their flight.

Presenting so much variety in their occupations and mode of life, it may naturally be supposed that a corresponding diversity exists in the structure of their limbs, and in their means of procuring their subsistence. The feet and claws of a perching bird could never be available for swimming, nor could the bill of a Snipe be used for the same purposes as the beak of an Eagle. In the classification of birds, therefore, the ornithologist is guided by certain characters, derived from their general shape and proportions, the structure of the mouth, bill, tongue, wings, tail, and legs, all of which are necessarily in relation with particular habits; and his constant endeavour is to detect and define, with brevity and precision, the most prominent features whereby different races are distinguishable.

In order to render such descriptions intelligible to the general reader, it will be necessary, not only to map out, as it were, the several parts that characterize the objects of our study, but to employ words and phrases of distinct and limited meaning, as expressions of the peculiarities they exhibit; we need, therefore, scarcely apologize for introducing our subject by a few preliminary remarks relative to the nomenclature adopted in the following pages.

The HEAD of a bird consists of the slinll, and the bill or beali, and is joined to the body by the neck.

The BЕAK or BILL consists of an upper jaw, called in ornithological language the Upper Mandible (Fig. 1, 12), and of the lower jaw, or Lower Mandible (13).

The UpPer Mandibe contains the orifices of the nostrils $(c)$, the shape of which varies in different birds. Its highest part is called the Culmen (b), while the corresponding ridge of the lowèr mandible is termed the Gonys $(h)$. 


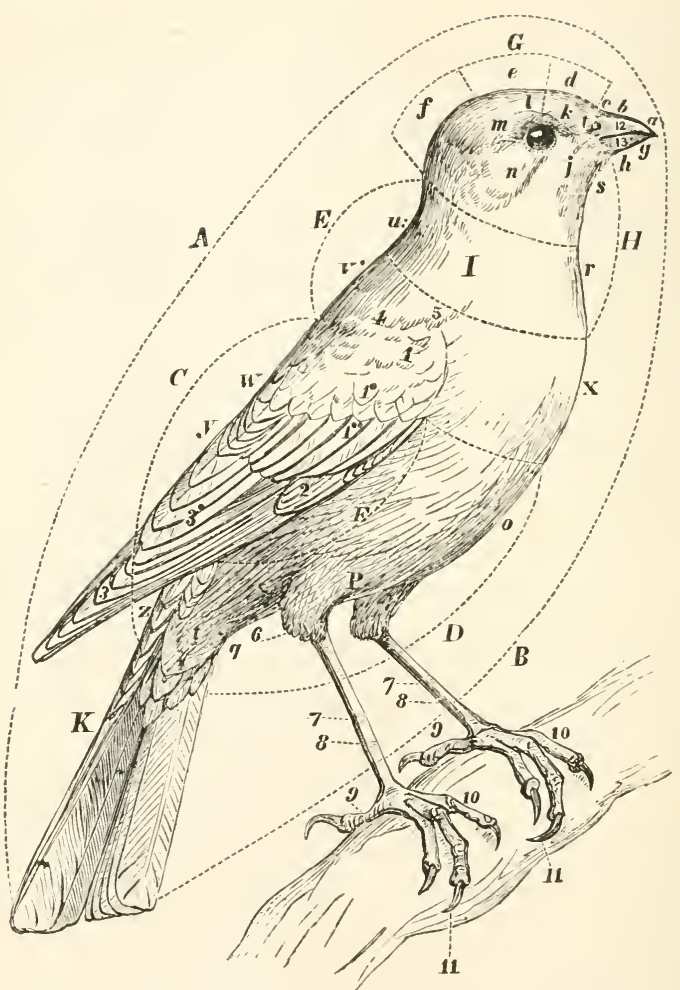

Fig. 1.-FIgLRE OF a BIRD, SHOWING ITS TECHNICAL DIVISIONS.

$A$, Dorsal region : 12 , upper mandible; $a$, the apex; $b$, the culmen ; $c$, the nostrils. $G$, The Head : $d$, the forehead; $e$, the vertex; $f$, the occiput. $E$, The Nape: comprehending, $u$, the upper neek; $v$, the lower neck, $C$, The Back : w, the interscapular space; $y$, the back proper; $z$, the rump. $k$, The Tail. $B$, The Ventral region: comprising, 13, the lower mandible; $g$, the apex ; $h$, the gonys. II, The Throat: $s$, the throat proper; $r$, the jugulum. $\boldsymbol{Y}$, The Breast. $D$, The Ahdomen : divided into $o$, the epigastrinm. $P$, The Belly : $q$, the crissum, or rent. The Neck $(I)$ comprehends the whole region between the head and the trunk. The head is further dirided into $(m)$ the ophthalmic region, $(l)$ the supraciliary region, $(k)$ the cheek, $(n)$ the parotid region, and $(j)$ the lorum. The Sides or Flanks $(F)$ are those parts covered by the wings when elosed.

The feathers which cover or which form the wings are distinguished into Tectrices, or wing-coverts; Remiges, or quill-feathers; and thumb-feathers (2), the last of which constitute the "bastard wing." The Tectrices are divided into the small wing-coverts (1), the middle wing-coverts $\left(1^{\circ}\right)$, and the large wing-coverts $\left(l^{*}\right)$., The Remiges are called primaries (3), or secondaries $\left(3^{\circ}\right)$. The wing itself is divided into the shoulder (4), and the elbow (5).

The legs, at their junction with the tarsus (6), form the heel. The tarsus may be distinguished into a hinder portion (7), and an anterior portion ( 8 ).

The foot is divisible into the thumb, or hallux (9), and the toes (10), which are terminated by the claws (11). 
The Margins of the mandibles are their lateral edges, which meet when the bill is closed. In some birds the margins of the upper mandible overlap those of the lower, while in others the two edges exactly meet; the line thus formed by the meeting of the mandibles is termed the Commissure.

The commissure may be either straight, as in the Woodpecker; festooned, as in the Sparrow-hawk; unclulated, as in the Tanager; archerl, as in the Hoopoe; or angulated at its base, as in the Starling.

The Upper Mandible is sometimes continued orer the forehead, so as to form a sort of helmet. In rapacious birds and Parrots its base is covered with a soft skin called the Cere.

The Wing of a bird is constructed upon the same general plan as the human arm, or the fore-leg of quadrupeds, and when denuded of its feathers, it is not difficult to perceive the relationship between these apparently different organs.

The QuilL-FEATHERs of the wing are divided into three sets, distinguished as the primaries, the secondaries, and the tertiaries.

The Primaries are always the longest, and in swift-flying birds, like the Swallows, are of double the length of any of the other quills : they are usually nine or ten in number, sometimes eleven, and are attached to the metacarpus, or those bones which represent the hand of the human skeleton (3).

The Secondaries are implanted in the cubit or fore-arm, and are usually only half the length of the primaries $\left(3^{*}\right)$.

The 'Tertiaries are those attached to the upper' arm, or humerus.

The origins of the quills are overlapped, and protected by smaller feathers, arranged something like the tiles of a house, and called the WING-Coverts (1 $\left.1^{\prime} 1^{\prime \prime}\right)$.

The power of flight possessed by any bird depends upon the arrangement, the proportionate size, and the shape of the wings: hence it will be necessary 
to explain the principal modifications observable in these admirable structures.

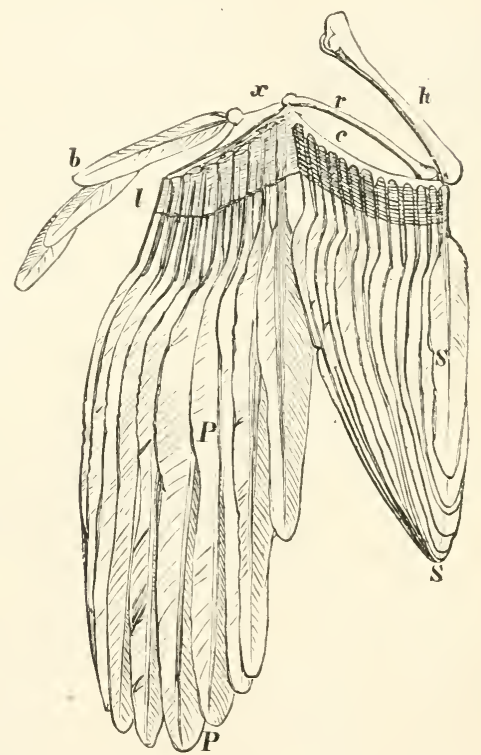

FIG. 2.-FIGURE OF WING, SHOWING THE ORIGINS OF THE QUILL-FEATHERS.

(h) The bumerus; $(r)$ the radius; $(c)$ the cubital bone, the outer side of which is entirely occupied by the insertion of the secondary quills $(S)$, which are separated by a small space from the primaries $(P)$, all of which take their origin from the metacarpal bone representing the hand. The joint (x) representing the wrist-joint, indicates the point of separation between the primary and the secondary quills. The bastard quills, or those attached to the thumb, are indicated by the letter $b$.

The formation of the wing in reference to its office depends almost entirely upon the arrangement, the proportions, and the shape of the quills; and these again determine the powers of flight.

The principal modifications in the structure of these important organs are therefore briefly expressed by simple epithets, the precise meaning of which it will be necessary to remember.

In regard to their comparative length, a wing, however otherwise constructed, is termed long when . 
it extends beyond the middle of the tail ; morlercte, when it reaches nearly or quite to that member; and short when it does not extend to the base of the tail.

As relates to their shape-

Acuminated wings are those adapted for the most rapid and long-continued flight. In wings of this déscription the first quill is generally the longest, although it sometimes happens that there is scarcely any perceptible difference between that and the

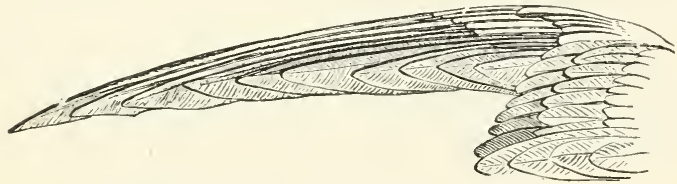

Fig. 3.-ACUMrNated WING.-SWallow.

second; the rest, however, rapidly diminish at almost equal intervals, until they reach the lesser quills, which are little more than one-third the length of the exterior primaries.

It is obvious that in wings of this description nearly the whole power of the stroke is thrown into the primary quills, which are those principally employed in flight.

Falcated or Sword-shaped wings are only possessed by the Humming-birds. In these, the two

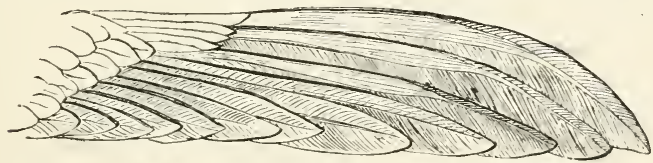

Fig. t.-Falcated WiNg of HeMMiNg-Bird.

or three primaries are curved towards the ends, which are rather suddenly rounded off, while all the succeeding ones are straight.

PonNted wings come nearest to those termed acuminated, and the passage from one of these forms to the other is susceptible of numerous gradations, almost too refined for popular explanation. 
Pointed wings may be divided into two sorts. In the first, the outermost quill is either the longest, or nearly' equal to the next one or two; but the secondaries and tertiaries are of the ordinary length; that is, they are two-thirds as long as the primaries.

In the second description of pointed wing the first quill is little more than half the length of those which are longest, which are generally the fourth or fifth.

Eurarginated wings are characterized by having a sudden notch, or sinuosity more or less abrupt, on the margin of the inner shaft of the longest quills;

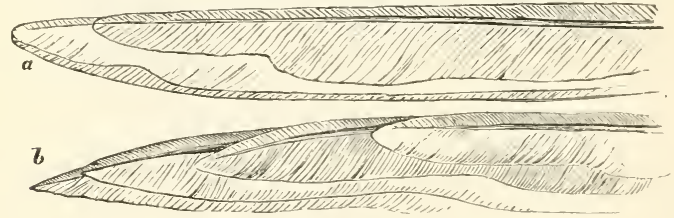

Fig. 5.-EMarginated WiNgs.
$a$, Falcon.
b, Sparrow-hawk.

this notch, in some cases (True Falcons), is situated near the end of the shaft; in other's (the ignoble Hawks) it is placed near the base (Fig. 5).

Rounded wings are always short, and there is so little difference between the last six or seven primaries and the secondaries, that the distinction between the two series is scarcely perceptible. The tertiaries also are nearly of the same dimensions, so that when the wing is fully expanded, the contour forms a semicircle.

RAsORIAL wings are characterized by their peculiar shape, and by the great development of the secondary quills; these latter being so long as nearly to equal the primaries. The primary quills in their substance have an unusual strength and rigidity; their shape is almost falcate, and they are very narrow; their curved shape gives to the wing a great degree of convexity, and also indicates much strength. 
Ayple wings have the primaries short, and the secondaries and tertiaries remarkably broad. The flight of birds possessing wings of this description is slow and heavy, but regular, lofty, and can be long sustained. By this broad expanse of wing the Heron mounts high in the air, flying steadily, but slowly, to its distant retreat.

ABortive wings are such as are incapable of being used as instruments of flight. These are of two kinds; the first belongs to land birds of the Ostrich race, the second to the Penguins, Auks, and other swimming birds.

The tail of a bird is a very important auxiliary in flight, during which it is expanded, and used as a rudder. There are very few species without this

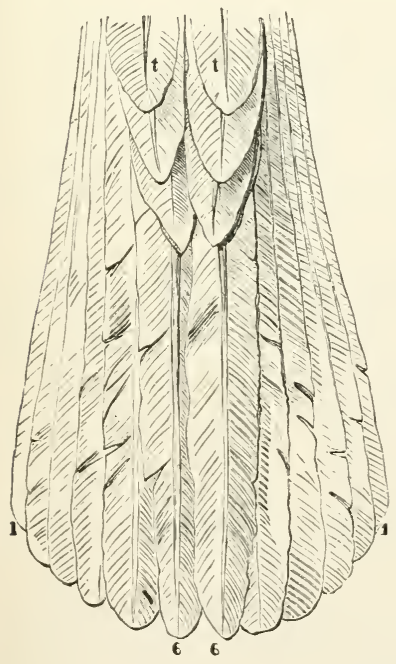

Fig. 6.-TAIL-FEATHERS.

'Tper surface of the tail of a bird, showing the disposition of the twelve quill-feathers of which it is usually composed. The feathers of the tail are counted from the outer to th: inner; consequently the first tailfeather (1) is the most external, from which they are named $2 \mathrm{nd}, 3 \mathrm{rd}, 4 \mathrm{th}$, and $5 \mathrm{th}$, to the $6 \mathrm{tb}$, or middle feathers of the tail (6). The feathers which cover the roots of the tail-feathers are the tail-coverts $(t)$.

ornamental appendage, though in some it is extremely short. The terms short and long, however, being very indefinite, it is usual, when speaking of the comparative length of this part, to call that a short tail which does not exceed half the length of 
the wings; a moderate tail is about equal to the length of the body; and all longer than this are called long tails.

A Pereect tail consists of twelve feathers; but in some Gallinaceous birds the number amounts to eighteen; while in a very few species there are only eight.

The root or base of the tail-feathers is protected both above and below by others, which are termed the uper and under tail-coierts.

In speaking of the various forms of the tail, it will be necessary in the following pages to make use of terms, such as even, rounded, fan-shajed, gratuated, cuneated, arcuated, spatulate, slender, forlied, \&c. : these we will briefly explain.

An Even 'TaIl implies that the feathers when expanded are all of the same length.

A Rounded Tatu has the outermost feathers progressively shorter than those in the middle.

A FAN-shaped 'TaIL, as its name indicates, is so much rounded, that the two middle feathers are the longest, all the others gradually diminishing in length.

Graduated Tams not only exhibit a greater degree of circularity than those which are simply romnded, but they possess this peculiarity, that the external feathers, instead of being very slightly shorter than those in the middle, are abruptly abbreviated, so as to resemble the steps in a flight of stairs.

A Cuneated or Wedge-shaped Tall has each feather gradually narrowed from the middle, and terminating in a point.

Arcuated or Arched Tails somewhat resemble the last; but the feathers, instead of being straight, are gently arched; and those in the middle are so convex, that they lap over, as if to protect the others. The common Pheasant exhibits this form in perfection.

Spatulate or Racket-shaped Tails.-The pechliarity of this tail is that the middle feathers have 
their shafts, for a certain space towards their ends, entirely destitute of webs on either side; the webs suddenly appearing again only at the top, giving the feather the appearance of a spoon or battledore.

Slender Tails are generally of moderate length, the feathers being slender throughout, and sometimes so abruptly truncated, that their extremities appear to be cut oft.

In Forked Thils the two outer feathers are by far the longest; the inner ones gradually shortening until the gradation terminates in the central pair.

In Lyre-shaped Tauls the gradation in the length of the feathers is precisely similar to that in a simply forked tail, but they are curved outwards, so as to resemble in some sort the frame of an ancient lyre.

BOAT'-SHAPED TAILS are still more extraordinary; their sides, when expanded, are bent up like the sides of a boat, so as to leave the central part hollow and very concare. This appearance is generally lost in preserved specimens.

Compressed or ERect Talls are well exemplified in that of the barn-door cock.

Lastly, Fasciculated or Pluned Tails are those in which the feathers seem to have no regular or determinate arrangement, but form bunches of plumes, like that of the Ostrich.

The hinder limb or LEg of a bird is composed of,-1. the tibia, generally but erroneously called the thigh; 2. the tuisus, or shank, usually denominated the leg; and 3 . the toes or digits. Of these last, one, which when present is usually turned backward, or in opposition to the rest, is distinguished as the fullux. The toes are all of them terminated by claus, variable in their size and shape, and of great importance in the classification of different races.

The TArsus by which name we shall designate the shank, is either featlered, as in many of the birds of prey (Fig. 7), or nalied, as in the generality of birds. A NAKED tarsus is protected by Scales (scutel- 
lated); and next to the relative length of the tarsus, the form and disposition of these scales supply us with the best discriminative characters taken from this part of the bird. The generality of nakedfooted birds have the tarsus protected by three series of scales, each of which is frequently of a peculiar form. The first series is in front, the second occupy the two sides, and the third is at the back of the leg.

The fiont scales, called also the anterior, are either composed of one or several pieces. When the anterior scale is simple, or composed of one piece, it extends from the front of the knee as far as the hinder toe, and its external surface is quite smooth. Generally, however, this front plate is marked by transverse divisions, or composed of pieces, which sometimes overlap each other. In many birds, both the front and sides of the tarsus are covered with numerous small scales that do not touch each other, but are so disposed that the interstices, or spaces between them, resemble the lines of a net: such a tarsus is said to be reticulated.

The lateral scales of the tarsus are not always present; frequently their office is supplied by the anterior scales, which are then extended round the leg, so as nearly to envelop it.

The posterior scales are very frequently wanting, and when present seldom extend much below the upper part of the tarsus.

The Toes of birds, by their leading variations, furnish the primary characters whereby the whole class is divided into orders, and the subordinate modifications of their structure indicate for the most part natural groups.

The great majority have four toes on each foot, three of which are usually placed before, and one (the hallux) behind. The exceptions to this number of toes and to their disposition are comparatively few. They will be noticed when speaking of the particular races in which they exist. 


\section{B I R D S.}

ORDER I.

ACCIPITRE* (Limmens).

Birds of Pres.

The Birds of Prey hold the same position among the feathered tribes as the Lion, the Tiger, the Hriena, and other carnivorous races among mammiferous quadrupeds. They live upon flesh, and for the most part, pursue and destroy the animals that constitute their food. Their flight is therefore powerful, and the weapons with which they are armed of a most formidable character. Their beak is strong, sharp, and curved downwards towards the tip, and their feet are furnished with hooked talons well adapted to pierce and secure their strugghing quarry. The muscles of their thighs and the strength of their legs indicate the power of their claws, while the length and expanse of their wings testify to the velocity of their flight. Their general appearance is indicative of the ferocity of their nature, and their whole life is devoted to carnage and rapine. The Raptorial Birds are divisible into two sections, - those that fly only in the daytime, and those that are nocturnal in their habits. To the first of these divisions belong the Eagles, the Tultures, and the Falcons, distinguished by having

* Accipiter, a hawk, from accipio, to take hy force. 
their eyes placed upon the sides of their head, so that they can see in every direction; while in the noctmrnal Birds of Prey both the eyes are directed forwards.

\section{SUB-ORDER.}

\section{Accipitres Diurni.*}

\section{Diurnal Birds of Prey.}

In addition to the lateral position of the eyes referred to above, the dinmal birds of prey are recognisable by having the base of their beak covered with a soft skin, called, from its wax-like appearance, the "cere," in which the orifices of the nostrils are generally situated. Their feet are furnished with three toes in front and one behind; all quite destitute of feathers; their plumage is closeset, their wings strong, and their flight rapid. They form two great groups, the first embracing those that feed principally on animals killed by themselves, the second including such as live more or less upon carrion. The former were classed by Linnas under the general name of Falcons, the latter, constituting an equally natural group, embraces the Vultures, those miclean birds that must first occupy our attention as constituting the type of the rapacions order to which they belong. $\dagger$

* Diurnus, belonging to the day.

† It may seem strange to the unscientific reader that these ignoble birds should be selected as the type or pattern of the rapacious tribes, in preference to the more highly gifted Eagles and Hawks; and it may therefore be necessary to explain in this place what is the exact meaning attached to the words "type," "typical form," and "typical species," which will occur so frequently in the following pages. The type of any given tribe or family of Birds is by no means that genus or species which is the most remarkably endowed with any particular faculty or attribute, but, on the contrary, is selected rather from its want of any extraordinary or exaggerated development of the peculiarities charac- 


\section{FAMILY I.}

\section{VULTURIDA.}

\section{The Vultures.}

General Characteristics.-Beak somewhat lengthened; upper mandible nearly straight, curved at the point only ; head and neek in a greater or less dégree naked, or clothed only with a thin down; talons comparatively weak. Food exclusively the flesh of dead animals.

The birds belonging to this widely distributed family present considerable diversity in their habits, as well as in their general conformation. Some differ from the rest of the vulturine race, by having their head and neck completely clothed with feathers; thus combining, to a certain extent, the habits of the Vulture with the garb of the Eagle. The American Vultures are remarkable for the possession of fleshy appendages, that surmount the base of their beak, and give a very distinctive character to their physiognomy. It is to the true Vultures only-the types of the family - that the above general description is strictly applicable; from which the rest are more or less aberrant.

Equally diversified are their modes of life. In

teristic of the group which it typifies. If, for example, the zoologist is asked to select a species which shall be the type or exemplar of Birds generally, he will, in all probability, point to the Crow, as possessing in a medium degree of perfection the qualities belonging to all races of Birds concentrated in itself. It is true that it cannot soar so high as the Eagle, or fly with the swiftness of the Swallow; but it can fly very well, and with moderate rapidity. It does not run with the fleetness of an Ostrich, or hop with the vivacity of many of the smaller birds ; but it can both walk and hop, when it thinks proper, with eonsiderable alacrity. It is not a wading bird, but it has no objection to wade into the water either of the marsh or of the sea-shore, in search of food. It is equally at home when perched upon a tree, and feeds indiscriminately upon all sorts of substances, whether animal or vegetable; thus combining the characteristics of all the feathered races.

In the same way the Vulture is selected as the type of the Rapacious Birds. It is not the monarch of the sky, but its powers of flight are very respectable; and although it is too weak to do battle with animals possessed of much strength, it will nevertheless kill and devour such feeble game as its cowardice permits it to attack. 
lot climates they are more frequently seen npon plaius than in elevated situations; sometimes they approach villages, and at early dawn spread themselves through the streets and lanes, rendering much service by devouring all kinds of carrion. In temperate climates they only frequent the highest mountains and most inaccessible cliffs, where some of them prefer killing their own gane. Such differences, both in their appearance and mode of life, have rendered it expedient to divide them into several Sub-families, each distinguished from the rest by certain characteristic peculiarities. 'Thns we have the Bearded Vultures (Gymätince), the Condors (Sarcoramplinince), the Vultures proper (Vulturine), and the Eagle-Vultures (Gypotien(ince), each of which will require separate notice.

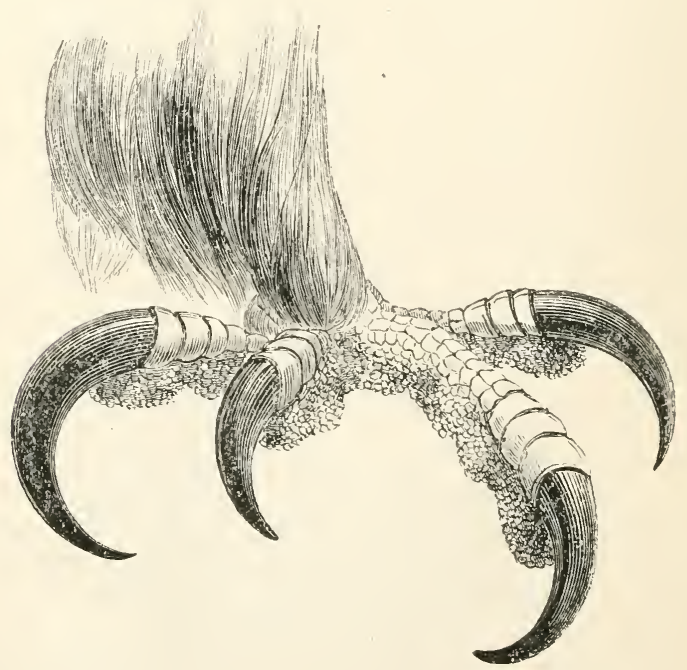

FIG, 7.- FOOT OF EAGLE. 


\section{$S U B-F A M I L Y I$.}
GYPAETIN.E.
The Bearded Vultures.

GEN. CHARAc.-Head and neck completely clothed with feathers; cere of the hase of the upper mandible entirely hidden by projecting bristles.

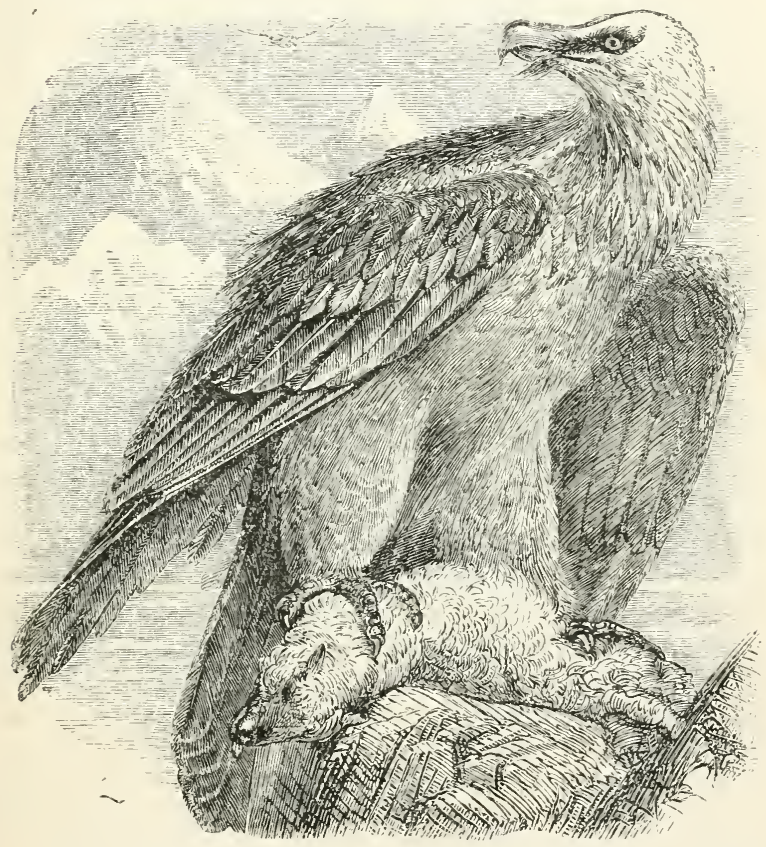

Fig. S.—THE LÄMMER GEYER.

(Gypaëtus burbatus )

The type of this sub-family-

The Bearded Vulture (Gypaëtost barbatus), well known on the continent of Europe as the Lämmer Geyer, or Lamb Vulture, is the largest of the birds of prey found

* It will be observed, that while the Families of Birds are designated by the Greek patronymic ide, the Sub-families are distinguished by the diminutive inice.

$+\gamma \dot{v} \psi$, gyps, a vulture; áєtóc, aëtos, an eagle; Eagle-Vulture. 
in the Eastern hemisphere. Its usual morle of killing the animals that constitute its food is to drive them over the edge of some precipitous cliff, and devour their remains when shattered by the fall: hence it was known to the ancients under the name of the "bonebreaker" (ossifraga). From the descriptions given of this formidable bird, it is not to be wondered at that much exaggeration has crept into its history. Fourteen, and even eighteen, feet in the extent of its wings have been attributed to the Lämmer Geyer, and an amount of strength correspondent with such Roc-like dimensions. A distinguished naturalist, however, Picot la Perouse, who has observed this species in the Pyrenees, and described it very carefully, considerably reduces the magnitude attributed to it by earlier writers. He gives it the following dimensions:-Extent across the wings, eight feet and a half; total length, three feet ten inches; weight, about ten pounds. The beak is four inches long; it is covered above at its base as far as the centre with numerous long black hairs directed forwards, while underneath hangs a tuft of similar hairs forming a true beard an inch and a half in length: it is from this last extraordinary appendage that its specific name, barbatus, bearded, is derived. As may easily be imagined, a bird of such proportions, and possessing an appetite correspondent with its size, is terribly destructive to the flocks that pasture in the Alpine valleys, where it wages cruel war on sheep, lambs, she-goats, and even calves; while the chamois, the hare, the marmot, and other wild quadrupeds, also become its victims; even children,* occasionally, have been the objects of the indiscriminating rapacity of these marauders; and man himself is not safe should he incautiously approach their wild retreats.

The nest of the Laimmer Geyer is usually built on the most inaccessible heights, and constructed of larchbranches intertwined with wool, hair, and feathers; its surface is flat, and its superficies about four feet in diameter. Upon this nest, or rather platform, the female deposits two or three eggs of a bluish-white colour, spotted with reddish-brown or ochreous yellow.

* In 1819 these birds were numerous in Saxe Gotha. They killed two children, and Government was induced to offer a reward for their destruction. 
Ges. Charac.-Bill lengthened and rather slender, with the basal portion more or less eorered with a soft cere; the apical part strong, much eurved, and acutely hooked at the tip; nostrils placed in the cere, with the opening large, exposed, oblong, and longitudinal; wings lengthened and pointed; tarsi long, and covered with small reticulated seales; the middle toe lengthened, the lateral ones short, equal, and united with the midd'e toe by a membrane; hind toe generally short and weak.

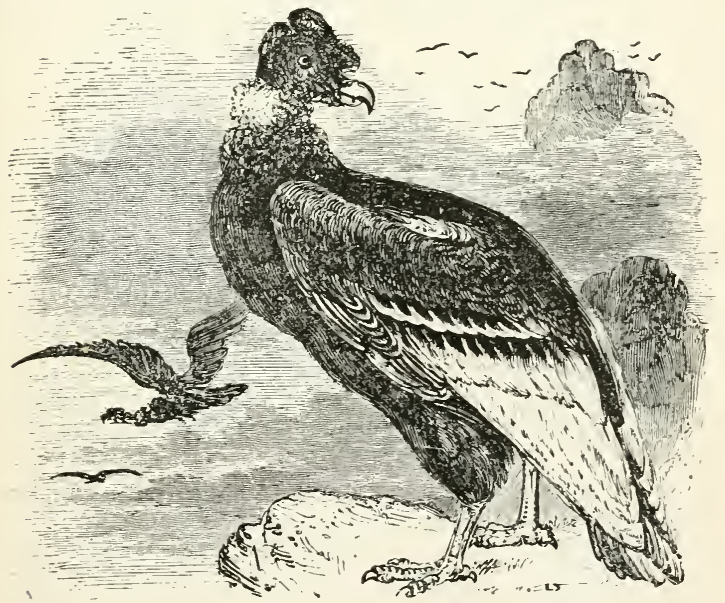

Fig. 9.-THE conpor.

(Sureoramphus Gryphus.)

The sub-family of the Condors embraces birds met with in countries very remote from each other, and differing much in size; but agreeing in their appetite for carrion. Some of them (Neopleron) are found in Africa and India, where they live in large flocks, and in Egypt, where they are held in great respect, on account of the services they render to the country by purifying it from the garbage upon

* $\sigma \dot{a} \rho \xi, \sigma \alpha \rho \kappa o ́ s$, sarx, sarcos, flesh; $\dot{\alpha} \mu \phi o s$, ramphos, a crooked beak. 
which they feed. Others (Cathartes) are migratory, and are found scattered over the various parts of the American continent, the West Indies, and the Falkland Islands, whore they may be often seen at a great height, wheeling round and round, and performing the most graceful evolutions. Here, likewise, they devour dead carcases, and every kind of filth, during the hot season; while those that inhabit the sca-coasts and islands, subsist on dead seals and varions kinds of refuse, cast up by the waves: small animals, however, and eggs, more especially those of alligators, aiso form a portion of their food.

The typical species, and the giant of the race, is-

The Condor (Sarcoramphus Gryphus), "generally regarded as the largest of predaceous birds. The name Sareormphus is derived from the circumstance that the head of the male, in addition to a broal fleshy crest, which extends over the top of its head, has another beneath its beak, somewhat revembling the wattles of the barn-door fowl. The nostrils are pierced completely through the fleshy cere from side to side; the skin of the head and neck is quite naked, and thrown into voluminous folds, while round the base of the neck is a frill of white feathers.

The Condor has been rendered celebrated by exaggerated accounts of its size and ferocity. It is, in reality, not much larger than the Limmer Geyer of Europe, which it also resembles in its habits. It frequents the lighest mountains of the Cordilleras of the Andes, in South America. Of all birds its flight is the most lofty ; and even the situation that it chooses for its breelingplace varies from 10,000 to 15,000 feet above the level of the sea. These birds generally live in pairs; but among the inland basaltic cliffs of Santa Cruz they sometimes collect together in great numbers; and it is a grand spectacle to see twenty or thirty of them start heavily from their resting-places and wheel away in majestic circles. So aërial and buoyant is their flight, that except when rising from the ground they are scarcely ever observed to move their wings.

* Gryphus, a grifin, from $\gamma \rho v \pi o ́ \varsigma$, grypos, having a hooked beak. 
The Condor feeds upon dead and putrefying carcases, hut two or more will sometimes unite to overpower the llama and other large animals. They will eren attack a heifer; they pursue it for a long time, wounding it with their beak and talons until the poor animal sinks to the ground breathless and overwhelmed with fatigue.

The female Condor makes no nest, but lays her eggs upon the bare rock, simply selecting a spot where there are cavities large enough to prevent them from rolling down when she descends upon or rises from them. The situations chosen for incubation are always nearly inaccessible. The egos are white, and are said to be usually two in number.

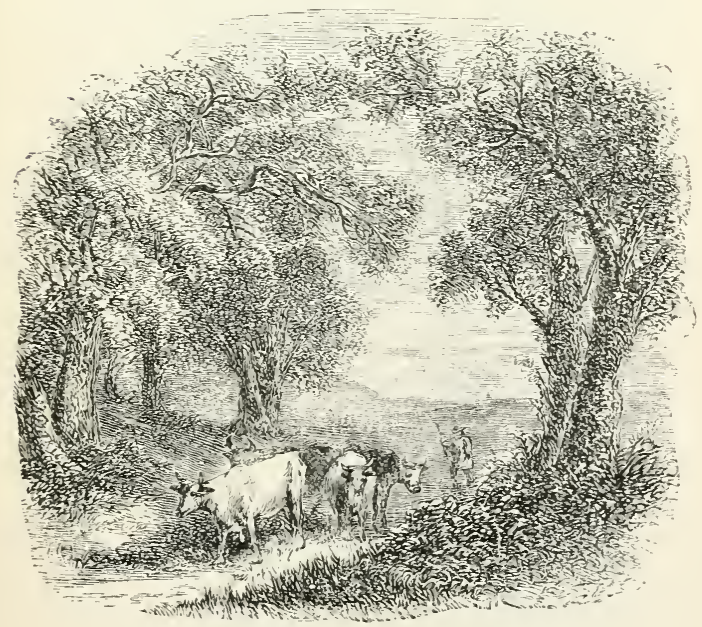




\section{$S U B-F A W I L Y I I I$.}

\section{VILTURINe.}

The Vultures proper.

Gen. Charac. - Bill long, strong, more elevated than broad, the sides more or less compressed, the base covered with a cere for nearly half the length of the bill, and the tip suddenly hooked over the lower mandible; nostrils placed in the cere, with their openings oblique and exposed; wings lengthened; tarsi covered with small scales; the middle toe longer than the tarsi, while the lateral toes are mueh shorter.

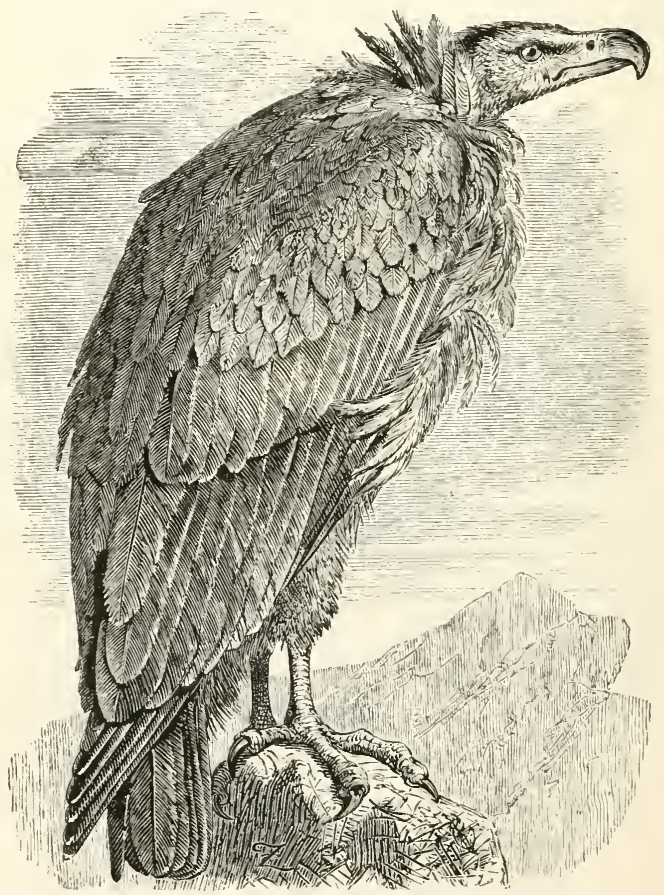

Fig, 10.-The arabian vilture.

( I ultur monuchus.)

This sub-family comprehends a number of large birds peculiar to the warmer parts of the Old World. 
They speedily collect in troops around the body of any dead animal, on which they glut themselves until they are incapable of moving : they will, however, sometimes attack living prey. Their flight is slow; but they are capable of mounting to a considerable height, by means of a series of circular evolutions, which serve them, not only in ascending, but in descending. Their nest is slightly formed of sticks, on the most inaccessible parts of rocks, and the parents nourish their young by disgorging into their throats a portion of their own half-digested food.

The true Vultures are at once distinguishable by the peculiarity of their aspect. A part of their head, of greater or less extent, and sometimes the neck also, is denuded of feathers; thus ensuring the comparative cleanliness of the bird, and preserving it from the filth that would accumulate were the head and neck clothed as in other birds. The strength of their talons is not proportionate to their size; so that they make more use of their beak than of their claws in procuring food. Their wings are so long that, when upon the ground, they are obliged to hold them in a half-extended position. They are all cowardly in their habits, and generally feed upon carrion, rarely upon living prey. When satiated with food, their distended crop projects, a fetid fluid runs from their nostrils, and they become, from very repletion, reduced to a state of helpless inactivity. Among filth and putridity they seem to be in their native element, and they, themselves, have a rank and disagreeable odour. When they first rise from the ground, their flight is heavy and embarrassed; but after a few circuits it becomes rapid and well-sustained; so that when fairly on the wing they can rise to a considerable elevation. There is something ignoble in the gait of the whole race, and the vileness of their disposition is indicated by their attitude. Their wings hang down, and their tail drags on the ground: their whole appearance is repulsive. Nevertheless, in hot climates 
their presence is of essential service, in removing filth, which would otherwise pollute the atmosphere. Hence, in some comntries, laws are enacted for their protection, and they may be seen upon the roofs of houses, or even frequenting the streets, where their presence is not only tolerated, but encouraged. Indeed, besides their usefulness when living, they have an additional security in their utter worthlessness when dead.

Vultures are gregarious, and often associate in flocks of from twenty to thirty, or more, seeking in concert the carrion upon which they feed. When thus employed, they wheel in large cireles that seem to intersect each other, as if forming an immense chain of rounded links, and thus inspect a considerable extent of country. A flock of twenty can in this manner easily survey an area of two miles. Some fly at a considerable altitude, whilst others keep near the ground, so that not a spot is left uncxamined. The moment a dead animal is discovered, the lucky bird rounds to, and by the impetuosity of its movements attracts the notice of its nearest companion, who immediately hastens to share the feast, and is successively followed by all the rest. Thus, the furthest from the discoverer, although at a considerable distance, goes in a straight line towards the spot indicated by the flight of the others, as though attracted by an extraordinary acuteness of smelling, erroneonsly attributed to these birds. If the object discovered is large, lately dead, and covered with a skin too tough to be torn asumder, they remain about it, or linger in the vicinity, perched on the dead branches of high trees. In this conspicuous position they are easily seen by other Vultures, who through habit well know the meaning of such stoppages, and join the first flock. Around the spot they remain, some of them from time to time examining the dead body, giving it a tug in those parts most accessible, until they find its putridity sufficiently advanced. 
The accumulated number then fall to work, exhibiting a most disgusting picture of famished voracity, the strongest driving oft the weakest, and the latter harassing the former with all the animosity that a disappointed hungry stomach can excite. They may then be seen jumping off the carcase, re-attacking it, entering it and wrestling for portions partly swallowed by two or more of them; hissing. at a furious rate, and every moment clearing their nostrils from the filth that enter's there and stops their breathing. The carcase is soon reduced to a mere skeleton, no portion of it being now too tough to be torn apart and swallowed, so that nothing is left but the bare bones. The repast finished, the gorged Vultures slowly fly to the highest branches of the nearest trees, and remain there until the full digestion of all the food they have swallowed is completed. This takes, oftentimes, more than a day, when successively, and very often singly, each $V$ ulture is seen to depart.

The type of this sub-family-

The Arabian Vuiture (Vultur monachus) measures about four feet in length, and the extent of its wings is proportionately wicle; nevertheless, in spite of its large size and great muscular strength, it is not a dangerous neighbour even to the farmer; for unless pressed by hunger, it seems to have a dread of living animals, and contents itself with feeding upon any carrion that may come in its way.

The specific name of monachus, or monk, was given to it by Linnæus, on account of the hood-like ruff round its neck, its bald head, and the general colour of its dress, much resembling the garb of the monastics formerly so numerous in Arabia and Palestine.

Its nest is built upon the most inaccessible cliffs, where it forms a flat mass of sticks three or four feet in diameter. Upon this platform the female deposits two or rarely three eggs, which are white, with a faint bluish tinge.

The range of the Arabian Vulture extends over the whole of northern Africa, Arabia, Persia, India, and the more mountainous parts of the south of Europe. 


\section{SUB-FAMILYIV.}

\section{Gypohieracine.*}

The Eagle-Vultures.

Gev. Charac.-Bill lengthened, much compressed on the sides, and the base covered with a cere for one-third of the length of the bill; wings lengthened and poiuted; tarsi covered with rather large reticulated seales.

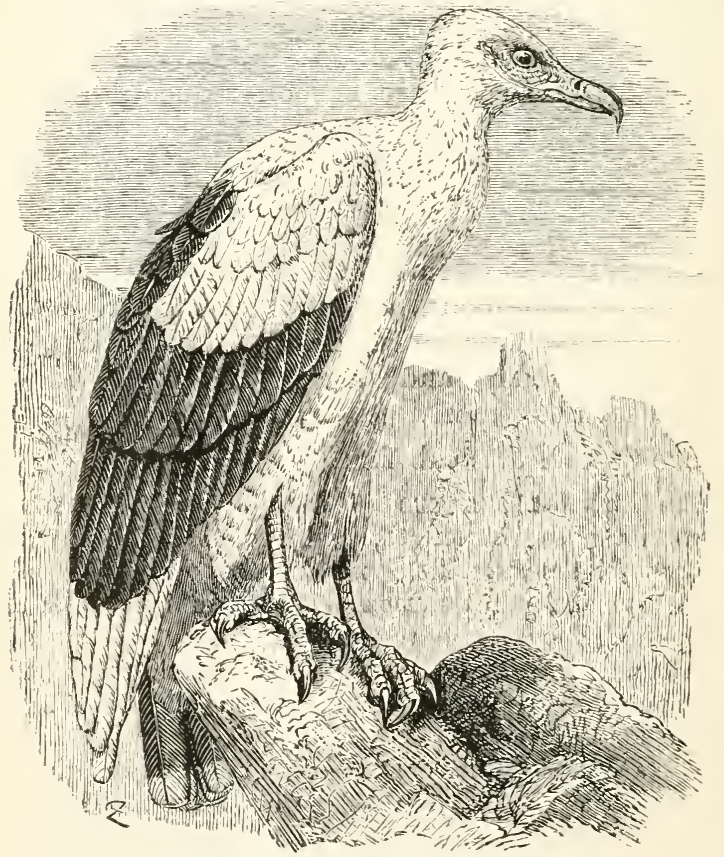

Fig. 11 -the Asgola rulture.

(Gypohierax Angolensis.)

The type of this sub-family-

The Angola Vulture (Gypohierax Angolensis) is supposed to be peculiar to Western Africa, but its habits are, on account of its rarity, at present entirely unknown.

* ýv 


\section{FAMILY II.}

Falconide.

\section{The Falcons.}

Grex. Charac.-Bill partly covered at the base by a cere, compressed on the sides, with the culmen curved from the cere to the tip, which is hooked and acute, and the lateral margins either toothed or festooned; wings long and pointed; tail moderate and broad; tarsi aud toes of various lengths and strong; claws long, curved, and acute, especially those of the inner and hind toes. The head and neck are covered with feathers, and the eyes placed laterally, deep.y sunk, and prctected by a bony biow.

The Falcons, as a group, are easily to be recognized among the other birds of prey. Their head and neck are covered with feathers, and their eyes, placed upon the sides of their head, are overshadowed and protected by a prominent eyebrow, which gives them the appearance of being deeply sunk, and thus imparts to their physiognomy a peculiarly ferocious and determined expression. For the most part they subsist upon prey killed by themselves; but they differ widely in the amount of courage displayed in the pursuit of their quarry; there are, however, a few species that will share with the Vultures their disgusting meal. The Falcons usually seize and carry off their victims by means of their powerfully-armed feet, and their beak is, in most cases, only used for tearing it to pieces. Some of them feed almost exclusively on birds and small quadrupeds; others upon snakes, frogs, and lizards; there are a few that live upon fishes, while a considerable number derive a great portion of their nourishment exclusively from insects. Their mode of capturing prey is also greatly diversified. Some hover in the air or sail slowly along until the quarry appears in sight, when they plunge down upon it with the rapidity of lightning. Some pursue their game with the greatest pertinacity, until they get an opportunity of clutching it with their murderous talons; whilst others frequent woods and thickets, where, like cats, they appear to lie in wait for their victims. 
The plumage of the young birds is often very different from that of the adults, a circumstance which has caused the number of species to be mistakenly multiplied. 'They make their nests of dried sticks among rocks or in tall trees, wherein they lay from two to five coggs. The fimales are generally laroer than the males, but inferior to them in the beauty of their plumage.

This family includes the Caracaras, the Buzzards, the Eagles, the Falcons, the Kites, the Sparrowhawks, and the Horriers.

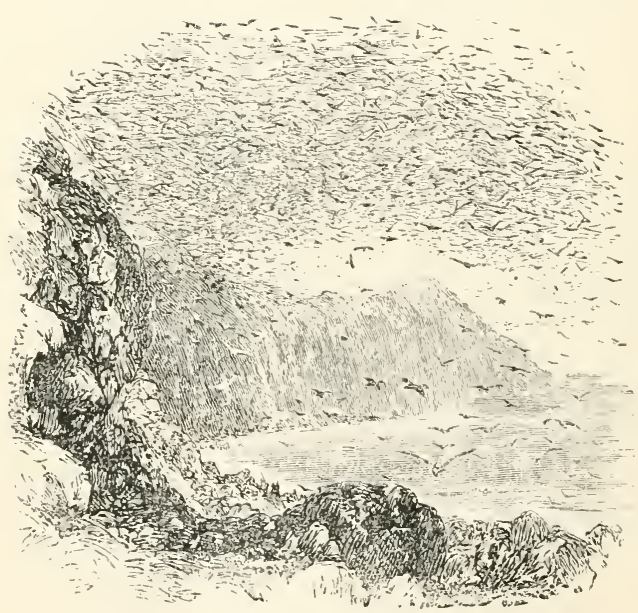




\section{SCB-FAUILYI.}

\section{Polyborina.*}

The Caracaras.

GeN CHarac.-Bill compressed at the sides, slightly hooked at the tip, and the lateral margins slightly festooned; wings long, with the third to the fifth quills the longest; tarsilong, slender, and covered with irregular seales; toes noderate, strongly scaled above, and all armed with strong acute claws.

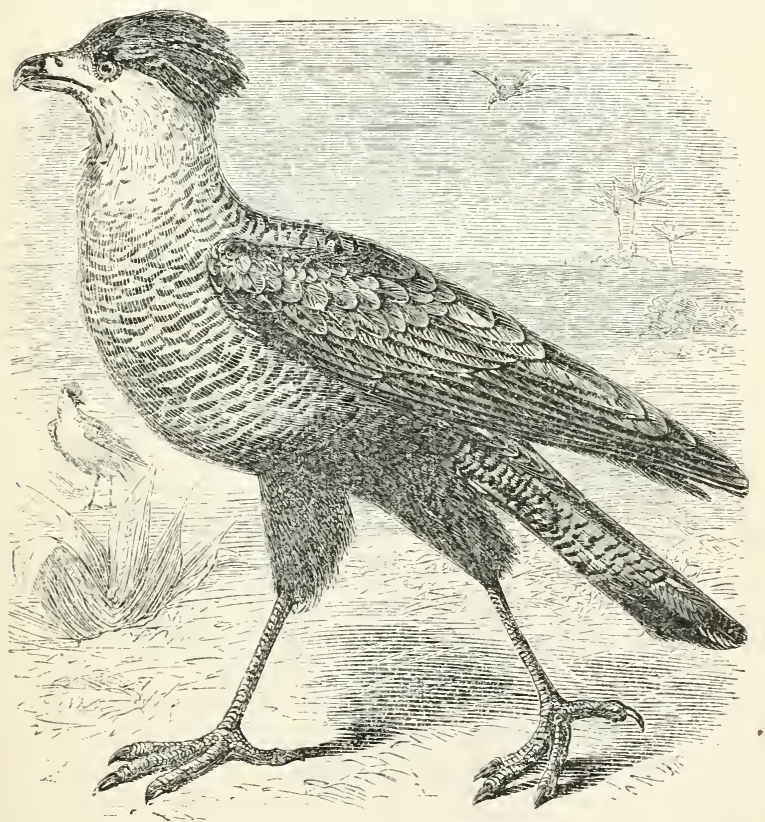

Fig. 12.-The brazilian kite.

(Polyborus Braziliensis.)

The birds composing this sub-family are all peculiar to the warmer parts of South America and the adjacent islands. Their flight is heavy and indolent, and they do not soar into the air, but only fly from place to place. On the ground they are very active, and run with great quickness, after the manner of

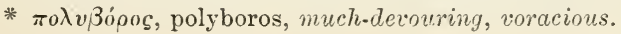


the gallinaceous birds. 'Their food consists of carrion, worms, larva of insects, and even the roots of plants; while some frequent the. sea-shore, or the borders of lakes and swamps, seeking for small fishes. Sometimes they may be seen in small parties attacking birds and other animals, especially those that are in a sickly state. After they have gorged themselves with food their craws become protuberant like those of Vultures.

\section{The type of the group-}

The Caracara (Polyborus Braziliensis), called also the Carancha, derives its vernacular name from its peculiar ery, which resembles the sound of the Spanish guttural $\mathrm{G}$, followed by a rough double $\mathrm{r} r$. This bird is about the size of our common kite, and has a tail nine inches in length; it is generally met with throughout South America, to which continent it is peculiar.

The Carancha feeds indifferently upon carrion, insects, or snails, and will sometimes attack new-born lambs. It does not generally give chase to birds, but, on the contrary, is attacked by them whenever it flies ; chickens, however, are not safe from its depredations, and it will even seize upon game shot by the sportsman. It is rather an indolent bird, especially when gorged with food, and never flies to any great height, but, on the ground, it runs with facility. Along the banks of the Rio de la Plata, they may be seen upon the ground watching the slaughter-houses, and devouring the offal, or they will track the course pursued by the hunters, in hopes of obtaining the rejected portions of the animals slain. They likewise frequent the sea-shore, where they eat crabs, dead fish, and other garbage thrown up by the waves. They have, however, been known to kill partridges, and during the breeding season they destroy the eggs of various birds.

Their nest is commonly built upon trees or upon the ledges of rocks; the female lays five or six eggs, which are pointed at one end, and of a reddish-brown colour, spotted with red.

Under the name of the Mexican Eagle, the figure of the Caracara is embroidered on the banners of the Mexican Government. 
Buteonin.e.

The Buzzards.

GEx. CHaRAc.-Bill short, broad at the base, with the culmen much eurred to the tip, which is acute, and the lateral margins festooned; the cere covers more than the basal half of the beak; wings long, the third and fourth quills generally the longest; tarsi lengthened, generally naked, and eovered both in front and behind with broad transverse scales; toes, including the hind one, rather short.

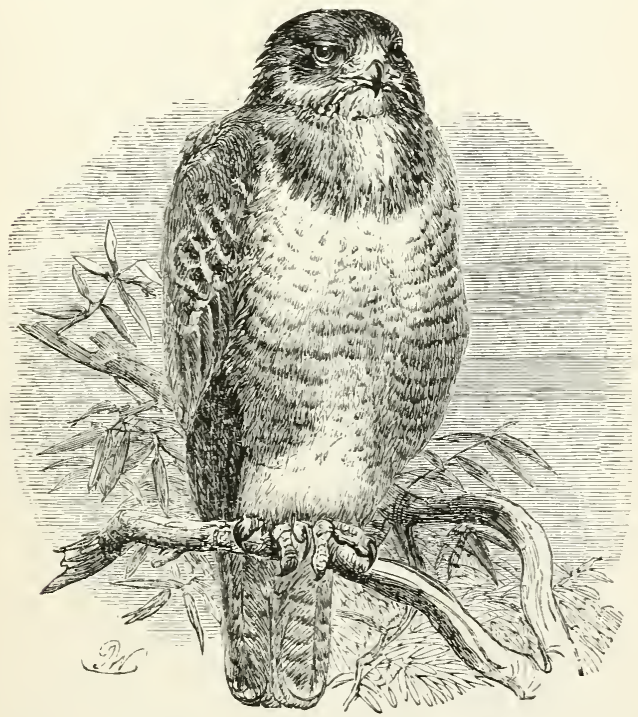

Fig. 13.-тHE COMMON BCZZARD.

(Buteo vulguris.)

These birds are found in most parts of the world: they have a heavy and indolent appearance, and generally inhabit woods and forests. Their flight, which is sometimes performed during the twilight, is easy and buoyant, and generally taken in extensive sweeps over meadows and marshes, near the surface of the ground. They live upon small birds, 
quadrupeds, and reptiles, which they either seize while flying or strike upon the ground, darting upon them from the top of a tree or hillock, from whence they have been watching. They breed in woods, or sometimes upon rocks, or on the sides of deep ravines. Their nest is composed of sticks, and lined with wool, hay, and other soft materials, or occasionally they will take possession of the nests of other birds. Their eggs are usually two or three in number.

The typical species,-

The Common Buzzard (Buteo* vulgaris) is met with in many parts of Europe, and is well known in the British Isles. It is rather an inactive bird, but may be often seen soaring to a great height, and sailing round in circles. When in pursuit of prey, it glides over the fields at no great distance from the gromnd, and pounces lown upon any rictim that may come within the range of its rision. It lives upon small birds, and is most destructive to young grouse and partridges; nothing, however, seems to come amiss to its appetite, and small fuarliupeds, reptiles, and even earthworms, are equally acceptable, but it does not often pursue feathered prey upon the wing. The Buzzard is a bird of very sylvan habits, delighting in the most extensive chases and jarks, where there is abundance of aged timber. It las often been described as being in the habit of watching from an eminence or lofty tree, and thence sweeping down on prey that may happen to come into its vicinity ; for this purpose it is said to remain for hours in one situation; it is probable, however, that these long stationary perches are simply the result of repletion, or for the purpose of rest after the exertion of hunting.

The nest of the Buzzard is composed of sticks mixed with heath, and lined with wool and grass. The eggs are three or four in number, oval in shape, and of a dull or slightly bluish-white, sometimes nearly spotless, but nsually spotted with rusty brown. The young accompany the old birds for some time after quitting their nest, it circumstance unusual amongst birds of prey.

* Buteo, a buzzard. 


\section{$S C L B-F A M I L Y \quad I I I$.}

\section{Aquiline.}

\section{The Eagies.}

Ger. Charac.-Bill moderate, culmen elerated and straight at the base, and then much arched to the-tip, which is hooked and acute, the sides much compressed, and the lateral margins more or less festooned; nostrils placed t in front of the eere, large, and generally oval; wings lengthened and acute, with the third, fourth, and fifth quills usually the longest ; tail long, ample, and mostly rounded at the eud : tarsi long, clothed with feathers to the base of the toes, or naked and covered with variously.formed scales; toes long, strong, united at the base (especially the two outer); lateral toes nnequal both in length and strength, the inner being the strongest; claws long, strong, much curved, and acute, that of the inner toe the strongest.

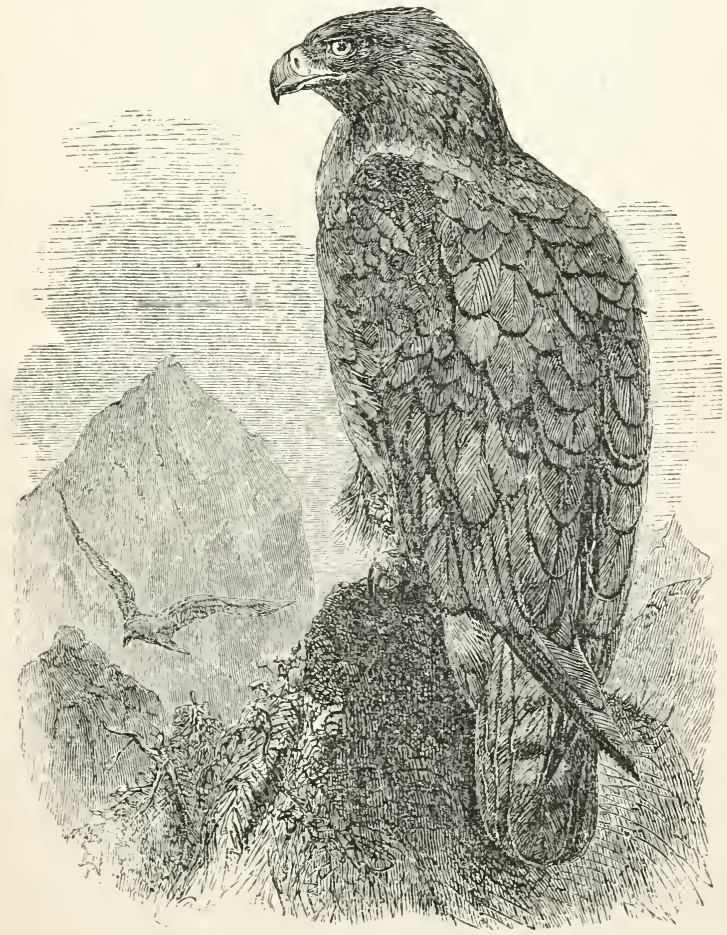

Fig 14.-TIE GOLDEN EAgLE.

(Aquilu chrysiëlos) 
These noble birds are to be met with in most parts af the world, regardless of temperature, but preferring the mountainous districts. They usually soar to a great height in the air, and from this elevation they will descend upon their victims. They may, however, sometimes be seen sailing along at no great altitude over woody valleys, ravines, and the declivities of mountains, as well as over cultivated land, or seated on a rock, patiently awaiting the approach of some quadruped or bird upon which they can prey. Although usually addicted to live upon much nobler game, lizards, insects, and even carrion, are not always beneath their notice. Their flight is easy, and usually performed in lofty circuitous sweeps. Their nest is composed of branches, sticks, heather, and other materials, and covers a large space of ground: it is generally placed upon a projecting part of some inaccessible cliff, or on the summit of a large tree. The eggs are ordinarily two in number.

\section{The type of the race-}

The Golden Eagle (Aquila chryscuëtos)* is amongst the largest of European birds ; the female, which throughout the Falcon family is larger than the male, often measures three feet and a half in length, and upwards of eight feet across when the wings are extended. Bewick mentions a very large specimen killed at Warkworth, in Northumberland, which measured eleven feet in its extent of wing. Its prey consists of large quadrupeds, and birds, fawns, lambs, black and red grouse ; and it is only under the extremity of hunger that it will feed upon carrion, or attack a dead carcase. The stoop of the Eagle is one of the grandest displays of force in the whole range of animated nature, and is generally at once fatal from the violence of the shock: should it, however, fail in destroying life, the clutch instantly follows; in giving which the whole strength of the bird, in the utmost excitement, with the head elevated, the neck

* xpvrós, chrysos, gold; áєrós, aëtos, an eagle; Golden Eagle. 
stiff, the feathers of the head and neck erected, and the wings shivering, so as to keep up the pressure on the instruments of death, is concentrated on the talons, with which alone these birds kill their victims. In general the prey is borne off, but in some cases it is deroured upon the spot.

The ordinary habits of the Eagle are thus graphically described by Mr. MacGillivray:- "There he stands, nearly erect, with his tail depressed, his large wings half raised from his sides, his neck stretched out, and his eye glistening as he glances around. Like other robbers of the desert, he has a noble aspect, an imperative mien, a look of prond defiance; but his nobility has a dash of clownishmess, and his falconship a vulturine tinge. Still he is a noble bird, powerful, independent, but ferocious, regardless of the weal or woe of others, and intent solely on the gratification of his own appetites; without generosity, without honour, bold against the defenceless, but ever ready to sneak from danger. Such is his nobility, about which men have so raved. Suddenly he raises his wings, for he has heard the whistle of the shepherd in the corry, and bending forward he springs into the air. Hardly do those vigorous flappings serve at first to prevent his descent; but now, curving upwards, he glides majestically along. As he passes the corner of that buttressed and battlemented crag, forth rush two ravens from their nest, croaking fiercely. While one flies above him, the other steals beneath, and they essay to strike him, but dare not, for they have an instinctive knowledge of the power of his grasp, and after following him a little way they return to their home, exulting in the thought that they have driven him from their neighbourhood. Bent on a far journey, he advances forwards in a direct course, flapping his great wings at regular intervals, then shooting along without appearing to move them. In ten minutes he has advanced three miles, although he is in no haste. Over the moors he sweeps, at the height of two or three hundred feet, bending his course to either side, his wings wide spread, his neck and feet retracted, now beating the air, and again sailing smoothly. Suddenly he stops, poises himself for a moment, stoops, but recovers himself before reaching the ground. The object of his regards, a Golrlen Plover, 
has eluded him, and he cares not to pursue it. Now he ascends a little, wheels in short curves, presently rushes down headlong, assumes the horizontal position when close to the ground, and prevents himself from being dashed against it by expanding his wings and tail ; he now thrusts forth his talons, and grasping a poor terrified Ptarmigan that sat cowering among the grey lichens, squeezes it to death. He raises his head exultingly, emits a shrill cry, and springing from the gromnd pursues his journey. In passing a tall cliff that overhangs a small lake, he is assailed by a fierce Peregrine Falcon, which darts and plunges at him, as if determined to deprive him of his booty or drive him leadlong to the ground. This proves a more dangerons foe than the Raven, and the Eagle yelps, screams, and throws himself into postures of defence; but, at length, the Falcon, seeing that the tyrant is not bent on plundering her nest, leaves him to pursue his course unmolested. Over woods and scattered hamlets speeds the Eagle, and now the long narrow valley of the Dee appears in sight, near the upper end of which is dimly seen, through the grey mist, the rock of his retreat. About a mile from it he meets his mate, who has been abroad upon a similar errand, and is returning with a white Hare in her talons; they congratulate each other with loud yelping cries, which rouse the drowsy shepherd in the strath below, who, mindful of the lambs carried off in spring time, sends after them his maledictions. Now they reach their nest, and are greeted by their young with loud clamour. The locality where the nest is situated is the shelf of a rock, concealed by a projecting angle, so that it cannot be injured from above, and too distant from the base to be reached by a shot. The nest is a bulky fabric, five feet at least in diameter, rudely constructed of dead sticks, twigs, and heath, flat in the centre, where it is a little hollowed, and covered with wool and feathers. Slovenly creatures you would think those two young birds, covered with white down, amongst which the feathers project, and you see that if the nest had been formed more compactly and of softer materials it would have been less comfortable. Strewn around are fragments of lambs, hares, grouse, and other birds, in various stages of decay. Alighting on the edges of the nest, the Eagles deposit their prey, partially 
pluck off the hairs and feathers, and rudely tearing off the flesh, lay it before their hungry young."

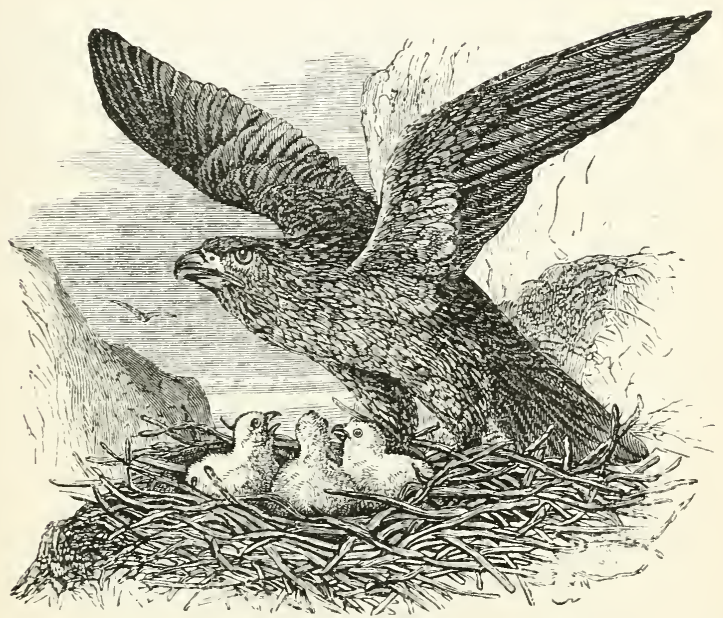

Fig. 15 -EAGLE'S NEST.

The Golden Eagle seems formeriy to have been by no means an uncommon bird in the British isles, but the increase of population, and the cultivation of the land, have driven it to the remoter parts of the kingdom, and it is now only to, be found in the Highlands of the North, the wildernesses of Ireland, and occasionally in Wales. On the Continent it is more abundant, particularly in the northern and hilly countries, as in Norway, Sweden, and some parts of Russia. It is also found, but more rarely, in Germany and France, and still less frequently in Italy or farther southwards.

The extensive sub-family of the Eagles includes a great number of birds more or less agreeing in their habits with the description of the Golden Eagle given above, but nevertheless divisible by certain peculiarities into several distinct groups, distinguished by different names; among these it will be 
necessary to select one or two of the most remarkable, in order to exemplify the general character of this formidable race.

The Sea-Fagles (IKaliä̈tus*) are large and powerful birds inhubiting both the Old and New Worlds. They are usually found in mountainous districts near the sea, or on precipices that border inland lakes. Fishes constitute their principal food, which are generally obtained, as described hereafter, in no very honest manner; but they likewise prey upon large quadrupeds and aquatic birds, or even feed freely upon carrion. The borders of inland lakes, and the rocky margins of the larger rivers, are in turn made the scenes of their predatory exploits. "In such situations, this ruthless tyrant may be seen perched in an erect attitude on the highest summit of the tallest tree, from whence his glistening but stern eye looks down on the scene beneath. He listens attentively to every sound, glancing now and then around, lest even the light tread of the fawn should pass unheard. His mate is perched on the opposite bank of the river, and should all be silent, warns him by a cry to remain patient. At this well-known call, the male partly opens his broar wings, inclines his body a little downwards, and answers to her voice in tones not unlike the laugh of a maniac. The next moment he resumes his erect attitude, and all is again silent. Ducks of many species, the Teal, the Widgeon, the Mallard, and others, are seen passing and following the course of the current; but the Eagle heeds them not, they are at this time beneath his attention. The next moment, howerer, the wild trumpet-like scream of a yet distant but approaching swan is heard. A shriek from the female Eagle comes across the stream, for she is fully as alert as her mate. The latter suddenly shakes himself, and with a few touches of his beak arranges his plumage. The snow-white bird is now in sight, her long neck is stretched forward, her eye is on the watch, vigilant as that of her enemy-she approaches, however, and the Eagle has marked her for his prey. As the Swan is passing the dreaded pair, the male Eagle starts fiom his perch with an awful scream, that to the Swan's ear brings more terror than the report of a gun. Now

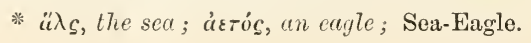


is the moment to witness the Eagle's powers; he glicles through the air like a falling star, and comes upon the timorous quarry, which, in an agony of despair, seeks by various mancuvres to elude the grasp of his cruel talons. It mounts, it doubles, and willingly would plunge into the stream, were it not prevented by the Eagle, which,

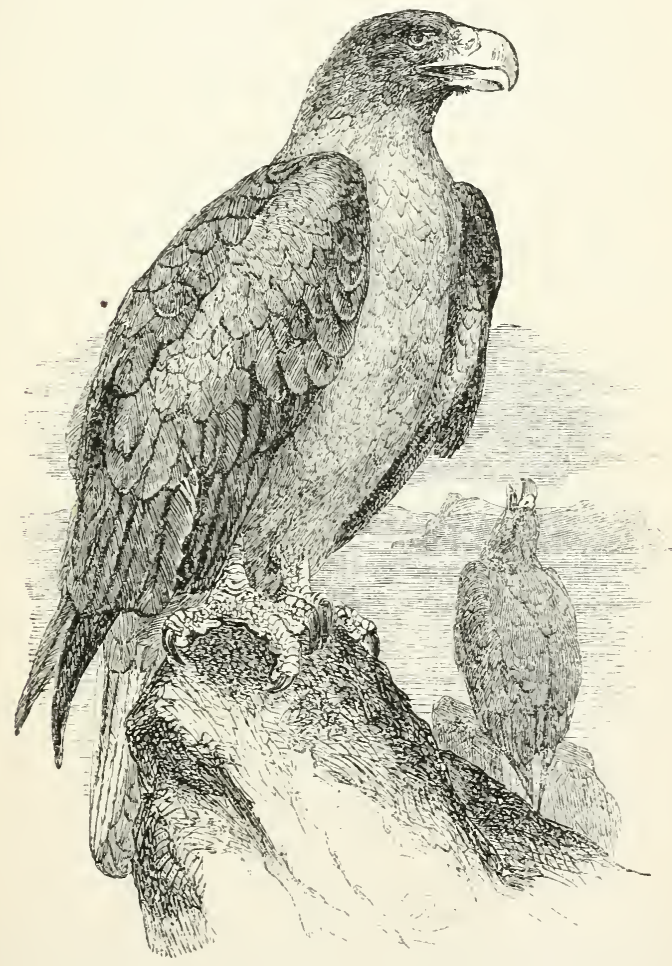

FIG, 16. THE SEA-EAGLE.

(Haliciëus Albicilla.)

long possessed of the knowledge that by such a stratagem the Swan might escape him, forces it to remain in the air by attempting to strike it with his talons from beneath. The poor Swan has now become much ex- 
hausted, and its strength fails it-it is almost at its last gasp, when its ferocious pursuer strikes with his claws the under side of its wing, and with unresisted power forces the bird to fall in a slanting direction upon the nearest shore. And now the Eagle presses down his powerful feet, and drives his talons deep into the heart of the dying Swan-he shrieks with delight as he feels the last convulsions of his prey, and the female who has watched every movement of her mate, now sails to the spot to participate in the gory banquet."-(Audubor.)

The nest of these birds is of considerable size, and composed of the branches of trees and sticks. The eggs are white, and two in number.

The Ospreys (Pandion*), more commonly known as the Fish-Hawks, only resile in the vicinity of the sea, or of lakes and rivers abounding with fish, tpon which they principally subsist. Their slender form is admirably adapted to this pursuit, and their strong talons enable them to seize with a firm grasp their scaly and slippery prey. Their flight is heavy but easy, and they fly equally well either in a straight line or in circles high in the air, where they may be seen wheeling round and round, apparently without the least exertion, and rarely even moving their wings.

A rencontre between the Fish-Hawk and the SeaEingle, so eloquently described by Wilson, equally illustrates the habits of both these tyrants of the sky.

"Elevated on the high dead limb of some gigantic tree that commands a wide view of the neighbouring shore and ocean, the Sea-Eagle seems calmly to contemplate the motions of the various feathered tribes that pursue their arocations below; the snow-white Gulls slowly winnowing the air ; the busy Sand-pipers coursing along the sands ; trains of Ducks streaming over the surface; silent and watchful Cranes intent and wading; clamorous Crows, and all the winged multitudes that subsist by the bounty of this vast magazine of nature. High over all there hovers one whose action instantly arrests his whole attention. By his wide curvature of wing and sudden suspension in air, he knows him to be the Fish-Hawk settling over some devoted victim in the 
deep. His eye kindles at the sight, and balancing him. self with half-opened wings on the branch, he watches the result. Down, rapil as an arrow from heaven, descends the distant olject of his attention, the roar of his wings reaching the ear as it disappears in the deep, making the surges foam around! At this moment the eager looks of the Eagle are all ardour, and levelling his neck for flight, he sees the Fish-Hawk emerge, struggling with his prey, and mounting in the air with wild screams of exultation. These are the signals for our hero, who,

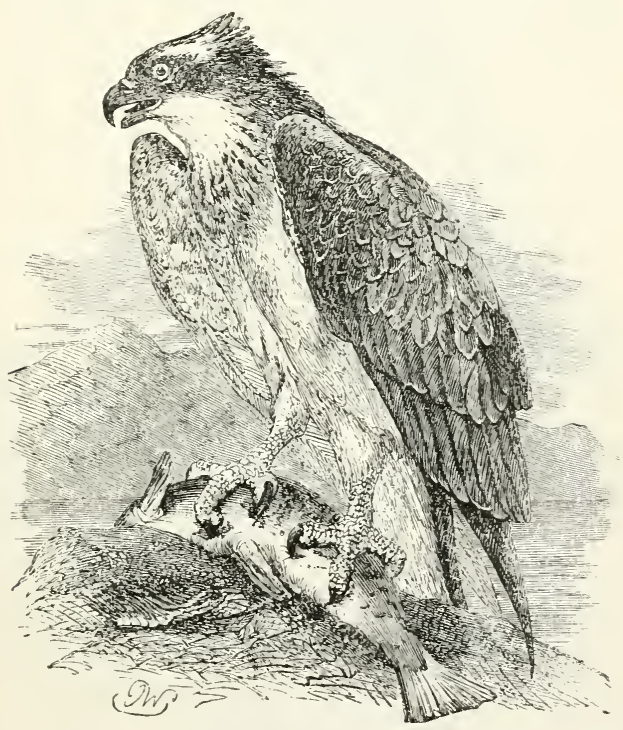

FIG. 17.-THE OSPREY.

(Pandion.)

launching forth, instantly gives chase, and soon gains on the Fish-Hawk, while each exerts his utmost to mount above the other, displaying in these rencontres the most elegant and sublime aërial evolutions. The unencumbered Eagle rapidly advances, and is just on the point of reaching his opponent, when, with a sudden scream of despair and honest execration, the latter diops his fish. The Eagle, poising himself for a moment, as if to take a 
more certain aim, descends like a whirlwind, snatches it in his grasp ere it reaches the water, and bears his illgotten booty silently away to the woods."

The nest of the O-prey is usually built on the top of a decayed tree. It is composed entirely of sticks from half an inch to an inch and a half in diameter, and two or three feet in length, piled to the height of four or five feet. These are intermixed with straw, sea-weed, and pieces of turf heaped together in large quantities, and lined with dry sea-grass. These materials are so well put together as often to adhere in large fragments, after being blown down by the wind.

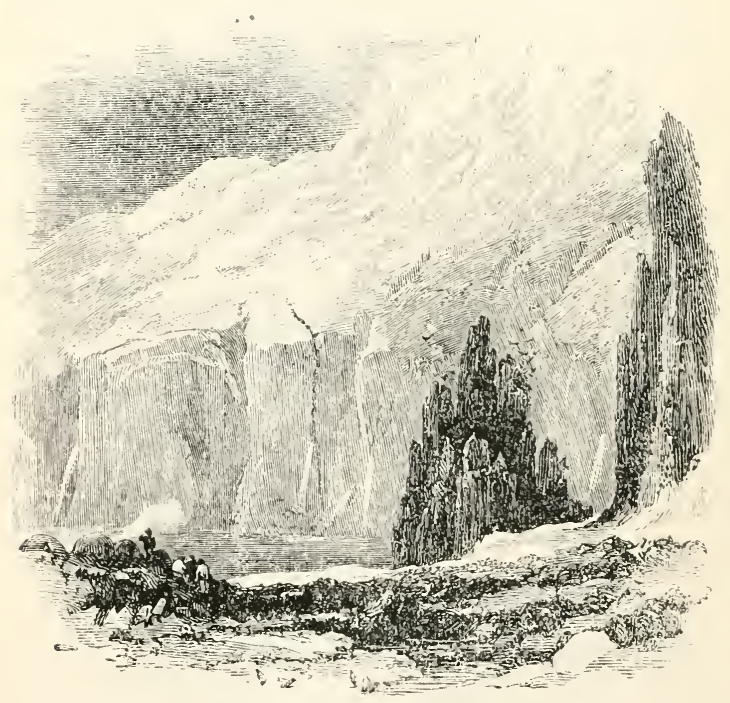




\section{SUB-FAMILYIV.}

Fatconis.e.

The Fulcons proper.

Gex. Charac.-Bill short, the culmen eured from the base to the tip, which on the sides is more or less toothed; cere covering the nostrils, sometimes rounded, and sometimes long and linear; wings lengthened and pointed, with the second and third quills generally the longest; tail lengthened, and more or less rounded; feet of various proportions; toes usually long and slender.

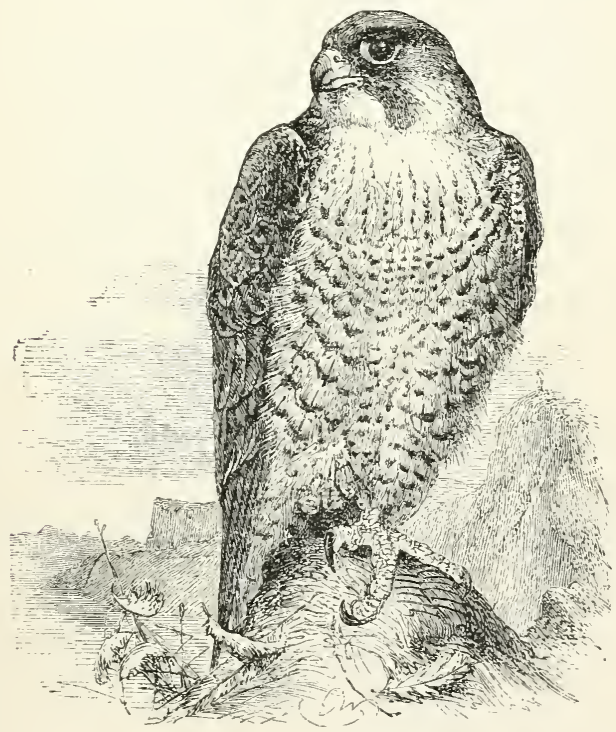

Fig. 18.-THE PEREGRIXE FALCos.

(Fuleo peregrinus.)

These birds are, in proportion to their size, the most courageous of the feathered race, a quality which is in perfect correspondence with the strength of their armature and the velocity of their flight. The length of their wing-quills causes their forward course, in a calm atmosphere, to be rery oblique, so that they are obliged, when they wish to mount 
directly upwards, to fly against the wind. Nevertheless, there is an elegance in their port and a boldness in their aspect, which distinguishes them at a glance, while their astonishing power of wing and great muscular strength render them the noblest of predaceous birds. 'They are extremely docile: they may be taught to pursue game, and to return, when called, to the hand of their master; qualities of which man has not failed to avail himself. Among the most celebrated species is the type of the race-

The Peregrine Falcon (Falco peregrinus). This noble bird is at once recognizable by a broad triangular moustache of black feathers on the cheeks. It usually measures from fifteen to eighteen inches in length, and the female is considerably larger than the male. Such is its power of flight, that it may almost be said to be ubiquitous. It extends its range over the northern part of both hemispheres, and is equally to be met with in the United States of America, the south of Europe, India, the Straits of Magellan, and the Cape of Good Hope. It is from this celebrated species that the chase of game by means of birds of prey derives its name. It descends upon its prey vertically, as if it fell from the sky; hence it catches birds on the wing. In most districts, grouse and partridges constitute its favourite food, and it is at such game that it is taught to fly ; but in the vicinity of water it destroys numbers of aquatic birds, swooping down and carrying them off in its talons. Rabbits and leverets are also frequently destroyed by these marauders, and their boldness is such that they have been known to strike grouse sprung by the sportsman's dog before they had risen high enough to be shot at.

When searching after prey, this Falcon often adopts a flight resembling that of the tame pigeon, until perceiving its victim, it redoubles its flappings, and pursues the fugitive with a rapidity scarcely to be conceived. Its turnings and windings through the air are now surprising. It follows and nears the timorons quarry at every turn which the latter attempts. Arrived within a few feet of the prey, the Falcon extends his powerful legs and talons to their full stretch; his wings almost close for a moment, and the next instant he grapples his prize, which, if too 
heavy to be carried off directly, he forces obliquely towards the ground, sometimes a hundred feet from the place where it was seized, to kill it and devour it on the spot.

Under other circumstances, when the female Falcon comes within sight of her quarry, she bounds upwards, every stroke of the wings producing a perpendicular leap, as if she were climbing those gigantic stairs into which Nature moulds her basaltic rocks, and when she has "got the sky" of her prey to a sufficient height for gaining the necessary impetus, her wings shiver for a moment, as she works herself into perfect command and poise. Then, prone she dashes, with so much velocity that the impression of her path remains on the eye, in the same manner as that of the shooting meteor or the flashing lightning. The observer fancies that there is a torrent of Falcon rushing for fathoms through the air. The stroke is as mnerring as the motion is tleet. If it take effect in the body, the bird is trussed, and the hunt is over; but if a wing only is broken, the maimed bird is allowed to flutter to the earth, and another is marked for the collision of death.

The Falcon's command of the air is truly wonderful ; a few strokes of its powerful wing will send it up till it is hardly visible, or bring it from the top of its flight to within a short distance from the ground. At times it will ride motionless, as if anchored in the sky, and anon, with hardly any perceptible morement of the wings, shoot down with the rapidity of an arrow. The collision with their prey is terribly effective. It is no slight force which can break a wing, strike off a head, or burst a bird asunder, when it is not merely suspended in the air but in rapid motion, away from the striker. If the Falcon misses, we need not wonder that the game escapes before its pursuer recovers himself-_(Mudie.)

The Peregrine Falcon usually builds a nest amongst nearly inaccessible rocks on the sea-coast, but sometimes selects an inlaud station. The nest is a bulky structure, composed of sticks and dried plants, and in it the female lays three or four eggs, of a dull light red colour, with darker spots. 


\section{S'UB-FALIILY I.}

MiLine.

The kites.

GEx. CHARAC-Bill short, weak, with the tip hooked and acute, and the lateral margins sinuated; nostrils basal and lateral, with the opening mostly in the form of an oblique slit; wings long and pointed; tarsi hardly longer than the hind toe, and robust; toes moderate, broad, and padded beneath.

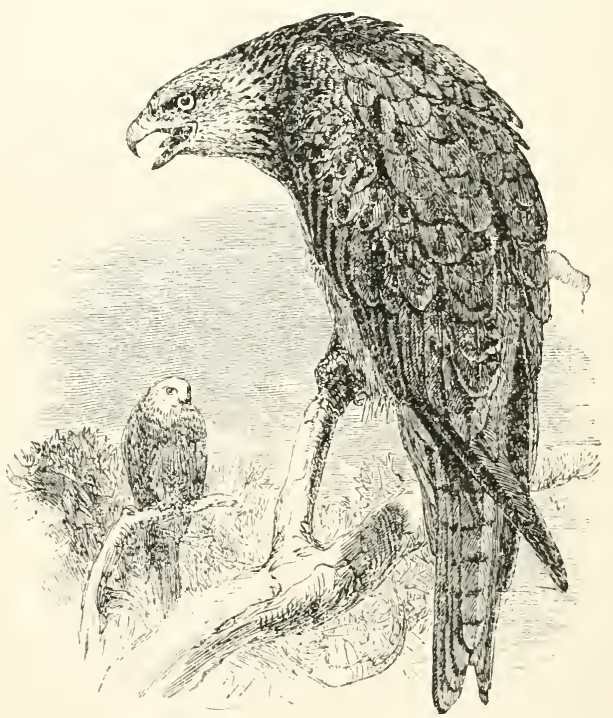

Fig. 19, THE COMMON KITE.

(Milvus regalis.)

The shortness of their legs and the feebleness of their talons, conjoined with a beak equally disproportioned to their size, causes the Kites to be the most cowardly of the Falcon race; while, on the other hand, the excessive length of their wings and their forked tail cnable them to fly with wonderful ease and elegance. These birds, indeed, appear to 
support themselves in the air without the least exertion. They glide smoothly along, rising, descending, and wheeling round in graceful circles, without any movement of their wings, but simply by the guidance of their rudder-like tail. It is from this beautiful gliding motion that they seem to have received, from our Saxon ancestors, the name of Gled or Glead.

The Kites are met with in rarious parts of the world; in hot climates, more especially, they may be seen in great numbers watching from some lofty tree for whaterer may present itself in the way of food, or they sometimes soar to a great height in the air. Nevertheless they seize their prey mpon the ground. They live chiefly upon young hares, rats, birds, and lizards, but are by no means averse to carrion. Their nest is built in a fork of some large tree, and is made of sticks, lined with various soft materials.

\section{The type of this sub-family, -}

The Common Kite (Milvus regatis), although now become scarce in England, is still seen occasionally in the Lake districts of Cumberland, and in the south-eastern parts of Scotland. On the Continent of Europe it is not uncommon, its range extending eastward into Siberia. In the more northern regions it is only a summer resident, migrating southward in the autumn. The Kite is a bird of considerable size, measuring from twenty-five to twenty-seven inches in length, including the long forked tail with which it is fumished. It has been usual to divide the rapacious birds into two great sections, one comprising the noble races, or such as feed exclusively on prey killed by themselves, and the other the ignoble species, whose appetite, not so fastidious, permits them to feast upon carrion. The Kites must certainly be placed in the latter category, feeding as they do not only upon dead animals, but eren upon the vilest garbage. Indeed, there was a time when these birds appear to have rendered the same service in the thoroughfares of London as the Vultures do at the present day in some of the crowded cities of the East. We real that not longer ago than the 
reign of Henry VIII. our metropolis swarmed with Kites, attracted thither by the offal thrown into the streets, into which they fearlessly desceuded to perform the scavenger's office, it being forbidden to kill them. Shakespeare makes Hamlet say,_- "Ere this I should have fatted all the region Kites with this slave's offal," and the words had a significance in those days which fortunately, in modern times, is but imperfectly appreciated.

While on the wing, performing its aërial evolutions, the Kite will sometimes hover for a long time over the same spot with very little exertion of the wings, even if there should be a fresh breeze. There are times, however, probably when it has lost sight of some prize on the ground, at which it will "give itself to the wind," and drift to leeward in very beautiful style, apparently with complete self-possession. This manceuvre, though held in great contempt by the Falcons, is by no means ungraceful or uninteresting; the bird rides lightly on the gale, but retains its self-command, so that it can take a new direction whenever it pleases.

The nest, built with sticks, and lined with feathel's and moss, is placed in some lofty tree. The eggs are from four to six in number.

"The Indian Kite (Milvus Govind $\iota$ ) is one of the most abundant and common birds in India, found at all elevations up to 8,000 feet, especially near large towns and cantonments, and its vast numbers and fearlessness surprise the stranger from England, where birds of prey are so rare. Every large town, cantonment, and even village, has its colony of Kites, which ply their busy vocation from before sumrise to some time after sunset. Every large camp, too, is followed by these useful scarengers, and the tent even of a single traveller is daily visited by one or more, according to the numbers in the neighbourhood. As is well known, Kites pick up garbage of all kinds, fragments of meat and fish, and generally the refuse of man's food. When a basket of refuse or offal is thrown out into the streets to be carted away, the Kites of the immediate neighbourhood, who appear to be quite cognizant of the usual time at which this is done, are all on the look-out, and dash down on it impetuously; some of them seizing the most tempting morsels by a rapid swoop, others deliberately sitting 
down on the heaps, along with the dogs and crows, and selecting their scraps. On such an occasion, too, there is many a struggle to retain a larger fragment than usual ; for the possessor no sooner emerges from its swoop than several empty-clawed spectator's instantly pursue it eagerly, till the owner finds the chase too hot, and drops the bone of contention, which is generally picked up long before it reaches the ground, again and again to change owners, and perhaps finally to revert to its original proprietor. On such occasions there is a considerable amount of squealing going on. Though it is generally on sufficiently good terms with the crows in company on a heap of garbage, yet I have frequently seen it pursue a crow and force it to relinquish a coveted morsel. The Crows, however, often tease a Kite, apparently without any object but that of a little amusement to themselves. The food of the Kite is usually devoured on the wing, or if too large, carried to the nearest house or tree. Mr. Blyth notices their collecting in numbers without any apparent object, especially towards evening. This I have frequently observed at all large stations, where all the Kites of the neighbourhood, before retiring to roost, appear to hold conclave."-Jerdare, "Birds of India." 


\section{SUB-FAMILY VI.}

ACCIPITRINA.

The Sparrow-Hawks.

Gex. Charac.-Bill short, much arched from the base to the tip, which is acnte, the sides compressed, and the lateral margins greatly festooned; wings generally long; tail ample; tarsi lengthened and shielded in front; toes of various length, and generally slender; claws long, and very acute.

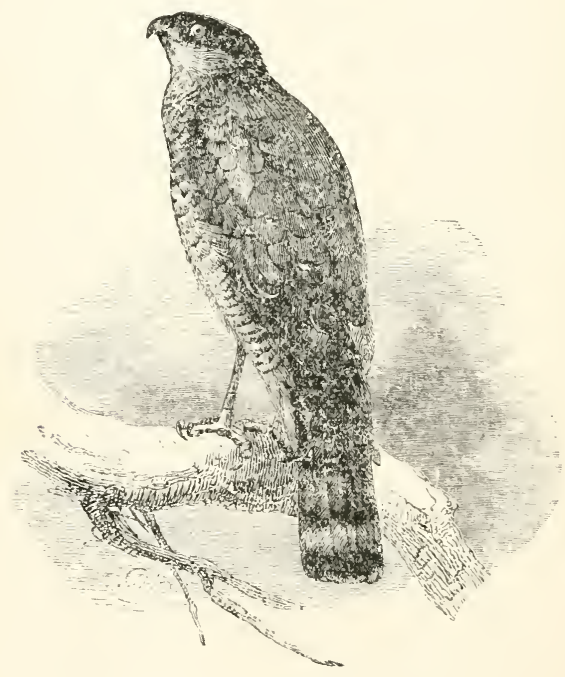

Fig. 20.-THE SPARRoW-HAWK.

(Accipiter nisus.)

These birds are found in various parts of the world, generally frequenting valleys and wooded districts. They are very courageous : their flight is low, sweeping near the ground with much rapidity, and they pounce upon their prey while on the wing with deadly certainty. Their food consists almost exclusively of birds, such as partridges and pigeons; but sometimes they devour lizards and other small animals. Their nest is built upon low trees, or in a 
bush, and is composed of slender sticks. 'They lay from four to six egrgs.

The type of the race is -

The Sparrow-Hawk (Accipiter nisus), one of the must abundant of our British Hawks. It is exceedingly elegant in its form, and active in its habits, the length of its wings permitting it to fly with great rapidity, while its broad and powerful tail enables it to perform astonishing evolutions. When hunting for its prey, it usually glides swiftly along at the height of only a few feet from the ground, occasionally passing up one side of a hedge and down another. It sometimes pursues birds upon the wing, but usually pounces upon them while resting either upon the ground, or on the branch of a tree or bush.

Of all the smaller European birds of prey, the Sparrow-Hawk is one of the boldest and most intrepid; unlike many of the true Falcons of its own size, which live in a gieat measure upon insects, it preys almost exclusively upon feathered game, and hence is peculiarly obnoxious in preserves, especially during the breeding season. Quick-eyed and rapid, it darts upon its quarry like an arrow, and pursues it with unrelenting pertinacity, undaunted even by the presence of man, to whom the terrified fugitive has often been known to trust in the desperate emergency-indeed many instances are on record of the Lark or the Pigeon rushing into houses through the open windows, followed by their undaunted foe.

The flight of the Sparrow-Hawk is not of that soaring character which distinguishes the true Falcons. Instead of descending on its prey from aloft, and striking it down, or, if missing the stroke, mounting again and repeating the assanlt, it darts at it without rising to any altitude, and follows up the chase until able to effect its capture.

The Sparrow-Hawk is universally but moderately distributed throughout Europe, Asia, and Africa. It builds its nest in trees; the eggs are generally four in number, of a dull bluish-white marked with angular red blotches. 


\section{SUB-FAIILY VII.}

Circina.

The Harriers.

Gex. Charac.-Bill moderate, short, with the culmen mueh eurved to the tip, which is hooked; sides eompressed, and the lateral margins festooned; wings lengthened and pointed; tail long, broad, and even or rounded at the end; tarsi usually lengthened and slender; toes rather short.

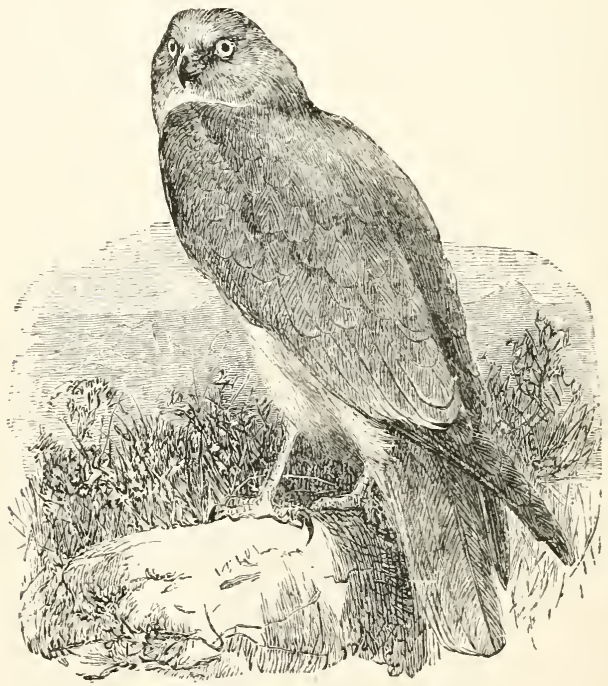

Fig. 2I.-THE HEN-HARRIER.

(Circus cyaneus.)

The Hawks to which the name of Harrier is applied, of all the diurnal predaceous birds, make the nearest approach to the Owls. The softness of their plumage, accompanied in certain species by a radiated arrangement of the feathers of the face, give some of them a very owl-like appearance. They are described by many writers as deriving their name of "Harriers" from their mode of seeking their prey. When thus engaged, they Hy 
slowly, at but a little distance from the ground, beating over every part of the surface like a dog hunting for game. Others, more familiar with north-country language, derive the name from the Border word to "harry," which means to make a raid upon cattle.

\section{- The type of the race is-}

The Hen-Harrier (Circus* cyaneus), a British bird usually met with in flat marshy districts, or on low moors and commons, where it finds abundance of small quadrupeds, such as young rabbits, leverets, rats, and mice, as well as snakes, frogs, and unfledged birds. Upon these it pounces suddenly, when it finds them among the herbage. It does not hesitate upon oceasions to attack a grouse or a partridge, and has even been known to seize upon a pheasant. Indeed, we rather suspect that its name of Hen-Harrier would indicate its propensity for plundering - that is, "harrying," the poultry-yard when an opportunity presents itself.

The flight of the Hen-Harrier while in quest of its prey is altogether peculiar. It is light and buoyant, but performed at no great elevation from the ground, which it quarters with the utmost regularity, traversing a certain extent of country, and returning nearly to the same place at a given time for many days together. While thus skimming along with noiseless wings, it strongly reminds us of the Owls, and, like them, it pounces down upon its prey with unerring precision.

The Hen-Harrier makes its nest upon the ground in wild and solitary situations among the tufted herbage most prevalent upon the spot selected, and here it incubates and rears its young. The eggs very much resemble those of an Owl, but are larger. They are of a dull, dirty white colour, without any spots.

* кiрко, kirkos, a kind of hawk, which flies in circles. 


\section{STR-ORDER II.}

\section{Accipitres Nocturin. \\ Nocturnal Biris of Prey.}

This sub-order comprises lut one Famil!y.

\section{STrRIGID.e.}

The Ouls.

GEN. CHarac.-Bill short, with the sides compressed, and the base eoncealed ly projecting bristles; enlmen much arehed to the tip, which is hooked; wings usually moderate and rounded; tail broad and of various length; tarsi generally short and feathered to the toes; toes usually short, and either clothed with plumes or slightly covered with hairs; claws long, and rery acute; eyes large and eneompassed with a radiated circle of slender hairy feathers forming a facial disk.

The plumage of the Owls is peculiarly soft and downy, rendering their flight perfectly noiseless, so that they steal unperceived upon their prey. Their eyes, which are of large size, as though to receive every ray of light that may be available for vision, look directly forwards. In a strong light their sight is very imperfect, so that they stand in a state of complete bewilderment, staring in a most ludicrous manner at any olject presented to them, and taking every opportunity of concealing themselves in some obscure corner. The ears are more conspicuous than those of any other birds, and are usually furnished with a sort of lid. The head is large, and there is no ridge over the eyes, as in the Falconidic. The feather's of the face project more or less forwards, and conceal the cere at the base of the bill. The outer toe is reversible, and capable of being turned backwards like that of a parrot. These birds are recluse in their habits, living in pairs in the holes of trees, or in old buildings and other retired places, where they hide during the daytime; but in the evening issue forth to seek their prey, which consists principally of small quadrupeds and birds. The smaller Owls frequently eatch such 
insects as come abroad in the twilight, more particularly moths and beetles. The indigestible portions of their food are disgorged in the shape of pellets, composed of the bones, hair, and fur of their victims. 'Their voices are generally loud and discordant. The Owls have been arranged in four sub-families; namely, the Hawk-Owls, the Horned Owls, the Owlets, and the Owls proper.

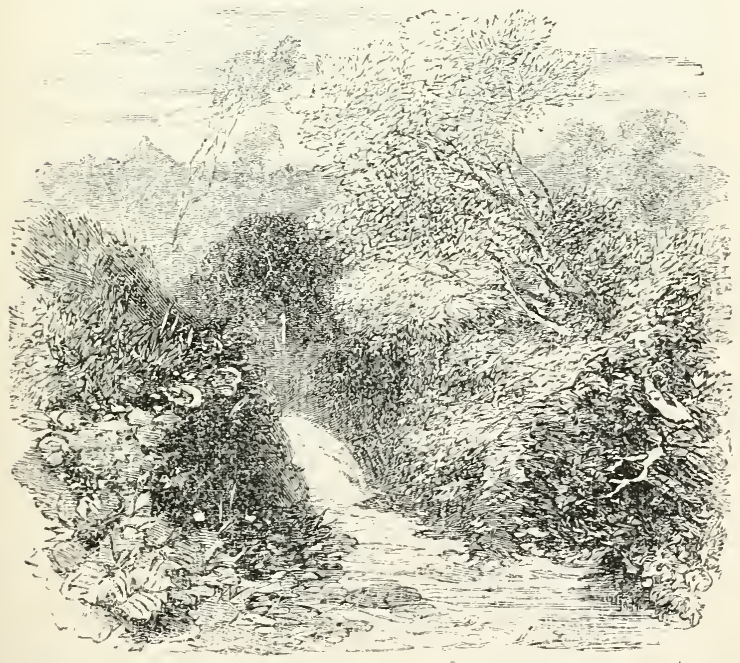


SURNINA.

The IIarvk-Owls.

GeN. Charac.-Head small, without tufts, and the facial disk imperfect over the eyes.

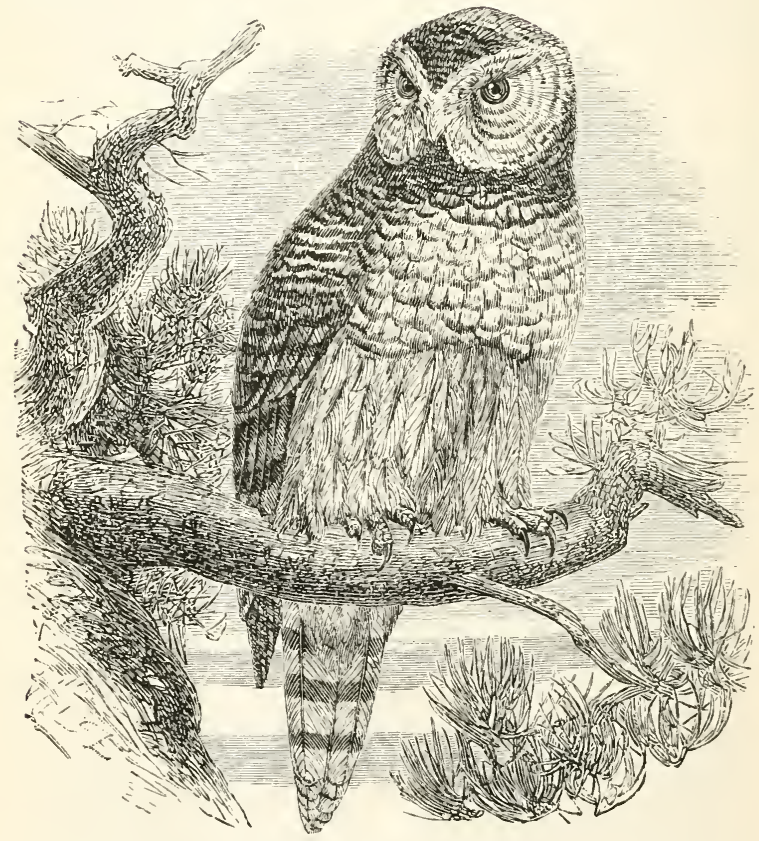

Fig. 22.-The caNada OWL.

(Surnia Ulula.)

These birds inhabit the northern parts of Europe and America, but are by no means peculiar to cold climates, as they are likewise met with in the southern parts of Africa. 'Their food chiefly consists of mice, birds, and insects ; but during the winter, those of the northern latitudes feed principally on ptarmigans. Their nest is built on trees, and is composed of sticks, grass, and feathers. The female lays two eggs. 
The type of this sub-family,-

The Canada Owl (Surnia Ulula), is very common in the northern parts of North America, where it is remarkable for its daring disposition.

In Canada it is almost impossible to travel eight or ten miles in any of the retired woods without seeing several of them even in broad day; and at the approach of night their cries are heard proceeding from every part of the forest. Should the weather be lowering, and indicative of the approach of rain, their rociferous hootings are so multiplied, especially in the evening, and they respond to each other in tones so strange, that one might imagine some elfish revelry in progress. On approaching one closely, its gesticulations are seen to be of a very extraordinary nature. The position of the bird, which is generally erect, is immediately changed. It inclines its body to watch the motions of the intruder, throws forward the lateral feathers of its head, which has thus the appearance of being surrounded by a broad ruff, looks towards him as if half blind, and moves its head to and fro in such a manner as almost to induce a belief that it is separated from the body. It follows the stranger with its eyes, and should it suspect any treacherous intentions, flies off to a short distance, alighting with its back to the intruder; but immediately turning about with a single jump, recommences its scrutiny. In this way it may be followed to a considerable distance; but if shot at and missed, it removes itself out of reach, after which its whah, whah, whah is uttered with ludicrous pomposity.

These Owls will answer the imitation of their own cries, and are frequently destroyed by this artifice. Their flight is smooth, noiseless, and greatly protracted. They have been seen to pursue a direct course for more than two miles until they were lost in the distance. So very lightly do they $\mathrm{fly}$, that they are frequently discovered while passing over a person only a few yards distant by their shadow on the ground cast by the clear moonlight, when not the faintest rustling of their wings can be heard. 
Bubonine.

The Horned Ouls.

Gen. Charac.-Head large, broad, flat on the top, and furnished with two prominent tufts; facial disk imperfect above the eyes.

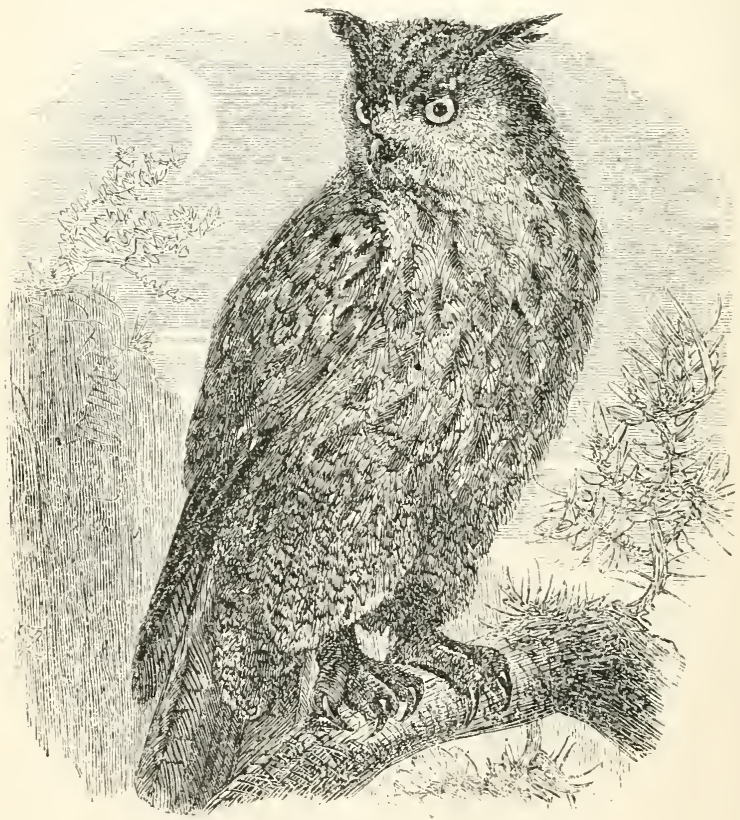

FIG. 23. -THE EAGLE.OWL.

(Bubo maximus.)

The Owls belonging to this sub-family inhabit most parts of the world, regardless of climate. They frequent old buildings, holes in the sides of trees, precipitous hills, and ravines of the mountains, or they may be seen in the deep shades of the swamps of large forests. Their food is sought for principally during the night, and consists of small quadrupeds, 
birds, lizards, and the larger insects. Some of the species have been observed to catch fish, which they strike at and seize with their foot: during the night they emit a loud prolonged hoot, and when alarmed hiss at their assailant and make a loud snapping noise with their beak. Their nest is built amid ruins, in rocks, in the hollows or upon the fork of a tall tree-it is composed of sticks piled in considerable quantities, lined with dry leaves and a few feathers. The members of one genus (Ketupa) belonging to the continent and archipelago of India, fly well by day, are constantly found on the banks of rivers, and live principally upon fish and crabs.

The typical species,-

The Great Eared Owl, or Eagle-0wl (Bubo* maximus), is an inhabitant of Europe, where it is tolerably common, but it is only a rare and occasional visitor to the British islands. When full grown, it measures from twenty-four to twenty-eight inches in length. The head is ornamented with two large tufts of feathers, which stand up above the eyes like horns. It can endure light better than some of its allies, but the season of its activity is principally during the night.

"Along the mountainous shores of the Ohio, and amidst the deep forests of Indiana," says Wilson, "this ghostly watchman has frequently warned me of the approach of morning, and amused me with his singular exclamations, sometimes sweeping down and around my fire, uttering a loud and sudden 'Waugh ho! Waugh ho!' sufficient to have alarmed a whole garrison. He has other nocturnal solos no less melodions, one of which very strikingly resembles the half-suppressed screams of a person suffocating or half-throttled, which cannot fail to be exceedingly entertaining to a lonely benighted traveller in the midst of an Indian wilderness."

When hard pressed, this $\mathrm{Owl}$ is said to throw itself upon its back and defend itself vigorously with its claws : it has even been described as contending successfully witli the Eagle.

At all events, it may be considered as one of the * Bubo, a long-eared owl. 
most powerful of its race, boldly preying upon the largest gatne. Perched upon some hranch, and obscured by the shadows of evening, it marks its ili-fated quarry, - the fawn roposing among the fern, the hare nibbling the grass, the grouse crouching anong the heath. Silently and rapilly down it pounces, strikes its victim, and commences the work of destruction. Less noble game, such as moles, rats, and lizards, may be also ranked ammong the articles of its food. This fine bird chooses the clefts of rocks, or the hollows of decayed trees of antique growth, for the purpose of nidification, laying three eggs of a rounded shape and white colour.

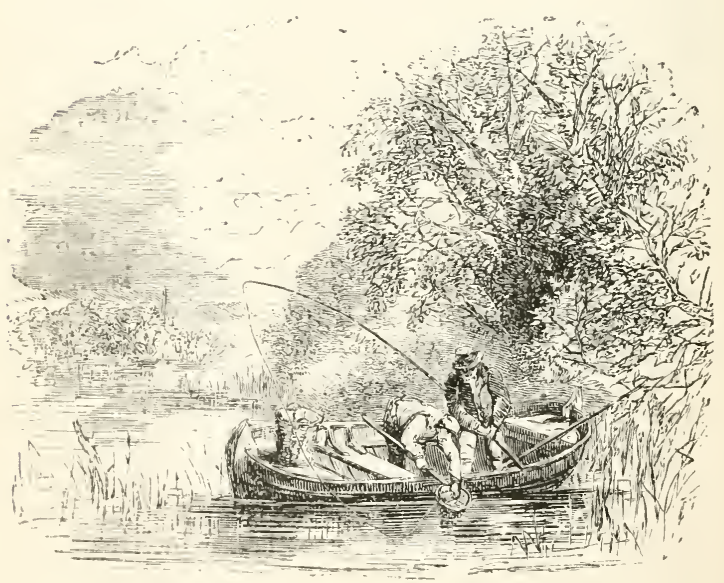


Gex. Charac.-Headlarge, smooth, and furnished with two small tufts ; facial disk moderate and complete, or nearly so.

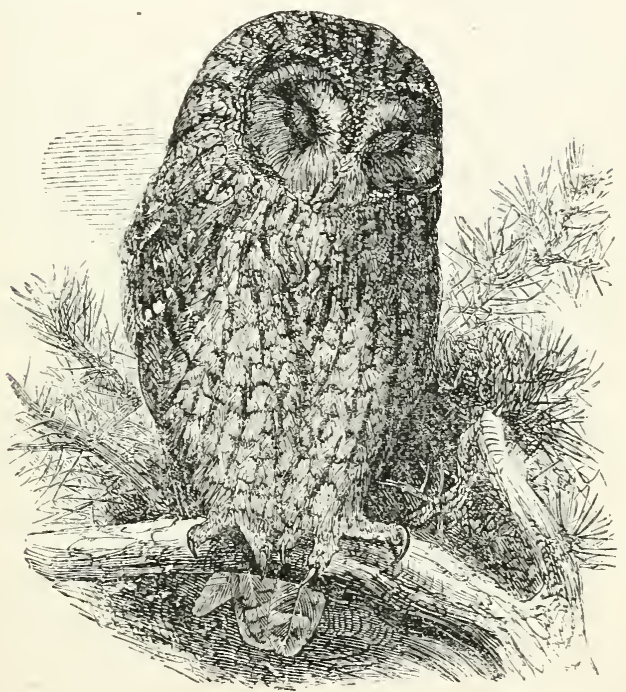

FIG. 2t.THE BROWN OWL

(Surnium Aluco.)

The Owlets are found in various parts of the world, even in very high latitudes, hunting in the shady woods and thick plantations for a short time before the sun sinks below the horizon, but hiding. themselves during the day in ruins and hollow trees. In the northern latitudes they may frequently be seen flying about even at midday, and their flight is gliding and noiseless. They live upon small quadrupeds, birds, and fish, all of which they strike with their foot. They build amidst rocks or upon lofty trees, and the nest is composed of a considerable quantity 
of sticks, lined with a few feathers. Some species, howorer, lay their coros in the descred nests of other birds or scrape a slight hollow on the ground in the midst of heath; while the nests of others (Nyctule) are built of grass, and generally placed in holes or clefts of pine trees.

The typical species,-

The Brown Owl (Syrnium Aluco), sometimes called the Tawny Owl, is not uncommon in England. It is strictly nocturnal; the glare of day dazzles and renders it quite helpless, and it shows the wisdom that might have been expected from the favourite of Minerva, by retreating during the hright hours to the gloom of some thick wood, where it reposes among the dense foliage. In the evening, howerer, it quits its concealment to satisfy its somewhat indiscriminate appetite. Flitting along with noiseless wing, it surprises the smaller quadrupeds, and even seizes young rabbits and birds, varying this sulper sometimes with frogs, insects, and even fish, which it will capture in shallow water: it likewise will devour earthworms. While engaged in its predatory excursions it emits a loud doleful cry, resembling hoo, hoo, hoo, and occasionally utter's a shrill scream.

The nest of the Brown Owl is composerl principally of the dried pellets of undigested bones and fur or feather's, which all (Owh are in the habit of disgorging. It is usually placed in a hollow tree, and here the female lays whout four eggs, from which emerge, in due time, as many grotesque-looking bodies, enveloped in a soft plush, which are destined, in time, to become Brown Owls. The eggs are of large size, measuring nearly two inches in length by an inch and a half in their transverse diameter. They are equally round at both ends, and perfectly white. The females begin to sit as soon as they have laid their first $\mathrm{egg}$; so that the nestlings are usually of different ages. The parent birds attend upon their brond with great assiduity, and supply them plentifully with mice, shrews, moles, and the young of various other quadrupeds.

The nestlings of the Brown Owl are easily brought ip by hand, and are very useful in barns and granaries, being most excellent mousers. 
STRIGINA. The Owls proper.

Ger. Charac.-Head smooth, with the facial disk rery large, subtriangular, and complete.

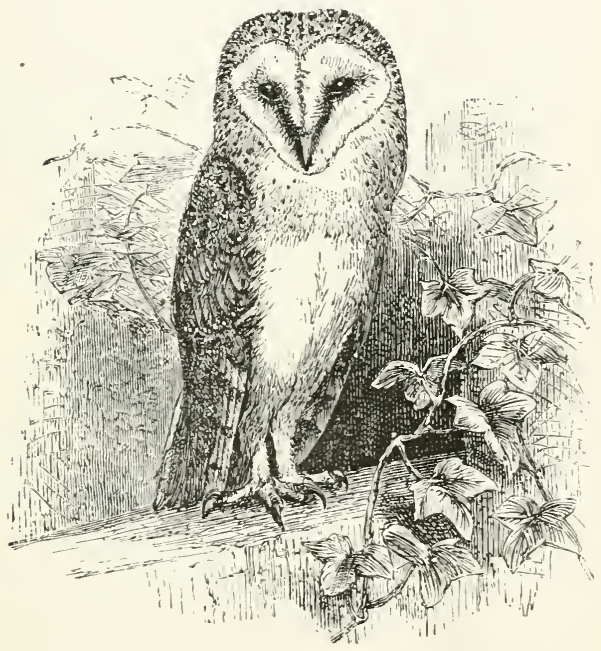

Fiร. 25. - THE BARN OWL.

(Strix flammea.)

The Owls belonging to this sub-family are distributed throughout most climates. 'They are strictly' nocturmal. The softness of their plumage and the peculiar form of their quills give them a buoyant and noiseless flight, which enables them to steal upon their prey unsuspected. They live principally upon mice and other small quadrupeds, which they swallow whole; the hairs, bones, and other indigestible parts being subsequently disgorged in oval pellets. Some species live on crustaceous animals. They build their nests on old towers, in the roofs of churches, 
the thatch of barns, or in the hollows of trees. The female lays from two to five eggs.

The type of this sub-family is-

The Barn Owl (Strix* flemmea), sometimes called the Screech Oul, commonly met with in the British islands and generally throughout the Eastern hemisphere. It is from fourteen to fifteen inches in length, the females being slightly larger than the males. The Barn Owl approaches boldly to the dwelling-places of man, and seeks for food in the midst of towns and villages, and in the cultivated fields surrounding them. His chosen abode is some dark hole or corner of an old building, the tower of a church, or the roof of a barn, or sometimes a hollow tree. In this retreat he dozes away the bright hours, and if driven from his concealment in the daytime, is so dazzled by the light as to be quite bewildered and helpless. As evening approaches, his sight becomes keen enough, and he glides out on noiseless pinions in search of prey. He may then be seen dashing round the stacks and buildings in the farm-yard, or skimming orer the fields and along the hedgerows, in pursuit of small animals that are abroad at night. While thus upon the wing, he drops suddenly down upon his prey, seizes it in his claws, and uttering a loud cry or screech, flies off with it to his nest. In this way rats, mice, and small animals of all kinds, including young hares and rabbits, are captured by this nocturnal marauder. The Barn Owl also destroys larks and other small birds, and often catches the moths and beetles so abundant during summer evenings. His principal food, however, consists of mice, which abound in stackyards and cornfields. These are swallowed whole, their bones and other indigestible parts being disgorged as pellets, which accumulate in the roosting-place of their destroyer. The benefits these birds confer upon the farmer by ilestroying vermin are therefore considerable The nest consists of sticks and straws, and the number of eggs varies from two to five.

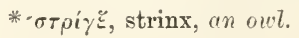




\section{Passeres.}

The birds belonging to this order are frequently termed Insessores, or Perchers, seeing that they are, for the most part, expressly adapted for a life among the branches of trees or bushes, upon which they perch, and hop from twig to twig. 'Their feet are, consequently, more or less constructed for this purpose. Their legs are of moderate length, and the toes, usually placed three in front and one behind, are provided with sharp and slender claws, and of sufficient strength to secure the bird firmly on its perch. This arrangement of the toes is, however, subject to certain exceptions, as we shall see when speaking of particular species. There are other general characters, which, taken in conjunction with those given above, will, in doubtful cases, frequently enable us to determine whether a bird belongs to this order or not. The tarsi are covered with shield-like horny plates, so disposed that while in front there are several of these pieces, the back of the leg is usually covered by a single long shield. The outer toe of each foot is generally mited to the middle one for a greater or less extent, sometimes only at the base, but occasionally nearly to the extremity. The claws with which the toes are armed are either of moderate length or very long and slender. The wings are well developed, so that many of the Passerine races fly remarkably well. The primary quill-feathers in the wings are usually ten in number, and the number of quill-feathers in the tail is likewise generally ten.

This Order is divided into the following Tribes.*

$$
\text { * See "Animal Creation," page } 418 .
$$




\section{TRIBE.I.}

\section{Fisstrostres.*}

T'he Fissirostral Passerine birds constitute a small, but very natural group, distinguished by the structure of their beak, which is broad at the base, short, hooked at the tip, and opening with a very wide gape, extending to beneath, or even beyond, the eyes, and thus adapted to catch and swallow insects while on the wing. It comprises two principal sections; the first including those species that fly by night,-Fissirosties Nocturni; the other comprehending such as seek their food in the daytime,Fissirostres Diurni. The first of these sections embraces the Goatsuckers, or Nightjars ; the second, the extensive race of Swallows and Swifts.

\section{SUB-TRIBE I.}

Fissirostres Nocturin.

Nocturnal Fissirosties.

The birds belonging to this sub-tribe are remarkable for the size of their eyes, which are very large, and easily dazzled by the light of day, thongh well fitted to descry objects in the obscurity of the evening. 'Their plumage is generally soft and fleecy, like that of the Owls; thus enabling them to fly without noise.

\section{FAMILY I.}

Caprinulgide.

The Goatsuckers.

Gen. ChaRAC.-Bill short, depressed, very broad, gape extending beneath the eyes; toes long and rather strong, hind toe united to the base of the inner toe.

* Fissus, cleft, and rostrum, a beak; Cleft-beaks. 
Gex Charac.-Beak short, generally strong, and eurved to the tip, which is hooked; the sides are dilated and the gape rery wide; the base of the bill is covered with projecting plumes and bipectinated bristles.

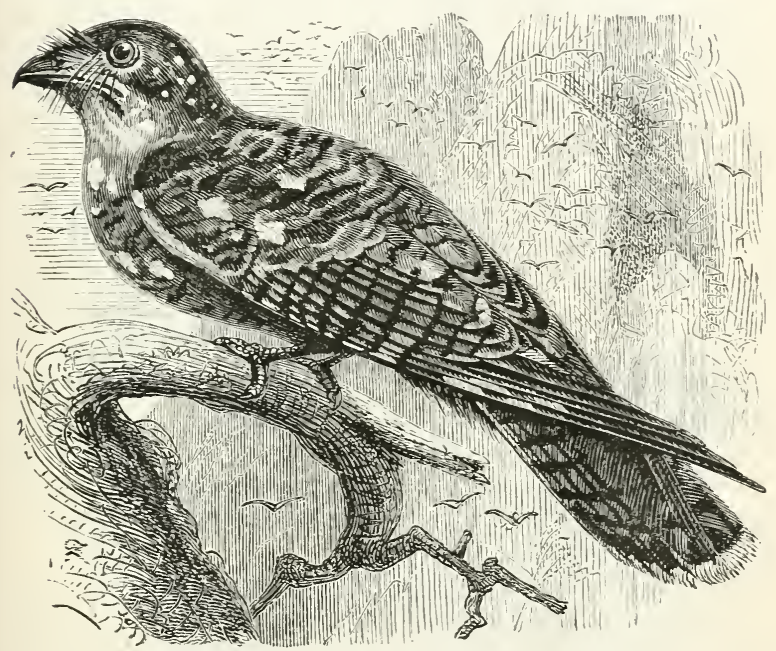

FIG. 26.-THE OIL-BIR.

(Steatornis Caripensis.)

The principal localities where these birds are known to exist are certain caverns on the sea-shore of the islands of Guadaloupe and Trinidad, and also in several parts of South America. 'Their food consists of the fruits of a plant called Semilla del. Guacharo, upon which they become so excessively fat that their grease is compared to olive-oil, and, as such, is rnsed as an article of food. Their voice is hoarse and sharp : they avoid the light of day,

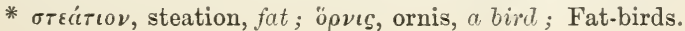


and only sally from their hiding-places during the night, or at least after' sunset. 'Their nests are built on the rocky walls of caverns, in which they rear their young.

The typical species-

The Guacharo, or Trinidad Goatsucker (Steatormis* (aripensis), known in the tropical regions of America as the "Oil-bird," is about the size of a pigeon. Unlike the other species of Goatsuckers, the Guacharos feed entirely "1] on fruits and seeds. For the sake of the oil which they furnish, numbers of the young are destroyed every year. The nestlings are immediately opened, and the fat removed from them; it is afterwards melted in clay pots aurl stored up for use. The oil thus obtained is semifluid, transparent, and inodorous, and so pure that it may he kept more than a year without becoming rancid. The most noted locality for this oil-harvest is a cavern at Caripe, called the Cueva del Guacharo. Into this cave, as we are told by Humboldt, the Indians enter once a vear, about the festival of St. John. They take with them long poles, with which they destroy all the nests within reach, and thus kill many thousands of the young brood, while the poor Oil-birds, as if to defend their nestlings, sail over the heads of their assailants, uttering the most discordant cries.

This celebrated cavern is pierced in a vertical rock; its entrance measures eighty feet in wilth, and seventytwo in height, while through its gloony labyrinths there runs, far removed from the light of day, a subterranean torrent. For a distance of upwards of four luundred feet the daylight still struggles with the darkness, and the seeds brought in by the birds to feed their young, but accidentally dropped by the way, germinate in the scanty soil of the floor, producing etiolated shoots, which might be taken for the pliantoms of plants banished from the outer world. Further in, the loud and discordant cries of the Guacharos are heard, repeated and increased by the echoes on every side. The seeds found in the crops of the young birds are supposed by the Indians to possess medicinal virtues, and are carefully preserved under the name of Semilla del Guacharo.

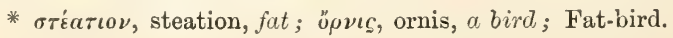




\section{SUB-FAMILY II.}

\section{Caprimelgise. \\ The Goatsuckers proper.}

Gex. Снarac - Bill short and weak, with the gape extending under each eye, extremely broad, and furnished with more or less lengthened bristles; the wings long and usually pointed; the tail more or less lengthened, and ronnd or graduated, and sometimes forked; the tarsi more or less short, and almost clothed throughout with short plumes, or entirely deuuded and scaled; the toes moderate, with the lateral ones shorter than the middle toe, and of equal length; the elaws of the middle toe large and peetinated on the sides, those of the other toes small.

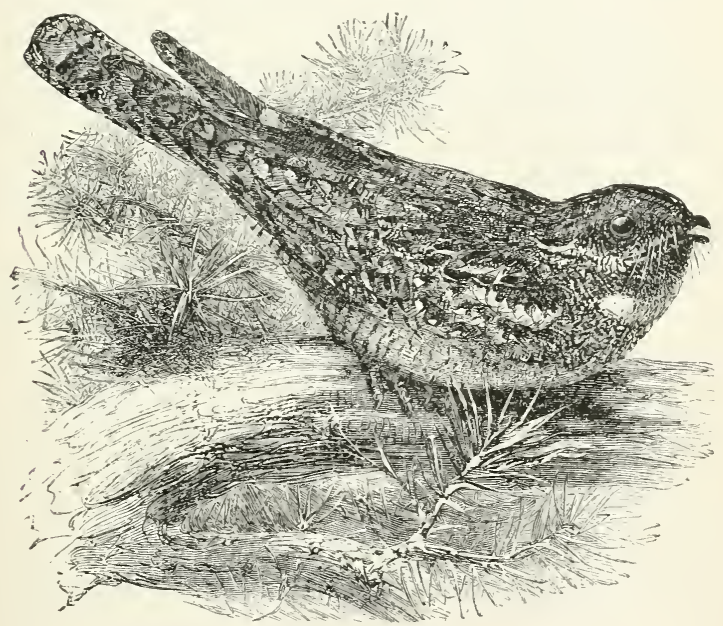

Fig. 27.-THE Night-Jak.

(Caprimulgus Europ๕us.)

The Goatsuckers constitute a very numerous race, distributed in all parts of the habitable world. They are migratory, and generally live in woods, or on dry tracts of habitable land: they feed on moths and beetles, which they catch on the wing, either in the dusk of the evening, or at early dawn, retiring to some dark retreat among the brushwood 
during the day. When seizing prey, their mouth is widely opened, and the long rigid hairs with which its base is surrounded materially assist in the capture of insects. The flight of these birds is exceedingly rapid, and accompanied by graceful evolutions similar to those of the Swallow, but performed with even greater ease and facility. Their eyes are large and of the true nocturnal character. Although the beak is small, the gape is enormons, extending below the eyes, and reminding us of the mouth of a toad; hence these birds are called by the French "Crapauds volants." The plumage is full and soft, and beautifully variegated with dots, bars, dashes, and zig-zag markings, of mingled grey, brown, fawn-colour, black, and white; difficult to describe, and almost as difficult to imitate. Rapid and abrupt as is the flight of these birds, it is noiseless, resembling in that respect the flight of the Owl, although from the form of their wing's it is of a different character.

The Goatsuckers form no nest; but generally deposit two eggs on some dry spot beneath the shelter of ferns and other underwood.

The type of this family-

The European Goatsucker (Caprimulyus* Europous), is not uncommon in England; it is, however, a bird of passage, retiring to the warm regions of the South in the autumn, and returning in the month of May. It measures about ten or eleven inches in length, including the tail, which is rather long. The bill and legs are short and feeble, so that it perches with difficulty, and when resting on the bough of a tree, places itself lengthways upon the branch, upon which it eronches, as if fearful of falling off. The middle anterior toe is considerably longer than the others, and terminated by a claw singularly toothed, so as to resemble a comb. The Goatsucker is usually met with about moors, heaths, and commons; but it also firequents woods. Its period of activity is the twilight, when it may be seen hawking after its favourite food,

$$
\text { * Cama, a she-goat; mulgeo, to milk; Goat-milker. }
$$


sweeping swiftly round trees frequented by heetles and moths, which it devours in great numbers. It frequently emits a sort of whirring sound, resembling the noise made by a spinning-wheel: hence it is known as the Wheelbird in some districts, and in others as the Night-char r, Night-jar, and Chum Owl. It is likewise called the Night-hawk, and the Dor-hawk, from its appetite for night-flying beetles, called Dors; and likewise the Fern Owl, from its frequenting fern brakes. The name Goatsucker is derived from its supposed habit of sucking the milk of goats during the night, a false suspicion, which has doubtless given the bird a bad character in the eyes of farmers, whilst by the destruction of vast quantities of Cockehafers, it is, in reality, one of their best friends.

"When the moon shines bright," says Mr. Waterton, "you may have a fair opportunity of examining the Goatsucker ; you will see it close by the cows, goats, and sheep, jumping up every now and then under their bellies. Approach a little nearer; he is not shy: 'he fears no danger, for he knows no sin.' See how the nocturnal flies are tormenting the kine, and with what dexterity he springs up and catches them as fast as they alight on the belly, legs, and udders of the poor animals. Observe how quietly they stand, and how sensible they seem of his good offices; for they neither strike at him, nor hit him with their tail, nor tread on him, nor try to drive him away as an uncivil intruder. Were you to dissect him, and inspect his stomach, you would find no milk there; it is full of the flies that have been annoying the herd." Doubtless the same habit thus noted by Mr. Waterton must have been observed by the ancients in southern Europe, who, mistaking the object of the bird, bestowed on it its vernacular name.

The cries uttered by many species of these birls are very peculiar. "A Goatsucker" inhabits Demerara (about the size of an English wood-owl), whose voice is so remarkable that, when once heard, it is not easily to be forgotten. A stranger would never believe it to be the cry of a bird, but would say it was the departing voice of a midnight-murdered victim, or the last wailing of poor Niobe for her children, before she was turned to stone. Suppose a person in hopeless sorrow, beginning with a high loud note, 'ha, ha ; ha, ha ; ha, ha, ha ;' each 
note lower and lower, till the last is scarcely heard, fausing a moment or two between each exclamation, and you will have some idea of the moaning of the Great Goatsucker of Demerara. Other species articulate some words so distinctly, that they have received their names fiom the sentences they utter, and absolutely bewilder a stranger on his arrival in their vicinity. One sits down close to your door, or flies and alights three or four yards

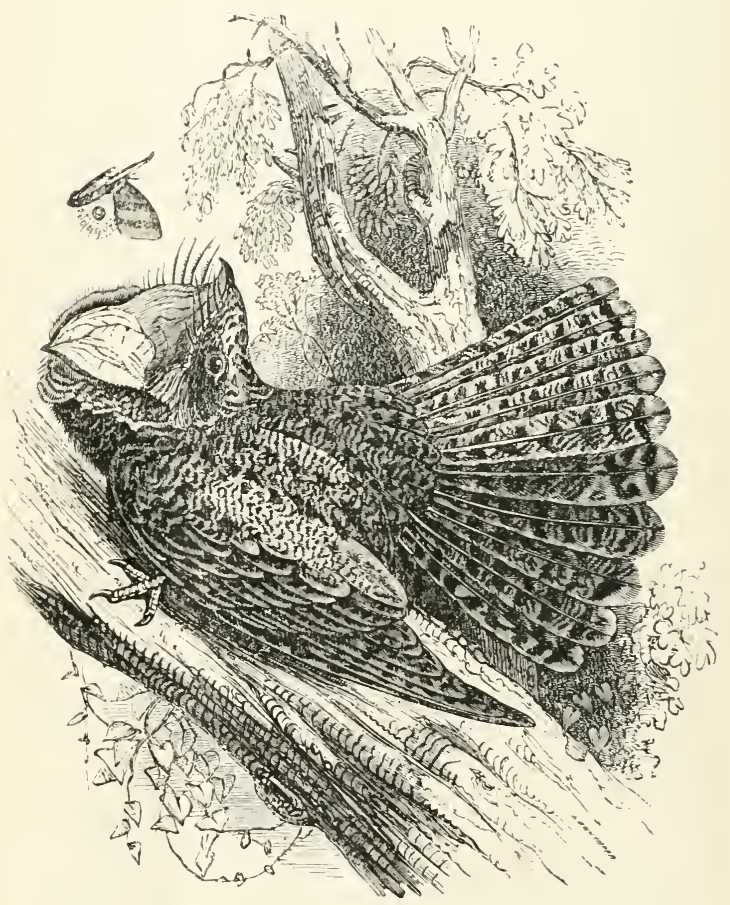

FIG, 28.-CHUCK WILL'S WIDOW.

h. fore you as you walk along the road, crying, who are you, who, who are you. Another bids you work away, "rork, work, work away. A third cries mounfully, ' Willy-come-go, Willy, Willy, Willy-come-go ;' and a fourth 
tells you to Whip poor Will, Whip poor Will, in tones wonderfully clear and startling." - Waterton.

The appended figure represents another of these vociferous birds, named from its cry "Chuck Will's widow."

The eggs of the Goatsucker are deposited in a depression or cavity on the surface of the ground, under the shelter of a bush, generally without any attempt at a nest. They are usually two in number, of a white colour, clouded with bluish-grey.

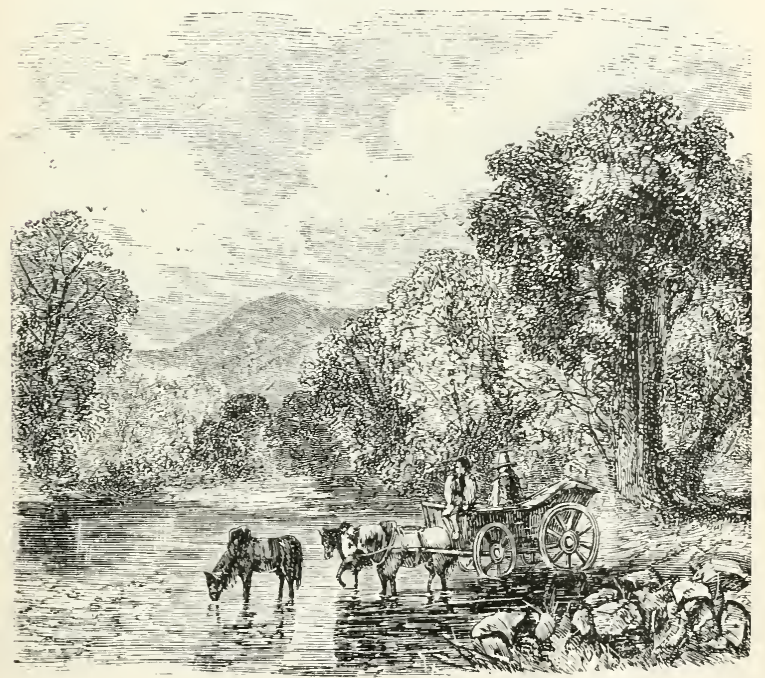




\section{Podagrin.e.}

The Podagers.

Gex. Charac.-Bill much flattened, eurved, and compressed at the sides of the tip, which is hooked; the gape is furnished with stiff hairs, as in the Goatsuekers; the wings are long and pointed, and the tail broad; the tarsi are more or less plumed, or, when devoid of feathers, covered in front with transverse scales; the inner toe is generally longer than the outer, and both inner and outer toes are more or less united to the middle one, which is the largest of all, and armed with a large serrated elaw.

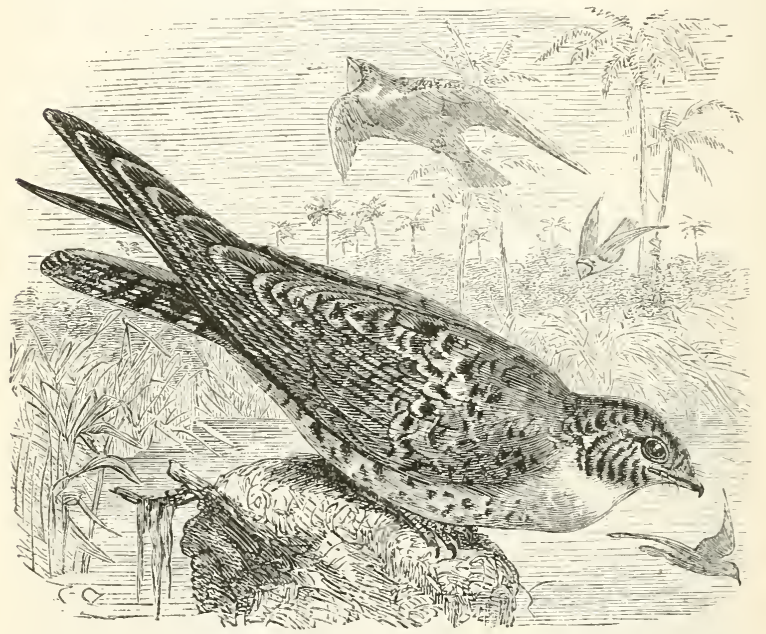

Fig. 29.-GOLLD'S PODAGRR.

(Poduger Gouldii.)

The Polagers are met with in the warmer parts of South America and Australia, where they frequent fields and moist places, usually in pairs, although they have sometimes been observed in troops of a hundred together, chasing insects in broad daylight. 'The female deposits two ego's on the bare ground, without any kind of nest. As an example of the race we have selected-

Gould's Podager (l'odager Gouldii). 


\section{SUB-TRIBE II.}

\section{Fissirostres Diurni, Diumal Fissirosties.}

The Fissirostral birds that fly by day are at once distinguishable from the nocturnal species by the closeness of their plumage, which is quite devoid of that fleecy appearance so eminently characteristic of the preceding tribe.

\section{FAMILY I.}

HiRUNDINID.E.

The Swallows.

GEx. Charac.-Bill short and weak, very broad at the base, and suddenly compressed towards the tip; the wings are long, narrow, and pointed; the tail forked; and the tarsi very short and feeble. This group comprises the Swifts and the Swallows.

These birds are remarkable for their powers of flight and insectivorous appetite. Threir legs are short, and comparatively feeble; but the toes are furnished with sharp hooked claws, constructed for the purpose of clinging to walls or the sides of rocks. In the Swifts, the toes are all directed forwards; in the true Swallows, the hind toe is reversible. The wings are long and pointed, and the quill-feathers of a firm texture; the general plumage is close-set, smooth, sometimes polished and glossy. The beak is small, depressed, broad at the base, and with a wide gape. Their food, consisting of the smaller species of insects, is always taken on the wing, and they often completely fill their throat with insect prey, so as to distend it like a pouch, doubtless in order that their nestlings may have a full supply at each visit. The whole of the active existence of these birds is passed in the air. 
'They skim along with marvellons rapidity, and quarter their ground over meadows, lakes, and river's, wheel round barns and steeples, and dash along apparently as untired when evening closes as when they began their aërial exercise with the first dawn of day. They feed and drink on the wing, and pursue each other in sportive chase, performing the most rapid and beautiful evolutions.

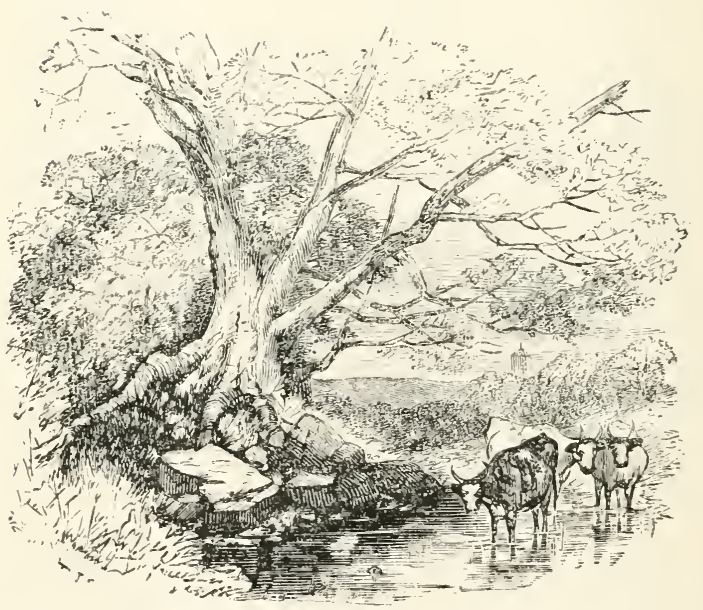


C'yseline.

The Swifts.

Gex. Charac,-Bill short, depressed, broad at the base, the sides suddenly compressed to the tip, and the margins inflected; the nostrils large and longitudinal on each side of the culmen; the wings extremely long and curved; the tarsi short and weak; the toes short, thick, and armed with short, strong, and much-curved claws; the hind toe usually directed forwards.

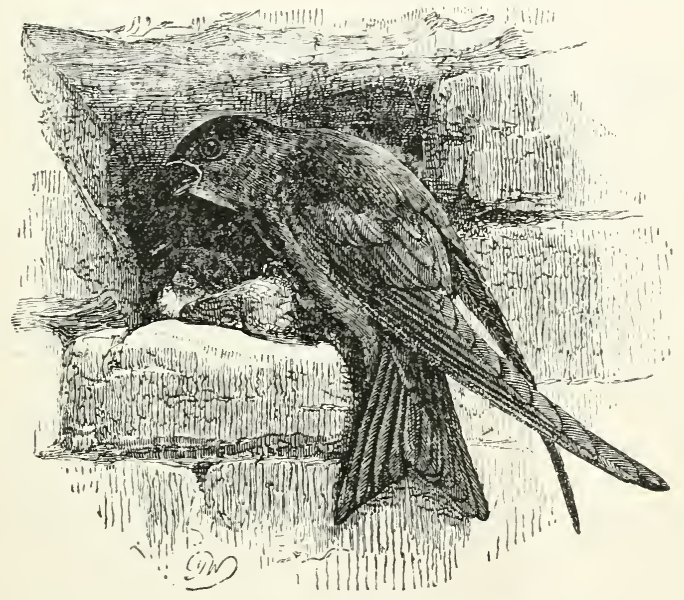

Fig. 30.-the swift.

('ypxelus арив.)

The Swifts are all birds of migratory habits. They pass most of their days in the air, for which their slender forms and powerful wings are admirably adapted. Their flight is rapid, performed in lengthened sweeps, or in extensive curves, with marvellous ease and grace. The height to which they ascend is regulated by the state of the atmosphere. On fine days they fly in numbers together, at a great elevation ; but during gloomy 
or damp weather perform their evolutions closer to the ground, or they sometimes skim the surface of lakes and rivers, in pursuit of their food, which consists entirely of insects. They usually rest and pass the night in a hole in some high building or lofty tree, and in such places they also rear their young. 'Their nest is composed of straw, and similar' materials, cemented together with a glutinous secretion, furnished by certain glands that are peculiar to birds of this sub-family. The egges are usually two in number.

The Common Swift (Cypselus* apus) usually arrives in Europe about the beginning of May. It leaves us again generally about the midlle of August, so that its stay in Britain hardly exceeds three months. On the continent of Africa these birds are seen as far south as the Cape of Good Hope, but their proper winter residence appear's to be between the tropics. Their migratory instincts are truly wonderful. They will often return after an absence of eight or nine months, and a voyage of several thousand miles, to the very same spot where they built their nests and reared their young the year before. On its arrival, the Swift takes up its abode in holes and other sheltered places, in church steeples, towers, ruins, or under the eaves of houses. From these nooks and corners it clashes forth in fine weather to wheel about in the air with amazing rapidity in pusuit of insects, accompanying its headlong flight with loud screaming cries; but when the day is unfavomable, and especially when there is a high wind, the Swifts, notwithstanding their power of wing, usually keep elose within their snug retreats.

The voice of the Swift is not very pleasing. "He has no roundelay; he neither warbles nor carols, he does not even twitter. His whole melody is a scream, unmusical, but most joyous; a squeak would be a better name, but that, instead of conveying a notion that it results from pain, it is full of rollicking delight. Some compare it to the noise made by the sharpening of a saw : to me it seems such an expression of peut-up joy as little

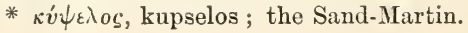


children would make if mexpectedly released from school, furnished with wings, and flung up into the air for a game at hide-and-seek among the clouds. Such soarings aloft, such chasings round the pinnacles of the church-tower and the gables of the farm-houses; no wonder that they camnot contain themselves for joy." * The food of these birds consists entirely of insects, which they capture and devour on the wing. They do not at once gulp down their prey, but, as it usually consists of gnats, midges, and other compressible species, they collect a number in their mouths before swallowing them. The insects caught for the nourishment of their young are stored up in the same way.

Their nest is composed of fragments of straw, dry grass, and bits of rag, with a few feathers, and these materials are cemented together by means of their glutinous saliva. The eggs are usually two in number, but vary from two to four. The young are hatched about the end of June, and do not leave the nest till the end of July; during all this period the parents feed them with great care. After the young birds have come out they are left to provide for themselves, which they are well able to do, and in the course of a short time are strong enough to commence their long journey into unknown regions. The type of this sub-family-

The Alpine Swift (Cypselus Melba) can scarcely be called a British species, although it has been occasionally killed in this country. Its true home is in the Swiss Alps and other mountain-ranges in the South of Europe. Its flight is more rapid than that of the Common Swift. These birds, indeed, may be said to perform all the functious of life on the wing, except sleeping and incubation; and even when they rest, it is against the perpendicular face of a rock or wall, to which their four toes, all pointing forwards, enable them to cling.

From the earliest dawn to sundown, and even later, this Swift is constantly hawking in the air, through which its various journeys must, at the most moderate computation, amount to many hundreds of miles in a day.

* See "British Birds and their Haunts," by the Rev. C. A. Johns. 


\section{SUBSFA.IILY II.}

\section{HiRtendiNine.}

The Swallous proper.

Gex. Charac.-Bill short, more or less depressed, with the gape very wide, and the sides gradually compressed towards the tip; the nostrils basal, lateral, and rounded; the wings lengthened, with the first quill the longest; the tail more or less forked; the tarsi short, generally naked and scutellated; the toes usually long and slender; and the claws moderate and slightly curved.

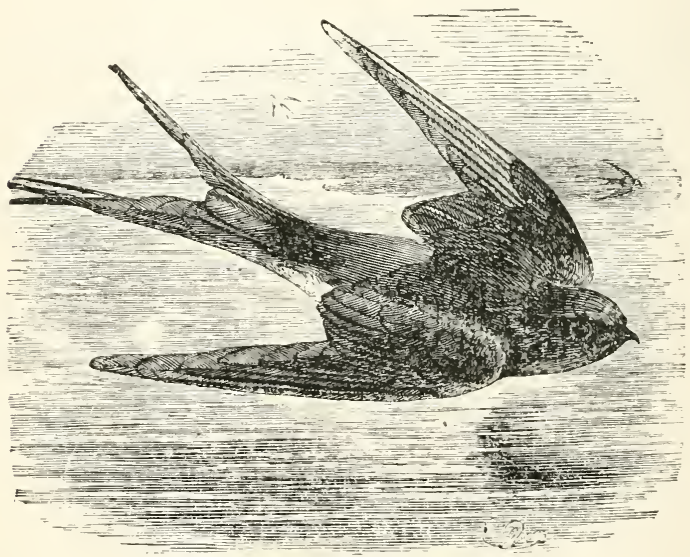

Fig. 31.-THE SWALLOW.

(Hirundo rusticu.)

Numerous species of birds belonging to this subfamily are distributed throughout most parts of both hemispheres, migrating from clime to clime, in search of their insect-food. When about to remove to a country of more genial temperature, they collect in immense flocks, and may be observed congregating upon trees, or on the roofs of houses, and other high buildings, before their departure; at other times they frequent the neighbourhood of lakes, rivers, and ponds, over which they fly in small 
parties, skimming rapidly in extensive sweeps near the surface of the water, and suddenly changing their course backwards and forwards, being all the time busily engaged in capturing the insects upon which they live. Sometimes they may be seen in the streets of towns, or ranging over plains, fields, and gardens, while at intervals they repose, after their exertions, upon the tops of buildings, or upon the branches of trees. T'heir nests are usually composed of clay or mud, mixed up with straws. They are variously shaped, and generally attached to the exterior of houses or in chimneys, or the interior of hollow trees. Some species construct their nests in holes in the ground, in which case they consist entirely of loose, dry grass, lined with feathers. The eggs are generally five or six in number.

The migration of the Swallows has now been set beyond a doubt by actual observation, made both on our own shores and on those of the Mediterranean, where they are seen taking their departure for the warm regions of Africa, in the autumn, and also making their way back in spring. In crossing the sea, they usually fly singly or in small parties of two or three, and it is remarkable that they arrive on the further side in a state of exhaustion, apparently as great as that of other birds of passage, whose power of wing is far inferior. The Channel fishermen state, that in hazy weather the Swallows very frequently alight in their boats; when they are a little way out at sea, so completely fatigued that it is with some difficulty that they muster strength to fly from one end of the boat to the other, when an attempt is made to seize them. In fine calm weather they are often seen to descend upon the smooth surface of the water with their wings widely extended, rising again after a short time seemingly much refreshed by their partial bath.

The type of the race- 
The Chimney Swallow (IIirundo rustica) * is one of the British species. It is very abundant in all parts of Europe during the summer, and in some parts of the Mediterranean district a few individuals remain during the winter. They arrive in this comntry early in April. On reaching its summer quarters the Swallow usually selects a spot for its place of aborle where the habitations of man lie in the vicinity of water, for, in conmon with a considerable majority of the members of this family, it has a great fondness for skimming over the surface of large ponds, lakes, and streams. The partiality exhibited for human habitations by this bird is very remarkable, and it is a no less curious circumstance that of the two familiar British species, one, the Swallow, frequents detached country places, villages, and farm-houses, whilst the other, the Martin, takes up its aborle in towns, so that Linnæus denominated the two species $H$. rustica and II. urbica.

Although the Chimney Swallow has received its most general name from the somewhat peculiar position in which it frequently builds its nest, it by no means confines itself to chimneys, but builds readily in almost any suitable sheltered position. Thus the disused shafts of mines and the sides of old wells are sometimes resorted to. Occasionally it will build in the roof of a barn or shed, attaching its nest to the rafters, or in a garret or passage, to which it may find easy access. In almost all cases it selects a point where some projection from the wall, "some coign of vantage ground," forms a buttress, on which its nest may be supporterl. The nest is constructed principally of mud or soft earth, collected in small pellets from the edges of ponds and other wet places. 'These are carried home in the bird's bill, and plastered on to the spot selected for the nest. Fresh pellets are then brought and added, together with numerous straws and leaves of grasses, until the whole is gradually moulded into the form of an open sancer. attached by one side to the wall of the chimney, or other place of retreat. A lining of feathers is then put into the nest, and upon these the eggs are laid. The eggs vary from four to six in number, and are of a white colour, speckled with ash-grey and dark red. Two

* Hirundo, a Swallow. 
brools are reared in the course of the summer: of these the first is usually ready to fly by the end of June, and the second by the end of August.

The Swallows have a short modulated strain, repeated at intervals, always ending in a shrill note rapidly shaken. Early in the morning they may be heard twittering from the "clay-built shed," or from the chimney-top, and previous to the autumnal migration, when groups collect together, they are voiceful, as if debating the great event of their journey, whether the due time has come, or the season will arhit of lingering a little longer.

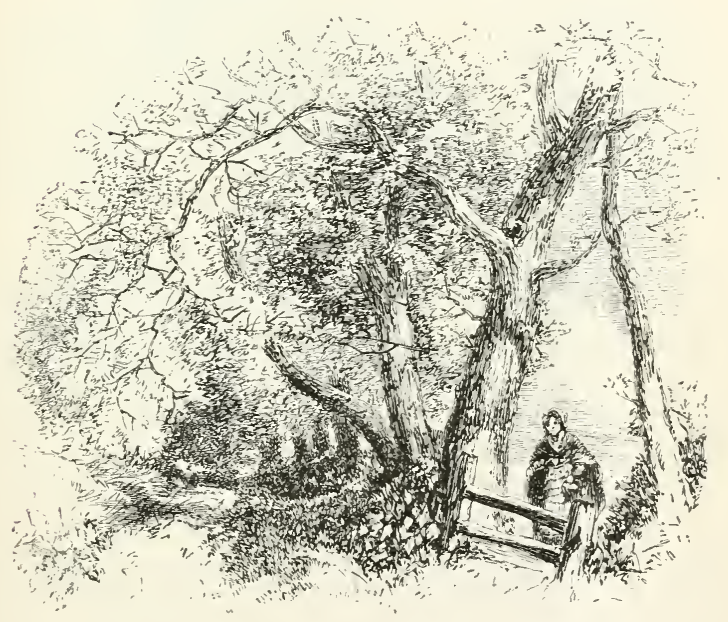




\section{TRIBE II.}

\section{'Tenuirostres.}

In this division of the Passerine, or Perching Birds, the bill is of varied length and shape, but always slender, with the tip of the upper mandible entire, and usually acute. 'The tarsi are short; the toes generally long, especially the hind toe, which is strong, and armed with a prominent claw.

\section{FAMILY I.}

UPUPIDE.

The Hoopoes.

Ges. Charac.-Bill lengthened, slender, curved or straight for its entire length; the sides compressed to the tip, which is acute; the nostrils basal and rather small; the wings long and rounded; the tail more or less long and rounded or even; the tarsi strong and usually short; the toes long and strong; the outer toe more or less united at its base, the hind toe long; the claws strong, long, and curred.

These birds are peculiar to the Eastern' hemisphere. They are found in Europe, Asia, and Africa, and are migratory at certain seasons. They prefer low and damp situations that border woods and forests; in such places they may be met with searching on the ground for insects and worms. They also seek for caterpillars on the trunks of trees, or more frequently among the foliage; and while in search of these devastators may frequently be seen hanging from a branch by their feet as they reach them from the leaves. The nest is generally placed in a hole of some decayed tree, or occasionally in a crevice of a wall or rock; it is constructed of dry grass, and is usually lined internally with feathers and other soft and warm materials. The female deposits four or five eggs, or more.

This family includes the Hoopoes and Plumebirds. 


\section{SLP-FAMILY I.}

UPCPINE.

The Hoopoes proper.

GEx. CHaRac.-Bill long, eurred or straight from the base; the culmen keeled, and the sides generally compressed suddenly at the base towards the tip, which is entire and acute; the nostrils basal, small, and mostly corered by a membranous scale; the wings long and rounded; the tail more or less long, graduated, and even; the tarsi generally short and strong; the toes long, the outer toe united at its base, the hind toe long and strong; the claws long, strong, curred, and acute.

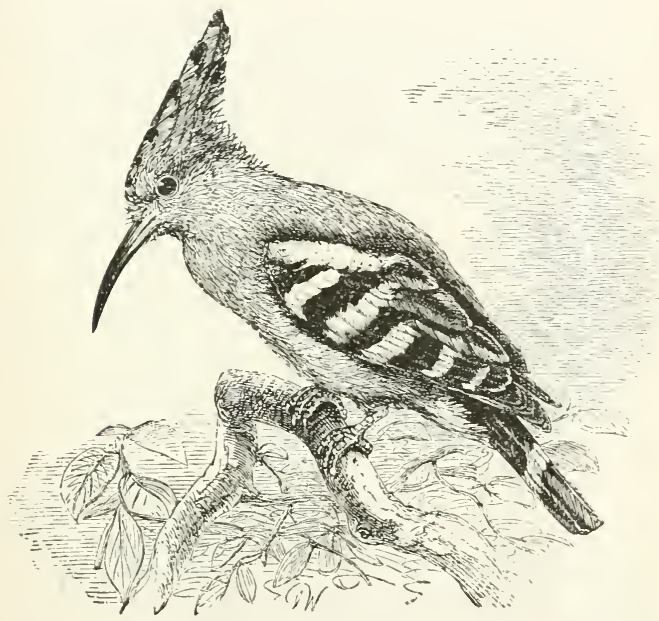

Fig. 32.-THE HОOРОЕ.

(Uрuра ерорs.)

The representative of this sub-family,-

The Common Hoopoe (Upupa epops), breeds in most parts of Europe, and is sometimes a visitor in the British Islands. These birds are generally met with in woods in the vicinity of marshes, where they seek their food. They walk and run upon the ground, when thus engaged, with great facility. In the neighbourhood of Bordeaux, Hoopoes are met with in great numbers upon an extensive range of marshy ground occupied by pollard willows grown 
for the sake of their long shoots. The rotting summits of the aged trunks of these trees are visited by flocks, which find in them an abmulant supply of insects. The nest is made of a few stalks of grasis nixed with feathers, and is placed in the hole of a tree; the eggs, six or eight in number, are of a pale lavender-grey colour. The Hoopoe likewise feeds on grubs and worms ; hence, in Egypt, it follows the retreat of the Nile, where the neighbouring plains swarm with insect life; it also fieguents ploughed lands and pasture ground, like the Crows. Great numbers are constantly to be found about the towns and villages of Ecypt, where they hecome very familiar with man, and build their nests in the immediate vicinity of his habitations.

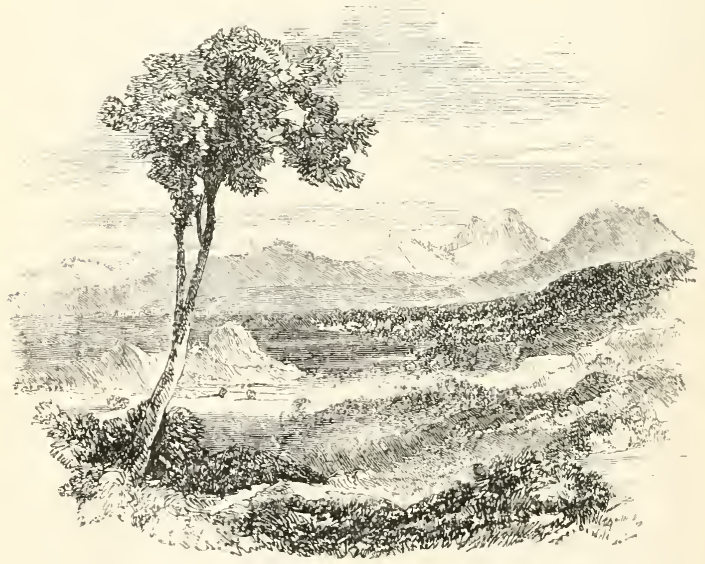


SC'B-FAMILY II.

\section{EPIMACHIN.e**}

The Plemed Birds.

Gex. Charac-Bill more or less lengthened, slender, and arched to the tips, which are acute; the nostrils lateral, and placed in a broad basal groove, which is mostly concealed by the projecting plumes of the forehead, learing the opening small and exposed ; wings moderate and rounded; tail of various lengths, sometimes even or graduated at its end; tarsi more or less long, robust, and usually covered with broad scales in front; toes long and strong, with the outer toe united at its base, the hind toe very long, strong, and armed with a powerful claw.

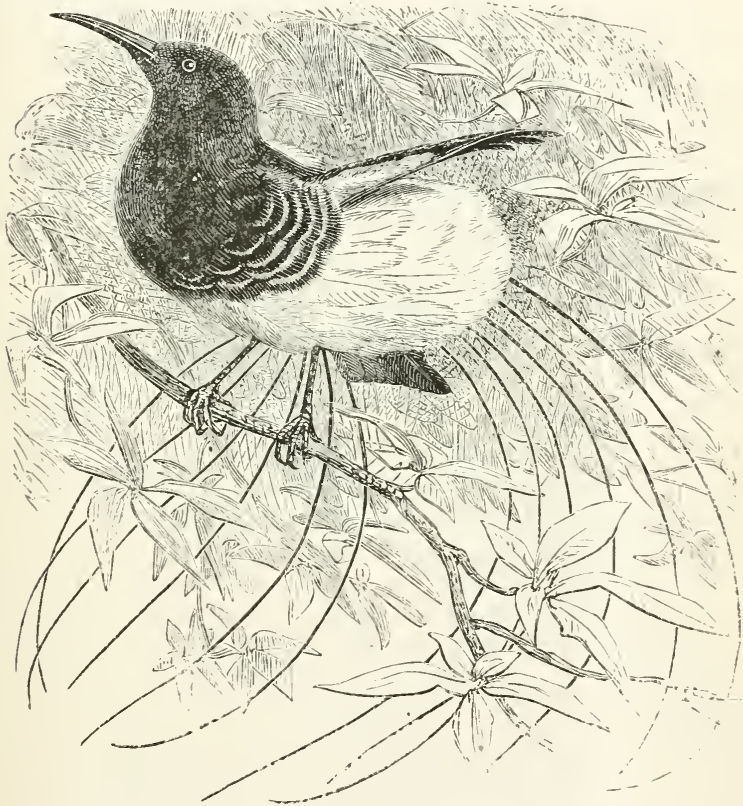

Fig. 33.-THE TWELVE-THREADED EPIMACHLS.

(Epimachus albus.)

The entire island of New Guinea, situated almost beneath the equator, is covered with one vast forest, composed of trees which from their stately dimensions are well calculated to strike the spectator with

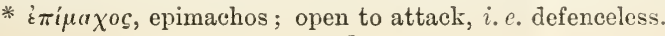


astonishment, some of them rising to the stupendous height of a hundred and fifty feet, an elevation to which the circumference of their trunks is quite proportionate. Shrubs and bushes have no existence among this exuberant vegetation; the very creepers are gigantic; the lianas, resembling enormous vines, climb to the summits of the largest trees, twining around them like serpents, and interlacing their stems among the branches. The brilliant tints that adorn these virgin forests constitute by no means their least striking feature. All hues of green are intermixed with flowers of ample dimensions, diversified with every shade of colour, and fruits no less remarkable from the singularity of their shape. Amid this wilderness, the lofty palmtrees are lost beneath the festoons of parasitic plants that wreathe around them, and enormous Mimosie bend beneath the weight of Orchids and gorgeous Epidendrons. It is in the midst of these solitudes, screened by the foliage from the intense heat of the sun, that the Epimachi are found in company with Hocks of Parakeets, Crowned Pigeons, Turtle-doves, and Birds of Paradise, even more splendidly decorated than they themselves. The Plumed Birds, indeed, resemble the Birds of Paradise in many particulars, more especially in having some of their feathers greatly developed, and also in the splendour of their plumage; they differ from them, however, in the shape of their bill, which is considerably attenuated. Most of the species are indigenous to New Guinea; but unfortunately, owing to the barbarism of the natives, their habits and manners are as yet unrecorded by naturalists. One species, found in Australia, is known to ascend the stems of trees in the manner of the creeping birds, and only exercises its powers of wing in flying from tree to tree, or to short distances in the forest.

We select as an example of these elegancies of creation-

The Twelve-threaded Epimachus (Epimachus albus). 


\section{FAMILI II.}

Promeropid.e.

The Sun-birds.

Grx. Снarac,-Bill more or less lengthened, slender, and curred throughout its whole length; the nostrils bare, and corered by a scale; the wings moderate; the tail of rarious lengths, even or graduated; the toes moderate, and armed with eurved and acute elaws.

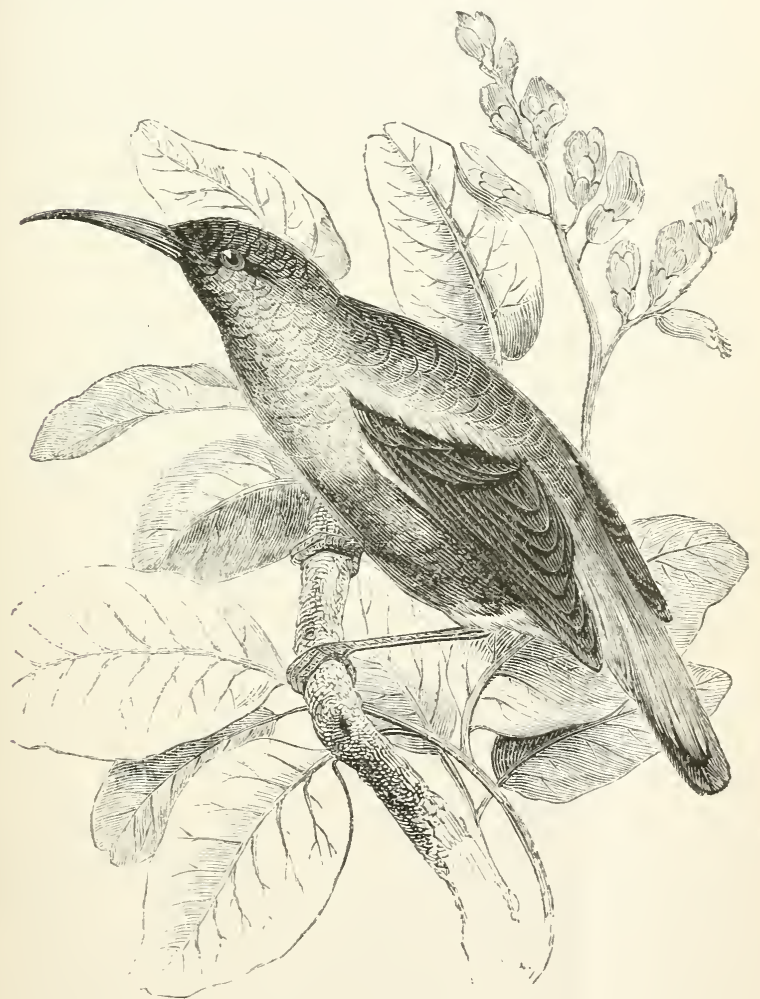

Fig. 34.-THE SUN-BIRD.

The birds belonging to this family are remarkable for their long slender bills, which are capable of 
penctrating into the nectary of flowers, from which they principally derive their subsistence. 'Their tongue is extensible and bifid at the tip, thus enabling them more casily to procure their honied food; insects, howerer, and perhaps soft fruits, constitute a considerable portion of their diet. In the breeding season the plumage of the male glows with netallic colours, approaching in splendour those of the Humming-birds, which indeed the members of this family seem to represent on the continents of the Old World, of which they are exclusively natives. They resemble the Humming-birds in their manners, and almost rival them in the brilliancy of their appearance as they hover on quivering wing's poised in the air, while they bury their long slender beaks in the corolla, from which they sip the sweets.

"It was at Singapore," says Mr. Arthur Adams, "that I first had the pleasure of seeing these tiny paragons of the East; they are ethereal, gay, and sprightly in their movements, flitting briskly from Hower to flower, and assuming a thousand lovely and agreeable attitudes. As the sumbeams glitter on their bodies, they sparkle like so many precious stones, and exhibit at every turn a variety of bright and evanescent hues. As they hover romd the honey-laden blossoms, they vibrate their tiny pinions so rapidly as to cause a slight whirring sound, but not so loud as the humming noise produced by the Trochilide (Humming-birds). Occasionally they may be seen, clinging by their feet and tail, busily engaged in rifling the blossoms of the trees. I weil remember a certain dark-leaved tree with scarlet Howers that especially courted the attention of the Sun-birds, and about its blossoms they continually darted with eager and vivacious movements. With this tree they seemed particularly delighted, clinging to the slender twigs, and coquetting with the Howers, thrusting in their slender beaks, and probing with their brush-like tongues for insects and nectar, hanging suspended by their feet, throwing back 
their little glossy heads, chasing each other on gicldy wing, and flirting and twittering, the gayest of the gay. Some were emerald-green, some vivid violet, and others yellow with a crimson wing."

Their nest is usually suspended, and of a hemispherical form, having generally an opening on one side, nearer the bottom than the top, with a small roof over it; it is composed of dry fibres mixed with moss, and lined with down within. The exterior portion is sometimes kept together by means of a thick spider's web, which the bird uses as a framework whereunto the various materials composing the nest are attached. The egg's are generally two in number.

This family comprises the True Sun-birds and the Guit-guits. 


\section{$S U B-F A I J Y Y$ I.}

\section{Promeropine. \\ The Sun-birds proper.}

(inx CHARAc.-Bill more or less eurved, with the sides eompressed to the

tip, which is aeute, and the lateral margin sometimes finely serrated; the nostrils hasal, and the opening elosed by a membranous seale; the wings moderate; the tail more or less long, with the middle feathers sometimes prolonged beyond the others; the tarsi usually short; the toes moterate, the outer toe rather longer than the immer, and united at its base; the claws moderate, curved, and acute.

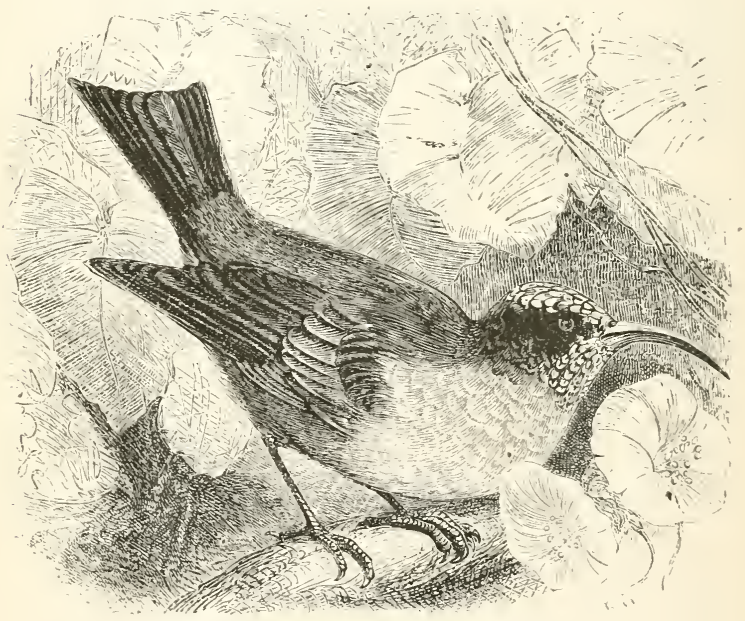

Fig. 35.-THE RED-BREASTED SOUI-MANGA.

(Cinnyris Senegulensis)

These showy birds are found throughont the continent of Africa, as well as in India and the adjacent islands. They are generally seen upon the upper twigs and smaller branches of trees and bushes; hopping quickly abont, and moving their wings in a tremulous manner while searching the blossoms; or occasionally hovering on the wing before flowers, engaged in the same occupation. Spiders also form 
a portion of their subsistence; these the bird drags from their hiding-places while fluttering in the air, and will occasionally snap at an insect whilst Hying. We have selected as the representative of this brilliant group-

\section{The Red-breasted Soui-manga (Cinnyris Senegalensis).}

Another species represented in the tabular view,-

The Famous Creeper (Nectarinia famosa), called also the Malachite Sun-bird, is an inhabitant of the Cape of Good Hope, where it remains throughout the year, and as it is in the habit of frequenting gardens, soon becomes familiar with the proprieturs. Sometimes these lovely birds may be seen in flocks of forty or fifty, congregating upon the branches of a favourite tree, and amusing themselves among its blossoms. The male bird, when dressed in full nuptial costume, is nearly double the size of any other species of this sub-family, often exceeding nine inches in length. The whole of its upper surface is rich golden green, marked with a reddish bronze. The feather's of the throat and forehead are of the same hue, but of so deep a tone that they appear at first sight to be velvety black. Whenever the bird moves, even by the act of respiration, waves of bright hues seem to ripple on its surface, cansed by the peculiar disposition of the feathers, which are black, and only coloured at their extremities. The wings and tail are black, and the secondaries and coverts are edged with green and violet, while a tuft of bright yellow feather's under each shoulder still further enlivens this gorgeous costume. The female is much smaller than her mate, of a dull olive-brown, except the exterior feathers of her tail, which are tinged with white. The brilliant adom. ments of the Sun-birds belong; as a general rule, only to the male sex, and even in the male the nuptial plumage has but a temporary existence, becoming developed only at the commencement of the breeding season, and being lost at the moult which follows the rearing of the young. At all other seasons the males are nearly as simply clothed as their mates. The nest of the Malachite Sun-bird is composed of very fine fibres, interwoven and lined with soft cottony down found on the seed-vessels of many plants, and ingeniously set round with various lichens, so as to 
give it a close resemblance to the tree in which it is placed. One species has even been known to make a thick spicler's web the foundation of its domicile, and to cover it with little bits of moss, lichens, paper, eloth, and all kinds of miseellaneous substances, so as entirely to destroy its nestlike appearance, and make it look like a chance bundle of scraps among the branches.

"My house in Colombo," says Sir James Emerson Temnent, "as is usual in the East, was surrounded by a verandah, up which crept, in tropical profusion, several speeies of Passiflora; to the flowers of these came the various Nectarinia for their morning and evening meals, rarely appearing in the heat of the day. They hovered about the starry flowers, thrusting in their eurved bills, in search of the minute insects on which they feed; oceasionally they would fly into the verandah and seize a small spider from its web, or from the crevices of the walls ; then they would betake themselves to the passionflowers, or to the branches of a pomegranate close by, where they plumed themselves and uttered a pleasing song. If two happened to come to the same flower-and from their numbers this has often oecurred-a battle always ensued, which ended in the ranquished bird retreating from the spot with shrill piping eries, while the conqueror would take up his position upon a flower or stem, and swinging his little body to and fro till his eoat of burnished steel gleamed and glistened in the sun, pour out his note of trimph. All this time the wings were expanded and closed alternately, every jerk of the body in $N$. A siatica and $N$. Latenia disclosing the brilliant yellow plumelets on either side of the breast." 


\section{$\triangle U B-F A M I L Y I I$.}

Cerebin.e.

The Guit-guits.

GEx. CHARAC.-Bill longer or shorter than the head, sometimes eurved throughout its length, or straight and acutely conical, the base broad, and the sides compressed, with the tip usually emarginated; the nostrils basal and lateral, and protected by a hard scale; the wings long and rather pointed;" the tail short and mostly eren; the tarsi short; the toes moderate, slender; and the outer united at its base.

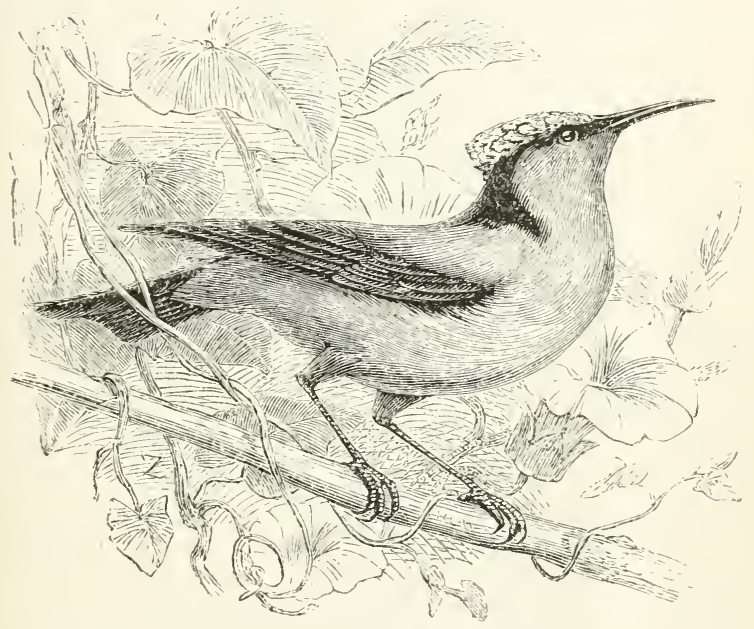

Fig. 36.-THE BLEE GLIT-GUIT.

(Careba cyanea.)

These birds are natives of the warmer parts of South America, where they are usually seen among. Howers, searching for small insects and honied juices, which they are able to extract by means of their tongue. Their nests are suspended from the end. of slender branches, and are sometimes in the form of a lengthened pear or chemist's retort, terminated by a long tube that bends towards the ground. This beautiful nest is composed of dried grass and slender. 
fibres. Other birds belonging to this sub-family build their nests after a different fashion, but with the same admirable skill in their construction. The Carthiola, for example, suspends its nest from the ends of the flexible branches of trees that hang over the middle of a stream. 'The nest is in the form of an ostrich's egro, composed of dried moss and dried grass exteriorly, but lined internally with cotton and the down of plants. The entrance is on the under side, which faces the water; and the interior is divided into two compartments, one of which forms a sort of antechamber leading to the larger division, wherein the female deposits her eggs, which are thus securely protected from the attacks of snakes and other destroyers.

The type of this sub-family is-

The Black and Blue Creeper (Coreba cyanea), so called from its feathers being deeply and gorgeously dyed with azure, verditer, and velvet-black, arranged in bold and striking contrast. This beautifully coloured species is an inhabitant of Cayene, Guiana, and other neighbouring localities. It is about the size of a common Sparrow, and frequents the various flowering trees and shrubs of its native land. The nest is pensile, and neatly woven, upon the extremity of some slender twig, which sways to and fro. Its shape resembles that of a Jargonelle pear, the lower extremity being produced into a long tube, with the mouth below, and the eggs placed in the upper dilated portion. The birds of this sub-family are gregarious, delighting to associate in large flocks, and haunting flowerbearing plants for the purpose of feeding on the sweet nectar and tiny insects found within the blossoms. In feeding, they thrust their long bill and tongue to the very bottom of the flower-bells, much after the mamner of bees. 


\section{FAMILY III.}

\section{Trochilide.}

The Humming-birds.

Gex. Charac. - Bill generally long, slender, straight, or curved, usually rounded, and the tip acute; the nostrils are basal, and corered by a large scale, which is sometimes plumose; the wings are generally long and of various forms; the tarsi very short and generally slender; the toes long and slender, the Jateral toes uuited at their base, hind toe moderate, and furnished with a more or less lengthened claw.

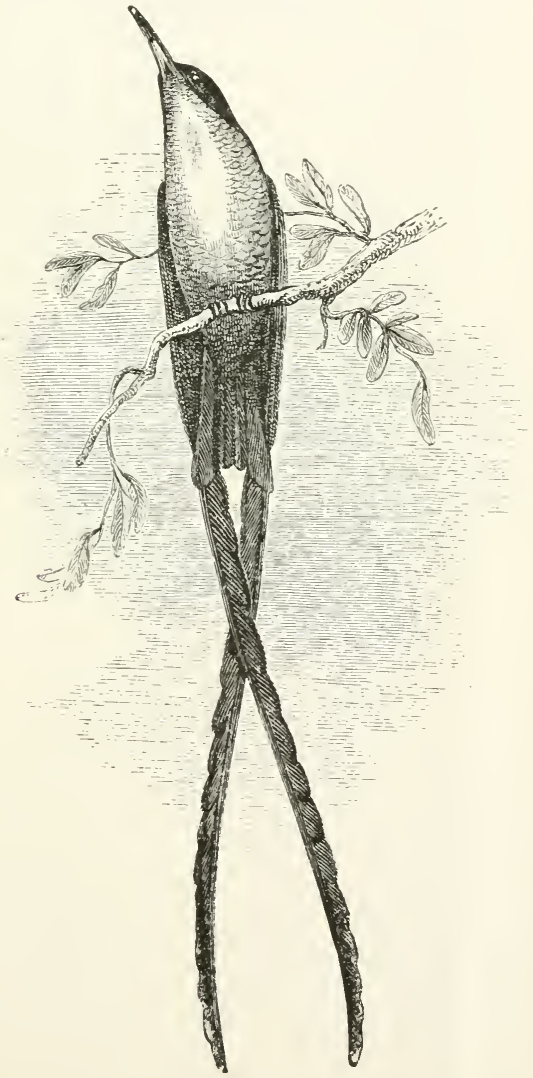

FIG. 37.-THE LONG-TAILED HCMMIXG-BIRD.

(Trockilus lungicauda.) 
The Humming-birds, some of which are the smallest of the feathered tribes, are peculiar to the New World, in the tropical parts of which they abound, adorning the gardens, fields, and woods, and even the mountain-side to a considerable height, with their swiftly-glancing, fairy-like forms, and brilliant, sparkling colours. Hovering in the air, with its wings in such rapid motion as to be quite invisible or only apparent like a grey mist on each side of the bird, the little Humming-bird buries its long bill in the interior of a flower, and then protruding its forked tongue, readily seizes the little beetles and other insects that are attracted by the nectar. While thus occupied, the rapidly-vibrating wings produce a humming sound; whence the origin of their name. Some of the species capture flies on the wing, by taking up a post of observation upon the tip of a dead branch or twig, and flying off' in pursuit of their prey as soon as it comes in sight.

Wherever a creeping vine opens its clusters, or wherever a tree-flower blooms, these little fairies may be seen. In the garden or in the woods, over the water, everywhere, they are darting about. Sometimes they are seen chasing each other in sport with a rapidity of flight and intricacy of path that the eye can scarcely follow, or, circling round and round, they rise high in mid-air, and then dart off like sparkles of light to some distant attraction. Now perched upon a little twig, they dress their plumes, and seem to delight in the dazzling hues of their glowing breasts; then starting off, they skim leisurely along, stopping capriciously to kiss the coquetting flowers. Often two meet in mid-air, and fight furiously, their crests and the feathers upon their throats erected and blazing, and altogether pictures of the most violent rage. Sometimes they may be seen battling with large black bees that frequent the same flowers, and may be supposed often to interfere provokingly. Like lightning, the little heroes come down, and again and again renew the 
attack, until their anger has expended itself by its own fury, or until the bee, roused from its apathy, puts forth powers that drive the invader from the field.

The domestic architecture of the Humming-birds is amongst the most interesting of the many singular features in their history. In form and size the nests vary much in different species, and a similar difference exists in the situations where they are placed. Some of these fairy cradles are not larger than the half of a wahnut-shell, and such coracle-shaped structures are amongst the neatest and most beautiful. The members of the genus Trochilus and their allies exhibit the greatest ingenuity, not so much in the construction of their nests as in the lavish decoration

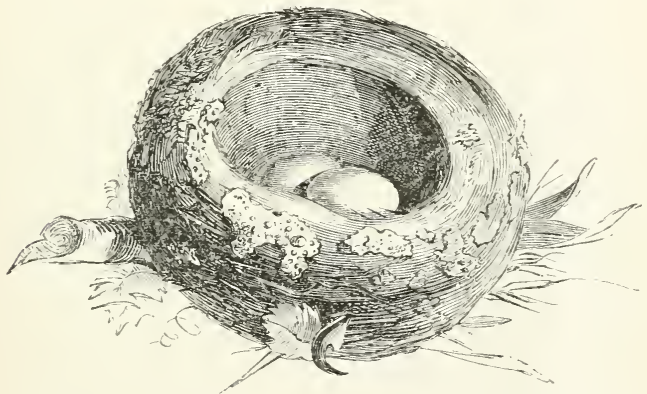

Fig. 38.-NEST OF HUMMING-BIRD.

of their outer walls. With the utmost skill they fasten to the exterior morsels of flat lichen, the larger pieces in the middle, and the smaller on the part attached to the branch. Now and then a pretty feather is intertwined or fastened to the outer side, the stem being always so disposed that the feather stands out beyond the surface. These little cup-shaped nests are frequently placed on the bifurcation of some horizontal branch near the ground, or, at other times, higher up towards the summit of the bush in which they are built. 
"The Humming-birds in Jamaica," says Lady Emmeline Stuart Wortley, "are lovely little creatures, and wonderfully tame and fearless of the approach of man. One of these charming feathered jewels had built its delicate nest close to one of the walls of the garden belonging to the house where we were staying. 'The branch, indeed, of the beautiful little shrub in which the fairy nest was suspended almost intruded into the walk, and, every time we sauntered by, there was much danger of sweeping against this projecting branch, with its precious charge, and doing it some injury, as very little would have demolished the exquisite fabric. In process of time two lovely little pear-shaped eggs appeared, and, while we were there, we had the great pleasure of seeing the minute living gems themselves disclosed, looking like two very small bees. The mother bird allowed us to look closely at her nest and to inspect her little nurslings, when she was flying about near, without appearing in the least disconcerted or alarmed. I never saw so tame or so bold a little pet. But she did not allow the same liberties to be taken by every one unchecked. One day, as Sir C. was walking in the pretty path beside which the fragile nest was delicately suspended amid sheltering: leaves, he paused in order to look at its Lilliputian inhabitants. While thus engaged, he felt a sharp rapping on the crown of his hat, which considerably surprised him. He looked round to ascertain from whence the singular and mexpected attack proceeded, but nothing was to be seen. Almost thinking he must have been mistaken, he continued his survey, when a much sharper and louder rat-tat-tattat-tat seemed to demand his immediate attention, and a little to jeopardize the perfect integrity and preservation of the fabric in question. Again he looked round, far from pleased with such extraordinary impertinence, when what should he see but the beautiful, delicate Humming-bird, with ruffled feathers and fiery eyes, who seemed by no means 
inclined to let him off without a further infliction of sharp taps and admonitory raps from her fairy beak. She looked like a little fury in miniature, a winged Xantippe. These pointed attentions apprised him that his company was not desired or acceptable. As to me and $V$., the darling little pet did not mind us in the least. She allowed us to watch her to our heart's content, and rather appeared to like our' society, and to have an air of saying, 'Do you think I manage it well, eh?" ",

These beautiful birds are divisible into three subfamilies, named respectively the Wedge-tailed, the Curve-billed, and the Straight-billed Hummingbirds.

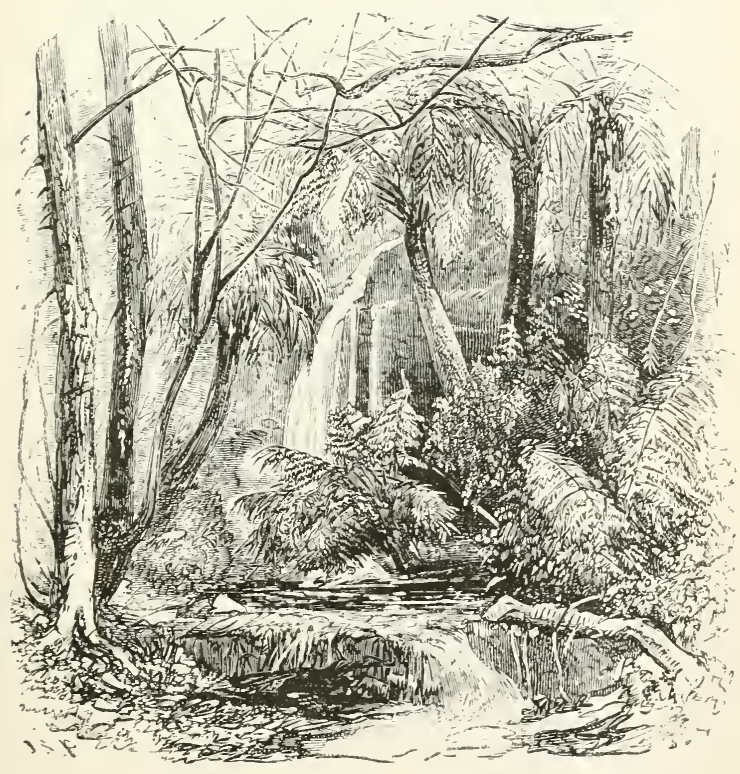




\section{Grvpris. The Wedge-tailed Humming-birds.}

GEN. CHarac.-Bill more or less long, slender, and generally eurved throughout its whole length, with the eulmen keeled at the base, and then rounded to the tip, which is acute, the lateral margins dilated and orerlapping the lower mandible; the nostrils basal and eovered by a seale; the wings long and pointed; the tail long, broad, and generally euneated; the tarsi short and slender; the toes long, slender, and sometimes united at their bases, the hind toe more or less long and slender; the anterior elaws long and slender, and that of the hind toe sometimes very small.

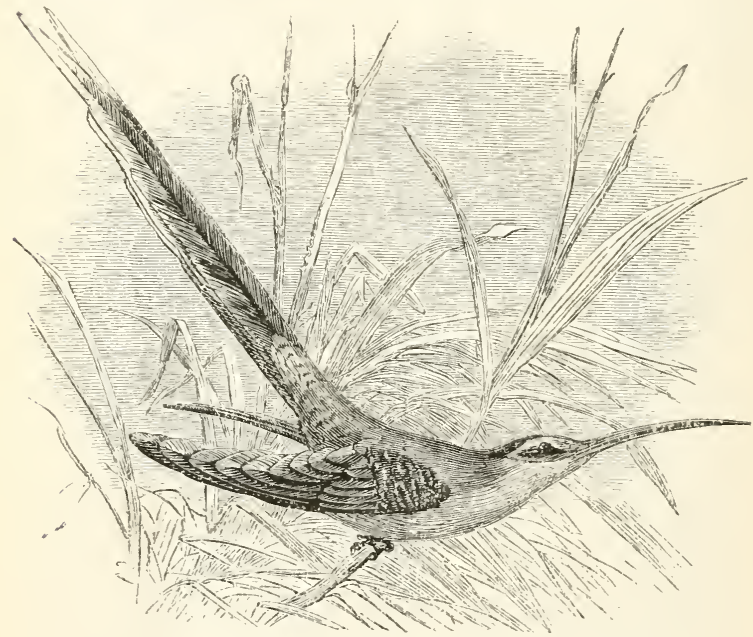

Fig. 39.-PRETRELS'S HERMit.

(Photomis Pretrei.)

These Humming-birds are remarkable among their glittering race for being destitute of metallic brilliancy, and, as their common name of "hermit" implies, for affecting dark and gloomy situations. They constitute perhaps the only group of the family which frequent the interior of the forests, and there obtain their insect food, some from the under side of the leaves of the great trees, while other's 
assiduously explore their stems in search of such lurking insects as may be concealed in the bark. It is said that spiders constitute the principal food of many species of this group; and the structure of their bills seems admirably adapted for the capture of prey of this description. 'To individualize by name any particular country in South America in which these birds are found is unnecessary, for they are generally. distributed over its temperate and hotter portions, but they are not to be met with either very far north or very far south of the equator; that is to say, their range is bounded northwardly by Southern Mexico and southwardly by Bolivia. Within these limits the high and the low lands are alike tenanted by them; it, howerer, is in the equatorial regions that they are most numerous, and there all, or nearly all, the genera have representatives. In the colouring of their plumage the sexes are alike.

The Spotted Hermit (Grypus novius) is common in all parts of the province of Santa Catherina in Brazil, but is more frequently met with in woody situations than elsewhere. Its flight is exceedingly noisy, very vigorous, and capable of being sustained for a great length of time, the bird rarely alighting. Its cry is so loud and piercing as to be heard above everything else, while it flutters around the various species of Orchids, from whence it derives its principal sustenance.

This Humming-bird builds a nest composed of fine vegetable fibres woven together, so as to look like an open network purse, the outer walls being so loosely made as to permit the eggs and lining to be visible : leaves, mosses, and lichens are also woven in, and are packed rather tightly under the eggs ; the edge, however, is always left loose. This nest is suspended at the end of a leaf, nsually that of a palm. 


\section{SUB-FAIILYII.}

Trochinin.e. The Curved-billed Humming-birds.

Gex. Charac.-Bill more or less long, slender, and eurved, the lateral margins usually dilated and overlapping the lower mandible; the nostrils basal, the opening covered with a large scale, which is sometimes entirely concealed by the projecting plumes; wings long and pointed; tail more or less long, and of various forms; tarsi very short; toes long and slender, with the lateral ones united at their base, the hind toe long, and armed with a more or less lengthened claw.

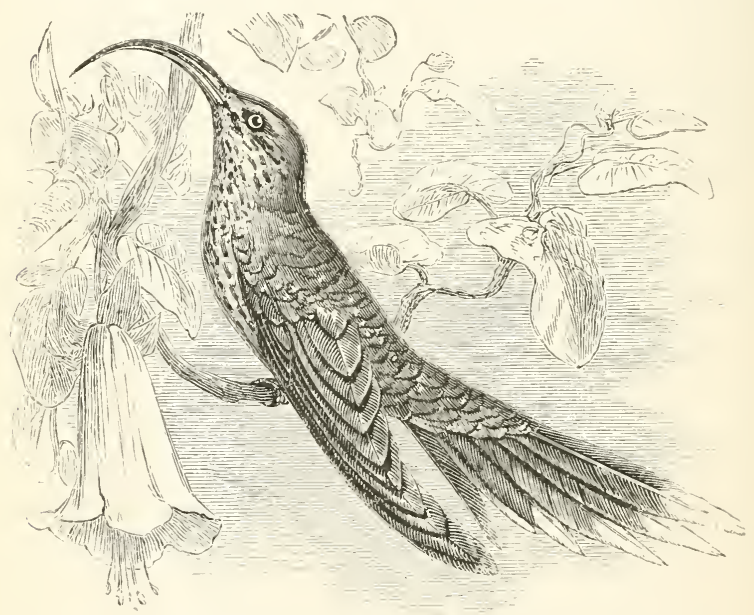

Fig, 10.-THE EAGLE HUMMING-BIRD.

(Polytimus aquila.)

The Humming-birds belonging to this sub-family are inhabitants of the central and warmer regions of America and of the West Indies; one of the prettiest,

The Topaz Humming-bird (Topuza pella), is an inhabitant of the low districts of Cayenne, Trinidarl, and Surinam, and also of the countries bordering the lower Amazon. The male measures about six inches in length, exclusive of a pair of elongated tail-feathers that are wanting in the female, which is also smaller than her 
mate. The whole of the back and wing-coverts in the male are deep crimson-red, verging to orange towards the tail, and gradually giving place to bronzed green in the upper tail-coverts. The head is deep violet-black, and from it a broad band passes down the sides of the neck and across the throat, enclosing a large space of the most brilliant golden green, glowing in the centre with the sheen of a topaz. The general colour of the female is bronzed green. "This species never shows his beanty to the sum. Residing close by the densely-wooded sides of rivers, and dark and lonely creeks, he leaves his retreat before sunrise to feed on insects near the water; but returns to its shelter as soon as the sun's rays become powerful, and only comes out again for a short time after sunset. The nest is built on a twig over the water in unfrequented places, of a material that looks like tanned cow-leather. This nest is of a deep cup-like form, with very thin walls, composed, apparently, of a sort of fungus resembling German tinder beld together by cobwebs." 


\section{SUUB-FA.IILY III.}

\section{Meldisugisæ.* The Straight-billed Humming-birds.}

GEx. Charar,-Bill more or less lengthened, slender, and straight, the lateral margins more or less dilated over the lower mandible; the nostrils basal, with the opening sometimes concealed by the projecting plumes; wings long and pointed; tail of varions length and forms; tarsi very short; toes more or less long, the outer toe united at its base, and the hind toe long, and armed usually with a long claw.

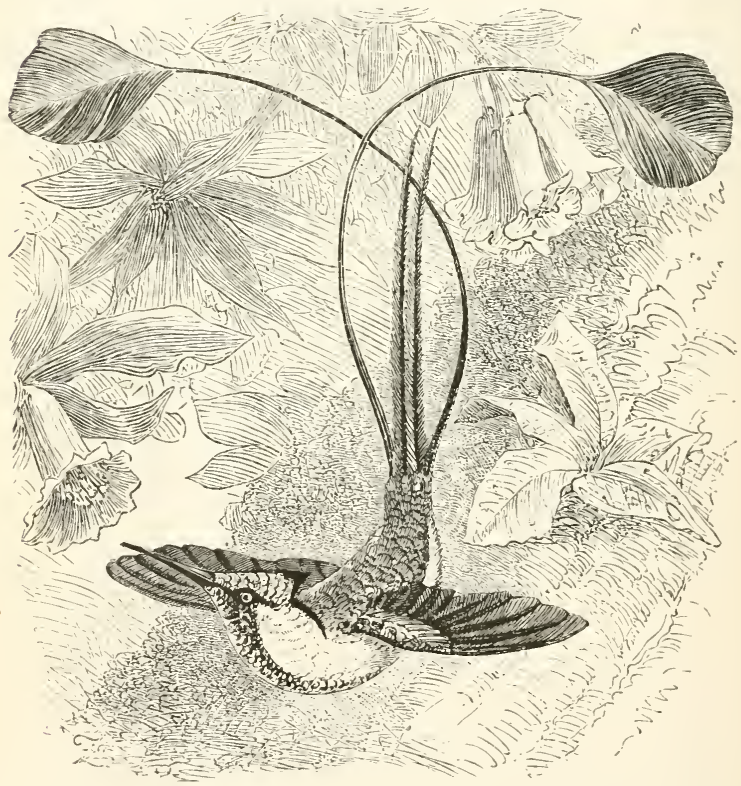

Fig, 41,-THE RACKET-TAILED HUMMING-BIRD.

(Mellisuga mirabilis.)

The Humming-birds belonging to this division frequent tubular flowers, before which they suspend themselves on the wing so steadily that their wings

* Mel, honey; sugere, to suck. 
become invisible, or appear only like a mist. Then one of these birds is thus poised, even the pupil of his eve is plainly distinguishable, looking round with great quickness and circumspection. When he alights, he always prefers the small dead twigs of a tree or bush, where he dresses or arranges his plumage with great nicety. His only note is a single chirp, not much louder than that of a cricket $\mathrm{or}^{\circ}$ grasshopper: this is generally uttered while passing from flower to flower, or when engaged in fight with his fellows; for when two males meet at the same bush or flower, a battle invariably ensues, and the combatants ascend into the air, chirping, darting, and circling round each other, till the eye is no longer able to follow them. The conqueror generally returns to the place to reap the fruits of victory. The flight of these birds much resembles that of a bee, but is so much more rapid that the insect appears to be a mere loiterer in comparison. It has generally been supposed that the food of the Humming-birds consists entirely of honey or the liquid sweet that they gather from the flowers; but observation has given rise to the belief that it is rather upon the minute insects that feast upon the farina of tubular flowers that they subsist. Sometimes, indeed, they may be seen employed, for half an hour at a time, in darting among the little groups of insects that dance in the air on a summer's erening, and then retiring into an adjoining bush to rest, renewing the attack at interrals with a dexterity far surpassing that of the ordinary Fly-catchers.

Their nest is usually fixed to the branch of a tree, at the distance of a few feet from the ground. It is a beautiful structure, very small, and composed externally of lichens taken from the trunks of trees or from palings: these are thickly glued on with the saliva of the bird, so as to give firmmess and consistency to the whole fabric, and effectively to keep out moisture. Within this are thick matted layers of the fine wings of certain seeds, closely laid together; 
and, lastly, the downy substance from the great Mullein and from the stalks of the common Ferm lines the whole. The base of the nest entwines the stem of the branch, to which it closely adheres. The eggs are two in number, and the female rears two broods in the course of the same season.

The Little Humming-bird (Mellisuga minima) may be regarded as the smallest species of the family. It is an inhabitant of St. Domingo and Jamaica. Of this little feathered fairy, Mr. Gosse observes:- "It is the only Humming-bird, with which I am acquainted, that has a real song: the others have only a pertinacious chirping. I have sometimes," he says, "watched with great delight the evolutions of this little species at a Maringa tree. When only one is present, he pursues the round of the blossoms soberly enough, sucking as he goes, and every now and then sitting quietly on a twig. But if two are about the tree, one will fly off, and suspending himself in the air a few yards distant, the other presently shoots off to him, and then, without touching each other, they mount upwards, with a strong rushing of wings, perhaps for five hundred feet. They then separate, and each shoots diagonally towards the ground, like a ball from a rifle, and, wheeling round, comes up to the blossoms again, and sucks and sucks as if it had not moved away at all. Frequently one alone will mount in this manner, or dart on invisible wing diagonally upwards, looking exactly like a 'humble bee.' The nest is a minute cup-shaped structure, placed npon or between the twigs of trees. It is composed of silk-cotton (the down of the Bombyx), and ornamented externally with fragments of lichen." 


\section{FAMILY IV.}

Meliphagid.E.*

The Honey-eaters.

GEx. ChARAC.-Bill more or less long, curved, and usually acnte at the tip, which is slightly emarginated; the nostrils placed in a large groove, and generally eovered by a membranous scale; wings moderate, the first three quills graduated; the tail long and broad; the tarsi rather short and strong, and the toes more or less long, the outer always united at its base; the tongue is extensile, and furnished at the tip with a pencil of short slender fibres.

The beautiful birds composing the family of the Honey-eaters, although nearly unknown to Linnæus, occupy a prominent and important situation in the ornithological department of nature. Chiefly confined to Australia, where they abound in every variety of form, and in an apparently inexhaustible multitude of species, they find a sufficient and never-failing. support in the peculiar vegetation of that country. There the fields are never without blossom, and different species of plants, particularly the Eucalypti, afford a constant succession of that food which is suitable to the tubular and brush-like tongue of these birds. It must not be supposed, however, that the food of the Meliphagide is restricted, as their name would imply, simply to the nectar of flowers. They, indeed, feed upon the honey, but combined with the numerous small insects lodged in most flowers, which they extract with their tongues, formed for that purpose.

This family embraces three subdivisions, named respectively the Honey-creepers, the Honey-eaters, and the Honey-feeders.

* $\mu \dot{\varepsilon} \lambda \iota$, meli, honey; $\phi \dot{c} \gamma(\omega$, phago, to eat ; Honey-eater. 


\section{SUB-FALILYI.}

MYZOMELINA:

The Iloney-creepers.

Gex. Charac,-Bill more or less long, slender, curved, and acute at the tip, which is slightly emarginated; the nostrils basal, and the opening covered by a membranous seale; the wings rather short, with the third and fourth quill. usually the longest; the tail short and even; the tarsi short; toes moderate, the outer toe longer than the inner, and united at the base.

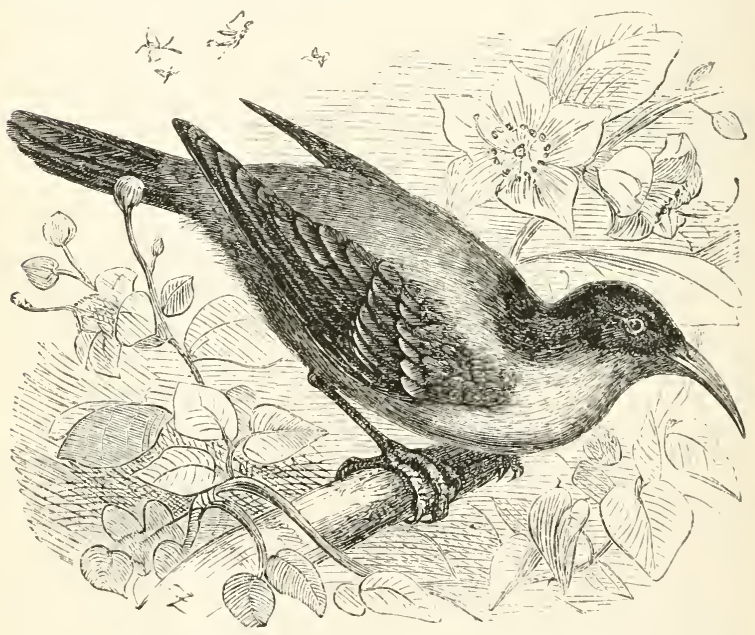

Fig. 42-THE SANGUINEOLS HONEI-CREePER.

(Myzomela chermesinia.)

The Honey-creepers are found only in Australia, where they frequent various plants, from the flowers of which they collect the nectar, as well as the small insects found in them. 'They exhibit great activity, and are continually moving from flower to flower, and from branch to branch, in search of their sul), sistence. Occasionally they may be seen perched on a dead bough, and uttering a weak, plaintive note.

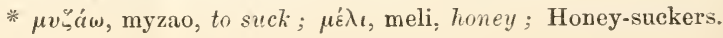


'Their nest is composed of grasses, wherein the female deposits two egg's.

The type of this sub-family,-

The Sanguineous Honey-creeper (Myzomela chermesinia), is a beantiful little bird, an inhabitant of the thick brushes of New South Wales, particularly those near the coast, and those clothing the hilly portions of the interior. It is rarely, if ever, found among the trees in the open part of the country; and there is reason to believe that the south-eastern side of the continent is its natural and restricted habitat. It gives a decided preference to those parts of the forest that abound with Howering plants, whose fragrant blossoms attract large numbers of insects of various kinds, upon which, and the pollen of the flower-cups, it chiefly subsists.

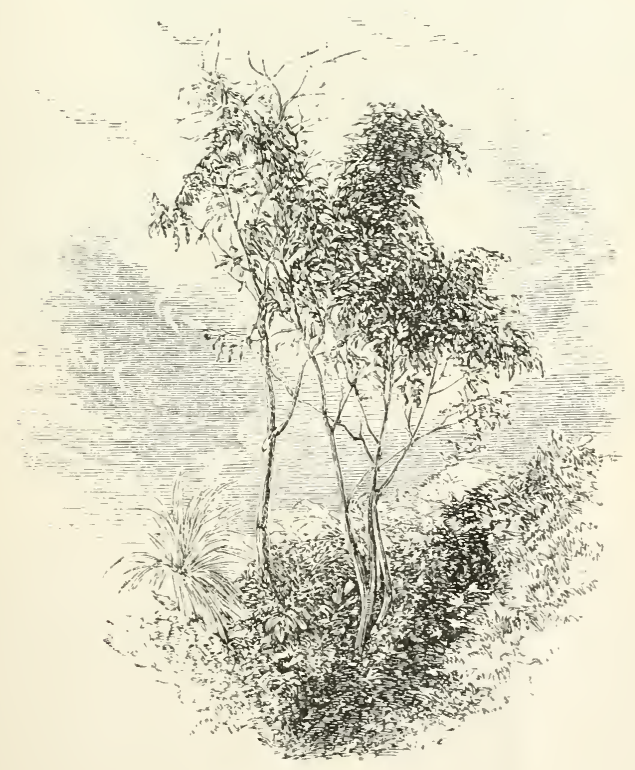




\section{SUP-FAMILYII.}

Meliphagine.

The IIoney-eaters proper.

Gex. Charac.-Bill more or less loug and slender, with the tip slightly emarginated, and usually aeute; wings moderate and rounded, with the fourth to the sixth quills generally the longest; tarsi generally short and strong; toes moderate, with the outer toe longer than the inner, and united at its base, the hind toe long and strong; the elaws moderate, eurved, and very acute.

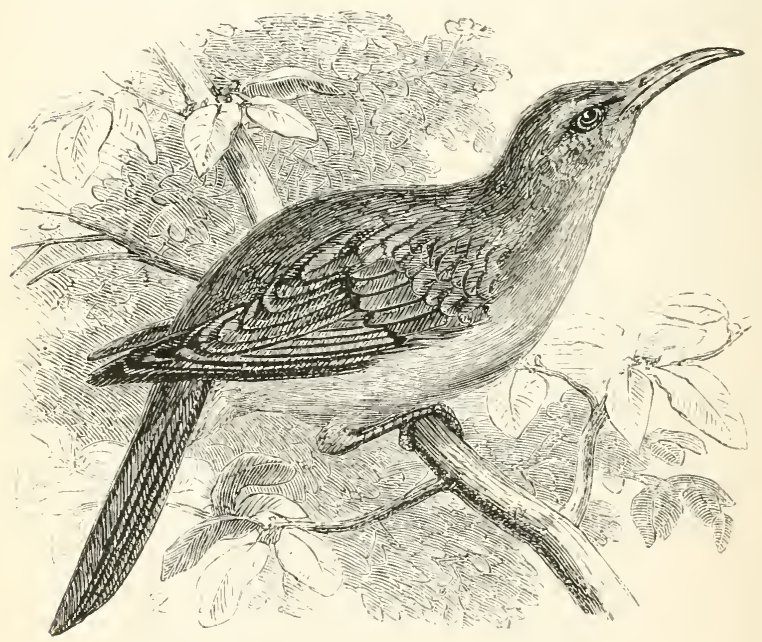

Fig. 43,-THE PLAIN TROPIDORHYNCHUS.

(Tropidorkynchus inornatus.)

'The Honey-eaters likewise belong' to the Australian continent, though a few have been discovered on islands that present almost a tropical climate.

Wherever the Evealypti and the Banlisias are in flower, there these birds may be seen, sucking the nectar from their blossoms. "They also feed on the -mall insects that lie concealed in flowers and on the fruits and berries of various plants. Their movements among the branches are active and graceful, 
but their rapid and jerking flight is only extended from tree to tree. Their note consists of a lond whistle, which in many species is agreeable to the car. Their nest is usually built in some low tree or' bush; it is composed of small twigs, coarse grass, moss, and chips of bark, lined internally with soft materials principally derived from plants. The egors are two or three in number.

The type of the race,-

The Tropidorhynchus inornatus, is found in most part. of Australia and New Grinea. They are usually seen on the various trees in blossom, the flowers of which they search for the purpose of extracting the pollen, and for the various insects which frequent them for a similar purpose. Berries, wild figs, and the juice which exudes from wounds in trees, are also said to form a part of their subsistence. They are often observed in small parties on the upper branches, to which they cling, and hang in various graceful positions while seeking their food : whilst thus engaged, they emit a lond and monotonous cry. The eggs are deposited by the female of one species on the top' of the domed nests of the Pomatorhini, whilst others form suspended nests, of a large size, in the form of a cup, and composed of stringy bark, wool, and twigs, lined with grass and fibrous roots. The eggs are usually two or three in number. 


\section{SUUB-IAULYIII.}

MELITHREPTIN.E. *

The Honey-feeders.

GEN. Charac.- Bill short, sub-conie, slightly eurved, and the sides mueh compressed towards the tip, which is sometimes emarginated and aeute; the wings more or less long, with the fourth to the seventh quills generally the longest; the tarsi short and strong; the toes more or less long, the lateral toes unequal, the outer the longest, and united at its base; the claws moderate, compressed, and acute.

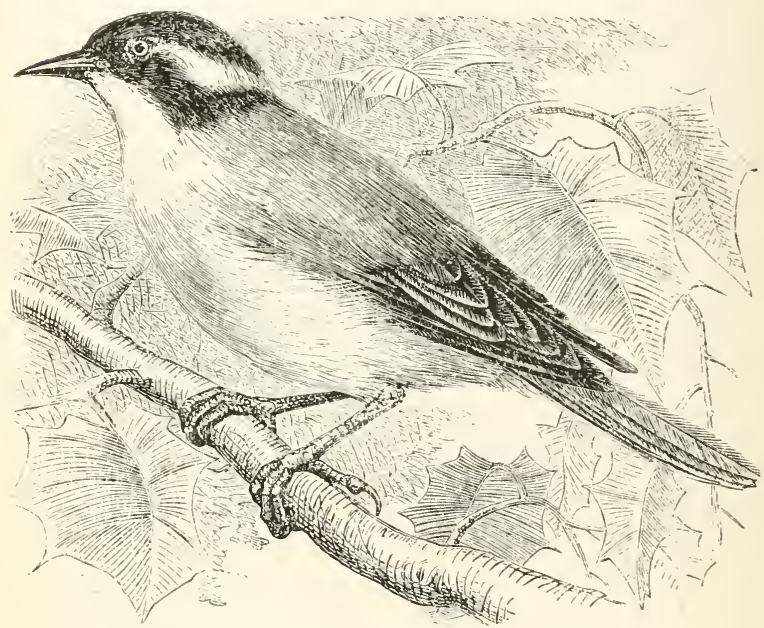

Fig. H4, - the white-throated Honey. FeEder.

(Melithreptus gularis.)

'The Honey-feeders constitute another group peculiar to Australia, where they may be seen, in small parties, frequenting the Eucalypti and Acacias. They usually creep about the leafy and flower-bearing branches with perfect ease and great rapidity, searching for insects and the pollen of flowers; they also frequent orchards, to feed upon the fruit, amongst which they commit great havoc. Sometimes they

* $\mu \dot{\varepsilon} \lambda$, meli, honey; $\theta \rho \varepsilon \pi \tau o ́ s$, threptos, nourished. 
may be secn motionless upon the topmost dead or bare boughs, uttering a loud whistling note, which at unce betrays their locality.

The Lunated Honey-feeder (Molithereptus lunotus), distinguished from the preceding Honey-eater's by the possession of a stronger and more conical bill, is abundant in many parts of the Australian contment. The nest of this bird is nsually attached to the slender twigs which grow at the top of the prodigious Eucalypti, and at this sreat height it is only discernible to an experienced observer. The fabric is ingeniously constructed of the inner rind or "liber" of the "stringy-bark," and other gum-trees, a material resembling the "bass" used by gardeners. The hair of various animals is mixed with the bark; and since sheep have been introduced into Australia, the bird has availed itself of their wool, finding that it can be worked well into the side, and seems to bind the walls firmly together. As the nest is always hung by the rim to the twigs, strength of substance is an absolute necessity ; so that the toughness of fibre, and the felting property of the wool, make it a most valuable addition to the building material employed. For the lining of the nest, the Lunated Honey-eater. uses the fur of the Phalanger, which has the advantage of being very soft, very warm, of retaining its elasticity, and of not adhering to the claws of the immates, as would be the case with wool.

The typical form is the White-throated Honeyfeeder (Melithreptus guluris). 


\section{FAMILY V.}

\section{Certhiade.}

The T'ree-creepers.

Gex. Charac.-Bill more or less long, and generally slender, with the tip entire and slightly arched; nostrils usually small, and eovered by a membranous scale; the wings sometimes rounded and sometimes rather pointed; the tail varying very much in length and form; the tarsi and toes differ much in length, especially the latter, forming characters whereby the subfamilies of this large group are distinguished.

The Creepers somewhat resemble the Woodpeckers in the mode of progression, which is by extremely rapid short hops or starts upon the bark of trees, to which they cling with their sharp claws, at the same time using their tail to assist them in climbing. To adapt it to such an office, the tailfeathers are stiff and strong, and the shafts project as sharp points beyond the webs. The tarsi are generally short, the toes long, and armed with long curved claws. This is especially the case with the more typical species, which are organized for running on the trunks and branches of trees in search of insects that constitute their food. It is from this circumstance they have received their name of "Creepers." Indeed, their movements and general aspect, when engaged in hunting for their subsistence, are so like those of small quadrupeds, that at the first glance they might be easily mistaken for mice. Many of them make a nest in the holes of trees, where they rear a numerous progeny.

This family, which is rather numerous, embraces the Oven-birds, the Sharp-tails, the Tree-creepers, the Creepers, the Nuthatches, the Mohouas, and the Wrens. 
Furvarix.e.

The Oven-bircls.

GEx. CHarac.-Toes rather long, the lateral ones unequal, the outer onea rather the longest, and slightly united at is base, the inner toe free at its hase.

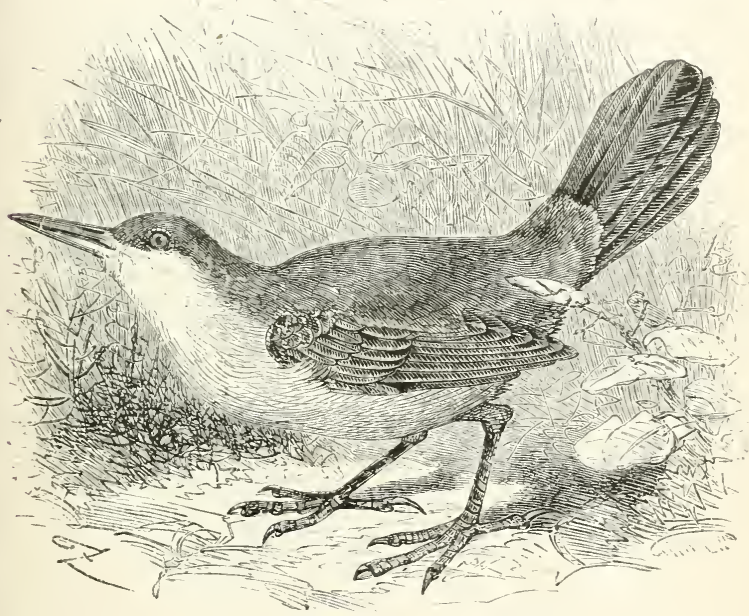

Fig 45.-THE BLACK-TAILED ENICORNIS.

(Enicornis melanura.)

These small birds are found in the warmer parts of South America, especially in bushes, on the bank: of the rivers, or near the dwellings of man, or even in open places. They are always seen in pairs, are very active, and capable of rumning and walking with great rapidity. 'Their flight is only from bush to bush, which they minutely examine for insects, chiefly those of the coleopterous kind, although they occasionally feed on seeds.

The male utters a series of loud shrill notes, of a very peculiar character. Their singular nest, from 
which they derive the name of Oven-birds, is generally built in an exposed situation on a thick leafless branch or on the top of a paling; sometimes, even, in the interior of houses. Both sexes labour at its construction, each alternately bringing a lunip of clay, a piece of straw, or of the dry stems of plants. This remarkable structure, when finished, has the appearance of an oven, six or eight inches in diameter, and about an inch in thickness. From the entrance, which is on one side, a passage reaches to the roof, and terminates by a circular opening in an inner chamber, where the eggs are deposited on a bed of feathers or grass.

The species figured in the Tabular View,

The Patagonian Cinclodes (Cinclodes Patagonica), is found principally upon the western coast of South America, especially towards the southern extremity of that continent.

The type of this sub-family is-

The Black-tailed Enicornis (Enicomis melanura), represented in our engraving. 


\section{SU UB-FAMLY II.}

SYNALLAXIN.E*

The Sharpiails.

Gras. CHarac.-Toes moderate and strong, with the lateral toes mnequal, the outer one the longest and mnited to near the first joint, and the imer slightly united at the base, the hind toe strong and long; the claws strong, con. pressed, and curved.

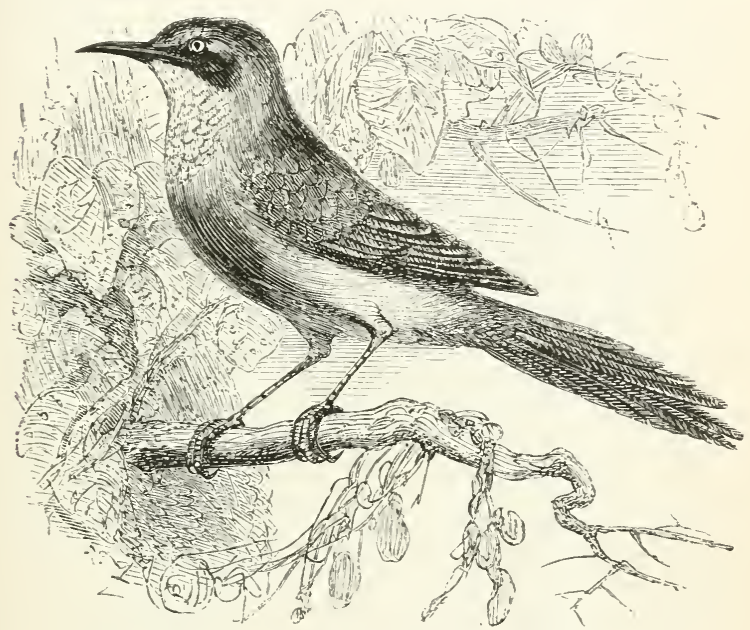

FIG. 46. - THE CHILIA SYXALLAXIS

(Synalluxis ruficapilla.)

The birds composing this sub-family are likewise peculiar to South America. They are usually found in pairs, but sometimes in little flocks of twelve or fourteen, on the borders of lakes and rivers, or on rushy inundated places, where they may be seen flitting from reed to reed, upon which they run up and down in search of minute insects. They usually carry their heads erect, and utter, at intervals, a shrill note, quickly repeated. 'Their Hight is jerking, and they walk on the ground with con-

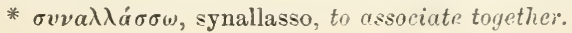


siderable ease and activity, collecting food from the withered herbage. Their nests are cylindrical, very large, and generally placed in the middle of a compact bush. They are composed outwardly of prickly twigs, with the entrance at the upper end, from which a curved passage leads to the interior, which is lined with feather's and hair.

Some species build a nursery for their young of very elaborate construction, placed at the extremity of the branch of a prickly tree, or occasionally in the middle of an isolated bush : the size of this nest is enormous when we take into account the small dimensions of its little artificers; it measures sometimes two feet in height, and a foot and a half in diameter. This large structure is of an elongated, oval form, having the broadest part below. Externally it is protected by many large thorny branches, intertwined with such art that they cannot be pulled asunder without destroying the entire fabric, which is lined with feathers, hair, and straws. Intermally it consists of two chamber's, of which one is rather spacious, and opens on the side or top. In this chamber there is a corridor, which at first ascends, and then leads down to a second compartment, better furnished with feather's and other warm materials, on which the female lays four or five eggs. The parent birds take great care of these nests, in the repair of which they seem to be constantly engaged, and from which they drive their young as soon as they are able to take care of themselves.

In the woodland scenery of Bahia, in Brazil, the nests of these birds form very striking objects, being sometimes three or four feet long, and resembling at a distance thick twists of bean-stalks, thrown amongst the branches by accident. Both the male and female may generally be seen near their remarkable domiciles, uttering a shrill monotonous chirp.

The type of this sub-family is the-

Chilian Synallaxis (Synallaxis ruficapilla). 


\section{SUP-FAIILY III.}

\section{Dendrocolaptin..* The Tree-creepers proper.}

GEN. Charac. - Bill of various length and form, more or less eurved, and compressed on the sides to the tip, which is usually entire; the nostrils hasal, lateral, small, and exposed; the wings moderate and generally rounded; the tail long, broad, and graduated, with the shaft of each feather prolonged beyond the web, and acute; the tarsi moderate, strong, and broadly scaled; the toes long, the outer toe rather longer than the middle one, and united for some distance from the base, the inner short and slightly united at the base, the hind toe long; the claws long, compressed, much curved, and acute.

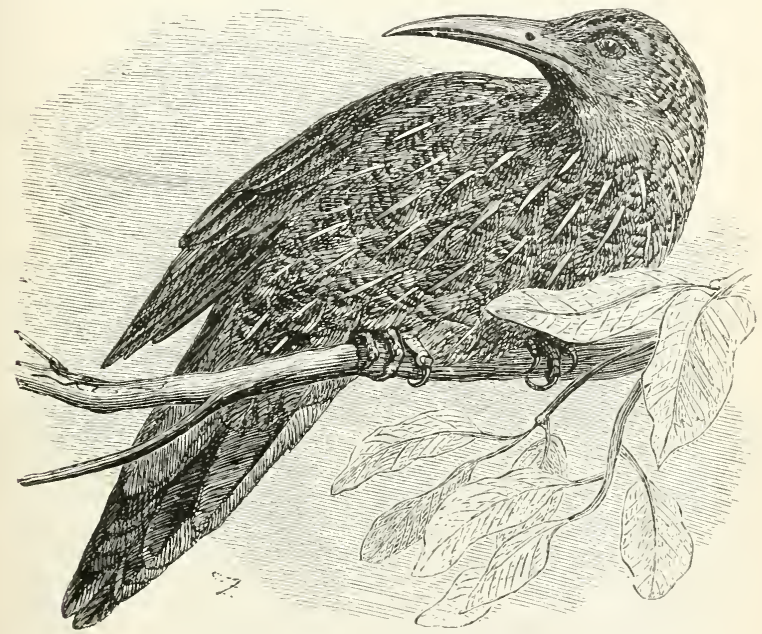

Fig, 17.-THE STRIPED-HEADED TREE-CREEPER.

(Dendrocolaptes lineatocephalus.)

The Tree-creepers are distinguished by the structure of their tail, which is long, broad, and graduated. The typical species inhabit the vast forests of the warmer parts of South America. They are usually observed clinging to the trunks and

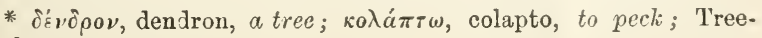
peckers. 
branches of trees, by means of their strong curved claws, and supported by the rigid points of their tail-feathers, examining the cracks in the bark, and prying among the foliage for insects or their larva, upon which they principally subsist. Their manners and habits closely assimilate to those of our Common Creeper. 'The female deposits three or four egg's in the hollow trunk of a tree.

The type of this Sub-family is the Dentiocoluptes limentocephalus.

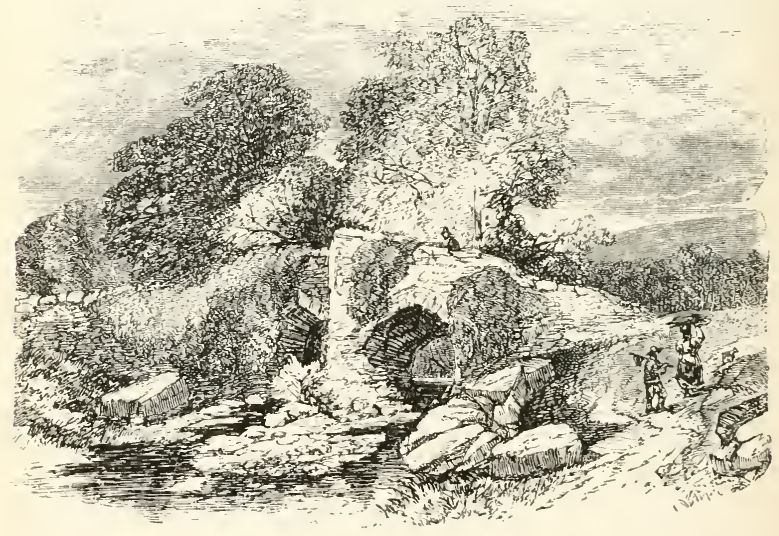


Certhine.

The Cruepers.

GEx. CHARAC.-Toes very long and slender, the outer toe longer than the inner, united beyond the first joint, and the inner toe as far as the first joint of the middle toe, the hind toe very long and slender; the claus long, much eompressed, and curved.

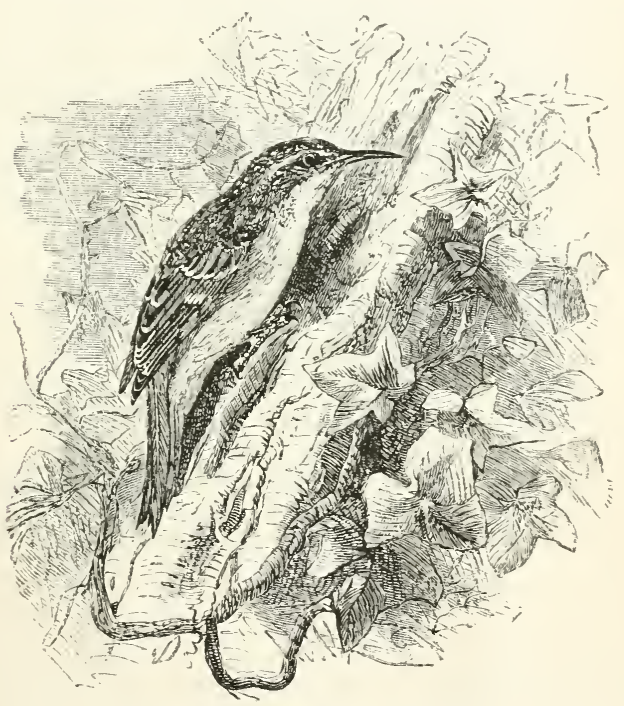

FIG. 48,-THE COMMON CREEPEK

(Certhia fumiliaris)

The Creepers constitute a group of beautiful small birds, inhabiting Europe, Asia, and the temperate parts of North America. They are met with wherever trees are abundant, where they may be seen creeping upon the trunks, generally commencing at the bottom and rumning upwards in a straight or spiral direction, using their stiff-pointed tail to assist them in the ascent. Sometimes they 
may be noticed on the branches, along the under surface of which they are able to run with perfect facility, in search of the insects that lie concealed in holes and crevices of the bark.

The type of this sub-family, -

The Common Creeper (Certhia familiaris), is a most active and restless little bird, ever on the alert, and climbing about the trunks and branches of trees, intent on picking up its insect food. Though comparatively comnion, and a constant resident in Britain, it is not easily seen, for its celerity in shifting its position makes it very difficult to follow it with the eye. At one instant it is before the spectator, and the next is hidden from his view by the intervening trunk or branch, to the opposite side of which it has passed in a moment. The form of the tail, and structure of the feet, are beautifully adapted for this sort of rapid locomotion. 


\section{SUB-FAMILY I.}

SITTIX.E.

The Nuthatches.

Gex. Charac.-Toes slender, with the outer toe shorter than the middle one, and united at the base to the first joint, the inner toe shorter than the outer one, and slightly united at the base.

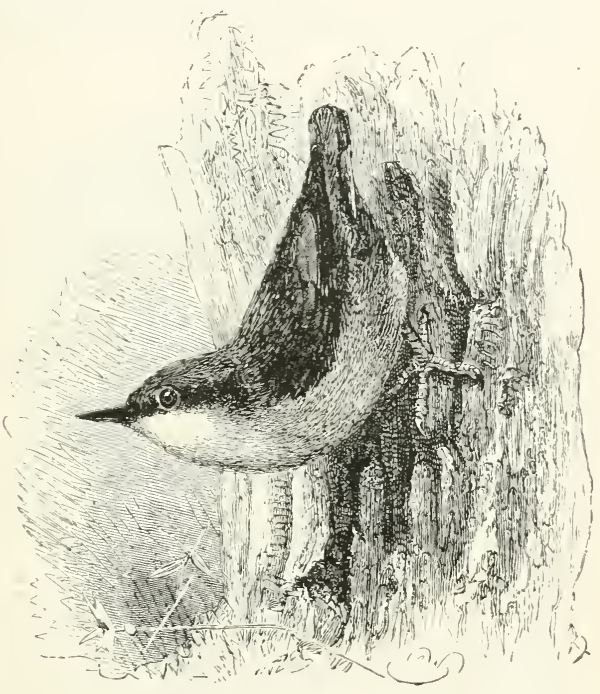

Fig. 49,-THE eUropeas vuthatch.

(Sitta Europaca.)

The Nuthatches are found throughout Europe and North America, and some species have been met with in various parts of India and the adjacent islands. They prefer forests and dense woods, where they may be seen moving rapidly about on the trunks of trees, running both upwards and downwards in a spiral direction, or creeping round the small branches, probing into the cracks, and occasionally removing pieces of the bark in search of spiders and insects. In severe weather they sometimes approach the dwellings of man, when they do not refuse to feed upon grain. The seeds 
of the pine-cone, and the kernels of filberts and hazel-nuts, also form a portion of their subsistence. These latter they break by placing the nut in a chink and striking it with their bill until they have made a hole in the shell sutficiently large to enable them to get at the kernel. They deposit their egg's in the hole of a tree, or in the deserted nest of a woodpecker, upon a small collection of dead leaves, principally those of the oak.

The type of the race, -

The European Nuthatch (Sitta Europece), has a stouter and straighter bill than the generality of the Creepers. It is a small bird, measuring little more than five inches and a half in length, and is common in many parts of Europe, especially in the South. 


\section{SUBB-FAIIILY VI.}

\section{ORTHONYCHA. *}

The Nohouas.

GEx. CHARAC. - Toes long and very strong, the outer toe nearly as long as the middle one, and united slightly at the base, the hind toe moderate and very strong ; the claws remarkably long, strong, slightly curved, and acute.

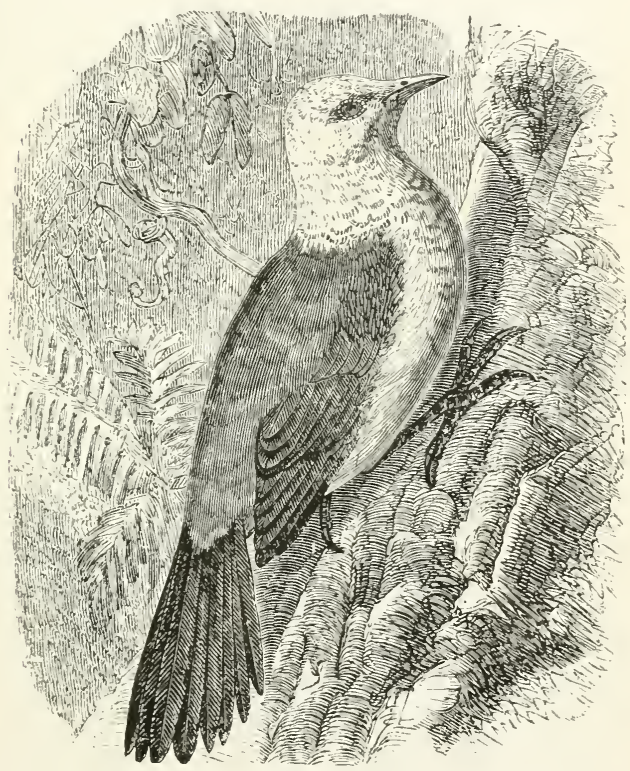

Fig. 50, -THE YELLOW-HEADED ORTHONYX.

(Orthoreys achrocephulus.)

'This sub-family embraces a small group of birds found in the islands of the South Seas, and also in New Zealand. Like the true Creepers, they are usually seen running upon the trunks of trees, searching for their subsistence, which chiefly consists

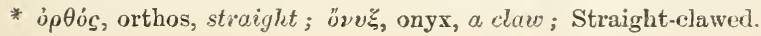


of minute insects, though they occasionally feed on small seeds.

'The typical species,-

The Spine-tailed Orthonyx (Orthonyx spinicauda), is rather more than eight inches in length. It has the shafts of the tail-feathers prolonged beyond the webs, forming, as indicated by the name, a set of spines at the apex of the tail. This bird is found in the most retired spots in the bushes skirting the coast of the southeastern angle of Australia. Here it is seen rumning over the fallen trunks of trees, and mossy stones, in search of the insects, principally beetles, which constitute its food.

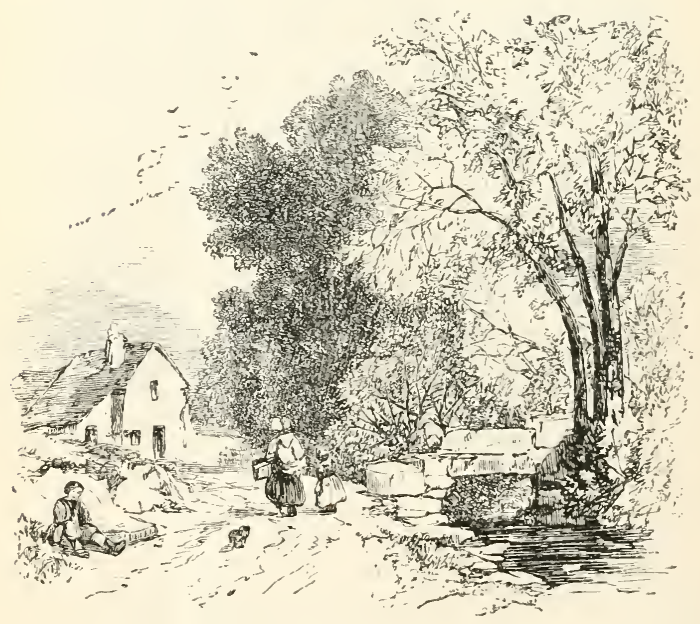




\section{SUB-FAUILY III.}

\section{MenURin.e.*}

The Wrens.

Gex. Charac.-Bill more or less long and slender, with the culmen usually slightly curved, and the sides compressed to the tip, which is searcely emarginated; the nostrils lateral, with the opening protected hy a horny scale or membrane; the wings more or less short and rounded; the tail of varions lengths, but generally rounded; the tarsi more or less long and slender ; the toes generally long, with the outer toe longer than the inner, and slightly united at the base, the hind toe long and strong; the elaws long, and more or less curved.

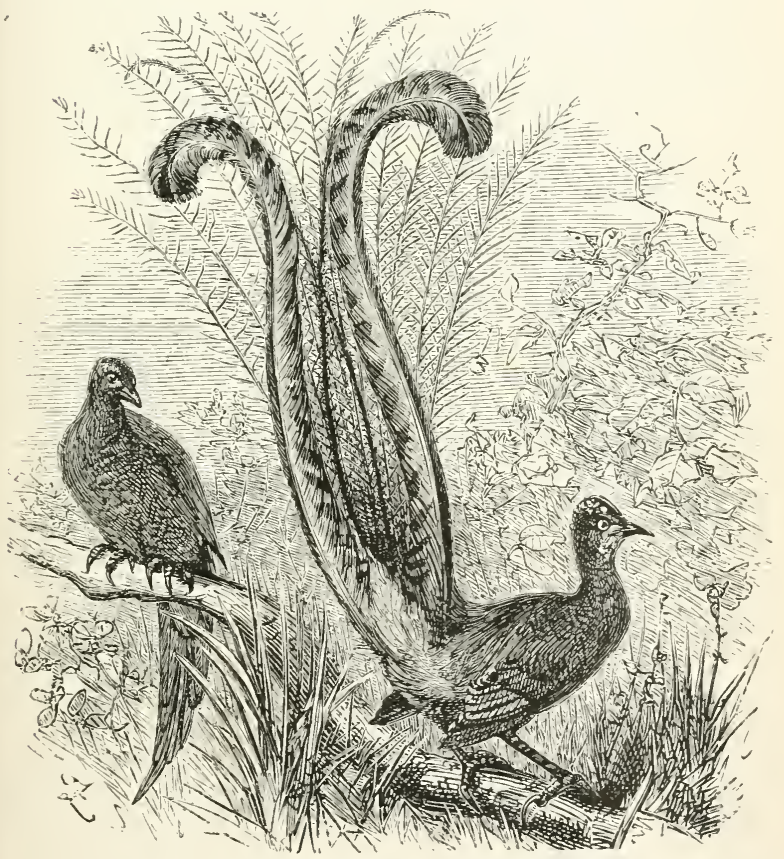

FIG. 51. -THE LIRE-BIKU.

(Menura superba.)

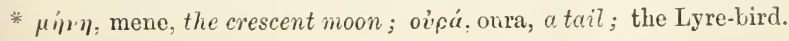


'The birds belonging to this sub-family are generally seen in pairs, examining the low thickets or coarse herbage in open plains, or on the outskirts and open places of woods and forests, and even in the neighbourhood of honses. Their flight is low and short, and they are in the habit of concealing themselves amongst the foliage of thickets, or in holes and crevices, and reappearing mexpectedly in another quarter. Tarious kinds of insects, either. in the perfect state or that of the larva, form their principal subsistence, and some species thus render infinite service to gardens and cultivated places. Most of them possess a sweet, lively, and powerful whistling song, which they utter with great animation, often repeating the same note orer and over again. Their nest is placed against the branch of a tree, a bank, the wall of a house, or any place that offers warmth and security for their young. It is composed of moss and other soft materials, put together usually in an oval form, leaving only a small entrance on one side, near the top. The eggs are generally four in number. Although the birds belonging to this sub-family are ordinarily of small dimensions, the selected type of the race is a large and handsome species, called from its peculiar plumage -

The Lyre-bird (Menura superba). The Lyre-bird is a native of New Sonth Wales, where it inhabits the brushwood upon the coast and upon the mountains in the interior. It equals in size our own common Pheasant; but its limbs are longer in proportion, and its feet much larger. In the male, the feathers of the head are elongated into a crest, and the general plumage is full, soft, and downy. The most striking feature, however, is the tail, which is converted into a beantiful plume-like ornament, representing, when erect and expanded, the figure of a lyre; whence is derived the name of its possessor. This ornamental appendage, however, is confined to the male; in the female, the tail is long and graduated, and the feathers are perfectly webbed on both sides of the shaft. 


\section{T R I B E I I I.}

IENTIROSTRES.

T'He birds forming this division of the Passerine order are distinguished by having a more or less distinct tooth or notch on each side of the upper mandible, near the tip, which is usually more or less hooked.* The bill is sometimes slender and weak, sometimes stout and powerful; in the latter case, the tooth-like projections are generally strong, and the birds as predacious in their habits as some of the smaller hawks. The feet are slender, but usually armed with curved and acnte claws.

\section{FAMTLY I.}

LC'SCINID.e.

The Wrarblers.

Gex. Charac.-Bill subulate, more or less slender and straight, with the upper mandible curved and emarginated, the base sometimes broad, but the bill always compressed towards the tip; the nostrils basal, and placed in a membranous groove, with the opening exposed; the wings more or less long, sometimes rounded and sometimes pointed; the tail of various lengths, truncated at the end, or rounded, and sometimes graduated; the tarsi more or less long, always slender: the toes varying in lengtb, with the outer toe more or less united to the middle toe.

In these birds the sides of the upper mandible are but slightly toothed; the wings are long, the tarsi slender, and the toes terminated by claws of moderate length. They are for the most part distinguished for great power of song. Their food consists almost entirely of insects and worms, so that those which inhabit cold and temperate regions are for the most part migratory.

To this family belong the Soft-tailed Warblers, the Warbler's, the Robins, the Accentors, the Titmice, the Wagtails, and the Wood-Warblers.

* See Animal Creation, p. 419. 


\section{$S U B-F A . I I L Y I$ I.}

\section{MALURIN.E.*}

\section{The Soft-tailed Wurblers.}

Gex. Charac.-Bill moderate, more or less slender and straight, with the tip of the upper mandible curved, and sometimes emarginated, the sides compressed; the nostrils basal, and placed in a membranous groove, with the opening exposed; wings short and rounded; tail more or less lengthened and rounded; tarsi generally long and slender; toes more or less long, and always slender, with the outer toe united to the middle one at the base, the hind toe long, and armed with a strong claw.

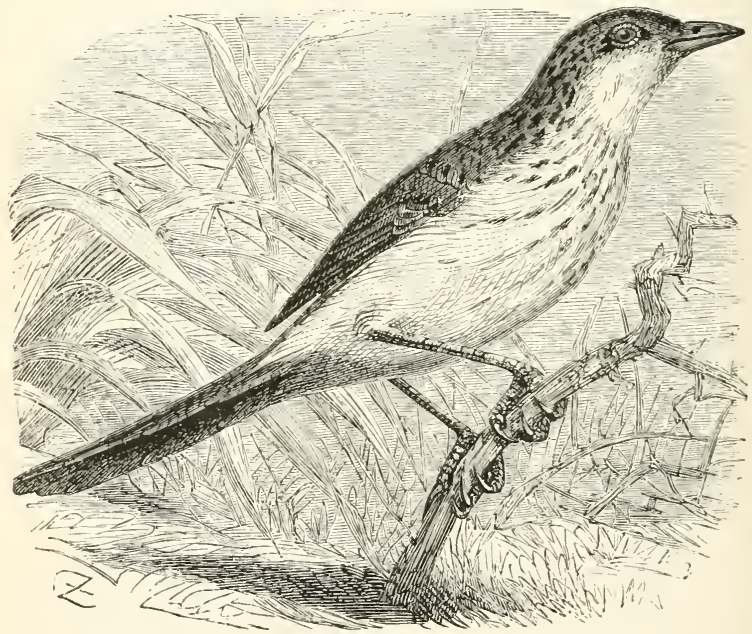

Fig. 52.-THE YELLOW MEGALLRUS.

(Megulurus citrinus.)

These elegant birds generally frequent open spaces scattered over with low brushwood or bushes, especially in the vicinity of rivers; but in the winter season they fearlessly approach the abode of man. They are usually seen on the ground in pairs or small

* $\mu a \lambda \lambda o ́ s$, mallos, wool; oủpú, oura, the tail; Soft-tailed. 
flocks, moring rapidly from place to place by a series of bounding hops, or prying about in search of insects upon or beneath the fallen trunks of trees. Their flight is feeble, and only extends over short distances.

The Malurus cyaneus (named by the colonists the Superb Warbler, Blue Wren, \&c.) is an inhabitant of New South Wales, where its favourite haunts are of a wild and sterile character, thinly covered with low scrubby brush wood, near the borders of rivers and ravines. These birds are of a very wandering disposition, but seldom travel far beyond the district where they were bred. During the winter they associate in small flocks, but as spring advances they separate into pairs; the male at this period undergoing a most remarkable change of plumage, indeed its whole character and nature seem to receive $a$ new impulse. The little creature now displays great vivacity, proudly showing off its gorgeous attire, and pouring forth an animated song, almost unceasingly, until the female has completed her work of incubation. Two, if not three broods are reared in a season. The song is a hurried strain, something like that of the European Wren.

The typical form of this sulb-family is the Yellow Megalurus (1. Megalurus citrinus). 


\section{$S U B-F A I I L Y I I$.}

\section{LUSCININA.}

The Warblers proper.

Gen. Charac,-Bill more or less long, slender, and straight, with the eulmen curved at the tip, which is slightly emarginated; the sides compressed, and the gonys long and ascending; the nostrils basal, and placed in a membranous groove, with the opening usually exposed; the wings moderate, and sometimes rounded; the tail moderate and rounded at the end; the tarsi more or less lengthened, slender, and covered with broad scales, the divisions of which are sometimes obliterated; the toes more or less long, slender, and covered with broad seales, the divisions of which are sometimes ohliterated, the outer toe generally longer than the iuner, and united at its base; the claws long, curved, and acute.

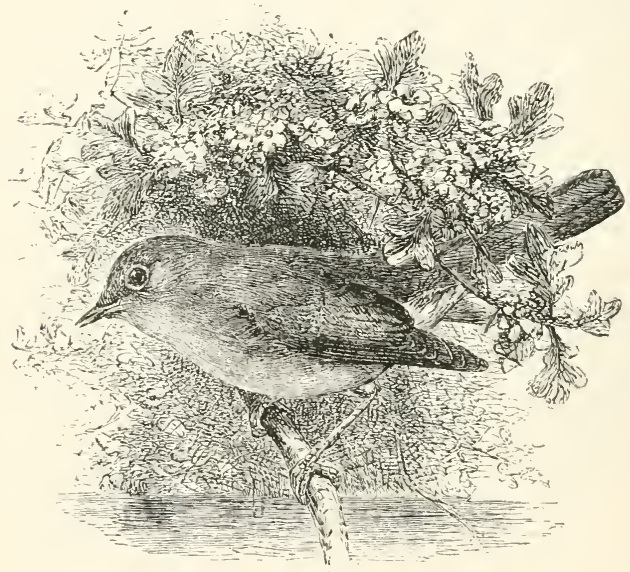

Fig. 53.-The nightingale.

(Philomela luscinia.)

The species that compose this sub-family are peculiar to the Old World, and are migratory at certain seasons of the year. They are usually seen in woods and thickets, in which they hide themselves, and through which they flit with great swiftness when alarmed. They search actively among the leaves for insects; they also feed on the seeds of the 
ivy and other soft berries. Some place themselves on the summit of a bush, and pour forth at intervals their clear and well-defined notes; others utter their song on the wing, as they rise from the ground to a great elevation in the air, and then return slowly to the spot whence they had started. They build their nests in low bushes or among nettles, constructing them with the stems of plants, and lining the interior with hair and fine fibres of roots. The eggs are generally four in number.

The type of this musical sub-family is-

The Nightingale (Philomela luscinia). This "Queen of Song" is by no means remarkable for the beanty of its plumage, although most elegant in shape. Its general colour is brown, tinged with red above, and dullish greywhite beneath. The Nightingale arrives in this country about the middle of April, the males making their appear ance a few days sooner than their mates. They are not found in the extreme west parts of England, nor in Ireland; and they do not penetrate further northward than Yorkshire, although on the Continent they are seen in Sweden. They frequent woods, plantations, and orchards, and feed on insects and spiders. The observations of MIr. Gould, respecting the migrations of the Nightingale, lead him to the conclusion that, after leaving England, it proceeds to the opposite shores of the Continent, and gradually makes its way southward until it arrives in Africa, which is its ultimate resting-place during our winter months. In Africa, moreover, it seems to be confined to the northern districts, never having been obtained from the central or southern parts of that continent. In no part of Europe is it more abundant than in Spain and Italy, from whence, however, as from our own climate, it regularly migrates on the approach of winter. The Nightingale is exceedingly shy, living in low swampy coppices, close thickets, liedges, and similar situations. It is seldom seen, its retreat being only discovered by its peculiar call-note, and its song, which for richness and power is unrivalled.

Unlike most of the smaller birds, Nightingales never associate in flocks. Their food consists principally 
of insects, small worms, eggs of ants, and berries of various kinds.

Their nest is made in the lower part of a hedge or a thick bush, where it is sheltered securely. It is formed of grass, leaves, and moss, softly lined with hair and down. Whilst the female is sitting on her eggs, her mate, perched hard by, pours forth his varied song, to

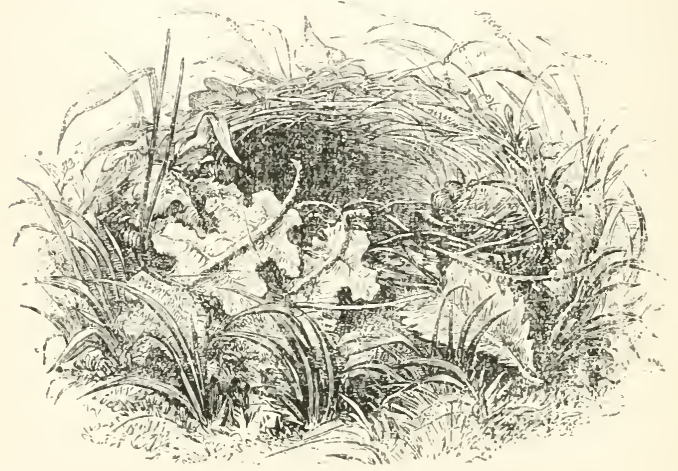

Fig. 54.-NigHTINGALE'S NEST.

while away the tedious hours and enliven her by his warblings; but when the brood is hatched, he ceases his melody, and betakes himself to the active employment of providing for his family. Sometimes the first brood is suceeeled by a second, and a third,-in hot countries even by a fourth.

The voice of the Nightingale excels that of any other bircl, and is the more delightful, beeause it breaks upon us in the stillness of the erening when all else is silent. Aucients and moderns have alike borne testimony to its inimitable sweetness. "The Nightingale," says Pliny, "that for fifteen days and nights, hid in the thickest shales, continues her note without intermission, deserves our attention and wonder. How surprising that so great a voice can reside in so small a body! Such persercrance in so tiny an animal! With what a musical propriety are the sounds it produces modulated! The note at one time drawn out with a long breath, now stealing off into a difierent cadence, now interrupted by a break; 
then changing into a new note by an unexpected transition; now seeming to renew the same strain, then deceiving expectation. She sometimes seems to nummul within herself; and then her song bursts forth full, deep, sharp, swift, drawling, trembling; now at the top, the midlle, and the bottom of the scale. In short, in that little bill seems to reside all that melody which man has vainly laboured to bring from a variety of musical instruments. Some even seem to be possessed of a different song from the rest, and contend witl rach other with great ardom:"

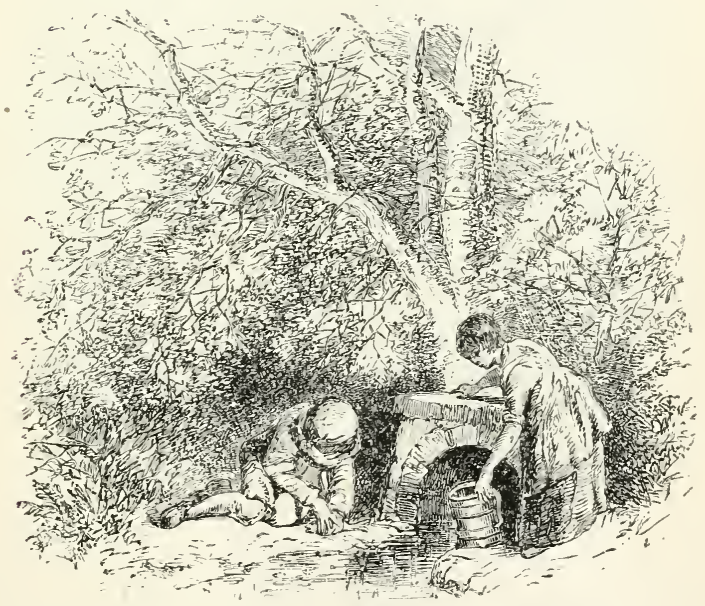


Gen. Charac.-Bill moderate, more or less slender, and rather depressed at the base, with the eulmen slightly eurved, and the sides gradually compressed to the tip, which is entire, the lateral margins straight and sometimes inflexed, the gape more or less furnished with bristles; wings generally short and rounded, though sometimes long and pointed; the tail usually short and hroad, sometimes eren and rounded at the end; the tarsi lengthened, slenter, and covered with an entire scale; the toes moderate, the lateral ones unequal, and the elaws moderate, eurved, and aeute.

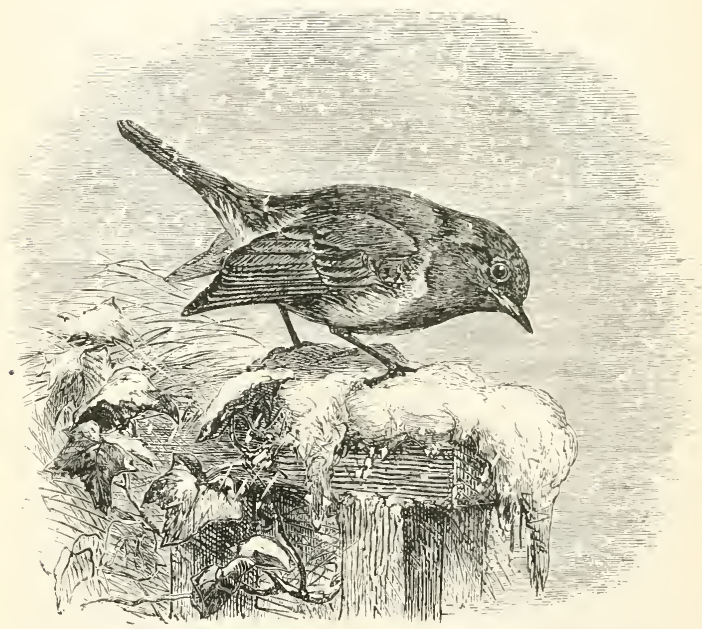

Fig. 55.-THE REDBREast.

(Erythaca rubecula.)

The Robins are represented by a single species, found in Europe, where during the summer months it resides in the thickest woods; but on the approach of winter it leaves its solitary abode, and may generally be observed in the vicinity of human habitations. It is of a solitary disposition, never con-

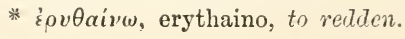


gregating in flocks, even when performing its partial migrations. It subsists principally on insects and their larve, and also on worms, which it beats to death and cleanses before eating. It shows great boldness in attacking other birds, should they approach the vicinity of its nest or the place that it has selected for its own peculiar province during the winter.

The type of this sub-family is-

The Robin Redbreast (Erythaca rubecula). This lively and familiar bird is strictly indigenous to Europe; its range only extending eastward as far as the border. line of Asia Minor. In Europe, the middle and northern regions are those in which it appears to be most abundant, and over which it is universally spread. Its fearless confidence in man, which leads it to frequent his gardens and the precincts of his house; its sprightly manners, and its animated song, poured forth morning and evening, even throughout the autumn and colder part of the year, when all other songsters are silent,-make it a most welcome visitor to his habitation. Attractive as the Robin is on account of its pleasing manners, it is of a quarrelsome and pugnacious disposition. Two males seldom agree to live in the same garden, or within a certain distance ; the stronger always driving away the weaker. During the greater part of the year its food consists of worms, grubs, the softer caterpillars, and small insects, together with berries and fruits when in season; but in the depth of winter, when its natural food cannot be procured, it subsists upon the crumbs freely offered wherever it presents itself.

In spring, the Robin retiring with his mate to the woods, begins to build a nest for the use of his future family. Moss and dried leaves, intermixed with hair, form the nest, which is cup-shaped and lined with feathers. It is placed near the ground, sheltered by the roots of trees, or sometimes in old buildings, but always hidden as much as possible. While the hen bird sits on her eggs, the male, perched close by, makes the woods resound with his cheerful song, and vigilantly looks out that no intruder shall approach his nest. As soon as the 
young are hatched and able to provide for themselves, he leaves the woods, and approaches again the abode of man; and when the frost becomes severe, and the snow covers the ground, he draws near to the house.

" Half afraid, he first

Against the window beats, then brisk alights On the warm hearth; then hopping on the floor, Eyes all the smiling family askance, And pecks, and starts, and wonders where he is, Till more familiar grown, the table erumbs Attract his slender feet."-Thomson.

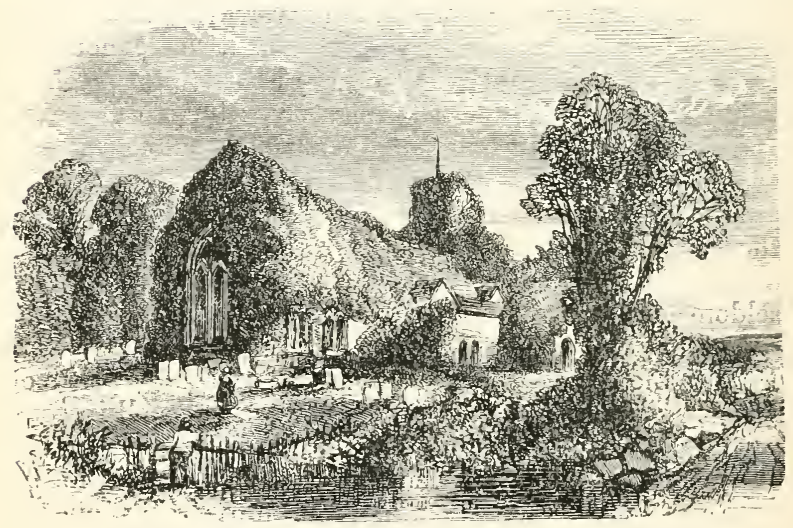


Accentorix.e.* The Accentor's.

Gex. Сharac.-Bill short, straight, and sometimes conical, with the culnen sloping, and the sides eompressed to the tip, which is slightly emarginated; the nostrils basal, and placed in a membranous groove with the opening exposed; wings more or less long, pointed, and sometimes rounded; the tail moderate, and generally rather rounded; tarsi moderate, and rather strong; toes rather long, the outer toe united at its base, the bind toe long ard armed with a strong claw.

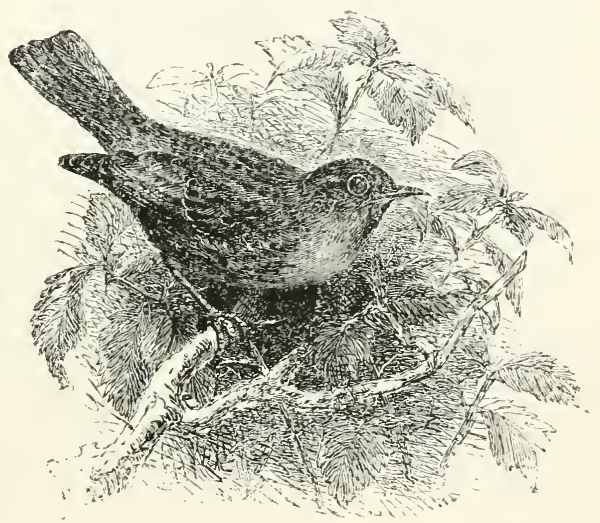

FIG. 5 fj-THE HEDGE SPARKOW.

(Acentos jodularis.)

The birds composing this sub-family inhabit both Europe and Asia, migrating according to the season of the year. They are to be seen beneath low bushes, searching for worms among the fallen leaves and stones; they also feed on seeds and insects of various kinds. Some species, should the winter be severe, repair to the neighbourhood of farms and villages. Their song, which consists of various notes, is sweet, though feeble, and commences early in the season.

* Accentor, one who joins another in singing. 
'The nest, generally hidden in a thick bush, is formed of moss and wool, lined with hair. 'The female lays from four to six eggrs.

'The typical species-

The Alpine Accentor (Accentor Alpinus), inhabits the Alps and Pyrenees, where it selects for its retreat the most unfrequented places in those wild mountains. In the prtois of the regions it frequents, it is called Pegot or Pée, which means an idiot, and its claims to the name seem fully justified by its remarkable stupidity. These birds never leave their native mountains except when their desolate abode is swept by some storm or tempest, to escape firm which, they precipitate themselves into the valleys, hide in the rifts of the rocks, or take refuge among the bushes, where, either from fright or simplicity, they even become the sport of children, who amuse themselves by killing them with sticks. On the summits of the mountains they may be seen by the adventurous pedestrian sitting in pairs upon the ground, or climbing among the rocks with the assistance of their wings. The approach of man does not seem to frighten them, neither will they take the trouble to get out of his way. These birds run like partridges or quails, and do not hop like the rest of their tribe. They make a circular nest, composed of moss and grasses, in the cleft of some rock, and always with al southern aspect. The female lays five or six eggs. 
PARINe.

The Titmice.

GEN. CHARAC.-Bill strong, slightly compressed; first primary short, second shorter than the first, fourth and fifth longest; hind claw strongest and most hooked; tarsus short.

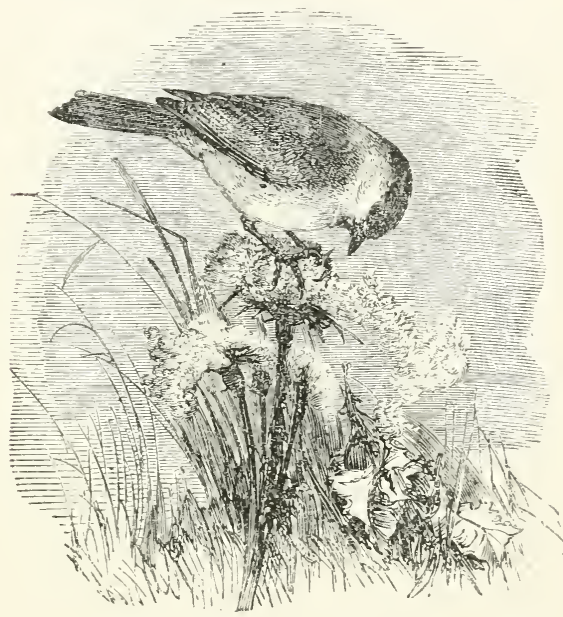

FIG. 57.-THE MARSH TITMOTSE.

The birds composing this sub-family are distributed throughout Europe, Asia, Africa, and North America. They usually frequent woods and gardens, and are very lively little birds, flitting from bush to bush, ruming up and down branches with great celerity, and hanging in various attitudes among the foliage. Their food consists of insects, grubs, and caterpillars; but at times they will peck up grain or seeds, and even feed upon flesh. They will sometimes attack weak and sickly birds, which they kill, fracturing their skulls by repeated strokes of their strong and pointed bill. The nests of some species 
are formed in the holes of decayed trees or old walls, and are composed of moss and lined with hair and feathers. Others select the fork of a tree or the middle of a bush, wherein they construct an ovalshaped nest, made of lichens and wool intermixed, and lined with feather's. 'The eggs are usually from six to ten in number.

The majority of the Titmice-especially those which frequent woods, thickets, and orchards-are courageous, and even ferocious; they will attack the Owl with greater boldness than any other bird, being always foremost in darting upon him, and trying to peck at his eyes. They express their little rage and fury by the swelling of their plumes, by violent attitudes and precipitate motions. They peck sharply the hand that holds them, and seem by theil cries to call others to their assistance-an appeal which usually attracts them in crowds. There are many traits in their manners and character resembling those of the Shrikes, Pies, and Crows; they have the same appetite for flesh, and the same custom of tearing the food to pieces before they eat it. Though fierce, they are social, seek out the company of their own species, and form little flocks, more or less numerous; and if any accident should separate them, they call each other mutually, and are soon reunited. They seek their food in common; visit the clefts of rocks and walls, and tear, with their bills, lichens or the moss of trees, to find insects or their eggs. They also feed on seeds, but do not break them, like the Bullfinches and Limnets; they place them under their claws, and pierce them with their bills, like the Nuthatches, with which they sometimes associate during the winter.

The type of this sub-family-

The Great Tit (Parus major), is a handsome, vivacious little fellow, common in England; during the summer frequenting woods and shrubberies, and in the winter resorting to gardens and orchards, clinging to the branches, 
and searching diligently for the insects which, at that season of the year, are hidden in the crevices of the bark. These birds feed much upon carrion, and will even kill small birds by frequent strokes of their sharp, hard bill upon the head of the unfortunate victim, whose brains they afterwards pick ont and devour. The nest of the Great Tit is placed in a hole in a tree or wall, and is con-

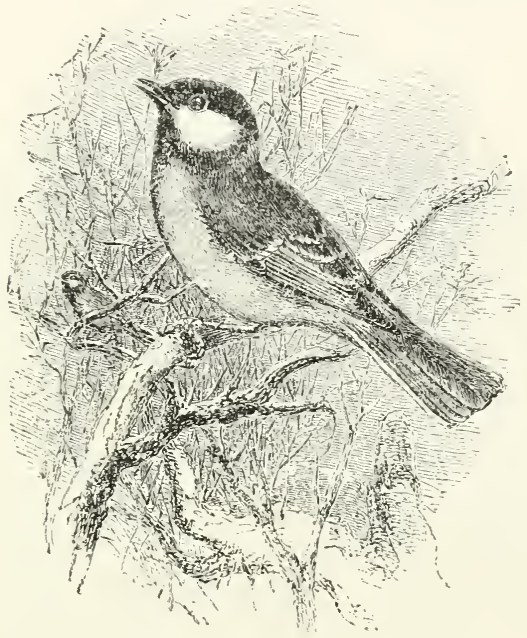

Fig. 53.-THE GREAT TITAKOL'E.

\section{(Purus incrjor)}

posed of moss, hair, and feathers. The female lays usually fiom eight to ten eggs, although occasionally sixteen, $\mathrm{or}^{\circ}$ even eighteen have been found in one nest. They are white, with pale red spots. When threatened by an intruder, the mother-bird stoutly defends her brood; she puff's out her feathers, hissing loudly, and boldly pecks at the assialant. 


\section{$S C B-F A M I L Y$ VI.}
Motacillixæ.
The I'agtails.

Gkr. Cirarac.-Bill slender, angular between the nostrils, the upper man. dible notched; wings with one of the scapulars as long as the closed wing; tail long; legs long.

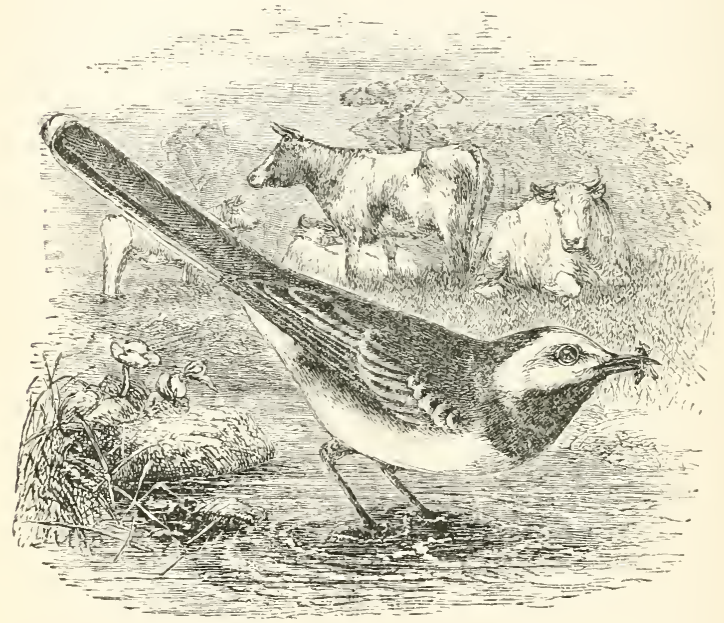

Fig. 59.-The White Wagtail.

(Motacilla alba.)

These well-known birds frequent meadows and humid or marshy places, delighting in the borders of rivulets and ponds.

The White Wagtails have a mode of life peculiar to themselves, and more readily approach man and his habitation than the rest of their congeners: the others, more wild, inhabit the vicinity of meadows. The former prefer stagnant waters; the latter are generally seen on the borders of springs and running streams. Both run with the cattle, fly about the labourer, and follow the plough, in pursuit of smal 
worms and larvæ, of which the newly-turned furrows present a vast abundance. These birds, indeed, are as useful as the Fly-catcher's and the Swallows; sometimes during their flight, but more frequently on the ground amidst the herbage, they seize upon the flies and gnats which have escaped the bills of their other pursuers in the air. The insect population of ponds and marshes, however, constitute their chief nourishment. Their slight forms, small head, delicate feet, and long tail, distinguish them at once from all the other Dentirostral birds.

\section{The type of this sub-family-}

The White Wagtail (Motacilla alba), is everywhere to be seen frequenting the margins of ponds and streams. It does not hop, like most of its near relatives, but runs about in search of its insect food, which it pecks from the ground, or occasionally rising with a short jerking flight, snaps at it in the air.

When on the ground, they are constantly employed in beating the surface with their tails, probably to rouse the insects upon which they feed. They delight in being near the eilge of the water, and often approach the washerwomen; and, moreover, seem to imitate with their tails the beating of linen. Hence the French have given them the name of Lavandières; while, in England, they are not unfrequently called by the less elegant name of Dish-washers. They run lightly with very nimble steps upon the strand, and their long legs enable them to enter the water to a small depth; but they are usually seen upon stones, or little hillocks in the stream. This Wagtail constructs its nest on the ground, under roots of trees, or at the edge of the water, under some hollow bank, in elevated piles of wood by the side of the river, and sometimes in heaps of stones. It is composed of dry grass, fibrous roots, and moss, connected carelessly together, and lined with horsehair and feathers in abundance. The eggs are of a bluish-white, spotted with brown. There are ustually two broods in the year. The male relieves the female during some hours of the day from the confinement of incubation. 
The Wood Warbler (Sylvice sylvicola), regarded by some as the type of another sub-family, is generally distributed thronghout England. It uswally appears in April, and takes up its abode in woods and plantations. Its food consists of insects and their larre. This bird

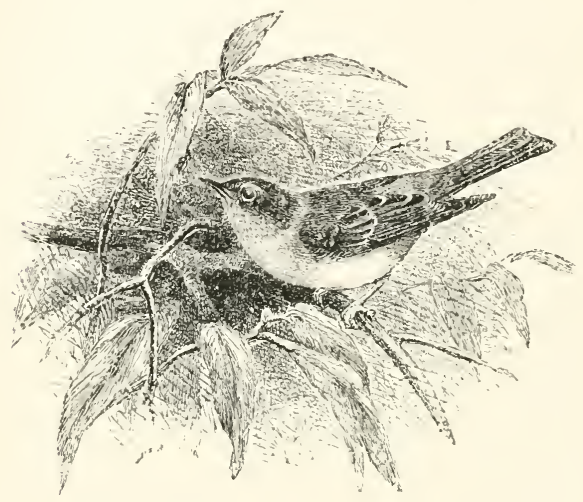

FiG. 60-THE WOOD WARILER

(syleia sylvicola.)

builds a domed nest npom the gromnd, amongst the herbage, forming it of dry grass, leaves, and moss ; and lining it with fine grass and hair, but with no feathers. The eggs are six in number, white, spotted all over with deep red and ash-colons: 


\title{
FAMILY II.
}

\author{
TIRDIDE.
}

The Thruskes.

Gex. CHARAC.-Bill of various lengths, and more or less strong, with the culmen generally keeled, curved, and the sides compressed to the tip, which is emarginated; the nostrils lateral, basal, and generally protected by a ntembranous scale; the wings more or less long and rounded or pointed; the tail mostly of moderate length; the tarsi more or less short, and usually covered with transverse scales; the toes of various lengths, and the outer toe generally longer than the inner one.

These birds are distributed in all parts of the world. Their food consists principally of insects, worms, and terrestrial mollusea, and also partly of fruits. Many of them possess great power of song.

This family includes the Ant-Thrushes, the Thrushes, the Babblers, the Orioles, and the Bulbuls. 


\section{SUB-FAMILYI.}

\section{Formicarise.}

The Ant-Thrushes.

Gex. Crrarac.-Bill more or less long and straight, with the eulmen eurved to the tip, which is emarginated and sometimes slightly hooked, the sides eompressed, and the gonys moderate and ascending; the nostrils lateral, placed in a membranous groove, with the frontal plumes projeeting to the opening, which is exposed; the wings generally rather short and rounded; the tail more or less short, and usually rounded; the tarsi rather long, and mostly eovered in front with slightly-divided seales; the toes long and slender, with the outer toe longer than the inner, and more or less united at the base.

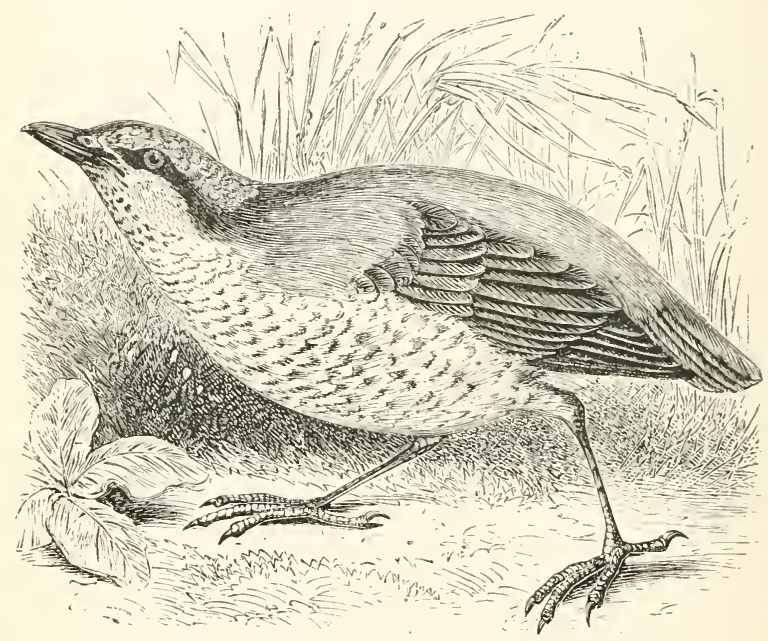

Fig. 61.-THE BLUE pitta.

(Pitta cyanea.)

These birds inhabit the tropical portions of America, where they are usually seen on the ground, or on the trunks of trees, on which they support themselves by means of their tails, searching for ants and other kinds of insects.

The Ant-Thrushes are so called from their anteating propensities : they form a small, but remark- 
able group of birds, differing greatly in colour and dimensions, but resembling each other considerably in their general form. Some species are sombrely clad in black, brown, and white; while the plumage of others is adorned with the brightest scarlet, blue, and purple.

The Garnet-coloured Pitta (Pitta granatina) is found in India, and the neighbouring islands, and also in Western Africa. These birds frequent the jungles and thick bushes, and, in India, sometimes visit the gardens and cultivated districts. Their food consists of insects and worms, which they usually seek for on the ground by scratching among the fallen leaves; they are believed, also, occasionally to feed upon berries and fruits. They seem to prefer the neighbourhood of water, and are seen wading up to their knees in the shallow streams. If disturbed, they either seek safety by running away, which they do very quickly, or by flying to a branch of some neighbouring tree, and remaining concealed for a time amidst the foliage. Like the Thrushes, the male and female closely resemble each other ; but it is curious to find that the young are plumed and coloured exactly like the adult from the time they leave the nest. Most of the species of Pitta are verv beautifully ornamented; the colours being generally in bright contrast. Some seek their insect-food among the thick cane-beds near the coast; others (P. cyanea), common in the islands of the Eastern Archipelago, run very quickly, and keep in the most sombre places. The adults fight like quails whenever they meet. The nest of the Garnet Pitta is formed among the bushes near the ground, and is frequently concealed from view by orchids and other parasitical plants. 


\section{$S^{\top} B-F A I I L Y I I$.}

TURDIN.E.

The Thrushes proper.

Gex. Charac.-Bill moderate, compressed at the point, upper mandible notehed and bending over the lower one; gape furnished with a few bristles; nostrils basal, lateral, oval, partly eovered with a naked membrane; tarsus longer than the middle toe; wings and tail moderate, first primary very short or almost abortive, second shorter than the third or fourth, which are the longest.

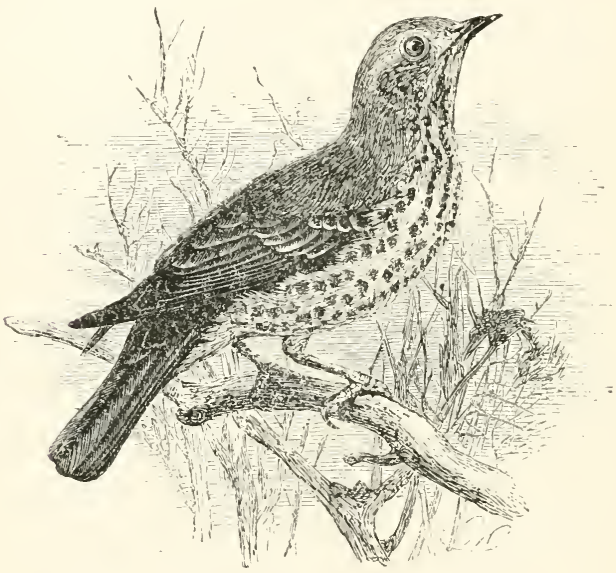

Fig. 62-THE MISSEL THRUSH.

(Turdus viscicorus.)

The true 'Thrushes are inferior to the Shrikes in the structure of their bill, which is much less toothed; their feet, however, are stronger, and as much adapted for walking as for perching. The Blackbird and the Fieldfare are familiar examples of this perfection of structure. They make their way upon the ground, on trees, or in the air, with equal facility. The form of their bill shows a superior adaptation for general purposes; the notch near the point is much slighter than in the Shrikes, yet it is sufficient to enab!e them to retain a firm hold of their prey, while the 
superior length of the beak enables them to obtain food beneath the surface of the soil. Thus we see them accompanying the Crows during autumn, in large flocks, spread over new-ploughed fields, and traversing the ground in search of the same kind of food. The Thrushes devour fruits quite as much as they do insects. In sweetness, compass, and rersatility, their song surpasses that of most of the feathered race. 'These birds are found in all parts of the world; they are of a shy disposition, and more or less migratory. The European species retire in large flocks to temperate regions in the winter season, returning to the northern countries as summer approaches. Some frequent the forests, outskirts of woods or thickets, and bushes in meadows and pastures, while other's retreat to rocky, mountainous districts. Worms, larve of insects, and mollusks form their chief summer subsistence; while in the winter they pluck the berries of various plants. Many of them ntter a lond whistling note, which in certain seasons is exchanged for a pleasing song, poured forth from the highest branches of small tiees.

The type of this sub-family is-

The Missel Thrush (Turdus viscivorus). Of all the Thrushes, this species is the most extensively spread over the old Continents; being not only found in Europe, but also in the Himalaya mountains, and the high lands of Asia, at an altitude which affords a temperature similar to that of our own climate. Thinly dispersed over the British isles, the Missel Thrush is a solitary and unsocial bird, differing considerably in its habits from the common favourite, the Song Thrush, which delights to dwell in the cultivated precincts of our shrubberies and gardens. Affecting remote situations, it retires from human society to pasture lands, wide commons, or meadows, skirted by orchards or groves, feeding, like its congeners, on snails, worms, and the larræ of insects during the spring and summer; but resorting to berries, especially those of the mountain ash, 
the haw, and the mistletoe, when autumn and winter deprive it of its more esteemed fare. The Missel Thrush is one of our earliest breeders; the commencement of March being with it the season of incubation. It builds its nest sometimes in orchard trees, at others in those of more lofty growth, such as the elm or oak; and the nest, with a view to its concealment, is artfully placed either close against the stem, or in a fork of one of the large branches; being composed, on the outside, of coarse lichen, grey moss, or such dried vegetation as may be found on the spot, corresponding with the colour of the tree. The materials are carelessly interwoven; but within this outside covering is placed a layer of mud, neatly lined with fine grasses. The eggs are five in number, of a pale bluish-white, spotted with dull red.

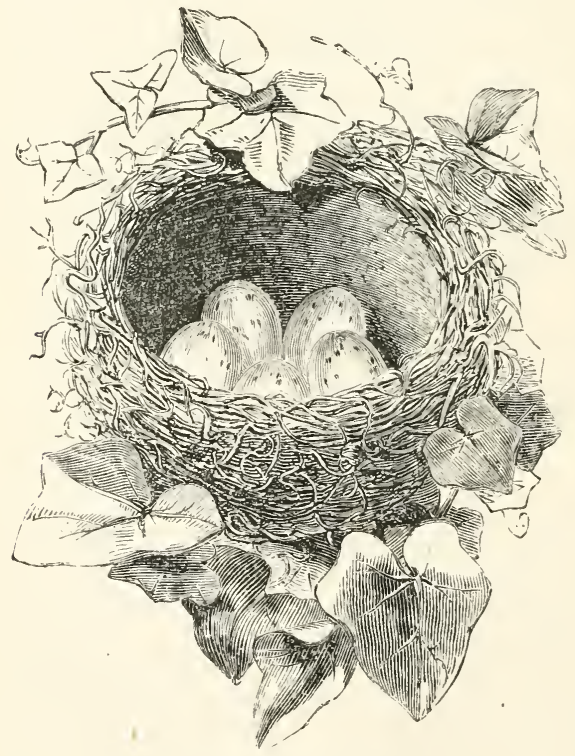

NEST OF SONG THRESH. 


\section{SUB-FAMILYIII.}

\section{Tinalise.}

The Babblers.

Ger. Charac.-Bill moderate, with the culmen much eurved and the sides compressed to the tip, which is generally entire or only slightly emarginated, the gonys long and ascending; the nostrils basal, and more or less exposed; the wings short and mueh rounded; the tail of various lengths and graduated; the tarsi lengthened, robust, and covered usually with an entire scale; the toes long, strong, and strongly scutellated above; the claws more or less long, compressed and acute.

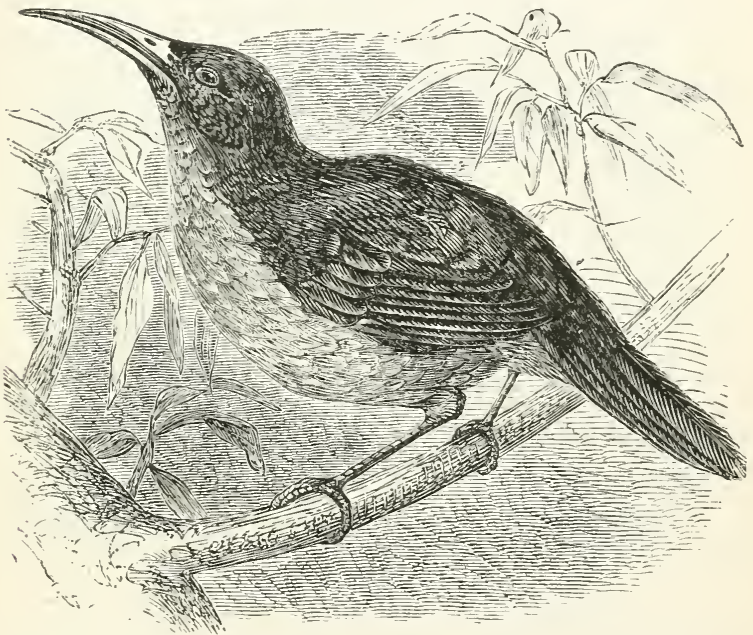

Fig. 63.-THE WHITE-NECKED BABBLER.

(Pomatorhinus albicollis.)

These birds are found in small flocks in the open jungles or in cultivated places round the villages of India and Java. They are generally seen on the ground, more especially near the trunks of large trees, searching for various kinds of seeds and insects : while thus employed, they continually utter a low chattering noise, which is occasionally changed into a low guttural cry; but sometimes they may be 
foumd perched upon a tree, pouring forth a remarkably sweet song. 'Their nest is built in trees at no great elevation; it is composed of small twigs carelessly put together: the female usually deposits fou egess.

The Common Grey Babbler ('Timalia grisea) is one of the commonest birds of the Indian Peninsula, where it may be seen in every garden, and about the hedge-row avenues, trees, and topes * throughout the Carnatic.

They may often be seen in flocks of six, eight, ten, or more. They feed chiefly on the gromnd, to which they may be seen to drop one after the other from the tree they may have perched on, and hop briskly about, picking up various seeds and insects, occasionally seeking the latter from heaps of manure. On being driven from the ground, or leaving it from choice, they fly up successively as they dropped down, and hop and climb upon the large branches of the nearest tree, seldom stopping till they have nearly reached the top or the other side, from which, if still watehed, they fly off one after the other to another tree. These birds have an incessant loud whispering kind of chatter, which they all repeat at once, especially when feeding, or on being observed by any one. The nest of this species is placed in a tree at no great height: it is made of small twigs and roots carelessly put together.

The type of this sub-family is the White-necked Babbler (Pomatorhinus albicollis).

* "The vast numbers of plantations made of mango-trees, especially throughout Bengal, afford ample range to their feathered inhabitants. Some of these plantations, or 'topes,' are of such extent, that an army of ten or twelve thousand men might encamp under shelter. In the hot season, the shade is both pleasant and salutary ; in the cold months, these woods afford shelter by keeping off the bleak winds; and during the rainy portion of the year, those trees which have the thickest foliage throw the water off from certain spots, and render them inhabitable." - Wallace, "Witl Sports of the West." 


\section{$S C B-F A M I L Y I I$.}

\section{ORIOLINA.}

The Orioles.

Gex. Charac.-Bill as long as the head, broad at the base, and compressed on the sides, with the culmen more or less elevated at the base and curred at the tip, which is emarginated; the nostrils lateral, basal, exposed, and partly covered by a membrane; the wings long, with the first three quills equally graduated, and the third or fourth the longest; the tarsi short and strongly scaled; the toes moderate, and the lateral toes usually unequal.

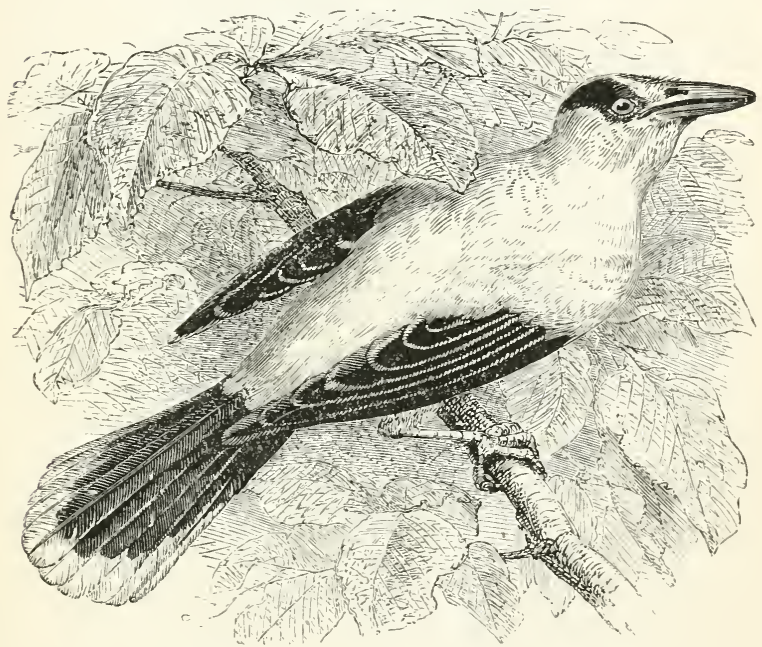

Fig. 64.-THE WEDGE-BILLED ORIOLE.

(Oriolus acrorhynchus.)

These migratory birds are met with in all parts of the world; they are usually found solitary or in pairs, but occasionally in small flocks, frequenting the skirts of forests, gardens, and orchards, in quest of various kinds of fruit and insects. Their flight is undulating, as they fly from one tree to another, to search the foliage for caterpillars. They emit a loud, mellow, plaintive cry. The nest is sometimes saucer- 
shaped, and generally placed in the fork of a bough, to both branches of which it is firmly attached; but in some species is long, pursc-shaped, and pendulous, hanging from the high branches of trees: it is constructed of sheep's wool and long slender. stalks of grass. 'The egg's are usually four or five in number.

The Golden Oriole (Oriolus galbula) is a shy and suspicious bird, haunting lonely groves, and thickets on the skirts of woods, excepting in the fruit season, when it always frequents orchards, to the no small loss of their owners. It is difficult to get near these birds, though they are sometimes approached by the sportsman, under the deception of his imitative whistle; but it requires gieat accuracy both of lips and ear to perform this fiand, for the least mistake or one false note will send the bird off' at once. The food of the Golden Oriole consists of insects and their larve, berries, and fruits, among which figs, grapes, and cherries are favourites. Its whistle is loud and flute-like. Bechstein expresses the sound by the word pullo.

When about to construct its nest, the Golden Oriole selects the forked extremity of the lower branch of some high tree, and wreathing the two forks round with straws, grisses, and other vegetable fibres proper for the purpose, at length connects the two ends; and then, continuing the straws from one side to the other, and crossing and interweaving them, forms a kind of basket, which is afterwards thickened with the stems of the finer grasses, intermixed with mosses and lichens, and lined with feathers and still softer materials. Almost the whole genus of Orioles build pensile nests. The Baltimore Oriole is so solicitous to procure the best materials for this purpose, that in the season for building, the women in the country are under the necessity of narrowly watching their thread that may be out bleaching, and the farmer of protecting his young grafts ; as the "Baltimore," finding the former, and the strings which enwrap the latter, so well adapted to the construction of its nest, frequently carries off' both, or', should the one be too heary, or the other too securely tied, he will tug at them for a considerable time before he gives up the attempt. Skeins 
of silk and hanks of thread are often found after the leaves have fallen, hanging about the nest, but so woven "1]' and entangled as to be quite unreclaimable. Before the introduction of Europeans, no such materials could

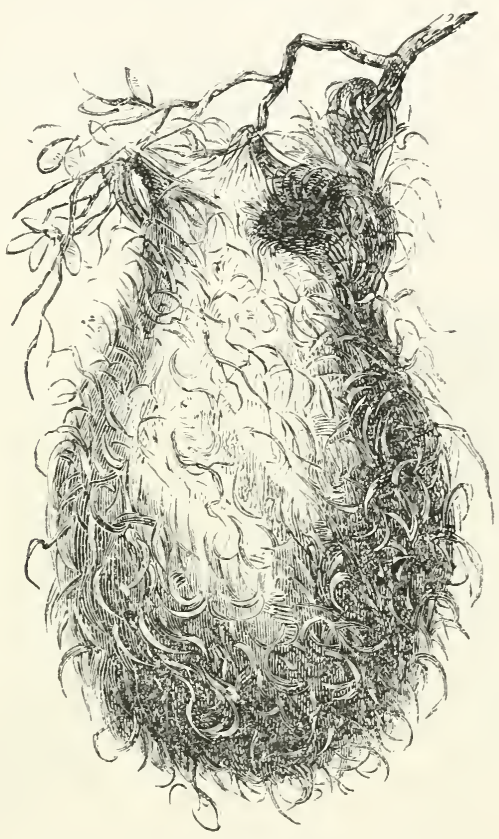

FIG. 65.-XEST OF BALTIMORE ORIOLE.

have been obtained in America; but, with the sagacity of a good architect, the bird has turned them to account, and the strongest and best threads are uniformly found in those parts by which the fabric is supported. The "Baltimore" inhabits North America, from Canada to Mexico, and even as far south as Brazil. Since the streets have been planted with Lombardy poplars, these birds are constantly in the habit of boldly entering the towns, where, amid the noise and tumult of coaches, drays, wheelloarrows, and the din of the multitude, they are heard chanting " their native wood-notes wild." 


\section{Picionotin.e*}

The Bulbuls.

GEx. CHARAC - Bill usually short, with the culmen eurved, and the sides compressed to the tip, which is emarginated; the gape furnished with more or less lengthened bristles; the nostrils hasal, and placed in a short membranous groove; the wings moderate and rounded; the tail long, broad, and generally rounded at the end; the tarsi as long as, or shorter than, the middle toe, and generally covered by an entire seale; the toes moderate, the onter toe sometimes longer than the inner, and united at the base, the hind toe long and strong.

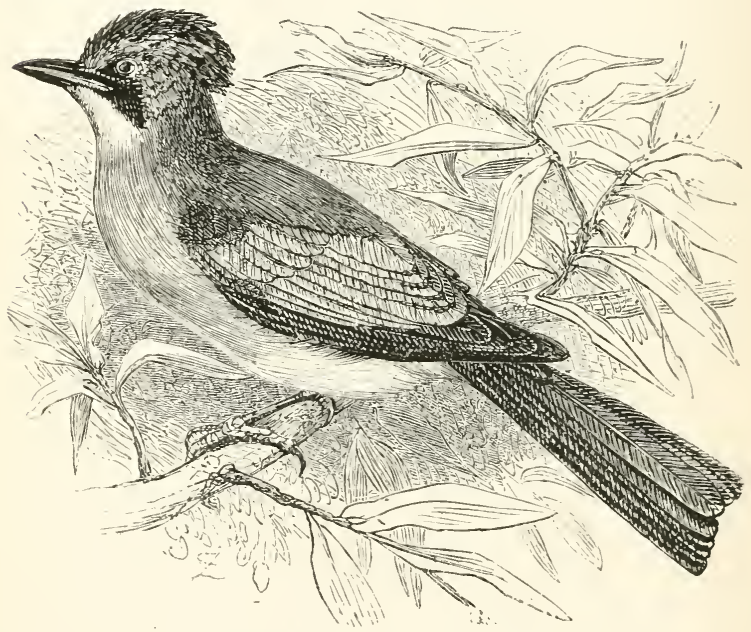

Fig, 66, - THE YELLOW PYCxONoTIS.

\section{(Pycnonotus flevela)}

These birds are found in the southern parts of Europe; also in Africa, Asia, and the Indian Archipelago. They frequent trees in the open country, in pairs or in small parties, and are usually seen hopping from branch to branch in search of fruits, berries, and insects; they sometimes commit great depreda-

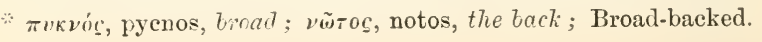


tions in gardens, flying in a direct line from tree to tree, with a quick flapping of the wings, and usually uttering at the same time a whistling note; they have also the power of imitating the cries of variou: birds. The Bulbuls, so well known by repeated references to them in Oriental writings, are many of them possessed of remarkably sweet voices, and are popularly called Nightingales. They are easily tamed, and can be taught to perform many interesting tricks. One species is kept for the purpose of fighting, and is trained with this object, as ganecocks were formerly trained, for the amusement of their cruel owners. In a wild state, they are generally found in the woods and jungles, but are in the habit of visiting gardens for the sake of feeding upon the ripened fruits and insects. They are all exotic birds, and are all natives of the Eastern hemisphere.

The Jocose Bulbul (Pycnonotus jocosus) is an Inrlian species, a constant visitor both in woods and gardens; it is active and lively, always on the move, and contimually warbling its pleasant notes, which are possessed of considerable sweetness. The food of these birds consists principally of fruits and seeds, but they also eat insects. They are great favourites with the Hindoos, who train them to sit upon the hand, and carry them to their bazaars and other places of resort.

The type of this sub-family is-

The Yellow Pycnonotus (Pycronotus flavula). 


\section{FAMILY IJI.}

MÚSCICAPID.E.*

The Flycatchers.

Giv. Charac.-Bill of various lengths, generally broad and depressed at the hase, with the eulmen more or less eurved, and the sides eompressed to the tip, whieh is emarginate; the gape usually furnished with long and strong bristles; wings generally long; tail more or less long, and the outer toe generally united at the base.

The Flycatchers, as their name imports, feer exclusively upon insects, which are captured by their bill during flight; their organization is, therefore, in strict conformity with this habit. The wings are not formed for such rapidity of movement as those of the Swallows, since the Flycatchers do not pursue their prey to any distance; but this deficiency is compensated by a very unusual breadth of the mouth, the sides of which are moreover furnished with long rigid bristles pointing forwards. 'Thus provided, the Flycatcher darts upon an insect with merring certainty, since, if it fails to get a firm hold of it with its beak, the bristles standing out on each side restrain the struggles of its victim, and at the same time prevent either its eyes or face from being injured by the claws or wings of the insect. This structure is slightly developed in several groups of the Warblers, and, indeed, the two families are so closely related, that Ormithologists are perpetually confounding the one with the other. Both are fly-catching families, but with some remarkable differences. The Warblers pursue the chase from tree to tree,-they are continually wandering about and hunting up their game; whereas the true Flycatchers are sedentary; they choose some convenient station, generally near their nest, from which they dart upon their prey, and after every capture almost invariably return to the same perch. The family of the Flycatchers includes the Mourners, the Alectrures, the Tyrants, the Becards, the 'True Flycatchers, and the Greenlets.

* Musca, a fly; capio, to catch. 


\section{QLERULIXE.}

\section{The Mourners.}

Gex. Charac.-Bill rather long, slightly depressed, and broad at the luase, with the culmen gradually curved, and the sides gradually compressed to the tip, which is emarginated; the gape furnished with short bristles; the nostrils oval, and more or less covered by the frontal plumes; the wings more or less long, with the third and fourth quills the longest; the tail long and broad; the tarsi short; the toes rather short, the onter toe the longest and nnited at the base; the claws long, much eurved, and acute.

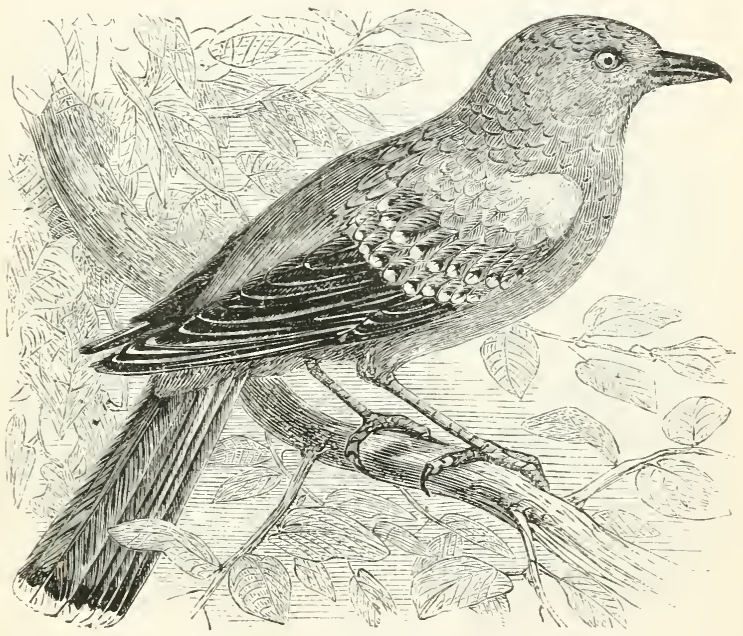

Fig, 67,-THE BRIGHT-SIDED QUERULA.

(Lipangus lateralis.)

These birds inhabit Guiana, where they reside in the woods, and live upon insects and fruits. They are of a lively disposition, and constantly in motion; collecting together in flocks, and seem particularly to cultivate the society of the Toucans, generally flying before these birds and uttering their sharp cry, "pi-an-hau," from which they derive their 
vernacular appellation. Their nest is placed on high inaccessible branches of the forest trees. The female is said to lay four egers.

The type of this sub-family is-

The Bright-sided Querula (Lipangus lateralis).

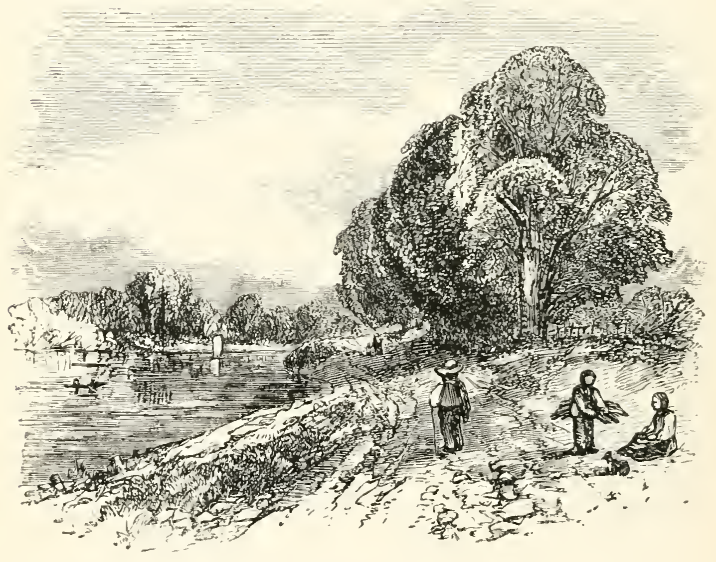




\section{$S U B-H A I L I I I$.}

\section{Alectrurine.*}

The Alectrures.

Gex. Charac.-Bill of rarious lengths, broad at the base and rather depressed, with the culmen sloping and rounded, the sides gradually compressed to the tip, which is emarginated; the gonys long and slightly ascending; the nostrils basal, rounded, and exposed; the wings more or less long; the tail of various lengths and forms; the tarsi more or less long and slender; the toes usually moderate, and armed with long, acute, curved claws.

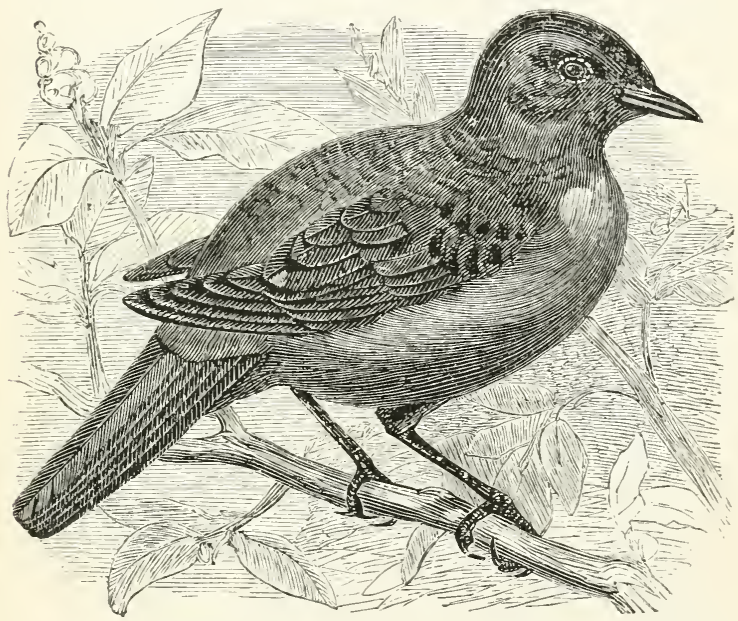

Fig. 68.-THE BLUE-BEAKED ALECTRURE.

(Fluvicola cyanirostris.)

The Cock-tailed Flycatchers are so called from their habit of raising their long and curiously-formed tail, in a manner similar to that of the domestic fowl. They are only found in South America, and are all of small dimensions, their average length being about six inches. There are many species of

* Alector, a poetical name for the barn-door cock; ovjpa, oura, a tail ; Cock-tailed. 
this group, and they differ considerably in theis habits and in the localities they frequent; some are fond of forest lands, perching upon lofty branches, and fluttering from their post in search of passing insects ; while other's shum the wooded districts, and are only found npon low-lying ground, where water is plentiful, and where they find their insect foor upon the leaves and stems of aquatic plants. Among these-

The Pied Alectrurus (Alectrurus tricolor) is remarkable. It is a native of tropical Sonth America, and nearly six inches in length, pied with black and white, but with its back ash-colour. It generally inhabits the vicinity of water, flies lightly, and perches upon rushes and other slender stems, but not upon the branches of trees. The male sometimes rises perpendicularly to a height of thirty or forty feet by rapid beats of its wings; and when thus engaged, he looks more like a large black-andwhite butterfly than a bird.

The typical form of this sub-family is-

The Blue-beaked Alectrure (Fluvicola cyanirostivis). 


\section{SUB-FAMILY III.}

\section{TyRANTINA.}

\section{The Tyrants.}

Gex. Charac.-Bill more or less long, broad, and depressed at the base, and the sides gradually compressed to the tip, which is hooked and emarginated; the gape sometimes furnished with long and strong bristles; the nostrils basal, with the opening small, usually rounded, and hidden by the projecting feathers and bristles; the wings more or less long, and generally pointed; the tail moderate, and sometimes emarginated; the tarsi short and corered with broad scales; the toes generally rather short, the onter longer than the inner, and united at the base, the hind toe moderate and padded beneath; the claws rather short, and very acute.

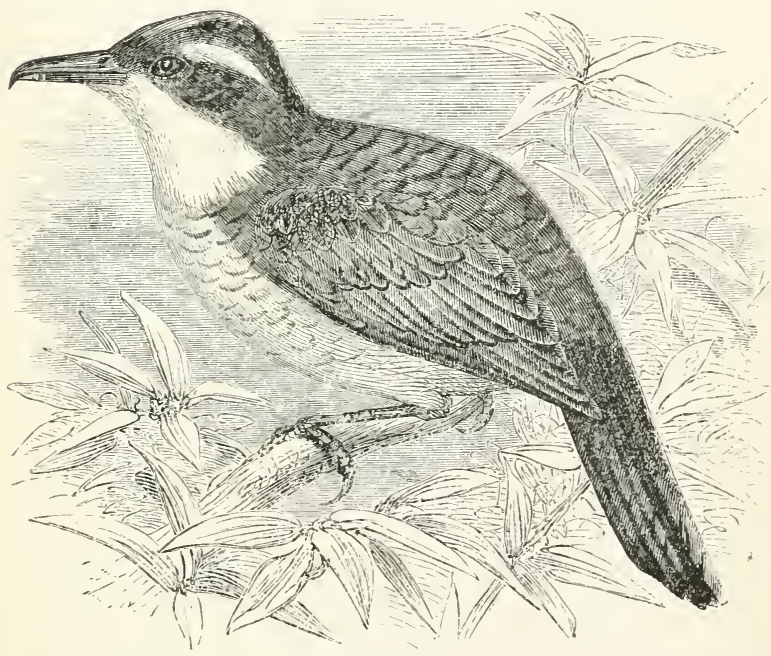

Fig. 69 -THE LizARD-EATEr.

(Saurophagus lictor.)

The birds which constitute the typical sub-family of the Flycatchers are generally seen sitting on trees, or on some prominent place, watching the approach of any insect rover, in pursuit of which they make a sweep, and having seized it, return to the same perch. It is not uncommon to see them 
take post on a twig overhanging water, into which they will dive repeatedly, and then remain for some time quiet to dry and dress their plumage in the sun. 'They also prey on small fish and reptiles, and occasionally feed on berries. Their flight is quick and rapid, and they may sometimes be observed hovering over the fields and rivers, as if watching for their food, which, having espied, they secure by a sudden swoop. Some of the species are remarkable for their courage, especially during the breeding season. Should a crow, hawk, or even an eagle, approach their nest, they launch into the air, mount to a considerable height above him, and dart down on his back, sometimes to the great annoyance of the intruder, who endeavours by various evolutions to rid himself of his Lilliputian adversary. The nest is built in trees, at no great height from the ground; exteriorly it is composed of twigs, well woven together with tow and wool, and lined with dry fibres, grass, and horsehair. Some species collect together loose hay, feathers of birds, hog's bristles, pieces of cast-off snake's skins, and dog's hair, in the hollow of a tree. The egg's are usually four or five in number.

\section{The hero of this sub-family-}

The Tyrant Flycatcher (Tyrannus intrepidus), called also the King-bird, is an example of an American group of Flycatchers in which the bill is large and strong, approximating that of the Shrike. The names of ling and tyrant bestowed upon this bird refer to the extraordinary authority which he arrogates to himself during the breeding season, over all the rest of the feathered creation. "At this period," says Wilson, " his extreme affection for his mate, and for his nest and young, makes him suspicious of every bird that happens to pass near his residence, so that he attacks, without discrimination, every intruder. In the months of May, June, and part of July, his life is one continued scene of broils and battles, in which, however, he generally comes off conqueror. Hawks and Crows, the Bald Eagle and the Great Black Eagle, all equally 
dread an encounter with this dauntless little champion, who, as soon as he perceives even one of these last approaching, launches out into the air to meet him, mounts to a considerable height above him, and darts down on his back, sometimes fixing there, to the great annoyance of his sovereign, who, if no convenient retreat or restingplace be near, endeavours in vain to rid himself of his merciless adversary. He teases the Eagle incessantly, sweeps upon him from right to left, remounts, that he may descend on his back with greater violence, all the while keeping up a shrill and rapid twittering, and continuing the attack, sometimes for more than a mile, till he is relieved by some other of his tribe, equally eager for the contest." This quarrelsome demeanour is laid aside by the King-bird at the close of the breeding season, and he then becomes a peaceable denizen of the wood or of the orchard. The nest of the Tyrant Flycatcher is built on the branch of a tree, and composed of small $t$ wigs and dried flowers, interwoven with hemp and wool, and made very compact : the lining consists of fine grass and horsehair. The eggs, which are usually five in number, are cream-coloured, with a few large purple spots, and smatl pale-brown markings, chiefly at the larger end. The only song of this bird is a shrill twitter. His food consists principally of insects, which he captures, sometimes by flying steadily orer the fields, and sometimes in the manner of the ordinary Flycatcher, by taking his position on the summit of a post or rail, and sweeping off after them as they pass.

The typical form of this group of birds is-

The Lizard-eater (Saurophagus lictor). 


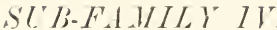

TITYRINE**

The Becards.

GEx. CHARAC,-Bill generally short and broad at the base, with the eulmen slightly depressed, rounded, and curred, and the sides suddenly compressed to the tip, which is emarginated; the nostrils lateral, rounded, and exposed; the wings long and pointed; the tail short and rounded on the sides; the tarsi short, and cosered in front with narrow seales; the toes moderate, with the lateral ones nearly equal; the claws morlerate, curred, and aente.

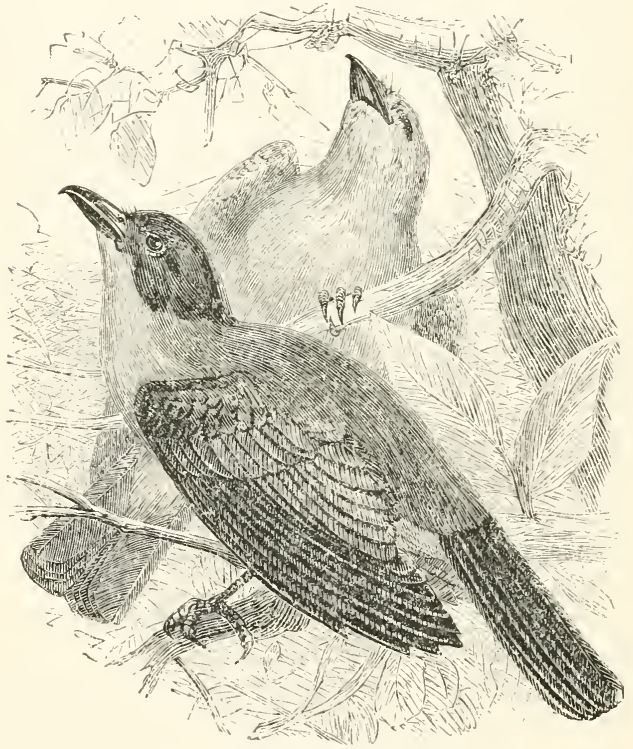

FIG. 70.-THE WHITE-BACKED TITYRA.

(Tityra leuconotus.)

The birds composing this sub-family are found in the warmer parts of South America and the islands of the West Indies. They migrate from place to

* "Tityre, tu patulæ recubans sub tegmine fagi,"in allusion to their sylvan habits. 
place, and are usually seen perched upon the highest branches of the lofty trees of the primeval forests. Insects form their chief subsistence; these they capture by short flights, and return again to the same perch, to watch for others passing within a certain range.

We extract from Mr. Gosse's beautiful work on the Birds of Jamaica the following account of-

The White-backed Tityra (Tityra leuconotus). "This species of Tityra is not uncommon in the mountain districts of Jamaica, where, from the remarkable diversity in the appearance of the male and female, they are distinguished by separate local names. The black male is known by the feminine appellation of Judy, while the chestnut-headed female receives the masculine soubriquet of Mountain Dick. Though more frequently seen at a considerable elevation from the sea, we occasionally meet with these birds in the lowlands; they are, however, rather recluse, affecting woods and lonely places. Here, as they hop from one twig to another, or sit hidden in the foliage of a thick tree, they utter a rapid and not unmusical succession of notes, as if attempting to compress them all into one. The notes are occasionally poured forth in the air, as the bird flits from tree to tree, but are very frequently heard from the male and female alternately, seated on two trees, perhaps on opposite sides of the road, thus :- The Mountain Dick calls, and the Judy immediately answers; then a little pause,-another call from Mountain Dick, and an instant answer from Judy, until, after a succession of such salutations, the Judy gallantly yields the point, and flies over to the other tree to join his friend. This species is fierce and bold in self-defence. When shot, and but slightly wounded, it would make vigorous efforts to escape by running; but on being taken in the hand, and held by the legs, it would elevate the crown feathers, turn the head up, and bite fiercely at the fingers, pinching the flesh with all its force; striving, at the same time, to clutch with its claws, and screaming vociferously. It does not appear to pursue other birds, after the manner of the true Tyrants, nor capture insects in the air, notwithstanding that the gape is defended by 
stifl bristles. Stationary insects are usually the contents of its stomach, particularly the large field-bugs (Pentatoma), and caterpillars, and sometimes the eggs of insects. In the winter, the berries of the Bursera, or Tropic Birch, constitute a large portion of its food. In A pril, the Judy hegins to arrange the domestic economy of the season, and if the cradle of his young be not so elaborate a structure as some others, it makes up in quantity what it lacks in quality. On a branch of a small cedar that overhangs the high road," says Mr. Gosse, "I had noticed, early in June, what appeared to be a heap of straw tossed up by a fork and lodged there, which the action of the weather had in some degree smoothed at the top, the ends trailing downwards. One day, however, as I was looking at it, I saw the brown female of this species emerge from the bottom, and presently return, entering at a narrow hole beneath. As it was not more than twelve feet from the gromnd, I immediately sent my lads to climb the tree and cut the branch, which they accordingly brought me, with the huge nest attached. The boys reported that it was empty, and that it had four entrances; but on examination, I found that every one of these was merely a hollow in the immense walls, produced by the receding of we part of the loose materials from another. While they held it up in the position it had occupied on the tree, I searched beneath for the true entrance, which, when I had found it, I had much difficulty to fiud again, so concealed was it among the draggling ends of the mass. On inserting my finger, however, I felt the soft and warm plumage of young burds, and pulled out three almost fully fledged." The nest was a flattened oblong mass ; flattened on two sides, measuring in height about two feet and a half, though the ends limng down to the length of four feet; in width more than two feet, and in thickness one foot. It was composed almost entirely of the stems and tendrils of passion-flowers, mixed, howerer, and that all through the structure, with bright yellow silky spiders' nests, and the downy filaments of some cottony herbs. The cavity was not larger than a man's two fists, and was not in any way lined. It descended within the entrance, although the latter faced the groumd. 


\section{$S U B-F A M L Y Y$.}

MísCiCAPIN.E.

The Flycatchers Proper.

Gex. Charac.-Bill moderate, broad at the base and narrowing to the tip, which is emarginated; the culmen more or less depressed and curred at the end; the gonys usually long and ascending, and the gape furnished with bristles; the wings generally long, and more or less pointed; the tarsi usually short and slender, and the toes short, with the outer toe longer than the inner one, the hind toe prominent; and the claws moderate, compressed, and acute.

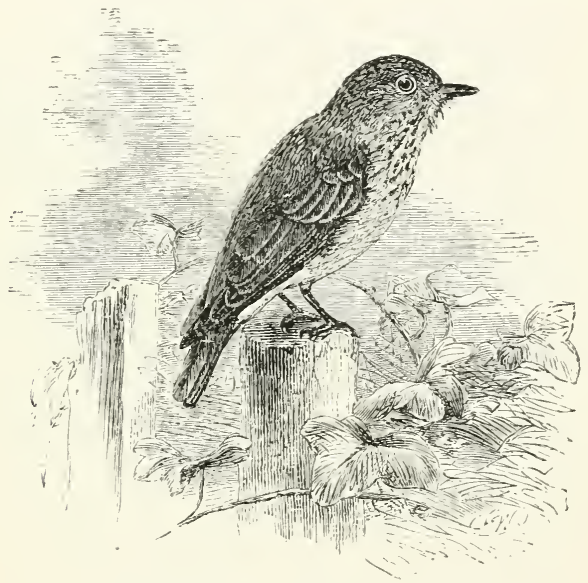

Fig. 71.-THE SPOTted FLYCATChER.

(Muscicapa grisola.)

The true Flycatchers are found in most parts of the Old Continent. They appear in the temperate regions during the winter, and retire to the colder climates during the summer, mostly frequenting wooded districts, cultivated grounds, gardens, and orchards. Their food consists entirely of insects, which they watch for, seated on a decaying bough or post, and catch on the wing, when they approach within a certain distance. The nest is formed in the forks of branches, or in the holes of trees. It is 
composed of leaves, moss, or hay, and small twigs, lined with hair and feathers. 'The female lays fou' or five eggs. These birds are of small size, and weak in their general conformation; none are so large as a sparrow. Their bill is flattened, and their whole structure light and delicate. 'Their colouring, though elegant, is devoid of vivid tints.

\section{We select for description-}

The Spotted Flycatcher (Muscicapa grisola). This pretty little bird is one of our summer visitors, arriving in our island in May, and departing at the close of September. The Flycatcher is retired in its halits, frequenting embowered retreats, shady gardens, orchards and groves, where the foliage affords it concealment; not, indeed, that it is timid, for, if not rudely disturbed, it will allow itself to be closely watched during the performance of its aërial evolutions in pursuit of its insect fool. It generally chooses for its perch and observatory, the hough of a fruit-tree, or one of the lower branches of the elm; whence it takes short, abrupt, circling flights, returning to the same, or to an adjacent twig; darting in ehase of its prey at almost regular intervals for half an hour together, and returning after each flight to the same post of observation. The note of the Flycatcher is a weak chirp, which is seldom uttered after the appearance of the young brood. Its nest is built in various situations, as convenience may dictate; sometimes between the branch of a trained fruit-tree and the wall, or in holes in the wall, hidden by foliage. It will also build in the holes of aged trees, or upon the ends of beams in outhouses, or, in short, in any appropriate place of concealment. The eggs are five in number, of a grevish-white, marked with pale orange-brown spots. When the young are able to fly, the parents lead them to some branch, and supply them with food; but they soon learn to chase their own prey, and become expert and quick in the pursuit. Penmant and other writers state that the Flycatcher is partial to cherries and various fruits; this is unquestionably a mistake; soft insects are its only food; but gardener's seem to think that all birds devour fruit, and frequent their gardens only for that purpose. 


\section{SUB-FAMILY VI.}

\section{Vireonis.e.}

The Greenlets.

Gev. Charac.-Bill rather short and straight, with the culmen slightly eurved, and the sides compressed to the tip, which is curved and emarginated; the gonys long and ascending; the gape furnished with short weak bristles; the nostrils rounded and exposed; the wings rather long and pointed; the tail moderate; the tarsi moderate, and corered with broad scales; the toes moderate, the lateral ones equal, and united at the base, especially the outer.

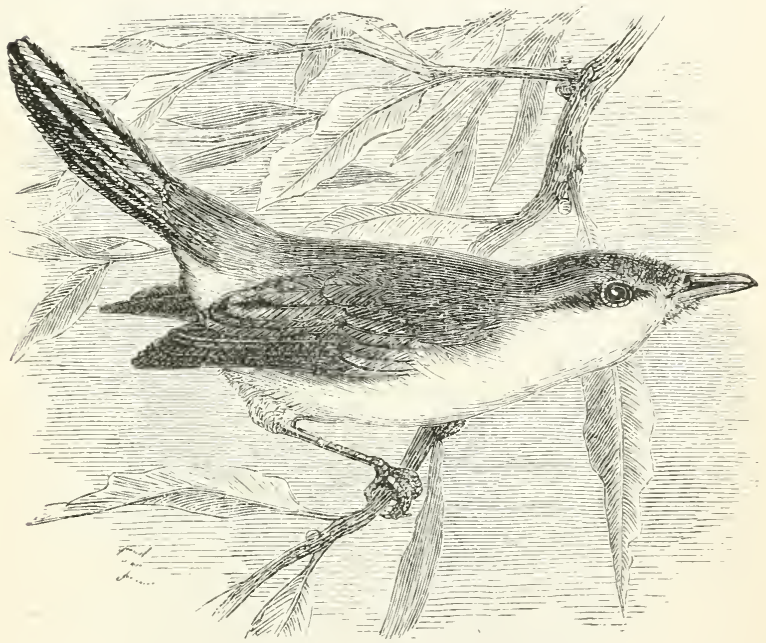

Fig. $72-T H E$ GREENLET.

(Tireo virescens.)

The Greenlets are so called on account of the constant presence of green on some part of their plumage. They are all little birds, and are confined to the New World, inhabiting the United States, Brazil, Guiana, and the West India islands. They are mostly insect-feeders, but will vary their diet with fruits, berries, and other vegetable food. Many species are known, and some are remarkable for 
their eccentric habits and curious mode of nesting. Some of them build a neat nest, in the form of an inverted cone, suspended by the upper edge. The materials of which the walls are composed are fragments of rotten wood, dry stalks, and similar articles; and it is remarkable that amongst these, pieces of paper are always found. Wilson says that the bird exhibits so great a predilection for fragments of newspapers, that some of his friends gave it the name of "The Politician." The materials of this pretty nest are held together with the silk of caterpillar's, and the lining consists of fine dry grass and hair.

The typical species is-

The Greenlet (Vireo virescens).

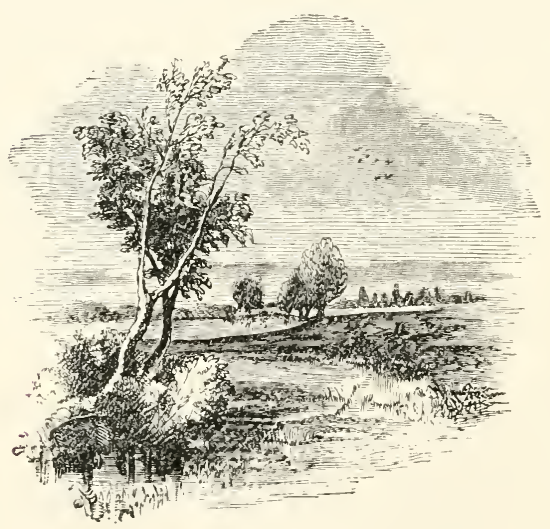




\section{FAMILY IV.}

\section{Ajpelin.e.}

\section{The Chatterers.}

GEx. CHARAC.-Bill moderate, more or less broad at the base and more or less depressed, with the sides gradually compressed to the tip, which is emarginated; the wings long, and generally rounded; the tail moderate, and usually eren at the end the tarsi generally short and slender; the toes moderate, with the outer more or less united to the base of the middle one; the claws short and curred.

In the members of this family, the notches, characteristic of the dentirostral birds, though small, are always distinctly to be seen on each side of the tip of the bill, which is rather short, broad, and depressed at the base, so that, when viewed from abore, it is nearly triangular. The wings are generally long and the tail short; the feet are slender, and the toes terminated by curved acute claws grooved along their lower surface. Most of them are met with in the warmer latitudes, where they feed upon insects and fruits. Their plumage is often rery beantiful and brilliant in its colouring.

The Chatterers are remarkable for the width of their gape, which, in many, is nearly as wide as that of a Goatsucker: they live almost entirely on soft berries and small fruits, which, being swallowed whole, require a rery wide passage down the throat. They are perpetually hopping about among the branches of frut-bearing trees, and seem to know, by wonderful instinct, the period when each species yields its fruit. They nerer walk upon the ground, the structure of their feet being only adapted for grasping boughs. These birds are most of them confined to the American continent; many of them are remarkable for the splendid tints of azure and purple with which, in the pairing season, the males are bedizened, but during the rest of the year the two sexes are equally clad in grey or brown plumage.

To this family belong the Thick-heads, the Manakins, the Chatterers proper, the Caterpillar-eater's, and the Drongo Shrikes. 


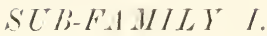

\section{PaChycephaline.*}

The Thick-tecads.

Gex. Charac. - Bill broad at the hase and compressed to the tip, which is emarginated; the gape furnished with a few slender bristles; the wings moderate and more or less rounded; the tarsi lengthened and slender; the toes long, with the outer one slightly united at the base to the middle one; the elaws short and eurved.

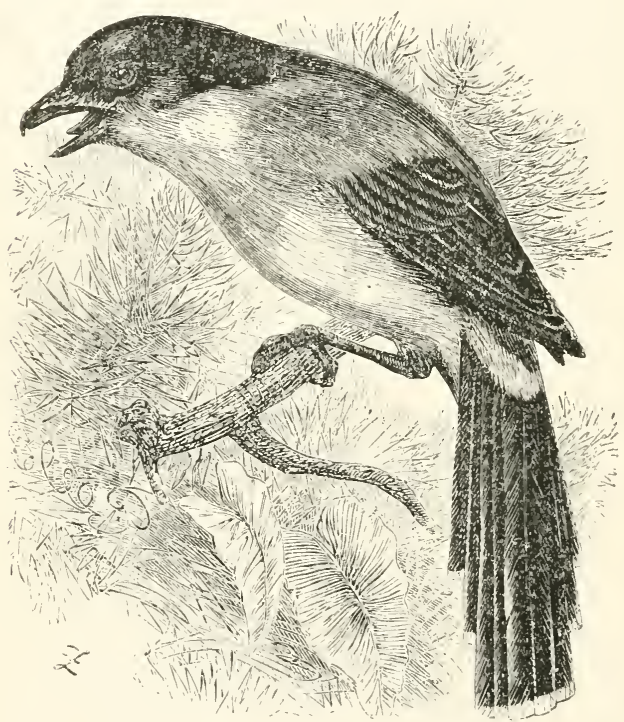

Fig. 73.-THE RED-BREASTED THICK-HEAD.

(Pteruthius mifiventris.)

Many of these birds are peculiar to Australia; some are met with in the East Indies and in South America; others in New Guinea and the islands of the South Seas. They are generally observed, solitary or in pairs, creeping and hopping among

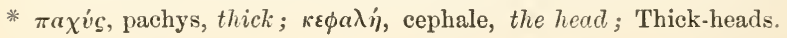


the foliage of the upper part of lofty trees in thick forests, or on shrubs. Their food consists of berries and of the larve of insects. The nest is formed on the small horizontal branches of large trees or in bushes, and is composed of interwoven twigs or fibrous roots. The eggs are three or more in number. Some species excavate a hole just large enough to admit the passage of their body, extending two or three feet in a nearly horizontal direction: at the end of this tunnel a chamber is formed, wherein the nest is constructed. In such cases, the nest itself is a beautiful structure, formed of strips of the inner bark of Eucalypti, and lined with finer fibres of the same or similar material.

\section{As an example of the group we select-}

\section{The Yellow-breasted Thick-head (Pachycephala gut-} turulis), an inhabitant of South Australia. "This species is rather abundantly dispersed over the forests of Eucalypti and the belts of Acacia, among the flowering branches of which the male displays himself to the greatest advantage, and shows off his rich yellow breast, as if desirous of outvying the beantiful blossoms with which he is surrounded. Its principal food consists of insects of various genera, which are sought for and captured among the flower's and leaves as well as on the ground. It is generally met with in pairs, but the males are more shy than the females. It flies in short and sudden starts, and seldom mounts far above the tops of the trees. The voice of the male is a single note seven or eight times repeated, and terminating with a sharp 'igher note, much resembling the smack of a whip. That of the female is very different, being a series of running alf-notes, forming a rather plaintive tune."-Gould.

The typical form is -

The Red-breasted Thick-head (Pteruthius rufiventris). 
Piprine.

The Manalins.

Gen. CuARAc.-Bill moderate, or short, and rather depressed, with the base very broad; the enlmen eurved, and the sides eompressed to the tip, which is enarginated; the nostrils lateral, and more or less hidden by the projecting plumes; the wings moderate and pointed; tail very short and even; tarsi more or less long and rather slender, with the onter toe united to beyond the seeond joint of the middle toe, and the inner slightly united.

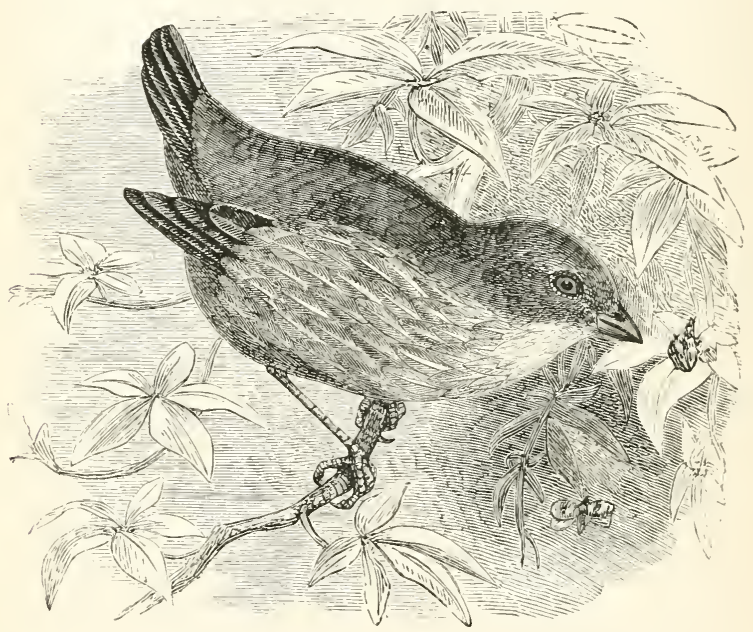

Fig. 74.-THE STREAKED MANAKIN.

(Pipra striolata.)

Most of these birds are found in the tropical regions of America, or the forests of Sumatra and singapore. They inhabit hot humid woods, in the skirts of which they live in flocks, searching for insects and small fruits. They are very lively and restless, and are frequently seen on the ground or sometimes perched on trees. The note of one species has been compared to the cracking of a nut. 
Some of them dwell in extensive woods, or in precipitous places formed by torrents; these are most usually seen on the fallen trunks of trees that have been rooted up by hurricanes. Their flight is low, and they seem restless, continually making quick and fluttering movements while on the branches. Their food consists principally of the fruits of a species of laurel and other shrubs. Their note is a hoarse repetition of the syllable "ket, ket, ket," forcibly uttered in a very sharp tone. The female builds her nest in a sinuosity of the rocks, sheltering it under some projecting point. It is properly of a circular form, but occasionally the shape is varied with the windings of the rocks. The nest is composed of a tissue of the fibres of roots plastered externally with moistened earth, and lined internally with fine vegetable fibres and hair. 'The young do not quit the nest until nearly full grown.

The type of this race is-

The Streaked IIanakin (Pipra striolate). 


\section{SUIB-FAHILI III.}

Ampeline.

The Chatterers proper.

Gex. Charac.-Bill more or less long, with the gape very wide, the eulmen rather depressed and eurved to the tip, which is emarginated, the sides compressed towards the apex; the gonys long and ascending; the nostrils lateral, mostly exposed, and somewhat oval; the wings moderate, with the second to the fourth quills generally the longest; the tail generally short and even; the tarsi mostly short; and the toes long, the outer toe slightly united at the base.

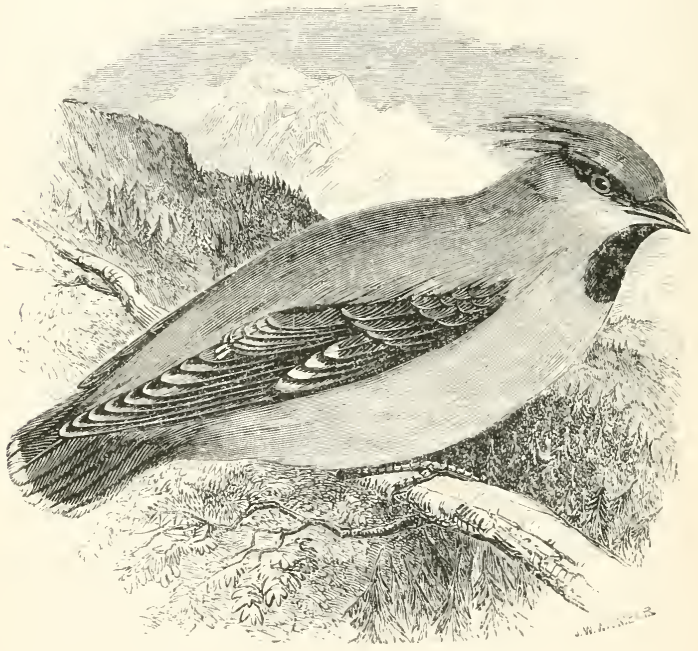

Fig, 75.-THE BOHEMIAX CHATTERER.

(Ampelis garrula.)

The birds composing this sub-family inhabit the northern parts of Europe, Asia, and North America, and are migratory, according to the seasons, making their appearance in more temperate latitudes on the approach of winter, and returning to their northern haunts in the summer. They are usually met with in small parties, but sometimes assemble in large 
flocks, consisting of many hundreds, especially when on their migrations. Their food consists of various kinds of fruit; and as the fruits become scarce they feed on insects, capturing them in the same way as the Flycatchers. Their nest is placed in the fork of a tree some few feet from the ground; it is composed of coarse grass, lined within with fine materials, on which are deposited three or four eggrs.

The only European example, and the type of the race, is-

The Bohemian or Wandering Wax-wing (Ampelis garrula), so called on account of its migrations. In its habits, the Wax-wing resembles the Tits, and it feeds on fruits, berries, and seeds, as well as insects. Its most distinctive feature, however, is, that in the adult bird four of the secondary quills, and sereral of the tertials, are terminated by flat palettes, resembling red sealingwax, attached to the extremity of the shaft of each feather; and from this circumstance it has receiver the appropriate name of Wax-wing.

The Wax-wings are gregarious birds, assembling in large flocks, and congregating so closely together that numbers have been killed by the discharge of a single gun. "Near Christiania, in Norway," writes a correspondent to the Field newspaper, "there have been for the last month immense flocks of Wax-wing Chatterers quite close to the house. They are not at all shy, allowing a person to approach easily within shot. They come into all the gardens round, by thousands, in quest of the berries of a tree, which I believe is the mountain ash. Some of the flocks contained several thousands, but are now diminished in numbers, on account of some having gone southwards, and others having been killed. They make a great noise when sitting together, as they do in large numbers. On one occasion I killed twenty at one shot, at another eighteen, and at another seventeen. So exactly do the red ornaments of the wings and tail resemble sealing-wax, that it is difficult to persuade an unaccustomed observer that they are the gifts of nature, and not rather purposely attached to the bird by some one desirous to impose on his eredulity." 


\section{SUB-FAMILY IV.}

\section{CAMPEPHAGine.*}

The Caterpillar-eaters.

GEN. Cinarac. - Bill short aud rather depressed, with the eulmen slightly eurved, and the sides compressed to the tip, which is emarginated, and sometimes hooked; the gape furnished with a few sbort bristles; the nostrils basal, rounded, and more or less exposed; the wings moderate, with the third, fourth, and fifth quills the longest; the tail long and rounded on the sides; the tarsi sbort and covered with transverse scales; the toes generally short, and the lateral ones unequal; the claws moderate, compressed, and much eurved.

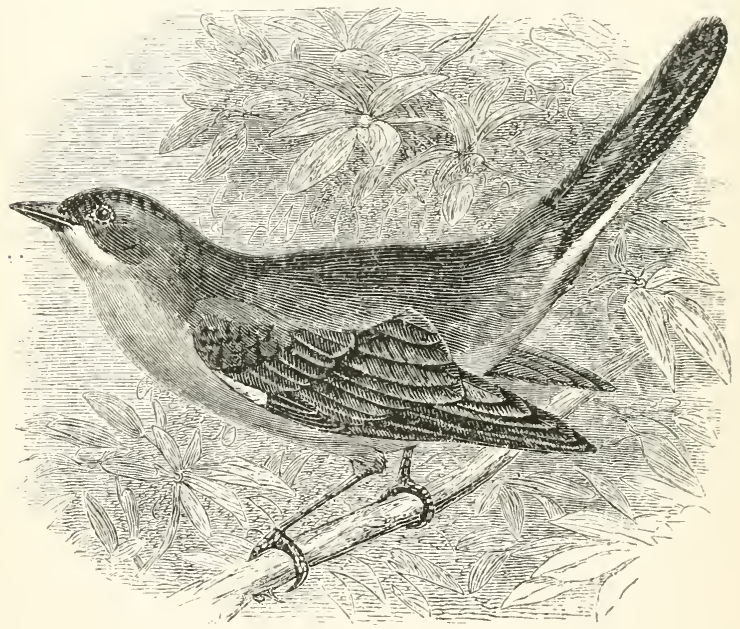

Fig. 76.-The bRaceleted Caterpillar-eater.

(Ptilogonys armillatus.)

These birds are found in Africa and Australia, as well as in India and the neighbouring islands. They are shy and wary, and are usually seen upon trees slowly and carefully searching among the foliage and examining the leaves for all kinds of

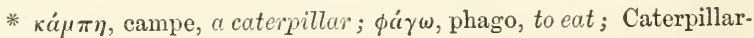
eater. 
soft insects, such as caterpillars, mantides, and grasshoppers; moreover, they occasionally feed on the fruit of the banyan tree. They continue their search, hopping from branch to branch, until every bough has been carefully inspected, when they fly off together to another tree. Their flight is undulating, powerful, and performed with few vibrations of the wings. 'They rarely fly, except to pass from one portion of the forest to another, or occasionally to take insects on the wing as they pass within a certain distance from them when perched. Their eggrs are usually two in number, and are deposited in a nest placed on the fork of a bough. It is composed of small dead twigs firmly matted together with a very fine white downy substance like a cobweb, intermixed with a species of lichen, and is extremely shallow.

The typical species is-

The Braceleted Caterpillar-eater (Ptilogonys armillatus). 


\section{SUB-FALILY T.}

DICRURINE.*

The Drongo shrities.

Gen. Charac,-Bill of varions lengths, l,road at the base, with the culmen more or less keeled and eurved to the tip, the sides compressed; the nost rils usually eoneealed by short compact plumes, and the gape furnished with strong bristles; the wings long, with the fourth and fifth quills generally the longest; the tarsi and toes short, and st rongly scutellated.

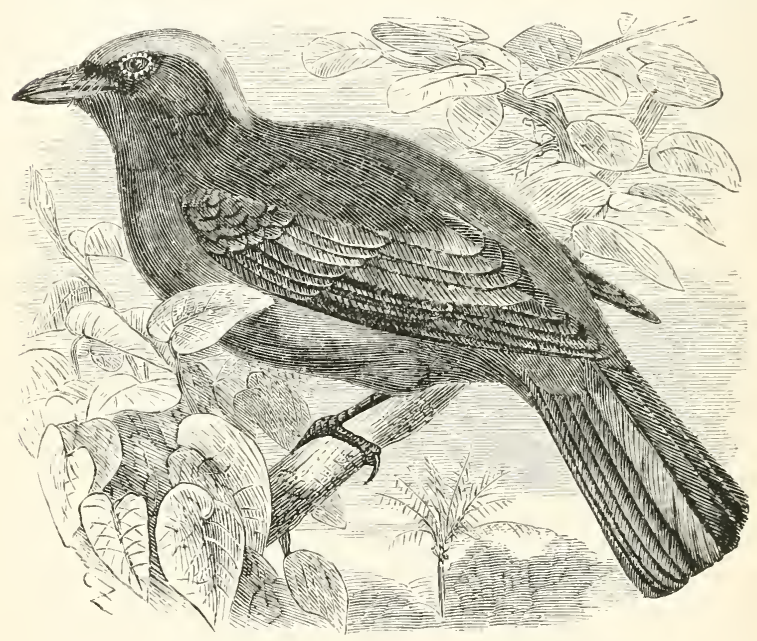

Fig. 77.-THE AZURE-BREASTED IRENA.

(Irena cyanogaster.)

The Drongos are inhabitants of India, its Archipelago, and the continent of Africa. They are usually seen singly, in pairs, or in small parties, perched on some elevated spot or upon the backs of cattle when grazing. From these stations they watch passing insects, and when they observe one, give rapid chase after it, sometimes returning to

* òic, dis, double; ov̉óa, oura, a tail ; Having a forked tail. 
the same perch to await the approach of other victims. Some are said to hunt in small parties, though at a distance from each other; others fly from tree to tree at a great elevation, making swoops: after insects in their progress. They show much courage in attacking birds far superior to themselves in size, and their great speed of flight enables them to attack and retreat with ease and safety. Some species, when about to seek a new locality, congregate in hundreds during the evening, and all roost together in bamboo and other thick jungles. All kinds of insects fall a prey to their beaks. Their nest is placed in the fork of a tree. It is composed of roots and twigs carelessly put together, and not lined interiorly. The eggs are about three in number.

The typical species is-

The Azure-breasted Irena (Irena cyanogaster). 


\section{FAMILY V.}

LANIIDA.

The Butcher-birds.

Gix. CHARAC.-Bill more or less long, strong, and straight, with the culmen curved, and the sides compressed to the tip, which is generally hooked and emarginated; the gonys long and aseending; the gape sometimes furnished with short bristles; wings moderate, rounded, or pointed; tail more or less lengthened, and usually rounded; the tarsi strong, and more or less long; toes moderate, with the hind toe long and broadly padded beneath; the claws long, eurved, and very acute.

The majority of the species belonging to this family are inhabitants of the Eastern hemisphere, a few only being found in the New World. Their food consists of insects, worms, and mollusca; but many of them, not content with such humble fare, kill and devour the smaller birds and quadrupeds. In fact, the hooked tip of the bill, the strong tooth-like fangs with which the upper mandible is armed, and the curved and acute claws, seem at once to indicate that the character of these birds is more predacious than that of their nearest allies. By Limmeus, and several of the older naturalists, they were classed with the Accipitres : indeed the Shrikes almost equal the Falcons in ferocity and daring. From their perch upon a bough they will suddenly dart upon their prey, which they kill with their beak, not with their feet. They have, moreover, the singular habit of impaling their victims upon a thorn, or hanging up small birds by the tendons of their wing : hence they have received the name of "Butcher-birds." They resemble the Thrushes, with which they insensibly blend, and, like them, are generally met with in woods and coppices. These birds live in companies, fly with unequal and precipitate flight, uttering sharp cries; they construct their nests with much neatness upon trees, and lay five or six eggs. They possess the faculty of accurately imitating the notes of the birds living in their vicinity.

This family comprehends the Butcher-birds and the Bush Shrikes. 


\section{SITB-FAULLYI.}

\section{LANIINE.}

\section{The Butcher-birds proper.}

Gex. Charac. - Bill moderate and strong, with the culmen eurred, and the sides generally much compressed near the tip, which is mostly hooked and emarginated; the gape sometimes furuished with short bristles; the nostrils lateral and rounded; the wings more or less long, and generally rounded; the tail of various lengths, and usually rounded; the tarsi rather short and strong; the toes rather long and strong, with the lateral ones generally unequal, the outer toe the longest, and united at its base, the hind toe long and broadly padded.

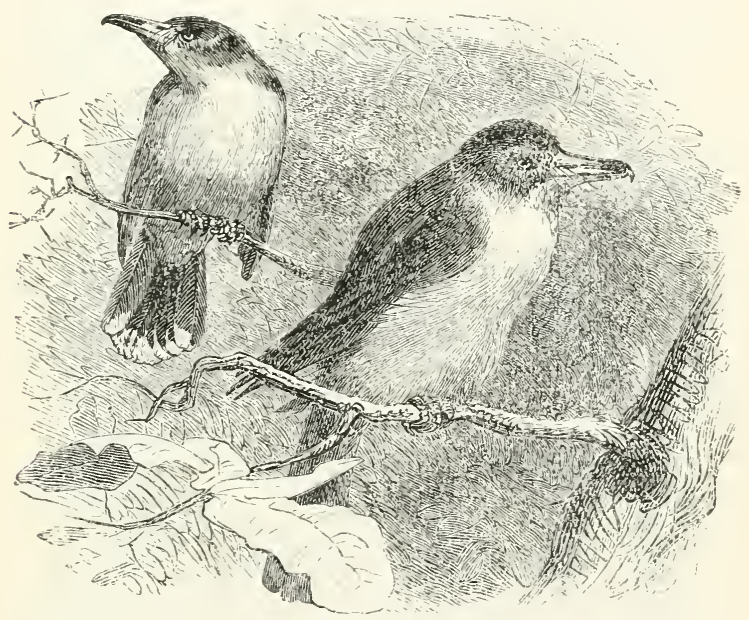

FiG. 78 -THE LONG.THHED BUTCHER BIRD.

(Lanius collurio.)

The Butcher-birds are found throughout Europe, Asia, Africa, and America. They are usually seen singly or in pairs, in woody or in bushy places. Their food consists of various kinds of insects, which they usually seize on the ground or from among the foliage, and even occasionally pursue while on the wing; they also attack lizards, small birds, and quadrupeds, which they destroy by strangulation. 
When life is extinct, they fix their prey on a thorn while feeding on it. 'Their comrage is very great, and prompts them to attack birds of far superior size, should they approach their haunts. Their flight is undulating, usually performed by jerks ; and while perched on a branch their tail is in constant motion. Their nest is placed in trees or bushes, and is composed of moss, wool, and dry grass, lined internally with hair. The eggs are five or seven in number.

The type of this sub-family is-

The Long-tailed Butcher-bird (Lanius collurio).

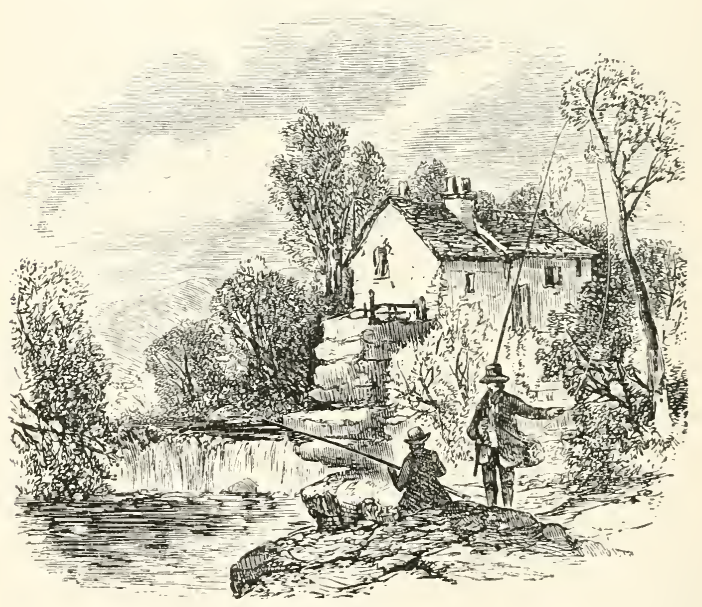




\section{$S U B-F A U I L Y I I$.}

Thampophimine.

The Bush Shrilies.

Gex. CHarac.-Bill more or less lengthened, compressed on the sides; the culmen straight but arched, hooked, and emarginated at the tip ; the gape more or less bristled; the nostrils basal, lateral, and mostly rounded; the wings moderate, and more or less rounded; the tail usually long and rounded; the tarsi moderate, and covered with broad scales; the toes moderate, the lateral ones mequal, and the outer toe united to the middle one at the lase.

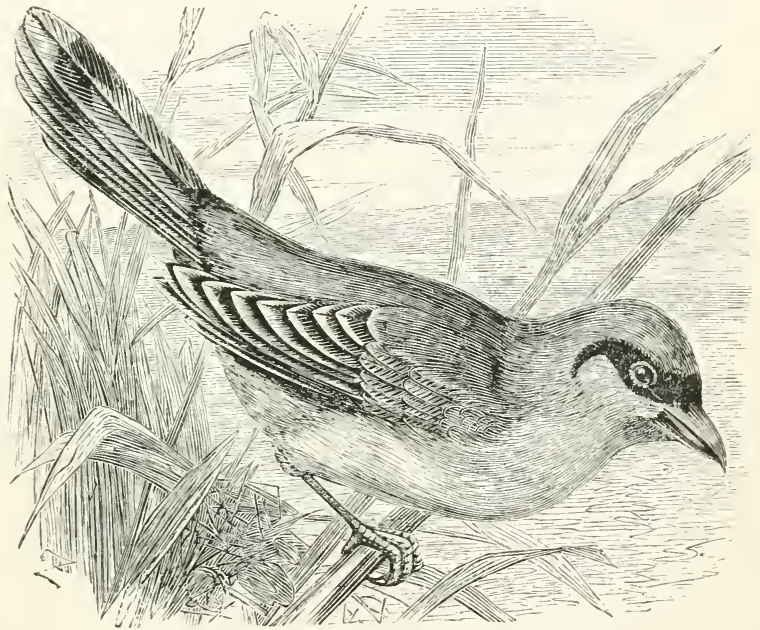

FIG. 79.-THE MANY-COLOURED BUSH SHRIKE.

(Laniarius multicolor.)

Most of these birds inhabit the tropical parts of America, yet a few of the species extend northwards as far as Canada. They usually reside in the forests, searching the foliage of the low bushes and the trunks of trees for the Coleopterous and other insects upon which they subsist. Their nests are usually placed in thick bushes, at no great distance from the ground; the exterior is frequently made of small spinous 
branches, the interior lined with hair. Their egg's vary from two to five in number.

One of the best-known species is-

The Spotted Bush Shrike (Thamnophilus navius), sometimes called Battara, from the name applied to them in their native country. The Spotted Battara inhabits Cayenne and Brazil, dwelling among the bushes, usually in prirs, and exhibits much familiarity, often approaching the dwellings of men. The food of this, and other species, consists of insects and their larvæ, which they generally capture among the branches: they rarely descend to the ground.

The typical form is-

The Many-coloured Bush Shrike (Laniarius multicolos'). 


\section{T R I B E I T.}

\section{Conirostres.}

THIs numerous division comprehends many wellknown families, distinguished by their short, thick, conical bill, which is stronger and stouter in proportion as they feed more exclusively on seeds.* They are most numerous in temperate and cold climates, of which they are generally permanent inhabitants.

The bill of the conirostral birds varies a good deal in length and thickness, and is sometimes more or less curved. The tip of the upper mandible is generally straight, and its margin unarmed; nevertheless, in some of the forms most nearly allied to the preceding section, the edges of the upper mandible are notched near the extremity, and the tip itself is slightly hooked. The food of the majority of the species belonging to this group, especially those with straight and stout conical bills, consists principally of seeds, for breaking which this form of beak is peculiarly adapted. There are, however, few, if any of them, which do not live partially on animal food, such as insects and their larvæ, whilst some appear to devour almost anything fitted to afford them nourishment.

* See Animal Creation, p. 428. 


\section{FAMILY I.}

('ORVID.E.

The Crous.

Gex. Cuarac.-Bill strong, with the hase of the culmen covered with projecting bristling plumes, arehed, and the sides compressed to the tip, which is more or less emarginated ; the nostrils basal, and more or less concealed by the basal plumes; the wings generally long and pointed; the tail moderate or lengthened; the tarsi and toes moderate.

This family includes the numerous species of Crows and other allied forms. They have a more or less elongated, strong, and compressed conical bill, in which the ridge of the upper mandible is curved, and its tip slightly notched on each side. The nostrils are placed at the base of the upper mandible, and concealed beneath a group of small feathers that grow there. The wings are generally long and powerful, and the feet of moderate length and size. These birds seem almost equally adapted to a terrestrial and an aërial existence; they walk and rum upon the ground with equal facility, rise easily from the earth, fly well, and display considerable activity among the branches of trees. They are very generally distributed over the face of the globe, and everywhere readily find the means of living; for most of them are by no means particular about their diet; some even attacking and devouring small birds, and such weakly animals as they can conveniently overcome. 'They are, for the most part, very noisy, with much slyness and drollery in their disposition, and many of them, especially when tame, exhibit a strong inclination for thievery and mischief.

The birds composing this sub-family bear so strong a resemblance to each other, that the most unpractised observer can scarcely fail to recognize them. They manifest a corresponding' similarity of instinct, being shy, easily alarmed, vigilant, and cumning. Omnivorous in the fullest sense, they 
devour flesh, fish, mollusca, grubs, insects, grains, seeds, and other animal and vegetable substances. When searching for food, they betake themselves to open places, walk in a sedate manner, keep a good look-out, and on the slightest appearance of danger Hy off to a distance. Their flight is steady, moderately rapid, and performed by regular beats. Their cry varies from a hoarse croak to a caw or chatter, and none of them, with the exception perhaps of the Piping Crows, can be called musical. They nestle in high places, trees, towers, buildings of various kinds, or rocks, and produce from three to nine eggs, which are deposited very early in the season. They repose at night in similar retreats, and when alarmed by day generally betake themselves to heights. Some species are gregarious, others are unsocial, the latter being the most carmivorous. They are all easily tamed, and may be taught to imitate the human voice, so as to produce a few articulate sounds.

To this family belong the Piping Crows, the Jays, the Tree Crows, the Crows, the Fruit Crows, and the Chonghs. 


\section{$S U^{\top} B-F A I I L Y I$.}

\section{Pitonegamin.*}

The P'iping Crows.

GEx. Charac.-Bill lengthened, with the base broad, the sides compressed, and the culmen broad, rounded, projeeting on the forehead, and more or less straight to the $t i p$, which is more or less emarginated; the nostrils basal, much exposed, and usually in the form of a long, narrow slit in the substance of the bill; the wings usually long and pointed or rounded; the tail long and even or rounded; the tarsi and the toes strong and strongly sealed, with the outer toe united at its base.

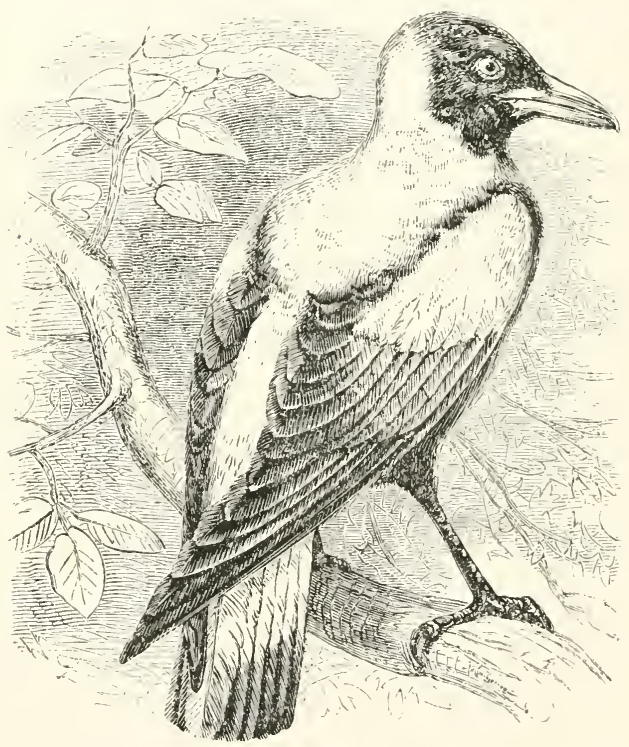

Fig. 80.-THE WHITE-BACKED GYNTORHINA.

(Gymnorlina leuconotus.)

The Piping Crows are inhabitants of the primeval forests of New Guinea and of New South Wales, where they may be seen perched on the upper

* $\phi \omega r$, phone, voice; $\gamma \dot{\mu} \mu \rho s$, gamos, marriage ; So called because they are especially noisy during the breeding season. 
branches of the large trees, the fruits of which form their principal subsistence. One species is said to make the whole forest vibrate with its various musical notes, which are clear, distinct, sonorous, and pass nearly through the whole gamut. Some species are found only in Australia, where they frequent cultivated places, and even approach the dwellings and stock-yards of the colonists ; but they prefer cleared lands, and open flats and plains skirted by belts of trees. These feed chiefly on insects, for which they search the ground; and they - devour immense numbers of locusts and grasshoppers. Their nests are formed outwardly of sticks, leaves, wool, \&c., and lined with fine materials. The egg's are usually three or four in number.

An example of this race of birds is-

The Piping Crow (Phonegama viridis), common in New South Wales, inhabiting the Blue Mountains in small flocks, and building in trees a nest composed of sticks lined with grass. It is said to make a loud whistling noise while perched on some lofty branch early in the morning, and not to be migratary. In captivity it is very amusing from its powers of mimicry : it imitates the voices of men and animals, and easily learns to whistle tunes; its notes being clear and powerful.

The typical form of the sub-family is-

The White-backed Gymnorhina (Gymnorhina leuconotus). 


\section{SUTB-F.L UILY II.}

('ARRILINE.

The .Jays.

Grv. Crarac.-Bill moderate, strong, laterally compressed, and the eulmen straight, hut suddenly eurved near the tip, which is emarginated; the nostrils generally eoneealed by projecting plumes; the wings moderate and rounded; the tail of various lengths, graduated or rounded; the tarsi moderate and much seutellated; and the toes long and strongly scaled.

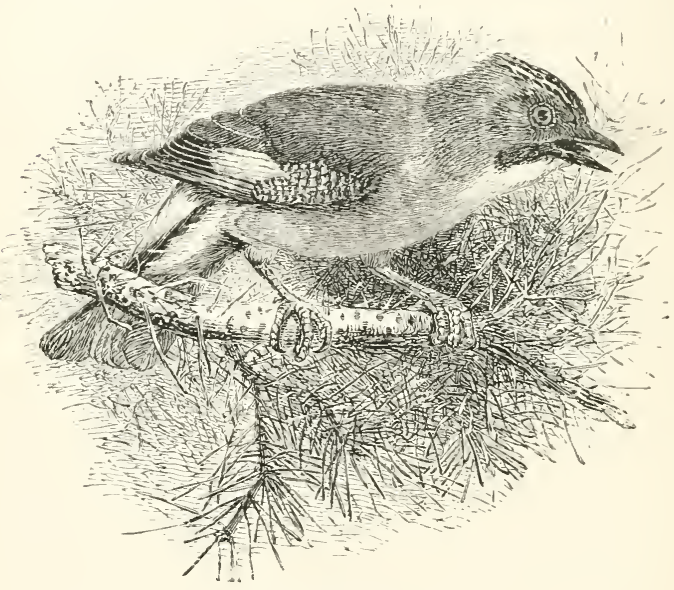

FIG. 81.-THE JAY.

(Garrulus glandarius.)

The Jays are peculiar to the Old World, and are usually found in pairs or small societies in forests, or wherever trees are growing together, preferring the thickest and closest parts, as they are very arboreal in their habits, and hop actively from branch to branch. It is on the trees that these birds find most of their food, which consists of various fruits and seeds; but they also visit cultivated grounds and orchards for the fruits and certain vegetables to which they are partial. They sometimes suck the 
eggs of birds in their nests, and even young birds do not escape them, especially those that are feeble and sickly; in preying upon these they place them under their feet, and with their bills tear them to pieces, swallowing each piece separately. The vocal imitations of quadrupeds, as well as birds, which are practised by the common species, are most exact and ludicrous. Their nest is composed of sticks, and lined with fibrous roots of plants : it is usually placed in the most unfrequented parts of the forest. The eggs are generally from five to six in number.

The type of this sub-family is-

The Common Jay (Garrulus glandarius); a handsome bird, well known in England and the south part of Scotland. It is abundant in the forests of Europe. The Jay inhabits thick woods; its food consists partly of insects and worms, and partly of vegetable matters, especially beech-nuts and acorns: its predilection for the last is allurled to in its specific name-Glans, an acorn. 


\section{SUERAMILY III.}

Calleatix.**

The Tree Crows.

Gex. Charac.-Bill short, with the culmen elevated at the base and mueh eurved to the tip, the sides eompressed, and the gonys long and straight; the wings short and rounded; the tail lengthened and graduated; the tarsi more or less long, and eorered in front with broad seales; the toes moderate, and the lateral ones unequal.

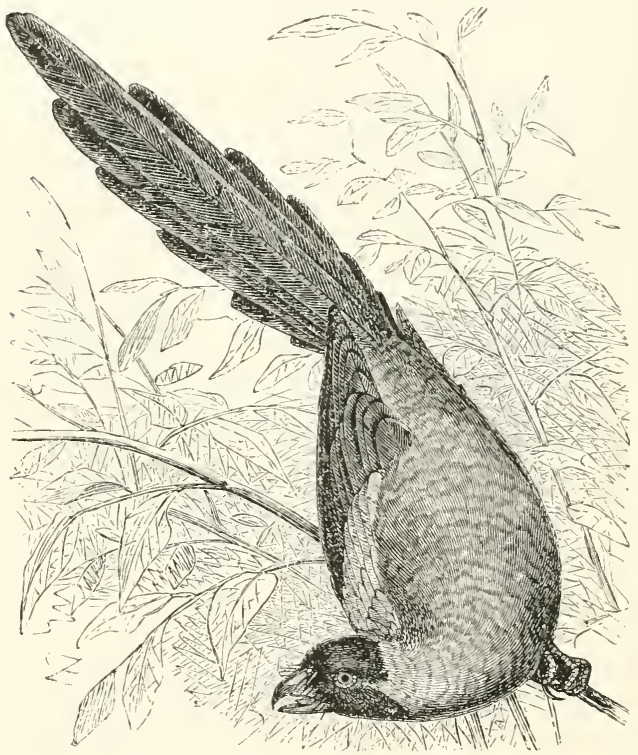

Fig. 82.-THE FRONTED DENDrocitta.

(Dendrocitta frontalis.)

The Tree Crows are found in both the islands of New Zealand, where they may be seen walking upon the ground, searching for the larva and grubs of insects. Occasionally they frequent trees of various

* $\kappa a ́ \lambda \lambda o s$, callos, beauty; So called from the symmetry of their shape. 
kinds, for the purpose of plucking their fruits and berries: they are also said to devour young birds. Some species inhabit the Australian continent, where they live in small companies of three or four together, on the topmost branches of the trees. 'They are extremely quick and restless, the whole company leaping from branch to branch in rapid succession, at the same time throwing up and expanding their tails and wings, actions which are generally accompanied by a harsh and unpleasant cry. Others inhabit the jungles of India, where their peculiar metallic or harsh rattling notes betray their presence, even among the thickest foliage.

The best-known species-

The Cinereous Wattle-bird (Callceas cinerea), is an inhabitant of India; it measures fourteen or fifteen inches from the beak to the extremity of the tail, and is remarkable for the possession of two fleshy, wattle-like appendages, dependent on each side from the base of the lower mandible. These wattles are of a blue colour at their base, but elsewhere of a bright orange-yellow, giving the bird a very singular appearance. The Wattlebird sometimes perches on trees, but is more frequently seen upon the ground, where it seeks its food, which consists of insects, worms, and berries. It is accused of killing young birds. Its voice is a sort of whistle, sometimes accompanied by a low murnuring sound, and is rather of an agreeable character.

The typical form is-

The Fronted Dendrocitta (Dendrocitta frontalis). 


\section{SCIB-FA.UILY II.}

\section{C'ORINAT.}

The Crows proper.

Gex. Charac.-Bill of various lengths, the base broad and the sides compressed, with the culmen more or less eurved to the tip, which is usually entire; the nostrils entirely concealed by the projecting frontal plumes, except when the head or eheeks are dented of feathers; the wings long and slightly rounded; the tarsi long, lengthened, and covered in front with broad seales; the toes moderate, strong, and the lateral ones of equal length.

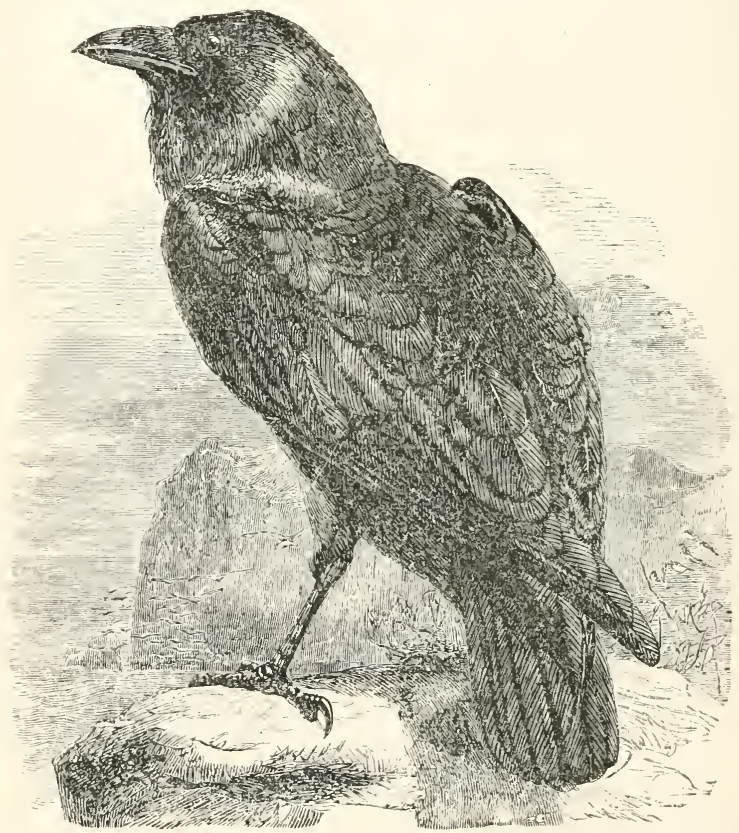

HIG, 83.-THE RAVEN.

(Corvus Corax.)

The birds belonging to this sub-family are found in most parts of the globe. Some remain stationary within a certain district, while others migrate from 
place to place on the change of season. They are generally observed in flocks in cultivated grounds, seeking carrion, or worms, grubs, caterpillar's, small animals, and the eggs and young of birds, which they destroy in great numbers. Some species are more commonly noticed at the sea-side searching for dead fishes, which the waves continually cast up. In such places they also find shell-fish, which they carry high into the air and drop on the rocks, in order to break the shells. Their cries are hoarse and discordant, especially during their first flight in

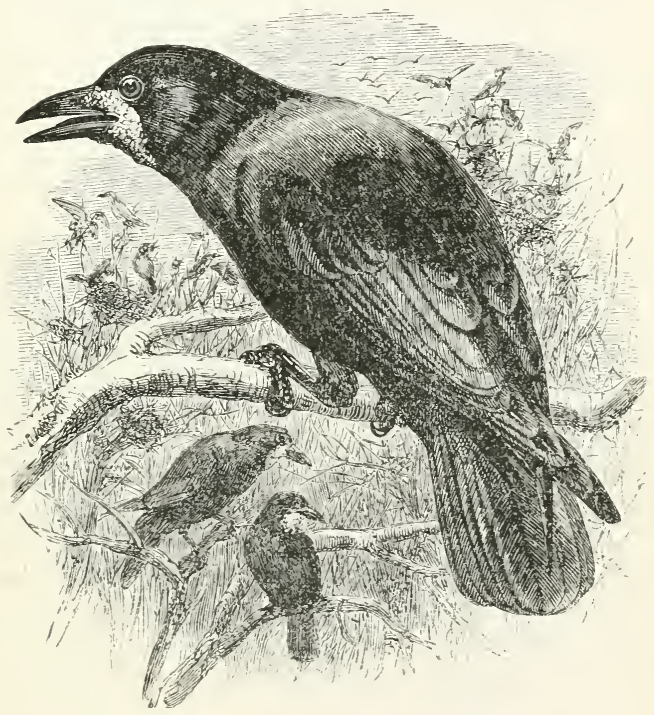

FIG. 84.-THE ROOK

(Corvus frugilegus.)

the morning, before they scatter themselves into smaller flocks in search of their food, and again on their re-assembling in the evening, and while selecting their separate roosting-places. 'The nest is generally built on the topmost branches of lofty 
trees; it is composed outwardly of sticks, moss, and small pieces of bark cemented together with moist earth, and the interior is usually lined with horsehair and some wool, whereon the female deposits four egos.

Of all birds, some members of the Crow family are the most social; for although numerous others live in companionship the greatest part of the year, yet when the period of incubation arrives, they generally separate and disperse. With the Rooks, however, the social principle is perfect, and they accordingly form aërial villages, fabricated on the summits of the loftiest trees, and rear their young in a perpetual scene of bustle and excitement. Their attachment to these spots is very remarkable, and has frequently given rise to obstinate battles between the last possessors and a stranger flock that has attempted to usurp the domain.

The type of the race-

The Raven (Corvus Corax), is the largest and most powerful of all the Corvidie, the adult male measuring about twenty inches in length. It has a long and strong bill of a black colour; the feathers springing from the base of the upper mandible and covering the nostrils are about an inch and a half long. This bird is found in all parts of the Northerm hemisphere, extending its range even into the frozen regions of the Aretic zone. It is usually an inhabitant of the wildest and most sechded districts, haunting the rocks of the sea-coast or the sides of mountains or forests, near extensive plains; and from its vigilance and sagacity, its destruction is by no means easy. 
Gen. Charac.-Bill strong, rather depressed and straight, with the culmen curved and the sides compressed to the tip, which is emarginated; the nostrils lateral, and placed in a membranous groove; the wings long and rather pointed; the tarsi more or less long, and covered in front with transverse seales; the toes rather long, with the outer toe nearly as long as the middle toe; the claws long, curred, and acute.

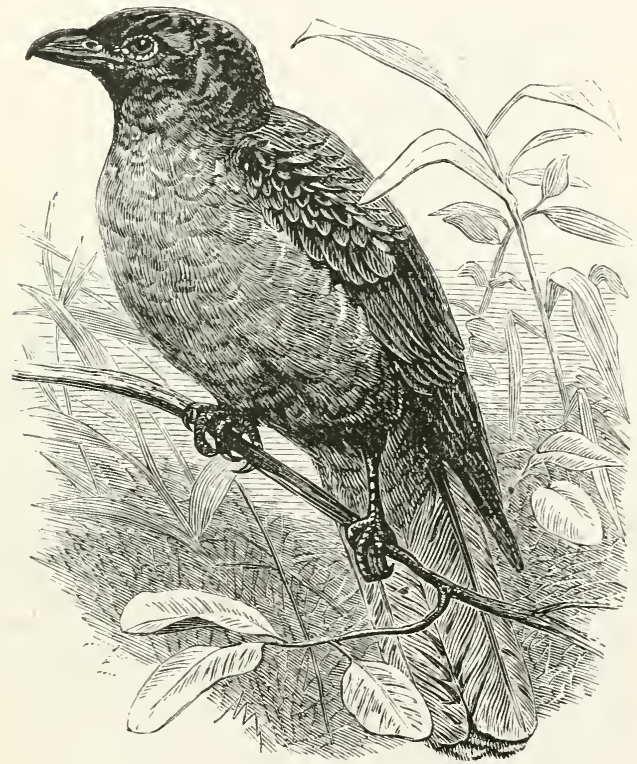

Fig. 85.-THE ORONOCO FRUIT.CROW.

(Coracina Orenocensis.)

The members of this group are found in Cayenne, Louisiana, and Guiana, where they inhabit forests, and at times visit the plantations for the purpose of

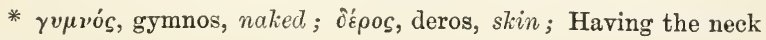
bare. 
procuring food, which consists of various fruits and berries. Other species are inhabitants of the northern parts of South America, where they mas be seen in the forests leaping from branch to branch. They wander from place to place in search of their food, and are restless and mischievous ; but if observed, they conceal themselves among the foliage. 'Their' nests are said to be constructed at the tops of high trees that border the great rivers.

The type of this sub-family is-

The Oronoco Fruit-Crow (Coracina Orenocensis).

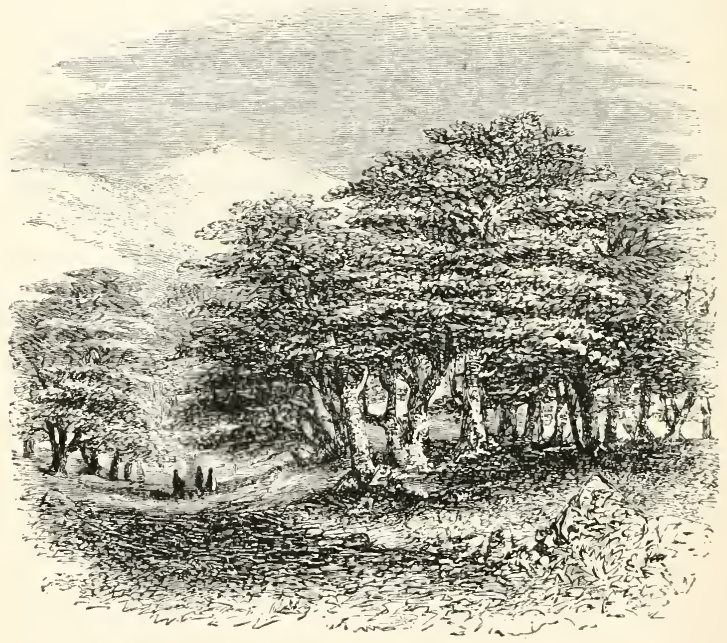




\section{$S U B-F A M I L Y$ VI.}

\section{Pyrrhocoracin.e.*}

The Choughs.

Gev. Charac.-Bill more or less long, slender, and slightly curved, with the culmen rounded and eurved to the tip, which is rather acute and slightly emarginated;" the nostrils broad, lateral, and hidden by the projecting feathers; the wings lengthened and pointed; the tail long and rounded, or егеn; the tarsi strong and rather short; the toes moderate, with the lateral ones nearly equal.

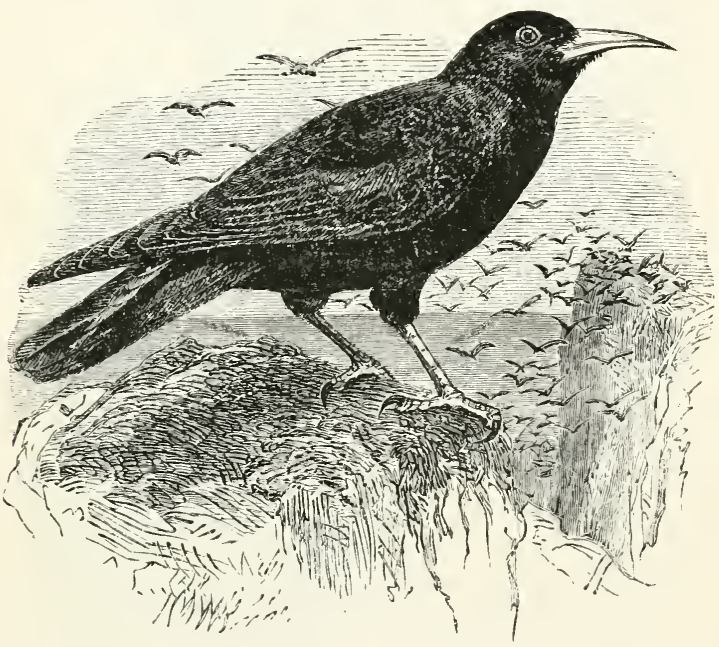

Fig. 86.-THE CHOUgh.

(Fregilus graculus.)

The Choughs are not a numerous race; in this country we have but a single species, and that confined to particular mountainous districts. On the continent, birds belonging to this sub-family are met with in the Swiss Alps and the Tyrol, frequenting the loftier regions, where they breed. With us,

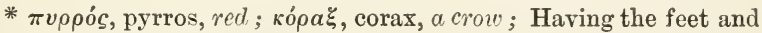
beak of a bright red colour. 
the Chough is seldom seen far inland, breeding on the sea-cliffis, or in old castles and the church towers near the shore. The nest is formed of sticks, and lined with a ereat quantity of wool and hair. The eggs are of a bluish-white colour, speckled with yellowish-brown. 'These birds are of lively gait, and of' a restless and crafty disposition, like many of the ( 'row genus. Their attention is particularly caught by glittering objects. Their natural food principally consists of insects, even the smallest of which they can reach, with their sharp bill, in the crevices of rocks and the joints of walls.

The type of this race of birds is -

The Cornish Chough (Fregilus graculus). 


\section{FAMILY II.}

PARADISEID.E.

The Birds of Paradise.

Gen. Charac.-Bill long, strong, with the eulmen eurred and the sides com. pressed to the tip, which is emarginated; the base of the upper mandible concealed by short feathers, which also cover the nostrils; the wings long and rounded; the tail of various lengths, even or rounded; the tarsi robust, long, and covered by a single membrane; the hind toe very long and robust; the claws long, strong, and curred.

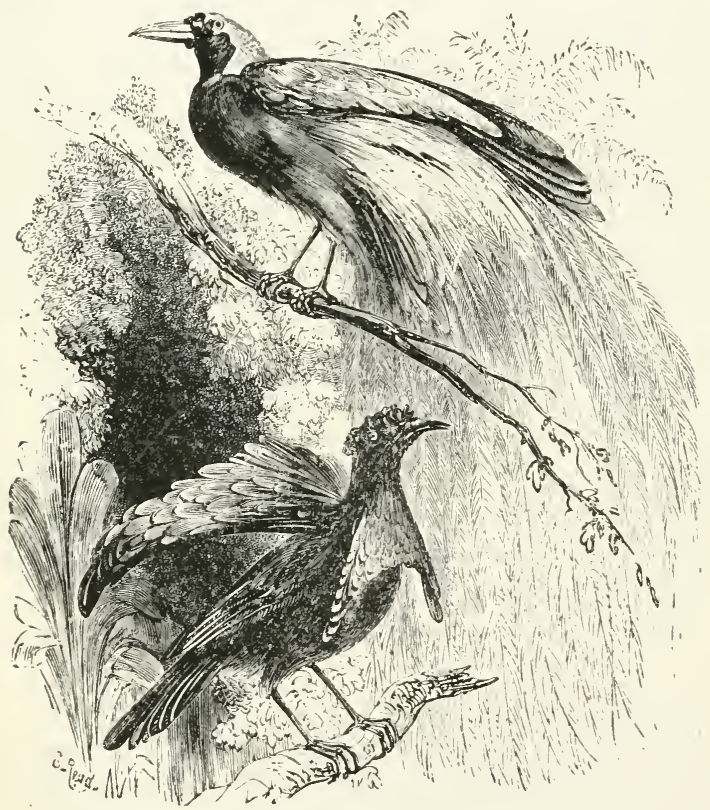

Fig. 87.-BIRDS OF PARAdISE.

(Parudisea upoda and P. superba.)

The most remarkable character of this family consists in the great development, in the males, of some portions of their plumage, usually of the feather's of the sides of the body and neck, which often 
present the most singular forms, and give their possessors a very peculiar appearance. In most cases they are adorned with brilliant colours. The Birds of Paradise are confined to a very limited portion of the cartl's surface, namely, New Guinea and the neighbouring islands. Amongst the luxuriant forests of these regions they live together in large troops, and their appearance when flitting about is most beautiful. They are polygamous, like the gallinaceous birds, which they resemble in the magnificent attire of the male. Their food consists principally of fruits. They are lively and active in their movements, and are usually observed upon high trees, though they descend in the morning and evening to the lower branches to search for food, and to hide among the foliage from the extreme heat of the sun. The fruits of the teak and fig-tree form the principal part of their subsistence, and they occasionally feed on insects, of which, if large, they reject the legs, wings, and hard parts. Their cry is loud, sonorous, and poured forth in a rapid succession of notes. "The first four notes," says Mr. Lay, "are very long, exactly intonated, very clear, and very sweet. The last three are repeated in a kind of caw, a very high refinement of the voice of a daw or a crow, yet possessing a striking resemblance."

There is but one sub-family, of which the type is -

The Emerald Bird of Paradise (Paradisea apoda); so called from the notion formerly universally prevalent in Europe, that the bird was naturally destitute of feet, and consequently, that it floated constantly in the air, only at times suspending itself for a few brief moments, from some lofty sun-illumined tree, by the peculiar lengthened feathers with which it is adorned. In accordance with this belief, it was thought that whatever individuals were obtained on earth, had fallen from their aërial heights immediately before their death.

The true residence and breeding-place of these beautiful 
creatures seems to be Papua, or New Guinea, from whence they make occasional excursions to the neighbouring islands. They fly in flocks of about thirty or forty, under the guidance of a single bird, which the natives call their chief. They appear habitually to prefer the most dense and secluded parts of the forests, where, when the sky is clear, they perch upon the tops of the highest trees. They fly with rapidity, but with an undulating motion, as is usual with birds adorned with long phumage, and always against the wind, a position which keeps their long plumes laid flat to their body ; for it is evident that, did they fly in any other direction, the wind, by blowing their plumage about, would materially interfere with the free play of their wings. When tlying, they make a noise like Starlings, but their common cry rather resembles that of a Raven, and is very audible in windy weather, when they dread the chance of being blown to the ground. In the Aru islands they are captured by the natives in various ways, - with birdlime, snares, and blunted arrows. Though many are taken alive, they are always immediately killed, embowelled, and their feet cut off : the plumed skins, fumigated with sulphur, are then dried for sale. They are said to feed on fruits and berries, and Limnæus says they devour the larger butterflies. 


\section{FAMILY III.}

STURNID.E.

The Starlings.

GeN. Charac.-Bill more or less long, with the sides compressed, the eulmen slightly curved or straight to the tip, which is sometimes emarginated, and the gape often angulated; the wings long and pointed; the tail generally long and even, or graduated; the tarsi more or less long, and covered in front with broad scales; the toes long and strong, the hind toe very long and robust; the claws long, curved, and acute.

'The birds of this family are nearly related to the Corvida, both in their structure and habits. They are for the most part sociable, collecting in flocks, especially during the autumn and winter, and even during the breeding season they are generally to be seen in company. Their food consists of worms, insects, fruit, and grain,_-articles which also constitute a considerable portion of the diet of Crows; but the Starlings do not appear to imitate the latter birds either in their taste for carrion or in their predatory propensities; they are, however, very sagacious, and become docile and amusing in captivity, when some of them may be taught various tricks, and even to speak a few words.

'T'o this family belong the Glossy Starlings, the Grakles, the Beef-eaters, the Starlings proper, the Boat-tails, the Hang-nests, and the Troop-birds. 


\section{SUB-FAMILYI.}

\section{PTILORHYACHIXæ.*}

The Glossy Starlings.

Gex. Charac.-Bill strong, moderate, with the sides compressed, and the culmen curred to the tip, which is emarginated; the wings moderate and pointed; the tail of rarious length, and graduated or eren; the tarsi strong and covered with broad scales; the toes long, strong, the lateral ones unequal, and hind toe long and strong.

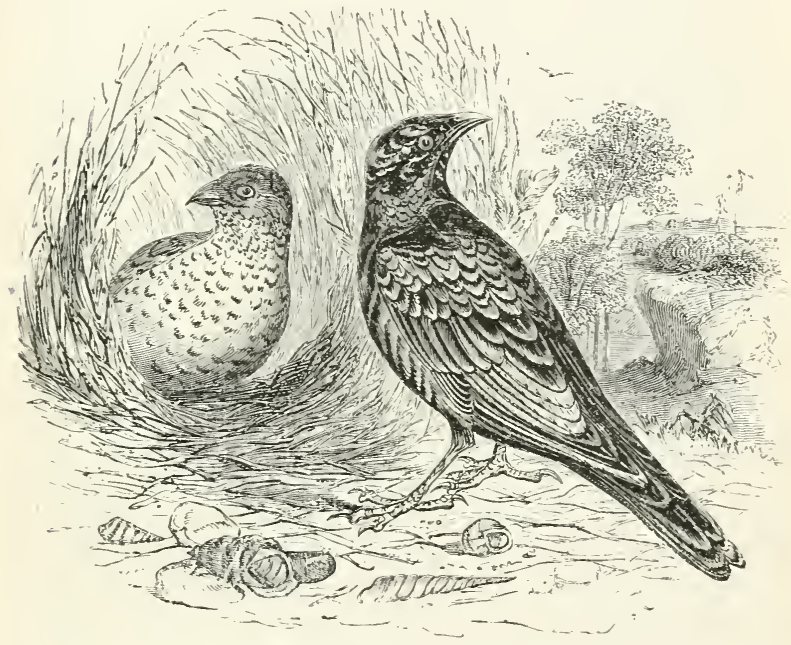

Fig. 55.-THE SATIN BOWER-BIRD.

(Ptilorhynchus holosericus.)

These remarkable birds, called by $\mathrm{Mr}$. Gould the Bower-birds, are peculiar to Australia, where they are found in the forests that border the principal river's, as well as in the cedar bushes. When perched on the lofty branches of the trees, they emit lond and harsh notes, which, with regard to one of the species, can only be compared to the noises of the domestic

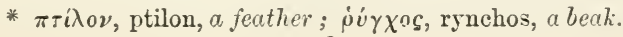


cat. In the autumn they congregate in small flocks, and are then often seen on the ground. The adult males of the Satin Bower-birds are more rarely seen than the females and old males, and these latter are supposed to be from two to three years old before they exhibit their rich glossy black plumage. They feed on various berries and fruits, especially wild figs and the native cherry, which, when ripe, forms their chief food. They are very destructive to the ripening crops of the settlers.

\section{The typieal species is named-}

The Satin Bower-bird (Ptilorhynchus holosericus). The localities favourable to the habits of the Satin-bird are the luxuriant and thickly-foliaged brushes stretching along the coast of the Australian continent, from Port Phillip to Moreton Bay. It is not migratory, but ranges from one district to another, either for the purpose of varying the'nature of its food or of obtaining a more. abundant supply. It appears to be wholly granivorous or frugivorous, or, if not exclusively so, insects form but a small portion of its diet. Independently of numerous berry-bearing plants and shrubs, the brushes it inhabits are studded with enormous fig-trees, some of them towering to the height of two hundred feet. Among the lofty branches of these giants of the forest, the Satin Bower-bird and several species of Pigeons find, in the small white fig with which the branches are loaded, an abundant supply of a favourite food; they also commit considerable depredations on ripening corn. These birds have the remarkable habit of forming a bower-like structure, which seems to serve them as a playing-ground or hall of assembly. Their bowers are usually placed under the shelter of the branches of some overhanging tree, in the most retired part of the forest. The base consists of an extensive and rather convex platform of sticks, firmly interwoven, on the centre of which the bower itself is built. This, like the platform on which it is placed, and with which it is interwoven, is formed of sticks and twigs, but of a more slender and flexible description, the tips of the twigs being so arranged as to curve inwards, and nearly meet at the top. In the interior of the bower the 
materials are so placed that the forks of the twigs are always presented outwards; by which arrangement not the slightest obstruction is atforded to the passage of the birds. The interest of this curious bower is much enhanced by the manner in which it is decorated, both at and near the entrance, with the most gaily-coloured articles that can be collected; as the blue tail-feathers of the Rose-hill and Pennantian Parrots, bleached bones, the shells of snails, \&c. Some of the feather's are stuck in among the twigs, while the bones and shells are strewed about near the entrances. The propensity of these birds to pick up and $\mathrm{H} y$ off with any attractive object is so well known to the natives, that they always search their bower's for any small missing article, such as the bowl of a pipe, dc., that may have been dropped accidentally in the brush. Mr. Gould found, at the entrance of one of them, a small neatly-worked stone tomahawk, of an inch and a half in length, together with some slips of blue cotton rags, which the birds had doubtless picked up at a deserted encampment of the natives. For what purpose these curious bowers are made is not yet fully understood ; they are certainly not used for a nest, but as a place of resort for many individuals of both sexes, which, when there assembled, run through and around the bower in a sportive and playful manner, and that so firequently, that it is seldom entirely deserted.

"Another species, the Chlamydera maculata, nearly allied to the Satin Bower-bird, constructs a bower even more extraordinary than that just described, and in which the decorative propensity is carried to a far greater extent. The bowers of this bird are considerably larger, and more avenue-like than those of the Satin Bower-bird, being in many instances as much as three feet in length. They are built of twigs, and beantifully lined with tall grasses, so disposed that their heads nearly meet; the decorations, moreover, are very profuse, and consist of bivalve shells, crania of small mammals, and other bones. Evident and beautiful indications of design are manifest throughout the whole of this strange edifice and its decorations, particularly in the manner in which the stones are placed within the enclosure, apparently to keep the

* $\chi \lambda a \mu \dot{s}$, , chlamys, a mantle; dépos, deros, the skin; So called because they have a rose-coloured band at the back of the neck. 
grasses with which it is lined fixed firmly in their places: these stones diverge from the mouth of the run on each side, so as to form little paths, while the immense collection of decorative materials, bones, shells, \&c., are placed in a heap, before the entrance of the avenue; this arrangement being the same at both ends. In some of the larger bowers, which had evidently been resorted to for many years, nearly half a bushel of bones, shells, and similar objects had acemmulated at each of the entrances.

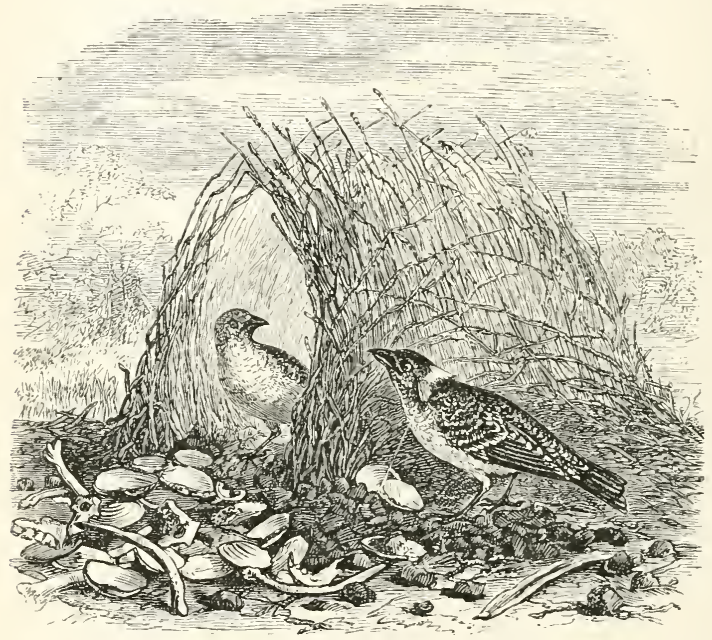

Fig. 89. - THE SPOTTED BOWER-BIRD.

(Chlamydera maculata.)

These structures are frequently found at a considerable distance from rivers, from the borders of which alone the birds could have proeured the shells and small round pebbly stones employed in their decoration. The collection and transportation of these must therefore be a task of great labour and difficulty ; and as these birds feed almost entirely upon seeds and fruits, the shells and bones camnot have been collected for any other purpose than ornament; besiles, it is only those that have been bleached in the sun, or such as have been roasted by the natives, and by this means whitened, that are made use of. 
Gen. Charac.-Bill more or less long, broad at the base, much eompressed on the sides, with the eulmen rather curved to the tip, which is slightly emarginated; the nostrils basal, lateral, rounded, exposed, with the frontal plumes advancing to or covering the opening; the wings long, with the first quill short, and the third and fourth the longest; the tail short, and even or slightly graduated; the tarsi short; the toes long and strongly seutellated.

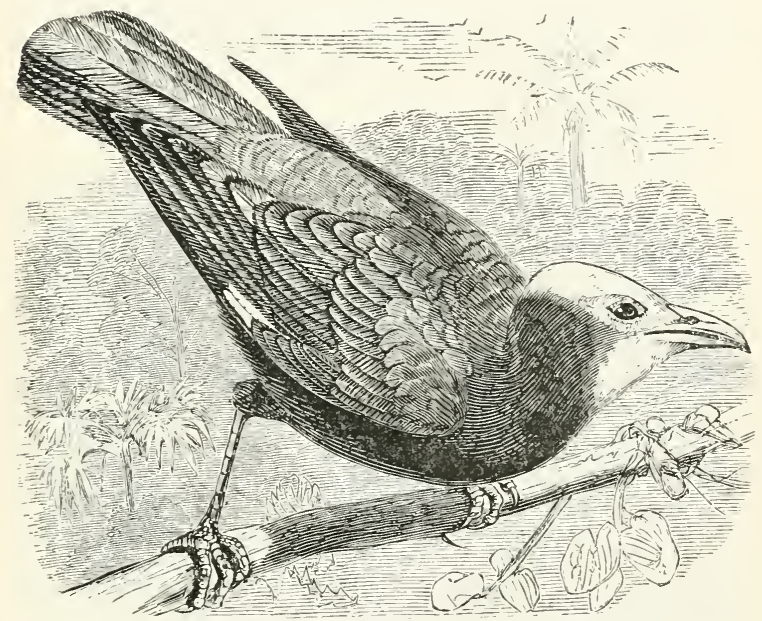

Fig. 90,-THE CROWNED GRAKLE.

(Gracula coronata.)

The true Grakles inhabit the lofty jungles of India. They are generally seen in pairs, or small parties of five or six individuals, frequenting the tops of the highest trees, seeking fruits, chiefly berries of various kinds. They are sometimes found in newly-made gardens where a few large trees are left standing, flying cheerfully from tree to tree, resting 
a few minutes and whistling, and then flying off again. 'Their song is rich, varied, and pleasing'; they have, however, several harsh notes, often heard in the jungles.

The Mina-bird (Gracula religiosa) is a native of India and the Imlian islands, where it is highly valued for its powers of imitation; indeed, it easily leams to repeat, not only words, but whole phrases, and that with surprising distinctness. Marsden says that it has the faculty of imitating human speech more perfectly than any other bird. In captivity, the Mina is lively, confident, and docile; it is about the size of a Thrush, and lives indiscriminately on insects and fruits. The Jungle Mina is often seen in cages in the South of India, where it is very highly prized, both for its powers of song and speech.

Another species, called-

The Paradise Grakle (Gracula tristis), also a native of India and the Philippine islands, is very voracious, and particularly fond of locusts and grasshoppers. In connection with these birds, Buffon relates the following instructive anecdote. "The Isle of Bourbon, where they were unknown, was overrun with locusts, which had been unfortunately introduced from Madagascar, their eggs having been imported in the soil brought with some plants from that island. In consequence of this, the governor and the intendant deliberated anxiously on the means of exterminating these noxious insects, and for that purpose caused several pairs of Grakles to be introduced into the island. The plan promised to succeed, but unfortunately some of the colonists observing the birds eagerly thrusting their bills into the earth of the new-sown fields, imagined that they were in quest of the grain, and reported that instead of proving beneficial, the Grakles would, on the contrary, be highly detrimental to the country. The case was considered in form. On the part of the bircts it was argued that they raked in the newly-ploughed fields, not for the sake of the grain, but of the insects, and were therefore worthy of protection. They were, however, proscribed by the comcil, and in the space of a few hours after the sentence was pronounced, not a Grakle was to be found in the island. This prompt execution was, 
however, followed by speedy repentance; the locusts gained the ascendancy, and the people, who only viewed the present, regretted the loss of the Grakles. In a few years afterwards a few pairs were again introduced, their preservation and breeding were made a state affair, the laws held out protection to them, and the physicians on their part declared their flesh to be unwholesome. The Grakles accordingly multiplied, and the locusts were destroyed."

The type of this sub-family is-

The Crowned Grakle (Giacula coronata).

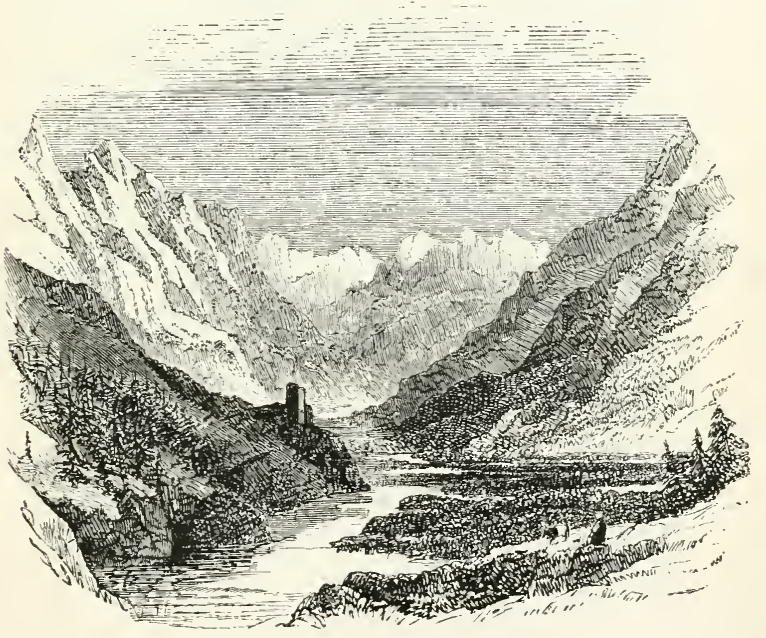




\section{Buphagin.e.*}

The Ox-peckers.

Gen. Charac.-Bill moderate, broad, with the eulmen slightly depressed and eurved to the tip, which is entire; the lateral sides of the lower man. dible broad, and the gonys short and ascending; the nostrils basal, small, and partly closed by a membrane; the wings long and pointed; the tail long and graduated, with the end of each feather pointed; the tarsi short and strong; the toes moderate, strong, and armed with moderate, much compressed, carved, and acute claws.

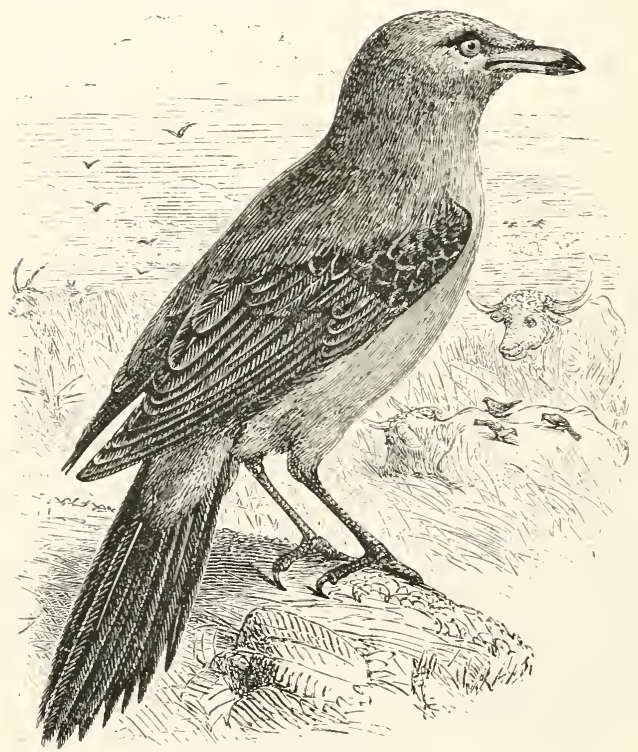

FIG. 9l.—THE OX PECKER.

(Buphagu Africunu.)

The Ox-peckers are found on the continent of Africa. They are always in company with cattle, on whose backs they are generally seen clinging

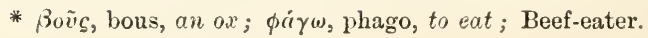


while seeking for the parasitical insects that annoy those animals.

\section{The type of the race-}

The 0x-pecker, or African Beef-eater (Buphaga Africana), is a common bird in many parts of Africa, where it follows the singular mode of life that has olvtained for it its name. Perching upon the backs of oxen, or other cattle, it sets to work busily to extract from their skins the larvæ of the Estride, or Bot-flies, with which they are almost constantly infested, and which often give rise to painful tumours. It creeps about in all directions upon the body of the ox by means of its powerful feet, which exhibit some resemblance to those of the Woodpecker, although the toes are in the ordinary position. The bill of the bird is well adapted for digging and squeezing out these larve; it is short and stout, and inflated towards its extremity. The cattle are said to submit with exemplary patience to the operation, as if aware of the benefit to be derived from it. The Ox-pecker measures between eight and nine inches in length; it lives in small bands, consisting of seven or eight individuals, and is very shy.

Besides the larva of the Breeze-fly, for which they show a decided preference, these birds eat all kinds of insects, bird-lice, and similar creatures. 


\section{SUB-FAIILY IV.}

STURNINA.

The Starlings proper.

Gex. Charac.-Bill more or less long, with the culmen eurved or straight to the tip, which is obtuse and somewhat flattened; the nostrils basal, placed in a membranous groove, and sometimes clothed with short feathers; the wings moderate; the tail rather short, and even or rounded; the tarsi rather long, strong, and covered with broad scales; the toes long and strong, armed with strong acute elaws.

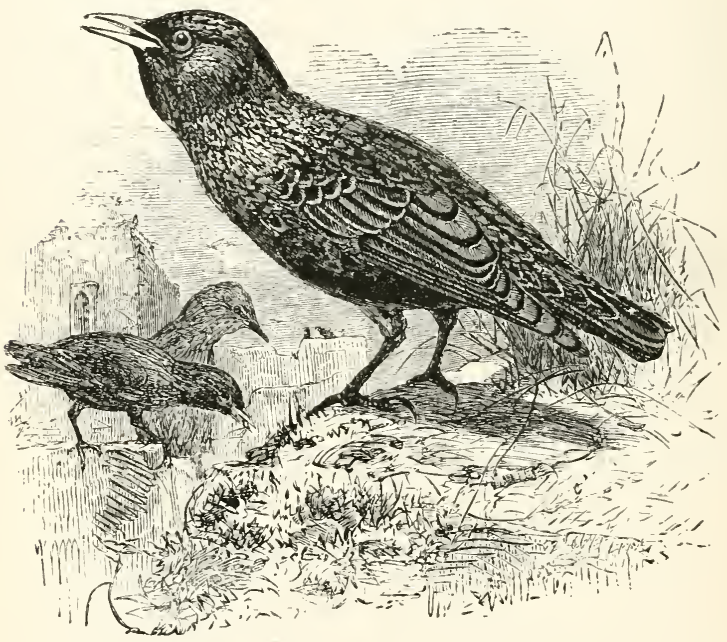

Fig. 92.-The common starling.

(Sturnus vulgaris.)

These birds are found in most parts of the world, migrating regularly in vast flocks, which occasions them to appear in different localities at stated periods. They mostly frequent swampy places, and are often seen in company with other birds of similar habits. While on the ground they walk with facility. Their food consists chiefly of worms and insects; but they also feed upon grain and seeds, 
which are usually obtained by searching for them on the ground. Their notes consist of a shrill whistle, occasionally varied by a chattering noise; and they often imitate the cries of birds and anmals. They make their nests of dry grass, in the holes of trees and buildings, and lay from four to five eggs.

The type of this sub-family is-

The Common Starling (Sturnus vulgaris). This wellknown bird appears to be generally distributed over the whole of the Eastern hemisphere. In the autumn, the Starlings collect in large flocks, consisting of old and young birds, which fly together in search of food, and roost together at night. Sometimes many of these flocks select some mass of trees as a common roosting-place, to which they come night after night in thousands. Their food consists of worms, insects, slugs, and snails, together with berries and seeds, the latter especially during the autumn and winter. In pursuit of insects and worms, they may be constantly seen in parties upon meadows and lawns, sometimes in company with Rooks and other birds : when thus engaged, they do not hop, but run, moving their feet alternately.

They alight in open pastures abruptly, without preparatory reconnoitring, and immediately disperse, running nimbly along in search of mollusca, worms, and other objects. On discovering traces of a subterranean larva or worm, they dig for it, with great dexterity, in the same manner as the Thrushes and the Crows. During their search they are seldom silent, some individuals commonly keeping up a chattering noise, and occasionally uttering a low scream; this scream prolonged and heightened is the intimation of alarm, and when heard from one or more of the flock, they immediately cease their search, look up, and if they judge it necessary, fly off with speed to a considerable distance. 
Quiscaline.

The Boot-tuils.

Gen. Charac.-Bill lengthened, with the eulmen straight and slightly curved at the tip; the nostrils basal, lateral, and placed in a triangular groove; wings moderate and pointed; tail lengthened and graduated, with the sides generally curved upwards; the tarsi and toes strong and much scutellated, the hind toe long, and armed with a strong curved claw.

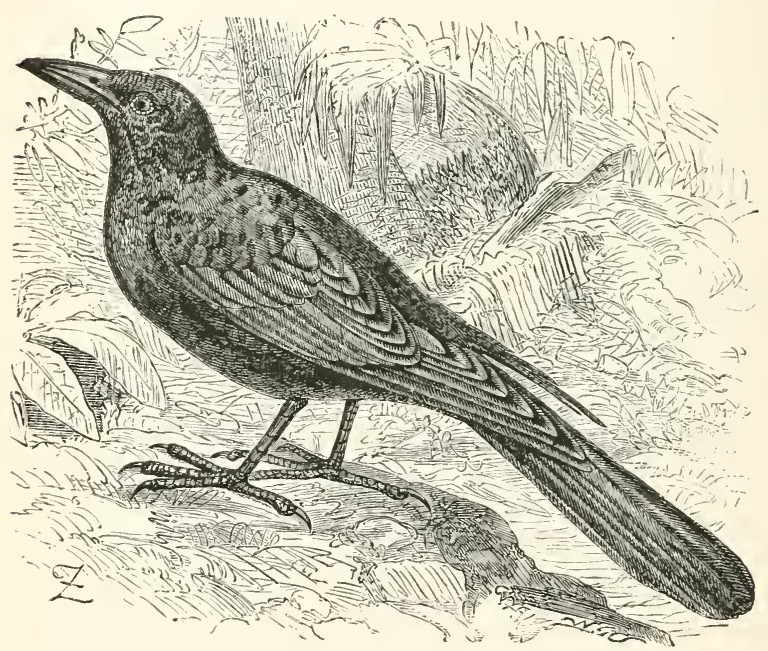

Fig. 93.-тHе вLACK воАT-таIL.

(Scaphidurus ater.)

These birds are migratory between the north and the more temperate parts of the American continent, according to the change of seasons. In the winter they assemble in considerable numbers, and entirely overrun the warmer south-eastern maritime regions, and are very destructive. In the spring they are usually seen flying about the swamps and ineadows, or following in the furrows after the plough. At this season they are very useful to the husbandman, as 
they destroy a prodigious number of worms, grubs, and caterpillars; on the other hand, they commit great depredations on the maize or Indian corn as soon as it appears above the ground, feeding on the sweet and sprouting stem, and scattering the leaves around as an evidence of their mischievous mode of life. This plant is again attacked when the grain is in the milky state to such an extent that one-fourth of the crop is supposed to be devoured by these hungry maranders. Previously to their departure to the Southern States, they collect from all parts in such hosts that the air is darkened by their numbers.

The best-known species-

The Purple Quiscalus (Quiscalus purpureus), generally called the Purple Grakle, is an annual visitor to the United States of North America. These birds frequent marshy districts, but in the month of March approach rural habitations, and pick up food in the farm-yards, or even at the doors of houses, where they will share the grain thrown out to the fowls. The woods, and more especially those of a marshy character, are selected as fit localities for building their nests, which are composed of the stems of dried grass, sedge, and fibrous roots, and strengthened externally with a coat of clay. The eggs are five or six in number, of a bluish colour, spotted, and streaked with dark brown or black. Two broods are reared in the course of the year.

The type of this sub-family is-

The Black Boat-tail (Scaphidurus ater). 


\title{
SUB-FAMILY VI.
}

\author{
ICTERINÆ.*
}

The IIang-nests.

Gex. Charac,-Bill more or less lengthened, with both mandibles straight or slightly curred towards the tips, which are acute and entire; the wings lengthened and pointed; the tail long and generally wedge-shaped; the tarsi as long as, or shorter than, the middle toe, and broadly scaled; toes moderate and formed for grasping.

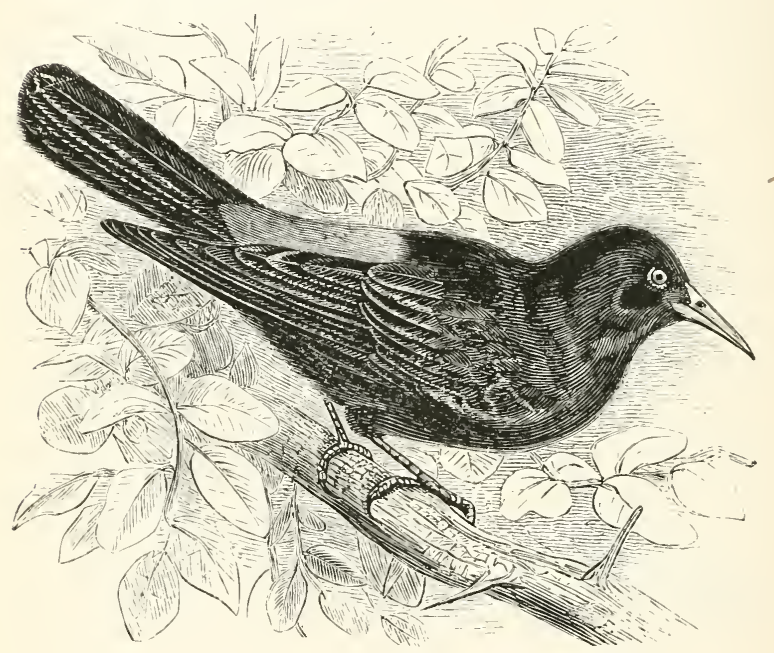

Fig. 94.-THE RED-RUMPED CASSICAN.

(Cassicus hamorhous.)

These are American birds, in their manners approximating to the Starlings, living, like them, in flocks, and constructing their nests near each other with singular skill and artifice, and suspending them from the horizontal branches of trees. Each nest is about a yard long, and resembles an enormous purse, with the lower end hemispherical and ten

* " i $\tau \varepsilon \rho o s$, icteros; a bird, mentioned by Pliny, of a yellowishgreen colour. 
inches wide. The male and female jointly manufacture this gigantic structure by interlacing or knitting together shreds of the bark of a species of aloe named Caraquata, small rushes, and the fibres of a parasitical plant called 'Tullandsia usneoides, or Old. man's beard. The bottom is lined with a thick layer of large dry leaves plucked from the tree itself. In this rocking-cradle the female lays three eggs, and feeds her young with worms till they have attained maturity, when they prefer to live on oranges and pine-apples.

The best-known members of the group are-

The Cassicans* (Cassicus), so called from the ingenuity with which they construct their pensile nests, crowding them together in such numbers as to form quite a feature in the landscape. Upon one tree, standing in the middle of a lake, and not more than ten feet high, forty-five of these nests have been counted, some depending one from another, and completely concealing all the upper branches except a few of the outermost leaves: at a distance, the whole resembled an immense basket. Often in such situations large trees are seen with hundreds of these nests hanging from their boughs, and swaying in the wind. "The Cassican," says Mr. Waterton, " in size is larger than a Starling, and courts the society of man, but disdains to live by his labours. When hungry, he repairs to a neighbouring forest, and there partakes of fruit and seeds; when his repast is over, he returns to man, and pays the little tribute that he owes him for protection; he takes his station on a tree close to his house, and there, for hours together, pours forth a succession of imitative notes. His own song is sweet, but very short. If a 'Toucan be yelping' in the neighbourhood, he drops his own notes and imitates him. Then he will amuse his protector with the cries of the different

* $\kappa \alpha \sigma \sigma v \omega$, cassuo, to sew together; So called because they form their nests of interwoven vegetable fibres. 
species of Woodpecker; and when the sheep bleat, he will distinctly answer them. Then comes his own song again; and if a puppy-dog or a guineafowl interrupt him, he takes them off admirably, and by his different gestures while doing so, you would think that he enjoys the sport; indeed, he imitates any sound so exactly, that he goes by no other name than that of the Mocking-bird among the colonists. At breeding-time, a number of these pretty choristers resort to a tree near the planter's house, and from its ontside branches weave their pendulous nests; so conscious do they seem that they never give offence, and so little suspicions are they of receiving any injury from man, that they will choose a tree within forty yards of his house, and occupy the branches so low down that he may peep into their nests."

The proportions of this bird are so fine that he may be said to be a model of symmetry in Ornithology.

The type of this sub-family is-

The Red-rumped Cassican (Cassicus hamorrhous). 


\section{SUB-FAHILY VII.}

Agelain.e.

The Troop-bircls.

Gen. Charac.-Bill the length of the head, or shorter, eompletely conical, with the sides gradually compressed towards the tip; the culmen straight, flattened, and more or less broad; the tarsi usually the length of the middle toe; the toes lengthened, slender, the outer united at the base with the middle one, the hind toe long, and all armed with long and rather curved claws.

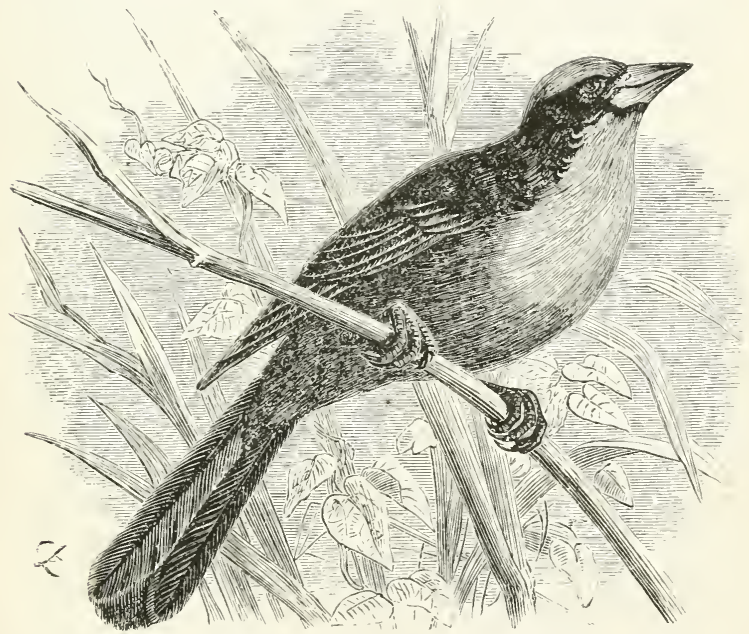

FIG. 95.-THE CAPPED TROOP-BIRD.

(Chrysomus frontulis.)

These birds are peculiar to the continent of America. The North-American species are migratory, and in winter visit the southern States in large Hocks, especially frequenting the vicinity of the seacoast near large fields of rice and corn. Wilson relates that he has frequently been amused by their aërial evolutions. Sometimes they appear driving about like an enormous black clund carried before 
the wind, and varying its shape every moment; sometimes suddenly rising from the fields around him with a noise like thunder, then descending like a torrent and covering the branches of some detached grove or clump of trees, the whole congregated multitude commenced a chorus which he could plainly distinguish at the distance of more than two miles. They arrive in Pennsylvania in the beginning of March in immense flocks, and commence their attack on the grubs, caterpillars, and other larva; for these they search in the ground at the roots of plants, in orchards and meadows, as well as among buds, leaves, and blossoms; and from their known voracity, the multitudes of insects destroyed by them must be immense. During August and September they pour down on the low countries near the coast in prodigious multitudes, wheeling and driving over the devoted cornfields, and filling the air with their numbers. Then commences the work of destruction on the corn, till little is left for the industrious husbandman, and on the seeds of the reeds and wild oats, and other plants that abound on the banks of the great rivers. In April they separate in pairs to begin their family preparations. The nest is sometimes placed among the high grass of a watery meadow, or in a tussock of rushes in a marsh, but more frequently about six or eight feet from the ground in a thicket of alders, or in a detached bush. The exterior is formed of rushes and long tough grass twined securely around the neighbouring twigs, to prevent its falling from its flexible support: a similar precaution is used when the nest is made amongst rushes. When placed on the ground, less care is necessary, and fewer materials are employed, the nest being much lighter and more simple : the lining is of fine bent. The female deposits five eggs.

The Cow-pen Bird, or Cow Bunting (Molothrus* bona-

* $\mu_{0} \lambda_{\varepsilon \tau} \nu$, molein, to transplant; from the habit of depositing its eggs in the nests of other birds. 
riensis), is remarkable for its habit of depositing its exgs in the nest of some other bird, like our Cuckoo. It is migratory at certain seasons, making its appearance in the middle States of the American Union at the end of March or the beginning of April, but it passes the winter in the southern States. The name Cow-pen Birt given to this species is due to its habit of frequenting the inclosures in which cattle are confined, where it seeks for reeds, worms, and insects. It is never known to build a nest, but drops its eggs singly in the nests of numerous species of small birds. The young Cow-bird, like the young of the European Cuckoo, is always found alone in the nest of its foster-parents, and probably resorts to the same means of getting ric of the rightful tenants that is adopted by the Cuckoo, as it is found that when the egg of the parasite is deposited before those of the owner, the latter deserts its nest, and thus the object of the intruder is defeated. It has been observed that the young of this bird, like that of the Cuckoo, seems to possess some power of attaching to itself the affections of almost all small birds, as these cannot see it in a helpless state without administering to its necessities. Wilson placert a young bird of this species in the same cage with a Cardinal Grosbeak, and the latter, as soon as his companion began to be clamorous for food, set to work to satisfy its appetite, and tended it like an affectionate nurse; when he found that a grasshopper which he brought to his nurseling was too large for it to swallow, he broke it into small pieces, which he passed through his bill to soften them, and then placed in the expectant mouth of the little Cow-bird with the greatest gentleness. The length of the Cow-pen Bird is about seren inches; its plumage is black with a greenish gloss. The female is of a brown colour, paler below.

The type of this sub-family is

The Capped Troop-bird (Chrysomus frontulis). 


\section{FAMILY IV.}

Frivgillide.

The Finclies.

Gex. Charac.-Bill short, thick, strong, and more or less conical, without emargination at the tip, but generally angular and thiek at the base.

In the family of the Finches, to which belong the Sparrow, the Bunting, the Greenfinch, the Goldfinch, and all our little thick-billed birds, the form of the bill is more decidedly conical than in any other Passeres. Their beak is generally short and stout, but tapering to a fine point; and the edges of the upper mandible are destitute of those notches near the tip, which, although specially characteristic of the Dentirostral tribes, occur in a less marked degree in many Conirostral species: in only one sub-family (the Tanagers), the upper mandible is distinctly notched, and bent over the lower. Their' tongue is rather fleshy, but horny towards the tip, where it usually presents a slit. The feet are slender, the tarsi generally covered in front with seven horny plates, which, however, are sometimes conjoined so as to form a single long shield. The toes are of moderate length, and terminated by rather slender curved claws. The tail is composed of twelve feathers.

The Finches are all small birds, and exhibit much activity as they hop along npon the ground, or leap from twig to twig among the trees and bushes. Their flight is undulatory, rising as by an effort through a certain space, and then sinking, as the wings are closed, for a similar distance. Their food consists principally of seeds, for the consumption of which the form of their bill is peculiarly adapted; but they also pick up insects and worms, especially during the breeding season. Their adaptation to a diet of hard regetable substances is further shown by the structure of their digestive organs, their 
cesophagus being dilated into a small crop, in which seeds are stored and partially softened; and they are possessed of a powerful gizzard for the comminution of their food. In some species, the colours of the plumage are exceedingly rich and beautifully combined, but the majority are clad in dull and homely attire. The race of Finches is distributed throughout all the temperate parts of the world, and some are even met with in the Arctic regions, since wherever regetation exists seeds are produced, and these, as we have seen, constitute their principal food.

The birds belonging to this family usually frequent open and cultivated places, but some prefer wild mountainous districts. They live in flocks, several species sometimęs associating together, especially during the winter months. 'Those that reside in the more northern parts of Europe migrate periodically to the warmer provinces; and those that frequent the mountains seek the lower ground on the approach of winter. Their song consists of three or four notes, which in some, though short, possess great sweetness, and are varied in delivery. Their nest is placed upon trees and in the bushes of mountainous districts, or else in those of gardens, orchards, and plantations. It is composed of grass, moss, and lichens interwoven with wool, and lined interiorly with feathers and hąir. 'The eg'g's are four or five in number.

This extensive family comprehends the Weaverbirds, the Hawfinches, the Tanagers, the Finches, the Buntings, the Larks, the Bullfinches, the Crossbills, and the Plant-cutters. 


\section{$S U B-F A M I L Y I$ I.}

\section{Phocein.e.*}

\section{The, IIeavers.}

GEN. Charac.-Bill strong and conical, with the culmen projecting on the forehead and arched to the tip, which is entire; the wings somewhat rounded, with the first quill remarkably short; the legs and toes robust, and strongly sealed, and the hind toe strong and nearly as long as the middle toe.

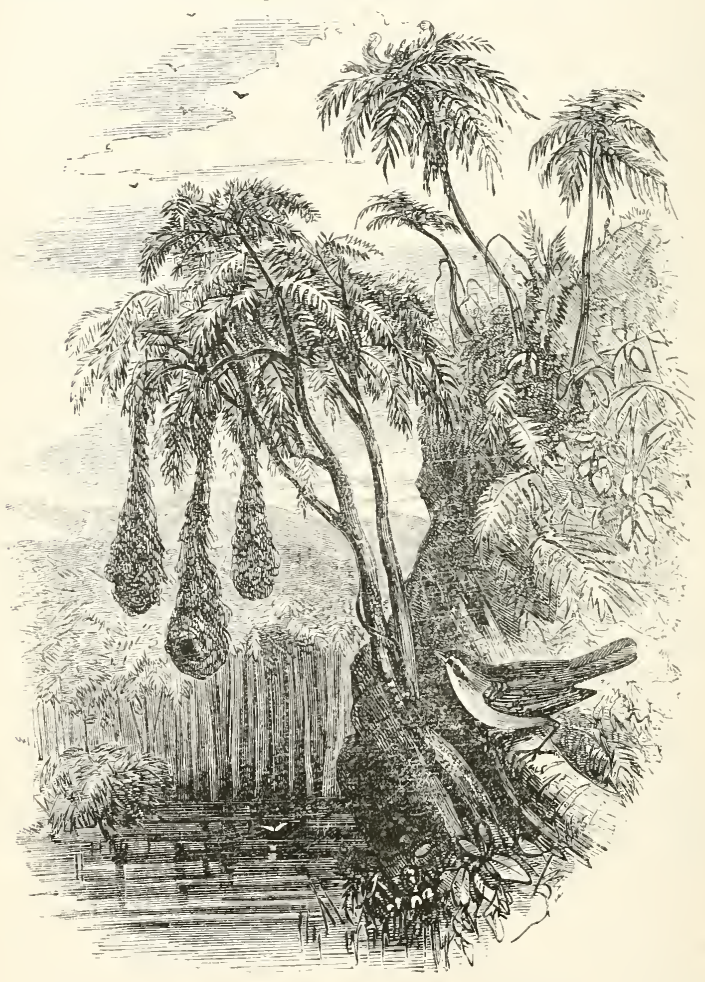

Fig. 96.-THE PHILIPPINE WEAVER-BIRD.

(Ploceus Philippinus.)

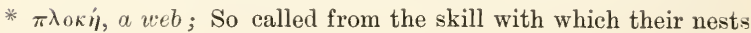
are woven. 
These birds inhabit India and Africa, where they are to be seen on trees near the banks of rivers: they feed on small fruits, rice, and seeds, and do considerable damage in gardens during the summer.

Sereral species build curious hanging nests, composed of the stalks of grasses, very neatly and closely interwoven, and have thus earned for themselves the name of Weacer-birds.

\section{The Philippine Weaver-bird (Ploceus Plilippinus) is} described as suspending its nest by a cord of considerable length from the branch of a tree, so as to be inaccessible to snakes and monkeys. This elegant structure is said to contain a chamber for the male, and another for the female, the former being situated close to the opening at the bottom of the nest, through which the birds obtain access to their snug apartments. Here the male stations himself, and the natives believe that he attaches to the walls of his chamber a patch of soft clay, to which he fastens a fire-fly to serve as a night-light. The Baya of India, which, if not identical with, is very nearly allied to the Philippine species, is better known, and, from the observations of European residents in India, we obtain more accurate information of its proceedings. The nest of this species is usually suspended from the tips of the leaves of the fan-palm, where it hangs perfectly secure from all plunderers, or sometimes from the leaves of the Babul, a species of mimosa, whose formidable thorns serve to keep all intruders at a distance. It is composed of dried grass, closely interwoven, and resembles a gradually enlarging purse of thirteen or fourteen inches in lengtl, and about seren inches in diameter at the lowest part, where the true nest is situated. This consists only of a single chamber, the opening of which is at one side, access to it being obtained by means of a cylindrical passage hanging down from the bottom of the nest. The male has a separate, but less perfect nest of his own, and in this Mr. Layard always found two masses of clay attached on each side of the perch occupied by the biril. The Cingalese asserted that these were for the reception of the fire-flies, which they believe the male bird takes into his abode on the approach of night; but Mr. Layard was unable to verify this supposition. 
Many other species belonging to this sub-family are equally remarkable for the beauty and unusual structure of their nests. Some are gregarious even during the breeding season, hanging their nests close together on the same tree; and as each bird, on building a new nest, places it in close juxtaposition with the old ones, an apparently solid mass of nests is at length collected, consisting of numerous apartments each tenanted by a pair of birds, but having the external appearance of one single dwelling.

\section{Of these-}

The Sociable Grosbeak (Ploceus socius), an inhabitant of the interior of Africa, near the Cape of Good Hope, is one of the most remarkable. These birds build their nests in mimosa trees, which grow to a large size, and

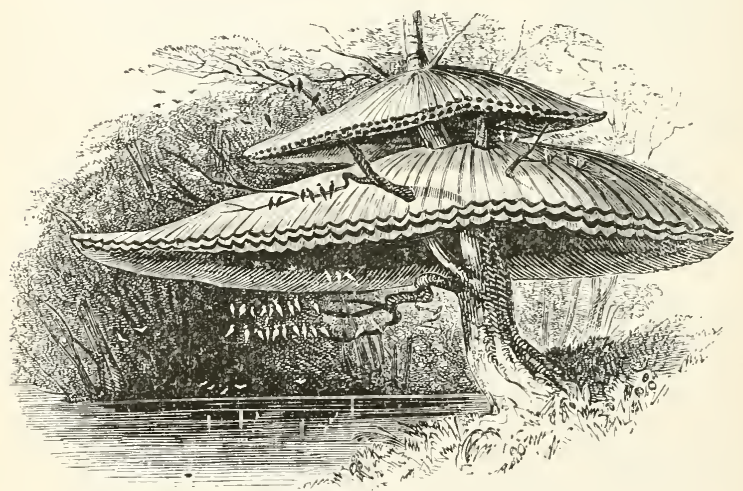

Fig. 97.-Nest of the sociable grosbeak.

(Ploceus socius.)

appear to be peculiarly adapted for the purpose, as the smoothness of their trunks prevents the occupants from being attacked by monkeys and other noxious animals.

"On one tree," says Mr. Paterson, "there could not be less than from eight hundred to a thousand of these nests, under one general roof. I call it a roof because it resembles that of a thatched house, and projects over 
the entrance of the nest below in a very singular manner. The industry of these birds seems almost equal to that of the bee. Throughout the day they appear to be busily employed in carrying a species of fine grass, which is the principal material they employ for the purpese of erecting this extraordinary work, as well as for additions and repairs. Though my very short stay in the country was not sufticient to satisfy me by ocular proof that they added to their nest as they annually increased in numbers, still, from the many trees that I have seen borne down by the weight, and others which I have observed with their boughs completely covered over, this would appear to be really the case. When the tree which is the support of this aërial city is obliged to give way to the increase of weight, it is obvious that they are no longer protecter, and are under the necessity of rebuilding in other trees. One of these deserted nests I had the curiosity to break down to inform myself of the internal structure, and found it equally ingenious with that of the external. There are many entrances, each of which forms a regular street, with nests on both sides at about two inches' distance from each other. The grass with which they build is called the Bushman's grass, and I believe the seed of it to be their principal food, though, on examining their nests, I found the wings and legs of different insects. From every appearance, the nest which I dissected had been inhabited for many years, and some parts were more complete than others. This, therefore, I conceive to be an additional proof that the animals adided to it at different times, as they found necessary from the increase of the family, or rather, of the nation or conmmuity."

But the most celebrated of these ingenious architects is the "Tailor-bird," whose nest is a perfect curiosity. When about to build a cradle for their progeny, the Tailor-birds first select a plant with large leaves, and then, gathering real cotton from the cotton-plant, spin it into a thread by means of their bill and feet, and literally sew the leaves together so as to form a sort of pensile bag, in which the young are reared. Much obscurity hangs over the true affinities of this little bird ; it is generally known by the name of Sylvia sutoria, or Tailor Warbler. Dr. Latham describes its nest as composed of a single leaf of a fibrous rough texture, about six inches 
long and five inches and a half in breadth, ending in a point. The sides of this leaf are drawn together so as to meet within three-quarters of an inch; within this is the nest, which is about four inches deep and two broad, opening at the top; and the bottom of the leaf is drawn upwards to assist in supporting it. This inward nest is composed of white down, with here and there a feather. The stalk of the leaf, from which the whole fabric hangs, is about five inches long. The specimen above described was brought from China.

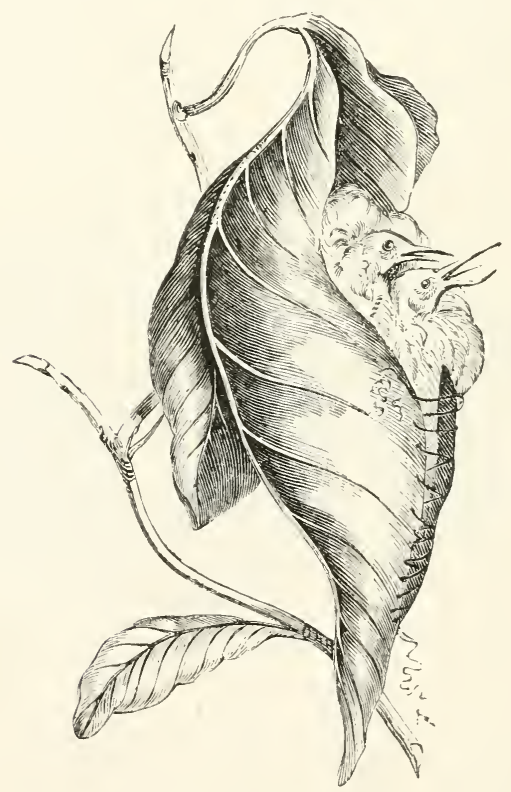

FIG. 98. -NEST OF TAILOR-BIRD. 


\title{
SUB-FAMILYII.
}

\author{
Coccothraustinæ.*
}

The II aurfinches.

Gen. Charac.-Bill large, short, strong, conic, and very broad at the base; the culmen and gonys more or less equally curved at the tip; the lateral margins more or less angulated at their base; the wings lengthened and more or less pointed; the tail in general short; the tarsi as long as or shorter than the middle toe, robust, and strongly sealed, and the hind toe as long as, or rather shorter than, the inner one, and strong.

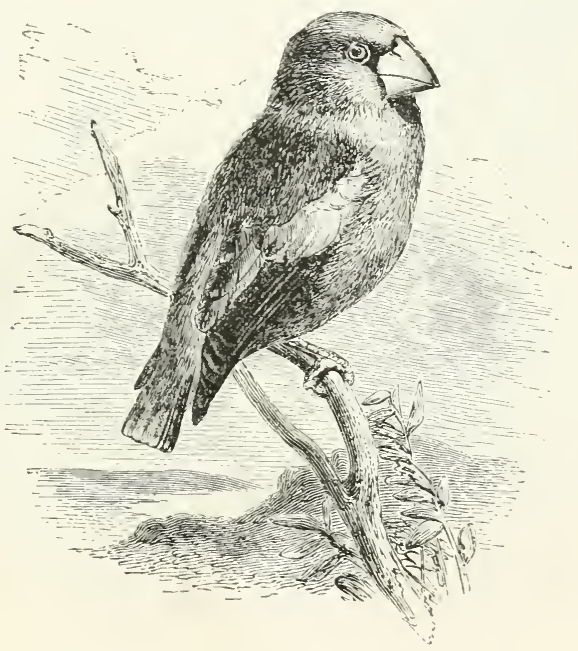

Fig. 99.一тне нашғгхсн.

(Coccothruustes vulgaris.)

'These birds are found in various parts of Europe, North America, and the northern parts of India, where they migrate periodically in search of the seeds and fruits on which they feed. The great strength of their bills allows them to break cherry-

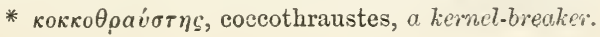


stones and almonds for the kernels; they likewise seed upon haws and other winter berries.*

The type of this sub-family,-

The Hawfinch (Coccothraustes vulgaris), from its general conformation, is evidently adapted to some laborious occupation. Its short tail and wings unfit it for long aërial voyages, and its thick neck and ponderous bill denote great muscular power. Hawfinches may be seen in winter diligently picking up and cracking the stones of laurel cherries, from which Blackbirds had, a few months before, stripped the pulp. They are not uncommon in cherry orchards, where their visits may be detected by the ground being eovered with halves of cherry-stones, which these birds split with their powerful beaks, as cleverly as a workman could divide them with his chisel ; they likewise feed on hazel nuts, the kernels of the fruit of the hawthorn, seeds of various kinds, and, when they can get them, green peas.

The nest is built sometimes in a bush, and sometimes among the branches of a tree : it is composed of twigs, intermixed with a larger or smaller quantity of fragments of grey lichen. The latter is never wanting, and sometimes constitutes the greater part of the nest. The materials are loosely put together, and the cavity is lined with fine roots and hair; the eggs are from four to six in number, of a pale olive colour, spotted with brown and streaked with grey.

* Hence the Hawfinch is called by the Germans, Kernbeisser, Kirsch Kernbeisser, Kerschfink, Nussbeisser, \&c. 
TANAGRINE.

The Tanagers.

Gev. Charac.-Bill more or less triangular at the base, with the culmen more or less arched to the tip, which is more or less emarginated; the wings moderate and somewhat pointed; the tarsi and toes short and slender, the hind toe rather lengthened and strong, with the claws strong and curved.

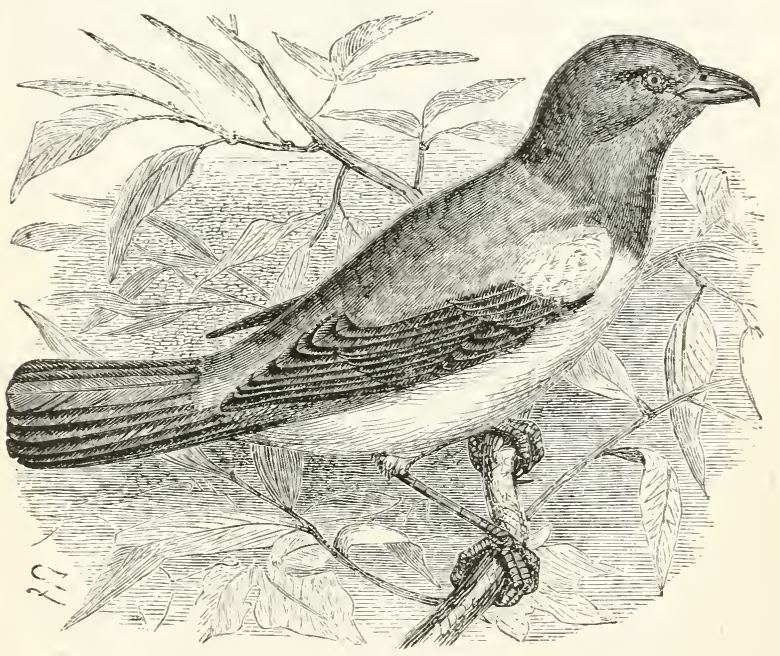

FIG. 100.-THE RED-HEADED PYRANGA.

(Pyranga ruliceps.)

The Tanagers are distinguished from the other Finches by their bill having a distinct and welldefined notch near the end of the upper mandible. They are all natives of the warmer parts of America, abounding most in those regions which lie nearest to the equinoctial line. They are in general small birds, the largest being intermediate in size between a sparrow and a thrush, while the majority do not exceed the size of a limet : some are smaller. It is 
quite evident, from the great strength of the bill possessed by some, and by the notch which is conspicuous in all, that these birds feed both upon seeds and insects, picked from the branches of trees; for they are rarely seen upon the ground. Their colour's are generally bright, and in many species particularly rich and beautiful; some, indeed, are ornamented with the most vivid hues, or glossed with rich reflections of gold, rendering them inferior only to the Humming-birds. A few possess considerable vocal powers, and the notes of the sub-genus Euphonia, as its name implies, are particularly musical. The impossibility of providing 'Tanagers with their native insect food has prevented them from ever being brought alive to Europe.

The type of this sub-family is-

The Red-headed Pyranga (Pyranga rubiceps). 


\section{$S U B-F A M I L Y I V$.}

FriNGILLINA.
The Finches proper.

Gen. Charac.-Bill short, conic, and more or less broad at the base, with the culmen sloping and the sides compressed to the tip, which is generally entire; the gonys long and advaneing upwards; the wings more or less lengthened and pointed; the tail varying in length, sometimes with the end of the feathers acuminated; the tarsi as long as, or shorter than, the middle toe, slender and transversely sealed; the toes more or less long and slender, the hind toe moderate; the elaws generally long, curved, and acute.

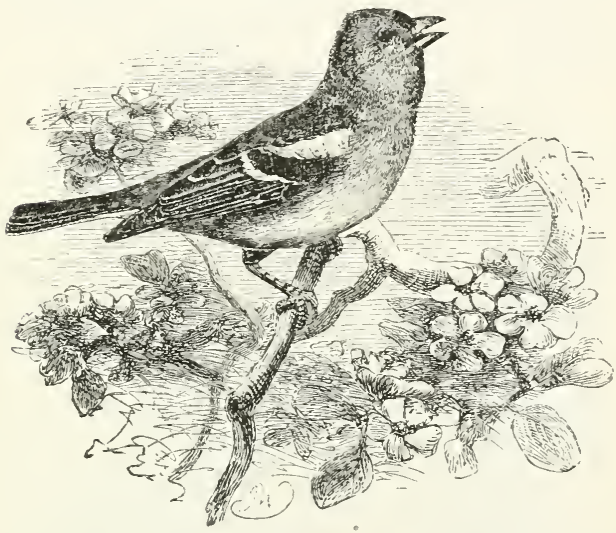

FIg. 101.- THE CHAFFINCH.

(Fringilla coelebs.)

Birds belonging to this sub-family are found in various parts of Europe, Asia, Africa, both North and South America, and Australia. They generally frequent open and cultivated places, but some prefer' the wild and mountainous districts; they live in flocks, several species sometimes congregating together, especially during the winter months. Those that reside in the more northern latitudes migrate southwards during the cold season, and those inhabiting the higher altitudes of the mountains seek the lower grounds on the approach of winter. Their 
food consists, during the winter months, of seeds of various plants and trees, such as the alder, maple, \&c.; they likewise feed upon grains, which they seek for on the ground, especially in stubble lands; many, however, live on insects and their larvæ when procurable. Their song consists of three or four notes, which, though short, frequently possess great sweetness, and are agreeably varied. The nest of some is formed upon trees and in bushes of mountainous districts, while others prefer gardens, orchards, and plantations ; it is composed of grass, moss, and lichens, interwoven with wool, and lined with feathers and hair. The egg's are four or five in number.

The type of this sub-family is-

The Chaffinch (Fringilla colebs). The Chaffinch is generally spread through Europe from Sweden to Gibraltar, and is even found on the coast of Africa. Some of these birds migrate in great numbers in autumn; but these flocks are said to consist of females only, while the males remain in their native country; indeed, the specific name (Coelebs, or the bachelor), given by Linneus to this bird, is in allusion to the lonely condition of the deserted males. It is not impossible, however, that there may be some mistake in this, for, from the moulting time to the month of February, and more particularly in autumn, the two sexes exhibit colours nearly similar. At all events, it is quite certain that many females remain, as well as males, and assist in forming, together with the Tree-finches, Greenfinches, Buntings, and other birds, those innumerable flocks which during winter are seen in our fields, and which, when the earth is covered with snow, come before our barns to share the daily food of our domestic fowls. From the early days of spring they begin to pair, and the mated couples isolate themselves. Some resort to our gardens and orchards, others retire into coppice-woods, which they animate by their gaiety, and also by their song, which is by no means devoid of melody ; indeed, the Chaffinch, when taken from the nest, will imitate the notes of the Canary and of the 
Nightingale, if kept near those birds, and can even be taught to articulate some words.

Their song usually consists of a sharp repetition of a sound resembling the word "Fink" or "Pink," and it is from the former of these that the word Finch is derived. Although his musical powers are by no means perfect, the note of the Chaffinch is always heard with pleasure, being associated with early spring; and the sprightliness of the little bird renders him a universal favourite except with gardeners, whose radish-seed, sowed at a period when food is usually rather scarce, is too great a temptation for him to resist, and which he will frequently steal, almost before it has been covered by the soil.

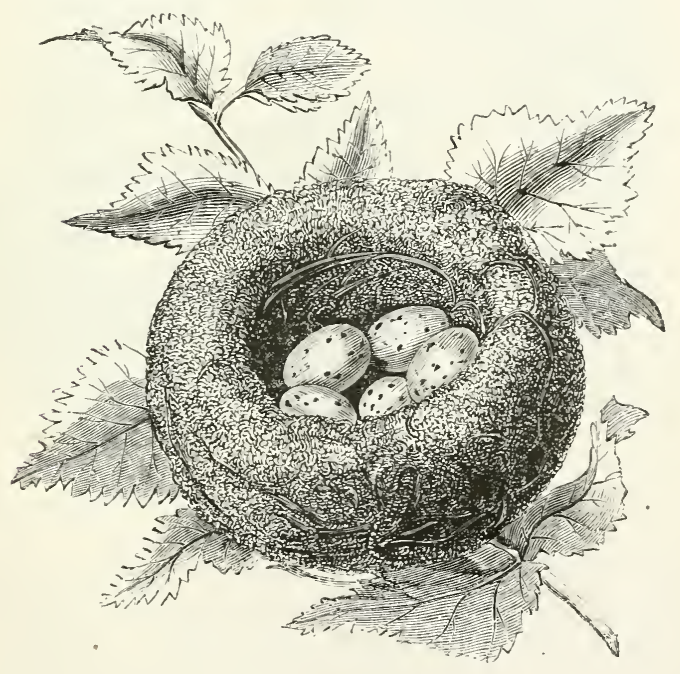

NEST OF GOLDFINCH. 
Ger. Charac.-Bill eonical, acute, compressed, with the eulmen more or less straight to the tip, the lateral margins sinuated, and more or less inflected; the interior of the upper mandible furnished with a palatine knob, which is more or less apparent; the wings moderate and somewhat pointed; the tarsi ahout the length of the middle toe, and seutellated; the hind toe longer than the inner, and robust; the claws slender, and more or less eurred.

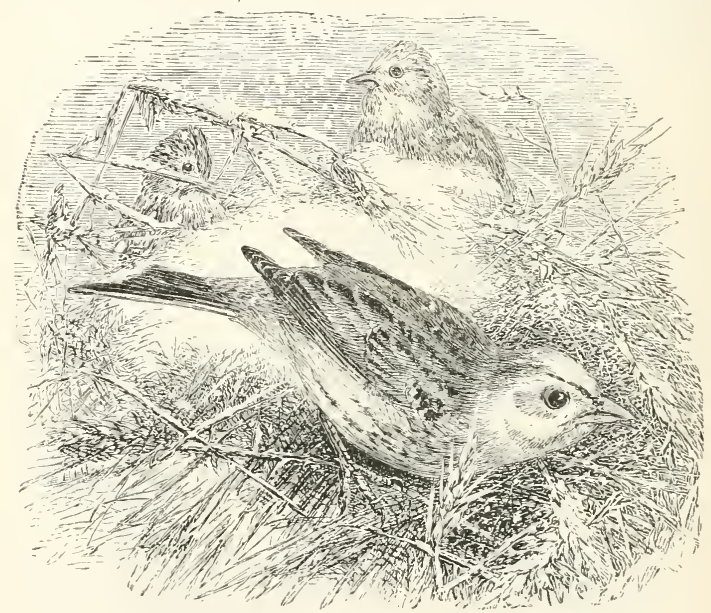

Fig. 102.-THE YELLOW AMHER

(Emberiza citrinellu.)

The birds which compose this family are met with both in the Old and New World, but especially in the former. They collect together in flocks by themselves, or in company with other seed-feeding birds, at the approach of winter, and remain in society till the return of spring, when they scatter themselves singly or in pair's over the open country. They do not. remove to any great distance in their migrations; their flight is undulating and quick; 
their food consists of the seeds of plants, grasses, and reeds, and, in warm weather, insects. They build in low bushes, or on the ground, behind tufts of grass. Their nest is composed of dried grasses lined with softer materials. They lay from four to six egors.

The Buntings are distinguished from other Passerine birds by their conical, short, and straight bill, but more especially by the existence of a knob in the roof of the upper mandible, which is made use of as an anvil on which to break and comminute liard seeds. 'They do not, however, feed exclusively on regetable matter, but, like most of their order, subsist partly upon animal substances.

\section{The type of the race is-}

The Yellow Ammer (Emberiza citrinella). Few of our native lirds are more delicately or more beantifully coloured than the Yellow Ammer, or Yellow Bunting, but, heing very abundant, it is less noticed than it deserves, except as an intruder, with other granivorous birds, into the stack-yard. During the winter the Yellow Ammers collect in small flocks, or associate with flocks of the Common Bunting (Emberiza miliaris). In spring, during the pairing season, the male may often be observed on the topmost twig of a hedgerow, uttering a monotonous chirp : if approached, it flies off, keeping along the herge, and settles at a little distance; if followed, it repeats this short flight again and again. The Iellow Ammer builds on the ground, in low bushes, in beds of nettles or other herbage : its nest is formed of dried grasses, with a lining of hair. The eggs are of a pale purplish white, with streaks and waving marks of chocolate-colour. This species is to be met with throughout the greater part of Europe.

We owe to Mr. Yarrell the restoration to this bird of its original name Yellow Ammer, so often printed and pronounced "Yellow Hammer." The word "Ammer" is the common German word for Bunting; as, for example, "Schnee Ammer," Snow Bunting ; "Garten Ammer," Garden Bunting; "Roinr Ammer," Reed Bunting, \&c. 
Our mode of prefixing the letter $\mathrm{H}$ to the word is erroneous. In Italy these bircls are caught in great numbers and fattened for the table, in the same way as the Ortolan.*

* The Ortolan Bunting (Emberiza hortulanus), so esteemed as a dainty, appears to be confined to the southern parts of Europe, where, however, it is to a certain extent migratory. When they first arrive in France they are far from fat; but human ingenuity soon makes them in good condition. They are taken in great numbers with nets, and fattened by shutting them in a dark chamber, in which is placed a lantern surrounded plentifully with oats and millet. The darkness seems to have the effect of confining the whole attention of the bird to its favourite food, thus placed within view ; and it is said they will thus die of suffocation from their own fat, if left entirely to themselves. Another mode is by confining them in cages which admit a little light only to the box containing their food. When thus fattened, the Ortolan is said to be one of the most exquisite morsels in the epicure's carte du jour.

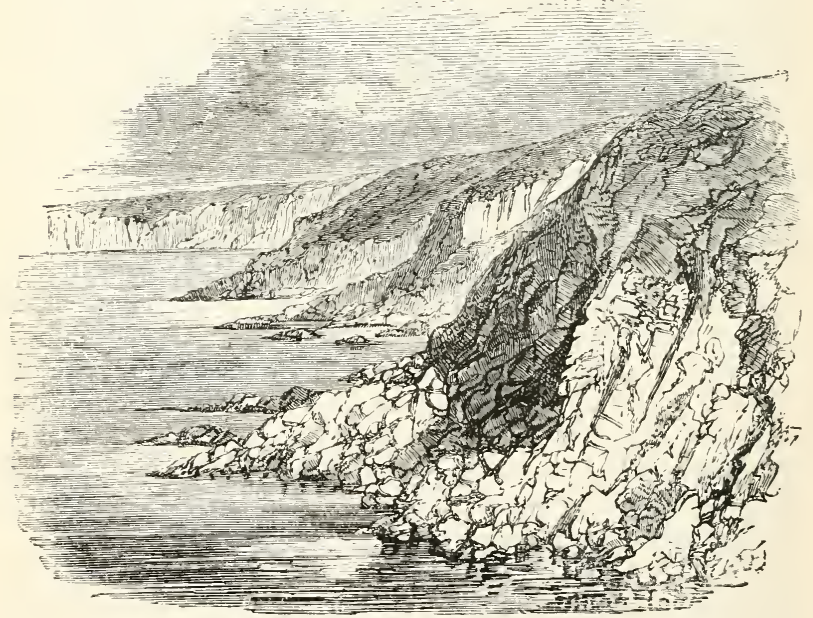




\section{$S U B-F A M I L Y$ VI.}

ALAUDIN.E.

The Larks.

Gen. Charac.-Bill short, and more or less lengthened and conical; the wings with the tertials generally as long as the primaries; the claws lengthened, more or less curved, and the hind one rery long and generally straight.

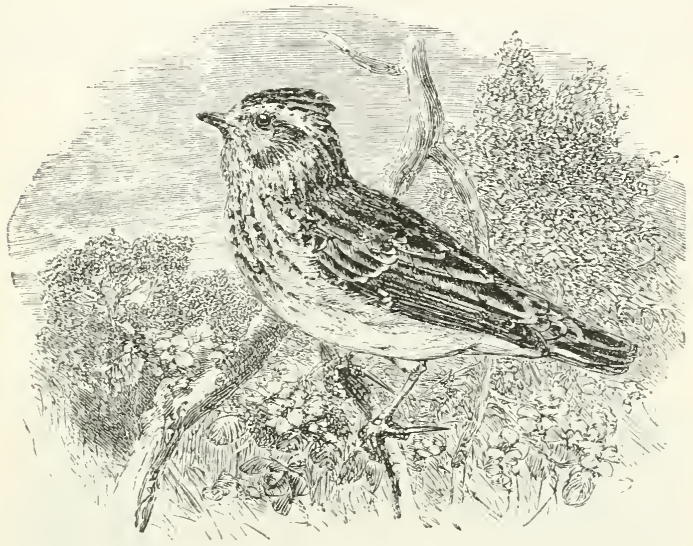

FIG. IUS. -THE WOODLARK.

(Alanda arborea.)

The birds composing this sub-family are peculiar to the Old World. They are generally found in open arable land, or on plains, though some seem to prefer cultivated ground. As the winter approaches, they migrate southwards, congregating in Hocks. Some of the species sing while rising into the air, mounting to an immense height. Their Hight is undulating, and they walk and run on the ground with ease. They delight to roll in the dust. Grain and various seeds form their principal food, but in summer they procure grasshoppers, gnats, 
and small worms. Their nests are of very simple construction, and placed upon the ground.

\section{The type of the race is-}

The Skylark (Alaula arvensis), the musician of the fielks; its delightful song, like a hymn of joy, announces the approaching spring, and accompanies the earliest b]ush of morning. It is heard from the very commencement of those fine days which succeed the cold and gloom of winter, and its notes are the first to welcome the ploughman to his task. During the noontide of day it is silent, but when the sun declines towards the west, the lark fills the air with his varied and tuneful warblings.

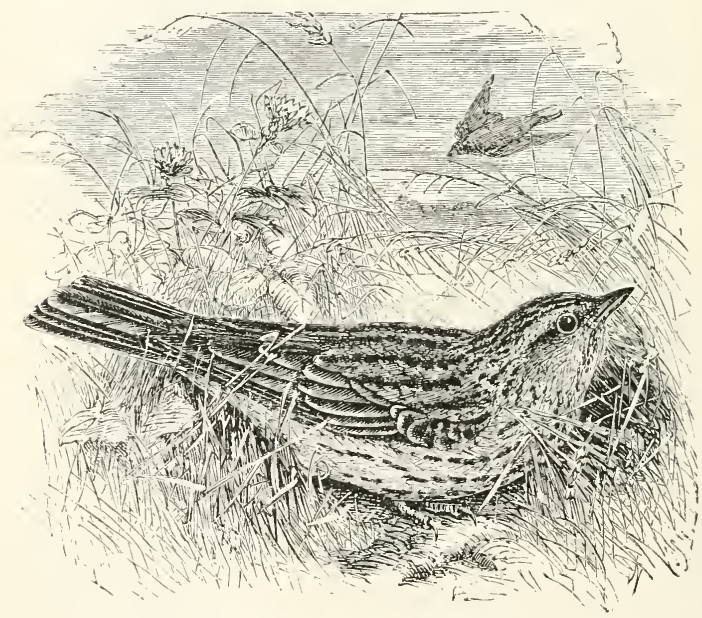

Fig. 104.-THE SKTLARK.

(Alauda arvensis.)

"Rising, as it were by a sudden impulse, from its nest ol" lowly retreat, it bursts forth, while but yet a few feet from the ground, into exuberant song; and with its head turned to the breeze, now ascending perpendicularly, now veering to the right or left, but not describing circles, it pours forth an unbroken stream of melody, until it has 
reached an elevation computed to be alout a thousand feet: to an observer on the earth it has dwindled to a mere speck. It then begins to descend, not with an uniform downward motion, but by a series of droppings, with intervals of simple hovering, during which it seems to be resting on its wings. Finally, as it draws near the earth, it ceases its song, and descends more rapidly ; but before it tonches the ground, it recovers itself, sweeps away with an ahmost horizontal flight for a short distance, and disalpears in the herbage."-liev. C. A. Johns.

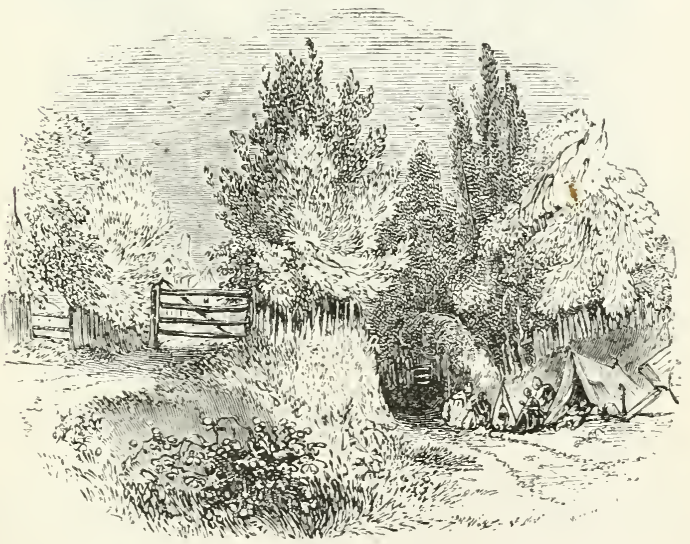




\title{
$S C B-F A L I L Y$ VII.
}

\author{
PYRRHULINA.*
}

The Bullfinches.

Gen. Charac.-Bill very short, strong, more or less compressed, and entire, with the culmen arched and convex; the wings moderate and somewhat rounded; the tail moderate and slightly emarginated; the tarsi short and scutellated; and the toes moderate, the lateral ones generally unequal.

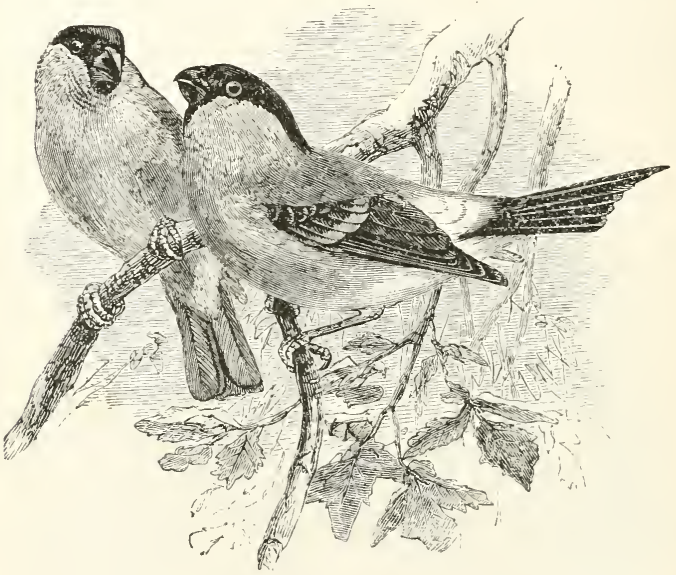

FIG. 10j.-THE BLLLFINCH.

(Pyrrhula rubicillu.)

The birds composing this sub-family are inhabitants of Europe and the northern parts of India, where they are usually found in the woods and jungles. They are generally seen in pairs during the spring, and afterwards congregate in small parties for the remainder of the year. Their food varies with the season; in the spring it consists principally of buds, and at this time the Bullfinches occasion much injury to the fruit and other trees;

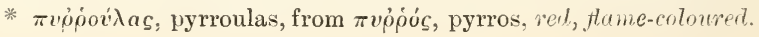


while during the summer and autumn they seem to. prefer the seeds of various plants. Their nest is carelessly put together and shallow, formed of small twigs lined with fibres of roots, and placed in the forked branch of a tree. The eggs are from four to five in number.

The type of this sub-family is-

The Bullfinch (Pyrrhula rubicilla), a bird equally remarkable for the simple elegance of its plumage and the variety of its song; it is, moreover, but too well known from the devastation which it causes among our fruittrees. During winter the food of the Bullfinches consists exclusively of seeds of rarious kinds, either picked up, from the ground or gathered from herbs and shrubs. In spring, unfortunately for the gardener, their taste alters, and nothing will satisfy them but the blossoms of fruittrees, especially those which are cultivated. They attack, indeed, the buds of the sloe and hawthorn as well, but of these, being valueless, no one takes any note. Keeping together in small family parties, all uninvited, they pay most un welcome visits to gooseberries, plums, and cherries, and, if undisturbed, continue to haunt the same trees until all hope of a crop is destroyed. Gooseberry bushes are left denuded of flower-buds, which have been deliberately picked off and crushed between their strong mandibles; while the leaf-buds, situated principally at the extremity of the branches, are neglected. Plums and cherry trees are treated in like manner, until the ground is strewed with the bud-scales and rudiments of flowers.

The Bullfinch builds its nest in some secluded copse or thick hedge, employing as materials small twigs and dry grass, with a lining of fibrous roots : it usually lays five eggs. Less frequently it places its nest in a shrubbery or garden hedge.

The ordinary notes of the Bullfinch are not musical; but these birds possess a remarkable talent for imitation, and, when taken young, may be taught to whistle many tunes with considerable accuracy. Their musical instruction is generally communicated by means of a bird-organ, and requires considerable time and care, as the birds must be in the habit of hearing the tunes they have to learn for many months, in order that they may acquire them per- 
- fectly; and when they begin to exert their musical powers, they must be kept from hearing other birds, and from time to time assisted in their recollection, lest they should transpose the passages in any way, or mix two airs together. Hence a good piping Bullfinch necessarily fetches a high price. Great numbers of them are, however, trained in Germany, and imported into London every year.

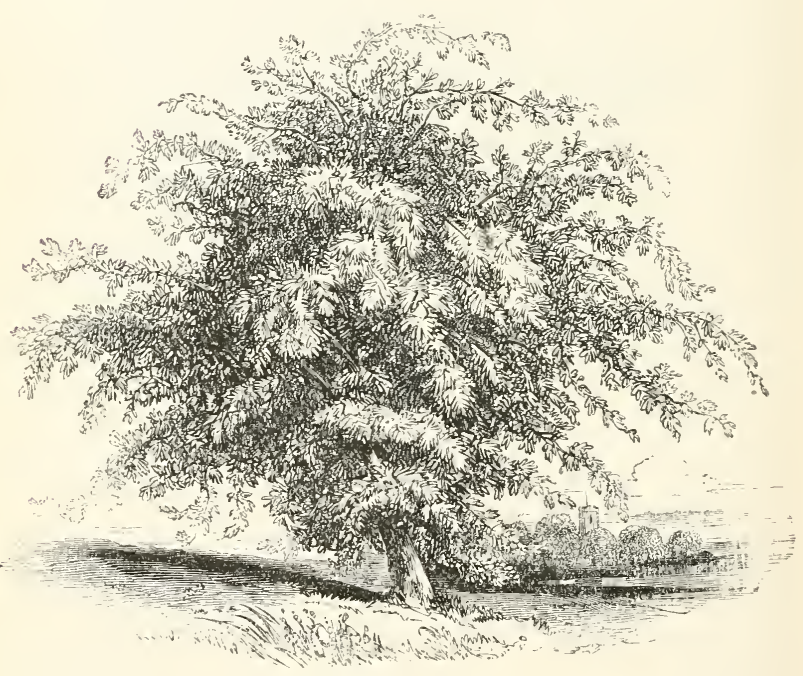




\section{SUP-FALILY VIII.}

LOXIAXE.*

The C'rossbills.

Gex. Charac.-Bill more or less broad, but eompressed towards the tips, which sometimes cross each other, and curved, or the upper overhanging that of the lower mandible; the wings more or less lengthened, pointed, and sometimes rounded; the tail moderate and emarginated, or graduated the tarsi short, with the toes molerate.

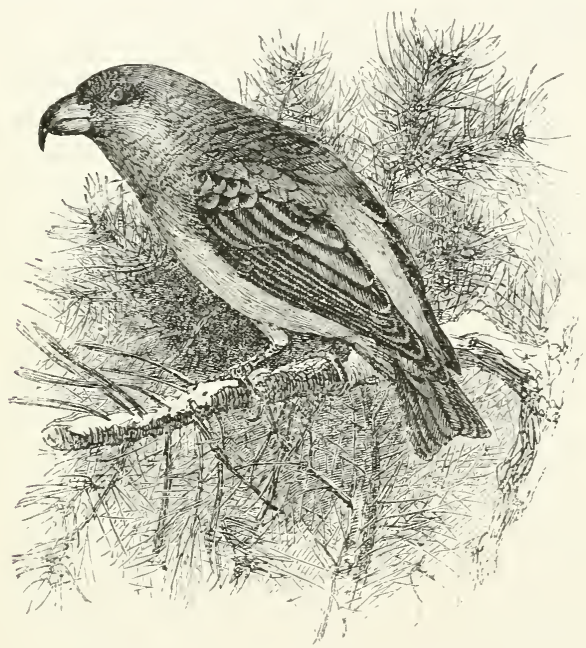

Fig. 106 - THE commox crossbill.

(Loxia curvirostra.)

These birds are found in the North of Europe, America, and Asia, migrating in summer to the higher latitudes, where they frequent the great forests of pine and fir trees, the seeds of which form their principal subsistence. These seeds are detached by means of the strong lever they possess in the remarkable formation of their bill, which is

* $\lambda o \xi o c$, loxos, slanting, cross-vise; So called from the shape of the beak. 
admirably adapted for wrenching asunder the scales of the cones; it also enables them to slit open apples and pears for the purpose of obtaining the pips, and they thus occasionally commit great havoc in orchards.

Their nest is built among the branches of pinetrees, and is composed of straws, with a few twigs upon the ontside, and a lining of fine grass and hair within. The young birds, while in the nest, do not present the peculiar crossing of the mandibles characteristic of the adult, this being unnecessary to them so long as they are supplied with food by their parent. In confinement these birds are very parrotlike in many of their actions, frequently climbing about the wires of the cage with their hooked bill; hence they are sometimes called German Parrots. In Germany, where they are abundant, Crossbills constitute a favourite article of food, and are regularly exposed for sale in the markets.

The Common Crossbill (Loxia curvirostra) is by no means of unfrequent necurrence in the northern parts of our own country. These birds feed principally on the seeds of varions kinds of firs, which they extract from the cone by the joint action of their beak and tongue. The alder and other trees are sometimes visited, and they have been noticed to resort to thistles and pick out the seeds from them. Their mode of operation is this: they first fix themselves across the cone, then bring the points of their mandibles from a crossed or lateral position to be immediately over each other; in this reduced compass they insinuate their beak between the scales, and then opening them, not in the usual manner, but by drawing the inferior mandible sideways, force open the scales. At this stage, the end of the tongue becomes necessary, and this organ is no less admirably adipted for the service required. While the points of the beak press the scale from the body of the cone, the tongne is enabled to direct and insert its cutting scoop underneath the seed, and the food thus dislodged is transferred to the mouth. When the mandibles are separated laterally in the performance of this operation, the bird has an uninterrupted view of 
the seed in the cavity, with the eye on that side to which the under mandible is curved, and thus can direct the movements of its tongue with the greatest precision. The beak of the Crossbill, then, far from being a defect in the organization of this bird, is a perfect instrument always at its owner's command ; faultless alike in design and execution, and exquisitely adapted to its work-not an easy one-of performing, by a single process, the offices of splitting, opening, and securing the contents of a fir-cone ; and he must be a bold man who would venture to suggest an improvement in the mechanism.

"The nest of the Crossbill is placed on two small branches of a young spruce-pine tree, or at the end of at leafy bough, often at a considerable height from the ground. It is circular, and composed of the small twigs of the spruce-pine. This nest is of large dimensions, the diameter being two feet or more. The entrance is round, but so small that the bind must nece-sarily squeeze itself into it: the interior is not larger than a man's fist. Such are the nests prepared for the winter. Those intended for the summer are much less in size, more open, and of a much lighter construction. This bird, therefore, builds its nest differently according to the season of the year and the temperature. The female lays from three to four eggs of a somewhat small size, and of a dinty white colour, thickly marked with brown spots. When the young leave the nest, they follow the mother, who feeds them, but at this period the male deserts the family: he is never seen in company with a female that has newlyfledged young. These accompany their mother; they keep up a terrible noise, screech most unmercifully, and flutter their wings. When feeding the young, the female allows the cone to fall to the ground. The young follow her to the cone, out of which she plucks the seeds, while they, gaping and screeching, surround her on all sides."Lloyd's Scandinavian Advertures. 


\section{SUB-FAMIILY LX.}

Phytotonise.*

The Plant-cutters.

Ger. Charac,-Bill short, conical, with the lateral margins serrated.

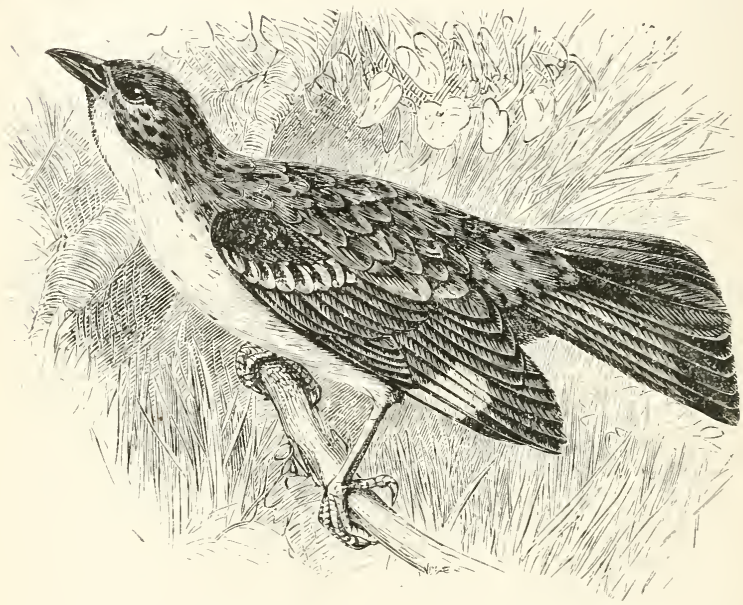

Fig. 107.-THE CHILiAN PLANT-CUtTer.

(Phytotoma rara.)

The Plant-cutters constitute another group of the large-billed Finches. These birds are peculiar to the temperate regions of South America, where they frequently visit the environs of inhabited and cultivated places. They live in pairs or in small troops, despoiling gardens and orchards, and devastating plantations by cutting off the buds and fruits. Their flight is short and low, but sometimes prolonged, and their habits resemble those of the Tanagers. Their note is excessively disagreeable,

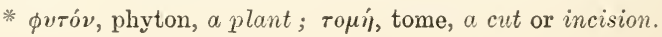


approaching the noise made by the sharpening of a saw. They feed on grains, buds, and insects. 'They are generally of moderate size, about equalling the Bullfinch in their dimensions. In order to enable them to obtain their food, the margins of the upper mandible are finely toothed.

The type of this sub-family-

The Chilian Plant-cutter (Phytotoma rara), is rather a large species, being equal to a thrush in its dimensions. It is a common bird in its native country, and is most destructive to the crops. It is very fond of sprouting coln, and, not content with eating the green blades, it seems to find such pleasure in the exercise of its bill, that it cuts down hundreds of stalks, as if in mere wantomness, and leaves the green stems strewed upon the ground. ()n accourit of these destructive propensities, it is greatly persecuted by the agriculturists, who assiduously shoot and trap it ; and further aid in its extermination hy setting a price on its head, giving a certain sum to any one who will bring in a dead bird. The nest is made on the summit of a tree, and in some very retired situation ; so that, in spite of all the persecution which it meets with, the Plant-cutter still holds its ground against the farmers. Its cry is rough, and resembles the name Rara, given to it by the inhabitants of Chili. 


\section{FAMILY V.}

\section{COLIDA.}

Gen. Charac, - Bill moderate, with the culmen elevated at the base, and the sides compressed to the tip, which is acute; the nostrils placed in the middle of a large membranous groove, with the opening small and exposed; the wings short; the tail much lengthened and graduated; the tarsi robust, and the toes lengthened, the outer as long as the inner, the hind toe moderate, united at the base of the inner toe, and directed forwards.

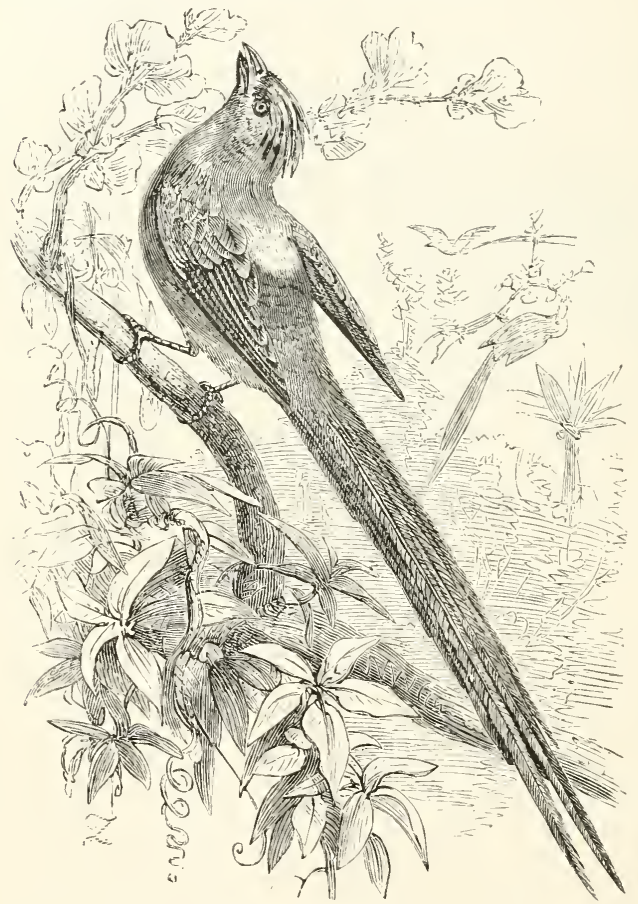

Fig. 108.-THE WHITE.BACKED COLY.

(Colius leuconotus.)

These birds are peculiar to the continent of Africa, where they perch upon trees, amongst the branches 
of which they may be seen hopping from one to another in search of the fruits or freshly-formed buds. Their flight consists of little more than flitting from tree to tree; and they have a peculiar habit of suspending themselves by one foot, with the head hanging downwards. Their feet are constructed like those of the Swifts, with all four toes tumed forward. 'The tarsus, considering the size of the bird, is unusually thick and strong; and the claws of all the toes are more curved than in ordinary birds. They are rarely observed on the ground, the peculiar formation of their feet not permitting them to walk with ease. They build their nests in society, - closely packed together on the same branch. The nest is composed of flexible twigs, and lined with feathers. Their eggs are from four to six in number.

The White-backed Coly (Colius leuconotus) is found in Africa. It is a pretty bird, and as it traverses the branches has a peculiarly elegant appearance, its long tail seeming to balance the body, in the extratordinary and varied attitudes it assumes; and its highly moveable crest being continually raised and depressed, gives it a very spirited aspect. It is gregarious, living in little companies of four or five in number, and is continually running and jumping from bough to bough in search of its food, which consists of fruit and buds. The grasp' of its feet is very powerful, as much so as that of the Parrot, so that it may often be seen hanging by its feet, with its head downwards, and occasionally remaining for some time suspended by a single foot; indeed, Le Vaillant says that this bird, in common with other members of the same family, is in the habit of sleeping in this singular attitude; and that in the early morning it may be often found so benumber with cold, that it may be taken by hand before it can loose its hold from the bough, which it grasps so firmly. Owing to the structure of its feet, which are almost wholly formed for climbing; it is seldom seen on the ground, and when it has alighted, is awkward in its movements. Among the boughs, however, it is all life and energy, leaping about with a vivacity 
that reminds the observer of our common long-tailed Titmouse. In mounting fiom branch to branch, as in lowering themselves, the Colies frequently use their beaks to aid them, after the well-known practice of the Parrots. The nests of the Colies are large and rounded, and are generally placed in close proximity to each other, five ${ }^{\circ}$ six being often found on the same branch. They are comstructed of slender twigs externally, and lined with mosses and soft feathers. The number of eggs is from form to six. When fat and in good condition, the flesh of these birds is said to be delicate and tender.

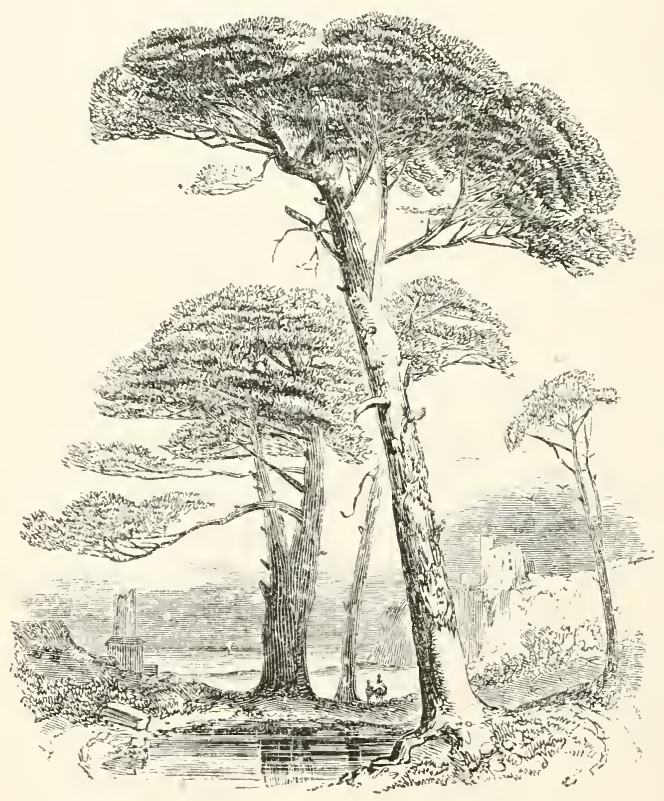




\section{FAMILY VI.}

Musophagide. *

The Plantain-eaters.

Gex. Charac.-Bill moderate, broad at the base; the eulmen much elevated, curved, and the sides much eompressed towards the tip, which is strongly emarginated; the wings more or less lengthened and rounded; the tail long and broad; the tarsi moderate, strong, and covered in front with liroad transverse scales; the toes long, and the outer one sometimes versatile.

Among the many adaptations of a more general character whereby the ormithologist is enabled, from the mere examination of a skin, or a glance at a stuffed specimen, to indicate the usual food and general habits of birds submitted to inspection, it occasionally happens that special peculiarities are observable, the object of which it is difficult to understand withont a knowledge of the circumstances miler which a given species subsists. Many localities produce delicious fruits in rich abundance, and to obtain these more conveniently, the birds appointed to feed upon them present remarkable modifications of structure. The plantains, for example, throughont many regions of tropical countries, afford a supply of food so plentiful, that a whole family of the feathered creation has been named from its predilection for this particular diet.

This family embraces the Plantain-eaters and the Hoaitzins.

* Musa, the plautain; $\phi \dot{\alpha} \gamma(\omega$, phago, to eat. 


\section{SUB-FAMILYI.}

\section{Musophagin.e. The Plantain-eaters moper.}

Gex. Charac.-The outer toe capable of being placed posteriorly.

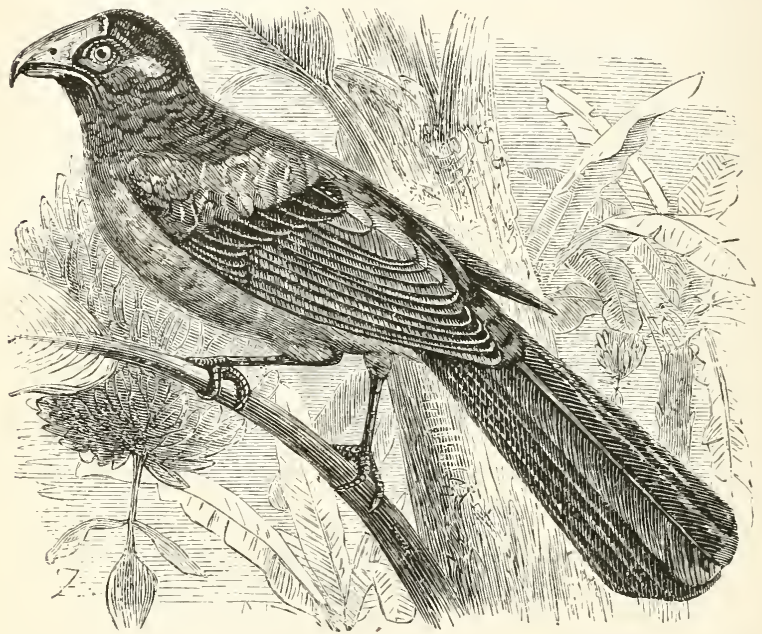

Fig. 109 -THE VIOLET PlantaiN•Eater

(.Musophaga violacea.)

These birds are natives of Africa, where they are not at all uncommon, and may be often seen in the forests, flitting among the branches of lofty trees, gliding among the boughs with great adroitness, and displaying their silky plumes to the best advantage. They are wary birds, and seem to have tolerably accurate ideas respecting the range of shot; for they generally keep to the higher parts of the trees, and seldom allow themselves to be approached within the range of a gun. Their food consists almost entirely of plantains and other fruits, which their large beak seems especially formed to procure. 
'They are all handsome birds, their dimensions resembling those of the European Jay, and their plumage glancing with violet, green, purple, and red of different shades.

\section{The type of the race is-}

The Violet Plantain-eater (ILusophrogr violacen). This bird is found about Senegal and the Gold Coast. It is remarkable for the extraordinary shape and dimensions of the beak, which is everywhere large and prominent, but especially swollen towards the base, where it expands into a large shield-like mass of horny substance, which spreads over the forehead as far as the crown, where it terminates in a semicircular thickened line. The ridge of the beak is greatly arched, and its sides are much compressed. Its colour is as singular as its shape-a fine golden yellow, passing into crimson on the upper part of the base. The top of the head is crimson, not unlike that of the beak, and the feathers are very soft and fine, having a velvety or plush-like aspect. The general colour of the plumage is very deep violet, appearing black in the shade, and glossed with rich green in certain lights.

Another species found in Southern Africa and in the extensive eastern forests, Le Vaillant represents as being of so inquisitive a disposition, that it spontaneously approaches a man or a quadruped, leaping from tree to tree, and uttering a cry of satisfaction, which is expressed by the syllable cor uttered with a prolonged and guttural articulation, and with a quiver of the tongue. Its lovecall has been represented by the word corouv uttered eight or ten times in succession, and its note of alarm has been compared to the abrupt sounds of a military trumpet. The female lays four bluish-white eggs in the large holes of trees. 
GEx. CHarac, - Toes lengthened, and the outer toe not eapable of being placed posteriorly.

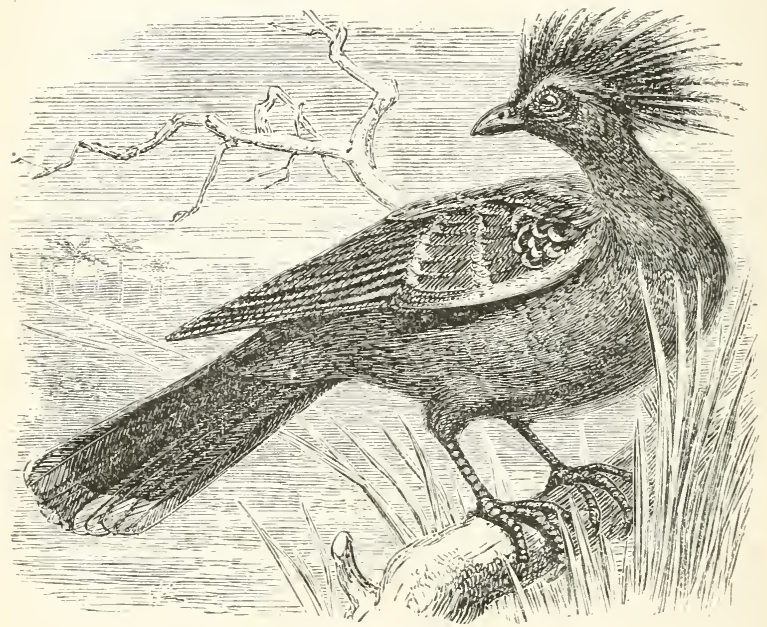

Fig. 110.-THE HOAITZIN.

(Opisthocomus cristatus.)

These remarkable birds are peculiar to the northern parts of South America. They live in small flocks on the banks of rivers, and are by no means shy, allowing the hunters to approach very near. If alarmed at the report of a gun, the flock takes flight, crying cra, cra, and they all alight on the same branch a few paces further off. Their food consists of the leaves of a tree, called by the natives Avingo, or of those of the Arum arborescens, which

* ö $\iota \tau \theta \varepsilon$, opisthe, behind; кó $\mu \eta$, kome, a lock of hair; So called from the crest at the back of the head. 
causes the flesh to have a musky smell, and to be used as a bait for certain fishes.

The Hoaitzin (Opisthocomus cristatus). The true position of this curious bird must still be considered as doubtful. Originally described as a Pheasant by Linneus, it has been shifted about by different authors between the Gallinaceous and Passerine birds, its singular structure presenting a combination of both. It has a large convex bill, with the nostrils pierced in the middle of the upper mandible. The mandibles are denticulated within the margins, and the head is furnished with a large erectile crest. In these, and some other particulars the Hoaitzin would seem to approach the Musophagidæ, with which Mr. G. R. Gray has placed it.

Whatever may be its due systematic position, the Hoaitzin is a very remarkable bird. It is nearly as large as a Peacock, which it resembles in many of its movements. Its plumage is tawny-brown, with numerous white spots and streaks upon the wings and tail. The naked skin about its face and throat is bluish, and the elongated slender feathers which form its crest are white upon one side and black on the other. These birds exhibit little fear of man, and as their flesh possesses such a disagreeable odour, compounded of musk and castorem, as to be quite useless for food, they are probably seldom risturbed. 


\section{'T R I B E V.}

SYNDACTYLE.

The Fifth Tribe of Passerine birds comprehends several families, recognizable by the peculiar conformation of their feet.* Their external toe is almost as long as the middle toe, to which it is joined by a membrane that reaches as far as the last joint but one, a structure obviously intended to give great firmness to the grasp while in the act of perching. In this division Cuvier included the Beeeaters, the Todies, the Motmots, the Kingfishers, and the Hornbills, with which various other birds have been associated by subsequent writers. $\dagger$

\section{FAMILY I.}

Coracide.

The Rollers.

Gen. Charac.-Bill more or less lengthened and broad at the base, with the sides compressed towards the tip, which is hooked; the nostrils basal, lateral, with the opening linear or oval; the wings long and pointed; the tail generally short and even; the tarsi short; the toes moderate, sometimes free, or the outer toe united at the base with the middle one.

These birds are distinguished by great beauty of plumage; they are for the most part confined to hot countries, a few only being inhabitants of the more temperate regions. Their food consists mostly of insects, but some of them subsist wholly or in part upon vegetable substances.

To this family belong the Rollers proper, the Todies, the Boatbills, and the Motmots.

* See "Animal Creation," p. 431.

† In the Tabular Views these birds will be found arranged with the Fissirostres. 


\section{$S U B-F A M I I L Y$ I.}

\section{Coraciasine.}

The Rollers proper.

GEs. CHARAC.-The Rollers have the wings of moderate dimensions; the tail moderate, with the side feathers sometimes lengthened; the tarsi short; the toes moderate, and free at the base.

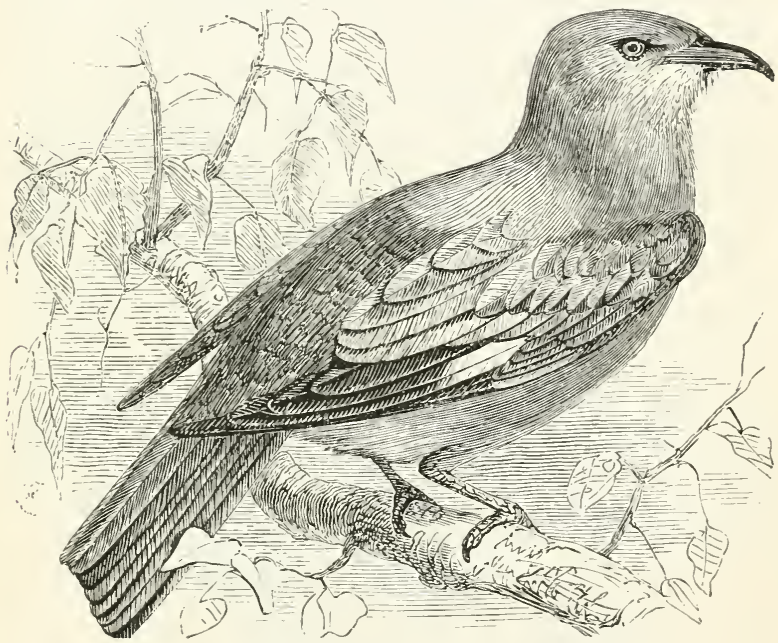

Fig. 111.-THE GaRRLLOUS JAY, OR COMMON ROLLER.

(Coracias garrula.)

These birds are indigenous to Africa, India, New Guinea, and Australia, but, owing to their migratory habits, are sometimes met with in various parts of Europe, and even in England. As their food consists of insects and fruits, they are obliged to move from place to place, according to the seasons. They mostly frequent wooded districts, where they may be met with, either singly or in pairs, perched on the dead branch of some tree, from whence they occasionally take flight to a short distance to capture 
an insect, and having seized it, return to the same spot. Their nest is placed in a hole of some decayed tree. 'The female lays four or five eggs.

The Garrulous Jay, or Common Roller (Coracias garrula), is an inhabitant of Africa, but visits Europe, and even Great Britain, in the summer time. On the steples of Southern Russia it is abundant, and goes by the name of the Steppe Parrot, partly on account of its squalling voice, partly on accotint of its beautiful plumage, in which green, blue, yellow, and black strive for supremacy ; indeed, it is described as " resembling a moving rainbow" when flying in the sunshine. In Malta and the Mediterranean islands it stays throughout the summer, and breeds. In central Europe it usually inhabits dense forests, where it builds its nest in the holes of trees, generally preferring the birch; whence it is known in Germany as the Birch Jay. Where trees are scarce, as in Malti, it breeds upon the ground, or in holes of old buildings; and in the treeless regions of Southern Russia it makes its nest in holes in the clay banks of rivers. Its eggs, which are usually four in number, are exactly similar in shape and in their pure white colour, to those of our common Kingfisher and Bee-eater, to which it is nearly related. It is a noisy and restless bird. In the autumn the young become very fat, and acquire a good flavour, so that they are eagerly sought after for the table. 


\section{SUB-FAMILYII.}

TODINE.

The Todies.

Gex. Charac.-Bill lengthened, much depressed, and slightly compressed towards the tip, which is rounded or pointed; the gonys long, slightly ascending and rounded beneath; the nostrils lateral, with the opening anterior and exposed; the wings short and ronnded; the tail moderate, and rather emarginated; the tarsi moderate and slender; the toes unequal, the outer toe longer than the inner, and both more or less united at the base, the hind toe short; the claws small.

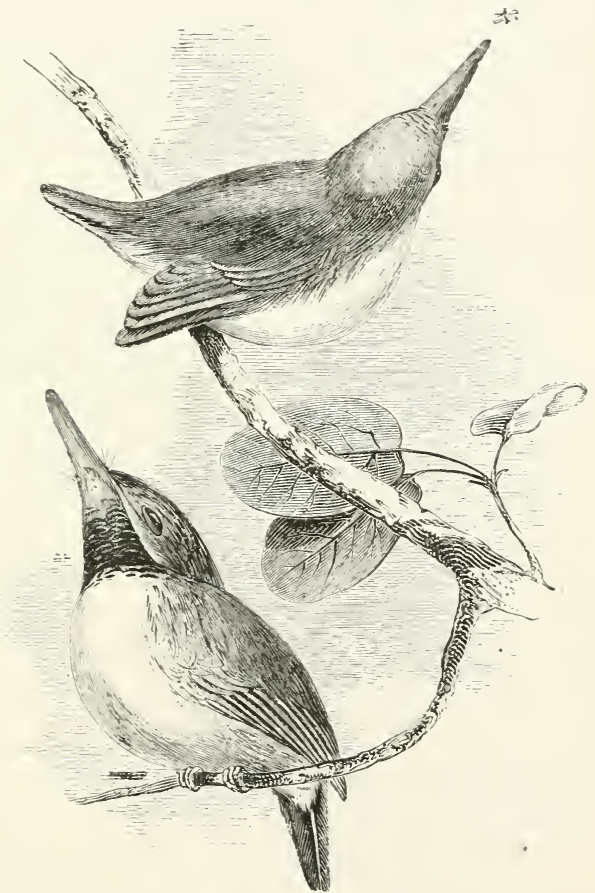

FIG. 112.-THE GREEN TODY.

(Todus viridix.)

These birds are found in the tropical parts of America, and in the West-India islands. They are 
usually seen singly, in lone and moist places, sitting. in a crouching manner on the branch of a bush, with the head drawn in between the shoulders. They exhibit little timidity, and may be approached so near as sometimes to be caught by the hand. They live principally upon orthopterous and other insects, which they seize with avidity.

\section{The typical species is-}

The Green Tody (Todus virilis), a very small bird, scarcely bigger than a wren, common in all parts of Jamaica, where, conspicuous from its bright grass-green coat and crimson velvet gorget, it hops about the trees, searching for minute insects, and occasionally uttering a querulous sibilant note; but more usually it is seen sitting patiently on a twig, with the head drawn in, the beak pointing upwards, and its loose plumage puffed out, so that it appears much larger than it really is, and presents a general aspect of stupidity. But this abstraction is more apparent than real; if we watch it, we shall see that its odd-looking grey eyes are glancing hither and thither, and that ever and anon the bird sallies forth upon a short flight, snaps at something in the air, and returns to his twig. "One captured with a net, and turned into a room, began immediately to catch flies and other minute insects that flitted about, particularly the destructive little clothes-moths. At this employment he continued incessantly from earliest dawn till dusk. He would sit on the edge of the table, on shelves, or on the floor, ever glancing about, and now and then flitting into the air, when the snap of his beak announced a capture, and he would return to the same station to eat it. He would peep into the lowest and darkest corners, even under the tables, for the little globose long-legged spider, which he would drag from their webs and swallow. He sought them also about the ceiling and walls, and found very many. I have said that he continued all day at this employment without intermission, and though I took no account, I judged that on an average he made a capture per minute: we may thus form some idea of the immense number of insects destroyed by these and similar birds, bearing in mind that this was in a room where the human 
eye scarcely recognized half a dozen insects altogether, and that in the free air insects must be much more numerous."-Mr. Gosse.

The Green Tody is exclusively an insect-feeder, and burrows in the earth to breed. The banks of ravines, and the scirps of dry ditches, are excavated by its feet, in which two out of the three front toes are united together, having only the terminal joint free. The hole runs into the bank some eight inches or a foot, forming a winding gallery, rounded at the bottom and terminating in a sufficiently widle lodging lined with pliant fibres, dry moss, and cotton. In this retreat four or five grey-brown spotted eggs are laid, and the young are fed till they are fully fledged. Mr. Gosse observes that the inhabitants of Jamaica are not in the habit of domesticating many of the native birds, else there is one of the species that would hecome a favourite pet. In a state of liberty it attracts the admiration of the most unobservant, and an European is charmed with it. As it sits on a twig in the verdure of spring, its grass-green plumage is sometimes undistinguishable from the leaves in which it is embowered; itself looking like a leaf, a little change of position bringing its throat into the sun's rays, the light suddenly gleams as from a glowing coal. Occasionally, too, this crimson plumage is puffed out into a globose form, when it might easily be mistaken for a beautiful fruit. 


\title{
$S U B-F A M I L Y$ III.
}

\author{
Eurghamine.*
}

The Boatbills.

Grix. CuAnic.-Bill large, more or less depressed, and extremely broad at the hase, with the enlmen eurved, and the sides gradually compressed to the tip, which is slightly emarginated; the gonys long and ascending; the nostrils lateral, more or less near to the base, and exposed; the wings moderate, with the third and fourth quills equal and longest; the tail generally moderate, graduated, or forked; the tarsi short; and the toes long, with the lateral ones unequal, and the outer toe united to the middle one for some distance.

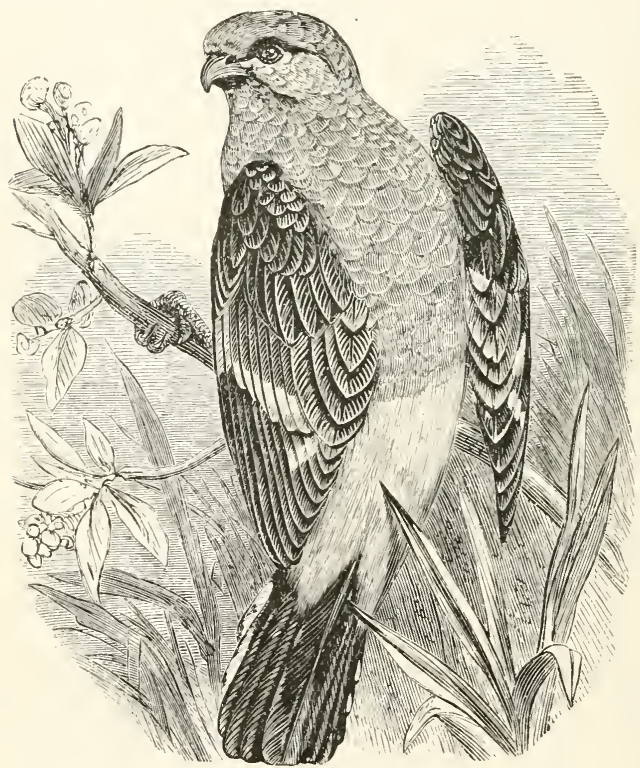

Fig 113 - THE COLLARED ELRYLAIHLS.

(Euvylaimus ochromalus.)

'These birds are found in India and the neighbouring islands: they reside in small flocks in the humid

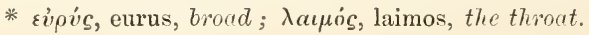


forests and jungles, especially such as abound with rivers and marshes. Their food consists of insects and worns; at times they feed also on berries and fruits.

The typical species is-

The Collared Eurylaimus (Eurylaimus ochromalus), described only from stuffed specimens.

Sir Stamford Rathles says, "The Eurylaimus Javanicus frequents the banks of rivers and lakes, feeding on insects and worms. It builds its nest pendent from the branch of a tree or bush which overhangs the water." Mr. Horsfield found it in Jara, in one of the most distant and inaccessible parts, covered with extensive forests, and abounding with rivers and marshes. Nothing further is known of the habits of these birrls.

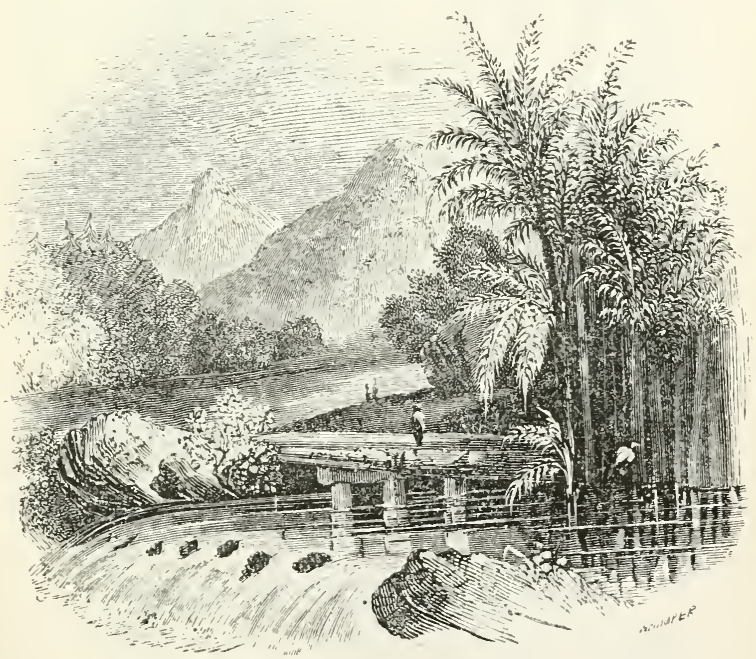




\section{SUB-FAIILY IV.}

MomotiNe.

The Wotmots.

Grex. Charac-Bill rather long, straight, more or less elerated and broad at the base, with the sides compressed to the tip, which is slightly hooked and ohtuse, the lateral margins more or less strongly serrated; the gonys long and slightly ascending; the nostrils basal and lateral, with the opening small and rounded; wings moderate and rounded, with the fourth, fifth, and sixth quills nearly equal and longest; tail lengthened and graduated, with the two middle feathers usually longer than the others; tarsi as long as the middle toe, and covered in front with narrow transverse seales; toes unequal, the inner toe short, and slightly united, the hind toe rather short and weak; the claws moderate, much compressed, and curred.

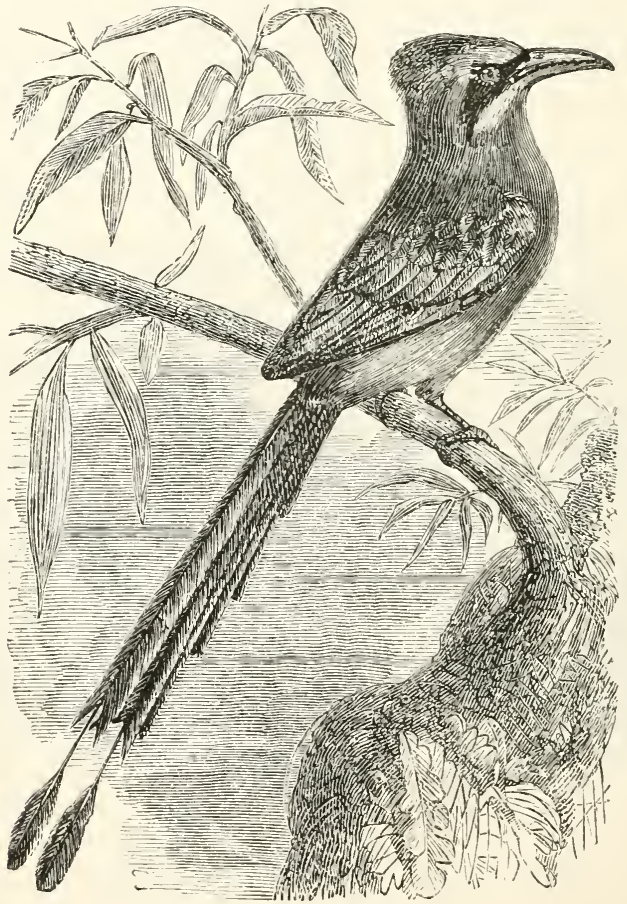

FIg. 114.-THE Мотмот.

(Prionites MLomota.) 
The Motmots are distinguished from the Todies by having the margins of the mandibles distinctly serrated for a considerable portion of their length ; they also possess a pectinated tongue. Their tail is long, and the shafts of the two middle feathers, which are the longest, are entirely bare of barbs for a considerable portion of their length; the base is furnished with barbs, then comes the bare portion, and the tip again presents the ordinary appearance of a feather.

The Motmots are peculiar to the tropical parts of America, and to some of the West India islands. They seem to prefer the deep shade of the forests, or the dark recesses of buildings. They are usually seen perched on a branch or on some projection, keeping their head drawn in between the shoulders, with a peculiarly solemn expression, uttering from time to time a melancholy croak. Early in the morning, and in the dusk of the evening, they appear more lively, watching for any passing insect that may approach sufficiently near, upon which they dart with a short flight. They likewise feed on frogs, lizards, and small snakes: these are seized with the point of the bill, and then, by a toss of the head, jerked into the throat and swallowed. The egges of birds also form a portion of their food. The nest of one species is stated by Sir W. Jardine to have been found at the end of a long gallery excavated in a bank of mud, and running for five feet in a direct line into the ground, terminating in another gallery of similar length placed at an angle with the first. The end of this long passage was enlarged, and in the enlargement were three young Motmots, huddled up on the top of a moving heap of maggots, mixed with the remains of beetles and other insects. It is probable that the barbs of the tail feathers of the old birds may be worm away by friction against the walls of the narrow tunnel leading to their nest. Occasionally they will build in the deserted burrow of a Cavy or Armadillo. 
Dr. Azara describes some of these birds kept in (aptivity as heary and stiff' in their movements, shuffling along on the ground by sudden and oblique leaps, with their leg's very wide apart; their tail was in eonstant motion. T'hey were fed with bread and raw meat, the latter of which they preferred. If a small bird or a mouse were let loose in the chamber in which the Motmots were kept, they would pursme it in a determined manner; and when possessed of their prey, would strike it violently against the ground with their bill. This did not appear to be done merely for the purpose of killing it, but to break the bones, in order to swallow the whole more easily.

The type of this sub-family is-

The Mrotmot (Prionites Momota).

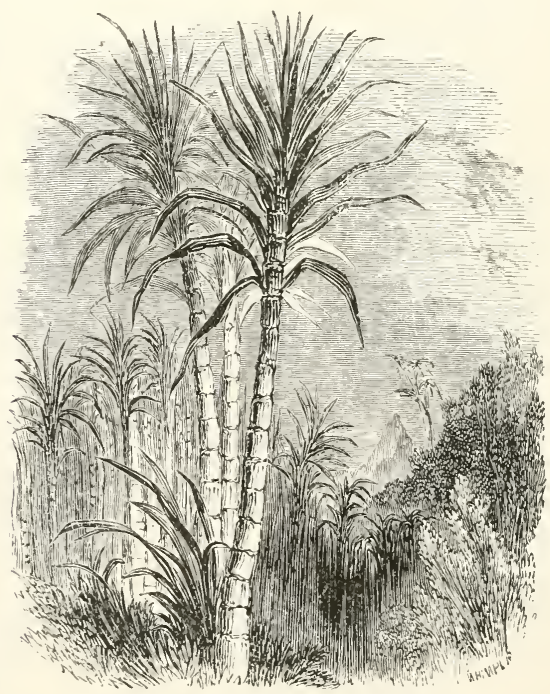




\section{FAMILY II.}

MEROPIDe.

The liee-eaters.

Grv. Charac,-Bill longer than the head, with both mandibles curved and acutely pointed, the sides compressed and sloping from the culmen; nostrils basal, lateral, rounded, and partly hidden by short bristles; wings more or less long and pointed; tail long, broad, and the middle feathers sometimes prolonged beyond the lateral ones; tarsi very short; toes long, with the lateral ones more or less united to the middle toe, the hind toe long and broadly padded beneath.

These birds, remarkable from the brilliancy of their plumage, are found in most parts of the Old Continent. 'They seek the warmer climates during' the winter, and in summer visit temperate localities in pursuit of their food, which consists almost exchusively of insects. They usually perch singly, or in small parties, on some prominent branch, or on any objects from which they can see to a distance around them. When an insect is observed, they fly off, capture it on the wing, and then generally return to the perch just quitted, where they again station themselves to await the approach of another victim. During the morning and evening they sometimes congregate in companies, flying about with much activity, and eatching insects after the manner of Swallows. Their flight is graceful and capable of being sustained during a lengthened migration. Their cry is lond, and consists of harsh whistling notes, continually repeated during their morning and evening excursions. The young are reared in holes, excavated horizontally in the sandy banks of rivers, or in cliffs which are sufficiently soft to be easily penetrated: these excavations are prolonged interiorly to the depth of a yard and more. The entrance is small, and the further end expanded into a chamber of such dimensions that the bird can turn in it with facility. Here the egg's, usually four or five in number, are deposited on the bare sand, or on a bed of moss or other soft material. 


\section{SUB-FALILY.}

\section{Meropin.e. The Bee-eaters proper.}

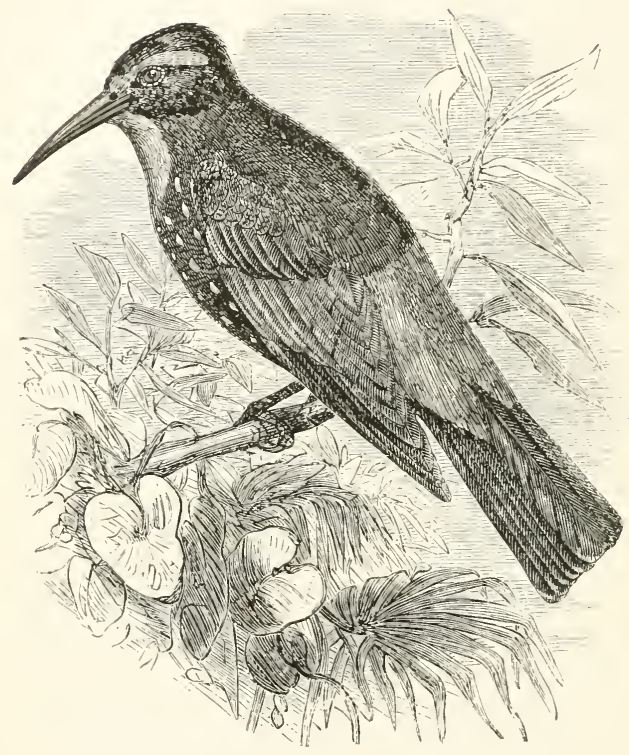

Fig. 115 -THE THROATED BEE.EATER.

(Melittophagus guluris.)

This, the only sub-family, embraces numerous species common in Africa and the East, but one only is accustomed to show itself in Europe, named by English writers-

The Common Bee-eater (Merops Apiaster). It is in this country, however, one of the rarest of the feathered race. It arrives in the southern parts of the Continent in March, and departs to warmer regions in September. It flies in flocks, usually at a considerable elevation, and 
utters, with hoarse and guttural voice, in startling disaccordance with its slender aspect, a continual cry of gra! gra! gra! It builds in deep horizontal holes in sandy banks, which it excavates in whole or in part, working vigorously with its feet and bill, and kicking out the dry earth behind it with great perseverance. It lays six or seven eggs, white, lucid, and almost spherical. When the young are partly fledged, but not able to fly, they creep to the mouths of their hole, where they seem to enjoy the happy summer light and genial sunshine; but on the least alarm they retreat, tail foremost, into the recesses of their burrow, where they lie concealed. So accustomed do they seem to this peculiar movement, that when taken from the nest and placed in any more exposed position, they endeavour to escape by running backwards ; indeed, for a time, they seem unable to walk in any other direction. The Bee-eaters are exclusively insectivorous, and prey almost entirely upon the hymenopterous tribes. Although they often take their food upon the wing, they also gather it from the ground; and whenever they espy the small hole which leads into the nest of Wasp or Bembex, they place themselves close beside it, and snap up the industrious tenants on their exit or arrival. The appearance of these birds in England is accidental, and they are unknown in America.

The type of the sub-family is-

The Throated Bee-eater (Melittophagus gularis). 


\section{FAMIIIT III.}

TrogONID.E.

The, Trogons.

Gri. Charac,-Bill short, strong, subtriangular, broader at the base than elevated, with the tip and the margins generally toothed; the gape furnished with bristles; the nostrils basal, lateral, more or less concealed by the projecting feathers; the wings moderate and rounded, with the fourth and fifth quills usually the longest; the tail long and even, with the lateral feathers graduated; the tarsi short, and more or less covered with feathers; the toes placed two anteriorly and two posteriorly, each pair unequal.

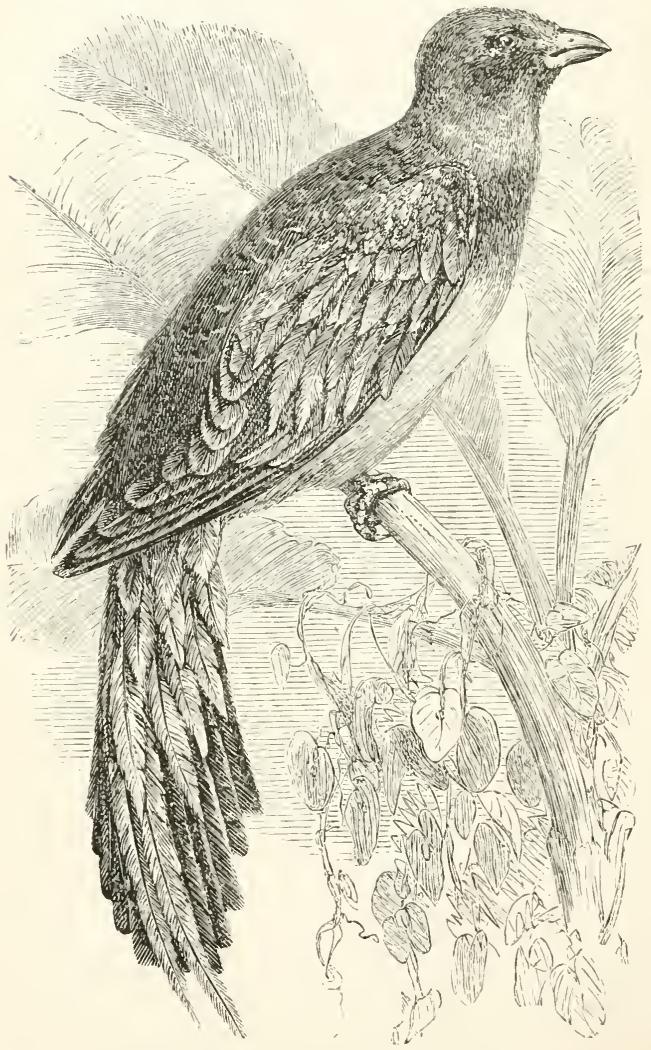

Fig. 116-THE GOLDEN-HEADED CALURUS.

(Culurus unireps.) 


\section{STB-FAMILY.}

Trogonixi.

The Trogons proper.

'The 'Trogons proper (the only sub-family of this group), like the Toncans and the Cuckoos, have two toes in front and two behind, and on this account are not unfrequently regarded as belonging to the Scansorial order; but the hinder toes are placed perfectly posteriorly, and as, from the manner of their connection with the foot, they are incapable of being moved from their ordinary position, the Trogons may be regarded as the or birds whose toes are absolutely in pairs. They are perhaps the most sedentary birds in creation, and hence their feet are the weakest, and seem to be constructed for the sole purpose of sitting still. In addition to their toes being in pairs, it may be remarked that the two anterior are by far the longest, and are connected together for nearly half their length : the two posterior toes are separated, and the outer one is nearly half the length of the inmer.

These splendid birds are many of them peculiar to tropical America, but several species are met with in India and the Eastern islands, as well as in Sonth Africa. They live solitarily in the gloomy shades of forests, where they may be seen motionless on the branches, among the thickest foliage, during the heat of the day ; but early in the morning and in the evening they seek the more open though still shady parts, and take up some position from which they can see and dart after the insects flying near, on which they principally subsist. Their flight is rapid and undulating, but is not prolonged to any considerable distance.

On the banks of the Amazon these birds are rery numerous, differing in size from the Trogon viriclis, a small species whose body is scarcely bigger than one 
of our sparrows, to the Curugua grande (Calurus auriceps), twice the size of a jay. All have spreading tails, and their loose plumage makes them look of greater dimensions than they really are. At intervals, they utter a mournful note, well imitated by their common name, Curuque. This cry would inevitably betray them to the hunter, but they are admirable ventriloquists, and it is often impossible to discover them, even when directly above the head of their pursuer. The species vary as much in colour as in size, but the backs of all are of a resplendent green or blue, while beneath they are conspicuously ornamented with red, or pink, or yellow. In the pairing season, the male has a very melancholy note, which is never uttered at any other time than when the female is sitting. They begin to pair about April, when they take possession of the hole of a rotten tree, or the excavations made by ants; and here the female lays three or four white eggrs in the decayed wood and dust; or, if there be no dust, they bruise the wood into powder by means of their strong beak. The young, when first hatched, are quite destitute of feathers, and the old birds feed them with small worms, caterpillars, and insects.

\section{The type of the sub-family,-}

The Peacock Trogon (Trogon pavoninus), is a native of the Amazonian forest, and well deserves its name, as it is not only splendid in the colours of its plumage but elegant in form. On account of the looseness of its feathers, it is not able to chare insects in the air with as much adroitness as is exhibited by some other Trogous having firmer plumage; hence it feeds chiefly upon berries, firuits, and the insects it can pick off the branchess without being obliged to pursue them on the wing. While engaged in search after food it is an active bird, running about the boughs with great agility, and clinging with its powerful feet in every attitude, seeming to care little whether it be sitting on a branch. after the custom of most birds, or hanging with its head downwards like the Parrots. Although brilliant in its bedizenment, it is not so 
easily seen as might be supposed, for its colour harmonizes well with the foliage and bark of the trees among which it dwells, and even the rich carmine of its under surface

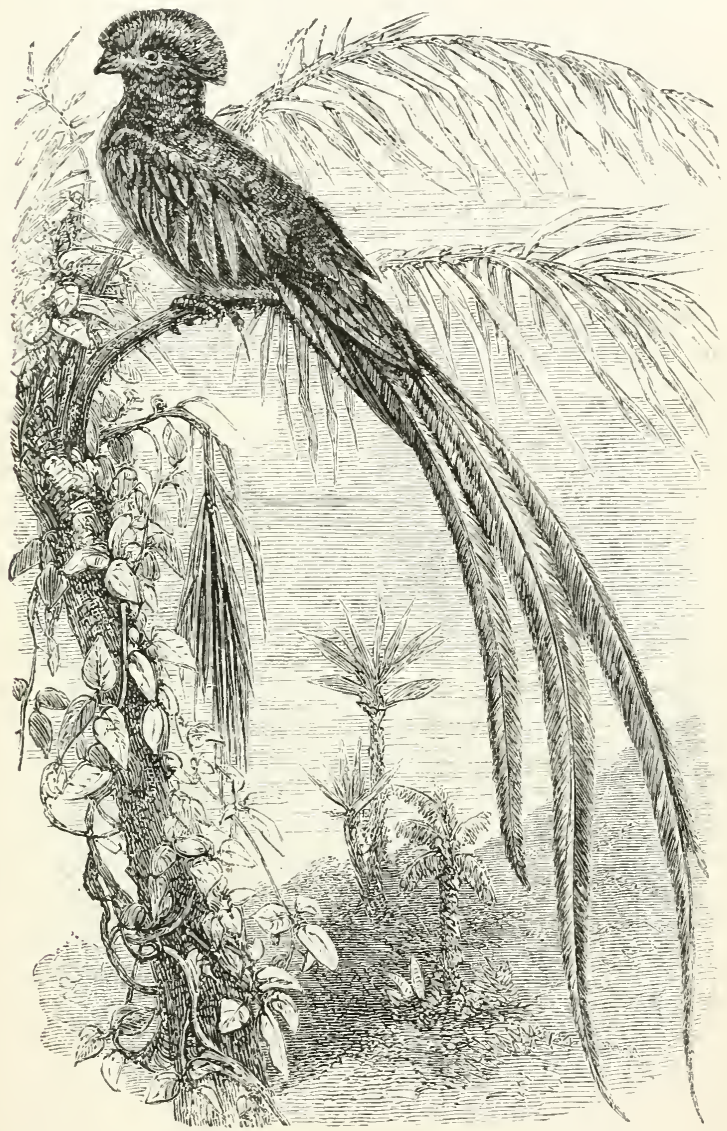

Fig, 117.-THE PEACOCK TROGOX.

(Trogon pavoninus.)

is not very conspicuous in that land of flowers. Its head is decorated with a curiously-shaped tuft of slight and elastic feathers that spring from the forehead, and by 
their peculiar curve overshadow the nostrils and a considerable portion of the beak. This crest, together with the head, the throat, the back, wing-coverts, and upler tail-corerts, is of the richest imaginable green shot with gold, and glowing with a changeable sheen as the breese plays with the delicate fibres of the plumage. The quill feathers of the wing are black, as are the central feathers of the tail. The upper tail-coverts are very long, flowing gracefully over the stiffer feathers by which they are sul)ported, and contrasting beautifully with their glossy black. The breast and remainder of the under surface of the borly ate of a rich carmine.

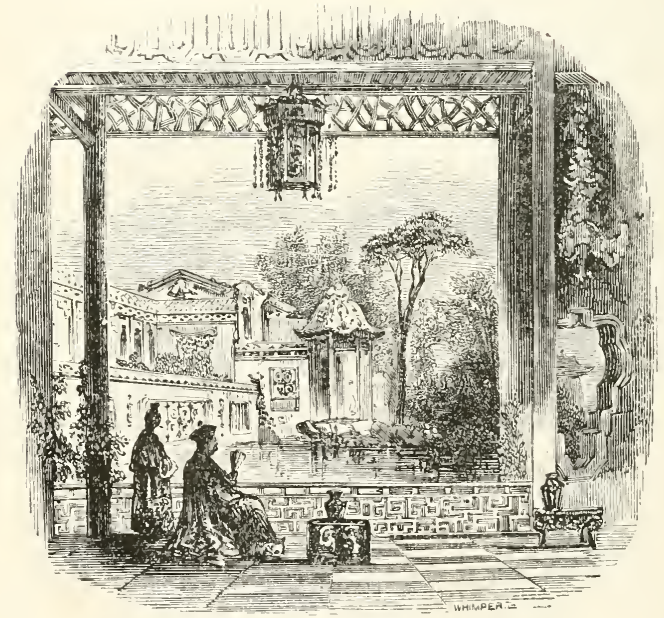




\section{FAMILI IV.}

A LCEDINID.E.*

The Kingfiskers.

GEN. Charac. - Bill more or less lengthened, generally straight, broad at the base, with the tips of both mandibles usually acute; the nostrils lateral; the wings nore or less long and rounded; the tail mostly short and rounded at the sides; the toes long, sometimes three before and one behind, sometimes two and two, and of various lengths.

This family includes, not only the Kingfishers, but other nearly allied forms, characterized by the shape of the beak, which is elongated and generally quite straight, stout, broad at the base, and sharp at the point; they are likewise remarkable for the small size of the tail and the shortness of the tarsi. The toes are variable both in number and arrangement; sometimes there are three in front and one behind, as in birds in general, while in rare instances one toe is altogether deficient, and the foot has only two toes in front and one behind. The wings are long and rounded, and consequently these birds possess considerable powers of flight. They all live upon animal substances ; some, like our common Kingfisher, capture fish with great dexterity, whilst many feed upon insects or upon small reptiles. In other respects they exhibit great variety of habit.

To this family belong the Puff-birds, the Crabhunters, the true Kingfisher's, and the Jacamar's.

* Alcedo (Lat.), the hingfisher. 


\section{SUB-FAMILYI.}

Bucconina.

The Puff-birds.

Gen. Charac.-Bill of various lengths, elevated and broad at the base, with the tip curved, and sometimes hooked over that of the lower mandible; nostrils lateral, basal, and hidden by the frontal plumes and bristles; wings more or less long, with the third to the fifth quills usually the longest; tail mostly of moderate length; tarsi short and robust, with the toes two before and two behind, and of various lengths, the outer anterior toe the longest.

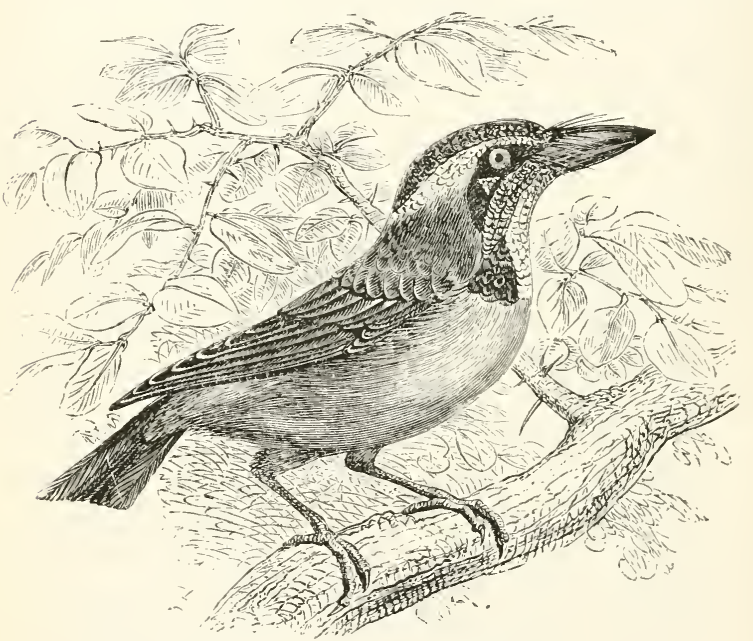

Fig. 118.-The variegated PUFF-BIED.

(Bucco versicolor.)

These birds are found in the tropical parts of America; they appear to live solitary, pensive, and silent in the most retired parts of the forests, where they choose some branch upon which they perch for a long time, with their large head resting upon their shoulders; they are, however, soon called into activity by the appearance of some coleopterous insect, after which they dart, and having secured it, 
return to the same perch, which they are said to frequent for months. They make their nests in the holes of trees.

The best-known species is-

The Greater Pied Barbet (Bucco macrorhynchus). In shape these birds bear a close resemblance to the Kingfishers. Their food consists chiefly of insects, which they procure much after the manner of the Woodpeckers, prying into the hollows of trees, and striking away the bark in their endeavours to secure the concealed prey. They can cling to the perpendicular trunk of a tree, and support themselves by the pressure of their short stiff tails against the bark. They also possess some of the habits that belong to the Elycatchers, and, taking their perch upon a twig, will wait patiently until an unfortunate insect passes within a short distance, when they launch themselves on the devoted creature, and return to the twig from which they started.

The type of this sub-family is-

The Variegated Puff-bird (Bucco versicolor).

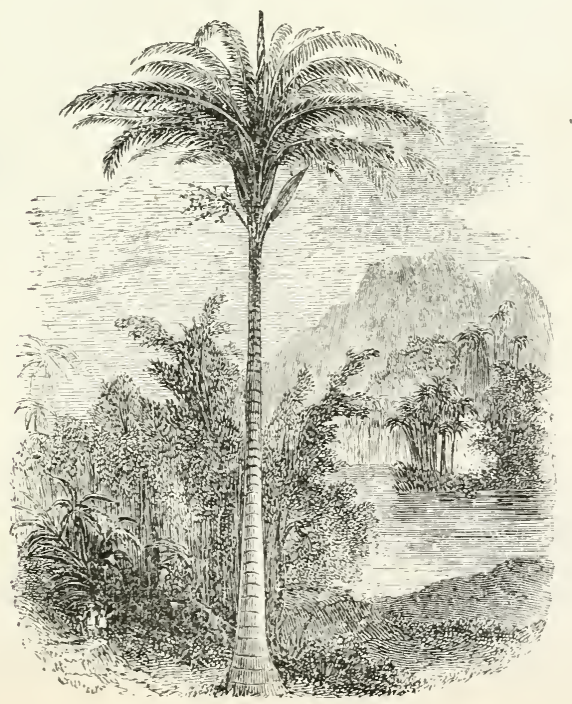




\title{
SUB-FAMILY II.
}

\author{
HALCTONINA.*
}

The Crab-hunters.

GEN. CHARAC.-Bill broad at the base, and gradually compressed towards the tip, the lateral margins straight or turned upwards towards the end of the upper mandible; the gonys lengthened aud gradually ascending, or curred upwards to the tip of the lower mandible.

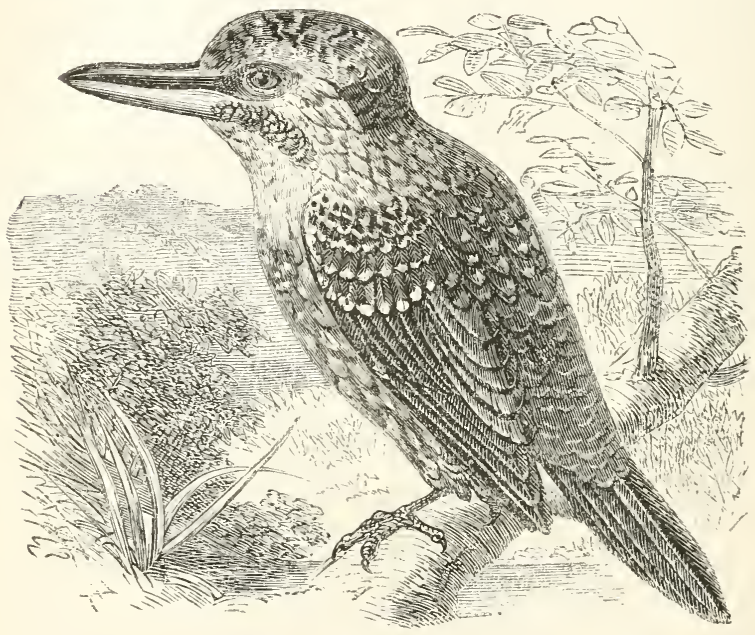

Fig. 119 -LINDSAY'S CRAB-HUNTER.

(Haleyore Lisdsayi.)

These birds are very widely distributed; they occur in India and its Archipelago, in Africa, Australia, and the islands of the South Sea. They generally reside in open forests and in jungles, by the sides of rivers and brooks; some species, however, are rarely observed in the vicinity of water, while others frequent cultivated places and plains. They will often sit for a long time on a pole or the

* $\dot{\alpha} \lambda_{\kappa v \omega \nu}$, halcyon, the Kingfisher, from ä $\lambda$, hals, the sea, and $\kappa v i$, kuo, to conceire; So called because the Kingfisher was said by the ancients to hatch its eggrs upon the sea. 
lower branch of a tree, watching the space aromnd for the appearance of small reptiles, fish, crabs, or insects, from all of which they derive their subsistence: some species examine the flowers of the cocoa-nut for insects contained within them. Their nest is built in the hollow trunk of a tree, and the eggs are usually three or four in number.

One of the best-known species belonging to this sub-family is-

The Gigantic Kingfisher (Dacelo* gigas). This remarkable bird is not uncommon among the wooded mountain districts in many parts of the Australian continent, where it may frequently be observed sitting in solitary state

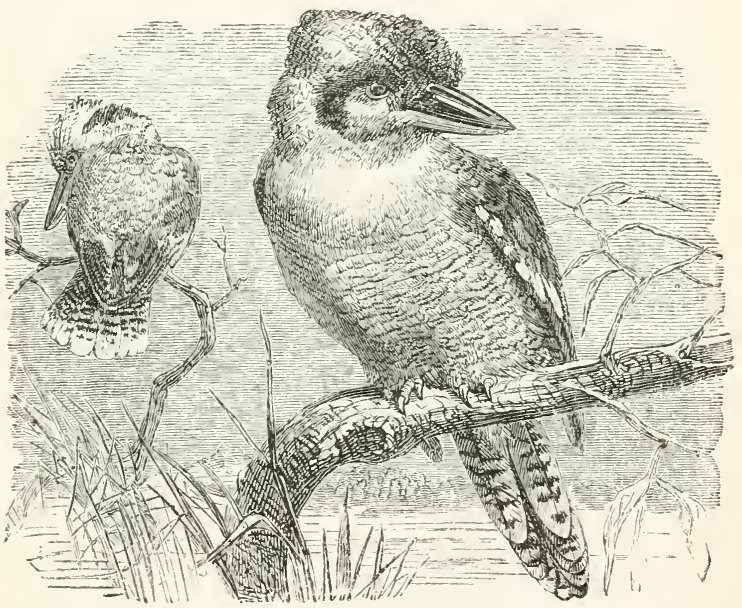

Fig. 120.-THE LAUGHING JaCKass.

(Ducelo gigas.)

watching for its prey. Unqualified for plunging into water, the Dacelo is vigilant in pursuit of reptiles and insects. Snakes are its favourite food, and it may be often seen flying to a tree with one of these reptiles in its beak, holding it just behind the head, and thus securing

* A fanciful name, made by transposing the letters of the word Alcedo. 
immunity from its bite. Generally the snake is killed before being carried away, but sometimes the bird is observed to break the creature's head to pieces on a branch by means of its powerful beak. Occasionally the Gigantic Kingfisher will kill young chickens, and carry away eggs; but its services in destroying reptiles abundantly compensate the settler for these petty depredations. The most striking feature, however, in the history of the Dacelo is its peculiar ery; ever and anon it breaks out into a singular abrupt laugh, somewhat resembling the syllables yah! yan! yah! commencing in a low, and gradually rising to a high and loud tone, that is perfectly startling when heard amidst the solitudes of the forest. From this wild and discordant cry it has obtained from the colonists the names of the "Laughing Jackass," "Feathered Jackass," and "Laughing Kingtisher." The Laughing Kingfisher, or "Settler's Clock," as it is sometimes called by the colonists, was for many years a doomerl bird in Australia, merely from ignorance of its natural habits; for having been seen occasionally to pounce upon and devour a chicken in the absence of its usual supply of snakes or mice, it was regarded as one of the destroyers of the poultry-yard; and from the general destruction of these birds that was instituted, a corresponding increase of reptiles and vermin of all kinds was experienced on every farm. Its utility being better understood, it is now seldom or never molested; its peculiar laugh and singular scream are again heard, and the "Settler's clocks" set a-going again, prove a benefit to the community, and have even become useful domesticated animals; they have, indeed, very much the habits of birds of prey, and, when kept as pets about a house or garden, will watch for small game like a cat. It is very common to see ten or twelve of these birds perched upon the branch of a large gum-tree (Eucalyptus), and on the traveller trying to imitate their peculiar note, instead of flying away, one of the party will set up its laugh ; this is immediately followed by a second; a third will then take up the cry, and bark away until they all chime in with a most extraordinary compound of noises.

The typical form of this sub-family is-

Lindsay's Halcyon (Halcyon Lindsayi), of which, however, little is known bat the skin. 


\section{SUB-FAIILY III.}

\section{Alcedinis.e. \\ The hingfishers proper.}

Gev. Charac.-Bill more or less long, straight, and slender, with the culmen sloping to the tip, which is acute, the sides much compressed, and the gonys long and ascending.

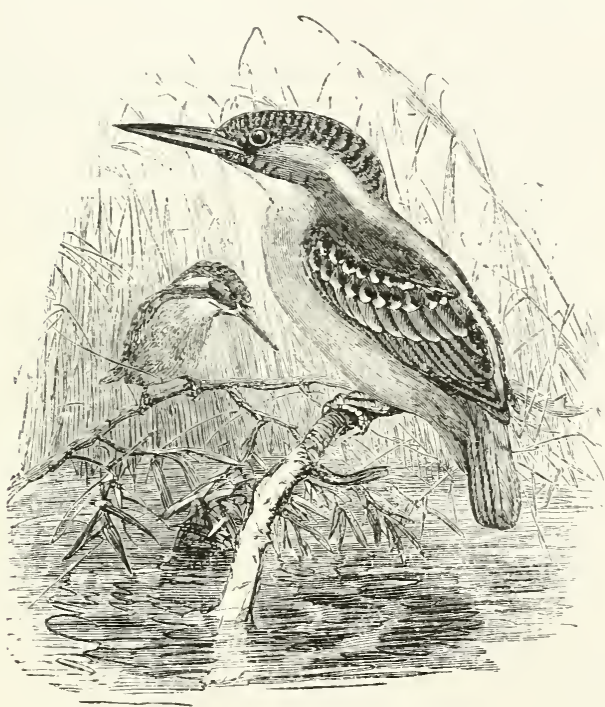

FIG. 121.-THE COMMON KINGFISHER.

(Alcedo Ispida.)

The race of the true Kingfishers is distributed over most parts of the world. They frequent the banks of rivers, and are usually seen perched solitarily upon a branch that overhangs the stream, or flying near the surface of the water in quest of their prey, which consists principally of fish. They may sometimes be observed fluttering over the stream, and then suddenly precipitating themselves upon 
some poor minnow that happens to come into their vicinity.

\section{The type of this sub-family is-}

The Common Kingfisher (Alcedo Ispidru), the only European representative of the group. It is one of the most heantiful of our British birds, and its appearance as it dashes along in the sunshine is extremely brilliant. It is an inhabitant of all parts of Europe except the extreme north, and is also widely spread over Asia aud Africa. This species is always found in the vicinity of water, over which it may be seen shooting along like a little meteor. Its food consists not only of small fishes, but also of aquatic insects and leeches.

The appetite of the Kingfisher is voracious, and his manners shy and retiring; dwelling near lonely and sequestered brooks and rivers, he sits for hours together, motionless and solitary, on some bough overhauging the stream, patiently watching the motion of the smaller fishes which constitute his food, waiting for a favourable moment to dart with the velocity of an arrow upon the first that comes near enough to the surface, and seldom failing in his aim. He then returns to his former station on some large stone or branch, where he kills his captive by shifting its position in his bill, so as to grasp it firmly near the tail, and striking its head smartly against the object on which he rests; he then reverses its position and swallows it, head foremost: the indigestible parts are afterwards ejected in a manner analogous to that of 0 wls and other birds of prey. The Kingfisher, however, does not confine himself to this mode of watching in motionless solitude; but should the stream be broad, or no favourable station for espionage present itself, he may be seen poising himself over it at an altitude of ten or fitteen feet, scrutinizing the element below for his food, and plumging upon it with a velocity which often carries him considerably below the surface. For these habits his nuscular wedge-shaped body, increasing gradually from a long pointed bill, and his sleek plumage, which, while it passes freely through the water, is impervious to wet, seem expressly to adapt him ; and his wings are short but powerful: hence his flight is smooth, even, and exceedingly rapid. Silent, except during the pairing and 
breeding season, when he occasionally utters a sharp piercing cry, indicative perhaps of attachment, and equally solitary and unsocial in his habits, the Kingfisher dwells alone, seldom consorting with others, or even with his mate except during the rearing of the young, when both sexes discharge with assiduity the duty of procuring requisite supplies of food. The places selected for incubation are steep and secluded banks overhanging ponds and rivers, where in a hole, generally at a considerable distance alove the surface of the water, and extending to the dep,th of two or three feet into the bank, the female, without making a nest, lays five or six eggs, of a beautiful pinky white. As soon as the young are hatched, the parent birds may be seen incessantly passing to and from the hole with food, the ejected remains of which in : short time accumulate around the unfledged broscl. The young do not leave the hole until fully fledged, when, seated on some neighbouring branch, they may be known by their clamoious twittering as they greet their pareuts, from whom they impatiently expect supplies of food. In a short time, however, they commence fishing for themselves, assuming at that early age a plumage nearly resembling the adult. The young appear to possess habits of partial migration, at least in our own island; they wander firom the interior of the country along the rivers to the coast, and in the antumnal and winter months frequent the moliths of small rivulets and dykes near the sea. 


\section{SUB-FAIILY IV.}

Galbulinæ.

The Jacamars.

Gex. Charac.-Bill long, slender, straight, or slightly eurred and acute; tail long and graduated; tarsi short; toes either arranged in two pairs or two toes in front and one behind, the anterior toes united.

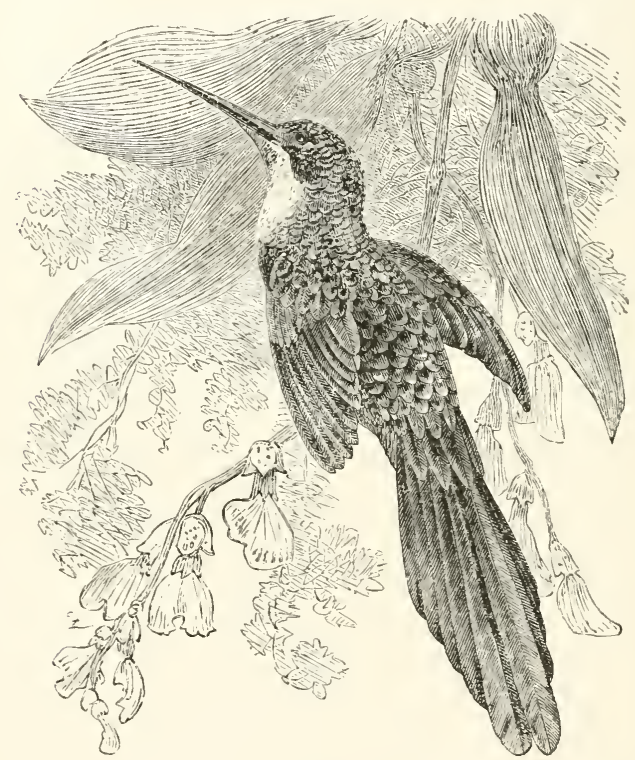

Fig. 122.-THE RED-TAILED JACAMAR.

(Galbula ruficauda.)

These birds, remarkable for their brilliant plumage, inhabit the tropical parts of the Western hemisphere. They are met with most numerously in Brazil and Guiana, where they live in the penetralia of the forest, and pass their lives in solitude. They are all of moderate size, and feed entirely upon insects, 
which they pursue by short and rapid flights. Their eggs are deposited in hollow trees.

The typical species,-

The Red-tailed Jacamar (Galbula ruficauda), inhabits South America, frequenting trees in damp and shady places. They generally sit on the low naked branches in the forests, from which they dart upon buttertlies, spearing them with their long bills; their haunts, indeed, may frequently be discorered by the ground being strewn with the beautiful wings of their victims.

"A bird called Jacamar," says Mr. Waterton, " is often mistaken for a kingfisher, but it has no relationship (in its habits) with that tribe; it frequently sits on the trees orerhanging the water, and as its beak bears some resemblance to that of a kingfisher, this may probably account for its being taken for one. It feeds entirely upon insects, sits on a branch in motionless expectation, and as soon as a fly, butterfly, or moth passes by, it darts at it, and returns to the branch it had just left. It seems an indolent, sedentary bird, shunning the society of all others. It never visits cultivated grounds, but remains all the year round in the woods. There are four species of Jacamar in Demerara; they are all beantiful, the largest superb. Its plumage is of so fine a changing blue and golden-green, that it may take rank with the choicest of the Humming-birds." 


\section{FAMILY V.}

Bucerotid..* *

The Hornbills.

Grin. Charac.-Bill more or less lengthened, curred, broad at the base and compressed to the end, with the culmen furnished with a singularly-formed helmet, or only curved to the tip, which is acute; the nostrils basal, and usually rounded; the wings moderate; the tail generally long, broad, and more or less graduated; the tarsi, in most, short and strong; the toes moderate, strong, and more or less united at their base, especially the outer one; the claws short and rather obtuse.

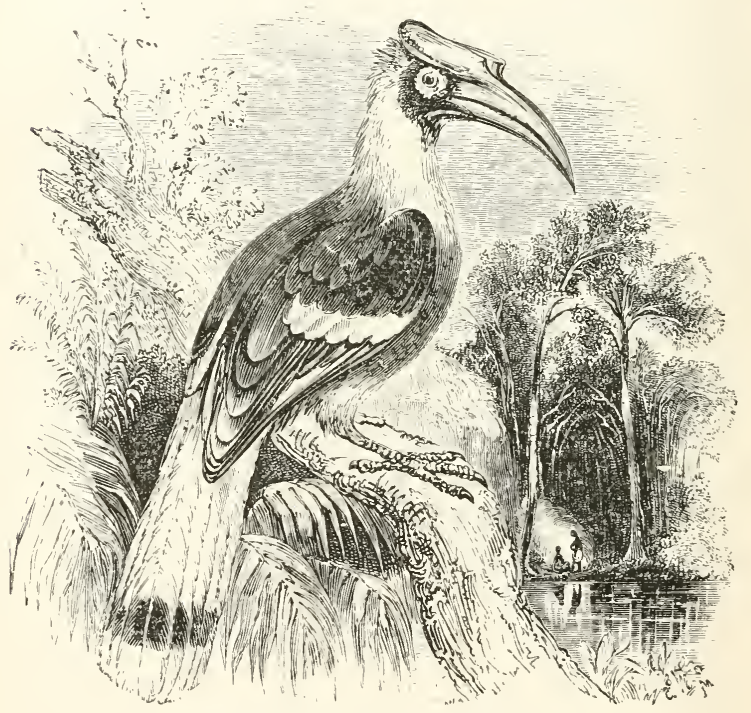

Fig. 123. - THE CRESTED hORNBILL.

(Buceros coronatus.)

The birds of this family are at once distinguished by the great size of their bills, which are often so

* Boṽ s, bous, an ox ; képas, keras, a horn; So called because the bill somewhat resembles the horn of an ox.

+ In the Tabular View this family is placed with the Con IROSTRES. 
enormous as to appear almost a deformity; whilst in many species the disproportion of this part to the rest of the body is increased by the presence of a singular helmet-like swelling at the base. The bill, with this appendage, looks like a ponderous and nnwieldy burden for the slender neck of the bird; but the whole structure is composed of very light materials, a thin outer case supported by an interlacing bony network filled with air, and so tender is the helmet-like protuberance in some species, that after the death of the bird, pressure with the thumb and finger is often sufficient to crush it. This remarkable beak is long, curved, and pointed, with the margins of the upper mandible often irregularly toothed, as if small fragments had been hacked out. 'The anterior toes of the stont powerful feet are more or less united together, the outer one, especially, being attached to its neighbour to such an extent as to lead Cuvier to place the Hornbills with the Kingfishers and Bee-eaters in his gromp of Syndactyle birds. These birds have tolerably large wings, and possess considerable powers of flight.

The only sub-family, -

Bucerotixe,

The Hornbills proper,

have the characters given above.

These birds are inhabitants of the warmer parts of the Old World, most of the species being found in the Eastern islands and in Africa. They are generally of large size. In a state of nature their food consists principally of fruits, but they are said by some writers to feast upon carrion; and specimens in confinement have been seen to capture rats and mice, which they swallow whole, after crushing them a little with their enormous mandibles. They probably feed on almost anything that comes in their way. Lesson thinks that the eastern species are very fond of nutmegs, from which their flesh derives a delicious flavour. They usually live in flocks in 
the forests, where they perch upon the highest branches. During flight, their head is drawn back, and the movement of their wings is very rapid, producing a considerable rushing sound as the birds pass through the air. This is heightened by a constant clattering of their large mandibles, and the occasional utterance of a loud croak. In fact, according to Lesson, the noise produced by a flock of Hornbills when passing along in the air is very alarming to those who are unaware of its origin, for it has no distant resemblance to one of those sudden and violent winds which often come on unexpectedly in tropical climates. "Their voice is composed of the transient blast of a bugle and the sudden hiss of an exploding sky-rocket; they seem to utter these. calls periodically, without any obvious reason, as if to relieve the monotony of their still and melancholy lives." An Abyssinian species is reported by Major Denham to live upon insects, fish, and serpents, to the latter of which it is directed by a special instinct. "It discovers their vicinity while they are yet under ground, digs on the spot, destroys the nest, and feeds on the venomous inhabitant and its eggs." The Hornbill makes its nest in the hole of some decaying tree, plastering up the entrance with mud, so as to leave a very small aperture. The following account of the nest of the Red-breasted Hornbill is given by Dr. Livingstone :- " The first time that I saw this bird was at Kolobeng, where I had gone to the forest for some timber. Standing by a tree, a native looked behind me, and exclaimed, 'There is the nest of a Korwé.' I saw a slit, only about half an inch wide and three or four inches long in a slight hollow of the tree. Thinking the word ' Korwé' denoted some small animal, I waited with interest to see what he would extract. He broke the clay which surrounded the slit, put his arm into the hole, and brought ont a Tockas or Red-breasted Hornbill, which he killed. He informed me that when the female enters her nest she submits to real 
confinement; the male plasters up the entrance, leaving only a narrow slit by which to feed his mate, and which exactly suits the form of his beak. The female makes a nest of her own feathers, lays her eggs, hatches them, and remains with the young till they are fully fledged. During all this time, which is stated to be two or three months, the male continues to feed her and the young family. The prisoner generally becomes fat, and is esteemed a very dainty morsel by the natives, while the poor slave of a husband gets so lean, that on the sudden lowering of the temperature which sometimes happens after a fall of rain, he is benumbed, falls down, and dies."

The type of this sub-family is-

The Crested Hornbill (Buceros coronatus), delineated in the figure given abore.

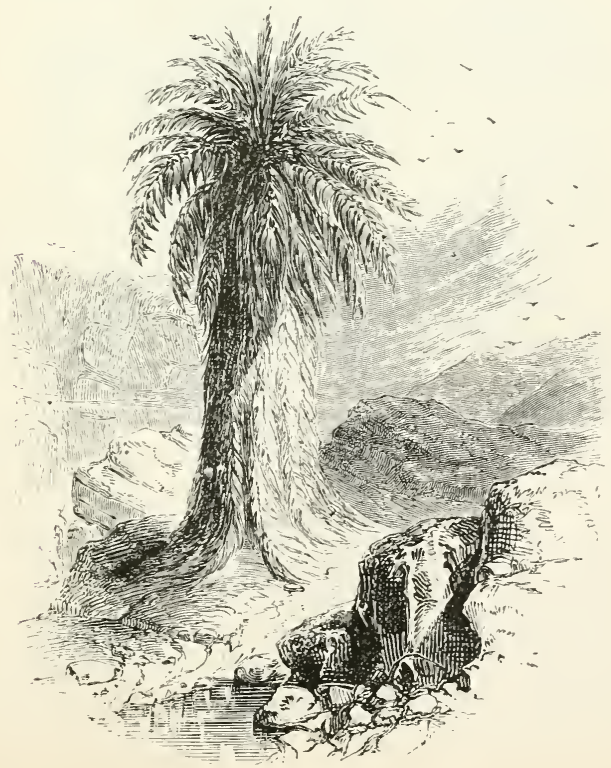




\section{OR D ER III.}

\section{SCANSORES.}

The Scansorial or C'limbing Birds are distinguished by the structure of their feet. The outer toe is tmrned backward, so that the foot exhibits two toes in front and two behind.* This is really the only character common to all the birds placed in the order Scansores; the structure of the other parts from which distinctive characters are usually derired varying greatly in different members of the group, so that it includes species of very different aspects and modes of life. It will, moreover, be observed that in many of the Passerine birds, the outer toe, although not permanently reversed, is capable of assuming the Scansorial character, adding not a little to the difficulty of drawing a clear line of demarcation between the two orders.

The structure of their feet enables most of the Scansorial birds to cling with great tenacity to the branches and trunks of trees, and to climb up the steepest surface. Few of them are possessed of great powers of flight; they spend most of their life among trees, and find on them their favourite food. In some of the families this consists of berries and other fruits ; in others almost exclusively of insects and grubs. Most of them rear their young in the holes of rotting timber, simply depositing their egg's among the clétris of the wood, without any nest. The Scansores are divisible into four families, of which the Toucan, the Parrot, the Woodpecker, and the Cuckoo are familiar examples.

* See "Animal Creation," page 437. 


\section{FAIILY I.}

\section{RAMPHASTID.E.*}

\section{The Toucans.}

Gex. Charac. - Bill much prolonged, broad at the base, with the eulmen curved, the sides compressed to the tip, and the lateral margins more or less serrated.

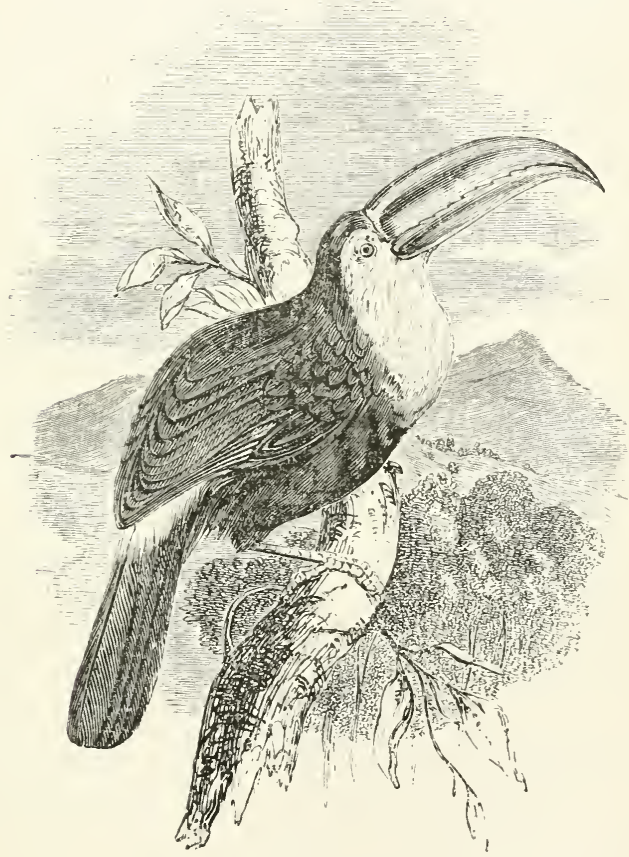

FIG. 124.-THE RED-BEAKED TOLCAY.

(Ramphastos erythrorhynchus.)

The Toucans are remarkable for the great development of their bill, which is sometimes nearly as large as the bird itself. The general form of the beak is

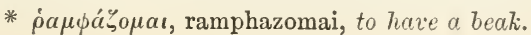


very similar to that prevailing in the Hornbills, but usually less tapering towards its extremity. It is also destitute of those remarkable protuberances which give some of the Hormbills such a singular aspect. As in the Hornbill, however, the substance of the beak is cellular or spongy ; so that, notwithstanding its apparently unwieldy bulk, it is too light to present any obstacle to the tolerably active morements of its possessor. The margins of both mandibles are denticulated throughout their length, and the curved tip of the bill is ordinarily sharp. The tongue in these birds is even more remarkable than the bill, being shaped exactly like a feather. A strong cartilaginous stalk runs up the centre, bordered on each side with long and slender barbs, placed close together, and increasing in length as they approach the extremity of this singular tongue. The Indians of South A merica attribute extraordinary virtnes to this feather-like organ, and employ it as a remedy in various diseases. The tarsi are short, but terminated by long and powerful toes; and the proportions of the legs and feet adapt the Toucans but badly for moving on the ground, where they cannot walk, but hop along with a very awkward gait. The Toncans are exclusively inhabitants of the warmer regions of South America, where they abound in many parts of the forests. They are usually seen in small flocks, hopping from branch to branch of the highest trees. They are shy and cautious in their habits, and feed principally upon fruits, especially bananas, which they swallow whole. They do not migrate, but wander about, making their appearance in greater numbers in certain districts where some favourite food happens to be ripe. Fruits, however, are not their only diet; they feed freely upon animal substances, killing and devouring small birds and reptiles, plundering the nests of other birds of their eggs, and even occasionally making a meal upon fish, worms, and the larva of insects.

Even when in motion among the branches of the 
trees, the large beaks of the Toucans give them a certain air of gravity ; but this is vastly increased by the attitude they assume in repose. When they perch quietly, they puff out their plumage until they look like a round ball of feathers; at the same time the tail is thrown up over the back, the head is retracted, and the enormous bill laid sometimes on one side, sometimes on the other, or moved from side to side, and raised and depressed in a manner resembling so much the gesticulations of an orator addressing a numerous assembly, that, coupled with the serious aspect of the birds, it has obtained for them, from the French Creoles in Guiana, the name of oiseauc prêtheur's, or preaching birds. 'They breed in the holes of trees, usually taking possession of such as have been enlarged by the Woodpeckers. Here they lay two egros of a white colour and roundish form. Toucans occur in rast numbers throughout the forests along the course of the Amazon. When they alight, and begin climbing the trees, one of them acts the part of a sentinel, uttering a loud cry of tucrino, from which their name is derived. When the whole flock raise their lond and not overmelodious voices in concert, they produce a harsh scream that may be heard at the distance of a mile. Mr. Edwards tells us that these birds, when tamed, may be taught as many tricks as a parrot, but they are destitute of the faculty of speech.

The type of this family is-

The Beauharnais, or Curl-crested Toucan (Pteroglossus Beautearnaisii). 


\section{FAMILY II.}

Poittacide.

The Parrots.

GEx. CHARAC.-Bill more or less large and strong, with the culmen arched to the tip, which is prolonged and acute, the lateral margins sometimes dentated, and the base eovered by a cere, of greater or less size, in which the nostrils are placed; the wings and the tail generally long; and the tarsi usually very short and robust.

'The feet of the Parrots are furnished with two toes pointing forward and two backward, and, in most of the genera, are expressly formed for firm prehension and climbing, evidently indicating that woods and trees are the appropriate and natural habitat of the race. It is accordingly in those regions where the trees are clothed with perpetual verdure, and where a constant and never-failing snceession of fruits and seeds can always be procured, that the Parrots are found in the greatest numbers. Thus the recesses of the interminable forests of South America are enlivened by the presence of the superb Macaws; those of India and its islands by the elegantly-shaped and scarlet-clothed Lories; while those of Australia resound with the harsh voice of the Cockatoos, and the shriller screams of the long-tailed Parrakeets. In these, their natural situations, their movements are marked by an ease and gracefulness we can never see exhibited in a state of confinement. They are represented as climbing about the branches in every direction, and as suspending themselves from them in every possible attitude, in all which movements they are greatly assisted by their hooked and powerful bill, which is used both as an organ of prehension and for support. The pointed and ample wing, which prevails among the Parrots, indicates a corresponding power of flight; and, accordingly, we learn from those who have enjoyed the enviable opportunity of seeing and studying them in their native wilds, that it is rapid, 
elegant, and vigorous, capable of being long sustained, and that many of the species are in the habit of describing circles and other aërial evolutions, previous to their alighting upon the trees which afford them food. Many of the species are gregarious, and, except during the breeding season, are alwars seen in numerous bodies. Others, as the Black Cockatoos, are met with only in pairs or families. The places selected for hatching and rearing their young are the hollows of decayed trees : they make little or no nest, but deposit their eggs, which, according to the species, vary from two to six in number, upon the bare rotten wood. In these hollows they frequently roost for the night. The natural cry of the tribe consists entirely of hoarse, shrill, and piercing screams frequently reiterated; some species possess the power of imitating the human voice and learning to articulate a variety of words and sentences; but this faculty seems to be principally confined to the short and even-tailed parrots, in which the tongue is large, broad, and fleshy at the tip. These birds are tender and wellflavoured, and are frequently used as food in the districts they inhabit.

To this family belong the Ground-Parrots, the Macaws, the Lories, the true Parrots, and the Cockatoos. 


\section{$S U B-F A M L Y I$.}

Pezoporina.*

The Ground-Parrots.

Gen. Charac.-Bill moderate, with the eulmen usually rounded and arched to the tip, which is sometimes dentated; the tarsi more or less short and rolust; and the tail broad, lengthened, and more or less graduated, with the ends of the feathers narrowed, and rounded or pointed.

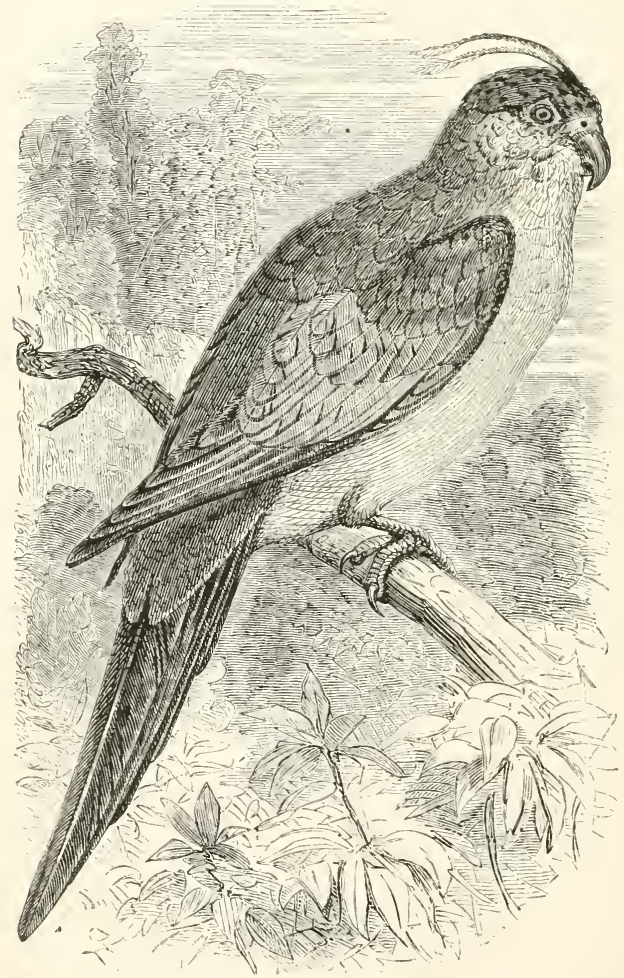

FIG. 125 - THE HORNED GROUND-PARROT.

(Platycercus cornutus.)

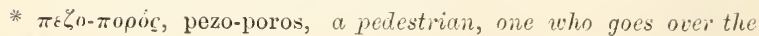
gionul on foot. 
The birds composing this sub-family are mostly found in Australia, where they inhabit shrubby or bushy places, and are uswally seen on the ground searching for the seeds of the grasses on which they subsist. When disturbed, they generally seek safety by a rapid flight, continued for a short distance, to the nearest trees, where they remain perched till the cause of their alarm has disappeared. Some species, met with most numeronsly in India, frequent the jungles and are often to be seen on cultivated ground and in gardens, where they commit great devastation, devouring various kinds of grain and fruits. During their migrations they generally keep close to the tops of the large trees, and on discorering food, take a short circle round the tree with a steady sailing flight, and, alighting on the branches, speedily commence their attack on the fruit.

\section{A well-known species is-}

The Beautiful Ground-Parrot (Pezoporus formosus). It is never seen to fly into a tree, or to take shelter among the branches, so that it is uncertain whether it possesses the power of perching. It usually frequents sandy sterile. districts covered with tufts of rank grass and herbage, or low swampy flats abounding with rushes, where, from its rery restless habits and great powers of rumning, it is seldom seen until it is flushed, and then only for a short time, as it soon alights and runs off to a place of seclusion, often under the cover of the Grass-tree (Nanthorrhoea), that abounds in the districts it frequents. It flies near the ground with great rapidity, often making several zigzag turns in the short distance of a hundred yards, beyond which it seldom passes without resting on the ground. Its flesh is excellent, being much more delicate than that of the Snipe, and equalling, if not surpassing, in flavour that of the Quail. Its white eggs are deposited on the ground. This species is met with both in Australia and Van Diemen's Land.

The typical form is -

The Horned Ground-Parrot (Platycercus cornutus), of which a figure is given above 


\section{SU BSFAIILY II.}

Araine.

The Nacaus.

GEx. Charac,-Bill large, the eulmen of the upper mandible much arched to the tip, which is prolonged and acute, the lower mandible deeper than long, and rather broader at the base than the upper, with the gonys adrancing upwards and rounded; the tail lengthened, graduated, and the tip of each feather narrowed.

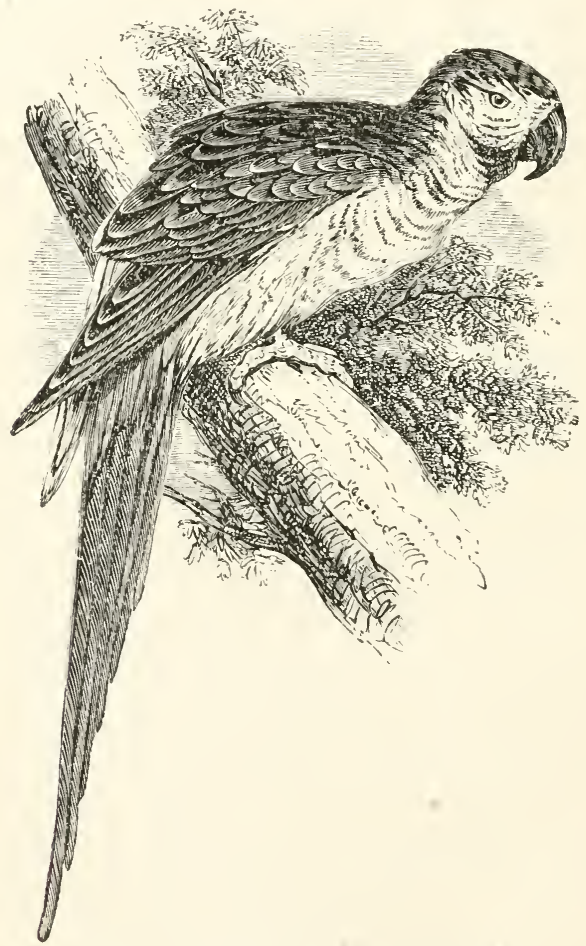

FIG. 126. -THE BLUE AND YELLOW MACAII.

( tra carulea)

'The Macaws are natives of the warmer regions of South America and the West Indies, and are amongst 
the largest of the Parrot race. They are easily domesticated, and become very familiar, but in their powers of imitation they fall very far short of the true Parrots. Their natural cries are harsh, discordant, and piercing; and the few words they are occasionally taught to utter are pronounced in a disagreeable tone. Their beak is of enormous size and strength, and their plumage remarkable for gaudy colouring. They perch on the highest part of lofty trees, preferring those that border the forests, and yet seldom show themselves at the extremity of the branches. They are generally seen in pairs, but sometimes in parties of six or eight together. When disturbed they shake themselves, and utter a scream, which is piercing, strong, and disagreeable. They are rarely noticed on the ground, but sometimes climb from branch to branch in quest of the fruits of the forest trees, and also of the palms in which they usually live. Their flight is horizontal, and not very elerated. They build their nest in hollow trees, or on large branches near the trunk, and lay two eggs. These birds are distinguished by the enormous size of their bills, of which the upper mandible is so much curved as to describe nearly a semicircle, and also by the naked skin, furmished with only a few scattered and minute feathers, which covers their cheeks. The natives of South America give the general name of Ara, or Aracara, to the Macaws, a denomination which is evidently in imitation of their note.

The type of this sub-family is-

The Blue and Yellow Macaw (Ara ccerulea), figured in the preceding page. 


\section{SUB-FAUILY III.}

\section{LORINA.}

\section{The Lories.}

Gex. Charac.-Bill large and slender, with the culmen curved to the tip, which is prolonged and pointed, the lateral margin sometimes sinuated and slightly notehed, and the gonys of the lower mandible lengthened and more or less curved and advancing upwards.

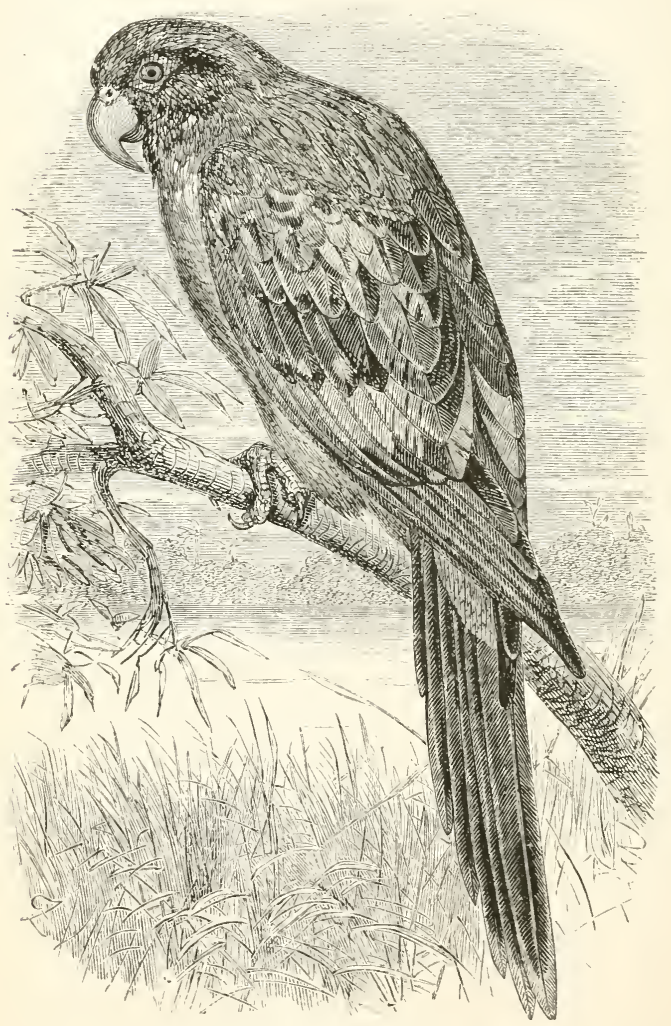

Fig, 127,-THE BLUE-STRIPED LORX.

(Eos cyanostriata.) 
Several small species of Parrots which inhabit the Eastern Islands and Polynesia are commonly called Lories. The characters upon which they are separated from the rest of the family, consist principally in the comparative weakness of the bill, and the peculiar structure of the tongue, which, instead of terminating in a soft fleshy cushion as in the true Parrots, is furnished with elongated papillæ, the latter sometimes even forming a sort of brush at the extremity of the organ. These birds live partly upon pulpy fruits, and partly upon the sweet juices of flowers : in collecting the latter, the papillæ of the tongue come into use. They are all remarkable for their brilliant colours, and for the softness of their plumage. They are lively, active birds, and do not lose their gaiety even in captivity. They are held in great estimation in many parts of the East.

The type of this sub-family is-

The Blue-striped Lory (Eos cyunostriata). 


\section{SCIS-FAMILY IV.}

PsitTacis.e.

The True Parrots.

Gex. Charac,-Bill more or less large, broad at hase, and the sides compressed, with the culmen much arehed to the tip, which is acute and pro. longed, the lateral margins dentated or festooned; the nostrils basal, lateral, and rounded; the wings more or less long and pointed; the tail usually short and squared; the tarsi short and covered with small scales; the toes mo lerate.

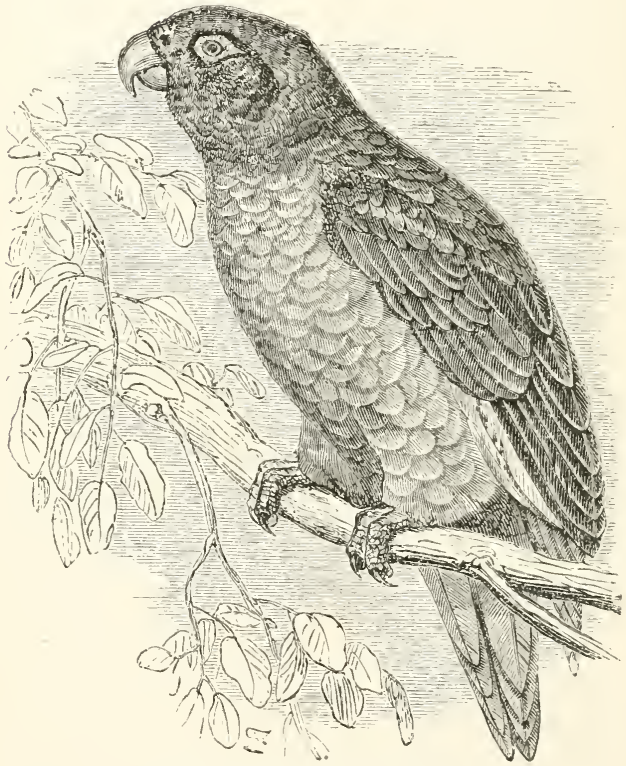

Fig. 128. - THE AUgUSt PARRot.

(Psittacus augustus.)

The True Parrots are natives of the continent of Africa, and of the warmer parts of South America. They inhabit forests, and are found on clusters of trees, especially those that grow in the neighbourhood of rivers; to these they resort for protection from the scorching heat of the sun, and as roosting- 
places during the night. On the first appearance of dawn, these birds are in the habit of assembling from their nocturnal retreats in vast flocks, and perching on dead trees, where they may be observed preening their feathers in the early rays of the sum, as if to dry them from the dew of the night. They then separate into small parties, and scatter themselves in search of their food, which consists chiefly of various fruits: they sometimes commit great destruction among the orange plantations. After having satisfied their hunger, they invariably proceed to the banks of the rivers to bathe, until the heat of the day drives them to seek the thick foliage of the trees, where they enjoy the refreshing coolness of the shade, and remain so quiet that their presence is not discoverable. At any alarm, however, the whole flock flies off hastily, uttering loud discordant screams, to another retreat. Towards evening they leave the trees, for the purpose of obtaining their second daily supply of food, after which all the flocks reassemble with much noise, and again visit the river to perform their second ablutions; and before going to rest, revisit the trees to preen and dry their plumage by the last rays of the sun. This completed; they separate and retire each to its own peculiar roosting-place, until the dawn of day again awakens them into active life. On the approach of the rainy season, these birds migrate to the warmer districts, and, during their migration, rise to so great an elevation in the air, that they are not visible to the naked eye, though their discordant notes are distinctly heard. They seek the quiet solitudes of the forests for rearing their young, and feed their nestlings by disgorging into their mouths half-masticated fruit, after the manner of Pigeons. The female deposits from two to four egg's on the bare wood in holes of trees.

The Ash-coloured, or Grey Parrot (Psittacus erythacus), is one of the species most frequently kept in England, and is familiar to all. It inhabits the woods of tropical Africa. 
Gex. Charac.-Bill generally large, of various lengths, broad at the base, more or less compressed on the sides, and the eulmen usually much arehed to the tip, which is very acute; the wings generally rather long and pointed; the tail more or less long, hroad, and mostly even; the tarsi short, robust, and covered with small seales; the toes unequal.

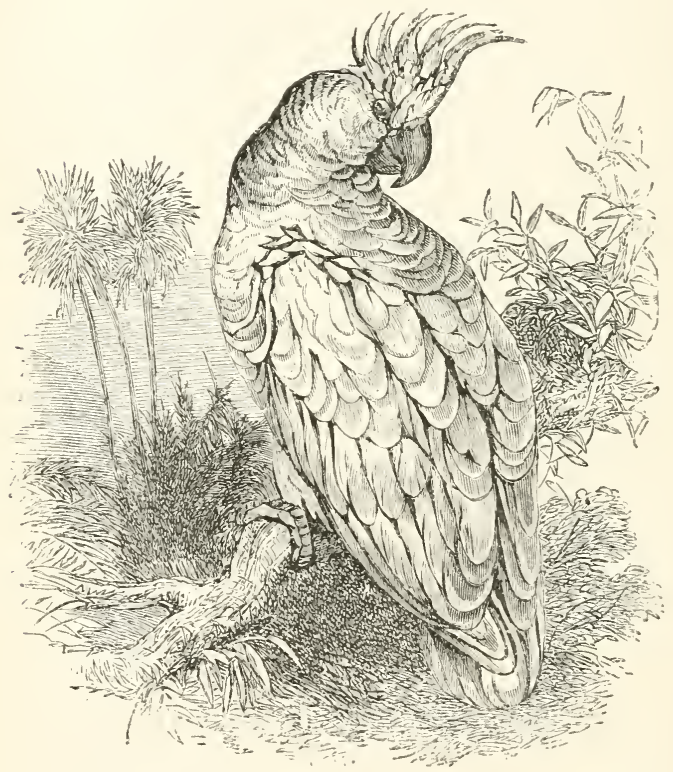

Fig. 1:9.-The sulpher crested cochttoo.

(Cucutua sulphurea.)

4

The Cuckatoos are readily distinguished from the preceding Parrots by the presence of a large crest, which the birds are able to elevate or depress at pleasure. Their name is an imitation of the peculiar cry of the species. These birds are found in the 
Molucca Islands and on the continent of Australia. Some prefer the lofty trees that border large river's, and such as are located in swamps; other species frequent such as grow in the open plains and clear lands. They are very shy, and it is therefore rather difficult to get near them; but though not usually seen, their presence is easily discovered by their loud screaming notes, the effect of which is much increased by their vast numbers. They subsist entirely on regetable substances, such as hard seeds, nuts, and small tuberous and bulbous roots, and they generally swallow stones along with their food. They commit great depredations in the fresh-cultivated lands, and on the smaller branches of trees, by stripping off the bark, which they sometimes cut into small pieces : the appearance of this work of devastation generally indicates that their nest is in a neighbouring tree. 


\section{FAMILY III.}

PICIDE.

The Woorlpeckers.

GEx. CHARAc.-Bill generally lengthened, acute, and straight, with the base more or less broad, and the sides much compressed towards the tip, which is usually obtuse.

The birds of this family have a rather long straight bill, of which the tip is commonly obtuse or truncated, and the sides marked with a longitudinal ridge.* Their feet are organized for rumning upon the bark of trees, being furnished with long spreading toes, armed at the extremity with strong sharp curved claws, which enable them readily to seize any small inequality of the bark; whilst the tarsus is so placed as to form a sort of sole, which gives the bird great firmness in its usual position. The tail also is of service in climbing; for this purpose it is rather short, and composed of stiff feathers, pointed at their extremities, which are generally more or less worn away. These birds, especially the more typical species (for some, as we shall see, differ from the rest in their habits), reside in the woods and forests of both hemispheres, principally in the warmer regions. They run with great activity and in every direction upon the trunks and branches of trees, searching for the insects that constitute the greater part of their food, and may be constantly seen tapping the bark with their bills, in order to discover soft or rotten places, such as are usually inhabited by bark-feeding insects. On meeting with a favourable spot, they immediately dig vigorously into the bark, and seize the insects or larvæ concealed beneath. The capture of the smaller insects is effected by means of their tongue, which, with its appurtenances, exhibits a beautiful structure. For the capture of the smaller insects,

* See "Animal Creation," page 139. 
which abound both under the bark and among the crevices at its surface, the tongue is sharp, pointed, barbed, and endued with a glutinous matter, furnished by large glands situated in the throat, and communicating with the front of the mouth by two long ducts; so that the glutinous coating is renewed every time the tongue is drawn within the bill. These birds feed also upon fruits and seeds. The Woodpeckers roost and breed in holes in trees, which they are able to enlarge by means of their strong, sharp beaks; their only nest consists of the chips and délits at the bottom of the excavation. Their egg's are variable in number, smooth, shining, and of a pure white colour.

This family embraces the Barbets, the Piculets, the Woodpeckers proper, the Green Woodpeckers, the Black Woodpecker's, the Ground Woodpeckers, and the Wrynecks. 


\section{SU'B-FA.UILY I.}

C'APITONIN.E.

The Barbets.

Grx. Charac.-Bill large, broad at the base, usually furnished with bristles and compressed towards the tip; the tail generally short, even, and the feathers rounded at the ends.

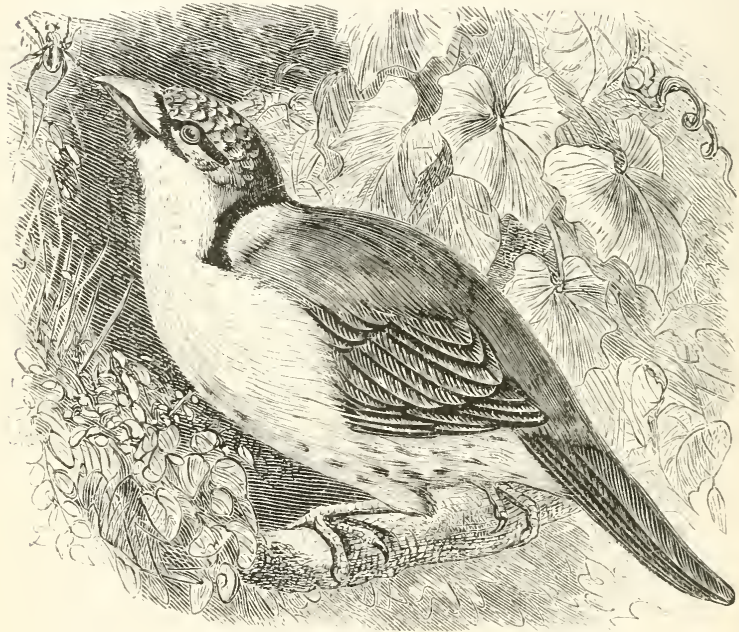

Fig. 130, - RICHARDSOA'S BARBET.

(Capito Richardroni.)

This snb-family embraces several genera, some of which inhabit the forests of Africa, where they live upon insects and fruits. They select a hole in some decaying tree, in which the female deposits her eggs on the bare wood. On quitting the nest, the young accompany their parents, and all live together in perfect harmony. These bands are so devoid of fear that it is easy to find the nest, it being only necessary to follow the little family to the hole where they reside, and to which they always retire to pass 
the night. Others are extremely aboundant in most parts of the continent of India, where the' seem to prefer open spaces in the jungles, or whererer a few trees are to be found upon which they can perch; or, being far from shy, they frequently approach gardens and groves. Their food consists of various fruits and insects, which they obtain whilst hopping amongst the branches. When roosting singly on the uppermost branch of a tree, they usually utter a momotonous note, that lasts for ten minutes or more : this note is very peculiar, and somewhat resembles a distant hammering of metal. Some of them have been observed picking holes in a horizontal rotten branch, wherein they build their nest, precisely in the manner of the Woodpeckers. Owing to the shortness of their wings, their general proportions are heary, and their flight is low.

The type of the race is-

Richardson's Barbet (Capito Richardsomi). 


$$
\text { SUER-FAIILYII. }
$$

Picumane.

The Piculets.

Gren. Charac.-Bill short, straight, the sides compressed towards the tip, which is rather acute; the gonys of the lower mandible lengthened, and advaneing upwards; and the tail short, with the tip of eacb feather lroad and round.

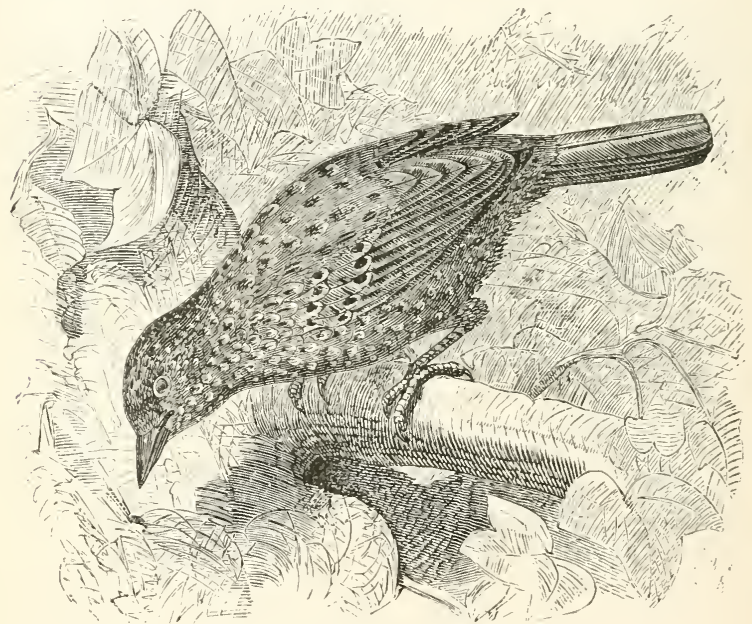

Fig. 131. - THE PIGMT PICUMNOS.

(Picumnus pygmaus.)

These little birds inhabit the forests of Sonth America and India. They are seen perched singly or in pairs on small trees, firmly grasping them with their toes. They possess the power of leaping from one branch to another, but they do not usually employ their tail in supporting themselves on the trunks, as is the case with the true Woodpeckers. They build their nest in rotten trunks of trees, in 
which the females deposit two egos. In a few Indian species, the feet are furnished with only three toes, two in front and one behind.

The type of this sub-family is-

The Pigmy Picumnus (Picumnus pygmons), represented above.

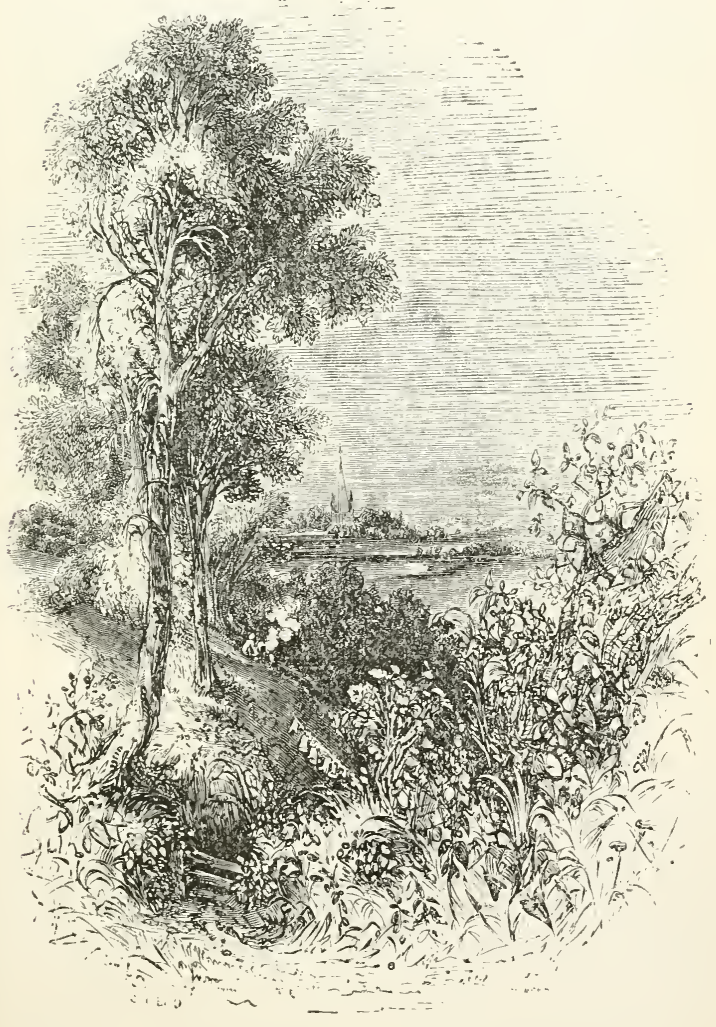




$$
\text { SUIB-FAMILY III. }
$$

T'ICIN.E.

The True Wroodpeckers.

GEx. Charac.-Bill more or less long, broad at the base, much compressed towards the tip, which is truneated, the sides of the npper mandible sloping, and furnished with a lateral ridge that springs from the middle at the base, gradually bends towards the lateral margin, and then extends above it to the tip; the outer posterior toe generally longer than the outer anterior toe.

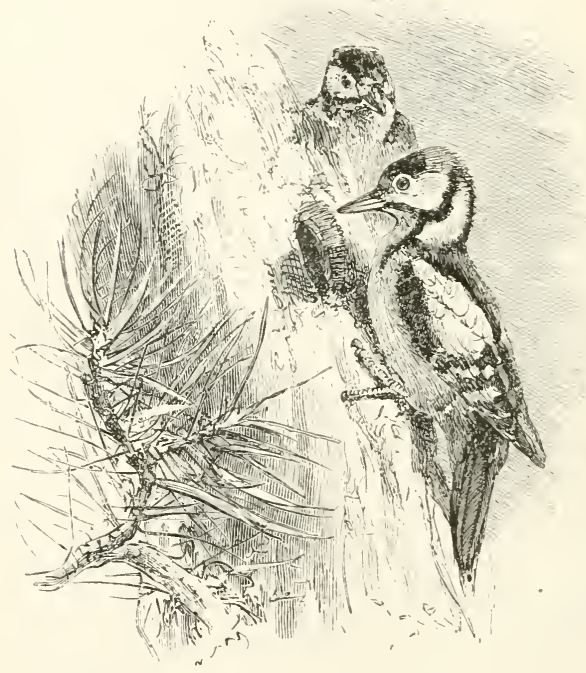

Fig. 132.-The great SPOtTED WOODPECKER.

(Picus major.)

The True Woodpeckers feed upon insects, which they capture in the woody structure and beneath the bark of trees. Their large and strong toes arranged in pairs give them great facility in maintaining their footing on a perpendicular surface, a faculty which is aided by their stiff and horny tail, composed of strong feathers, ending in sharp points, which act as a prop. Their beak is shaped like a wedge, 
almost as strong and hard as steel, terminated by a sharp, chisel-like extremity, wherewith, by repeated blows, the bird strikes off the bark of trees, and lays bare the insidious grubs beneath.

"All Woodpeckers are extremely expert at discovering insects in their lurking-places. No sooner have they alighted, than they stand for a few moments motionless and listening. If no movement is heard beneath the bark, the Woodpecker gives a smart rap with its bill, and bending its neck sideways, lays its head close to the tree, when the least crawling motion of a beetle, or even of a larva, is instantly discovered, and the bird forthwith removes the bark, and continues to dig until it reaches its prey, when it secures and swallows it. This mode of obtaining food is observed particularly during the winter, when few forest fruits are to be found. Woodpeckers are, howerer, by no means restricted to insect diet; cherries, peaches, pears, apples, figs, mulberries, and eren peas, constitute a considerable part of their nourishment. They likewise suck the eggs of small birds, and thus sometimes commit serious depredations." - Audubon.

The type of this sub-family is-

The Greater Spotted Woodpecker (Picus major), delineated above. 


\section{$S U B-F A M I L Y I V$.}

GECININE.*

The Green Woodpeckers.

Gen. Charac.-Bill more or less long, strong, and straight, with the base broad and the sides eompressed towards the tip, which is truneated and aente, the sides sloping, and furnished with a lateral ridge, whieh springs from above the nostrils and rums along near the culmen towards the end of the upper mandible for two-thirds of its length.

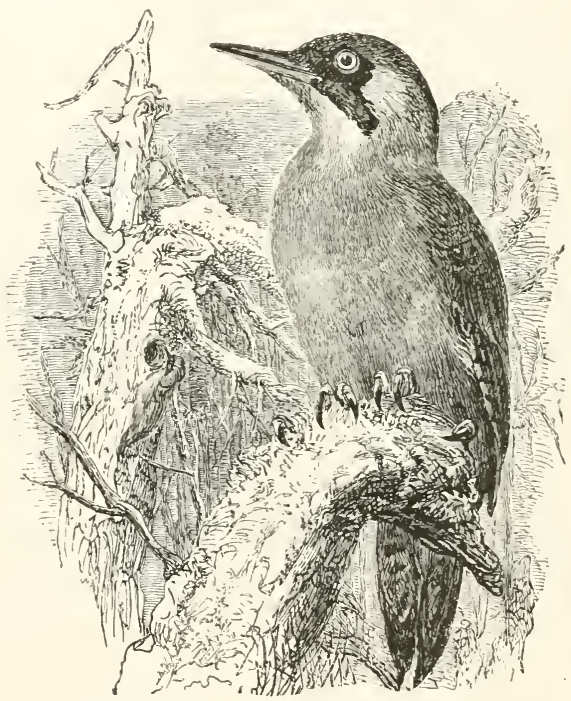

Fig. 133.-THE GREEN WOODPECKER.

(Gecinus viridis.)

These birds are found in most parts of the Old World. They reside singly or in pairs in forests and jungles.

The type of this sub-family,-

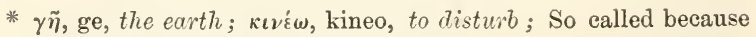
it scratches up the earth in search of food. 
The Green Woodpecker (Gecinus viridis), is the most common of our limited number of British Woodpeckers; on the continent of Europe it is widely distributed, inhabiting forests and woody districts, where its loud cry may be often heard though the bird itself remains unseen. In some of its habits this species differs from the Woodpeckers generally, especially in the circumstance of its often learing the trunks of trees and descending to the ground, where it searches for ants' nests, being extremely partial to those insects and their larva, picking them up very dexterously by means of its long tongue. It must not be supjosed, however, that these birds seek their food wholly on the ground; they search for insects under the bark of trees, or in the decaying wood, which they easily shiver by blows of their strong wedge-shaped bills. They scale the trunks of trees with great rapidity, climbing either straight up or in a spiral direction, but they descend tail foremost, moving as it were backwards. Their flight is rapid and undulating, and in flying from trunk to trunk, if the trees are not far from each other, they take only a single sweep. These Woodpeckers make their nests in hollow trees; or, if they meet with no natural hole fit for their purpose, they excavate one with their bills. In the performance of this duty the male and female labour by turns, hammering away with wonderful assiduity, their bills, while they are at work, going so fast that the strokes cannot be counted, either by the eye or the ear. 


\section{$S U B-F A M I L Y$ V.}

\section{Melanerpix.:* The Black Woodpeckers.}

Grex. Cinarac.-Bill more or less long, eompressed, and the lateral ridge placed nearly half-way between the culmen and lateral margin.

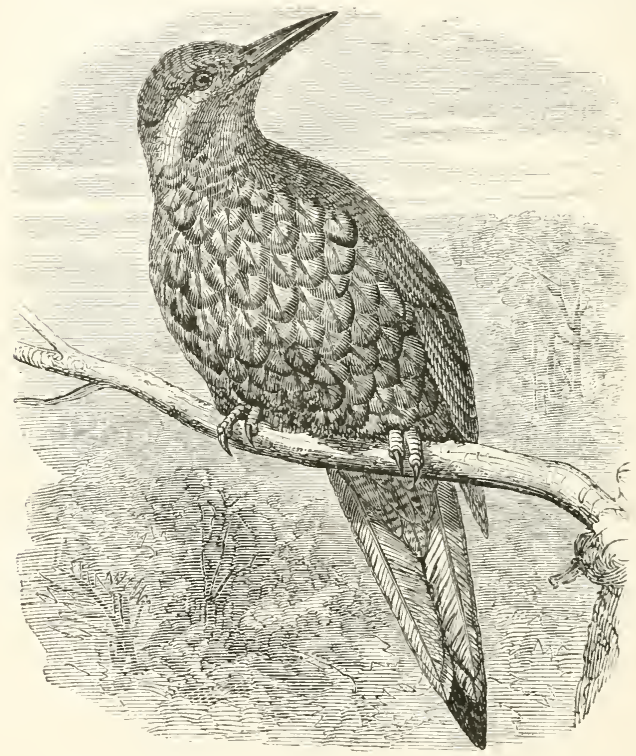

FiG. 131.-THE RUSTY MELANERPES.

(Melanerpes rubiginosus.)

These birds are found both in North and South America. They are seen in the woods, the orchards, and even on the fences in the neighbourhood of houses. Their chief food consists of insects, but they commit great devastation on fruits, berries, and Indian corn, and are said to enter dovecots for the

* $\mu \dot{\varepsilon} \lambda a \varsigma, \mu^{\prime} \lambda a \nu 0 \varsigma$, melas, melanos, black; " 
purpose of sucking the eggs of pigeons. Their note is lively, and so much resembles that of a species of tree-frog which frequents the same places, that it is sometimes difficult to distinguish the one from the other. They migrate during the night from north to south, flying high up in the air, and far apart, propelling themselves by flaps of their wings repeated at the end of each successive curve as they rise and sink in their flight. At the dawn of day they alight on the tops of dead trees about the plantations, and remain searching for food until the approach of sunset, when they again, one after the other, mount into the air and continue their journey. The nest is formed in the trunk or large branches of a tree. The female deposits six egg's, generally on the bare wood.

The type of this sub-family is-

The Rusty Melanerpes (Melanerpes rubiginosus).

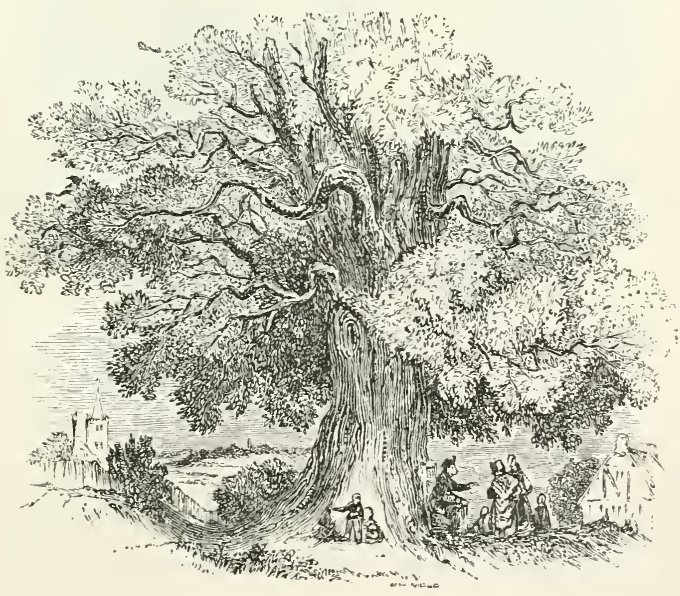




\section{SCBB-FAIJLY VI.}

\section{COLAPTIN.e** \\ The Ground Woodpeckers.}

GEx. Charac.-Bill broad at the hase, and the sides compressed to the end, with the culmen much curved to the tip, which is acute, the sides of the upper mandible sloping, and the lateral ridge scarcely visille or entirely wanting.

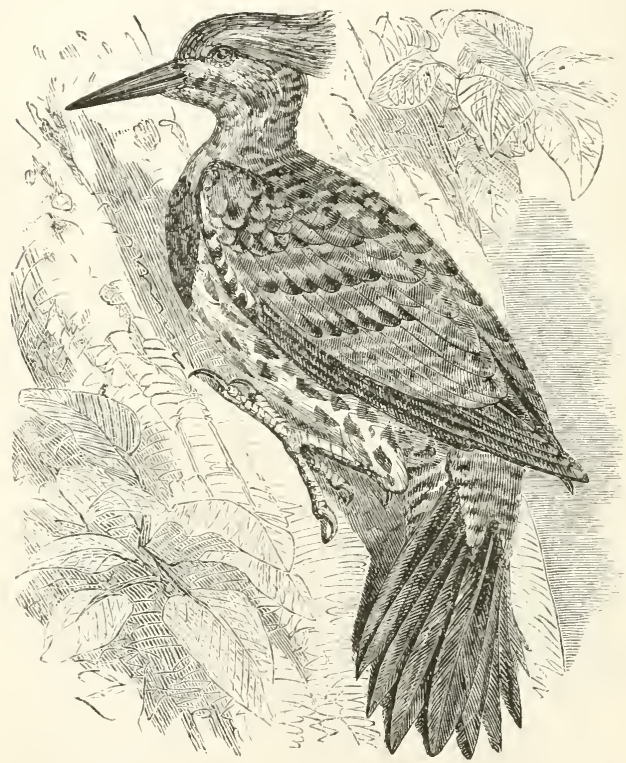

FIG. 135. -THE GOLDEN-WINGED WOODPECKER.

(Colaptes auratus.)

The denomination of Cuckoo-Woodpeckers would not be inappropriate to the members of this subfamily, seeing that in their structure the characters of both these birds seem to be combined. They have, in fact, the tail-feathers of the Woodpecker,

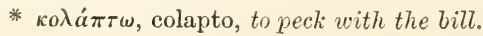


and a rounded, slightly-arched, and pointed beak, resembling that of the Cuckoos. They differ from the preceding: Woodpeckers in having their tongues much less extensible, and also. in many of their habits. They are very generally seen upon the ground, and do not climb trees, although they sometimes cling to their trunks by means of their claws, but without changing their position; nevertheless, they pereh readily upon the branches, and leap with facility from one twig to another; indeed they may sometimes be seen upon tall shrubs, upon the berries of which they feed with avidity, notwithstanding that insects and worms constitute their principal diet. 'They usually frequent coppices; they will approach villages during the winter, but in the spring they withdraw into the forests, where they avail themselves of the holes of other Woodpeckers in which to build their nests, seeing that they are without the means of excavating them for themselves.

These birds are found in North and South America, the West Indies, and South Africa. They may be seen on the ground, examining the manure of cattle for insects, or turning over the hillocks of ants, which yield their favourite food. Occasionally they frequent trees for ants that make their nests in them, and penetrate decayed or dead branches in search of wood-lice and the larva of insects. They live likewise on fruits, seeds, and grains. Their Hight is strong and prolonged. They propel themselves by numerous beats of the wings, with short intervals of sailing, during which they generally keep in a straight line. The nature of their chief food causes them to migrate from place to place. The female lays six eggs, which she deposits in the hole of a tree, on chips and dust of wood. The young soon leave the nest, and are enticed by the parents to the highest branches, where they are assiduously fed.

The type of this sub-family is-

The Golden-winged Woodpecker (Colaptes auratus). 


\section{SU'B-FA.MILY VII.}

YUNCINA.

The Wrynecks.

Gen. Charac.-Bill short, straight, with the tip acute; the wings moderate and pointed; the tail moderate, rounded, and composed of soft and flexible feathers; the tarsi short; and the toes moderate.

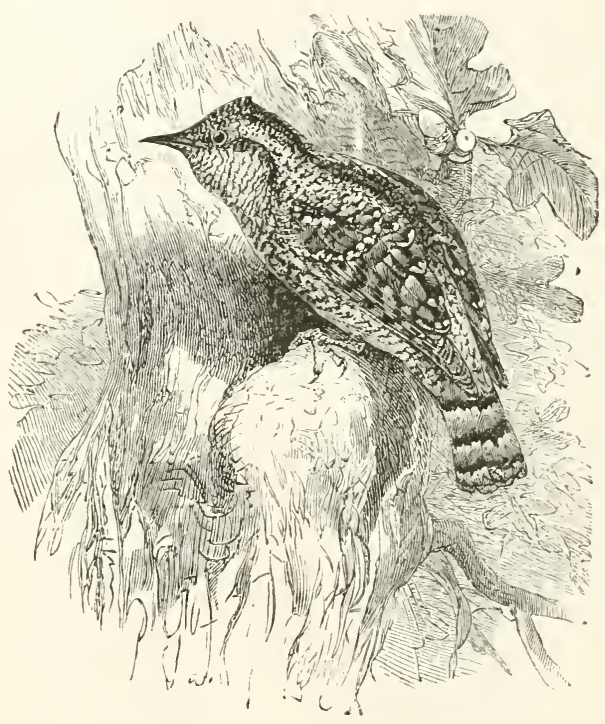

FIG. 136.-THE WRYNECK.

(

These birds are found in Europe, India, and Africa. In this country they make their appearance at the same time as the ants upon which they chiefly live. They obtain their favourite food by removing the earth with their bill, and then inserting their long, extensile, and glutinous tongue, to which the insects adhere. They are rarely seen on trees, as 
their soft tail is not strong enough to support them in climbing, although they make their nests in holes in an old tree trunk.

\section{The type of this sub-family-}

The Wryneck ( $\operatorname{un} x$ torquilla), a pretty little bird, about the size of a lark, is a summer visitor to our island; but though common in the southern and eastern counties, it is very rare in the north and west; and in Ireland, we believe, it is never seen. It arrives in this country in April, a few days before the appearance of the Cuckoo; and its loud cry of peep! peep! peep! monotonously repeated, is first heard when the leaves of the elm-tree are as large as a silver sixpence. Groves, orchards, and woods are the farourite resorts of the Wryneck, as also the lines of tall beech-trees along hedge-rows. Ants are its favourite food, and in search of them it traverses the trunks of trees, examining every crevice, and picking them up by means of its long worm-like tongue. In search of its insect prey it also visits the ground, where it hops and walks with considerable facility, searching for the nests of ants; and it is astonishing to see with what rapidity it devours its tiny victims, launching its long tongue at them, and withdrawing it so rapidly that the eye can scarcely follow its movements. Col. Montague informs us, that having captured a female Wryneck, which he confined for some days in a cage, he was enabled to watch its manners very minutely. "A quantity of mould with emmets and their eggs was given to it, and it was curious to see how the tongue was darted forth and retracted with such velocity, and such unerring aim, that it never returned without an ant or an egg adhering to it, - not transferred by the horny point, as some have imagined, but retained by a peculiar tenacious moisture provided for the purpose. While feeding, the body is motionless, the head only is turned to every side, and the motion of the tongue is so rapid that an ant's egg, which is of a light colour, and more conspicuous than the tongue, has somewhat the appearance of moving to the mouth by attraction, as a needle flies to a magnet. The bill is rarely used, except to remove the mould in order to get more readily at these insects. Where the earth is hollow, the tongue is thrust into all the cavities to arouse the ants, 
and for this purpose the horny appendage at its extremity is exceedingly serviceable."

The Wryneck breeds in the holes of decayed trees, but does not excavate a chamber like the Woolpecker, the strength of the beak being very inadequate for that purpose. The eggs, nine or ten in number, are laid upon the bare wood; they are of a pure transparent white colomr. When surprised upon her eggs, the Wryneck defends herself with great spirit, erecting the feather's at the top of her head, and hissing like a snake.

In provincial language, this bird is sometimes called the "Long-tongue," and "Emmet-hunter." The name Wryneck is given to it from its singular habit of twisting and writhing its neck with odd eontortions when alarmed or. irritated.

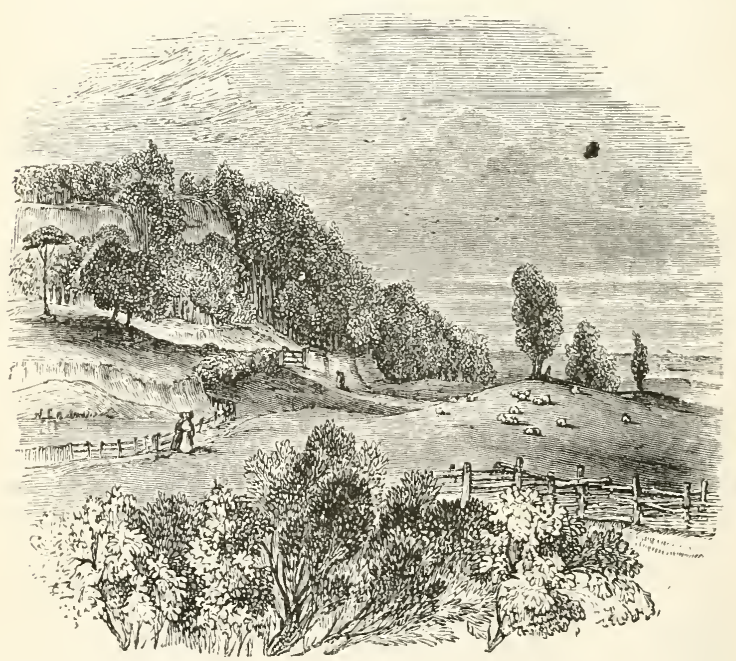




\title{
FAMILY IV.
}

\author{
Cucelide.
}

The Cuckoos.

Gev. Charac.-Bill of rarious lengths, generally slender, and more or less compressed on the sides, the culmen curved to the tip, which is more or less. emarginated; the nostrils lateral, and placed in a membranous groove; the wings long and generally pointed; the tail lengthened and rounded; the tarsi more or less long, and covered with broad transverse scales; the toe: long and unequal; the claws moderate, and more or less curved.

The Cuckoos have feet somewhat resembling those of the Parrots, but there is no breadth of sole; the tarsus is much more lengthened, and the toes, instead of being thick and strong, are slender and weak. These birds never climb, but as they sit much, and often for a long time, upon branches, it is necessary that their feet should be of such a form as to enable them to maintain an equal hold on all sides.

The members of this family occur in both hemispheres, and, indeed, in most parts of the world. They are especially abundant in warm climates, and those which are met with in cold or temperate countries are generally only summer visitors. They all feed principally upon insects. In their breeding habits they exhibit a remarkable dissimilarity ; for whilst many species build a nest and bring up their progeny, others, amongst which are our own Cuckoos, make over the labour of incubation and the care of rearing their young to other birds, in whose nests they deposit their eggs. With certain exceptions, the Cuculidx have long and pointed wings, and are distinguished by great powers of flight.

This family comprehends the Indicators, the Rain Cuckoos, the Ground Cuckoos, the Anis, and the Cuckoos properly so called. 


\section{SUP-FAUILYI.}

Indicatorine. The Indicators, or IIoney-yuides.

Gen. Charac.-Bill short, broad at the base, with the culmen curved, and the sides compressed to the tip, which is entire; the nostrils lateral and placed near the culmen in a membranous groove; the wings long and pointed; the tail moderate and emarginated; the tarsi very short, and eovered with transverse broad scales; the toes unequal, and the outer anterior toe the longest; the claws noderate and strong.

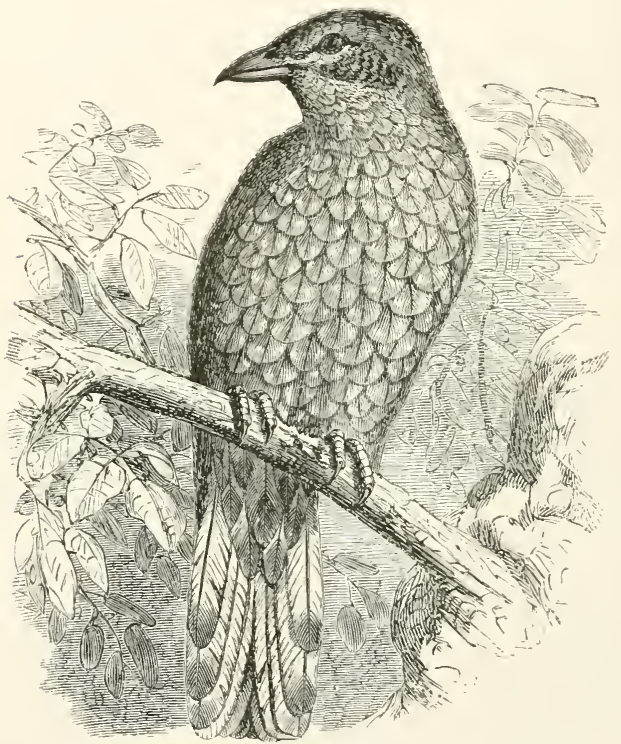

Fig. 137.-THE SPOTTED HONEY.GUIDE.

(Indicator maculatus.)

These birds inhabit the wooded districts of Africa, the forests of India, and the island of Borneo ; they are usually found in pairs near the nests of wild bees, which are located in the trunks of trees. The honey stored up in these nests constitutes their chief food, and they often pay dearly for their 
dainty fare, being sometimes found in the hives stung to death. In such a case, the bees corer the body with a vault of wax, that they may not be incommoded by its presence. Their flight is heary, and continued only for a short distance at a time; but they run upon the trunks and branches of trees with great facility, in the manner of the Woodpeckers. From the observations of M. Verreux, it would appear that they have the parasitic habits of the common Cuckoo, introducing their eggs into the nests of Woodpeckers, and sometimes into those of Orioles. The most celebrated species,-

\section{The White-beaked Honey-guide (Indicator albiros-} tris), is so called because it is said to serve as a guide to the inhabitants of the districts it frequents in their search for honey. We are told that this bird, fincling it rather a matter of difficulty to obtain the honey, of which it is extremely fond, has the remarkable instinct of calling Man to its assistance, and indicating the whereabouts of the nests of the bees by constantly repeating a sharp and peculiar cry, which, according to some travellers, may be compared to the words wicki, wicki, which in the langulage of the Hottentots means honey. In the deserts of Africa this cry may be heard in the morning and evening, and is eagerly watched for by the natives, who immediately reply to it in a graver tone, and hasten in the direction indicated. As soon as the bird perceives them coming, it places itself upon the tree in which a hive is concealed, and should the honey-seekers not adrance quickly enough, flies to them, and by repeatedly going backwards and forwards, shows them in an ummistakeable manner the position of the coveted treasure. Whilst the human marauders are rifling the contents of the hive, the Indicator remains perched in the vicinity, patiently waiting for the share of spoil which the Hottentots nerer fail to leave for its gratification. This strange instinct of the Honey-guide, we are told, is of essential service to the poor Africans, and they regard with no good will any person who kills one of these birds.

The type of this sub-family is-

The Spotted Indicator (Indicator maculatus). 


\section{$S U B-F A M I L Y \quad I I$.}

S'ALROTHERINA. *

The Rain Cruckoos.

FEx, CHARAC.-Bill long, with the culmen nearly straight towards the tip, which is suddenly curved and hooked; the sides much compressed, and the gonys long and slightly ascending; the nostrils lateral and partly exposed; the wings moderate and rounded; the tail lengthened and graduated; the tarsi more or less long, and covered in front with transverse scales; the toes more or less unequal; the claws moderate, curved, and acute.

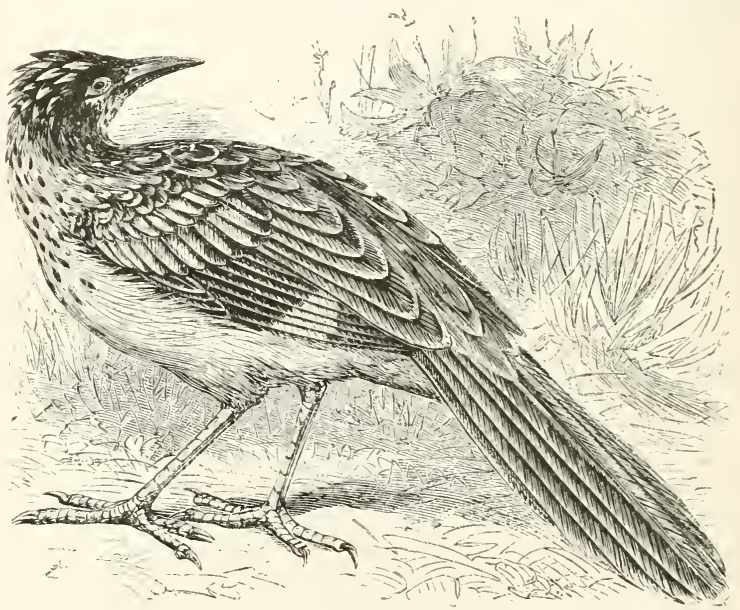

Fig. 138. -THE LONG BILled RaIN CUCKOo.

(Saurothera vetula.)

The Rain Cuckoos are found in the islands of the IVest Indies, and in South America. They frequent woods and hedges throughout the year, feeding on seeds, small worms, and caterpillars ; moreover, they are said to kill snakes, frogs, young rats, and smail birds. On the ground they move by leaps. Their

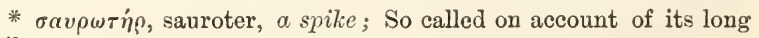
tail. 
flight is weak and short, extending only from bush to bush.

The type of this sub-family,-

The Long-billed Rain Cuckoo (Saurothera vetula), is common in St. Domingo, where it is known by several fimiliar names; such as the "Tacco," after one of its cries, and the "Pie," from another of its notes. It is generally known as the "Rain-bird," because it redoubles its noisy exclamations shortly before rain. It has likewise obtained the cognomen of the "Laugher," from the resemblance of its voice to a hearty laugh as it pronounces the syllables qua, qua, qua! or cra, cru, cra! sounds which it frequently gives utterance to when flying. In pronouncing its cry of tacco, the first syllable is loud and full, the second an octave lower. The Tacco frequents indifferently the cultivated lands or the broad savannas. or it may be met with in bushes or in forests. It feeds principally upon caterpillars and lizards, or gives chase to young rats, snakes, frogs, or even small birds. Its nest is composed of dry roots, moss, and leaves, and is generally constructed in the forked branch of a tree. The eggs are four or five in number, of a dingy white colour spotted with black.

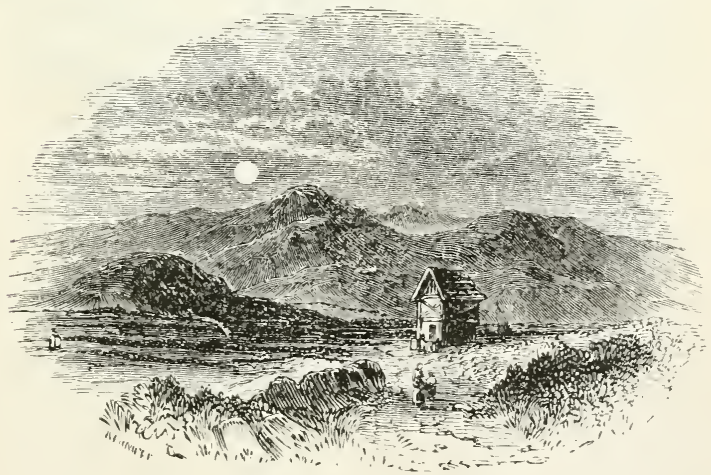




\section{$S U B-F A M I L Y I I I$.}

Coccrzin.e**

The Ground Cuckoos.

GEx. CHARAc.-Bill generally elevated at its base, with the eulmen arebed, and the sides mueh compressed to the tip, which is entire; the gonys usually long and straight; the nostrils basal, with the opening generally linear and partly closed by a seale; the wings moderate and more or less rounded; the tail long and graduated; the tarsi lengthened, and eovered with loroad scales; the toes unequal, and armed with variously-sized elaws.

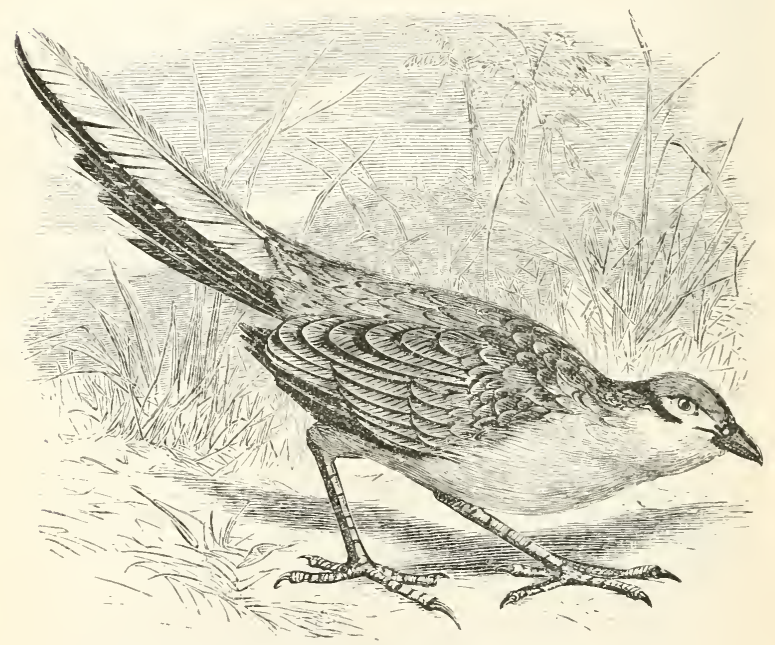

FIG. 139.-THE RED-HEADED GROUND CUCKOO.

(Coue ruficeps.)

These birds are found both in Central and North America, and sometimes in Europe. They make their abode in the densest woods, the borders of solitary swamps, and in orchards, seeking the thickest foliage for concealment. Their food consists of caterpillars and insects, shell-fish, snails, and small

* кокки̧́, coceyzo, to cry like a cuckoo. 
frogs; they feed, likewise, on berries and fruits, and are accused of sucking the egg's of other birds. In their migrations northwards they move singly, butwhen returning to warmer latitudes they appear to be gregarious, Hying high in the air, and in loose flocks.

\section{The best-known species is-}

The Carolina Cuckoo (Coccyzus Americanus). A stranger who visits the United States for the purpose of examining their natural productions, and passes through the woods in the month of May or June, will sometimes hear, as he traverses the borders of deep, retired, high-timbered hollows, an uncouth guttural sound or note, resembling the syllables kowe, kowe, kowe, kowe, kowe! beginning slowly, but ending so rapidly that the notes seem to run into each other. He will hear this frequently without being able to discover from whence it proceeds, as the bird producing it is both shy and solitary, always seeking the thickest foliage for concealment. From the sound of its note it is known in many parts by the name of the "Cow-bird ;" it is also called in Virginia the "Raincrow," being observed to be most clamorous immediately before rain.

This bird (unlike the European Cuckoo) builds its own nest, hatches its own eggs, rears its own young, and in conjugal and parental affection seems nowise behind any of its neighbours of the grove. Early in May they begin to pair, when obstinate battles take place among the males. The nest is usually fixed among the horizontal branches of an apple-tree, sometimes in a solitary thorn, crab, or cedar, in some retired part of the woods ; it is constructed with little art, and scarcely any concavity, of small sticks and twigs, intermixed with green weeds and blossoms of the common maple. On this almost flat bed the eggs, usually three or four in number, are placed: these are of an uniform greenish-blue colour, and of a size proportionable to that of the bird. While the female is sitting, the male is generally not far distant, and gives the alarm by his notes when any person is approaching. The female sits so close that you may almost reach her with your hand, and then precipitates herself to the ground, feigning lameness to draw you away from the 
spot, fluttering, trailing her wings, and tumbling over, after the mamner of the Partridge, Woodcock, and many other species. Both parents mite in providing food for the young : this consists, for the most part, of caterpillars, particularly such as infest apple-trees: the same insects constitute the chief part of their own sustenance. They are accused, and with some justice, of sucking the eggs of other birds, like the Crow, the Blue Jay, and other pillagers. They also occasionally eat various kinds of berries; but from the circumstance of destroying such numbers of very noxious larvæ they prove themselves the friends of the farmer, and are highly deserving of his protection.-Wilson.

The typical form is-

The Red-headed Ground Cuckoo (Coua ruficeps).

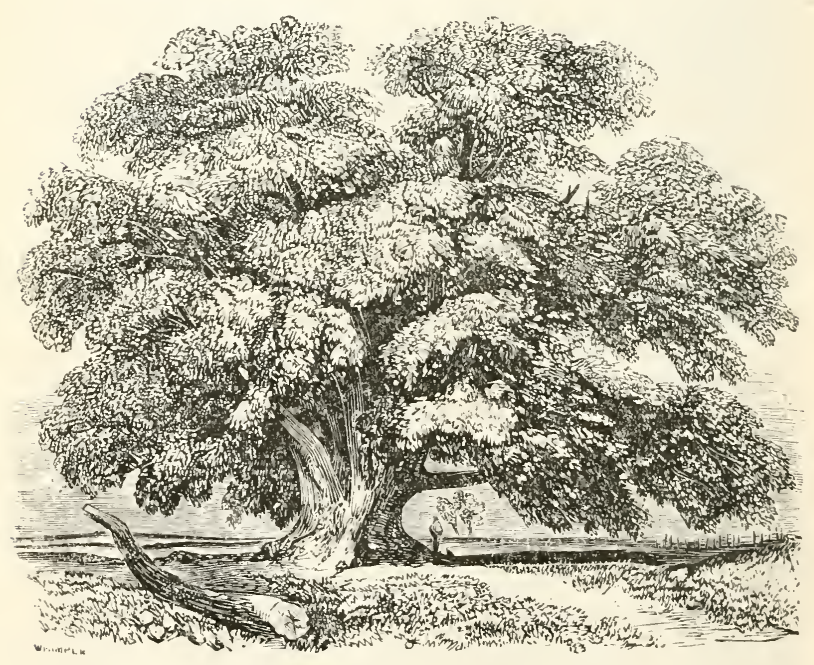




\title{
$S C B-F A M I L Y I V$.
}

\author{
Crotophagine.*
}

The Anis or Tick-eaters.

Gex. Charac.-Bill more or less lengthened, with the culmen arched, and the sides much compressed; the nostrils basal, lateral, and pierced in the substance of the bill; the wings short and rounded; the tail lengthened, broad, and graduated; the tarsi long, and eorered with broad transverse scales; the toes long, placed two and two, and the two outer ones the longest; the claws short and cursed.

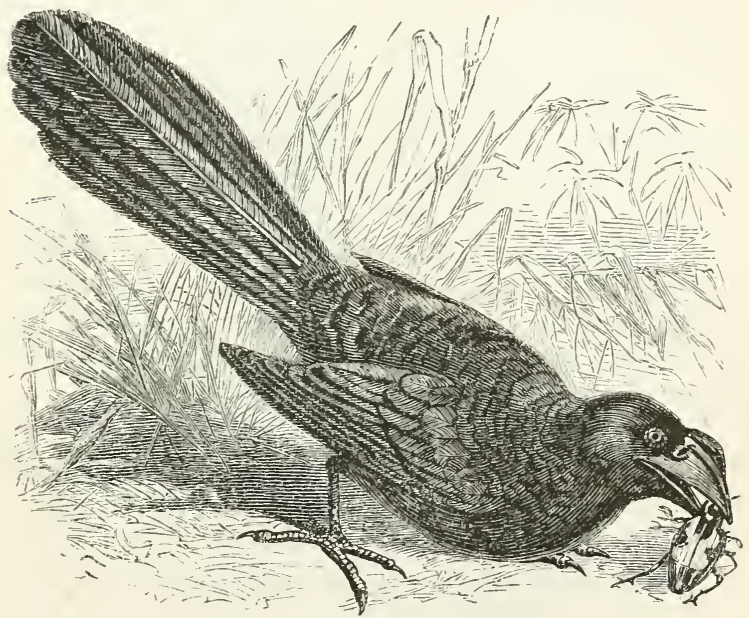

Fig. 140.-THE GREATER TICK-EATER.

(Crotophaga major.)

These birds inhabit the islands of the West Indies and the tropical parts of South America, preferring places under cultivation, and more especially land in the neighbourhood of clear pastures or low shrubberies and swamps. They easily make their way among the thickest foliage or grass by means of their sharp-edged bills, with which they scatter the

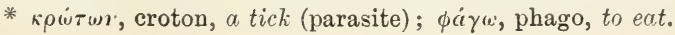


herbage on each side in their search after grasshoppers and other insects. 'They have been seen on the dead carcase of a sheep, but whether attracted by the flesh or by the larva of insects is uncertain. In the daytime they have been noticed in flocks of twenty or thirty individuals, about small rivulets, seeking for tadpoles, which they greedily devour. At other times they may be seen flying from shrub to shrub, uttering their peculiar note. Their nest is built in the fork of a tree, or in a bush covered with thick mistletoe; it is rudely-constructed of coarse materials, chiefly small sticks with the pliable portion placed inside, and totally destitute of any soft lining. The egg's are from five to seven or more in number. The young evince much activity in hopping from branch to branch: long before they are able to fly, they leave their nests, and may frequently be seen perched on the top of a shrub or thicket of vines, in company with a congregation of adult birds; and when the parents escape from an intruder by taking flight, the young, by long and rapid leaps, reach the ground and run off with great quickness.

These birds live chiefly upon ticks and other small vermin, and may frequently be seen jumping about cows and oxen in the fields; nay, they are often observed to fly upon their backs, and the eattle will even lie down for them if much troubled with ticks; but if the beast be heedless, they hop once or twice round it, looking it rery earnestly in the face every time they pass, as if they seemed to know that it was only requisite to be seen to be indulged. They are very noisy birds, and one of the commonest sorts in all the pastures of Jamaica. 'Their flight is low and short.-(Brown, Hist. Jamrica.)

The type of this sub-family is-

The Greater Tick-eater (Crotophaga major). 


\section{SUB-FAMILY V.}

Cuculin.e.

The Cuckoos proper.

Gex. Charac.-Bill broad, and rather depressed at the base; the culmen curred, and the sides compressed to the tip, which is entire or slightly emarginated; the nostrils basal and membranous, with the opening exposed; the wings long and generally pointed; the tail long and usually graduated; the tarsi short, partly clothed with feathers, and partly covered with broad scales.

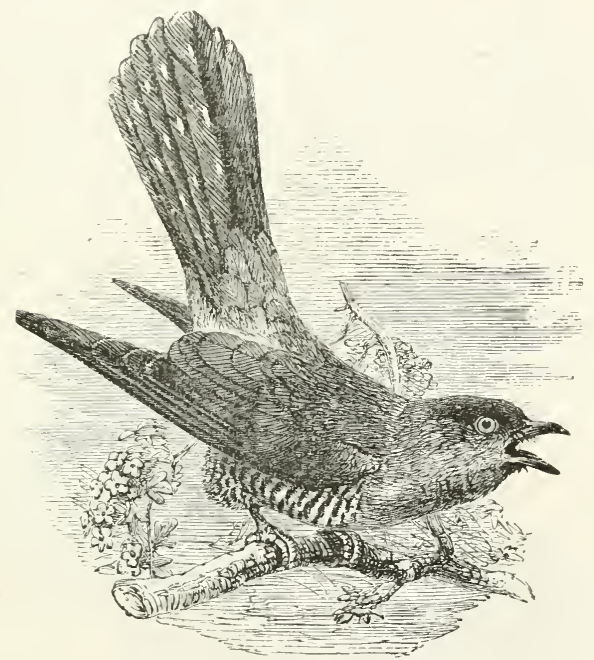

Fig. 141.-THE COMMON CECKOo.

(Cuculus canorus.)

These birds are peculiar to the warmer portions of the Old World. They are migratory and of solitary habits, frequenting woody places and gardens in quest of their subsistence ; and generally perch in bushes, or on the lower branches of trees, flying occasionally from one to another at short distances. Their food consists principally of caterpillars, which they 
kill by pressing them with their bill before swallowing them, usually cutting off' the hinder end of the insect, and by repeated jerks freeing it from extraneous matter; they sometimes feed on perfect lepidopterous insects. 'Their note is loud, and nttered in a lengthened and melancholy manner, especially early in the morning and at the decline of day, sometimes even during the night. It is remarkable that the females of our common species do not form any nest, but mostly deposit their egg's in the nests of sylvan birds, learing to the foster-parent the entire charge of hatching and rearing the young Cuckoo, which, if it finds itself incommoded by the rightful owners of the nest, casts them out to perish on the ground; so that the entire care of the fosterparent is ultimately bestowed upon the intruder.

The reason of this strange proceeding seems to be that the Cuckoos produce their egg's only at intervals of several days, and as their residence in temperate climates is but short, the young could hardly be brought to maturity by their own parents in time to take their departure with them. The egg of the Cuckoo is of very small size in comparison with the bird; its weight does not exceed that of a Skylark's egg, although the comparative size of the two birds is as four to one. Hence the egg of the parasite is readily introduced into the nest of its intended foster-parent, and the latter is not alarmed, as it might be, by the presence of an egg so large as to be positively inconvenient. This is of some consequence, as the birds whose nests are selected by the Cuckoo for the reception of its eggs are all much less than itself. The Cuckoo's egg is hatched in a shorter period than those of its foster-parent, and thus the young Cuckoo commonly makes its appearance before many of the eggs of the latter are hatched; moreorer, as it has to grow rapidly, it requires to be supplied with a much larger quantity of food than would fall to its share if the insects and worms collected by the old birds had to be divided among a nestful of 
hungry claimants. With this exceedingly selfish object in view, the young Cuckoo begins operations by gently insinuating his tail under the body of one of the young birds, which he then, with the assistance of his wings, contrives to hoist upon his back. With his load properly poised, the young Cuckoo goes backing until he reaches the edge of the nest, when, with a sudden jerk, he throws it out to perish. The other birds soon follow, and he then betakes himself to the unhatched eggrs, which are disposed of in the same way.

The type of this sub-family,-

The Common Cuckoo (Cuculus canorus), is with us only a summer visitant; it arrives about the beginning of April, and during the whole of its sojourn in this country leads a wandering life, building no nest, and attaching itself to no particular locality.

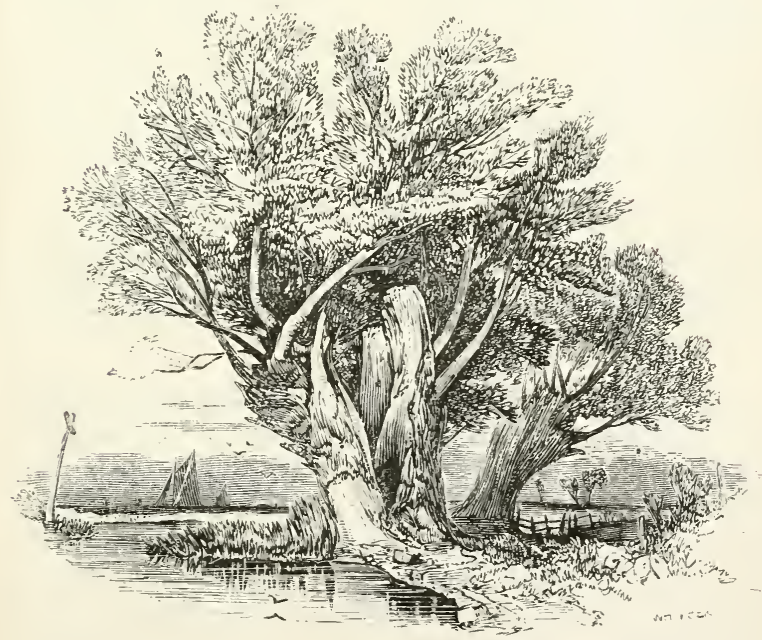




\section{O R D E R I T.}

\section{Galline.}

The Gallinaceons birds are all terrestrial. They have a short or moderately long beak, which is vanlted above. Their body is heavy, and their wings generally short. They all live rpon grain, and are furnished with a strong muscular gizzard; they delight in seeking their food upon the ground, and in scratching among the dust. 'To this order belong our game-birds and most of our poultry ; their flesh supplies a light and wholesome meat, and their feathers are applied to various purposes both ornamental and useful.

This order is divided by Cuvier into two sections-

The Galime properily so called, and the CoLUMBE.*

\section{SEC'TION I.}

\section{GaLLine properly so called.}

GEN. CHARAC.-Tarsi lengthened, robust, and sometimes armed with a spur or spurs; the toes more or less lengthened, but always connected at their base by a membrane, the hind toe more or less developed, and when present more or less elevated from the ground.

The Gallinaceous birds are so named because they present a general resemblance, both in their structure and habits, to our common barn-door fowls. They are usually of a moderate or rather large size, and of a stout and somewhat heavy shape. They have a small head, often partially or wholly denuded of feathers, and a bill of moderate length, of which the mpper mandible is distinctly arched, and overhangs the lower both at the tip and along

* See "Animal Creation," page 443. 
the margins. As they are all essentially terrestrial in their habits, their legs are always strong and welldeveloped. The tarsi are stout, and very commonly armed with a spur, or even with two or more such weapons, which are especially developed in the males. The toes are three in front and one behind, the latter being usually small and slightly elevated on the back of the tarsus, but sometimes more elongated, and then placed upon the same level as the other toes, so as to be efficient in grasping. The anterior toes are not very long, but stout, and often mnited by webs at their base; they are armed with strong and rather blunt nails, which are of great use in scratching up the ground in search of food,a habit common to most of the species, from which, indeed, many ornithologists give them the name of Rasores or Scrapers. The feathers of the legs are continued down to the articulation of the tarsus, and sometimes extend beyond this point, even to the extremities of the toes. The wings are generally short and weak in comparison with the weight of the body, so that they fly hearily, and only to short distances. Their plumage is firm, and often adorned with brilliant colours; and parts of it, especially in the males, are frequently developed to an extraordinary extent, sometimes giving them a grotesque appearance. The feathers are distinguished by the great development of the accessory plumules springing from the base of the stem, at its junction with the quill.

The Gallinaceous birds are spread over all parts of the world, but the finest species are inhabitants of the warm regions. Their food consists of fruits, seeds, herbage, insects, and worms. They are generally polygamous, each male collecting around him a seraglio as numerous as he can keep together. In keeping off the attentions of intrusive rivals, he is engaged in almost incessant combats. The females lay their egos, which are generally numerous, upon the ground in some sheltered situation. The young 
are usually able to rm as soon as they leave the ego, but at night, or on the approach of langer, they shelter themselves moler the wing of their mother.

'The Gallina may be generally described as being" that order more expecially set apart by their Gireat Creator for the service of man. Hence they are more easily domesticated than any other birds; their flesh is the most palatable, and their fecundity the greatest. They live almost entirely on the around, which consequently affords them their chicf nourishment in the seeds and grains of different plants. 'Their flesh and their egos are universally wholesome and very nutritions, while their feathers are employed for a variety of uses. They are peculiarly attentive to their offspring; and that the increase of the different races shonld keep pace with the wants of man, they are much more prolific than ordinary birds. They are social, live in societies, and are polygamons. They prefer escaping from danger by rumning, and only take to flight when compelled by necessity. 'They are fond of rolling' in the dust; some nestle on the ground and live only on plains, whilst others reside in forests and make their nests only in trees. 
('RACID.E.

The C'urassous.

GEv. CHARAC.-Bill moderate, of various forms, with the culmen more or less arched to the tip; the nostrils basal, lateral, and exposed; the wings short and much rounded; the tail lengthened and very broad; the tarsi lengthened and robust, with the toes lengthened and more or less slender, the hind toe long, and placed on the same plane with the others.

The first family of the Gallinæ includes a small number of species peculiar to South America, and known under the names of Guans and Curassows. These birds reside in the luxuriant forests of tropical America; they live chiefly on the ground, where they pick up the seeds and insects which constitute a great portion of their food. 'Their powers of flight are rather limited, but they rise freely into the trees, upon the branches of which they often roost and breed. 
PENELOPINe.

T'le Guans.

Ger. Charac.-Bill moderate, weak, slender, longer than high, with the eulmen at the base straight, and then vaulted to the tip; the nostrils large, covered with a membrane, and the opening large, anterior, and orate; the sides of the head and throat more or less naked.

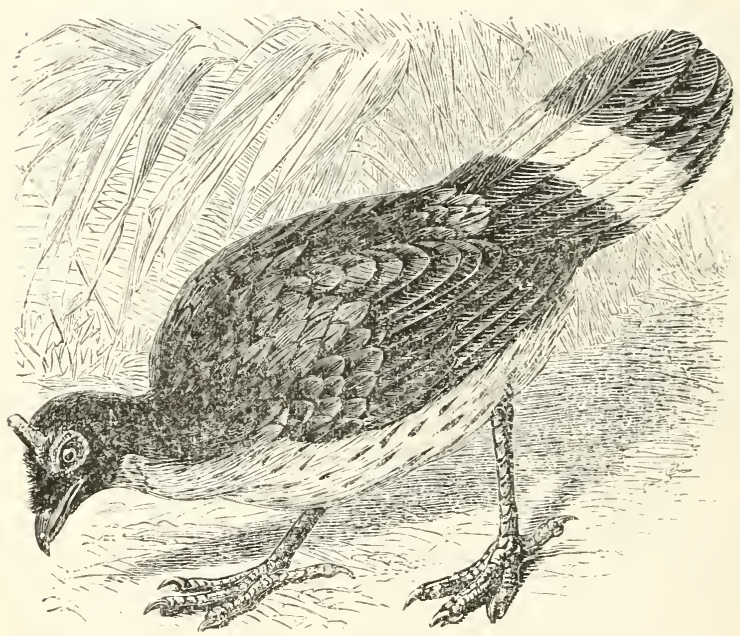

FIG. 142.-LORD DERBY's GUAN.

(Oreophasis Derbiunus.)

These birds are only found in the warm parts of South America. They are generally seen in forests on trees, near the tops of which they reside during the heat of the day, but in the cool of the morning and evening they are busily engaged in searching for fruits and insects. Their flight is heary, and performed with difficulty, owing to the shortness of their wings. They build their nests on the summits of trees: the female lays from two to five eggr.. 
Their note resembles the syllable $p i$ uttered in a sharp tone, and so loud, that when numbers are collected near the same spot, they make the woods resound with their clamorous cries.

The type of this sub-family is-

Lord Derby's Guan (Oreophasis Derbianus).

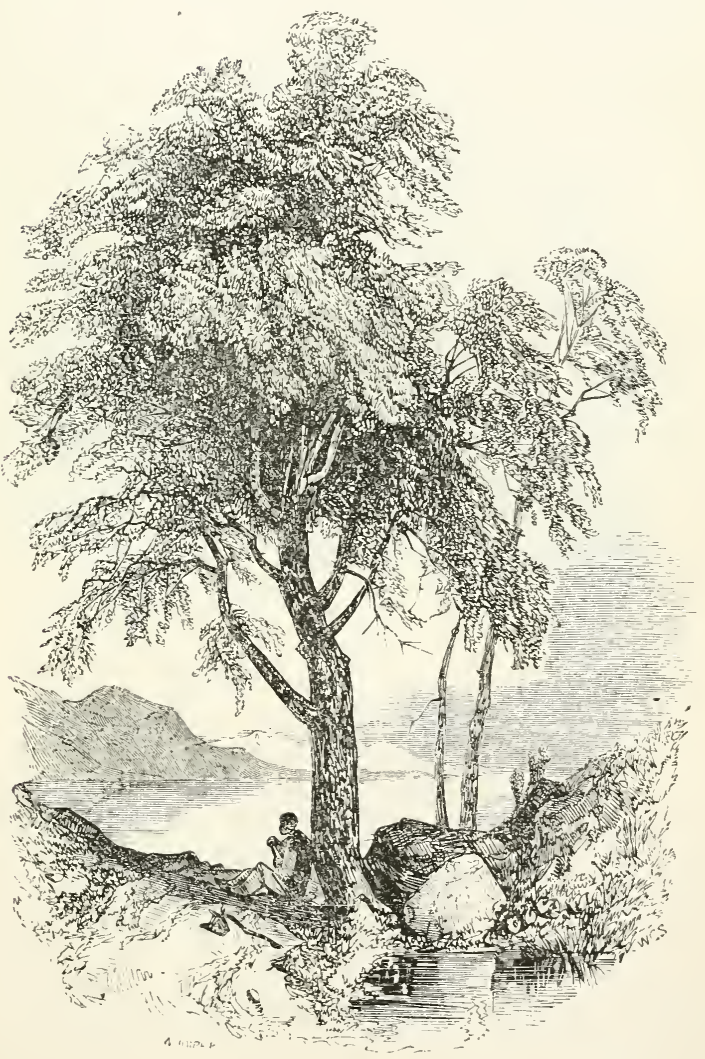




\section{$S C B-F L I I L Y I I$.}
('R.ACIN.E.
The C'urcessous proper.

Grx. CHaRAc.-Bill more or less long, and generally elevated at the base, the culmen eurved and the silles compressed to the tip, which is obtuse; the nostrils lateral and large, with the opening partly closed by a membrane erescent.shaped or rounded.

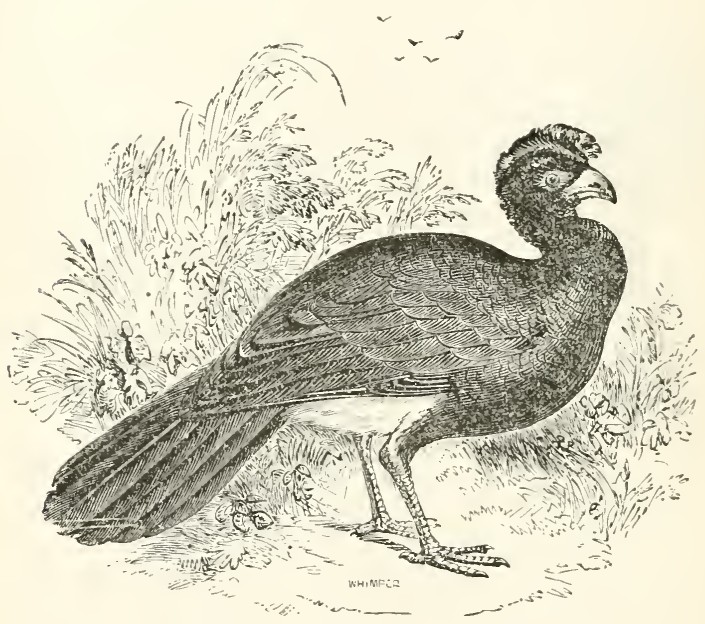

Fig. 143.-THE CRESTED CURASSOW.

(Crax cristatux.)

The Curassows are large fowls resembling'Turkeys, but having a rich plumage of glossy black, and bright red beaks. Unlike all other Gallinaceous birds, they reside habitually in the crowns of the lofty foresttrees, where the males with their numerous partners move about hidden in the foliage. These flocks, indeed, only betray their presence by uttering, now and then, a long-drawn whistling note resembling a sigh. Five distinct species of these magnificent birds inhabit the forests of the Amazon, where they 
are much songht after by the natives, both as food and as pet animals. Like the rest of the order, they subsist indiscriminately upon worms, insects, fruits, and the seeds of plants. 'Their nests are built on trees, and formed of sticks interlaced with stalks of herbaceons plants, and lined with leares. The eggs are five or six in number.

The Common Curassow (Crax Alector) is nearly as large as a Turkey, measuring about three feet in its total height. Its plumage is of a shining black, exhibiting purple and green tints according to the direction in which the light falls upon the feathers. The bill is stont and black, but the hasal part of both mandibles is occupied by a large yellow cere, and the eres are surrounded by a naked skin of the same colour. These birds, which are also called "Hoccos," are found in great flocks in the forests of tropical America. They exhibit very little fear of man, but when in the vicinity of human habitations they hecome more cautious, and are seldom seen more than two or three together. They are easily domesticated, and then become very familiar, recognizing those who feed them, and even pulling at their clothes when they think themselves neglected. This bird has bred freely in Holland ; it lays its eggs on the ground, and the young run as soon as they are hatched. 


\section{FADILY II.}

MEGAPODIDA. *

The Megapodes.

Gev. CHARAc.-Bill more or less rohust, with the apieal portion vaulted, and the tip rather obtuse; the wings moderate and much rounded; the tarsi long, robust, and usually covered with large scales; the toes lengthened, strong, and covered above with strong seales, the hind toe long and eutirely resting on the ground; the claws long, robust, and slightly curred.

The birds of this family are all inluabitants of the islands of the Eastern Archipelago and Australia. In their general conformation they have considerable relationship with the Cracidse, especially in the position of the hind toe, which is placed on the same level as the anterior ones; so that, in walking, its whole lower surface is applied to the ground.

The habits of these birds are most singular. They deposit their eggs in a heap of sand, or an accumulation of dead leaves, and trust to the heat of the sun, assisted in the latter case by the warmth produced by the decay of vegetable matter, to maintain the temperature necessary for the maturation of the young. The egg's are of enormous size, those of the common Megapode exceeding in bulk the eggs of the Swan. The eggs of the Talegalla are sinooth and white, about the size of those of the Pelican. Those of Leipoa and Megapodius are covered with a sort of epidermis, or sandy-coloured chalky layer, which is readily removed from the true shell beneath. With respect to the size of these egg's, the intent is evident; they are destined to imprison and afford food to the young chick, till it has grown to a comparatively large size. The young bird possesses great strength, and when it breaks the strong shell, it emerges completely clad, and works its way through the substance of the mound in which the egg was buried.

This family consists of the Talegallas or Brush 'T'urkeys, and the Mound-birds. foot.

* $\mu \dot{\varepsilon} \gamma a s$, megas great; $\pi 0 \tilde{v} s, \pi \circ \delta o ́ s$, pous, podos, a foot; Great- 


\section{SUB-FAUILYI.}

Talegalline.

The Talegallas.

Gen. Charac,-Bill moderate and rohust, with the culmen elevated at the base and eurved towards the tip, which is obtuse, the sides compressed, the lateral margins curred, and the gonys moderate and slightly ascending.

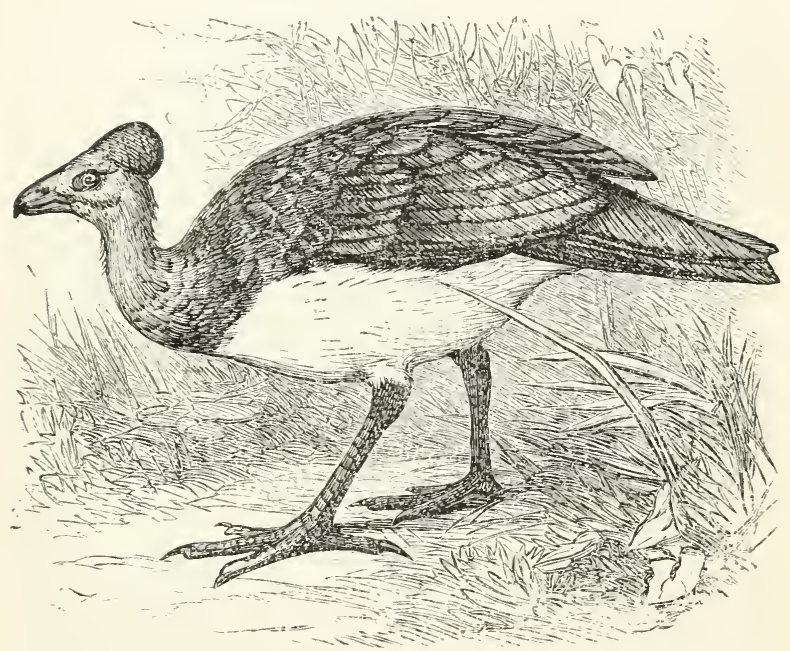

Fig. 141.-ThE RED-FOOTED TALEgalla.

(Megucephalon rufipes.)

These birds are found in the dense brushes, scrubby gullies, and primeval forests of Australia and New Guinea, where they are met with in small flocks on the ground; they are shy and fearful, and when disturbed endeavour to escape by rumning into the thick "brush," or by flying on to the branches of trees, and then ascending to the top, which they gain by leaping from bough to bough; and having attained the summit, sometimes fly off 
to a new locality in the underwood. During the mid-day sun they generally seek the shady branches of trees for shelter from the heat, often uttering a low elucking noise. 'They also dust themselves on the ground, after the manner of other Gallinaceous birels. 'Their food consists of seeds, berries, and insects. The Anstralian species forms a remarkable heap of decayed regetables in a retired and shady place. 'The vegetables are collected by their feet, until they have formed a heap of sufficient size, by completely destroying the plants growing in the neighbourhood. After a certain time has been allowed for the vegetables thus accumulated to engender some degree of heat, several female birds deposit their eggrs in the mound at a little distance from each other, and cover them to a depth of three feet. They are placed perfectly straight, with the large end npwards, and are thus left until they are hatched by the artificial heat of this remarkable hotbed. 'The young birds force their way out of the mound, and at the moment of their escape, they are completely clothed with feathers. The old birds are said to frequent the vicinity of the nest at the time when the young may be expected to appear, and frequently to moover the egros and cover them up again. 'This has been confirmed by the breeding' of a pair in the London Zoological Gardens; the male (not the female) being assiduous in attending to the eggs and assisting the young birds to make their escape.

'The type of this sub-family is-

The Wattled Talegallus (Ta'egallus Lathami). 


\section{$S U B-F A M I L Y I I$.}

\section{MEGAPODINE.}

The Mound-bivels.

Gex. Charac.-Bill moderate and rather weakened, with the basal portion of the culmen depressed, and the apical part rather strong and slightly vaulted, the sides compressed, and the gonys curred upwards or slightly aseending.

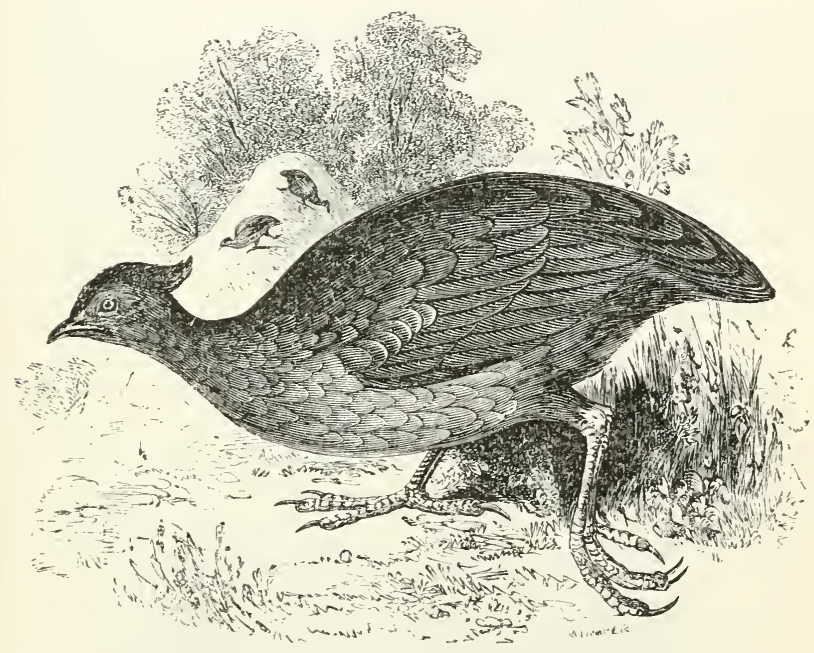

FIG. 145.-THE MOUND.BIRD.

(Megapodius.)

The birds belonging to the typical genus (Megapoctius) are found in all the islands of the Eastern Archipelago of Asia and the north-western parts of Australia. They are exclusively met with in pairs, in thick woods in the immediate neighbourhood of the sea ; and if disturbed, very quickly hide among'st the brushwood. They seek their food, which consists of fibrous roots, seeds, berries, and insects, on the ground.

Some species hide their eggs, to the number of a 
hundred or more, in holes, which they excavate to the depth of two or three feet, on the sea-shore. Others deposit their egg's in immense conical mounds, composed of sand and shells, with a large mixture of black soil and vegetable matter, the base generally resting on the sandy beach within a few feet of high water-mark. Some of these mounds measure from twenty to sixty feet in circumference, and from five to fifteen in height. The female lays her egges in the night, at intervals of several days, in perpendicular holes dug near the middle of the mound, to the depth of several feet. When she has deposited one, she collects a quantity of sand in the hole, until the cavity is filled up. The young are supposed by some to effect their escape from the mound unaided, while, on the other hand, it has been asserted that the parent birds, knowing when the young are ready to emerge from their confinement, scratch down and release them.

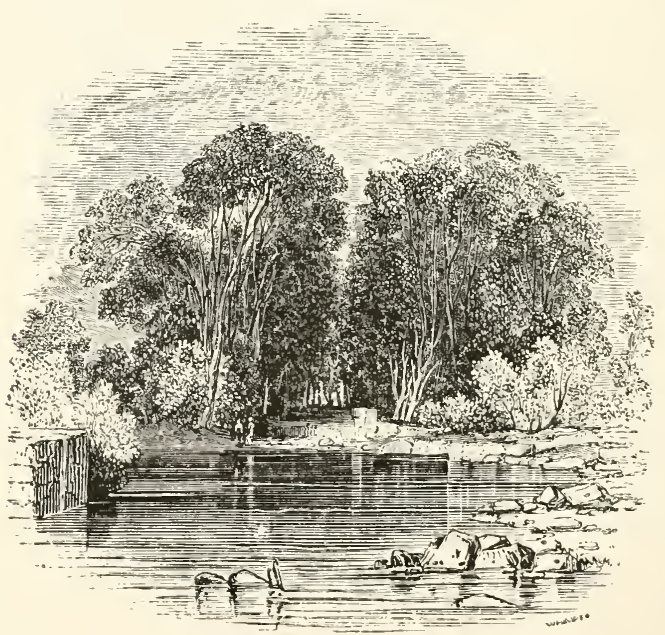




\title{
FAMILY III.
}

\author{
Phasianide.
}

The Pheasants.

GEN. CHARAC.-Bill moderate, with the culmen arched to the tip, which orerhangs that of the lower mandible, and the sides compressed; the wings moderate and much rounded; the tail more or less lengthened and broad; the tarsi moderate, usually armed with a spur or spurs; the toes moderate, the anterior toes united at their base by a membrane, the hind toe short and elerated.

The birds of this family, some of which are among the most elegant and splendid of their class, are nearly all inhabitants of the Eastern hemisphere, only two species being found in America; and even in the Old World their distribution is almost exclusively restricted to the warmer parts of the Asiatic continent and its dependent islands. They may all be classed under the following sub-families:- the Peacocks, the true Pheasants, the Jungle-fowls, the Turkeys, and the Monauls. 


\section{$S U B-F A M I L Y I$.}

Paronixe.

The Peacocks.

GEN. Charac. - Tail and its coverts much developed and depressed.

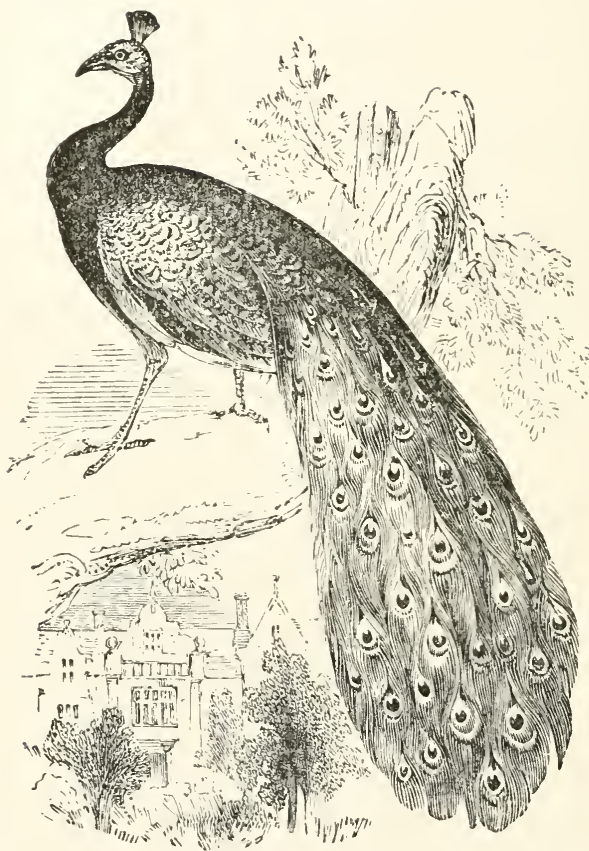

Frg. 115.-THE COMMON PEACOCK.

(Puco cristatus.)

These magnificent birds inhabit various parts of' India, Thibet, and some of the islands in the Indian Ocean. They abound most in the woody districts in the low jungles, but are met with even in gardens, in which they seek their food. The severe cold of 
the mountainons parts of Northern India does not hurt them. The male is three years old before he attains his full plumage. Their nest is formed amongst the thickest shrubs, or on high garden walls or roofs. When the young are bred in an elevated situation, they are said to be carried down to the ground by the parent on her back.

The type of the race,-

The Common Peacock (Pavo cristatus), is perhaps adorner with a more gorgeous plumage than any other bird. Nearly all his feathers exhibit more or less metallic lustre ; his head is crowned with an elegant tuft of slender stems, each supporting at its extremity a small brilliant palette; his neck and breast are of the deepest metallic b) he, with surface tints of golden green ; and his tailcoverts, enormously elongated, form a most magnificent train, adorned with hundreds of splendid eye-like spots. His general form also is exceedingly elegant ; and when he elevates and spreads his gorgeous train to the sun, displaying it in every way, as if conscious of the admiration he is exciting, the beholder is constrained to admit that there is no creature upon which Nature has lavished her powers of adornment with a more unsparing hand. 'T'he voice of the Peacock is exceedingly harsh and discordant, closely resembling the word paon, which is its French name. The colour's of the female, or Peahen, are plain and unobtrusive, and in her the train is wanting. The introduction of this bird into Europe is ascribed to Alexander the Great, but the date at which it was first brought to this country is unknown. Peacocks formed a favourite dish amongst the Romans, and also found a place in the feasts of the middle ages, when they were served up with great poml. 


\section{SUB-FAMILY II.}

Phasianine.

The True Pheasants.

GeN. Charac.-Tail more or less lengthened, greatly cuneated, and composed of narrow and euneated feathers.

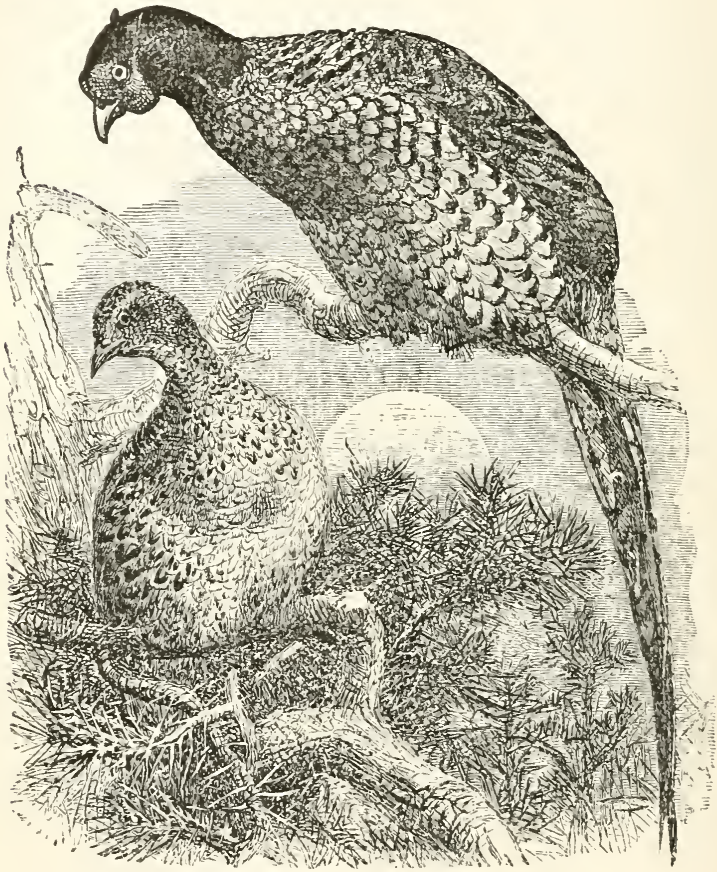

Fig. 117.-THE comMon PHEASANT.

(Phusiunus Colchicus.)

The native countries of these birds are the mountainous districts of Asia, extending even to Japan, but some of the species have become naturalized in the temperate parts of Europe. They are found 
lying concealed during the day in the jungles, covers, and long grass, living in divided societies of different sex. Towards the spring they separate in families, consisting of a male and several females; and the party generally takes possession of a certain locality, from which the commander is very particular in driving away all male intruders. When suddenly disturbed, they endeavour to escape by using their legs rather than their wings. Their flight is rapid and noisy when first started, but sustained only for a short distance. Various kinds of grain and insects form their principal food: these are usually sought for at sunset. They also seek for bulbous roots, which are obtained by means of their bill and feet. Their eggs are deposited on long grass, without any kind of nest, and are about ten in number.

\section{The typical species,-}

The Common Pheasant (Phasianus Colchicus), although abundant in most parts of Britain, is not a native of this country, but has been introduced here, and into the southern parts of Europe generally, from the south-west of the Asiatic continent. The particular district from which the progenitors of the Pheasants now inhabiting Europe were derived, is supposed to have been the banks of the river Phasis, in the ancient kingdom of Colchis, on the eastern shore of the Black Sea, and the bird is still abundant in a wild state in the Caucasian provinces. Its scientific name, Phasianus Colchicus, is derived from the river and kingdom above mentioned.

The favourite resort of the Pheasant is thick underwood abounding in brambles and long grass ; and here it lies concealed during the day, its time for feeting in the adjoining fields being at dawn and at sunset. In its progress to its feeding-ground it always runs, and on this account is very easily taken by wire snares set in the narrow paths that it makes through the long grass which it constantly frequents. Its habit of roosting upon trees is, however, still more fatal, since, being an object of considerable size, readily distinguished by its long tail, and sot easily frightened from its perch, it offers a sure mark 
during moonlight nights to the gun of the poacher. The roosting-place of the male bind is rery easily discovered, for he invariably "chnekles" when he first "trees," or goes to perch; and the female usually utters a faint chirp on the same oceasion. During smmmer and the period of noulting the Pheasant rarely perches, but retires for the night to the longest grass, or other thick cover, and does not begin to "momit" again until towards the end of September or the beginning of Uctober, having at that period renewed its flumage. Where pheasants are numerous, the males are in general found assoeiated during the winter, sejarate from the females; and it is not until alont the end of March that they allow the approach of the latter without signs of displeasure, or at least of indifference. At the above-mentioned time, however, the male bird assumes an altered appearance ; the scarlet of his cheeks, and around his eyes, aequires additional drpth of colour, and he walks with a more measured step, with his wings let down, and his tail earried in a more rect position. Being polygamous, he now takes possession of a certain "beat," firom whenee he drives every male intruder, and eommences his " erowing," attended with a peculiar elapping of his wings as a note of invitation to the other sex as well as of defiance to his own. The female makes a very inatificial nest upon the gromud, in long grass or thiek underwood, and not unfrequently in fields of clover ; she lays from ten to fourteen eggs of a clear oil-green eolour. The young are hatched during the months of Jume or July, and continue with the hen until they begin to moult and assume the adult plumage; after this period the young males are only to be distinguished from the older birds by the comparative shortness and bluntness of the tarsal spur. 


\section{$S C B-F A U I L Y I I I$.}

\section{(GALINE.}

The Jungle-Fowls.

Gen. Charac - Bill moderate, with the apical half raulted and arehed to the tip, which is ohtuse; the nostrils placed in a large membranous groove, with the opening large, nearly semicireular, and protected by a scale; the wings moderate, eoneave, much rounded, with the secondaries the length of the quills, ample and broad; the tail compressed, and gener ally arched; the tarsi as long as, or longer than, the middle toe, robust, and armed with a spur; the toes long, and the front ones united at their base by a membrane.

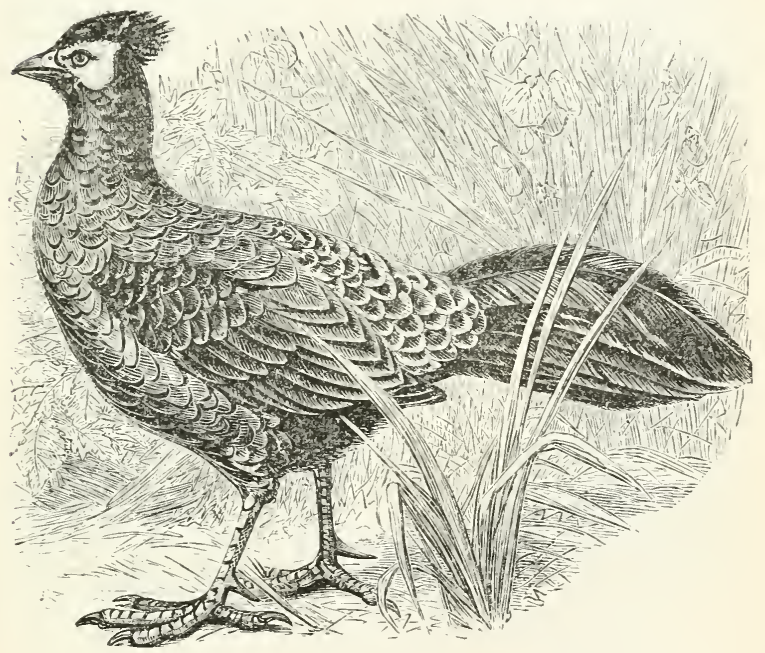

Fig. 148,-HORSEFIELD'S JUNGLE-FOWL.

(Euplocomus Horsefieldii.)

These birds are found in the forests of India and the neighbouring islands. They frequent the close brushwoods that cover the precipitous and rugged gorges of the mountains, but some species prefer level ground. They are generally seen in coveys of eight or ten individuals. When alarmed, they do not take wing, but endearour to hide themselves among 
the covers, rumning with great rapidity. 'Their note is a subdued melancholy chuck. 'Their food consists of seeds, wild berries, roots, insects, \&c.

\section{A beautiful species,-}

The Javan Fowl (Gollus Bankirc $($ ), is generally believed to be the original stock of our domestic poultry. It closely resembles in plumage some of the dunghill cocks of this country, although it is considerably less in size. This bird appears to have been domesticated in the East at a very early period, and must have been introduced into Europe in very ancient times. It was well known to the Greeks and Romans, who, like our own people at a very recent period, and many eastern nations at the present day, delighted in the cruel spectacle of a cock-fight. During the day they generally frequent the outskirts of forests and thick jungles, but on the least alarm conceal themselves in the thickest coverts. Their food consists of seeds, fruits, and the larve of insects ; the females construct a rude nest on the ground composed of grass.

The type of this sub-family is-

Horsefield's Jungle-Fowl (Euplocomus Horsefieldii). 


\section{SUE-FAIILY IV.}

\section{MELEAGRINE.}

The Trurkeys.

GEx. Charac.-Tail more or less short and pendent; the head and neck denuded of plumes, or only eovered with scattered hairs or caruneulated; the base of the lower mandible sometimes wattled.

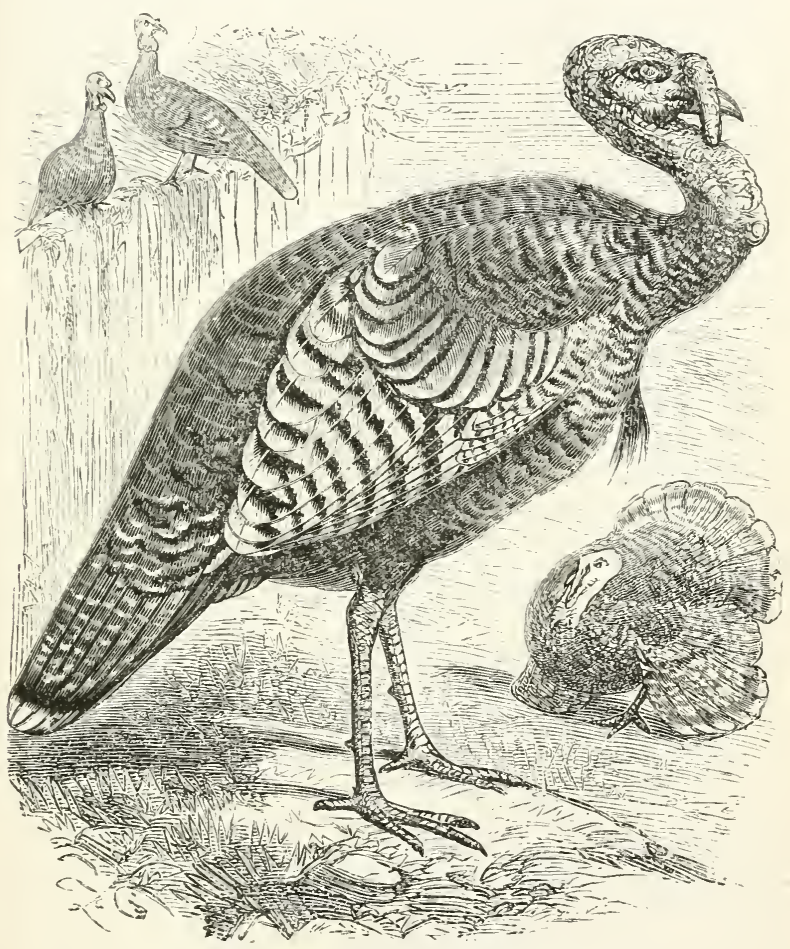

Fig. 149.-THE COMMON TLRKEY.

(Meleagris Galli-pavo.)

The wandering habits of these birds occasion them to be found in the forests, prairies, and open tracts of various parts of the northern continent of America. 'The males live in small societies of ten to a hundred, 
and seek their food apart from the females, who are ocempied in feeding their youmg and concealing them from the attacks of the other sex; but should the parties meet in some ground where their favourite food is very abundant, they intermix and partake of the repast. 'Turkeys are found in a wild state thromohout North America, from Canada to the Isthmus of Panama; and far from being improved by the care of man, they have become remarkably degenerated in a state of domesticity. The wild bird when at liberty will weigh from twenty to sixty pounds, and when standing upright will measure at least three feet in height. Formerly these birds were common in Canada and in the central parts of the United States, but they have gradually fallen back before the advance of cultivation, although they seem to yield their country to the husbandman only inch by inch. Still, it is not difficult to predict that the time of their complete extirpation is not remote. The wild Turkeys live for the most part in the forests, where they feed upon fruits. During the summer time they associate in little bands, but in the winter unite to form flocks, which issue from their retreat and approach inhabited districts. This season is called by the North American Indians the Turkey month, and during its continuance great numbers are killed, and preserved in a frozen state to be transported to the European settlements. It is only in the remote parts of the country that these birds can be said to be met with in abundance. They are very wild; and although much larger than the domesticated race, are not easily met with except by accident, in their chosen retreats; for, on the slightest alarm, they at once hide themselves among the long grass and impenetrable brushwood, which is likewise their usual defence against birds of prey. Moreover, they are naturally in the habit of acting as guardians to each other; the first who perceives the approach of a stranger, even at a distance, utters a cry of alarm, and in an instant they vanish among 
the herbage. The sportsman has no chance of getting within reach of them during the day, at least without the assistance of a dog well trained for the purpose; and even then he must fire very close, so as to kill them on the spot; for if they are only wounded, they rum so quickly with a sort of haltflight, that the fleetest Indian cannot overtake them. Abont sunset, however, they may be assailed with better success, as at that period of the day they betray the place of their retreat by incessant "gobblings," whereby they collect their scattered flocks. When they have all got together, they make their way in perfect silence to their accustomed roosting-places, where they perch themselves close together upon the large trees, particularly upon withered bonghs or branches stripped of their leaves. When thus perched, so secure do they think themselves, that they are readily approached; indeed, neither the sight of a man nor the report of a g'un seems to cause the slightest feeling of alarm. They will even see their companions fall from their side, killed by an arrow or still more murderous bullet, without stirring from their place. Their only indication of concern is a sort of low murmur, more indicative of surprise than fear ; indeed, they remain so stupidly immoreable, that under these circumstances they may all be killed one after the other, however numerons. At break of day, the Wild Turkers make the woods echo with their gobbling's, as they call to each other from tree to tree; but as the sun rises they come down from their perch, and the males, in the breeding season, proceed to display their plumage to the other sex, when fierce battles often take place.

The most beautiful species of this sub-family, -

The 0cellated Turkey (Meleagris ocellatus), is a native of Honduras, where it does not seem to be very abundant. It is about the size of the common Turkey, but far more splendid in its tints. The typical form is-

The Common Turkey (Meleagris Galli-pavo). 


\section{LOPIOPHORINE.*}

The Monauls.

Gex. Charac. - Bill moderate, broad at the base, and the tip of the upper mandible projecting over the lower; the nostrils partly exposed and partly covered with feathers and a membranous shield; the wings moderate; the tail ample; the tarsi short, strong, and covered with dirided shields; the toes lengthened, and the lateral ones united with the middle one; the claws short and eurved ; lores clothed with small feathers.

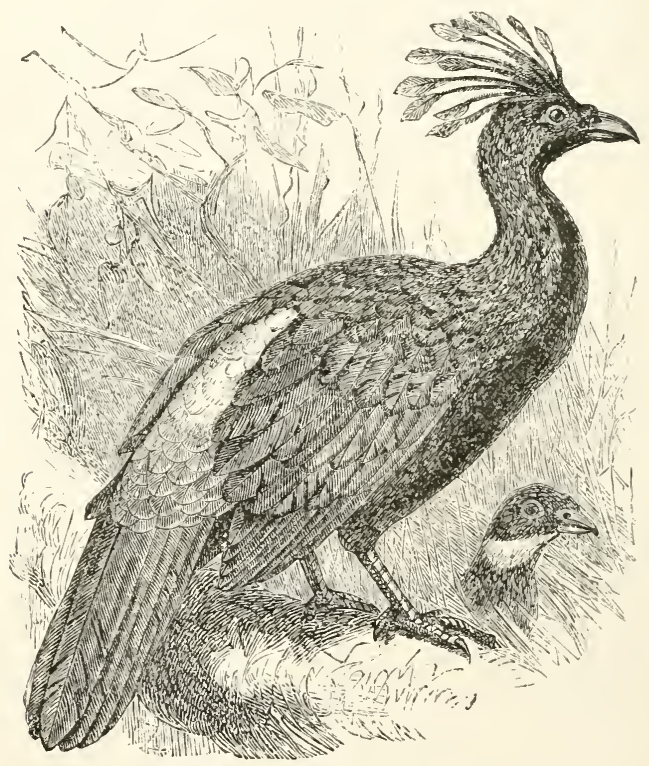

Fig. 150.-The munaul, or impeyan pheasant.

(Lophophorus Impeyanus.)

The single species constituting this sub-family is abundant in the inner margins of the Himalaya Mountains. When disturbed, these birds take wing

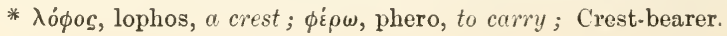


rapidly, uttering a loud and musical note, which they repeat at short intervals till they again alight. They are very fond of perching on some bare rock or stone, and from thence surveying the ground around them. In the morning and evening, while feeding, it is difficult to get at them, as they are very wary; but during the heat of the day they are found lazily reposing among the brushwood covers, and unwilling to rise. It is known when they are in any particular locality by the holes they make in the ground in search of food, which consists of bulbous roots and insects. The males are three years in attaining their showy plumage: when first fledged they are scarcely distinguishable from the females.

The only species,-

The Monaul, or Impeyan Pheasant (Lophophorus Impeyanus), is a splendid Indian bird, an inhabitant of the mountains of Nepaul and the Himalayas.

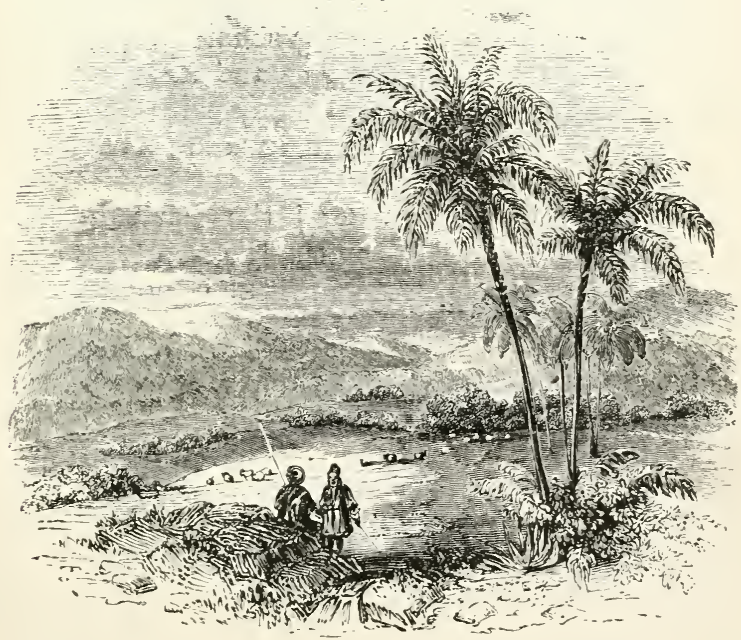




\section{FAMILY IV.}

Tetraonide.

The Grouse.

Gex. Charac.-Bill more or less long, broad at the base, and the sides compressed, with the culmen arched to the tip, which is obtuse; the nostrils basal, lateral, sometimes covered with feathers, or protected with a naked hard scale; the wings short and rounded; the tail more or less lengthened and rounded; the tarsi strong, sometimes clothed with plumes, or naked and scutellated; the hind toe moderate and elevated.

'The birds of this family are generally of smaller size than those of the preceding gronp, and far less striking, either for the elegance of their form or the brilliancy of their colour : they are very generally distributed over the surface of the globe, but the typical genera of the family inhabit the forests and heaths of mountainous countries. Their food consists of fruits, seeds, and the young shoots of plants and trees, and occasionally of worms and insects. Some of them are polygamous, but many pair; and, in the latter case at least, both the males and females assist in rearing their young.

In this family are arranged the Partridges, the Francolins, the Bush-Quails, the American Partridges, the Grouse proper, and the Sand Grouse. 


\section{Perdicis.e.}

The Partridyes.

Gex. Charac.-Margin of the bill entire, and the nostrils protected by a naked hard scale; the tarsi long, naked, corered in front with divided seales, and sometimes armed with spurs or blunt tubercles.

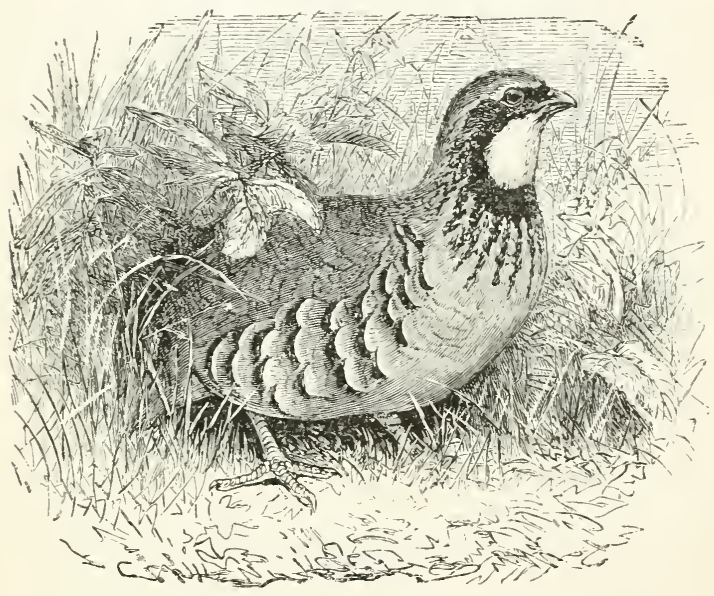

FIG. 1อ̃l.-THE RED-LEGGED PARTRIDGE.

(Perdix rifu.)

The true Partridges are peculiar to the temperate climates of the Old World, remaining sedentary in some places, and in others migrating according to the season. Some species frequent cultivated lands, while others are found in forests, where they may occasionally be seen perched on the branches of trees. They search the ground during the early portion of the morning, and again before the sui disappears, for their food, which consists of grain, bulbous roots, and insects.

Partridges are, fortunately for the sportsmam, very 
prolific, their egges being from twelve to twenty in number. 'The nest is merely a hole scratched in the dry monld, generally under the shelter of some bush or tuft of grass: the incubation lasts three weeks. 'The female sits exceedingly close on her nest during this period, especially towards the end of it, and offers a bold resistance to any birds seeking to plunder her; but being quietly approached, both she and her egges may be gently removed, and she will hatch her brood in confinement, departing with them to the fields as soon as the young are able to accompany her. The male Partridge takes no part in the labour of incubation, but, like all birds that pair, he is attentive to his mate, assists her in the defence of the brood, and uses many arts to lure visitors from the nest. 'The young ones menerally leave the nest on the same day that they break the shell, for their legs are at that time as strong, in proportion to the weight of their bodies, as those of mature birds, although the wings are scarcely developed.

The young feed on small insects, larva, and the eggs of insects : the old ones lead them to the places where these are deposited, and scrape away the monld. An ant-hill in a friable soil is a fat pasture, and multitudes of the ants and larva are eaten by young partridges. 


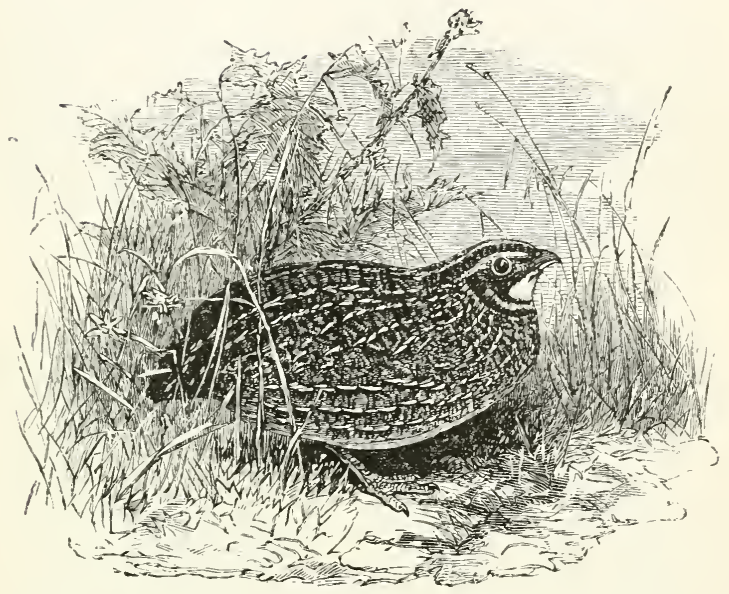

FIG. 152-THE COMMON Francoliy.

(Fruncolinus vulgaris.)

The Francolins are found in the warmer parts of the Old World, especially on the continent of Africa. Some species inhabit level plains, while others live in forests, perching sometimes on trees : if alarmed, they hide in the brushwood in the thickest part of the jungle, not venturing out again till all danger has gone by. If no hiding-place is near, they endeavour to escape by running, and have only recourse to their wings when they have no other means of escape. In their general habits they very much resemble the true Partridges; they breed at the same season, manifest the same care of their young, and are equally prolific. They differ, how- 
("ver, from Partridges, inasmuch as they do not frequent cultivated grounds; on the contrary, they prefer the neighbourhood of woods, where they seem to select damp localities abounding in reeds. 'They live upon berries quite as much as upon grain, and seek eagerly for worms and insects, such as abound in marshy soil; they likewise feed extensively on small bulbous roots, which they dig from the ground with their beaks. Moreover, they are rery fond of perching upon trees, more especially during the night; and their call is much more harsh and noisy than that of the Partridge. 'Their Hesh is excellent; indeed, the European species is regarded as one of the most dainty dishes.

\section{The typical species of this sub-family is-}

T'he Common Francolin (Francolinus vulgaris). Unlike its African congeners, which feed on bulbous roots, for procuring which their heak is specially adapted, our European kind differs little in form and food from the true Partridge ; it however exhibits a decided preference for moist and humid districts, and perches on trees. In Europe its labitat appears exclusively confined to the southern regions, as Sicily, Malta, and the Neapolitan territories; but it is also found in the North of Africa and over the greater portion of the Asiatic continent ; it has also been received in collections from the Himalaya momntains. Its flesh is very delicate, and much esteemed in India.

These hirds generally repair to trees on the approach of night, and remain there till the break of day again invites them to their feeding-places, which are commonly the banks of rivers. Among the grass which clothes such localities these birds wander during the greater part of the day, and when they are surprised in their retreats they run with considerable speed ; as, unless when sharply pressed, they generally prefer that mamer of effecting their escape to flying. The slightest alarm causes them to bend their course towards the jungle, in the deusest parts of which they conceal themselves until the danger is past; and on such occasions they not unfrequently perch "pon shrubs which are fully covered with foliage. 
When feeding, particularly early in the morning, and also occasionally towards evening, they utter their harsh and frequent calls, and these are often responded to by others of the species who may be scattered at a distance in the surrounding valleys. They feed upon small bulbs and insects, and also swallow a considerable quantity of gravel. - S'mith, "Illus. of the Zool. of S. Africa."

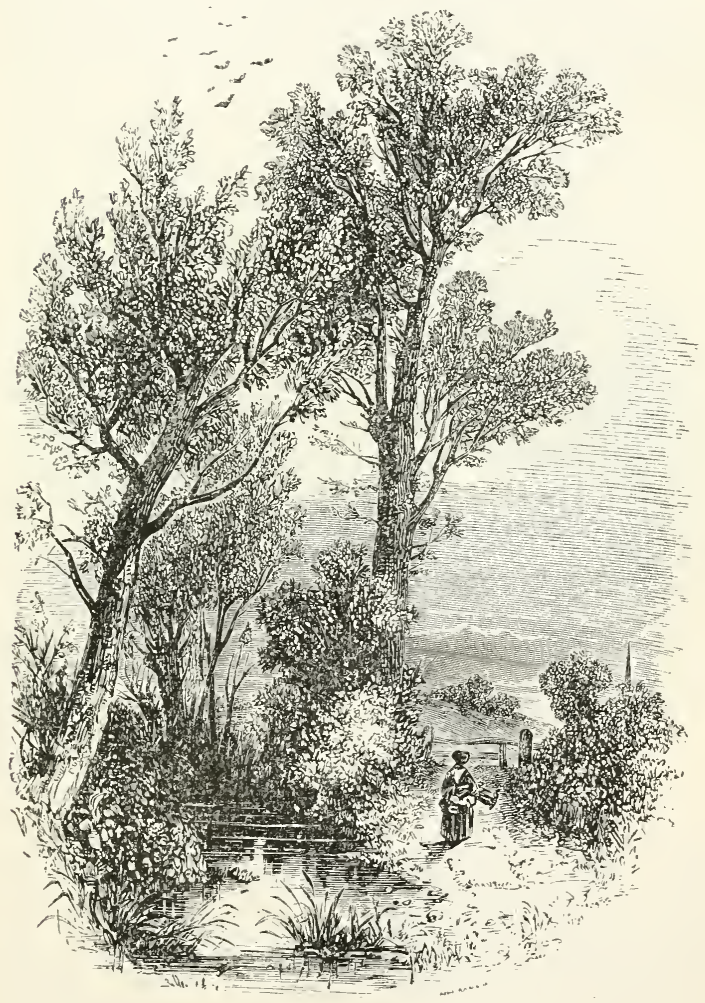




\section{SUB-FAIILY III.}

TURNiCINE.

The Bush Quails.

Gen. Charac.-Bill moderate, straight, and the sides compressed to the tip, which slightly overhangs that of the lower mandible; the nostrils lateral, and placed in a nasal groove that reaches beyond half the length of the bill, with the opening linear and protected by a long scale; the wings rather short and rounded; the tail short, and almost concealed by the dorsal feathers; the tarsi moderate and strong; the toes usually three in number, long, and free at their base, the outer toe longer than the inner.

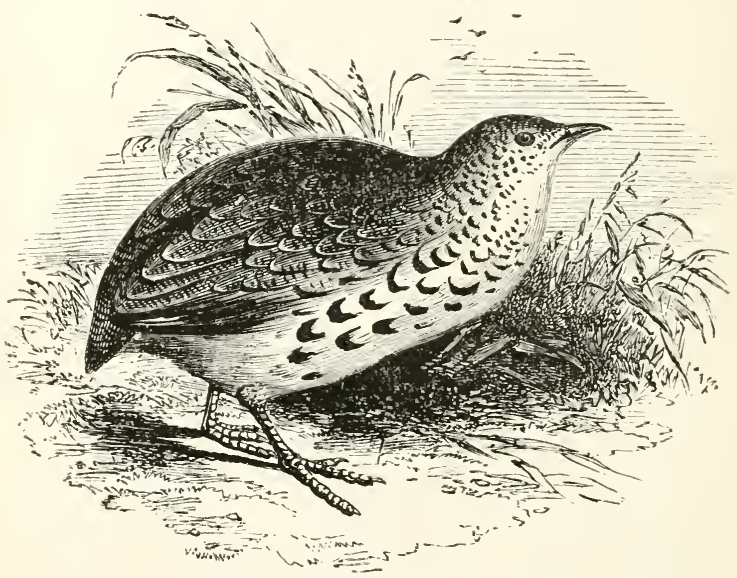

Fig, 153.-The AFrican bush QUAIL.

(Turnix Africanus)

'The Bush Quails are found in Southern Europe, India, Africa, Madagascar, and Australia. They are generally met with in small parties or in pairs, and frequent open places near rivers, or such as are thinly covered with grasses. They usually lie so close to the ground that it is difficult to discover them; and when flushed they make off with a rapid flight, but only to a short distance, flying within 
two or three feet from the ground, and then dropping to the earth to conceal themselves among the herbage, or run with great swiftness until they consider themselves safe from pursuit. The nest is composed of grasses, and is placed in a hollow on the surface of the ground, under the shelter of a tuft of grass. The female lays four egrgs.

The type of this sub-family is-

The African Bush Quail (Turnix Africanus). The Turnix is a small bird resembling the Quail both in size and plumage, but well distinguished by the absence of a hind toe. It is found in many parts of Sicily and Spain, and stragglers are sometimes seen in the plains of Languedoc ; it is met with also in the North of Africa, especially among the thickets and dwarf palms of Mount Atlas. The birds of this sub-family are inhabitants of the intertropical regions of the Old World; two species, it is true, have been discovered in the southern parts of Europe, but in such limited numbers as to prove satisfactorily that the northern part of Africa is their true habitat ; consequently, the southern parts of Spain, Italy, and the islands of the Mediterranean, are among the utniost limits of their range northwards. They differ from the true Quails (Coturnix) in the total absence of the hind toe, and in the long and slender form of their bills. These are the most diminutive birds of the gallinaceous tribe, being not more than half the size of the common Quail. They are polygamous, and they give a preference to sterile lands and the confines of deserts, over which they run with surprising quickness. 


\section{SUB-FAMILYIV.}

\section{Odontophonix.e.* The American Partridges.}

GEx. CHARAc.-Bill short, more or less compressed on the sides, and the culmen generally elevated at the hase, and arehed to the tip, which is obtuse, and prolonged over that of the lower mandible, the margin is bidentated on each side; the nostrils basal, and placed in a short and rounded groove, with the opening eovered by a membranous seale; the wings moderate, eoncave, and rounded; the tail more or less long, broad, and rounded; the tarsi generally slender, long, and covered by divided scales; the toes long, and the inner shorter than the outer toe; the elaws moderate, slightly enrved, and acute.

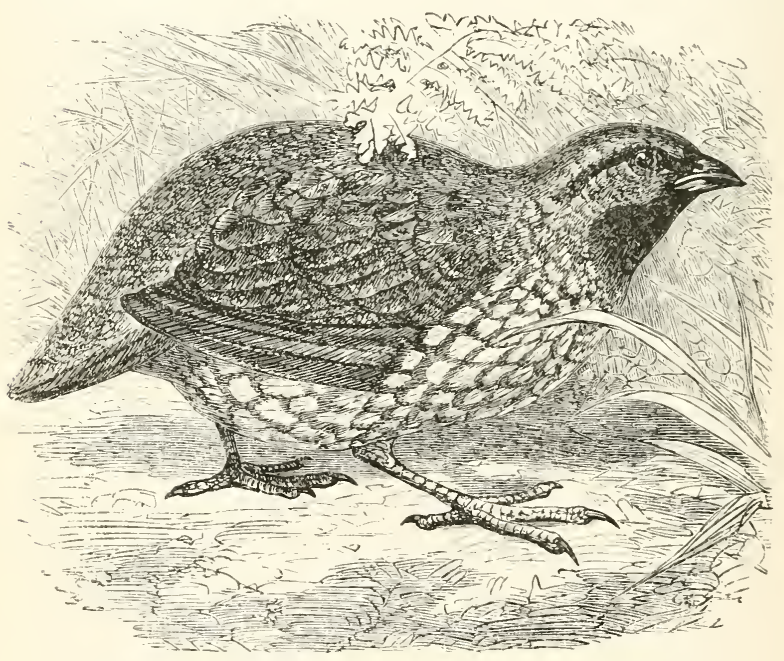

Fig. 154,-THE BLACK-THROATED AMERICAN PARTRIDGE.

(Ortyx nigrogularis.)

The Odontophorinæ are found in the tropical parts of the New Continent. They frequent the forests or thick woods, especially those that border upon rivers. Their usual food consists of grain and

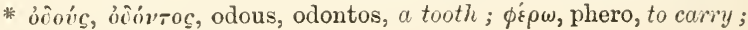
Having the bill toothed. 
insects, which they pick up among the dry leaves. All the members of this group arestrictly American, and by far the greater number of them are natives of that portion of the continent lying between the thirtieth degree of north latitude and the equator. Four species are now included in the fauna of North America, and four have been discovered in Brazil. Some few extend their range to the larger WestIndia islands, and several others inhabit the vast mountain-range of the Andes. They form a large and well-defined family, distinguishable from the Partridges and Quails of the Old World by the absence of any spur or spurlike appendage on the tarsi, and by the toothlike processes on the upper mandible. They are pugnacious in their" disposition, semi-arboreal in their habits, and deposit their eggs in a depression of the ground, or in a very inartificial nest. Their food consists of seeds, berries, fruits, and the tender leaves of grass, and other vegetables. Their flesh is white, tender, and well-flavoured. In the morning and erening twilight they perch on a low branch very near each other, when the males frequently give utterance to their cries, which reverberate through the forest to a great distance. If alarmed while on the ground, they usually hasten to a low branch, along which they run, and, crouching down, conceal themselves among the foliage. 'The nest is formed on the ground, in a thicket, or beneath a log. The female lays from eight to fifteen eggs.

The type of the race is-

The Black-throated American Partridge(O,tyx niyrogularis), 
Tetraonine.

The Grouse proper.

Gex. Charac.-Bill short, broader than long, elevated at the base, the sides gradually compressed to the tip; the nostrils entirely clothed with small feathers; the wings moderate and rounded; the tail ample and of various forms; the tarsi moderate, more or less clothed with feathers; the toes long, and sometimes covered with feathers.

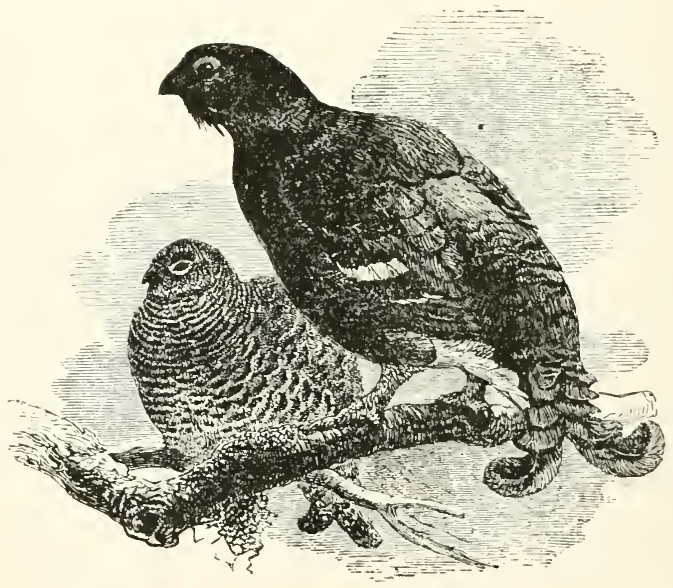

Fig. 155.-THE BLACK GROCSE.

(Tetrao Tetrix.)

These birds are found in the northern parts of Europe and America, inhabiting the great pine and spruce forests, especially of the higher mountains. During the autumn and winter they live harmoniously in flocks, till the return of spring, when the males separate, and each chooses some particular spot, to which he entices a female, who 
attends entirely to the hatching of the young. They reside principally on the ground during summer, but in the winter they seek the trees, whereon they chiefly find their food, which consists of seeds and berries of alpine plants and trees, and the tender shoots of pines, firs, and birch, \&c. They often visit arable lands in the vicinity of their retreats, and even approach the habitations of man during winter, sharing in the food of the poultry. The nest is composed of a few stalks arranged on the ground in marshy places, and concealed by a tuft of tall grass or a low bush. The female deposits from six to ten or fifteen egrgs.

'The type of this sub-family is-

The Black Grouse or Black Cock (Tetrao Tetrix), still met with in the mountainous districts of the North of England, and pretty abundantly in those of Scotland. It also occurs commonly in the North, and in the mountains of the South of Europe. The bases of the hills in heathy and mountainous districts, which are covered with a natural growth of birch, alder, and willow, and intersected by morasses clothed with long coarse herbage, are situations best suited to the habits of these birds, as are also the deep and wooded glens so frequently occurring in such extensive wastes.

During the months of autumn and winter the males associate and live in flocks, but separate in March or April, and each individual chooses some particular station from which he drives all intruders, and for the possession of which, when the birds are numerous, desperate conflicts often take place. At this station he posts himself early every morning and evening during the pairing season, repeating his call of invitation, and displaying a great variety of attitudes, not unlike those of a turkeycock, accompanied by a crowing note, and by another similar to the noise made by whetting a scythe. At this season his plumage exhibits the richest glosses, and the red skin of his eyebrows assumes a superior intensity of colour. The pairing season over, animosity ceases, and the male birds again associate and live harmoniously 
togrether. The female deposits her aggs in May, from six to ten in number, of a yellowish-grey colour blotched with reddish-brown. The nest is very artlessly constructed, on the ground, of a few dried stems of grass, muler shelter of a tall tuft or low bush, generally in marshy places, where long and coalse grasses abound.

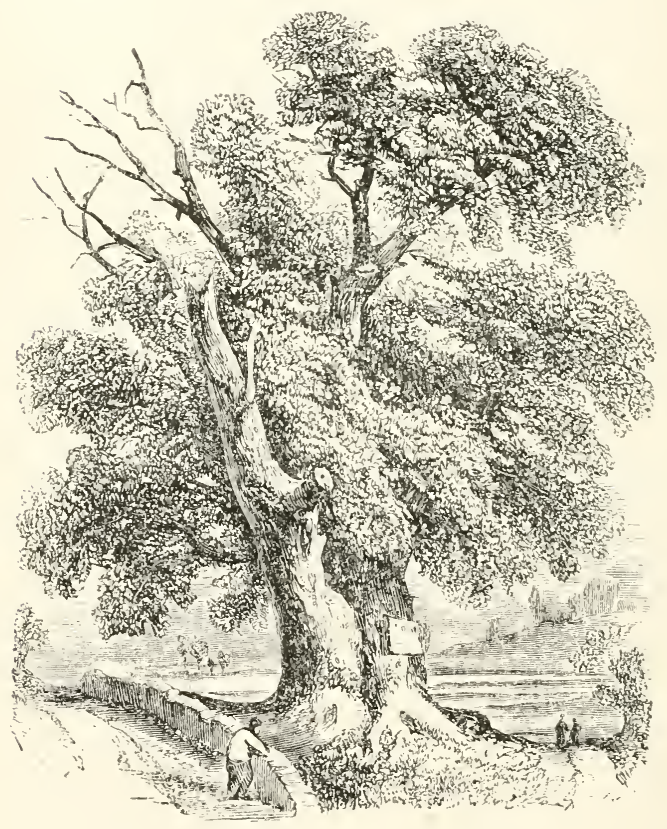




\section{SUB-FAMILY VI.}

P'TEROCLINE.

The Sand Grouse.

Gex. Charac.-Bill short, with the culmen eurved to the tip, and the sides compressed; the wings and tail lengthened and pointed; the tarsi longer than the middle toe, robust, and more or less eovered with feathers; the toes moderate and robust, the lateral toes more or less united to the middle one, and the hind toe rudimental.

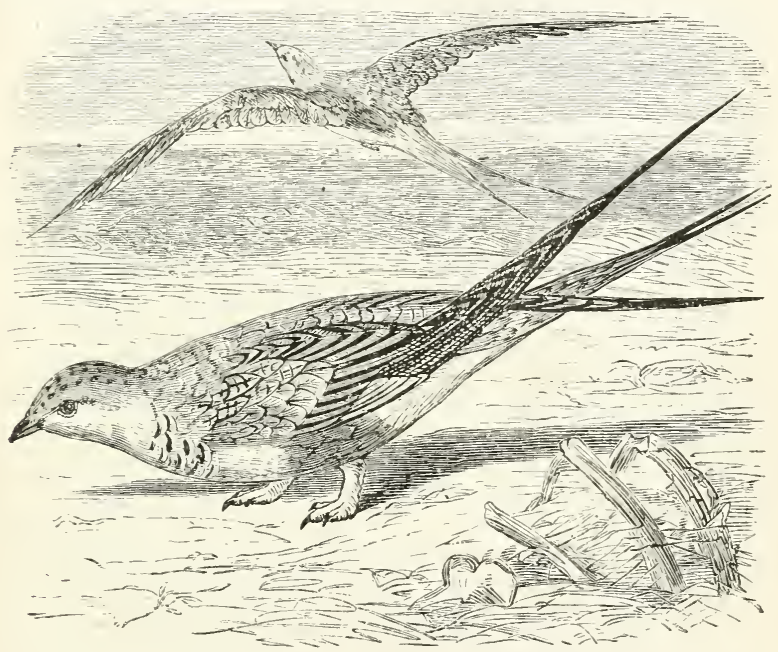

Fig. 156.-THE Paradoxical SAXD-Grolse.

Syrrhoptes puradoxus.)

These singular-looking birds inhabit Southeru Europe, Africa, and Asia, living in dry, sandy deserts, bare or rocky plains, or bushy and woody grounds, especially in the neighbourhood of low hills. They are usually found singly or in pairs, except when those of the desert resort to water, which they do in flocks. When flushed, they rise with a low chuckling call, take a short flight, 
and alight; then, if followed, run along the ground to a short distance, and with difficulty rise again. Others, however, according to Dr. Smith, "fly to a great height, and suddenly descend when they approach the water or their feeding-grounds; and sometimes the descent is not commenced till they are directly over the spot on which it is their purpose to alight. On such occasions they are obliged to make a semicircular or circular sweep before they can reach the desired locality. Their food consists of hard seeds, bulbs, and insects, mixed with fine gravel." The female lays from two to four eggs on the bare ground.

\section{The best-known species,-}

The Pintailed Sand Grouse (Pterocles alchuta), a native of the southern portion of Europe, the North of Africa, and the level and arid plains of Persia, is particularly abundant in Spain, Sicily, and through the whole of the Levant, visiting, at uncertain seasons and in small numbers, the southern provinces of France. It is a bird of migratory habits, and, like its congeners, prefers wild and barren districts. These birds abound in the stony districts beyond Jordan, and are there known by the name of "Katta." Burckhardt says, "The quantity of Kattas is beyond description; the whole plain seemed sometimes to rise, and far off in the air they were seen like large moving clouds. In the mountains of Edom they are in such numbers that two or three are often killed at a time by a stick thrown among them by the Arab boys; and such is their abundance in some parts of the year, that an ass-load may be taken at one shutting of the clasp-net."

Their flesh being black and hard, is never seen at the tables of the Franks, but it is nevertheless eaten by the Turks.

This grouse lays two or three eggs at a time, placed on the ground, without any nest; they are as large as those of a pigeon, and of a greenish-black : the Arabs eat them fried in butter.

Hasselquist and Burckhardt are both of opinion that this bird is the Quail (Selav) of the ancient Israelites. 


\section{FAMILY V.}

\section{Chionidide.*}

The Sheath-bills.

GeN. Charac.-Bill moderate, the culmen much arched to the tip, the sides much compressed; the nostrils basal, lateral, and protected by a bony covering, or only partly closed by a horny membrane; the wings long and pointed; the tail moderate; the tarsi short and strong; the toes long, and the anterior ones united at their base, the hind toe short and elevated.

This is a family containing a few species whose characters are so curious as to have rendered their position in the ornithological series somewhat doubtful. They have a short and stout bill, which is compressed at the tip and considerably arched. The nostrils are situated at the base of the upper mandible, and protected by a more or less inflated cartilaginous plate, an appendage the use of which is rather obscure. Like the birds of the preceding family, they have long and pointed wings; their tarsi are of moderate length and thickness, naked and reticulated quite up to the articulation, and terminated by four toes, of which the anterior are tolerably long, and the posterior small and slightly elevated upon the back of the tarsus. These singular birds are met with upon the sea-shores of Patagonia, New Zealand, and Australia, and also upon many of the islands of the Antarctic Sea.

* $\chi$ tòntos, chionios, snowy. 


\section{SUUB-FAMILYI.}

THinocorin.e* *

The Shore Larks.

Gex. Charac.-Bill short, rather slender, broad at the base, and compressed on the sides; the nostrils basal, lateral, ind exposed, with the opening lunate and mostly closed by a horny membrane, which is eovered by short feathers.

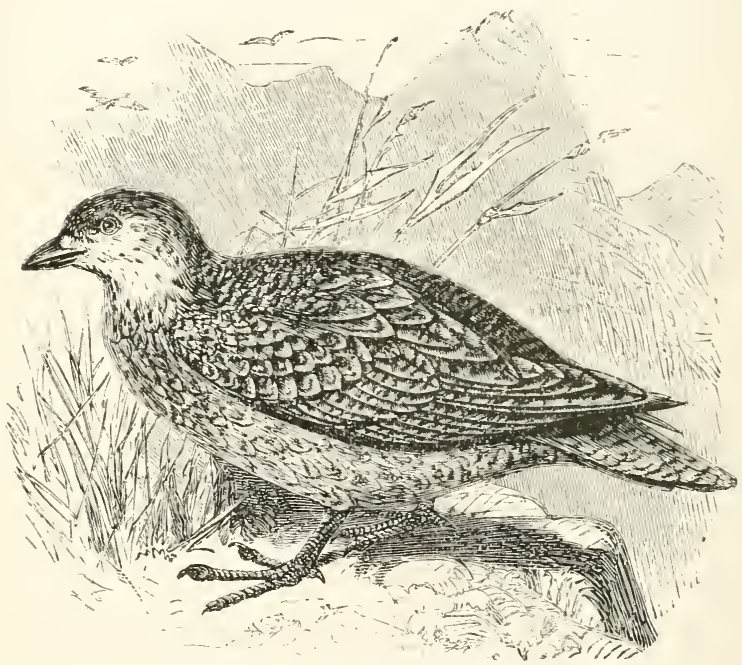

FiG. 157.-LATREILLE'S SHORE.LARK.

(Attagis Latreillii.)

'The Shore Larks inhabit South Africa and South America, spreading over at least twenty-three degrees of latitude. They are found in the elevated valleys of mountainous districts and inland plains, preferring the most desolate places. They are seen in pairs, or in small coveys of five or six, and sometimes

* Air, Alvós, thin, thinos, the shore; kop's, coreo, to sweep; sweeping over the shore. 
during the winter in flocks, consisting of many individuals. These birds frequent the same place for a long time. When flushed, they take a rapid and circular flight, often returning to the spot whence they arose; but if suddenly alarmed, they lie close to the ground, from which they can scarcely be distinguished. Their food consists of grass, of seeds, of plants, and sometimes of insects. The nest is said to be placed on the borders of lakes, although the bird itself is an inhabitant of the desert. The female lays from four to five egg's.

The best-known species is-

\section{D'Orbigny's Shore Lark (Thinocorus Oilignyanus).} These birds live in small troops in the valleys between the mountains of Chili. frequenting the most desolate spots, and feeding upon plants, seeds, and insects. They have very much the appearance of small Snipes.

The typical form is-

Latreille's Shore Lark (Attagis Latreillii).

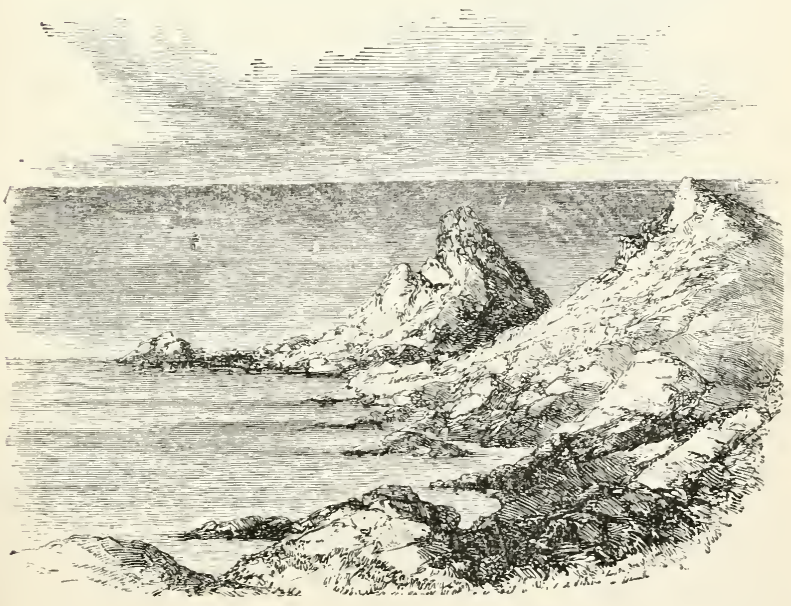




\section{SUB-FAIILYII.}

Chionidine.

Gex. Сharac.-Bill short, strong, compressed, with the sides and basal half coated by a horny covering which conceals the nostrils.

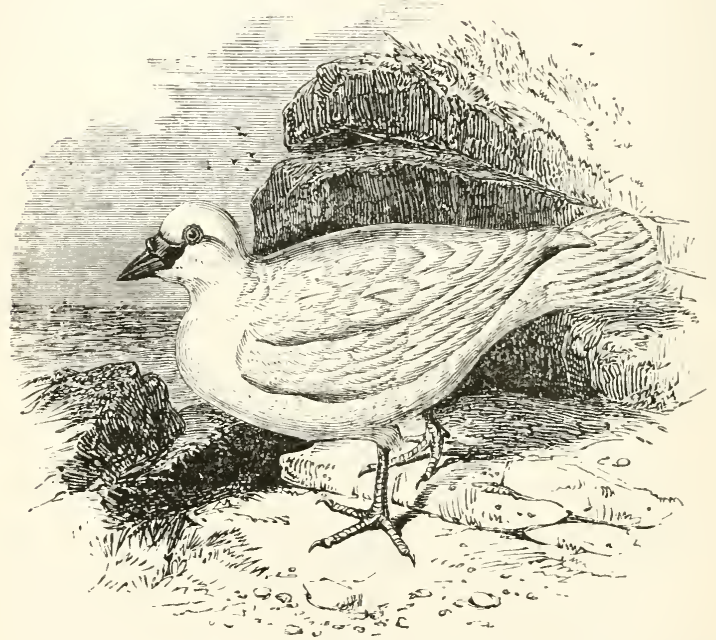

Fig. 158.-The white sheath-Bill.

(Chionis alba.)

These singular birds are found on the islands of the Antarctic Ocean, and at the southern extremity of South America. Their flight resembles that of pigeons. They frequent the shores, searching for their food, which consists of shell-fish, chiefly Limpets, seaweeds, and the remains of animals cast up by the sea, usually mixed up with a few small stones. These birds have been observed by southern voyagers in the open ocean at a great distance from land, where they are supposed to rest and feed on 
the seaweed and other refuse cast on the icebergs. The Sheath-bills are so called on account of the remarkable sheath of horny substance which is situated on the base of the bill, and under which lie the nostrils. The use of this appendage is unknown. The whole of the bill is short and stout, and it is considerably arched towards the tip.

The typical, and also one of the best-known species of this group, is-

The White Sheath-bill (Chionis alba), a native of Australia, New Zealand, and the neighbouring islands.

This bird is almost exclusively found upon the coasts, deriving its subsistence from the mollusks, small crustaceans, bestranded fish cast upon the beach, and other similar substances. Perhaps, under some circumstances, it may subsist on carrion, and thereby give an evil flavour to its flesh, as there are very contradictory reports as to its value for the table; some specimens having been of so vile an odour, that even the sailors, with their proverbial appetite for fresh meat, could not touch the ill-savoured dish ; while in other cases the bird is reported to be of excellent quality, and equal to Duck in tenderness and flavour. The legs of the Sheath-bill are rather long in proportion to its body, and as it always frequents the sea-side, running in and out of the water in search of its food, and possesses many of the habits of the Waders, it has been classed by some naturalists with those birds. The White Sheath-bill is a pretty bird, its whole plumage being pure white, and its legs reddish-black. The general name Chionis is derived from a Greek word* signifying "snow," and is given in allusion to its snow-white plumage.

* $\chi \omega \dot{\nu}$, chion, snow. 


\section{FAMILY VI.}

\section{Tixamide.}

The Tinamous.

GEN. CHARAC.-Bill as long as, or shorter than, the head, the culmen more or less straight, flattened, and covered at the base with a membrane, which also envelopes the nasal grooves, the tip generally suddenly hooked and overlapping that of the lower nandible; the nostrils large and more or less basal; the wings short, concave, and rounded; the tarsi moderate, and shielded in front; and the toes usually long, mostly four, but sometimes only three.

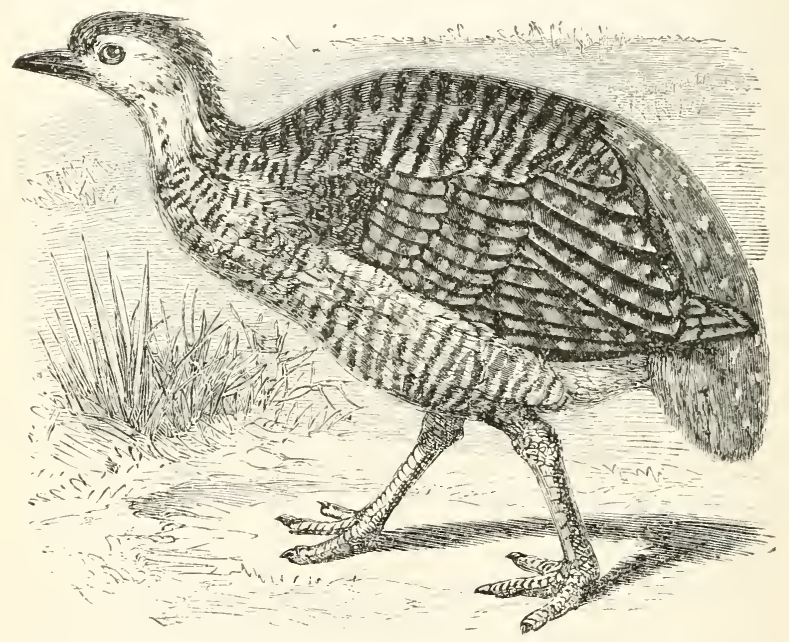

Fig. 159.-PENTLand's tinamotis.

(Tinemotis Fentlandii.)

The only sub-family-

\section{Tinamine,}

The Tinamous proper,

have the characters given above.

The Tinamous are only found in South America, where they are tolerably common. The word Tinamou is the native name for these birds, and as they 
bear some resemblance to Bustards, the generic title of 'linamotis,* although rather a barbarous combination of languages, has been conferred upon some species. The T'inamous are found in the open fields, preferring those which lie on the borders of woods. They are seldom known to perch, and are not very willing to use their wings, trusting to the swiftness of their legs. Of one species of T'inamon Mr. Darwin writes as follows :-

"These birds do not go in coreys, nor do they conceal themselves, like the English partridges. It appears a very silly bird. A man on horseback by riding round and round in a circle, or rather in a spire, so as to approach closer each time, may knock on the head as many as he pleases. The more common method is to catch them with a running noose or little lasso, made of an ostrich feather, fastened by the end to a long stick. A boy on a quiet horse will frequently thus catch thirty or forty in a day."

The food of the Tinamous consists mostly of grain; and after the fields of corn and maize are sown, they do considerable damage by rumning over the ground and picking out all the seeds which have not been entirely covered by the soil. 'The eg's of these birds are about seven or eight in number, and are laid in the centre of some convenient tuft of herbage.

The type of this sub-family is-

Pentland's Tinamotis (Tinamotis Pentlandii).

* Compounded of Tinamou, and otis, a bustard. 


\section{$S E C T I O N \quad I I$.}

Columbe.*

The Second Section of the Gallina comprehends a numerous race of birds, which however constitute but one family, $\dagger$

Columbide.

The Pigeons.

Grs. Charac.-Bill short, straight, and compressed, with the apical half of the mandibles more or less vaulted and strong, and the base more or less weak, and covered by a soft fleshy membrane, in which are placed the nostrils; the wings moderate; the tarsi more or less long and robust; the toes lengthened, divided, and padded beneath.

The place which the Pigeons ought to occupy in the zoological system has been a very fertile subject of dispute. Linnæus classed them with the Passeres; Buffon, Pennant, and Latham arrange them as an order by themselves; while Cuvier and others place them in the category of Gallinaceous birds. The settlement of this question is indeed a matter of considerable difficulty, as the habits of the entire race are in many respects very peculiar. Like the Passerine birds, they associate in pairs during the nuptial season, work together in the construction of their nest, and mutually assist in the incubation of their eggs and the care of their progeny; which latter, blind and helpless when they are first hatched, are fed in the nest that forms their cradle', and which they never quit until fully fledged; indeed, for some time afterwards, they are unable to supply their own wants, and depend entirely upon the assistance of their parents. The features in which they differ from the Passerine race are, however, equally well marked: these consist in their manner

* In the "Tabular View" this is given as a separate Order.

+ See "Animal Creation," p. 448. 
of drinking and of administering food to their young family, in the singularity of their caresses, in the nature of their plumage, and in their vocal capabilities. They neither sing nor utter any cry; their only voice, in the adult state, consists of a full, rolling sound, generally designated by the term "cooing." Other dissimilarities separate them from the Gallinaceous races, with which they have little in common, either in their instincts, their manner of life, or their mode of pairing. The Gallinæ, as the reader will have noticed, are almost all of them polygamists, and the females by laying numerous eggs produce a covey at a single brood. Moreover, in temperate climates this happens but once in the year. The Pigeons, on the contrary, are all of them strictly monogamous, and the female lays but two eggs for each sitting, although she has several broods. In the Gallinaceous tribes the male renders no assistance to the female, either in the construction of the nest or in the care of their progeny. The chickens are born with their eyesight perfect, and as soon as they escape from the eggshell are able to run about, and to procure for themselves their own food.

The principal distinctive character of the Columbæ is furnished by the structure of the bill. The upper mandible consists of a horny apical portion, which is often of considerable length and strength, but its base is formed by a convex cartilaginous plate, in the anterior portion of which the nostrils are situated. The skin covering the cartilaginous portion is of a soft texture, very different from the rest of the bill. It is sometimes smooth, and clothed with a sort of scurf, but in other cases it is warty, or even developed into a fleshy wattle. This is especially the case in some domesticated varieties of the Pigeon. The Columbæ are provided with short tarsi and moderately long toes, all scutellated. The toes are four in number, three in front and one behind. The anterior toes are not united by a membrane at the 
base. The hinder toe is placed on the same plane with those in front, and the whole sole of the foot is formed of soft papillated pads, which are usually a good deal wider than the scutellated upper portion of the toes. The wing's, which are generally long and pointed, contain ten primary quills, and the tail usually consists of twelve feathers, although in some cases there are sixteen. Another important character distinguishing these birds, as compared with the Gallina, is that their feathers are destitute of the plumules, or accessory plumes, which are greatly developed in Gallinaceous birds. The form of the wing in Pigeons is sufficient to indicate that they are capable of powerful flight, and many of them are remarkable for the speed with which they traverse the air, especially when engaged in their migrations. Most of them are arboreal, and nestle in the holes of trees; others frequent rocks, but all perch with great facility; nevertheless, they generally seek their food upon the ground, and walk or rum without difficulty. They are also remarkable for their mode of drinking, in which they differ from all other birds. The general practice of birds in drinking is to take up a small portion of water in the bill, and then by raising the head allow it to run down into the throat. The Pigeons, on the contrary, dip their bills into the water and hold them there till they have quenched their thirst. These birds are inhabitants of the warmer and temperate regions of the earth, but they are found in most abundance in hot climates, where, also, their plumage attains a brilliancy of which that of our native species gives us but an imperfect idea.

This extensive group has been divided by naturalists into five sub-families,-the Tree Pigeons, the Pigeons proper, the Ground Pigeons, the Toothbilled Pigeons, and the Dodos; the last of which, although existing up to a very recent period, are now, in all probability, extinct. 
Gex. Charac.-Bill short, with the ends of both mandibles vaulted, and of nearly equal thickness; the tarsi rery short, and more or less feathered; the toes divided at the base, the inner much shorter than the outer, and the claws short and curred.

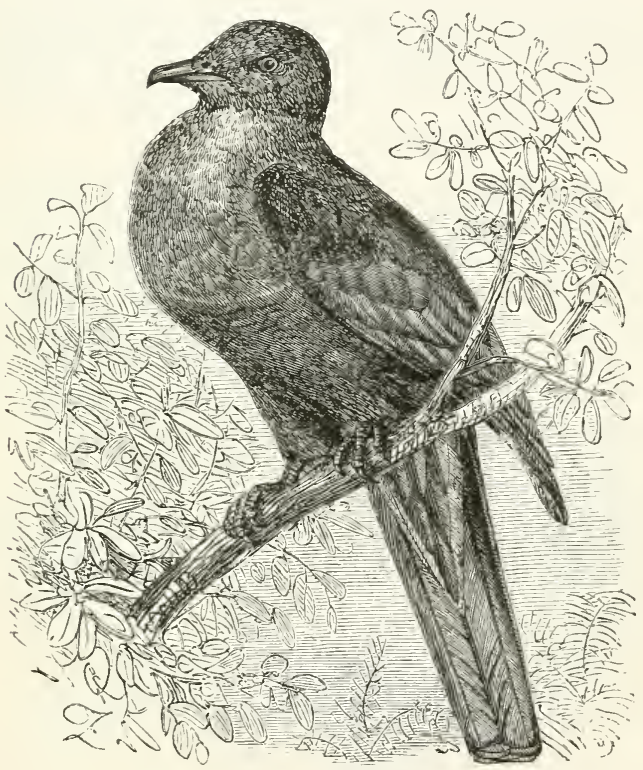

Fig. IfO -THE CAPPED TREE-PIGEOX.

(Ptilonopur occipitulis.)

The birds to which the name of "Tree Pigeons" has been given, are distinguished by their generally short, stout bill, in which the ridge of both mandibles is nearly equally arched, and by their very short tarsi, which are usually clothed with feathers

* $\tau \rho \dot{\eta} \rho \omega \nu$, treron, timorous, shy. 
for a greater or less distance below the hecl. The inner front toe is also shorter than the outer one. 'The shortness of the tarsi in these birds indicates that they are but little adapted for walking on the ground; consequently, in their habits they are preeminently arboreal, passing nearly their whole time amid the branches of trees, and feeding principally upon the fruits which they find in such situations. They are confined to the warmer parts of the Eastern hemisphere, and the majority of the species are inhabitants of Southern Asia and Australia; a few other species, however, are met with in Africa.

One of the best known is-

The Green-bellied Pigeon (Ptilonopus porphyreus). These showy birds are found principally in Malacea, Celebes, the north-west coast of Australia, and the islands of the Pacific Gcean. Their habits are peculiarly arboreal and solitary, living entirely in the deep forests, where they are only discovered by their incessant and loud cooing. The fruits of various trees form their food, especially that of the banyan.

The type of the sub-family is--

The Capped Tree-Pigeon (Ptilonopus occipitalis), delineated above. 


\title{
SUB-FAMILYII.
}

\author{
Colunibixa.
}

The Pigeons proper.

Gex. Charac.-Bill moderate, slender, the basal portion covered with a soft tumid skin, and the apical part hard, and slightly raulted and acute at the tip; the nostrils forming a longitudinal slit in the fore part of the soft basal portion of the bill; the wings moderate and pointed; the tail of various lengths, and usually rounded; the tarsi generally short; the toes lengthened, the lateral ones mostly equal, and the hind toe about the length of the tarsus.

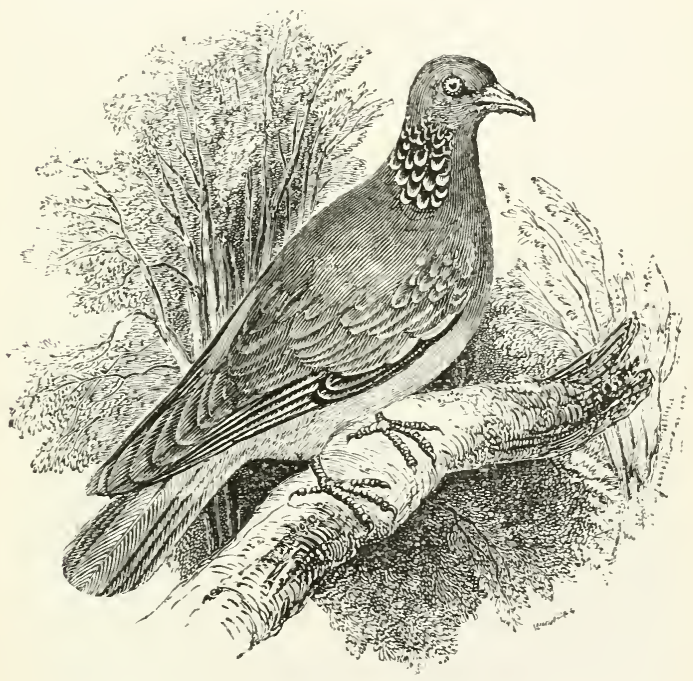

FIG. 161.-THE WOOD.PIGEON.

(Columba Palumbus.)

These birds are widely distributed throughout the world. During the summer months they are generally seen in pairs, but on the commencement of winter they congregate in flocks, and migrate to more southern latitudes. Most of the species feed 
on buckwheat and acorus, for which they frequent those localities that furmish the best supply; and when this kind of nourishment fails, they resort to cultivated fields. For this purpose they take their way early in the morning from their roosting-places in the woods, and when satisfied, fly to rest on the nearest trees, till the low of their evening meal, after which they again retire to the woods. Some species always inhabit rocky places and precipitous cliffs, especially those on the sea-coasts of Great Britain and Asia.

\section{The type of this sub-family,-}

The Ring-Dove (Columba Palumbus), called also the Cushat and the Wood-Pigeon, is the largest of the European species, some specimens measuring seventeen inches in length. It inhalits the woods both of this country and of the continent of Europe, but is most abundant in the south, being only a summer visitor to the more northern countries, such as Norway and Sweden. It is particularly fond of thick plantations of firs, in which it delights to build; and here its tender cooing notes may be heard thronghout the spring and summer. The food of these birds consists of young leaves and seeds of various kinds, according to the season of the year. In spring and summer they subsist principally on the tender leaves of growing plants, and often commit great ravages in fields of beans and peas. Spring-sown corn is attacked by them both in the grain and the blade, and as soon as young turnips have put forth their second pair of leaves, they, too, become objects for devastation. As the season advances, they visit the cornfields, especially those in the neighbourhood of their native woods. They are rery partial to oily seeds of any kind. At the approach of antumn, they assemble in small flocks, and resort to oak and beech woods, where acorns and beech-mast swallowed whole afford an abundant and nourishing diet. In winter the small flocks unite to form larger ones, so large, indeed, in severe seasons, that it becomes probable that their numbers are considerably angmented by arrivals from colder climates.

This pretty Dove is one of the commonest of our 
British birds, breeding in almost every copse of trees, and inhabiting the larger forests in great numbers. At the approach of the breeding season, and during its continuance, its soft complacent cooing, coo-goo-roo, coo-gooroo-0-0-o, is heard in every direction; and with a very slight search its nest may be found. It is a strange nest, and hardly deserving that name, being nothing more than a mere platform of sticks resting upon the fork of a bough, and placed so loosely across each other, that when the parent birt is away the light may sometimes be seen through the interstices of the nest, and the outline of the egg's made out. Generally the Ring-Dove chooses a rather lofty branch for its resting-place, but it occasionally builds at a very low elevation.

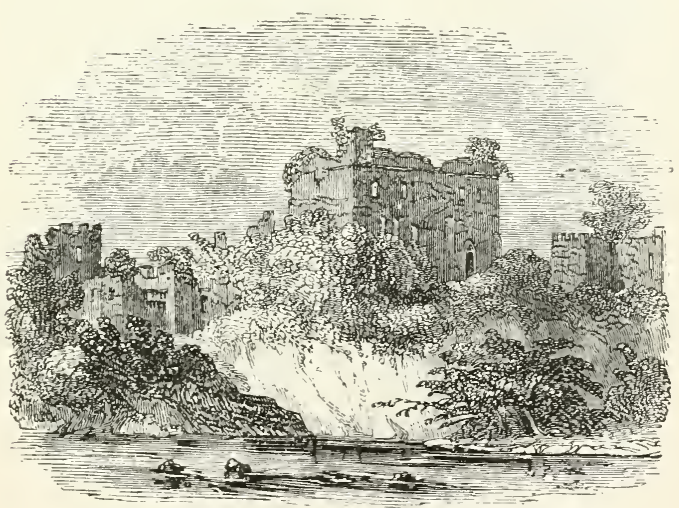




\section{SUB-FAIILY III.}

Gourixe. The Ground Pigeons.

Gen. Charac.-Bill moderate, more or less slender, straight, with the apical portion generally strong and vaulted; the wings moderate and pointed; the tail moderate and rounded on the sides; the tarsi as long as, or longer than, the middle toe, and robust; the toes long, and margined on their sides with a membrane, and the hind toe usually long and slender; the claws short and enrved.

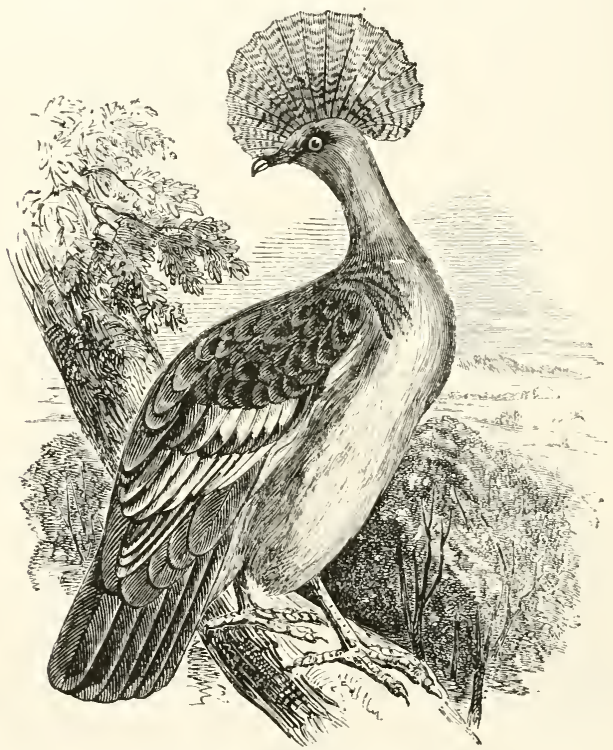

Fig. 162.-THE CROWNED PIGEON.

(Goura coronata.)

These handsome birds are found in the large islands of the Indian Archipelago and in New Guinea. They live in the dense forests, and feed upon berries, seeds, and grains, which they seek for 
on the ground. The nest is formed upon a tree. 'The female lays two eggs for each sitting.

The type of this sub-family is--

The Crowned Pigeon (Goura coronata). This splendid Pigeon is indisputably the most conspicuous of its tribe, its great size and splendid crest rendering it a most striking object, even at a considerable distance. So large and so un-pigeon-like is this bird, that few, on first seeing it, would be likely to recognize its relationship to the rest of the race. It is a native of Java, New Guinea, and Japan. In the Zoological Gardens in the Regent's Park there are several of these birds, whose manners are very curious and interesting. Their walk is quite of a royal character, stately and majestic, and well according with the beautiful feathered crown which they wear upon their heads. The crest seems always to be held expanded. They have the habit of sunning themselves upon the hot pavement of their prison by lying on one side, laying the head flat on the ground, tucking the lower wing under them, and spreading the other over their bodies, so as ti form a very shallow tent, each quill-feather being separated from its neighbour, and radiating around the body. Sometimes the bird varies this attitude by stretching the other wing to its full length, and holding it from the ground at an angle of twenty degrees or so, as if to take advantage of every sunbeam and waft of air. While lying in this unique attitude, it might easily pass at a distance for a moss-covered stone, a heap of withered leaves, or a rugged tree-stump with one broken branch projecting from the side : no one would think of taking it for a bird.-(Rev. J. G. Wood.) 


\section{$S U B-F A M I L Y I V$.}

\section{Didurculine.}

\section{Tooth-billed Pigeons.}

Ger. Charac.-Bill nearly as long as the head, with the eulmen depressed close to the forehead and then suddenly arched to the tip, which is hooked and acute, the sides slightly eompressed, the lower mandible armed with three distinct angular teeth near the tip, which is truneated; the nostrils pierced in the middle of the basal membranous space, with the opening oblique and linear; the wings moderate and concare; the tail rather short; the tarsi moderate and ratber strong; the toes rather long, and the lateral ones equal; the claws long and curred.

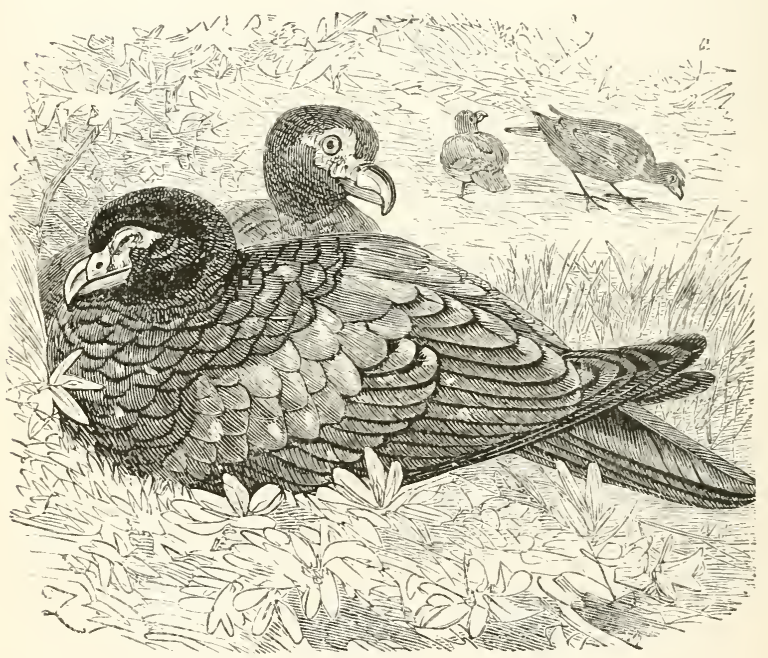

Fig. 163.-THE OWL-BEAKED DIDUNCULUS.

(Didunculus strigirostris.)

This sub-family includes only a single species,- -

The Didunculus (Didunculus strigirostris), which, moreover, presents a most extraordinary combination of characters. The Didunculus is rather larger than our common Partridge ; it has the head, neck, and breast of a glossy greenish-black, and the remainder of its plumage 
deep chestnut. The bill and the naked skin surrounding the eyes are bright flesh-colour. This singular bird inhabits the Samonan Islands in the Pacific Ocean. It is described as dwelling principally upon the branches of trees, and feeding upon fruits and berries. It flies well, and is said to breed among the rocks in the interior of the islands. The chief interest attaching to the Didumculus, however, is its near approach, especially in the for'm of the bill, to that most remarkable extinct bird, the Dodo of the Mauritius, described in the next page.

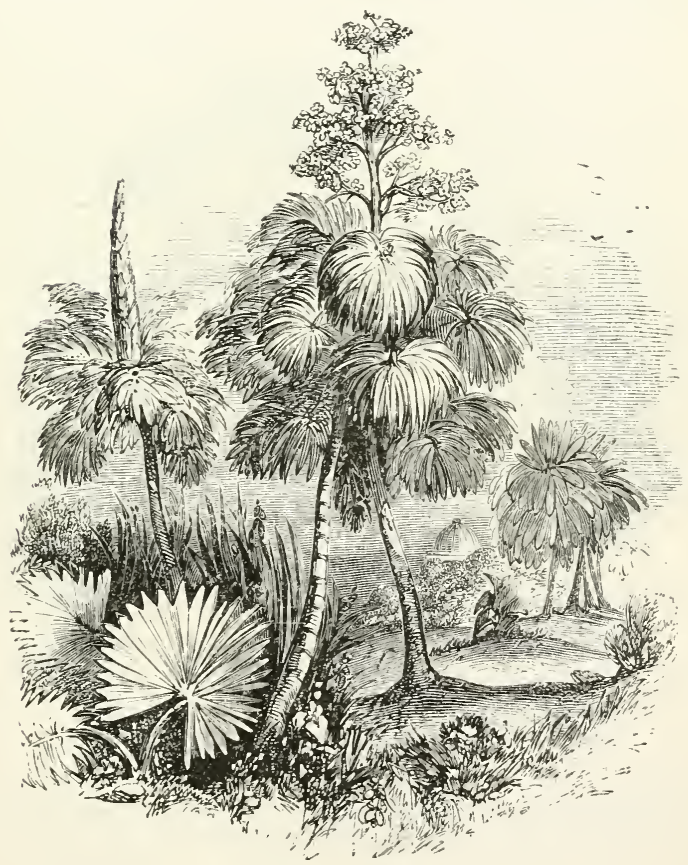


Didise.

The Doclos.

Gen. Charac.-Bill longer than the head, with the basal portion, for twothirds of its length, covered by a membrane, and the apical part corneous and vaulted, with the tip hooked and acute, the tip of the lower mandible overlapped by that of the upper mandible, and the gonys short and curved upwards; the nostrils placed in the fore part of the membranous portion of the bill, and near the lateral margin, with the opening exposed; the wings and tail imperfect; the tarsi short, robust, and covered with small irregular scales; the toes moderate, the fore ones free at their base, and the lateral ones equal, the hind toe long and strong.

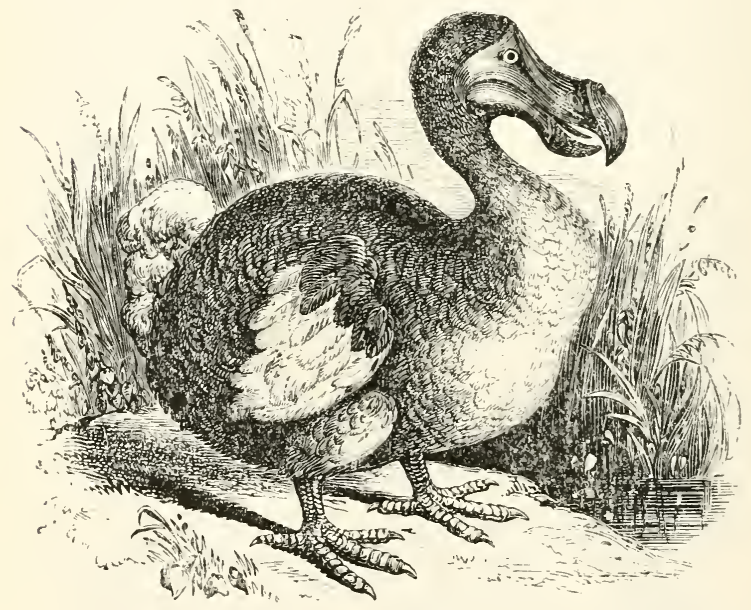

FIG. 164.-THE DODO.

(Didus ineptus.)

The Dodo (Didus ineptus), the extinct representative of this sub-family, formerly inhabited the island of Mauritius: it is supposed to have lived in the dense forests of palms that once covered the island, wandering from tree to tree, tearing with its powerful beak the frkits which strewed the ground, enjoying tranquillity 
and abundance until the arrival of man destroyed the balance of animal life, and put a term to its existence. The nest is stated by old voyagers to have been made of herbs and grass, heaped together in the depth of the forest; and the female is said to have laid but one egg. Of this bird Bontius gives the following description :"The Dronte- or Dod-aers is, for bigness, of mean size between an Ostrich and a Turkey, from which it partly differs in shape, and partly agrees with them, especially with the African Ostriches, if you consider the rump, quills, and feathers; so that it was like a pigmy amongst them, if you regard the shortness of its legs. It hath a great ill-favoured head, covered with a membrane resembling a hood, great black eyes, a bending, prominent, fat neck, an extraordinary long, strong, bluish-white bill; only the ends of each mandible are of a different colour, that of the upper, black, that of the nether, yellowish; both sharp-pointed and crooked. Its gape huge wide, as being naturally very voracious. Its body is fat and round, covered with soft grey feathers, after the manner of an Ustrich's; in each side, instead of hard wing-feathers or quills, it is furnished with small, soft-feathered wings of a yellowish ash-colour; and behind the rump, instead of a tail, is adorned with fine, small, curved feathers of the same colour. It hath yellow legs, thick, but very short; four toes on each foot, solid, long, as it were scaly, armed with strong black claws.

"It is a slow-paced and stupid bird, and which easily becomes a prey to its pursuers. The flesh, especially of the breast, is fat, esculent, and so copious, that three or four Dodos will sometimes suffice to fill one hundred seamen's bellies. If they be old or not well boiled, they are of difficult concoction, and are salted and stored up for provision and victual. There are found in their stomachs stones of an ash-colour of divers figures and magnitudes; yet not bred there, as the common people and seamen fancy, but swallowed by the bird, as though by this mark also, nature would manifest that these fowls are of the Ostrich kind, in that they swallow any hard things though they do not digest them."

This singular bird, therefore, was an inhabitant of the island of the Mauritius at the time of its discovery in the year 1598 , and was subsequently brought alive to Europe, 
on several occasions, by the Dutch navigators. Its extermal appearance is portrayed in a few pictures, into which its unwieldy form was fortunately introduced by the Dutch painters, at the beginning of the seventeenth century. The only parts of its structure still to be found in Europe consist of two heads, a foot, a few feathers, and some of its bones, which are scattered about in various museums in England and on the Continent. From the pictures above mentioned and the descriptions of the early voyagers, it appears that the Dodo was a bulky and heavy bird, larger than a Swan, and weighing sometimes as much as fifty pounds; it had a long and strong bill, with the basal portion of the upper mandible depressed and membranous; the apical part of this mandible was strong, horny, much arehed, hooked, and acute, giving the organ so much resemblance to that of a Vulture, that the Dodo was at one time regarded as allied to those birds of prey. The nostrils were placed in the sides of the basal part of the upper mandible; and in all respects the structure of the upper bill presents so great a similarity to that oceuring in the Didunculus, that on the discovery of the latter bird, the resemblance could not be overlooked. The feet of the Dodo were short and exceedingly stout, and although presenting a certain resemblance to those of a Pigeon, indicated clearly enough that their possessor was a strictly terrestrial bird. Indeed, its wings being very short, and furnished only with soft decomposed feathers, like the well-known Ostrich plumes, were quite incapable of raising it from the ground. The body of the Dodo seems to have terminated in a rounded extremity, and to have been destitute of true tail-feathers; but a tuft of plumes, similar to those of the wings, existed low duwn on its back, and probably represented the tail-coverts. The plumage was blackish, with the light feathers of the wings and so-called tail pale fawn-colour. That the occurrence of a large and sluggish bird like the Dodo upon the distant island of the Mauritius must have been a welcome phenomenon to the Dutch sailors who discovered it, cannot admit of doubt; and we can easily understand that in their subsequent voyages to the East Inclies, they were only too glad to avail themselves of the abundant supply of fresh meat afforded by the Dodos, after being restrieted for months to the salt 
movisions of their ship's stores. It is, however, remarkable that the only relics of so singular a bird, which was certainly living two centuries ago, and of which specimens were undoubtedly imported into Europe, should be of so fragmentary a description. This is still more strikingly the case with two other species allied to the Dodo, of which ouly a few bones are known to exist: these are-

The Solitaire (Didus solitarius), described by a French sailor named Leguat, and attaining a weight of forty-five pounds ; and-

The Nazarene (Didus Nazrrenus), described by another Frenchman named François Coache. It is said to have harl only three toes. The bones which are supposed to have belonged to this bird indicate that it must have been twice the bulk of the Dodo.

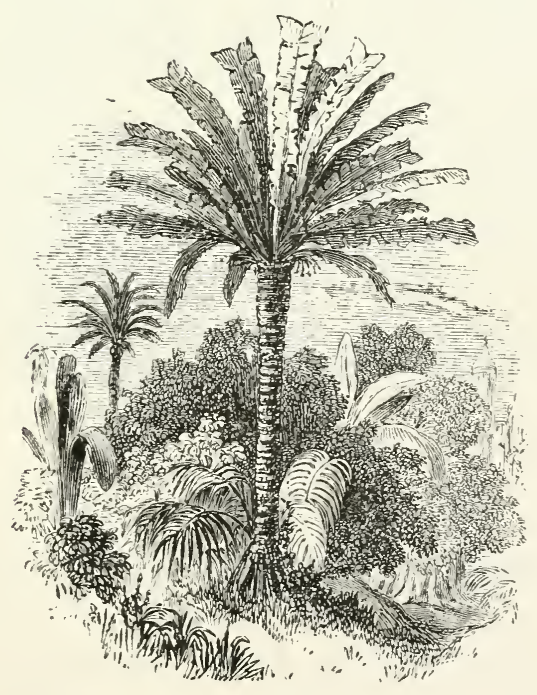




\section{O R D E R V.}

\section{Cursores.}

IT has long been the wish of Ornithologists to unite as a distinct Order, and under a common designation, certain birds that are strictly terrestrial in their habits, and are entirely deprived of the power of flying. Nevertheless, notwithstanding the high authority of those naturalists who have endeavoured to establish such an Order, it is obvious, from the uncertainty of its limits as defined by different authors, that it is not by any means marked out by any special peculiarities of structure, and forms rather an arbitrary assemblage than a group distinguishable by clearly recognizable features. In Cuvier's classification they form a simple division of the Order of Stilted Birds (Grallatores) characterized by the shortness of their wings, and hence named Brevipennes. It is quite evident that, owing to their great size, any natural exertion of muscular power would have been insufficient to raise them from the ground, and hence the power of flight has been denied to them altogether.*

They form but a single family-

STRUTHIONide.

The Ostriches.

This family comprehends the true Ostriches, the Bustards, and the Apteryx.

* See "Animal Creation," page 449. 


\section{$S U B-F A M I L Y I$.}

\section{Struthionixe.}

The true Ostriches.

Gev. Сhaвac.-Bill broad, depressed and rounded in front; the toes two or three in number, and all placed anteriorly.

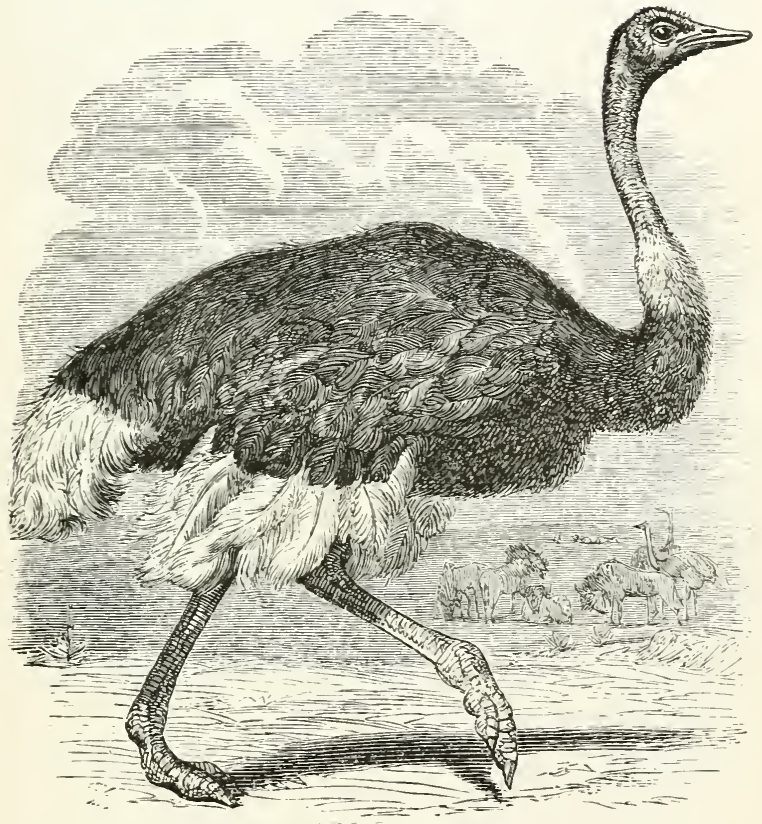

FIG. 165. -THE OSTRICH

(Struthio Camelus.)

This giant of the race is distinguished from all other birds by the structure of its feet, which have only two toes, of which the outer one is considerably shorter than the inner. Over the boundless African desert the Ostrich roams in flocks, trusting, like the antelopes, to swiftness of foot for security trom animals of prey or the pursuit of man. So rapid is its course, indeed, that the swiftest horse is unable to keep up with it. 
"The Ostrich is generally seen quietly feeding on some spot where no one can approach him without being detected by his wary eye. As the wagon moves on far to the windward, he thinks it is intending to circumvent him, so he rushes up a mile or so to the leeward, and so near to the front oxen, that one sometimes gets a shot at the silly bird. When he begins to run, all the game in sight follow his example. I have seen this folly taken advantage of when he was quietly feeding in'a valley open at both ends. A number of men would commence running, as if to cut off his retreat from the end through which the wind came; and although he had the whole country hundreds of miles before him by going to the other end, on he madly rushed to get past the men, and so was speared: he never swerves from the course he once alopts, but only increases his speed. When the Ostrich is feeding, his pace is from twenty to twenty-two inches, and when terrified, as in the case noticed, it is from eleven and a half to thirteen or fourteen feet in length. Only in one case was I at all satisfied of being able to count the rate of speed by a stop-watch, and, if I am not mistaken, there were thirty in ten seconds: generally, one's eye can no more follow the legs, than it could the spokes of a carriage-wheel in rapid motion. If we take the above number and twelve feet stride as the average pace, we have a speed of twenty-six miles an hour. It camnot be very much above that, and is therefore slower than a railway locomotive. They are sometimes shot by the horsemen making a cross-cut to their undeviating course; but few Englishmen ever succeed in killing them. The Ostrich begins to lay its eggs before she has fixed on a spot for a nest, which is only a hollow a few inches deep in the sand, and about a yard in diameter. Solitary eggs, named by the Bechuans 'losetla,' are thus found lying forsaken all over the country, and become a prey to the jackal. She seems averse to risking a spot for a nest, and often lays her eggs in that of another Ostrich ; so that as many as forty-five have been found in one nest. Some eggs contain small concretions of the matter which forms the shell, as occurs also in the case of the common fowl : this has given rise to the idea of stones in the eggs. Both male and female assist in the incubation; but the number of females being always the greatest, it is probable 
that cases occur in which the females have the entire charge. Several eggs lie out of the nest, and are thonght to be intended as food for the first of the newly-hatched brood, till the rest come out, and enable the whole to start in quest of food. I have seen several times newlyhatched young in charge of the male bird, who made a very good attempt to appear lame in the Plover fashion, in order to draw off the attention of pursuers. The young squat down and remain immoveable, when too

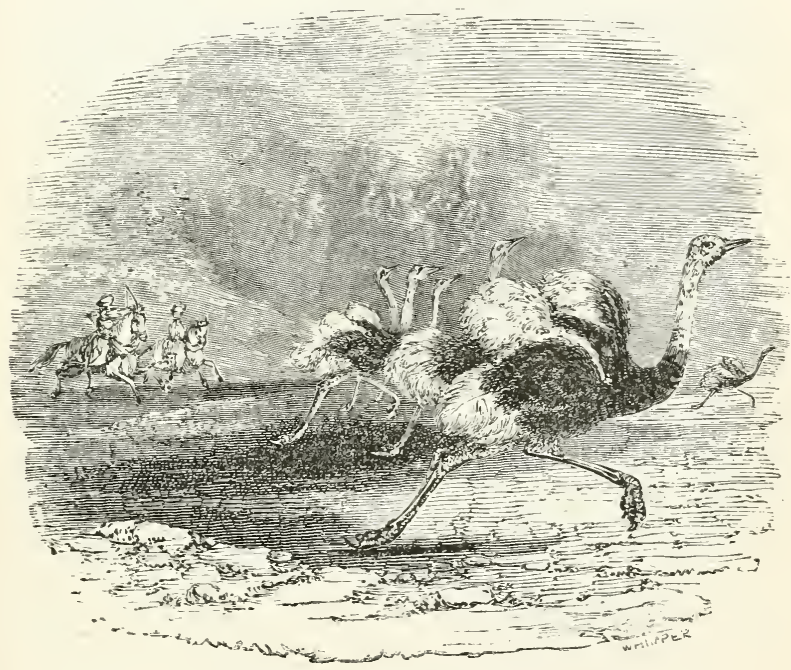

small to run far, but attain a wonderful degree of speed when about the size of common fowls. It cannot be asserted that Ostriches are polygamous, though they appear to be so. The egg is possessed of great vital power; one kept in a room during more than three months, in a temperature about $60^{\circ}$, when broken, was found to have a partially developed live chick in it. The food of the Ostrich consists of leaves of various kinds, with pods, seeds of different species of leguminous plants; and as these are often hard and dry, he picks up a great quantity of pebbles, many of which are as large as 
marbles. He picks up also some small bulbs, and occasionally a wild gourd to afford moisture ; for one was found with a melon, which had choked him by sticking in his throat. The plumage is of a glossy jet-black colour, with the single exception of the white feathers which are the objects of trade. Nothing can be finer than the adaptation of these feathers for the climate of Kalahare, where these birds abound; tor they afford a perfect shade to the body, with free ventilation beneath them. The hen is of a dark brownish-grey colour, and so are the half-grown cocks. The organs of vision in this bird are placed so high, that he can detect an enemy at a great distance; but the lion sometimes kills him. It seeks safety in flight: but when pursued by dogs, it may be seen to turn upon them and inflict a kick, which is vigorously applied and sometimes breaks the dog's back." Livingstone's Missionary Travels in South Africa.

The American 0strich (Rhea Americanc), called also the Nandu, is not more than half the size of the African species, from which it differs structurally in having three toes upon each foot, and the head and neck clothed with downy feathers, also in the total absence of tail-feathers. The plumes of the wings are elongated and decomposed, somewhat resembling in structure those of the African Ostrich, to which, however, they are very far inferior in delicacy, and are only employed in the manufacture of light brooms. These birds are found abundantly in the great plains of South America nearly down to its southern extremity. They live in flocks, and are polygamous; the male bird scratches a hole for the reception of the eggs, which he collects from the scattered places where they are frequently deposited by the females, and afterwards sits upon them. According to Mr. Darwin, the males when thus engaged sit so closely that they may almost be ridden over before they will stir ; but at the same time they are so fierce that if disturbed they will often attack the intruders, and have been known to leap up and endeavour to kick a man on horseback. These birds, Mr. Darwin informs us, show no reluctance to take the water, but will swim easily, but slowly, across even broad and rapid rivers, or from island to island in bays. They are hunted by men on horseback, and captured either by means of the lasso, or with an instrument composed of two large balls, or 
heary stones, united by a long leather thong. The latter instrument is thrown at the legs of the bird, which it binds together, and of course prevents all further progress.

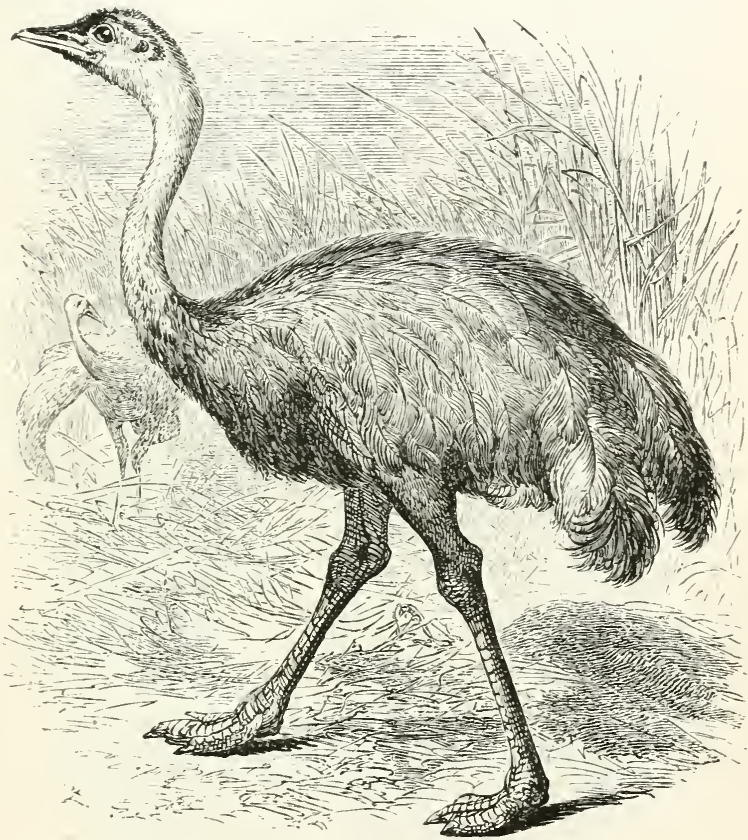

Fig. 166.-THE AMERICAN OSTRICH.

(Rhea Americana.)

In New Holland the Ostrich is represented by the Emu (Dromaius Novce Hollandce). In the Emu the feet have three toes. Its distinctive characters consist in the position of the nostrils, which open not far from the tip of the upper mandible, in the complete concealment of the wings under the hair-like feathers of the body, and in the claws of all the toes being nearly of equal length. This bird is inferior in size only to the African Ostrich, measuring from five to seven feet in height. The crown of 
its hearl and the back of the neck are clothed with feathers, but the throat is naked, and the phmmage, which hangs down like long hair on each side of the body, is of a mixture of brown and grey tints. The Emu is abundant in the southern parts of Australia, but is rapiclly becoming extinct in the British colonies. Its flesh is

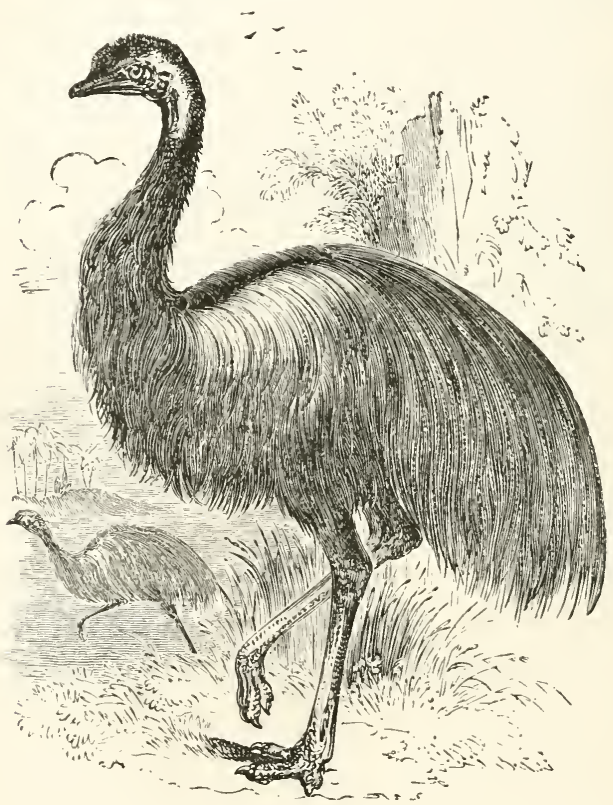

FIG. 167.-THE EMU.

(Dromaius Nove Hollanda.)

very good, that of the young bird being exceedingly delicate. The eggs, which are of a green colour, are also eaten both by natives and colonists; and the natives of some districts are said to live principally upon Emus' eggs during the breeding season of these birds. Unlike the Rhea, the Emu pair's, but the male hatches the eggs. 


\section{SUB-FAMILY II.}

\section{OTIDINE.}

The Bustards.

Gen. Charac.-Bill more or less lengthened and compressed on the sides, with the culmen straight abore the nasal groove, and then raulted to the tip, which is strongly emarginated; the nostrils basal, lateral, and placed in a large membranous groove, with the opening large and sub-oral; the wings moderate and rather pointed; the tail moderate, broad, and rounded; the tarsi long and covered with small scales; the toes short and covered with small narrow scales above; the claws short, broad, and blunt.

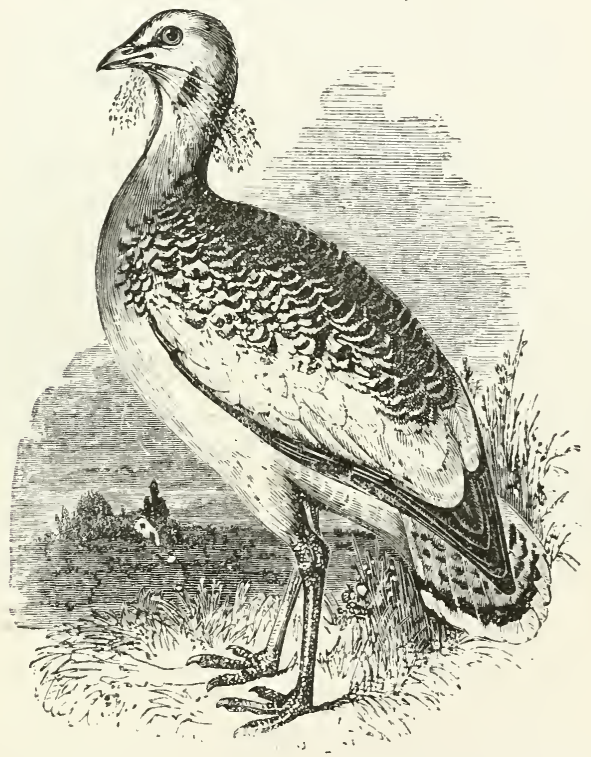

Fig. 168-THE GREAT BUStaRd.

(Otis tarda.)

Bustards are found on the dry, sandy, or grassy plains, and the open cultivated lands of Europe and Asia. They are shy and wary; when alarmed, they easily escape by flight, which is strong, swift, and at no great distance from the surface of the ground. 
Sometimes they alight after flying a little distance, and run off with considerable speed until they are at a sufficient distance to defy pursuit. The female and young generally conceal themselves by squatting down close among the tufts of brushwood and grass. They feed on grain and seeds, and are very destructive to young wheat and tops of turnips. Insects and worms also form a portion of their subsistence, and sometimes they swallow small quadrupeds. The females lay from two to five eggs on the bare ground, under cover of the herbage. The young, as soon as they are excluded, follow their parent, but for a long time are incapable of flying.

The type of this sub-family,-

The Great Bustard (Otis tarda), was formerly abundant in many parts of this country, but is now quite extinct in Britain. It occurs in Germany and France, and more or less abundantly throughout Southern Europe, always frequenting the wild and open parts of the country. The Bustard is the largest of European land birds. The male, when full grown, measures nearly four feet in length, and about nine feet from tip to tip of the extended wings; its weight is on an average twenty-five pounds. The female is smaller. The general colour of the plumage of the upper surface is buff, with numerous delicate transverse bars; the lower surface is white, and the head and neck are white with a greyish tinge. Bustards were formerly hunted with dogs in our own island. On the Continent they are now frequently shot with a rifle; and as they are very shy and wild, the sportsman has often great difficulty in stalking them. The flesh, of the young birds especially, is highly esteemed, and in many European countries they are often seen in the markets for sale. Bustards are polygamous, and the females lay two or three eggs in a small hollow in the ground. Their food consists partly of vegetable matter; but, in addition to worms and insects, they are said to kill and devour small quadrupeds and reptiles. 


\section{$S U B-F A M I L I I I$ II}

A PTERYGIN.E.

The Kivis.

Gex. СнавÁc.-Bill lengthened, very slender, the base covered by a long cere, broad, and rather depressed, with the tip hanging over that of the lower mandible; the nostrils placed at the tip, small and sublinear.

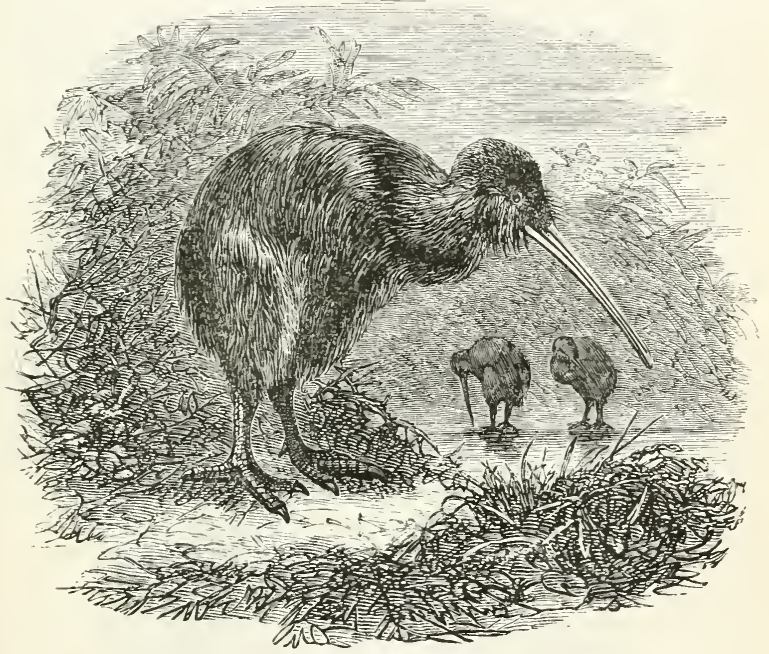

Fig. 169.-THE NEW ZEALAND APTERTX.

(Apteryx Australis)

The birds which constitute this family are distinguished from the Ostriches by the shortness of their legs, and the presence of a short hind toe armed with a strong claw on each foot. A further distinction is afforded by the form of the bill, which is elongated, nearly cylindrical, and slightly curved. The nostrils are situated quite at the tip of the upper mandible. The wings are rudimentary, and completely concealed beneath the feathers of the body. 
The type of the race is-

The New Zealand Apteryx (Apteryx Australis). In this remarkable bird there is searcely the slightest trace of wings, a peculiarity which has gained for it the title of Apteryx, or wingless. It is chiefly met with in the southern parts of the interior of New Zealand, where it is called by the natives "Kivi Kivi," in imitation of its cry. When seized, it defends itself vigorously with its powerful feet. Its activity is nocturnal, and it feeds principally upon earthworms, which it eaptures by driving its long bill into the soil, first of all, according to some authors, stamping upon the ground to ascertain the presence of its prey. These birds live in pairs, and construct a rough nest in the holes which they ordinarily fiequent; in this the female lays a single egg, about the size of that of a goose.

The favourite localities frequented by the Apteryx are those covered with extensive dense beds of fern, among which it conceals itself during the day. In running, it sets its head rather back, raises its neck, and plies its legs with a vigour little inferior to that of the Ostrich ; it is remarkably fleet of foot, and dives among the heavy ferneaves with singular adroitness. While undisturbed, the head is carried far back in the shoulders, with the bill pointing to the ground; but when pursued it runs with great swiftness, carrying its head elevated like the Ostrich. It is asserted to be almost exclusively nocturnal in its habits, and it is by torehlight that it is hunted with spears by the natives, by whom it is sought for with the utmost avidity. Its flesh is much esteemed by the New Zealanders, but a still higher value is placed upon the feathers and skins, which are employed in the manufacture of dresses for the chiefs, and no inferior person is permitted to wear them ; indeed, so much are they prized, that the natives cannot be induced to part with them. The feathers are also employed to construct artificial flies for the capture of fish, precisely after the European manner.

When attacked, the Apteryx defends itself very vigorously, striking rapid and dangerous blows with its powerful feet. The plumage is composed of rather curionslyshaped flat feathers, each being wide, and furnished with 
a soft shining silky down for the basal third of its length, and then narrowing rapidly towards the extremity, whicl is a single shaft with hair-like webs at the sides.

The birds of this family acquire additional interest from their obvious relationship with the extinct gigantic birds of New Zealand known by the name of Mod, one species of which must have stood nearly as high as the Giratfe. The bones of these giants of the feathered creation examined by Professor Owen are not fossil, and it is supposed that the last of the race has not been dead many years, the genus, like the Dodo, having been exterminated by the natives at a very recent period. Fragments of egg-shells have been found in some quantity in the detritus brought down by rivers; and the aborigines not only say that their fathers and grandfathers have often seen and killed them, but assert that some are still existing in the mountains; it is even reported that an Englishman one day saw one, but was so frightened that he threw down his gum and ran away.

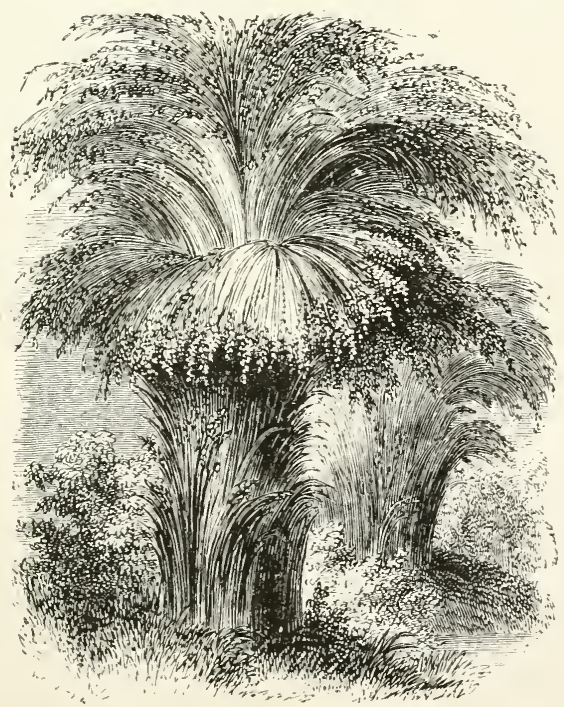




\section{O R D E R VI.}

Grallatores.*

THe word Grallatores, $†$ which literally means Stiltwalliers, is synonymous with the French term Les Echassiers, which Cuvier has given to the present order, and which is generally applicable to the birds included in it. They have by many naturalists been termed WADERS, a title which is strictly correct so far as regards the greater number of the species, but not all. The birds of this order, says Cuvier, are characterized by want of feathers at the lower part of the thighs, and by the great length of the tarsi,-two circumstances which permit them to wade to a certain depth without wetting their plumage, and thus to procure food by means of their neck and beak, the length of which is generally proportionate to that of their legs. Such as have the beak strong live on fish and reptiles; those in which it is feeble on worms and insects. A few feed partially on grains and herbage, and these live at a distance from water, frequenting open plains and extensive downs.

The principal food of the whole race consists of animal substances; so that they have membranous stomachs and not gizzards, though some have a slight approach to that structure. These last occasionally feed upon vegetables; they pick up seeds from the tops of high plants, and eat the leaves and tender shoots.

The Grallæ in their general haunts are associated with wildness and infertility. They give life to those places which man neglects. They take up the ground where the field birds end, and occupy it as far as a walking foot can go in search of foodto the uppermost part of the hill that will bear bent

* Grallæ, stitts; so called from their stilt-like legs.

† See "Animal Creation," p. 452. 
and rushes-to the farthest shallow in the lake and the river-through the sedges and reeds by the marsh, and on the beach as far as the ebbing tide retires. Mountainward they approach the haunts which are occupied in succession by the Black-game, the Grouse, and the Ptarmigan. Fieldward they border with the Partridge and the Rook, and nearer the waters they are the immediate neighbours of the swimming birds. The pastures which they occupy are more under the influence of the seasons than either the richer or more cultivated parts of the country. 'The supply of food along the shores is most abundant in the winter, as the waters, being in a state of stronger agitation, detach and cast to the strand a greater number and rariety of esculent matters; so that though the birds may be driven inland during the violence of a storm, they speedily throng back to the beach when it is over, to feast on the supplies which have been there collected. Their food consists of various matters, - of the spawn of fishes, of fry in a very young state, and of immumerable small animals that come ashore upon uprooted seaweeds, or are to be found under loosened stones, and in the general accumulations of sand, ooze, and other délris, which the troubled waters roll about while in agitation, and ultimately leave on the beaches, deposited in order of gravitation, and consequently with the organic portion uppermost. Nor are the land floods unserviceable in adding to this winter store of food, for they sweep from the beds and out of the torn banks of the rivers a vast multitude of little animals, which are then found in great abundance upon the oozy banks and in the slimy beds of the shallows of estuaries and creeks. It is in such localities only that the full value of the Grallatorial birds can be estimated, or the part that they act in the grand economy of Nature properly seen.-(Mudie.)

To this extensive order belong the Plovers, the Herons, the Snipes, the Screamers, and the Rails. 


\section{FAMILY I.}

Charadritd.e**

The Plorers.

Gev. CHARAC, - Bill short, with the base of the culmen rather depressed and weak and the apical part strong and swollen; the nostrils placed in a deep longitudinal groove of various length; the tarsi lengthened; the hind toe totally wanting, or small and elevated.

The habits of the Charadriidx vary. Some, which approach in structure the Gallinaceous birds, are attached to the land, while other families live on the sea-coast, or in places immediately contiguous to water, obtaining their food, in a great measure, from that element. The more terrestrial species, (m) the contrary, reside in the interior of the country, preferring open grounds and plains; whilst some of them even inhabit the arid sands of the desert. A great proportion of this family feed at twilight, or during the night, and have the eyes large, which is necessarily attended with a corresponding expansion of the socket, giving the head a bulky appearance ; and, indeed, this is one of their characteristic features. Their flight is in general strong and rapid, the wings being long, and usually brought to a point. Most of them moult twice in the year, undergoing a change of plumage immediately before the season of pairing.

This family includes the Thick-knees, the Coursers, the Pratincoles, the True Plovers, the Oystercatchers, and the Turnstones.

* $\chi \alpha \rho a \delta$ ctóc, charadrios, the name of a bird, so called from its

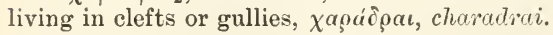




\title{
$S U B-F A M J L Y$ I.
}

\author{
GDicNevinte*
}

The Thick-knees.

Gex. Charac.-Bill as long as, or longer than, the head, with the culmen slightly depressed at the base and swollen at the tip, and the gonys more or less angulated; the tarsi lengthened, with three rather short toes in front.

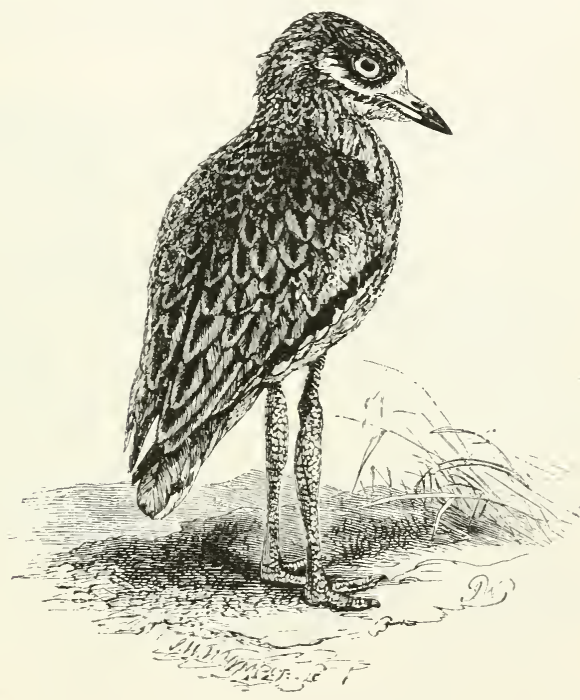

Fig. 170.-THE THICK-KNER.

(Edicnemus crepitans.)

The Thick-knees are migratory birds, inhabiting all parts of the world except North America, seeking the more temperate regions to rear their young, and the warmer latitudes to pass the winter. Their periodical flights are performed in flocks during the night with great swiftness. These birds are generally found in uncultivated open moorlands. Their

* oiớc $\omega$, oideo, to swell; $к \nu \eta \dot{\mu} \eta$, kneme, the leg; Having swollen legs. 
food is sought for dming the evening or at night. It consists of small quadrupeds and reptiles, but especially of worms and insects. During the day the Thick-knees sit closely squatted beneath a stone, or any other object sufticiently large to hide them ; but if disturbed, they fly to a short distance, and then r'un off with great rapidity to some place of refuge. The female deposits two eggs on the bare surface of the ground. The young are capable of following their parent as soon as they escape from the egg-shell.

The type of this sub-family,-

The Common Thick-knee (OEdicnemus crepitans), or, as it is frequently called, the Norfolk Plover and Stone Curlew, is a migratory bird, and one of our regular summer visitors. It generally arrives in England about the end of April or the beginning of May, and after performing the duties attendant upon incubation, as antumn advances, collects into flocks, and soon after retires into Africa, and the warmer latitudes of Europe, to pass the winter months. Wide hilly downs seem to afford situations that suit the economy of this bird, and in such localities it passes the period of its residence with us.

The Thick-knee is not destitute of courage, and it has been seen to defend its nest with vigour against the approach of sheep, or even dogs ; yet it is singularly shy, and carefully avoids human beings. When disturbed, it runs rapidly, and if it does take wing, flies for a considerable distance near the ground before mounting into the air. It utters a note which resembles the syllables "Curlui," and from this, and its hathit of frequenting waste and stony places, it has been called the Stone curlew. 


\section{$S U B-F A I I L Y I I$.}

CIIRSURINA: *

The Coursers.

GEN. Charac.-Bill moderate, slender, with the base of the culmen weak and somewhat cultrated above the nostrils, beyond which it is slightly arched to the tip; the nostrils lateral, placed in a short subtriangular membranous groove, with the opening longitudinal and exposed; the wings lengthened and pointed; the tail short; and the legs lengthened, scutellated in front and behind, and with only three slender toes in front.

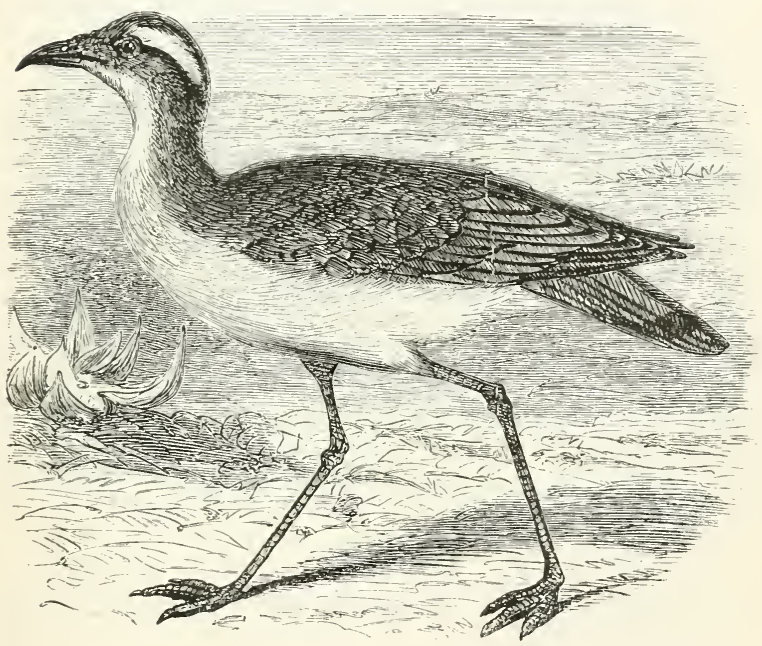

FIG. 171. - THE GALLISH COLRSER.

(Cursorius Gallicus.)

These birds are inhabitants of Europe, Asia, and Africa. They are found on sandy deserts or on open, stony, and grassy plains. In such places they are generally seen searching for insects and their larve. Their flight is rapid and powerful; while on the ground they are able to run with incredible speed.

* Cursor, a runner.

U 3 
The most interesting species is -

The Cream-coloured Courser (Cursorius isabellinus), one of the rarest visitor's to our shores; indeed, only three or four instances have been recorded of its appearance in Great Britain at various intervals since 178.5. Some years ago one was shot in Kent, and the following account is all that we possess of its history :-

It was first met with rumming over some light land, and so little fearful was it, that the person who afterwards shot it had time to send for a gun, which did not readily go off, having been charged some time, and in consequence he missed his aim. The report frightened the bird away; but after making a turn or two it again settled within a hundred yards, and was despatched. It was observed to r'un with incredible swiftness, and at intervals to pick up something from the ground, and was so bold as to render it difficult to make it rise, in order to shoot it while on the wing. The note was not like that of a Plover, nor, indeed, to be compared with that of any known bird.*

The Cream-coloured Courser is a native of Syria, Egypt, and Abyssinia, where it seems generally to frequent pools and other moist situations. Its winter residence is supposed to be the central lakes of Africa, from which it returns to the countries named above early in autumn, and disappears at the approach of winter. Nothing is known of its nidification.

The type of this sub-family is-

The Gaulish Courser (Cursorius Gallicus), figured at the head of the chapter.

* This specimen found its way into the Leverian Museum, at the sale of which it was purchased by Fichtel, who afterwards disposed of it to Dr. Donovan for the sum of eighty-three guineas. It is now in the British Museum. 


\section{$S U B-F A M I L Y$ III.}

Glarioline.*

The Pratincoles.

Gen. Charac.-Bill short, broad at the base, and laterally compressed to the tip; the wings rery long, with the first quill the longest; the legs moderate, with the tip of the tibia naked; the toes three in front and one posteriorly, which is elerated.

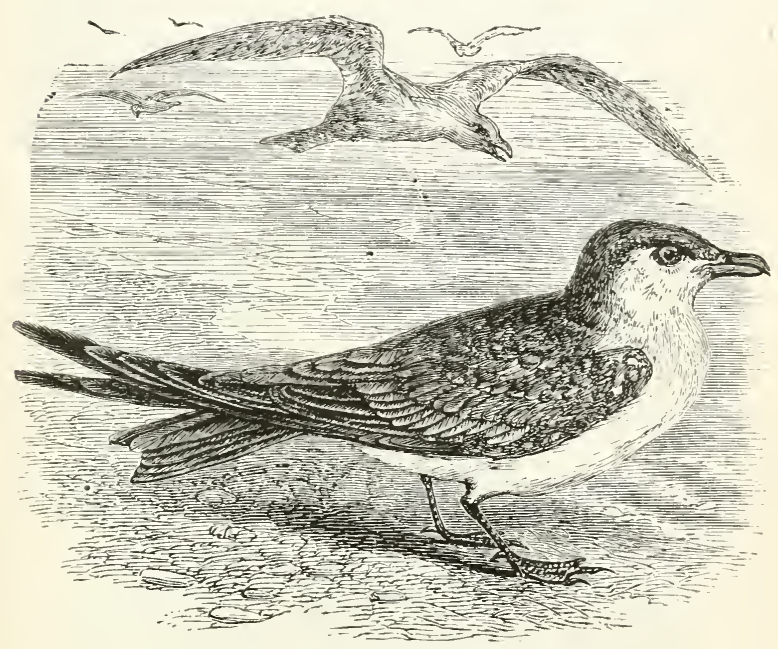

Fig, 172.-THE MiLKY PRATINCOLE.

(Glareola lactea.)

The Pratincoles inhabit the temperate and warmer climates of the old World. They frequent the borders of rivers, lakes, and mountains. Their food consists chiefly of insects, which they take on the wing, like Swallows, and on the ground, where they can run very quickly. They form a slight nest among rushes and thick herbage in the marshes. The eggs are three or four in number.

* Diminutive of glarea, gravel, indicative of the soil they generally frequent. 
The best-known species, -

The Austrian Pratincole (Glareola pratincola), callel on the Continent Perdrix de mer, or Sea Partridge, is a rare visitor to Great Britain, inhabiting for the most part the north of Africa, and the countries in the vicinity of the Don, the Volga, the Caspian, and the Black Sea. In some of its habits it resembles the Plovers, as it frequents open plains, and runs with great rapidity; in nidification, also, and in the shape, colour, and markings of its egg's it is associated with that tribe; while in its mode of Hight and habit of catching flies while on the wing, it approaches the Swallows. Its true place is, undoubtedly, among the Waders, several of which not only feed on insects, but are expert in catching them in the air. The eggs are deposited in the midst of a tuft of rushes or other herbage.

The typical form is-

The Milky Pratincole (Glareola lictea).

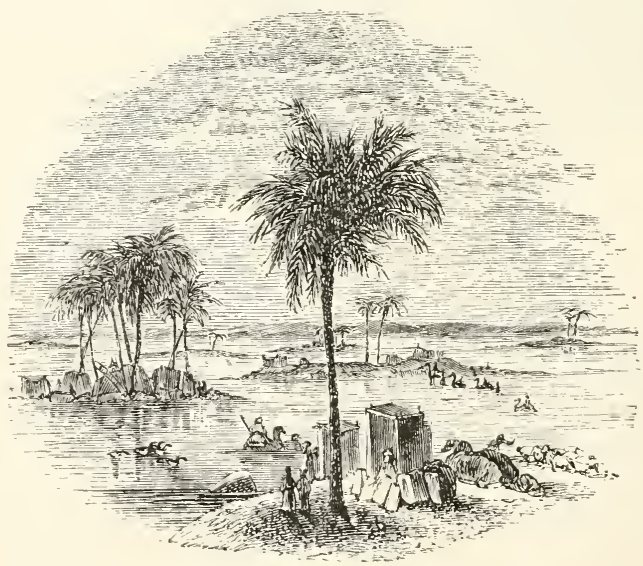


GEn. Charac.-Bill more or less long and slender, the eulmen depressed at the base but vaulted at the tip, the sides compressed and groored; the nostrils basal, linear, and placed in the groove of the upper mandible; the wings long and pointed; the tail moderate, broad, and generally even; the tarsi usually long and rather slender; the toes sometimes three and sometimes four in number, the outer toe longer than the inner, and more or less united at the base; the claws small, compressed, and curved.

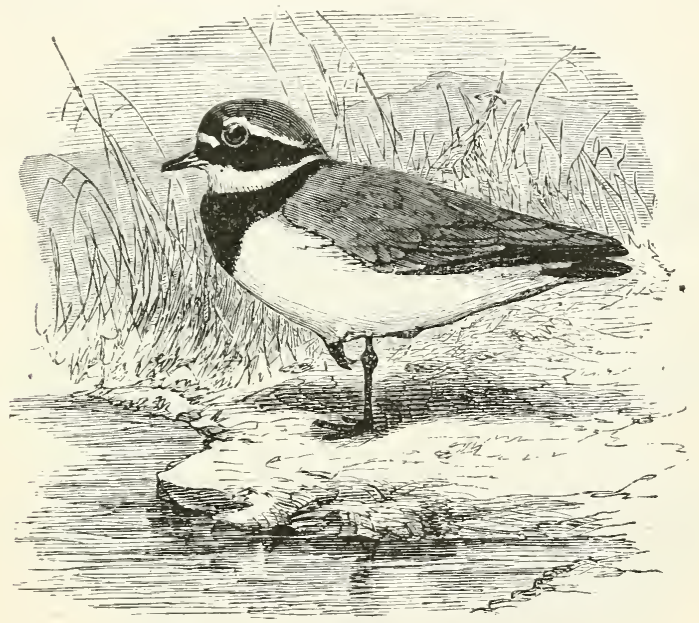

Fig. 173.-THE RINGED PLOVER.

(Charadrius Hiaticula.)

The 'True Plovers are found in most parts of the world. They are usually seen in small Hocks in the neighbourhood of the sea-coast, frequently near creeks and the mouths of rivers, where the shore is composed of gravel; but during the summer months they separate in pairs, and frequent the banks of rivers, inland lakes, elevated mountains, and open moors. Their food consists of small insects and 
molluscous animals of various kinds. These they seek in the evening or by night. Their flight is strong and rapid, but does not extend far at a time; they sometimes run with great swiftness. Their note is a plaintive whistle often repeated. The nest is a slight hollow, lined with a few stems of dry grass. The eggs are usually four in number, and when they are hatched, the parents protect the young brood with great courage and cunning till they are able to $\mathrm{fly}$. If disturbed by an enemy, they generally rum for some distance from the nest, and then usually pretend that they are wounded, tumbling over on the ground, or feigning lameness.

The type of this sub-family is-

The Ringed Plover (Charadrius Hiaticula), a small and prettily-marked bird, found throughout the year ujon all the coasts of Great Britain. 


\section{SUB-FAIILY V.}
HeMATOPODINE. *
The Oyster-catchers.

Gev. Charac.-Bill lengthened, strong, and with the apical half much compressed to the tip, which is obtuse; the nostrils linear, and placed in a membranous lateral groove; the wings long and pointed; the tail moderate; the tarsi robust, and covered with small scales; the toes three, the lateral toes united at the base by a membrane, especially the outer one; the claws strong, broad, and curved.

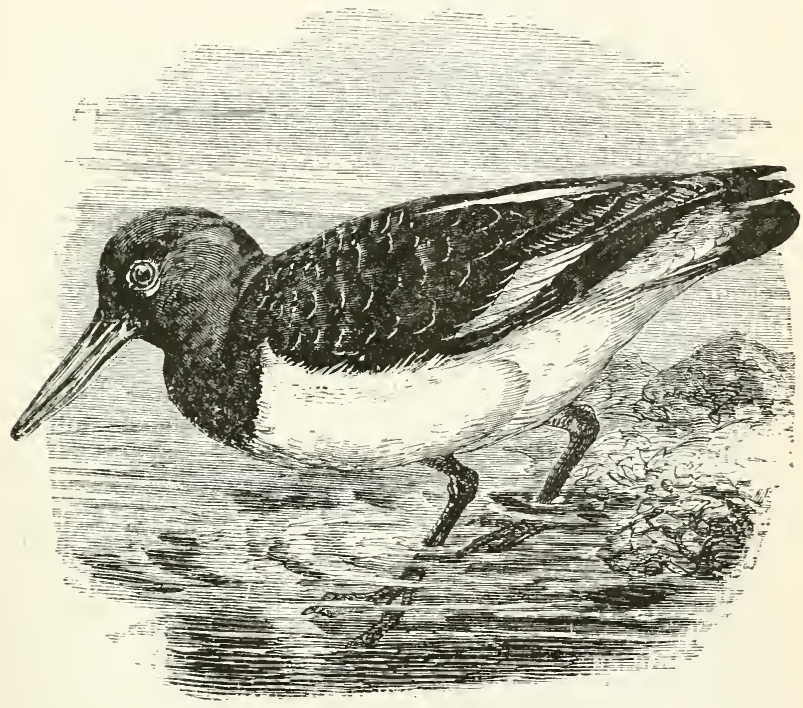

Fig. 174.-THE OXSTER-CATCHER.

(Hamatopus ostralegus.)

The Oyster-catchers frequent rocky promontories, or the broad banks of mud, sand, and ooze which stretch out into the sea from low portions of the coast. Here they feed on mussels and other bivalves,

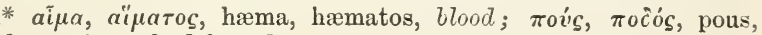
podos, a foot; Red-footed. 
limpets, worms, crustacea, and small fishes. When the mud-banks are covered by the tide, they move to a short distance inland, and pick up slugs and insects in the meadows. Their eggs are laid in a slight depression among the shingle above highwater mark; but on rocky shores they make an attempt at a nest by collecting a few blades of grass or scraps of seaweed. They lay three or four eggs, and the young are able to run after breaking the shell. They are sometimes called "Sea Pies."

\section{The only species is-}

\section{The Pied Oyster-catcher (Hamatopus ostralegus).} This singular bird, although nowhere numerous, inhabits ahmost every sea-shore, both on the Old and New Continent, but is never found inland. It is the only one of its genus hitherto discovered, and from the conformation of its parts one might almost be led to suppose that it had borrowed the eye of the Pheasant, the legs and feet of the Bustard, and the bill of the Woodpecker. During the summer the Oyster-catchers fiequent the sandy sea-beach of all parts of the Atlantic coast, roving about in small parties of two or three pairs together. They are extremely shy, and, except about the season of breeding, will seldom allow a person to approach within gunshot. They walk along the shore in a watchful, stately manner, at times probing it with their long wedge-like bills in search of shellfish. The small crabs, called "fiddlers," that burrow at the bottom of inlets, are frequently the prey of the Oyster-catchers, as also are limpets, mussels, and cockles. The former it can hitch from the rocks with great certainty by an oblique tap with its bill. Bivalve shells, when closed, it opens by striking them at the hinge, and in the case of the cockle by holding the shell steadily with its foot and wrenching with its bill, as with a crowbar.

It is said that this hird frequents oyster-beds and watches the opening of the shells, that it may drag out the unfortunate mollusks, and for this purpose its bill seems very well adapted. This account is, however, contradicted by dwellers on the coast, who state that the bird does not resort to the oyster-beds, but is always 
seen on the smooth beach bordering the ocean, and on the high, dry, level sand just beyond the reach of the summer tides. When the shores are flat and of a retentive nature, so that the surface remains covered with a shallow stratum of water after the tide has ebbed, the Oyster-catcher finds its prey readily, as the shells of the bivalves are then partially opened, and it can easily insert its wedge-shaped bill and wrench them asunder; but where the sand soon dries, and there are no rocks on which limpets can be had, it follows the line of the water both in its retreat and its advance.

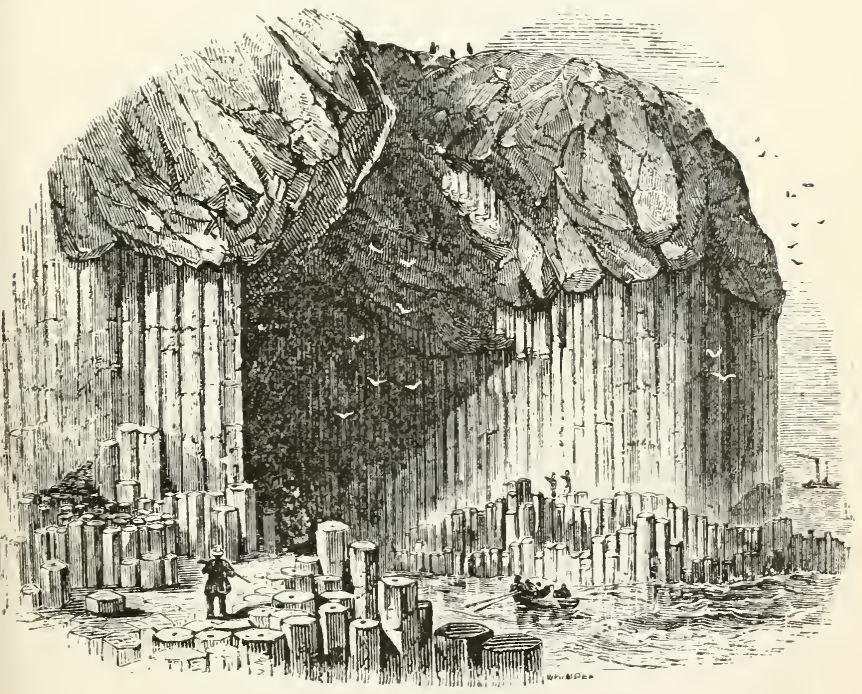




\section{SUB-FAMIIVI.}

CINCLIN.E.

The Turinstones.

Gex Charac.-Bill rather short and straight, with the culmen straight and sometimes raulted at the apical portion, the sides compressed to the tip, which is obtuse or acute; the nostrils placed in a membranous groove, with the opening linear and longitudinal; the wings lengthened, with the first quill the longest ; the tail rather short; the tarsi short, robust, and covered with small scales; the toes long, the lateral ones unequal and free at their bases, the hind toe rather long, slender, and elerated.

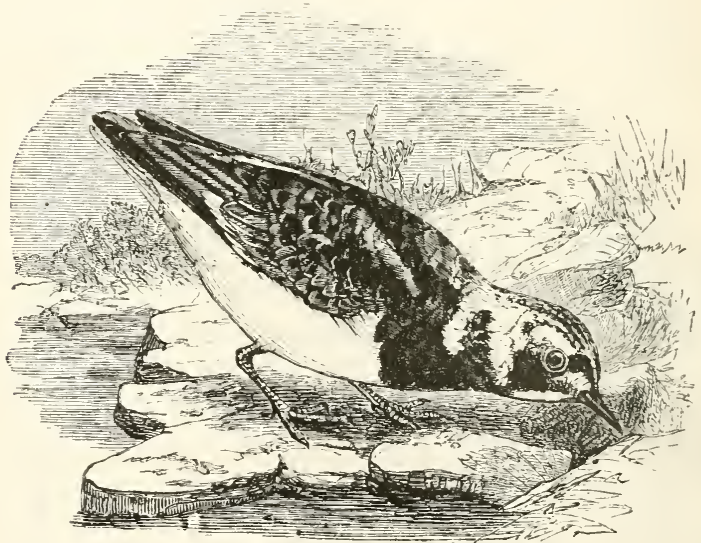

Fig. 175.-THE TURNSTONE SANDPIPER.

(Cinclus interpres.)

The 'Turnstones, owing to their migratory habits, are met with in most parts of the world. At certain seasons of the year they frequent the sea-shores, where they may be seen in small flocks of five or six individuals following the retreating waves in quest of shellfish, or searching amongst the seaweeds left by the tide for small crustacea. The females are said to deposit their eggrs on the sand of the sea-coast. 
The type of this sub-family,-

The Turnstone Sandpiper (Cinclus interpres), is a regular annual visitor to the shores of Great Britain, and indeed of almost every maritime country, having been observed as far north as Greenland, and as far south as the Straits of Magellan, but it is never seen inland. It is a bird of elegant form and beautiful parti-coloured plumage, active in its habits, a nimble runner, and an indefatigable hunter after food. In size it is almost as big as a thrush. It is difficult to get near enough to these birds to observe their mannuvres while engaged in the occupations from which they have derived their name, though their industry is often apparent from the number of pebbles and shells found dislodged from their sockets in the sands in places where a flock has been feeding.

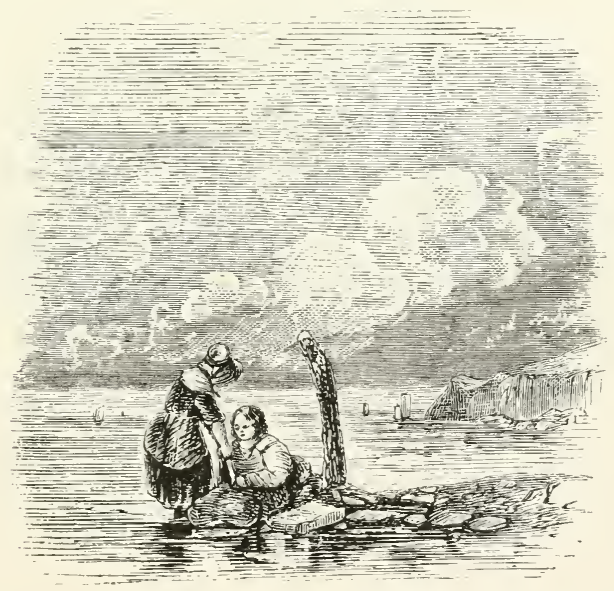




\section{FAMILI II.}

Ardeid.e.

The Herons.

Gev. Charac. - Bill more or le'ss long, and generally compressed on the sides, with the eulmen curved at the tip, which is sometimes emarginated and acute; the wings moderate and rounded; the tail mostly short and rounded on the sides; the tarsi lengthened and rather slender; the toes more or less long and rather slender, with the outer toe longer than the inner, and both united at their bases, the hind toe more or less short, and generally placed on the same level with the anterior toes.

The members of this family inhabit most parts of the world, making regular migrations according to the change of seasons and the scarcity of food. They are usually seen standing solitary in swamps, shallow rivers, or pools of water, with their necks drawn down between the shoulders, quietly waiting the approach of a fish, which they no sooner observ. than they suddenly dart their bill upon it and swal.. low it in an instant. They also feed upon smir. quadrupeds, frogs, and various kinds of insects; anc. some species have been observed perched on the backs of cattle, and feeding on the larva of insects that infest their hide. The nest is usually built on the loftiest trees, and on elevated buildings, or among the tall reeds on the borders of lakes and rivers, and is formed of sticks lined with small twigs loosely put together, which causes it to be large and flat. 'The eggs are usually four or five in number.

Belonging to this family are the 'Trumpeters, the Cranes, the Herons proper, the Storks, and the Ibises. 
SUB-FAMILY I.

Psophine.*

The Trumpeters.

GEx. CHARAc.-Bill moderate, with the culmen compressed at the base, vaulted at the apical portion, and curred to the tip, which overhangs the lower mandible and is obtuse; the nostrils placed in a membranous groove, with the frontal plumes adrancing to the opening; the toes moderate or short, and the two outer ones united at their bases, the hind toe short and rather elerated above the base of the anterior toes.

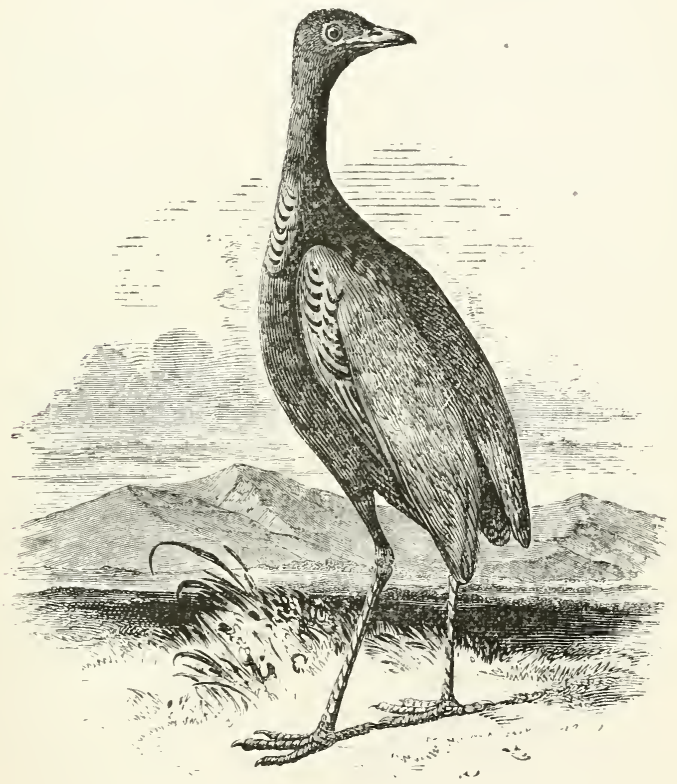

Fig. 176.-THE GOLD-BREASTEd TRUMPETER.

(Psophia crepitans.)

These remarkable birds inhabit the tropical forests of South America, where they search for grain and fruits. They are usually discovered by their pecu-

* †ódos, psophos, a noise. 
liar noisy cry, which has procured them the name of "Trumpeter." If disturbed, they seek safety by rumning with expanded wings. The nest is usually formed on the ground at the foot of a tree; the eggs are two in number.

\section{The typical species-}

The Gold-breasted Trumpeter (Psoplice crepitans), called also the Agami, is an inhabitant of the Antilles, and of the tropical parts of South America. In its wild state, it inhabits the densest recesses of the forests, far. remote from all human habitations: here it resides in small flocks, consisting of ten or twelve individuals, and feeds upon wild fruits and seeds. It walks and runs much better than it can fly ; indeed its flight is so heavy that it seldom rises more than a few feet from the ground. Like the Stork, it sleeps while standing upon one leg, keeping its head drawn back between its shoulders. When suddenly surprised, it runs away with great swiftness, uttering a sharp cry, resembling that of a Turkey. Its most striking characteristic, however, is the loud and trumpet-like sound which it sometimes produces, six or seven times in succession, without opening its beak, a sound so deep and sonorous that it seems to proceed from its whole body. This noise results, according to Pallas, from a peculiar construction of the wind-pipe, which is at first as thick as a swan's quill, but becomes more slender as it enters the chest, when it gives off two membranous semicircular sacs, or air-bags, of which that on the right is the more extensive, and divided into three or four cells. The hollow internal drumming, preceded by a wild cry, is evidently produced by the vibration of the air forced into these air-bags from the lungs by the action of the muscles of the chest and back. During the performance the chest heaves, as in birds when singing.

The Agami, when under the protection of man, soon becomes exceedingly tame and familiar; indeed, it seems to have an instinctive love for human society. It represents among the feathered races what the Dog is amongst quadrupeds, and appears equally susceptible of affectionate attachment. It obeys the voice of its master, follows him wherever he goes, and appears delighted at receiving 
his caresses; it welcomes his retum with alacrity, and seems to repine at his absence. In the same proportion it appreciates the favours bestowed upon it ; it is jealous of any rival, - should even a dog approach, it immediately assails it with its beak, and drives it to a distance with every demonstration of displeasure. It presents itself regularly at the dimner-table, from which it chases all the domestic animals; sometimes even the negroes who wait at table, should they happen to be strangers, and only asks for a share of the dimner when it has expelled from the room all who might aspire to favourable notice from the members of the family. It is remarkably courageous; dogs of ordinary size are obliged to cede to its anthority. It walks out alone without any danger of losing itself, and returns home when it thinks proper : it is even asserted that the Agami may be trusted with the care of a flock of sheep, and that every morning it will drive ducks and fowls to their pasture, and bring them home at night after carefully collecting any stragglers. As for the bird itself, it is never shut up, but sleeps just where it pleases, - mpon the roof of a barn or in the farm-yard. In short, the Agami is a faithful servant, intelligent, docile, and affectionate, and, like the Dog, to a considerable extent susceptible of education. The female, when about to lay, scrapes a hole in the earth at the foot of some large tree, in which she deposits her eggs without making any nest. The eggs are from ten to sixteen in number, according to the age of the bird ; they are of a spherical shape, larger than those of a fowl, and of a clear green colour. The flesh of the Trumpeter when young is tender and palatable, but that of the old birds is dry and generally tough.*

* Vieillot et Oudart, "Galerie des Oiseaux." 


\section{$S U B-F A M I L Y I I$.}

\section{(IRUINE.}

\section{The C'rumes.}

Gex. Charac.-Bill more or less lengthened, straight, strong, with the tips of both mandibles pointed and equal in length; the nostrils plaeed in a deep groove, which extends beyond the middle of the bill; the wings long, and the tertials lengthened and pendent; the tail short and even; the tarsi very tong and slender; the toes rather short.

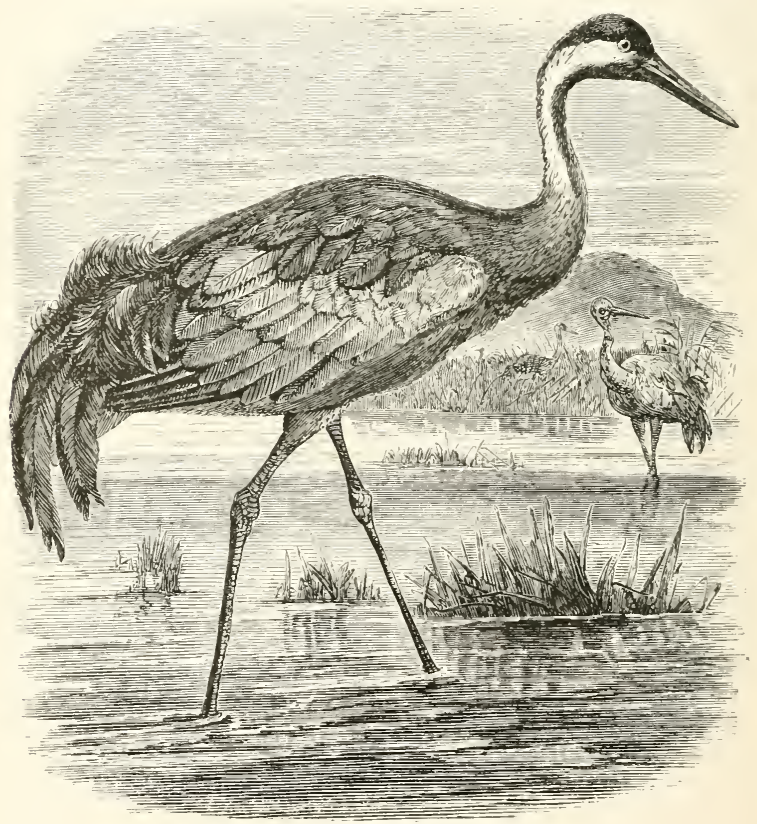

Fig. 177. - THE COMMOX CraNe.

(Grus cinerea.)

The Cranes which constitute the members of this sub-family are large and handsome birds, inhabiting for the most part the warmer regions of the globe. 
They have a large and strong bill, which is sometimes straight and pointed, sometimes more or less arched at the extremity ; their nostrils are placed in large grooves, and generally near the middle of the upper mandible. Their legs are of great length and rather slender, with the tarsi compressed and covered in front with broad shields, and the naked skin continued upwards to a considerable distance on the tibia. The toes are rather long, with the exception of the hinder one, which is small and elevated on the back of the tarsus, so that it does not touch the ground in walking; the two outer anterior toes are united at the base by a small membrane. The tail is usually very short, and in the true Cranes the tertiaries are greatly developed, forming elegant floating plumes, which hang gracefully over the hinder part of the bird, and often give it a most graceful appearance. The head is frequently adorned with a crest. The favourite haunts of the Crane are marshy districts, where it finds in abundance the worms, mollusks, and frogs that constitute a great part of its nourishment. Its nest is generally placed among the thick reeds, osiers, and luxuriant herbage of the marsh, but occasionally on the top of some rumed building. The female lays only two egg's.

\section{The type of this sub-family,-}

The Common Crane (Grus cinerea), is conmon in many parts of the Eastern Continent, passing the summer in temperate climates, and returning southwards on the approach of winter. The periodical migrations of these birds are remarkable for their punctuality, it having been observed that during a long series of years they have invariably traversed France in the month of October, returning during the latter half of the month of March. On these occasions they always fly in large flocks.

They move with rapidity, and alight during the day to rest and feed. At other seasons these birds cease to be gregarious, and repair to swamps and morasses, where in spring each pair builds a rude nest of reeds and rushes 
on a bank or stmmp of a tree, in which the female lays two eggs. Cranes may be called omnivorous, as they live indiscriminately upon animal or vegetable substances. 'Their note is loud and sonomous, but harsh. During their migrations, these birds always fly in two lines, which in fint meet in an acute angle, thus forming a figure somewhat resembling the Greek letter $\gamma$, which indeed from this vely circumstance is said to have derived its shape ; one of the company, therefore, always flies in advance of the rest, and thus constitutes the vertex of the angle; and if the movements of the flock are watched, it may readily be observed, that when this individual becomes fatigned by being the first to cleave the air, it falls to the rear, and leaves the next in succession to take its post. It has been noticed, moreover, that when the Cranes, in these their migratory flights, meet with a lofty mountain, they utter shrill cries, alpear anxions and restless, and fly without any kind of order. Gradually, and each for itself, they now ascend spirally until such time as they have attained sufficient height to pass over the olstacle, when, assuming their original formation, they proceed on their course. At times their flight is so very high, that, notwithstanding each individual occupies a considerable space, the birds themselves, though heard in the air, are not perceptible to the naked eye. Their shrill, loul, and trumpet-like note is audible far and near, and if at a short distance, is almost deafening. Their voices are rendered more powerful by the peculiar conformation of the windpipe, which forms several curvatures in the breast-bone before descending into and joining the lungs. The Crane is a tall and stately bird; when it stands rpright it reaches to the breast of a man, and the wings, wheli extended, are about seven feet in breadth. It is of a shy aud wary disposition; and when a large flock alight in a field, either for the purpose of feeding or resting, one or more of the party is always seen standing, at some little distance, with head erect, and evidently on the watch. On the approach of danger, this individual is the first to cive the alarm, and to take wing, on which the rest forthwith follow its example.-(Lloyd's "Scandinavian Adventures," vol. ii.)

While congenial localities still exister, Cranes regularly visited our own island: but cultivation and drainage 
have deprived them of their ancient haunts, and they are now but rarely seen in this country, although they were formerly esteemed valuable guests, and fines were imposed upon any who should take away the eggs of a Crane or of a Bustard. Willoughby tells us that "Cranes come often to us in England, and in the fen counties of Lincolnshire and Cambridgeshire there are great flocks of them." No less than two hundred and four were served up at a feast given by Archbishop Nevill in the reign of Edward IV.

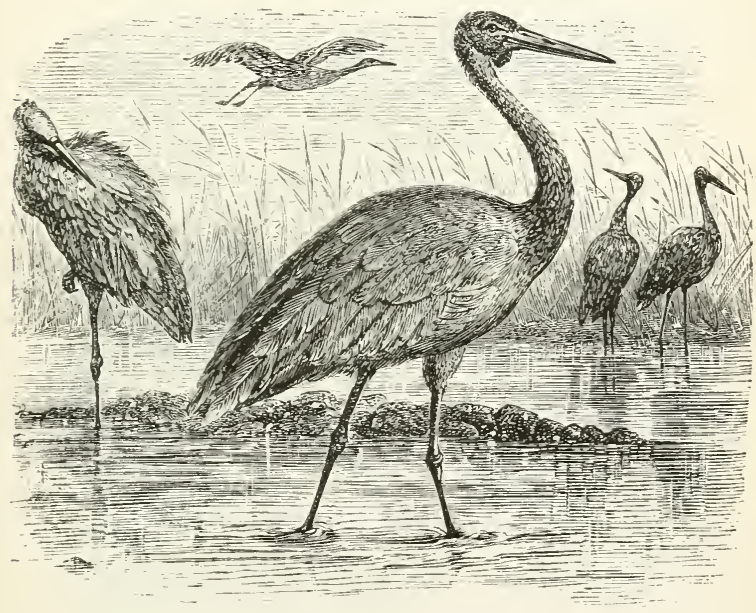

Fig. 175.-The alstralian crane.

(Grus Australis.) 


\section{SUCB-FAULY III.}

\section{ArdeINe.}

The Herous proper:

Gr.r. Charac,-Bill more or less lengthened, and generally acute, with the gape extending beneath each eye; the nostrils placed in the lateral groove, with the opening usually longitudinal, and partly elosed by a membrane; the wings usually long, and the first quills more or less graduated; the tail short and even; the tarsi long, slender, and eovered with transverse seutellations or retieulated seales; the toes long and more or less slender, the. outer toe usually united at the base, sometimes both toes are united at the hase for some distance.

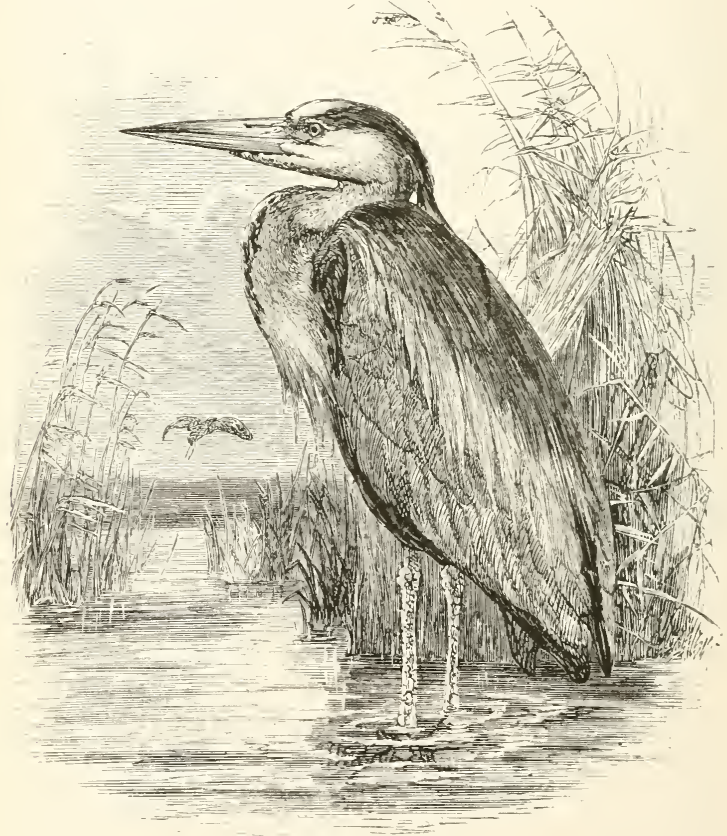

Fig. 17\%, - THE COMHON HERON.

(Ardea cinerea.)

Birds of this sub-family inhabit most parts of the world, migrating according to the change of 
seasons and the supply of food. Their usual haunts are swamps, shallow rivers, or pools, where they stand with their necks drawn down between their shoulders, quietly watching the approach of a fish, which they no sooner observe than they suddenly dart upon it with their bill, and swallow it in an instant ; they also feed upon small quadrupeds, frogs, and various kinds of insects. Some species have been observed perched upon the backs of cattle, and feeding upon the larva which infest their hide. The nest is usually built upon the loftiest trees, or on elevated buildings, or among the tall reeds on the borders of rivers and lakes: it is formed of sticks lined with small twigs loosely put together, so as to form a large flat expanse. The female lays from four to five egg's.

The type of this sub-family,-

The Common Heron (Ardea cinerea), though measuring three feet in length from the point of its beak to the extremity of the tail, and four feet and a half from the tip of one wing to that of the other, weighs but three pounds and a half; consequently, though not formed for rapid flight, its wings present so large a surface that it can support itself aloft with little exertion, and is enabled without fatigue to mount high in air when pursued by its natural enemies, the Falcons, to whom it would fall an easy prey if it could only skim along the plains, on account of the largeness of the mark presented to their downward swoop. The Heron is a successful fisher, but a tisher in shallow waters only, - to human anglers a very pattern of patience and resignation; up to its knees in the water, motionless as a statue, with the neck slightly stretched out, and the eye steadily fixed but wide awake to the motion of anything that has life, the Heron may be seen in the ford of a river, the margin of a lake or sea-side pool, or on the bank of an e-tuary. Suddenly its head is darted forward with unerring aim, a small fish is cap,tured and instantly swallowed head foremost; an eel of some size requires different treatment, and is brought to land that it may be beaten to death on the shingle. A large fish is impaled on its dagger-like beak, 
and, if worth the labour, is carried off to some safe retreat to be devoured at leisure. A frog is swallowed whole; a water-rat has its skull split before it discovers its enemy, and specdily is undergoing the process of digestion. Shrimps, small crabs, newts, water-beetles, share the same fate, - all is fish that comes to its comprehensive net. If, howerer, notwithstanding its watchfulness, the look-out be unsuccessful, the Heron rises a few feet into the air, and slowly flaps itself away to some little clistance, where perhaps, slightly altering its attitude, it stands on one leg, with its head thrown back, and awaits hetter fortune. While thus stationed, it is mute; but as it flies off it frequently utters its note, - a harsh, grating scream,--especially when other birds of the same species are in the neighbourhood. In the month of March Herons begin to congregate, and soon after repair to their hreeding-places, called Heronries : these are often chmms of lofty trees or groves, frequently near some old fimily mansion. The nests-linge masses of sticks a yard across, lined with a little grass and other soft materials-are placed near each other, as many, sometimes, as a hundred in a colony; or more rarely they are placeil among ivyclad rocks, old ruins, or on the ground. Each nest contains four or five eggs, on which the fenale sits almost three weeks, constantly fed by her partuer during the whole period of incubation. The capability of walking would be of little use to a young bird hatched at an elevation of fifty feet from the ground; the young Herons are comsequently helpless till they are sufficiently fledged to perch on the branches of the trees, where they are fed by their parents, who themselves are able to perch with the facility of a rook. Indeed, the favomite station of these lirds during a considerable part of the day is on the upper branches of a lofty tree, whither also they often rejair with a booty too large to be swallowed at once. 


\section{SUB-FA HILY IV.}

(UIONINE.

The Storks.

Gex. Снанас.-Bill lengthened, usually straight and conical, with the sides compressed to the tip, which is acute; the gonys long and ascending; the nostrils lateral, pierced in the substance of the bill, with the opening linear; the wings long and ample; the tail moderate and broad; the tarsi lengthened, and usually covered with reticulated scales; the toes moderate, with the anterior toes more or less united at the base, the hind toe long, elevated, and partly resting on the ground.

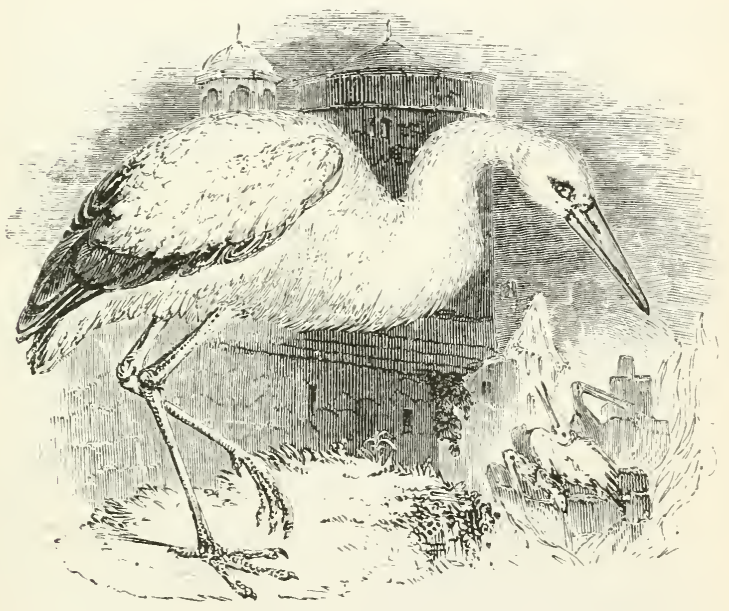

FIG. 150.-THE WHITL :TORK.

(Ci.onia alba.)

'These birds, in their migrations, visit various marshy districts in Europe, Asia, and Africa. They usually seek their food on the borders of rivers and streams, or in marshes. They live upon fishes, reptiles, small quadrupeds, and young birds, and sometimes search on open dry plains, or on cultivated ground, for grasshoppers and other insects. Their 
nest, composed of sticks and twigs, is placed on buildings, or on the decayed stumn of a tree. 'The female lays from three to five egoss.

\section{The typical species, -}

The White Stork (C'iconic ulba), is a well-known European bird, but is selkom seen in Britain. It is migratory, passing the summer in temperate or cold latitudes, but retiring during the winter to the banks of the Nile and the African swamps. It is a large and handsome species, measuring about three feet and a half in length, and is of a white colour, with the extremities of its wings black. The Stork frequents marshes and the bauks of rivers, devouring indiscriminately anv aquatic animals that may come in its way, and not even sparing the young of water-fowl; it also feeds freely on offal or carrion, and for this reason in many places its visits are regarded with great favour; and it may be seen, even in the crowded streets of large towns, stalking about with perfect confielence. On the continent of Europe, indeed, the Stork is a welcome visitor everywhere ; and the peasants, so far from wilfully injuring it, protect it to the utmost of their power. This kindly feeling is carried to such a length, as not only to subject a person ill-using it to unpleasant remarks but to actual danger; in some parts, indeed, it is looked upon as a sort of sin to molest it. In consequence of being thus favoured, the Stork becomes exceedingly tame, and will hardly get out of the way of the passer-by. It frequently makes its nest in the wilds of the forest, or, in the manner of the magpie, in detached trees immediately above human habitations; but it builds just as often on the roof, or it may be on the chimney of the cottage itself, where, to facilitate its operations, the peasants not unfrequently aftix a broken cart-wheel. The nest is composed of sticks and similar materials; and as it is often made use of for several generations, it becomes at length, from annual repairs and additions, of a most goodly size; occasionally, it is said to be from four to six feet in height. Numbers of sparrows usually breed in the sides of these gigantic structures. The Stork, according to popular belief, is not unmindful of the kindness shown to it; and the eggs, or young ones, as the case may be, that are frequently found 
wutside the nest, are considered by the peasants to be tokens of its gratitude. The female lays from four to five oval-shaped eggs, of a dirty white colour; they are two inches and seven-eighths in length, by two inches in their transverse diameter.

When the winter sets in, the morasses and swamps are frozen, and food is scarcely to be found; the Storks then assemble in multitudes, and prepare for their southern journey, which, like that of other bircls of passage, is probably begun in the night.

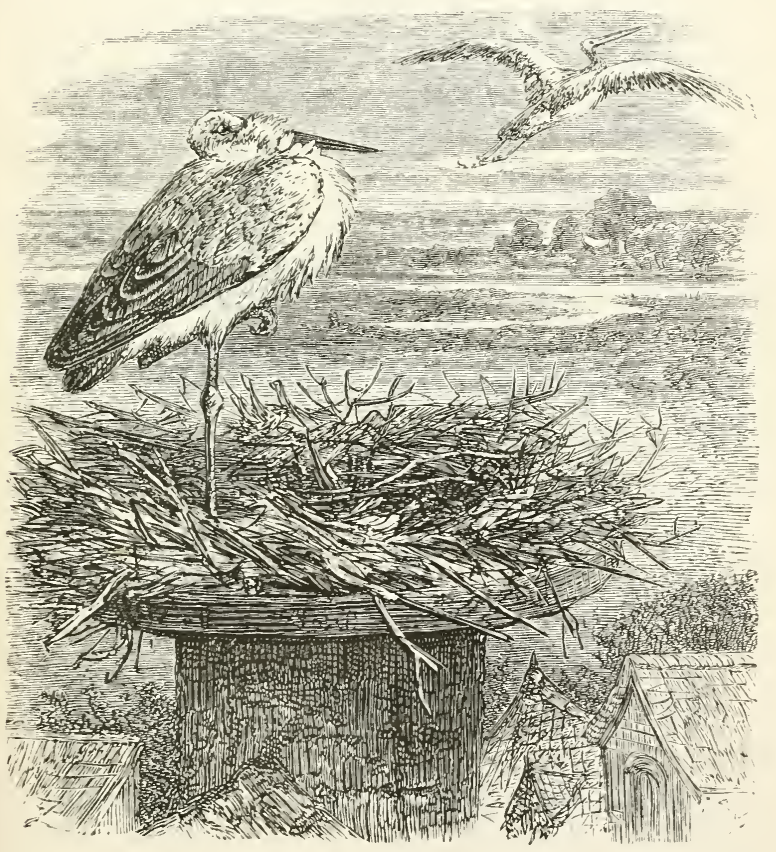

STORK'S NEST. 
TiNTheine.

The Ibises.

Gen. Charac.-Bill lengthened, more or less slender, and curved throughout its whole length, the sides gradually compressed to the tip, which is obtuse; the nostrils lateral, and sometimes placed in a lengthened groove, with the opening always linear and exposed; the wings rather long; the tail moderate and even; the tarsi of rarious lengths, usually robust, and eorered iu front with transverse or hexagonal seales; the toes long, the inner toe shorter than the outer, both more or less united at the base, the hind toe long and usually strong.

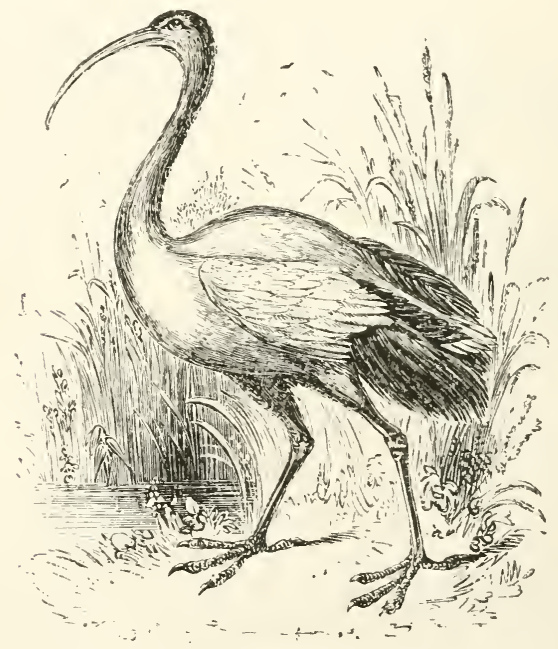

Fig. 181.-THE EGXPTIAN IBIS.

(Geronticus Ethiopicus.)

These birds are met with in the warmer parts of Asia, Africa, and America. They are to be seen in small and large flocks on the banks of rivers, lakes, or swampy places, or on land that has been recently overflowed, wading knee-deep in search of their food, which consists of frogs, water-lizards, various 
insects, and snails. Some species frequent the plains and open dry places, subsisting chiefly on insects and worms; while others have been observed standing on the decayed trunks of trees as they float down the streams, watching the approach of fish, on which they pounce with their long bills. Having satisfied their hunger, they usually perch on the exposed and elevated branches of the neighbouring trees, where they stand in an erect posture, resting their heavy bill upon their breast: in such situations they are extremely cautious and watchful. Their flight is usually performed in sweeps high up in the air ; but when migrating, which they often do in search of food, or on the change of season, they usually arrange themselves in two lines diverging from a leader. Their nest is placed on some lofty tree, or, by some species, upon the ground in marshy places.

\section{The typical species,-}

The Egyptian Ibis (Geronticus Ethiopicus), is also called "the Sacred Ibis," because it figures largely in an evidently sacred character on the hieroglyphics of ancient Egypt. It is a migratory bird, arriving in Egypt as soon as the waters of the Nile begin to rise, and remaining in that land until the waters have subsided, and thereby deprived it of its daily supplies of food. The bird, indeed, probably owes its sacred character to the fact that its appearance is coincident with the rising of the Nile. an annual phenomenon on which depends the prosperity of the whole country. Sometimes the Ibis stalks in solitary state along the banks of the river, or the many watercourses that intersect the low country, but sometimes associates in little flocks of eight or ten in number. Its food consists mostly of mollusks, both terrestrial and aquatic ; but it will eat worms and insects, and probably small reptiles. The Ibis was, at one time, thought to kill and eat snakes, and this idea was strengthened by the fact that Cuvier detected the scales and bones of snakes within a mummied corpse of an Ibis; recent specimens, however, seldom contain anything but mollusks and insects. Some species of Ilbis feed entirely on 
fishes and aquatic reptiles, of which they destroy an enormous quantity, in fact, more than they eat; for if they have been killing fish for half an hour, and have gorged themselves, they suffer the rest to lie on the water untouched, when it becomes food for alligators, crows, and vultures. To procure food of this description, they walk through shallow muddy lakes in numbers together. As soon as they have discovered a place abounding in fish, they lance, as it were, all through it until the water becomes thick with the mud stirred from the bottom by their feet. The fishes, on rising to the surface, are instantly struck by the beaks of the Ibises, and being deprived of life, they turn over, and so remain. In the course of ten or fifteen minutes hundreds of fishes, fiogs, young alligators, and water-snakes, cover the surface, and the birds greedily swallow them until they are completely gorged. 


\section{FAMILY III.}

SCOLOPACID.E.

The snipes.

Gex. Charac.-Bill generally long, slender, eurved or straight throughout its length, with the sides compressed and groored to the tip, which is obtuse ; the nostrils basal, longitudinal, closed by a membrane, and placed in the groove; the wings long and pointed; the tail usually short and even; the tarsi more or less long and slender; the toes generally long and slender, the lateral ones sometimes much united to the middle by a membrane, the hind toe short, resting on the ground, or entirely wanting.

These birds are among the smaller species of the order ; their bills are long, slender, and nearly cylindrical, obtuse at the end, and generally somewhat flexible and of a softer texture than in most birds. The upper mandible is a little longer than the lower, and usually grooved on each side; the nostrils are small, and situated at the base of the bill in the lateral grooves. In the development of the legs, the members of this sub-family differ considerably among themselves, some having their tarsi longer and more slender, in proportion to their size, than any other birds, whilst others are supported upon comparatively short limbs. The anterior toes are of moderate length, and frequently connected at their base by membranes; the posterior toe, when present, is small and slightly elevated, but sometimes this toe is entirely wanting; the wings are well developed, and these birds generally possess considerable powers of flight.

The members of this family are all inhabitants of marshy lands, the borders of swamps, lakes, and rivers, and the shores of the sea. Their food consists of worms, slugs, aquatic mollusca, \&c. Most of the genera procure their subsistence by thrusting their bill into the soft earth or the mud of the shore, whence they extract their prey. To facilitate this operation, their bill is at once a probe, a feeler, and an organ of prehension; an extraordinary develop- 
ment of nerve is distributed over its surface, but more especially at the tip, the membrane covering which is soft and pulpy, and endowed with an exquisite sense of touch. In many species the bill is further provided with a peculiar muscle, which operates so as to expand the pulpy points of the upper mandible, enabling the bird, with its bill buried in the ground, to seize prey the monent it is felt. From this peculiar mode of searching for their food, many species of the Snipe, the Woodcoek, de., have been called birds of suction. The distribution of the Scolopacida is very general; their power's of flight are considerable, and they are all more or less migratory in their habits. 'They incubate on the ground; the eggs are four in number, of a peeuliar form, being small and pointed at one end, large and obtuse at the other; and they are usually placed in the nest in a circle, with the acute ends meeting in the centre, so as to occupy as small a space as possible. The flesh of many is in high estimation.

This family comprehends the Godwits, the Longshanks, the Avocets, the Sandpipers, the Snipes proper, and the Phalaropes. 
LIMOSINA.

The Godwits.

Grv. Charac.-Bill generally long, slender, entirely curved or straight from the base, with the sides more or less grooved towards the tip, which usually overlaps that of the lower mandible, and is obtuse; the nostrils basal, and placed longitudinally in the lateral groove; the wings long and pointed; the tail usually short and even; the tarsi lengthened and slender; the toes long, the lateral ones united at the base to the middle toe, the hind toe short, avd sometimes wanting.

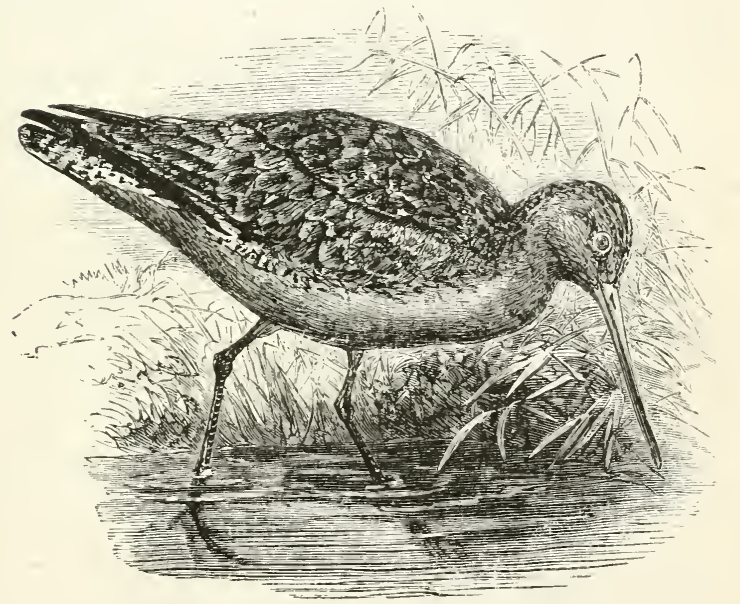

Fig. 181.-THE RED GODWIT.

(Limosa rufa.)

The Godwits are birds of considerable size; they inhabit marshes and the banks and mouths of rivers, where the muddy deposit is soft and deep, and in which, by probing with their long and semi-flexible bills, they find the materials upon which they feed. When thus engaged, these birds are frequently seen with their head entirely under water, and accordingly they are amply provided with the gland sitn- 
ated above the eye, whose function appears to be that of lubricating and defending this delicate organ from the effects of saline and other Huids. 'They are subjeet to a double moult, and their muptial dress is very different from the plumage they wear during the other parts of the rear. 'The females are much larger than the males. Like the other Scolopacida, they are migratory, and their passage takes place at the same periods.

'The birds of this sub-family have some resemblance to the Snipes, and also to the Tringas; but their leg's are longer, and perhaps also stouter, in proportion to their size, and their bodies more lightly made. 'The chief difference, however, is in the bill, which in birds that, as regards their haunts, are such close neighbours, is the most important. The bills of the Godwits are very long, soft, and flexible for their whole length, rather compressed and triangular at the base, depressed in the rest of the length, and dilated and obtuse at the tip, but not enlarged into a knob like that of the Snipes, nor having the upper mandible in the least hooked and projecting over the under. It is not a snapping bill, nor a boring bill, neither is it a scooping or a dabbling bill. It is not very easy to find a single epithet descriptive of the function that it perfor'ms, or rather of the manner in which it performs that function. It is not shovelling or scooping, for it does not remove from its place the sludge and sediment of the water among which it seeks its food; and it does not dabble and wash the mud, as Ducks do, till it finds the substance of which it is in quest. "Poking" is the nearest epithet, but does not express the action exactly, as the bird "tries about," and selects its food by the sense of touch, and not by sight. These birds are more of a warling habit than Snipes, as Snipes are more of waders than Woodcocks; yet the food is not found in the water, but in the ooze; and if that ooze is soft enough to be penetrated by the bill, the fact of its 
being with or without a small stratum of water over it is of little consequence. That food is chiefly mud worms, mud insects, and mud larvie; and the places which the birds frequent are those in which these most abound. The banks of the eddies of slow-rumning streams, or the accumulations of sludge that are left bare in the estuaries and creeks upon the shores of low and rich land, on the ebbing of the tide, and especially the runs of mud from the richer grounds into the pools of fens, are the favourite places with these birds. They breed in the fens, at a considerable distance inland if the ground is suitable, but they descend nearer to the sea in winter. In their inland haunts they hide themselves during the heat of the day among the long grass, where they have their nests; but when near the sea, their resting-time varies with that at which the tide leaves their feeding-places in the best condition. Godwits run very fast, more rapidly than Snipes or Tringas, and make their escape to a considerable distance on foot before they take wing ; when they do, they yelp and clamour in a very loud and rather harsh and bleating strain.

\section{The type of this sub-family is-}

The Red Godwit (Limosa rufa). These birds usually dwell in small societies, frequenting the mud-banks of river-mouths, or inlets of the sea abounding in oozy shores, where they readily meet with their usual food,worms, aquatic animals, and the smaller mollusea. Their flight is powerful though not very rapid, and when disturbed and raised on the wing, they utter a cry not unlike the bleat of a goat. In April the males have acquired their nuptial plumage, after which period they entirely desert our shores, retiring to more northern countries,Iceland, Lapland, and Sweden,-- to breed.

In Holland and the level parts of France, which afford them a congenial residence, they abound much more than in England, and are anmually killed in great numbers for the London market. 
Totanis.e.

The Longshanks.

Gex. Charac.-Bill long, slender, compressed, and grooved on the sides, with the culmen more or less straight, eurved, and acute at the tip; the nostrils linear and placed in the lateral groove, which extends to or beyond the middle of the bill; the wings long and pointed; the tail moderate, and even or rounded; the tarsi more or less long, slender, and covered in front with narrow transverse seales; the toes usually long and slender, the lateral ones unequal, and generally united at the base to the middle toe, especially the outer, the hind toe long, slender, and hardly touching the ground.

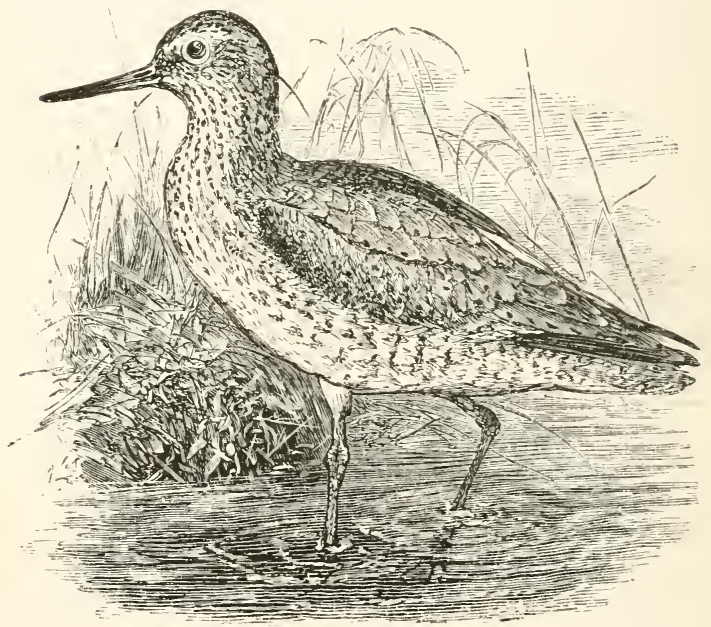

Fig. 183 -The COMMON REDSBAXK.

(Totanus calidivis.)

These migratory birds are found in both hemispheres, especially in the temperate and northern regions. They are usually seen in pairs, or in small Hocks, on thebanks of lakes and rivers, or sometimes on the shores of the ocean; but at certain seasons they resort to moist woods and marshes for the purpose 
of rearing their young. Their food is sought for on the ground, or among the gravel and stones, on the margins of lakes and rivers: it consists of insects, worms, small mollusks, and fishes. The nest is usually formed in a tuft of grass, or in a slight depression in the earth, lined with dry grass and other vegetable remains. The female lays four eggr, and if disturbed while incubating them, generally Hies round the intruder, uttering a succession of shrill notes for the purpose of engaging his attention, and leading him from the vicinity.

The birds belonging to this sub-family are distinguished by having the bill hard, with its tip pointed and sharp, and without the particular tactile structure possessed by the Snipes and Woodcocks. This difference in so important an organ indicates a correspondent diversity in their economy and mode of life; consequently, instead of seeking their food by probing in the soft sand or mud, they seize it upon the surface of the earth, or search for it among gravel or stones, on the shores of lakes and rivers, or on those of the ocean. Some of the species live entirely in the interior, and are but accidentally, if ever, found upon the sea-coast, which is to other's the place of habitual resort.

Some of these birds swim well, and even the young, before they are able to fly, will take to the water when threatened with danger. They can also dive with facility, and remain under water for a considerable time, coming up at a distance from the place where they went down : they are said to progress under water by the agency of their wings.

\section{The typical species is-}

The Redshank (Totanus calidris). During the winter the Redshank is found upon the sea-coast, and about the mouths of rivers, in small flocks; but on the approach of spring it retires inland to the fenny parts of the country, where it breeds. Its nest is placed in some large tuft of grass in the marshes, or on the ground in moist meadows, and is there formed by lining a shallow hole or depression 
with dry grasses and other vegetable remains. The eggs, fowr in number, are of a deep oil-green colour, blotcher with blackish-brown, the spots being most numerous at the larger end. During inculation, when disturbed from its nest, this bird is very vociferous, flying round the intrucler, and unceasingly uttering its shrill and piping notes. Upon the coast it is very wild and wary, and as it always gives a loud whistle on first rising, it sprearls the alarm amongst all other birds near at hand, and thereby often disappoints the shooter in his expectations of sport; hence it is a constant subject of nulediction, and has received the name of the "Tell-tale." 
Gex. Charac.-Bill lengthened and slender, with the sides grooved to the middle, and compressed towards the tip, which is acute; the nostrils linear and membranous; the wings long and pointed; the tail rather short and rounded; the tarsi long, slender, and covered in front with reticulated scales; the tibia long and denuded of feathers for some distance above the knee; the toes moderate, sometimes free and sometimes entirely united hy a web to the ends of the toes, the hind toe extremely short or wanting; the claws short.

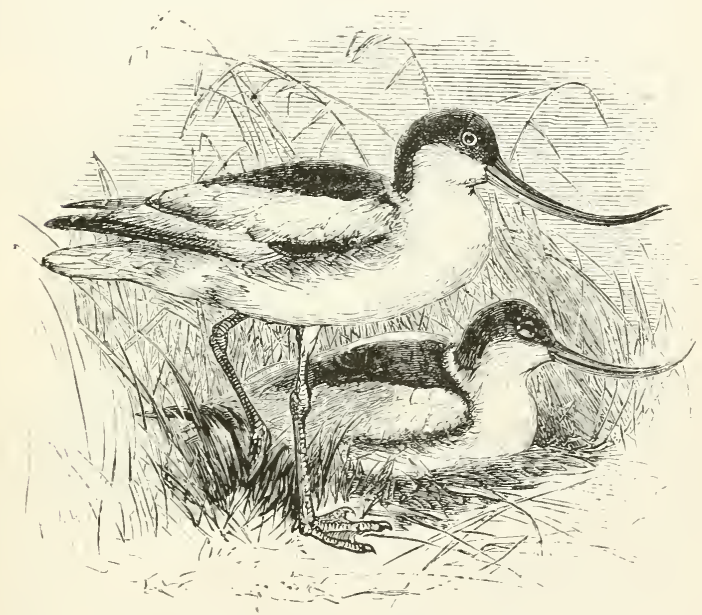

Fig. 18t-THE SCOOPING AYOCET.

(Recurcirostra Acocsta.)

'These birds are found in most parts of the globe ; they frequent swampy places on the margins of rivers, or in salt marshes, where they are usually seen in pools of shallow water, fluttering their wings, and shaking their half-bent legs, which causes them to appear as if they would tumble over, while at the same time they utter a sharp note, like the syllable 
rlich often repeated. Sometimes they may be noticed, collected in small parties, on open downs thinly covered with grasses and other kinds of regetation, rumming very gently, when, if alarmed, they frequently fly off in a straight line, and very close to the oround. Their mode of feeding is by scooping, or, as it seems, beating the soft ground with their flat and upturned bill ; and when thus engaged, they are frequently seen wading up to their breasts in the pools left by the receding tide. They never swim voluntarily, although furnished with feet so extensively palmated as to have induced the early systematists to place them amongst the swimming birds; nevertheless, this structure is an admirable provision for enabling them to traverse the soft and yielding mud in which they find their food.

The nest is generally formed of dry grasses, seaweeds, and small twigs, heaped up to the thickness of several inches, and placed among thick tufts of grass, in the neighbourhood of shallow water. The eggs are four in number.

The typical species is-

The Scooping Avocet (Recurvirostra Avocetta). The mpcurved form of the bill, which gives so singular an appearance to this bird, is most remarkable, being nnsuited to probe the ground, like that of the Snipe or Woodcock, or to break the shell of ordinary-sized mollusks ; the slightest frost, therefore drives the Avocet to the oozy muddy flats of estuaries, bays, and similar situations, where it can patter about with its wide-webbed feet, and gather small erustaceans and sea-worms. Those who have seen a Stork, or a Crane, with a frog at the tip of its long mandibles, and with an upward movement of the head drop it into its throat, will bave a good idea of the actions of the Avocet when it has eaptured a small shrimp, a marine insect, or any other small object upon which it lives, and will at once perceive that with such a peculiarly-formed beak it could not feed in any other manner. 


\section{SC'B.FAMILY IV.}

TRINGINe.

The Sandpipers.

Gex. Charac.-Bill generally longer than, or as long as, the head, slender, compressed on the sides, with the culmen near the tip slightly depressed and enlarged; the nostrils basal, and placed in a nasal groove that extends for two-thirds of the bill; the wings long and pointed; the tail moderate and rounded; the taris usually long and slender ; the toes more or less lons, and united at the base.

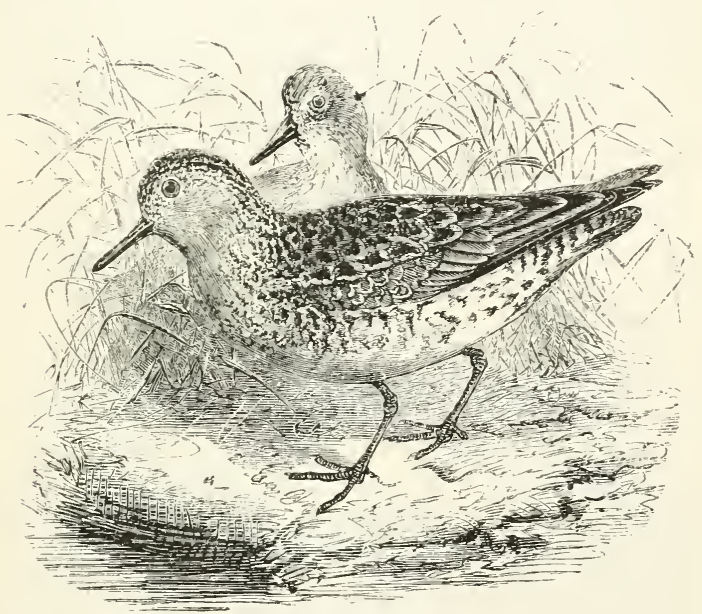

FIG 10.. THE KNOT SANDPIPER.

(Tinga canutux.)

These birds frequent marine marshes and the seashores as well as the borders of lakes and rivers. They visit the temperate climates during the winter, and return in large flocks to the colder latitudes to spend the summer months. Like many other birds which have this habit, they are common to both hemispheres, of which they seem to inhabit all the northern parts. During the recess of the tide, they may be seen upon the sea-shore collecting their food 
from the refuse of the ocean, or quietly and intently probing the moist sands in search of worms and small shell-fish; sometimes ruming quickly before the advancing surge, and profiting by what the wave leaves on its retreat. Their plumage is renewed twice in the year, and their summer, or, as it has been called, their nuptial attire, is very different from that with which they are clothed during the rest of the year. The upper plumage is black, with the feather's margined with reddish-brown and white, and the whole lower surface rich reddishchestmut. In the winter it is ashy-grey above, and white shaded with grey beneath. The colour of the two sexes is nearly alike, but the females are distingmished by their superior size.

The typical species, -

The Knot Sandpiper (Tringa canutus), is a winter resident in Great Britain; numbers of them arriving early in autumn, and spreading along our shores, take up their residence in bays, or at the mouths of rivers and other flat parts of the coast covered with ooze and sand, in which they find abundance of minute shell-fish, that constitute their usual fool. In such situations, collected in immense flocks, whose evolutions upon the wing are curious and very beantiful, they reside till the latter part of April or the beginning of May, when they again depart to the Arctic regions for the purposes of incubation and of rearing their young. Their polar migration extends to very high latitudes, as the Knot is enumerated by royagers as inhabiting the icy shores of Greenland and Spitzbergen.

When searching for food, the Knot Sandpiper traces the flow and recession of the waves along the beach with great nimbleness, warling and searching among the loose sand for its farourite food, which consists of the small, thin, oval, bivalve shell-fish, of a white or pearl colour, and not larger than the pips of an apple, which are common on the coast. These usually lie at a short depth below the surface, but in some places are seen at low water in heaps, like masses of wet grain. During the latter part of summer and autumn these minute shell-fish 
constitute the food of almost all those busy flocks that run with such activity along the sands among the flowing and retreating waters. They are always swallowed whole, but the action of the bird's stomach, assisted by the shells themselves, soon reduces them to a pulp, which must be very nutritious, as the tribes that feed on these little mollusks are, at this season, generally extremely fat. Digging for these in the hard sand would be a work of considerable labour, whereas, when the sand is loosenerl by the flowing of the sea, the birds collect them with great ease and dexterity. It is amusing to observe with what adroitness they follow and elude the tumbling surf, while at the same time they seem wholly intent on collecting their food. They are plump birds, and by those accustomed to the sedgy taste of their flesh, are esteemed excellent food.

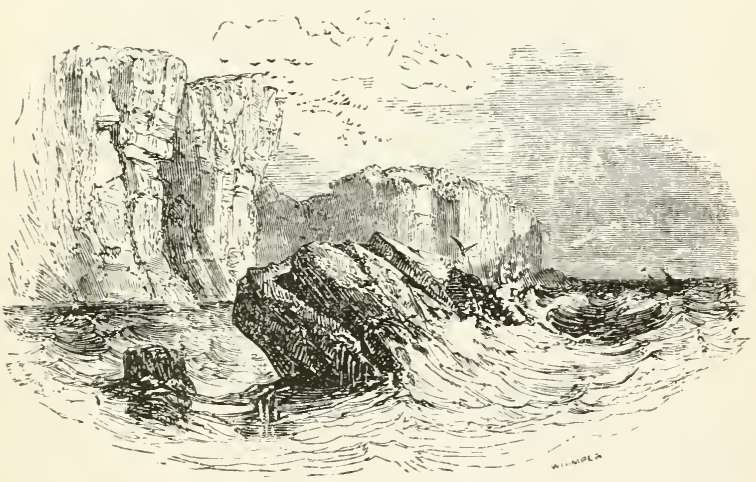




\section{S'UB-FALILY V.}

ŚROLOPAC'ISE.

The sinipes proper.

Grix. Снакіс--Bill long, straight, rather slender, compressed on the sides, and rather depressed and turned down near the tip, which is obtuse and hent wer that of the lower mandible; the nostrils placed in a narrow longitudinal groove, with the opening linear and covered by a membrane; the wings moderate and pointed; the tail short and rounded; the tarsi more or less long, and covered in front with narrow transverse scales; the toes long, rather slender, with the hind toe short, elevated, and reaching to the sround.

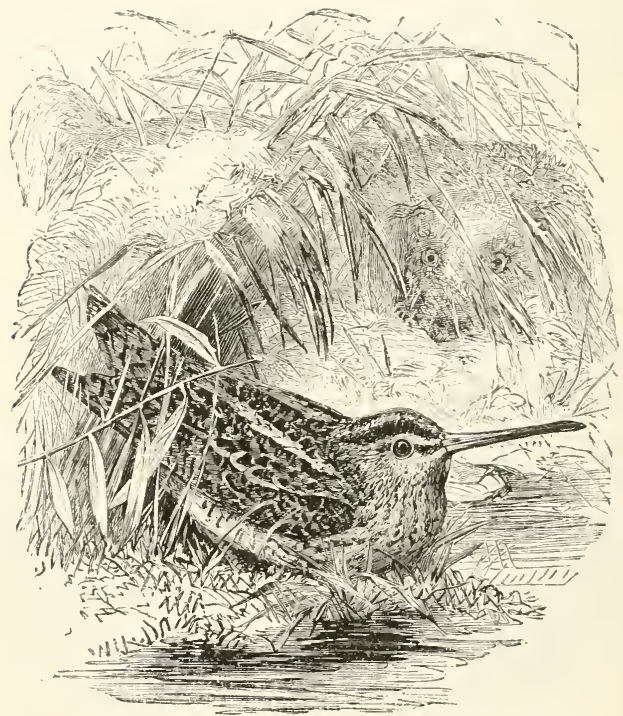

FIG. 186.- THE COMMOX SNHE.

(Scolopax gallinago.)

'These birds frequent swampy woods, marshes, morasses, and the borders of rivers. 'Their usual time for seeking their food is early in the morning' and during the twilight of the evening. They subsist principally upon insects and worms; for these 
they search among the decayed leaves, and probe the mud and ooze with their lengthened bills. When alarmed, they generally lie close to the ground, or among the grass, or, suddenly starting on the wing, escape by flight, which is short but elevated, rapid, and irregular. The eggs, which are four in number, are deposited on the ground. In the Snipe, and all its immediate allies, the bill is thickened, soft, and very tender at its extremity; so that this part, which is richly supplied with nerves, serves as a delicate organ of touch, and is used for searching in the soft ground for the insects and worms that constitute the food of these birds. It is migratory in its habits, and generally breeds in high northern latitudes; nevertheless, it is truly indigenons in this country, in all parts of which it is known to rear its young, but more especially towards the north.

The Common Snipe (Scolopax gallinago) is a small bird, weighing about four ounces. The bill is nearly three inches long, rather flat, and very smooth at the tip in the living bird, but after death it soon becomes shrunk and corrugated. The Snipe frequents marshy places and wet meadows, and in frosty weather the edges of rushy hills, where it is almost constantly probing and nibbling in the soft mul. Its food consists of worms, insects, and slugs, which abound in such places. In these retreats the Snipe, when undisturbed, walks leisurely with his head erect, but when alarmed it usually springs and takes flight beyond the reach of the gun, turning nimbly in a zigzag direction for two or three hundred paces, and sometimes soaring out of sight. The Snipe, like the Woodcock, shuns the extremes of heat and cold, by keeping upon the bleak moors in summer, and seeking the shelter of the valleys in winter. In severe frosts and storms of snow, driven by the extremity of the weather, these birds seek unfrozen marshy places, springing rills, or any open streamlet of water, and there they will sometimes sit till nearly trodden upon before they will take flight. Although it is well known that numbers of Snipes leave Great Britain in the spring, and return in the autumn, yet it is equally well ascertained that many 
constantly remain and breed in various parts of the country, for their nests and young ones have been so often found as to leave no doubt of the fact. The female makes her nest, which is very inartificially composed, of withered grasses and a few feathers, in some retired spot, generally under the stump of an alder or willow. The exos, which are large and usually four in number, are pale yellowish-or greenish-white, with rather elongated rusty spots at the larger end. Sir Humphry Davy describes the parent birds as being extremely attached to their young, and says that if any one approaches the nest, they make a loud and drumming noise above the head of the intruder, as if to divert his attention. The young rom off soon after they leave the shell, but they are attended by their parents until their bills have acquired sufficient tirmness to enable them to provide for themselves.

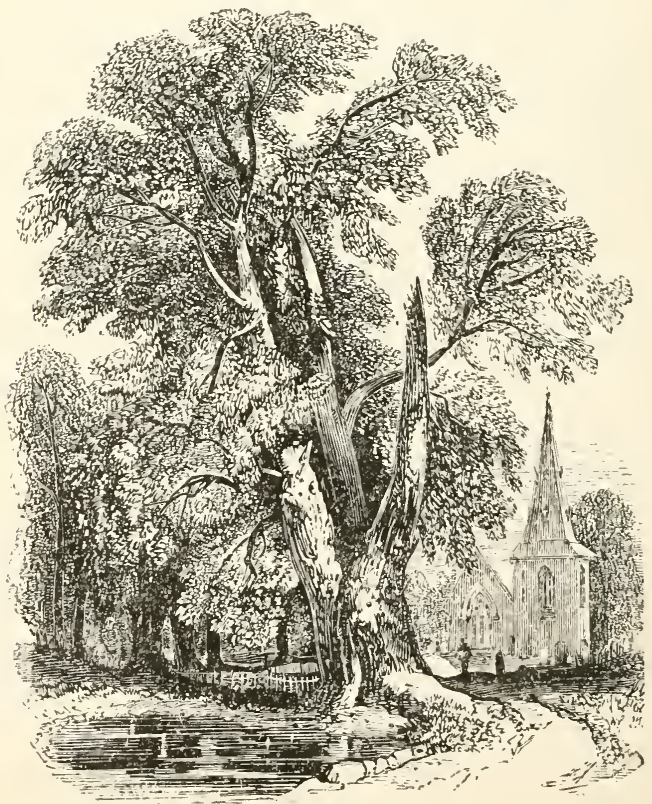




\section{$S C B-F A I I L Y$ VI.}

Phalaropodin.e**

The Phaluiopes.

Gex, Charac. - Bill as long as, or longer than, the head, more or less slender, and straight, the culmen straight, except at the tip, which is curved, the sides of the upper mandible curved for nearly its whole length; the nostrils placed in the lateral groove, with the opening linear; the wings long and pointed; the tail short and rounded; the tarsi short and more or les robust; the toes moderate, united at the base, and more or less lobed on the sides to the tips, the hind toe short, elevated, and margined slightly by a narrow membrane.

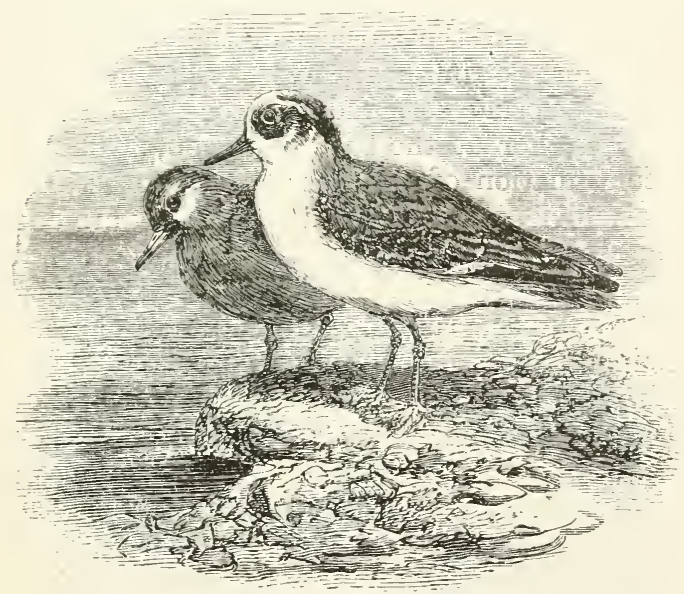

Fig. 187. -THE GREY PHALAROPE.

(Phalarope hyperborealis.)

These birds are inhabitants of the northern regions, but migrate to more temperate climates during severe winters. They are usually seen in pairs, or in small parties, swimming rapidly about on the sea, or on lakes, ponds, and streams of fresh water, generally near the margins, in search of floating seeds, aquatic insects, or small crustaceous

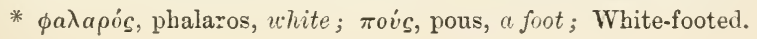


animals on which they subsist. 'They swim with great facility and swiftness, and their Hight is rapid and elevated.

In the Phalaropes the formation of the bill is nearly the same as that of the Knot, but it is mole depressed throughont its length, and the tip comes to a sharper and more determinate point. The general contour of the body is also similar to that of the 'Tringas, but the extensire development of the web connecting and bordering the margins of the toes, as well as the thick and closely-set plumage of the under parts of the body, indicate more aquatic habits; and accordingly we find that these birds are often seen upon the surface of the ocean, even in the midst of the roughest waves. Their plumage is thick and closely set, and the toes, besides being united together at the base by a web, are bordered by a contimuation of that membrane, so as to make the feet efficient paddles, although they are equally adapted for progression on dry land; so that these are birds of varied accomplishments, flying rapidly like the Snipes, running after the fashion of the Sandpipers, and swimming with the facility of Ducks. Their usual habitat is in the Arctic and Northern Seas. During the breeding season they repair to the coast, where they build a neat nest, composed of grass and weeds, upon the sea-shore, in some slight hollow on the ground. The eggs are four in number.

\section{The type of this sub-family is-}

\section{The Grey Phalarope, or Lobe-foot (Phalaropus hyper-} boreus). These birds are inhabitants of the north-eastern parts of Europe and Northern Asia, where they are numerous upon the large lakes and rivers of Siberia; they also abound in North America, but their range, even during their migrations southward, does not seem to extend far beyond the limits of the Arctic circle. In their habits they are much more aquatic than the Tringas, passing the greater part of their lives upon the water, where they swim with great buoyancy and ease. But it 
does not appear that they have ever been seen to dive, either while feeding or when endeavouring to escaje from threatened danger. They fly with great strength and swiftness, and when on the wing are not easily distinguished from the Tringas, although when on land they are inferior to them in lightness and agility. The lobed feet of the Phalaropes give them, however, a great advan. tage in enabling them to walk on the soft and oozy murl which covers the sides of creeks and estuaries, among which they find their principal food, consisting of insects, worms, and minute mollusca. Their most remarkable habit seems to be that of alighting at sea on berk of floating sea-weed, upon which they run with light and nimble pace, after the manner of a Wagtail : they are often met with thus employed a hundred miles from land. The Phalarope builds a nest of grass in the marshes, or on the islands of inland lakes, and lays four eggs, of a dark olive-colour closely spotted with black.

The length of this species is seven inches.

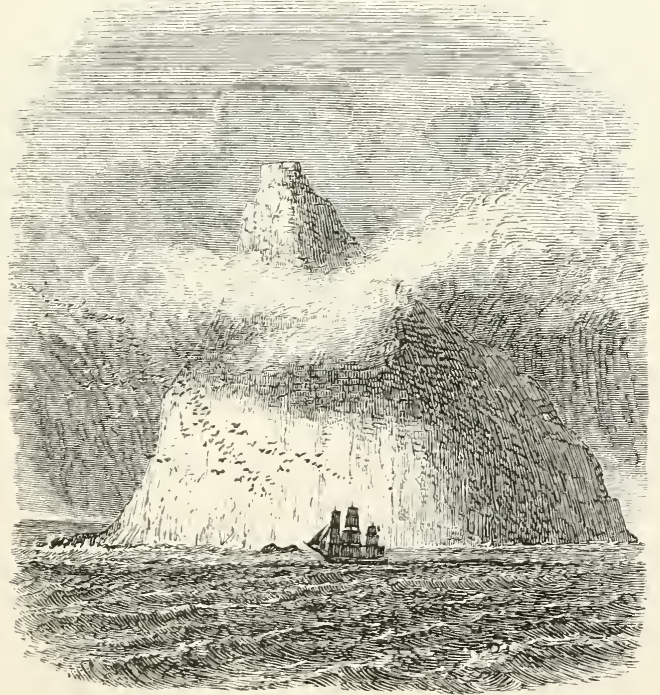




\section{FAIILY IV.}

PALAMEDEIDE.**

The Screamers.

GEx. CHARAc,-Bill generally long and slender, with the culmen depressed, straight at the base, the apical parts vaulted, and the tip overhanging that of the lower mandible, the gonys short and sometimes angulated; the nostrils lateral, generally placed near the middle of the bill, and longitudinal; the wings long, and generally armed at the shoulder with an aeute spine or blunt tuberele; the tail generally short and slightly rounded; the tarsi long and slender; the toes very long and slender, and furnished with long and straight, or short and slightly-curved claws, the hind toe long, and furnished with a more or less long and acute claw.

Widely as we have already seen the feathered tribes distributed, there are still localities to be met with as yet unfurnished with appropriate occupants. The surfaces of lakes and ponds, for example, in tropical countries are frequently covered over with luxuriant vegetation to such a degree that they might almost be said to be carpeted with verdure too unstable to support the weight of birds of ordinary construction, and at the same time too dense to give passage to swimming water-fowl. To meet the requirements of such situations, which from their great extent are by no means unimportant, a numerous family has been specially constructed, able, by means of their lengthened toes, to walk over the floating leaves, and to give animation by their cries and their quarrels to regions which without such contrivance would remain silent and desolate.

This family includes the Jacanas, or Tank-rumner's, and the Screamers properly so called.

* From $\pi a \lambda a \dot{\mu} \eta$, palame, the palm of the hand; So called from their great extent of foot. 


\section{$S U B-F A U I L Y I$.}

Parrixte.

The Jacanas.

Gen. Charac.-Bill lengthened, slender, with the culmen straight at the base and vaulted at the tip, which is entire; the nasal groove long and narrow, and the opening of the nostrils placed in the middle of the bill, small, and oval; the wings more or less long and pointed; the tail generally short; the tarsi long and slender; the toes very long, slender, and armed with long slender claws, especially the hind toe.

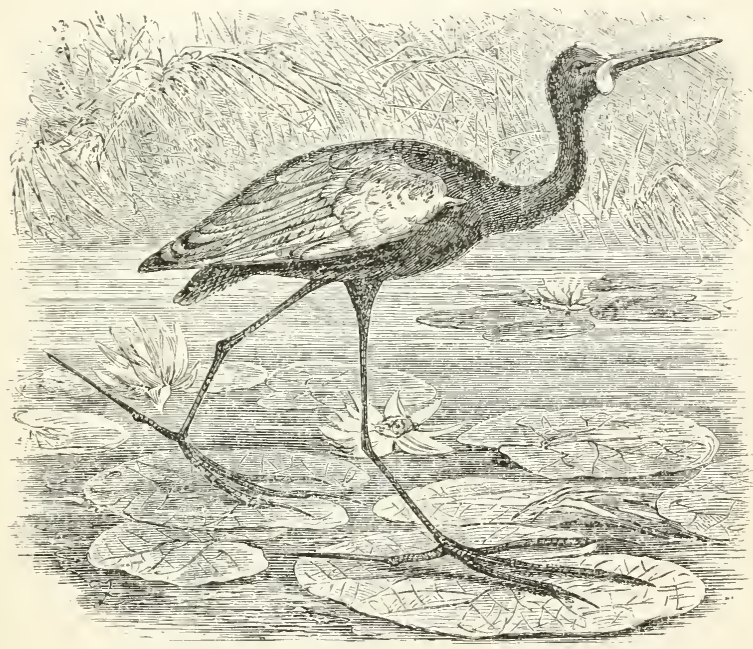

Fig. 188.-THE JACANA.

(Parra Jacana.)

These remarkably-footed birds are found in the warmer parts of Asia, Africa, and America. They frequent marshes and the sides of rivers and ponds, generally in pairs or small flocks. Their shy and timorous habits induce them, when alarmed, to dive into the water, and skulk among the reeds and other kinds of herbage : occasionally they seek safety by a short flight. The remarkable length of their toes 
and claws enables them to run with great facility over plants that float on the surface of the lakes and marshes in broad patches. 'Their food consists of aquatic insects and the buds and seeds of vegetables. The female makes her nest among reeds; her eggrs are four in number.

An African species, whose body is not larger than that of our common Snipe, has such enormous feet that its fore toes measure no less than three inches and a quarter, and its hind one two inches and a half in length. By this remarkable structure the Jacana is cnabled to walk upon half-floating leaves, and thus appears at a distance, where its support is not seen, to walk upon the surface of the lake. It is precisely upon the same principle that the snowshoes are constructed, whereby the Canadians are enabled to walk with ease upon the yielding snow.

The type of this sub-family is-

The Common American Jacana (Parra Jacana), met with abundantly throughout the warmer regions of the Western hemisphere. 


\section{Palahedeina. \\ The screamers proper.}

GEN. Charac.-Bill short, with the eulmen sloping and eurved to the tip, and the sides compressed; the nostrils large, and placed in a membranous groove, lateral, and exposed; the wings rather lengthened, with the shoulder armed with two strong spurs; the tail moderate; the tarsi lengthened, robust, and covered with numerous small seales; the toes lengthened, the anterior ones united by a short membrane; and the claws long and curred.

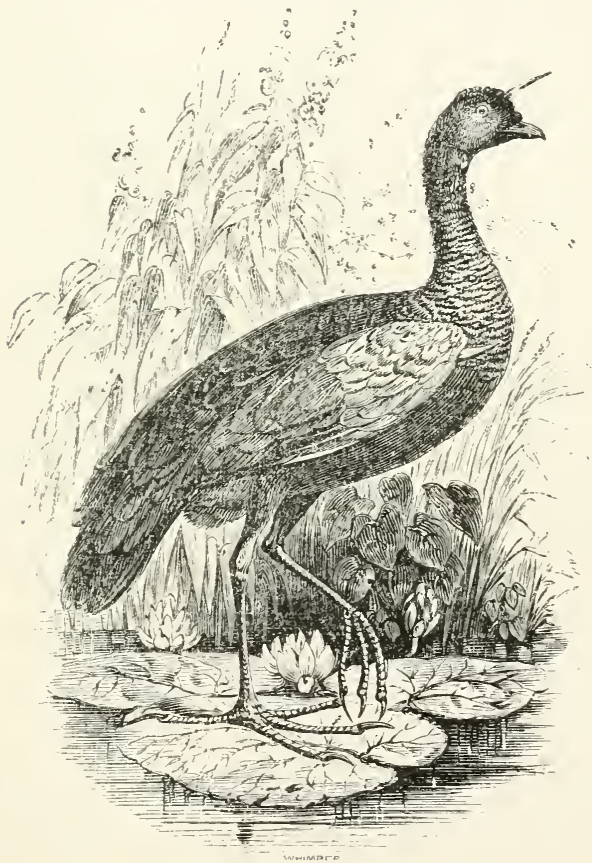

FIG. 189.-THE HORNED SCREAMER.

(Palamedea comuta.)

These birds inhabit the marshy grounds of the northern parts of South America, especially those that are situated near the sea. They are generally 
found associated in pairs, and are very shy and timid, but soon betray themselves by their vociferation. When at rest, they generally perch on the branches of lofty trees. Seeds and the leaves of aquatic plants constitute their usual diet. Their wings are armed with formidable claws, capable of being used with much effect as weapons of offence.

\section{The typical species,-}

The Horned Screamer (Palamedea cornuta), is found in Cayenne, Guiana, and Surinam, amid vast swamps and savannahs teeming with animal life. Here a continual discord of jarring sounds arises from the contending voices of the multifarious inhabitants; but above them all is heard the startling voice of the Horned Screamer, vyhoo ! vyhoo ! loud, clear, and shrill. But it is not for its voice alone that this bird is remarkable; on the elbow of each wing are two large hard spurs, projecting directly forwards. Snakes of various sizes, all rapacions, and all to be dreaded, lurk in the haunts frequented by the Screamer, and these formidable weapons enable the bird to defend itself and its young against their assaults. If not attacked, the screamer molests neither reptiles nor birds; its halits are shy, its manners are gentle, and it lives in pairs united for life. It wades in search of the leaves and seeds of aquatic plants, on which it feeds, and for which its muscular gizzard is adapted, though some have asserted that reptiles constitute its food. Its flight, as might be expected from the length and spread of its wings, is strong and sweeping, and when on the ground it walks with an air of pride, keeping its head elevated, so that it was formerly regarded by many as an aquatic kind of eagle. Upon its head is a curious horn-like appendage, from three to four inches in length, and about as thick as a goose-quill : the use of this remarkable horn is quite unknown. The roice of the Horned Screamer is loud, shrill, and uttered so suddenly, and with such vehemence, as to have a very startling effect. The female is said to build her nest on the ground at the foot of a tree, and to lay two eggs, resembling those of a Goose. 


\section{FAMILY V.}

RALlide.

The Rails.

GEx. CHARAC.-Bill more or less long, with the culmen sometimes advancing on the forehead, but always curved at the apex, and the sides compressed, the gonys usually ascending; the nostrils lateral, and placed in a membranous groove; the wings moderate and generally rounded; the tail more or less long and rounded; the tarsi long and rather slender; the toes mostly lengthened and slender; the claws short, compressed, and acute.

This family consists of several genera of birds, most of them of aquatic or semi-aquatic habits, ranging in this respect from the diving and swimming Coot to the terrestrial Land-Rail, and exhibiting modifications of the typical form according to the nature of the locality tenanted, be it lake, morass, or meadow. The members of this family are so constructed as to be able to thread their way through beds of the thickest stems of reeds, bulrushes, and other aquatic plants, among which they seek shelter or concealment,-or, as in the case of the Land-Rail, through the tall grass of the meadow, - and that so rapidly and noiselessly, that they elude pursuit with great ease, and seldom can be forced to take wing. To adapt them to such a mode of life, the shape of their body is much compressed on the sides, owing to the structure of the breastbone, which is very narrow. In all, the toes are long and spreading, enabling them to pass over soft ooze, or even the flat leaves of the plants which float in close array upon the surface of the water. Their beak is generally strong, often remarkably so ; but in this respect there is much variety in different genera. Many of them swim habitually and with facility. The feet of most of the species, however, are divided, and without webs; but in some (the Gallinules) the toes are bordered along their sides by a narrow edging, which is an extension, as it 
were, of the sole of the foot. The plumage of the Rallida is soft and loose, and their wings, with few exceptions, are short and rounded. 'They feed on aquatic plants, grasses, and seeds, as well as on worms, insects, and mollusca. 'They generally make a large nest, and lay numerous egos.

They are divisible into two sub-families, one of which comprehends the Rails proper, the other the Gallinules, or Moorhens.

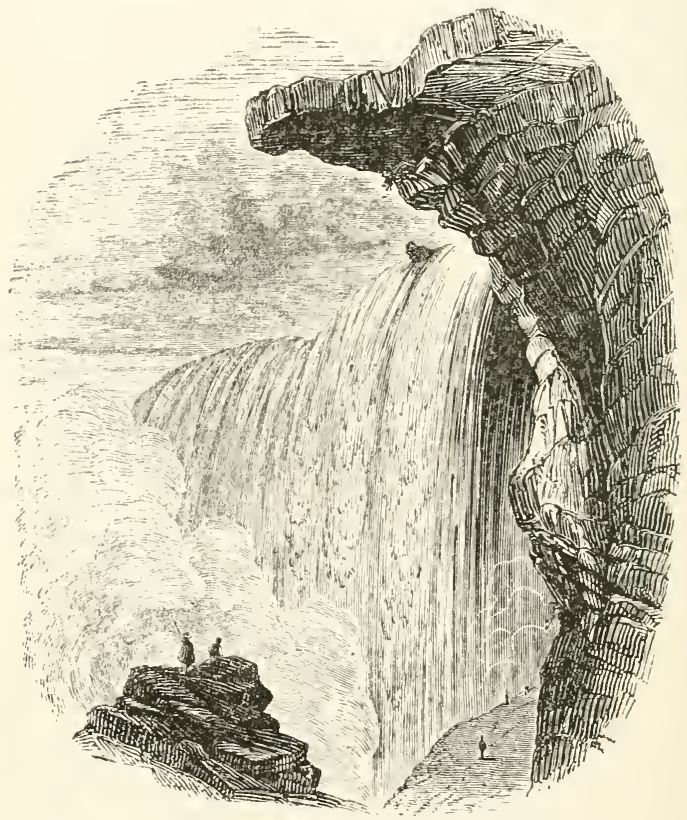


RALLINE.

The Rails proper.

Gen. Charac.-Bill more or less long and slender, with the culmen keeled and curved at the apex, and the sides compressed; the nostrils lateral, with the opening placed in a membranous groove; the wings moderate, with the first quills usually graduated; the tail mostly short and rounded; the tarsi long and slender; the toes more or less long and slender, and free at their base.

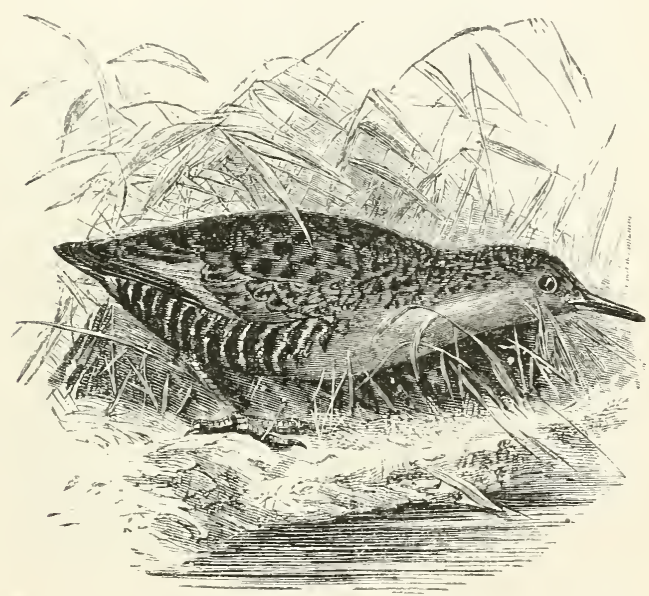

Fig. 190.-The Water-rail.

(Rallus aquatisus.)

The birds composing this sub-family are found in all temperate climates. They inhabit marshes and the borders of rivers, more especially those fringed with reeds or aquatic plants adapted to afford them refuge, and between which the compressed form of their body enables them to pass with facility. Their Hight is awkward and slow, but they are capable of swimming and diving, and, from the length of their toes, can run over the surface of the water, supported 
by the floating vegetation. Their food consists of worms, slugs, and insects, as well as the leaves and seeds of water-plants. The nest is composed of sedge and coarse grass. The egrgs are usually from ten to twelve in number.

\section{The typical species,-}

The Water-Rail (liallus aquaticus), is permanently resideut in this country, where it is to be found at all times of the year, although, from its shy and solitary habits, and the peculiar localities that it frequents, it is not so frequently seen as might be expected. The haunts of the Rail are marshes, pools, and water-courses, particularly such as are covered or bordered with dense aquatic herbage and reeds, in which it finds shelter and refuge, being enabled, by the narrow form of its head and body, to pass through the closest beds of these plants with great facility. To the above property is owing its principal security, as when forced upon wing its flight is awkward and slow, with the legs hanging down, and offering an easy aim to the sportsman. Few dogs are able to force it into view before it has gained its retreat, which is not unfrequently a rat-hole, or amidst the entangled roots of a stunted willow or alder-bush. When disturbed, it will occasionally run along the surface of the water, supported by the floating herbage, for which purpose its feet are well adlapted, covering, when expanded, a large area. It can also dive with readiness. Worms, slugs, and insects are its food, to which may be added the leaves and seeds of particular water-plants. The nest of the Water-Rail consists of a mass of sedges and coarse grass, collected amidst the thickest herbage of its haunts. The eggs are seven or eight in number, and their colour is buffy-white spotted with brown; the young are odd little creatures, -round, and covered with a soft thick down. Almost immediately after their emancipation from the egg-shell, these little puffy balls of down tumble into the water, and swim about as merrily as if they had been accustomed to the exercise for years. 


\section{SUB-FAMILY II.}

\section{Gallinuline.}

The Gallinules, or Moorhens.

Gen. Charac.-Bill short, with the culmen more or less elevated and advancing on the forehead, and the sides compressed; the wings short and rounded; the tail short and rounded; the tarsi long and slender; the toes very long, slender, and more or less margined on their sides, and the hind toe long; the claws generally long and slightly curved.

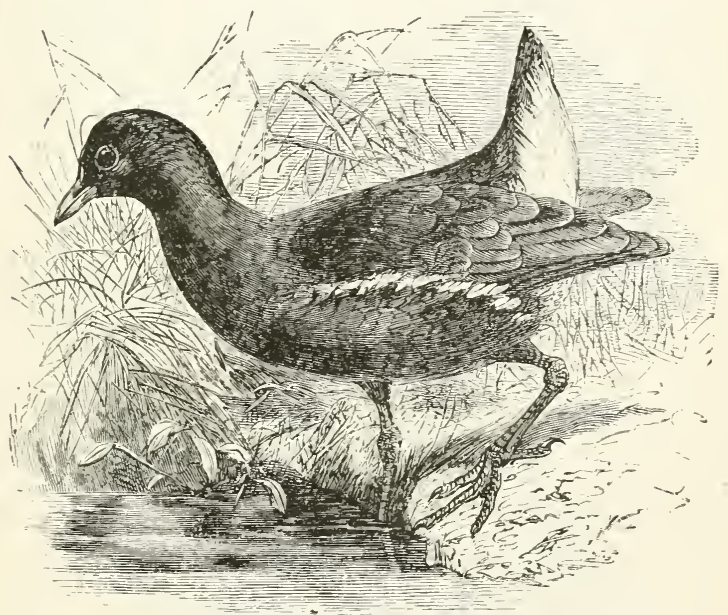

Fig. 191.-THE COMMON MOORHEN.

(Gallinula chloropus.)

These birds are much more aquatic in their habits than the Rails; they swim with ease in a singular floating manner, continually striking the water with their tails. When approached and alarmed, they have recourse to diving, using their wings to assist their progress under water, or they take wing, skimming along the surface to the first cover that may be available, where they remain concealed. On the land these birds walk about with facility, flirting up 
their tails at intervals, and are enabled, by the compressed form of their bodies, to run swiftly through covert and entangled herbage, and even to pass through very narrow openings. From the length of their toes they can walk over considerable spaces of still water, supported on the floating foliage of aquatic plants. 'Their food consists of slug's, worms, and insects, together with various kinds of grain and vrgetable substances. Their nest is usually formed in a retired spot, among the reeds by the side of the water : it is a thick mass of interlaced decayed herbage, rushes, and flags. These birds frequent the borders of rivers, lakes, and brooks, expecially where the current is slow and deep, and the stream bordered with reeds and sedges, amongst which they retire during the day.

\section{The typical species is-}

The Common Moorhen (Gallinula chloropus). The situations affected by the Moorhen are the sedgy banks of lakes and rivers, reedy pondś, moats, beds of osiers, wet ditches, \&c. It is naturally shy and rechuse, aroiding the presence of man by immediately retreating from the open parts to the thick covert, or shrouding itself from observation by diving and remaining half submerged - until the apprehended danger has disappeared. This natural shyness, however, is frequently orercome, and the bird rendered semi-domesticated, when its singular but graceful actions contribute to our pleasure and anusement. On the water the Moor-fowl is as bioyant as a cork, and its powers of swimming are as perfect as those of most of our water-birds ; neither is it by any means ungraceful on the land. Its neatly-trimmed body, richlycoloured bill, and red-gartered green legs, contrast strongly with the sombre tint of its plumage. It frequently leaves the sedgy coverts and walks quietly over the grassy meads, lawn, pleasure-ground, or garden, with all the ease of a land-bird, flirting its tail from side to side, and conspicuously displaying the white coverts, especially during the season of courtship. At this particular period the Moorhen becomes animated and noisy; the short harsh ery of the males is then heard from the midst of 
the thick reeds, and if a closer inspection were admissible, many battles and skirmishes between then would be witnessed for the choice of a mate. The Moorhen's energies are also aroused in an extraordinary manner when a rat swims across the river, and perchance lands in the neighbourhood of its nest. "I have seen," says Mr. Gould, "a Moorhen furious at such an intrusion; and from the manner in which the rat has been assailed, I suspect he would avoid that locality for the future. Boldness and pugnacity appear to be part of the Moorhen's nature, and its quarrelsome dispesition renders it an unpleasant neighbour to any peaceful bird that may live in close contiguity." His food consists of aquatic insects and their larvæ, mollusks of various kinds, every species of grain, and the shoots of young wheat and other cereals. The nest is sometimes placed on the flat branch of a tree, at others on stumps near the water's edge, among reeds, or on large floating masses of weeds. It is usually made of rushes, and is somewhat carelessly constructed. The eggs, which are from six to eight in number, are of a reddish-white, thinly spotted and speckled with dull orange-brown.

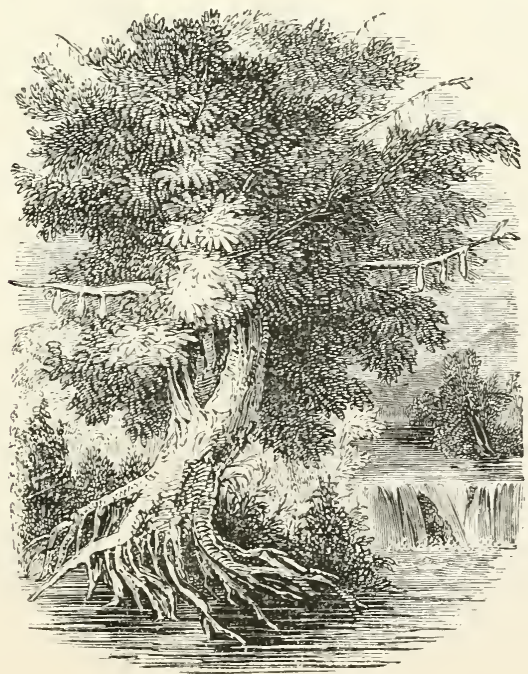




\section{O R D E R VII.}

Palmipedes.*

'THe birds belonging to this Order display decidedly aquatic habits. They swim with facility, haunting rivers, lakes, and seas, and their whole structure adapts them for such stations; hence they have obtained the expressive name of water-fowl. As a rule, they are awkward on land, and the more so the more exclusively they tenant the water, for in order to render the stroke of their paddle-feet effective, their legs are placed behind the centre of gravity, and thrown as far back as possible; hence, on the ground, these birds have either to maintain their balance by dint of muscular exertion, as we see in the Swan when it labours over the grassy bank, or, as in the Grebe, they are obliged to assume an erect attitude. The feet are webbed, but in a different manner in different families. 'The form of body in the water-birds is boat-like, and in those that dive the ribs are strong, and carried down so as almost entirely to surround and defend the internal viscera from undue pressure. The plumage is thick, close, and waterproof. There is a dense under-garment of down overlaid by large, sometimes silky feathers, which throw off the water as if their surface was oiled. In many the neck is long and the tail very short; in some the tail, composed of rigid plumes, acts as a rudder in the act of diving. A few are utterly incapable of flight, and use their wings as paddles in the water. From among these birds man has reclained several species for the sake of their flesh, which is excellent.

This Order comprises the Ducks, the Divers, the Auks, the Petrels, the Pelicans, and the Gulls.

* In the "Tabular View" this order is named Anseres. 


\section{FAMILY I.}

Axatide.

The Ducks.

Gex. Charac.-Bill generally depressed, broad, and always laminated on the sides, the lamination being more prominent in some species than in others.

The birds belonging to this family, of which the Geese and Ducks are familiar examples, are easily distinguished from all the rest of their order by the peculiar structure of their bill,* which is broad, and furnished with a covering of soft skin ; the edges of both mandibles, moreover, exhibit a series of fine tooth-like lamellæ, or plates, which interlock when the mandibles are nearly closed, so as to form a sort of strainer. The feet are well developed, and the anterior toes are united by an ample web. The hinder toe is small, free, and raised more or less on the back of the tarsus. The wings are tolerably large and powerful, enabling the birds, notwithstanding their bulky and rather heavy bodies, to fly with considerable ease and rapidity ; many of them, indeed, are migratory, and perform long journeys to and from their breeding-places, often at a considerable elevation. They are generally gregarious, and most of them frequent fresh water, although they are often seen on the sea-shore in the winter season. Their food consists chiefly of worms, aquatic insects, and mollusca, which they obtain by straining the mud and water through the fine lamella of their bills. For this purpose they have their tongues very largely developed, soft, and fleshy; and when we consider the particular use that the Duck makes of this organ, we shall perceive that it is endowed with great and unusual sensibility. The Duck, unlike other birds, discriminates its food, not by sight or by smell, but by

* See "Animal Creation," page 471. 
the tonch of its tongue. It thrusts its bill into the mud just as a fisherman casts his net into the sea, and brings up whatever it contains; from this monthful of stuff it selects, by the tongme alone, what is good for food, and everything else is rejected. The gizzard of the Anatida is muscular, and lined with a tough skin, so as to be able to grind down the substances on which they feed. 'The framework of the body of the Natatorial Birds is differently constructed from that of the Terrestrial Orders. 'In the aquatic tribes, the breast-bone and ribs extend along the entire length of the thorax and abdomen, and thus that part of them which is in the water does not move in the act of breathing, but remains perfectly steady. They are ribbed much in the same way as the hull of a ship, and any change of form which they undergo while swimming takes place in that part of their body which is raised above the water. Moreover, in their shape these birds are fashioned in strict conformity with the kind of life to which they are appointed. If their principal occupation requires them to remain nearly stationary, floating and dabbling in the water, their body is shaped somewhat like a punt; if they are to fly rapidly through the air, their form is narrowed posteriorly, as in the Terns, or Sea Swallows; and if destined to dive and shoot along wholly immersed in the water, they taper towards the forepart, as is exemplified in the Divers.

The nests of the Anatida are generally placed upon the ground, amidst coarse herbage, by the bank of a lake or river; they are principally composed of grass and other vegetation, and lined more or less carefully with down and feathers.

To this family belong the Flamingoes, the Spurwinged Geese, the Geese proper, the Swans, the River-Ducks, the Sea-Ducks, the Spine-tailed Ducks, and the Mergansers. 


\section{$S T B-F A M I L Y I$.}

Phomicopterin.e.*

The, Flamingoes.

Gex. Charac. - Bill large, compressed, suddenly bent downwards in the middle, and the lateral margins laminated; the tarsi very long, slender, with the tibia also lengthend and naked; the toes short, the anterior ones united by a membranous web.

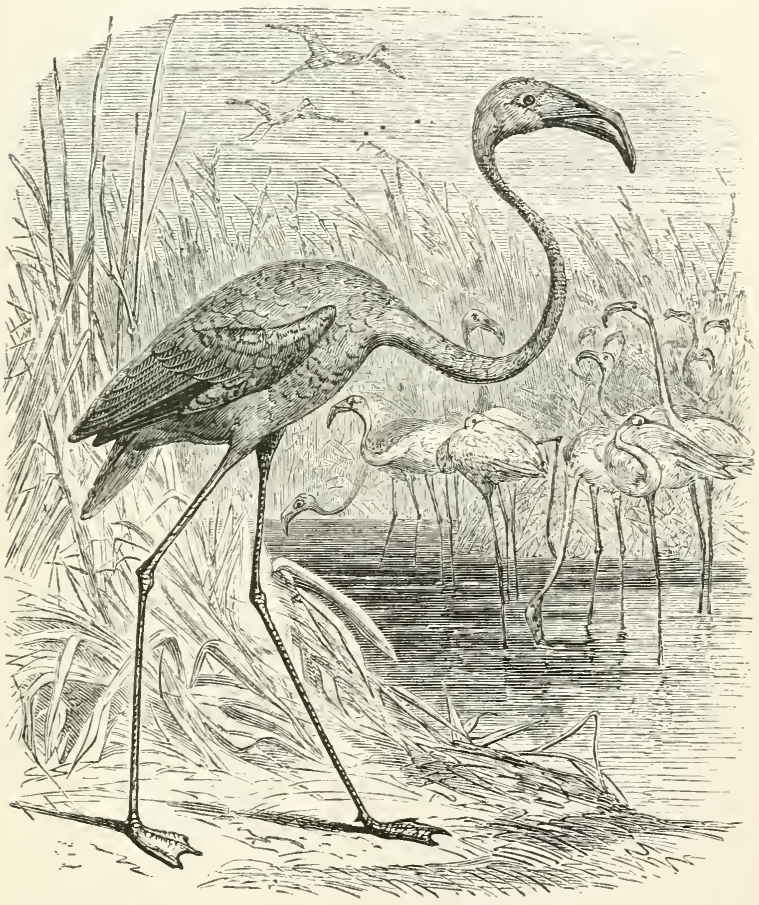

Fig. 192.-THE FLAMIXgo.

(Phonicopterus ruber.)

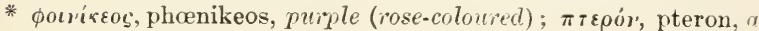
uing; Red-winged. 
These remarkable birds are widely distributed throughout the warmer parts of the world. They are nsually observed upon the sea-shore, or in the salt marshes, in flocks, consisting of many individuals, one of which generally acts as sentinel while the others are feeding or resting. They fly in a triangular phalanx, but alight in a straight line, and generally remain so while seeking their food. They are capable of running quickly, but when walking sometimes assist themselves by placing their upper mandible on the ground. They live upon shell-fish, the spawn of fishes, and marine animals, which they procure by means of their curiously-shaped bill, turning the upper mandible towards the ground, and using it as a scoop. As the Flamingo stalks abont upon its long stilt-like legs, or wades in the shallow waters, it holds down its long neck towards the ground, and the peculiarlyformed upper mandible is thus turned back downwards, and constitutes a receptacle for any small objects in the mud or water. These are strained out by the lamella of the mandibles, assisted by the spines which fringe the fleshy tongue; and the Flamingo is thus enabled to retain the small fishes, mollusca, and crustacea that constitute its food. The Flamingo is an inhabitant of sonthern Europe, Africa, and Asia ; it is a large birl, old males often standing nearly five feet in height; and as it is gregarious in its habits, collecting in large flocks upon the seacoast, its bright red wings give these parties a close resemblance to bodies of soldiers standing in line. 'The nest is a very curious structure, being a small hill of mud, about a foot and a half high, with a concavity in its summit. In this the female lays two or three eggs, of about the size of those of a goose, which she hatches by sitting astride upon the hillock. The young do not fly until they have nearly attained their full growth, though they can run very swiftly a few days after their exclusion from the egg. 


\section{The typical species,-}

The Red Flamingo (Phonicopterus ruber), is common on the American continent and in the West Indies. They abound on the island of Cuba, more especially on the sonthern side, either on its shores, or where many islets at some distance from the mainland afford them ample protection. In their flight they resemble Ibises, and they usually move in lines with the neck and legs fully extended, flapping the wings for twenty or thirty yards, and then sailing smoothly over a like space. Before alighting they generally fly in circles round the place for several minutes, when their glowing tints become more conspicuous. They very rarely alight on the shore itself, unless during the breeding season, but usnally in the water and on shallow banks, whether of mud or sanrl, from which, however, they often wade to the land Their walk is stately and slow, and their caution extreme, so that it is very difficult to approach them, as their great height enables them to perceive and watch the movements of their various enemies at a distance. When travelling over water, they rarely fly at a greater distance than eight or ten yards from the surface ; but when passing over the land, no matter how short the distance, they momt to a considerable elevation. The Red Flamingo builds upon the ground; the nest is an irregular mass of earth, dug in the saltponds, and entirely surrounded by water ; it is scooped up fiom the immediate vicinity to the height of two or three feet, and is hollow at the top: there is no lining, nor anything but the bare earth. The number of eggs is almost always two; the incubation is not known. The eggs are white, but on scraping the shell it has a bluish tinge. The colour of the young is nearly white, and they do not attain their full scarlet livery until two year's old. 


\section{STISFA.UII,Y II.}

\section{PLECTROPTERIX.e.* \\ The Spur-vinged Geese.}

GEx. Charac.-Bill long, generally of equal width throughout, and armed at the tip with a strong broad nail, the apieal part of the tibia and knee naked; the tarsi leugthened, compressed, and covered with small subquadrate seales; the toes moderate, and the anterior ones more or less united by a nembrane, the hind toe long, simple, aud generally elevated.

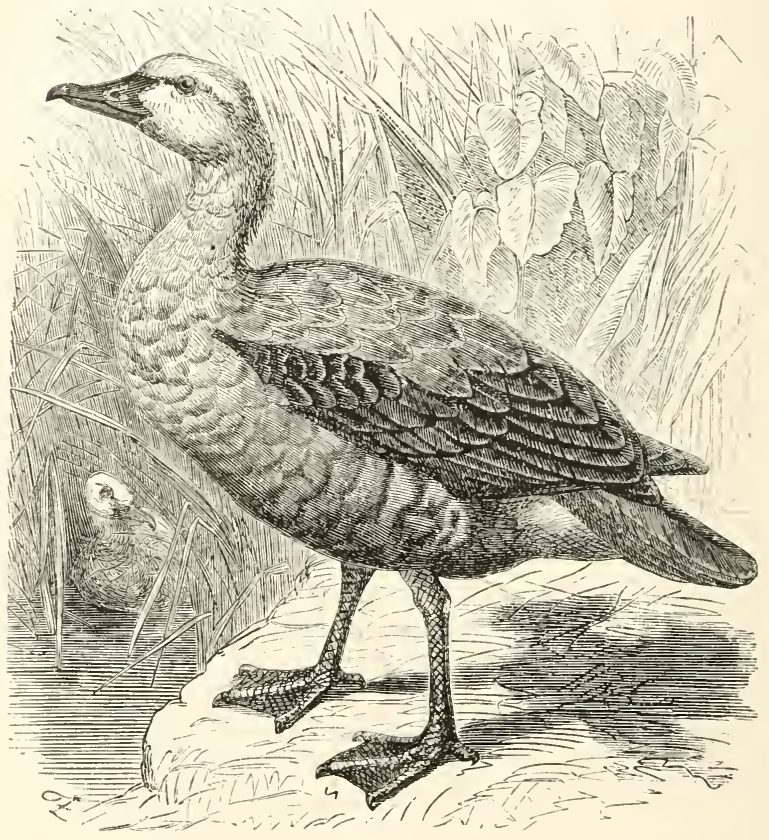

Fig. 193.-THE FOX-GOOSE.

(Chenalopex jubatus.)

The Geese belonging to this sub-family are remarkable on account of the structure of their wings, which are armed at the wrist with one or two sharp

* $\pi \lambda \tilde{j} \kappa \tau \rho o v '$, plektron, a cock's spur; $\pi \tau \varepsilon \rho o ́ v$, pteron, a wing; Spur-winged. 
spurs, somewhat resembling those on the legs of a fighting cock, wherewith they are able to inflict ugly wounds. Their flight is easy, and performed by slow flappings of their wings; and some of them have the faculty of perching, or even of roosting, upon trees. Most of the species are conspicuous on account of the glowing green colour of their wings and the varied tints of their plumage. They walk well, and are generally found in the neighbourhood of extensive marshes, where, on account of the length of their legs, they seem to prefer walking: to swimming. The best-known species,-

The Semi-palmated Goose (Anseranus melanoleucus), is peculiar to Australia. "When New South Wiales was first colonized, this fine species was very abundant on the Hawkesbury ; it is, however, no longer a denizen of that river, nor of any of the streams within the colony ; affording another proof that the progress of civilization invariably leads to the gradual extirpation of the more conspicuous of the natural productions of the countries over which it extends its sway. It is still abundant in such parts of the Port Phillip district as are unlocated by the settler, and as we progress northwards gradually becomes more numerous until we reach the rivers and lagoons which empty themselves into Torres Straits. Here it occurs in such countless multitudes that it forms one of the chief articles of the food of the aborigines. So dense are the flocks that occur in the northern parts of the country, that the natives are enabled to procure multitudes of them by spearing;--they only spear them when flying, and always crouch down when they see a flight of them approaching; the geese, however, know their enemies so well, that they immediately tum upon seeing a native rise and put his spear into the throwing-stick.(Gould, "Birds of Australia.")

The type of this sub-family is-

The Fox-Goose (Cherialope ${ }^{*}$ jubatus), so called, apluarently, on account of the tawny colour of many parts of its plumage.

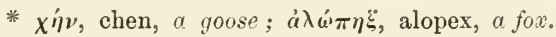




\section{$S U B-F A M I L Y I I I$.}

Axserin.e.

The True Geese.

GEx. Charac.-Bill as long as, or shorter than, the head, the culmen mueh elevated at the base, and gradually sloping to the tip, which is armed with a large broad nail, the sides compressed, and the marginal laminæ more or less apparent; the wings lengthened; the tarsi longer than the middle toe, and the knee naked; the toes short and strongly webbed, with the hind toe short, elevated, and searcely lobed.

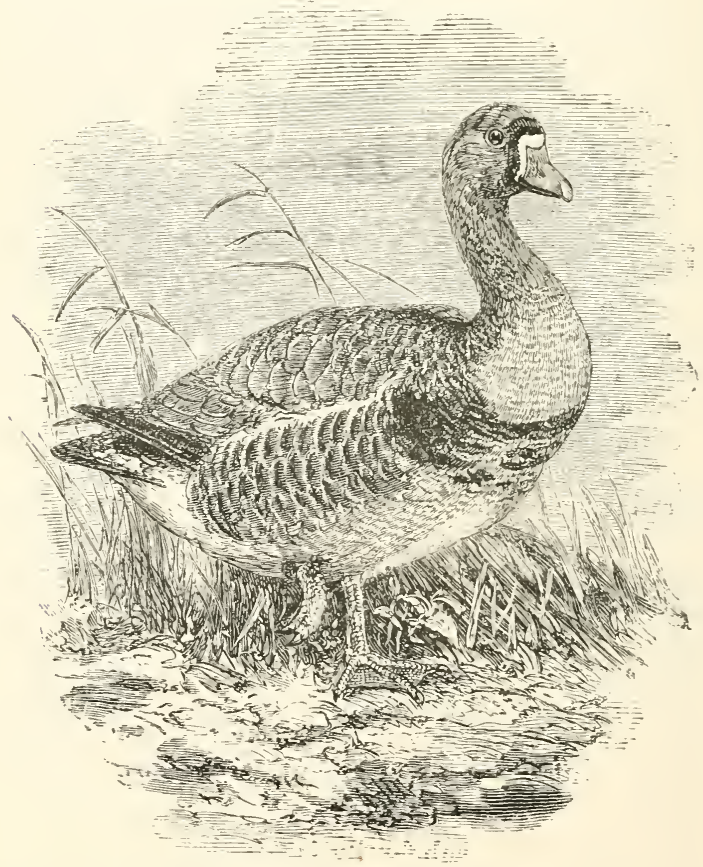

Fig. 191,-THE WHITE-FRONTED GOOSE.

(Anser allifrons.)

These birds seek the higher latitudes during the summer months, and as the winter appears, they 
return to the more temperate parts of Europe, Asia, and America.

From the central position of their legs, the moderate size of their feet, and the length of their tarsi, the Geese walk readily on land, and, indeed, are much more frequently seen there than on the water. They swim, however, with buoyancy and ease, but rarely dive, and only in cases of great emergency, when wounded or otherwise unable to escape.

In diet they are graminivorous as well as granivorous, that is, live upon grass as well as upon grain, indeed, chiefly on the former; and for procuring such kind of food their laminated bill is admirably adapted. For this purpose they seek the meadows of the interior of the country, and resort much to fields of young wheat and other grain. From the great size of their wings, their flight is strong, and they make rapid progress during their migratory journeys, as they can move at the rate of fifty or sixty miles an hour. In these flights ther advance in a diagonal line, or in two lines, meeting in a point like the letter $V$. They breed in the marshy districts of the countries to which they retire during the summer months, laying several eggs of a white or sullied white colour.

Many schemes are had recourse to in the north of Europe to capture wild geese. In Lapland they are taken during the spring in steel traps. 'These are set near to natural openings in the ice, where the birds are known to resort, and baited with the roots of the river horse-tail (Eyuisetum fluviatile), or of the Ranunculus aquatilis. When feeding in stubble-fields, or elsewhere, wild geese are also not unfrequently shot with the assistance of a stalkinghorse; and if the animal be well trained, great execution may thus at times be done. But in lieu of a steed, a so-called Slijut-Ko, or shooting-cow, is made use of. This apparatus, M. Grieff tells us, "is composed of strong canvas, in the form of a cow, and painted brown. For its easier transport, it is 
rolled up, and when used, is distended by means of several sticks. One of these is placed lengthwise, and one in each log, and there is besides an mattached stick, which serves to support the Skjut-Ko, when resting on the ground. At the shoulder there is a hole for the protrusion of the gum-barrel. The accompanying humorons sketch gives no bad idea of the device in question.

The type of this sub-family is-

The White-fronted Goose (Anser albifions).

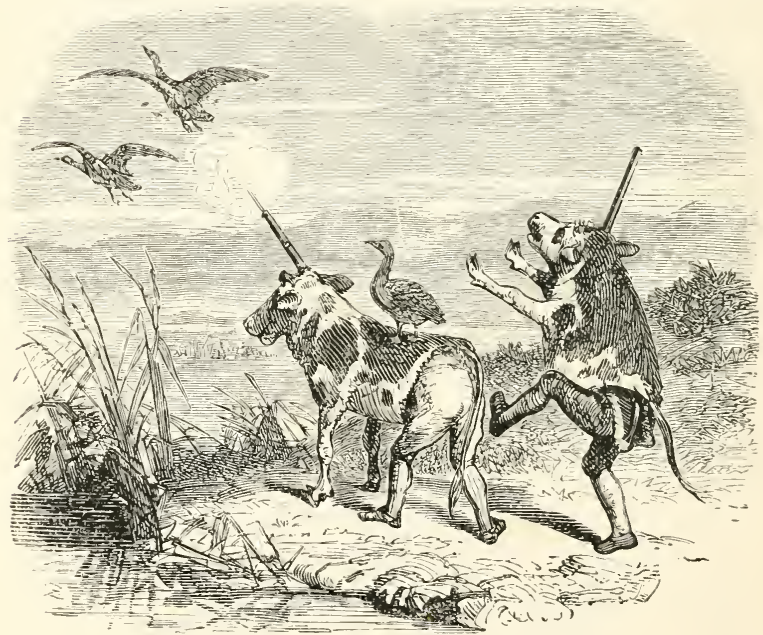

SKJUT-KO 
Cygnine:

The stwons.

Gex. Charac.-Bill nearly the length of the head, higher at the base than broad, and covered with a soft cere, which in most extends to each eye, the breadth of the bill uniform throughout; the tarsi moderate, and the toes lengthened, with the anterior one united by a full web, the hind toe short and not margined with a membranous lobe; the neck very loug.

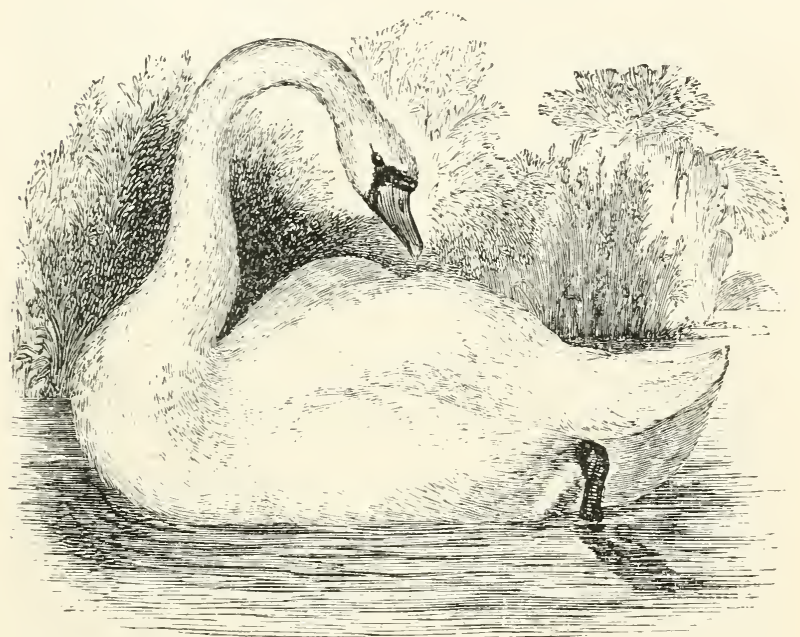

Fig. 195.-THE SWAN.

(Cygnes Olor.)

These graceful birds are principally distributed in the northern latitudes of Europe, Asia, and America. They appear, however, in the more genial portions of these three continents during extreme winters; and there are certain species peculiar to the southern parts of South America. They live in the lakes and rivers, in small parties of from five to thirty individuals. Various fishes and aquatic plants form their chief food, in seeking for which, 
they have the power of submerging their heads for some depth below the surface of the water, where they retain them for a considerable time. Their nest is formed of a heap of dry vegetable matter, and the female lays from five to seven ego's.

About the 1st of September, the Swans leave the Polar Sea, and resort to the lakes and rivers in and about the latitude of Hudson's Bay, where they remain preparing for a departure for the winter till October; when they collect in flocks of from twenty to thirty, and seizing a farourable opportunity, with the wind not opposed to the direction of their flight, they mount high in the air, form a prolonged wedge, and with loud screams depart for more genial climes. When making either their semi-amnual transmigration, or on shorter expeditions, an occasional scream, equal to "How do you all come on behind?" issues from the leader, which is almost immediately replied to by some posterior Swan, with an "all's well" vociferation. When the leader of the party becomes fatigued with his extra duty of cutting the air, he falls into the rear, and his neighbour takes his place. When mounted, as they sometimes are, several thousand feet above the earth, with their diminished and delicate outline hardly perceptible against the clear blue of heaven, this harsh sound, softened and modulated by distance, and issuing from the immense void above, assumes a supernatural character of tone.-(Fronlilin.)

"In flying, these birds make a strange appearance; their long necks protrude, and resemble at a distance long lines with black points, their heavy bodies and triangular wings seeming mere appendages to the prolonged neck. When thus in motion, their wings pass through so few degrees of a circle, that, unless seen horizontally, they appear almost quiescent, their movements being widely different from the semicircular sweep of the Goose. The Swan when migrating, with a moderate wind 
in his favour, and mounted high in the air, travels at the rate of 100 miles or more in an hour. I have often timed the flight of the Goose, and found one mile a minute a common rapidity; and when the two birds, in a change of feeding-ground, have been flying near each other, the Swan invariably passed with nearly double the velocity." - (Lloydl's "Scand. Advent.")

\section{The typical species, -}

The Mute Swan (Cygnus Olor), so called from its possessing only a soft and rather musical voice, very different from the harsh notes of the Wild Swan, is the well-known and graceful species so often seen adorning with its white plumage and elegant form the surface of our lakes, rivers, and ornamental waters. It is the only species which permanently resicles in this country, where, however, it is generally met with in a half domesticated condition. During the breeding season Swans live in pairs, each pair keeping to its own locality. At this time the male becomes exceedingly fierce, attacking any animal that intrudes upon his domains. The nest is formed of a mass of reeds, rushes, and other plants, and is placed close to the edge of the water, or amongst the plants growing upon some small bank which is hardly above the surface. The male is very attentive to his mate, assists her in making the nest, and when a sudden rise of the river renders such a step necessary, joins her with great assiduity in raising their cradle sufficiently high to prevent the eggs from being chillerl by contact with the water. In this proceeding they sometimes exhibit a very remarkable degree of foresight. A female Swan, who had constructed her nest on the river at Bishop's Stortford, was sitting on four or five eggs, and was observed to be very busy in collecting weeds, grasses, and such-like materials; a farming man was ordered to take down half a load of haulm, with which she most industriously raised her nest and the eggs two feet and a half: that very night there came down a tremendous fall of rain, which flooded the country and did great damage. Man made no preparation, the bird did. Instinct showed itself a faithful guardian; the Swan's eggs were above, and only just above, the water. In localities 
subject to sudden inmulations, the nest of the Swan is an immense pile of reeds, grass, and down; and at the end of the season, when the last-mentioned material is blown about by the wind, the floating flakes sometimes resemble a snow-storm. The eggs are six or seven in number; when hatched, the young birds accompany their parents, and occasionally the mother will take her young brood upon her back and swint about with them. The whole family remains together throughout the winter:

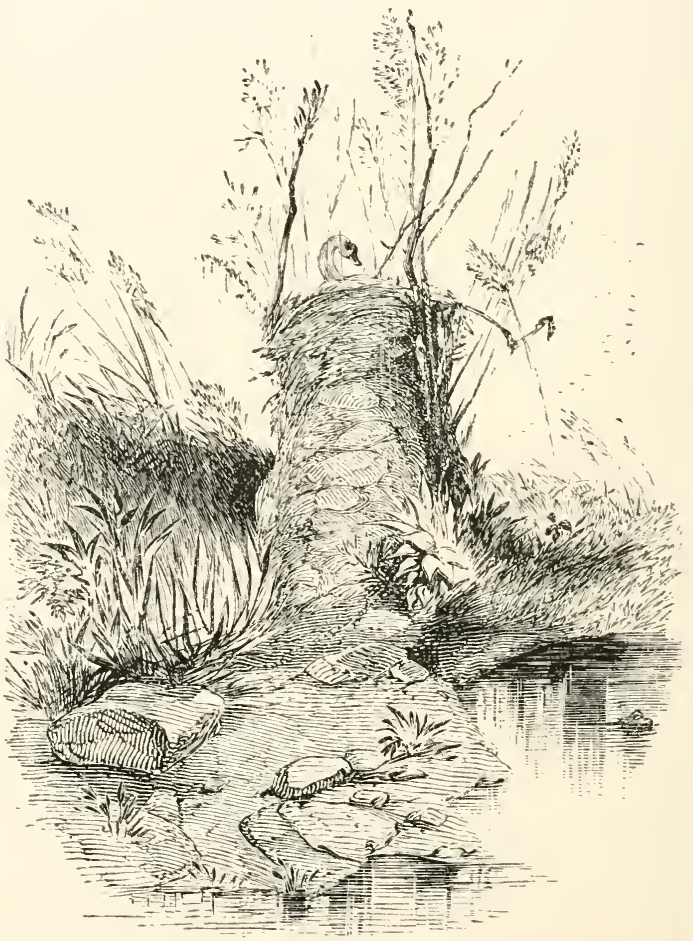

SWAN'S NEST 


\title{
SUB-FAMILY V.
}

\author{
Axatin.e. \\ The liver Duclis.
}

Gex. Charac,-Bill lengthened, more or less broad, depressed towards the tip, which is furnished with a hard nail, and the inner portions of the lateral margins more or less lamellated; the tarsi compressed, and generally the length of the inner toe; the bind toe lengthened, and slightly bordered with a membranous lobe from the base to the tip.

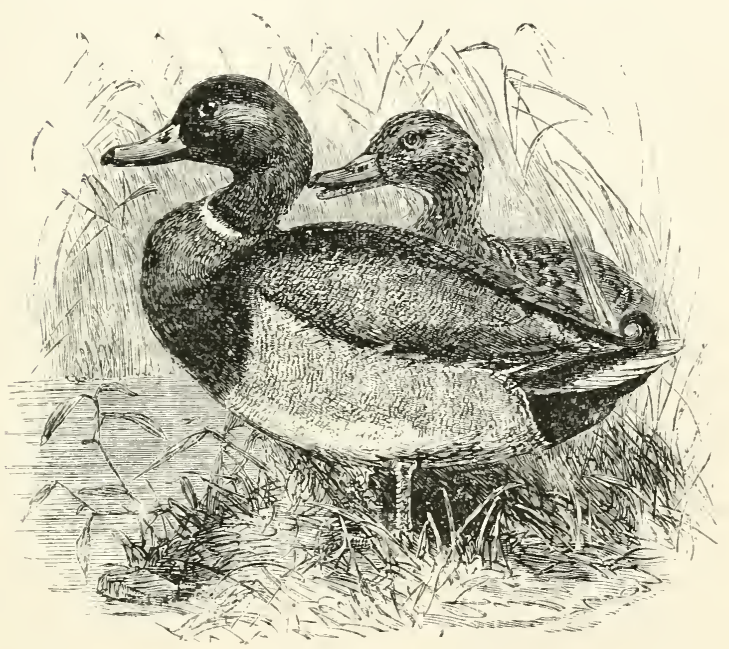

FIG. 196.-THE WILD DUCK.

(Anus Boschus.)

The birds composing this sub-family are too well known to need description.

The most beautiful of the race is-

The Chinese Teal, or Mandarin Duck (Aix galericulata), than which, when the male is in full nuptial dress, a more magnificently-clothed species can hardly be found. These birds are natives of China, where they are held in such esteem that they are scarcely obtainable at any price. 
They have the power of perching, and it is a curious sight to see them on the branches of the trees that overhang the pond in which they live; the male and female being always close together, the one gorgeous in purple, green, white, and chesnut, the other soberly apparelled in brown and grey. This handsome phumage of the male is lost during four months of the year, $i$. e. from May to August, when the bird throws off his fine crest, his wing-fans, all his brilliant colours, and assumes a sober-tinted dress, resembling that of its mate. The Mandarin Duck has been successfully reared at the Zoological Garrlens in London, some heing hatched under the parent bird, and others under a domestic hen, the latter hatching the eggs two days in advance of the former. The eggs are of a creamy-brown colour. 'These birds are regarded by the Chinese as emblems of conjugal fidelity, and are usually carried about in their marriage processions, a distinction of which they are by no means unworthy, as is abundantly proved by the following anecdote. "A drake of this species was stolen one night, along with some other birds, from the aviary of Mr. Beale, of Macao, of which mention has already been made. The beautiful male only was taken, the poor duck was left behind. The morning following the loss of her husband, the female was seen in a most disconsolate condition, brooling in secret sorrow in a retired part of the aviary. While she was thus giving herself up to grief, a gay prim drake, who had not long before lost his dear duck, which had been accidentally killed, trimmed his beantiful feathers, and appearing quite handsome, pitying the forlorn condition of the bereaved, waddled towards her, and after devoting much of his time, and all his attention, to the poor lady, offered her his protection; she, however, refused all his offers, having apparently made a solemn vow to live and die a widlow if her mate did not return. From the day when she met with her loss she neglected her usual avocations, her plumage became ragged and dirty, she was regardless of her appearance, forsook her food, and no consolation that could be offered had the least effect. Some time had elapsed since her bereavement, when a person accidentally passing a hut overheard some Chinese of the lower class conversing together, and understood sufficient of their language to know that one said, 'It 
would be a pity to destroy so handsome a bird.' ' How, then,' said another, 'can we dispose of it ?' The hut was noted, as it was immediately suspected that the lost Manlarin Duck was the subject of conversation. A servant was sent, who, after some trouble, recovered the lost drake by paying handsomely for him, and he was brought back to the aviary in one of the usual cane cages. As soon is the bird recognized the aviary, he expressed his joy l,y quacking vehemently and flapping his wings. An interval of three weeks had elapsed since he had been taken away by force; but when the poor forlorn duck heard the note of her lost husband, she quacked, even to screaming, with ecstasy, and flew as far as she could in the aviary to greet him. Being let out of the cage, the drake immediately joined his spouse; the happy couple were again united. They quacked, crossed necks, bathed together, and then are supposed to have related all their mutual hopes and fear's after their long separation; the female, in a most ungrateful manner, informing her drake of the gallant proposals made to her by the widower during his absence. It is merely a supposition that she did so, but at all events the result was, that the recovered drake attackerl the other the day subsequent to his retmm, pecked his eyes out, and inflicted on him so many injuries as to occision his death in a few days." - (Dr. Bennett's "Wandering/s in New South Wrales," rol. ii. page 64.) 


\section{SUB-FAMILY VI.}

Fuliguline.

The sea-Duckis.

Grin. Снarac.- Bill of various lengths, elevated at the base, and more or less broad and depressed towards the tip, which is armed with a broad strong nail; the wings moderate and pointed; the tail generally short, and more or less wedge.shaped; the tarsi much shorter than the middle toe, and compressed; the toes long and united by a full web, the onter as long as the middle toe, the hind toe short and deeply margined with a broad membranous web.

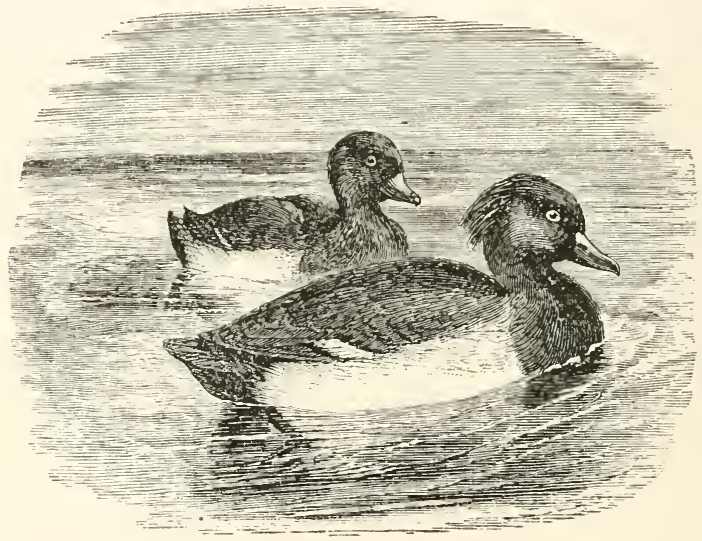

Fig. 197 - The tefted Sea-dick.

(Fuligula cristutu.)

'These birds are inhabitants of the northern regions of Europe, Asia, and America, migrating to the temperate districts on the approach of winter. One species, however, is peculiar to New Zealand. They are met with in pairs and small societies, frequenting fresh-water lakes and rivers, but some are more especially found on the sea-shore. Their food consists principally of small univalve and bivalve mollusca, for which they dive, or seek in the pools left on sand-banks after the tide has receded. 


\title{
SUB-FAMILY VII.
}

\author{
Erismaturine.* \\ The Spiny-tailed Ducks.
}

GRx. CHARAc.-Bill elerated at the base, and the anterior half much depressed to the tip, which is furnished with a nail; the wings short and coneave, with the ends of the quills incurved; the tail lengthened, and composed of narrow rigid feathers, which are but slightly protected with coverts both above and below; the tarsi shorter than the middle toe, and compressed; the toes lengthened, the anterior ones united by a full web, and the hind toe long and furnished with a broad web.

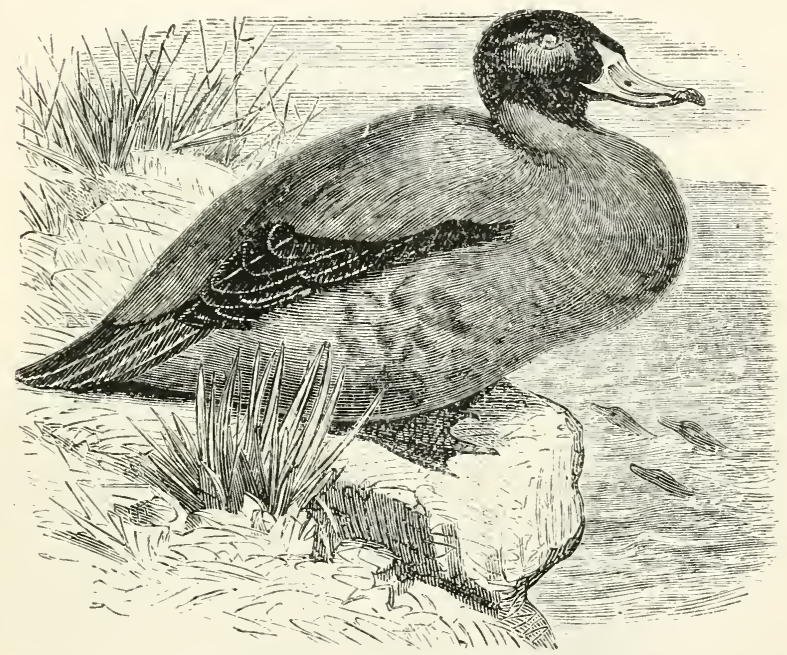

Fig. 198.-THE FERRUGINOUS SPINT-TAILED DUCK.

(Erismatura ferruginea.)

The Ducks belonging to this sub-family are met with in various parts of both hemispheres. They are peculiarly aquatic birds, living in large sheets of saline waters and rivers, especially in the vicinity of the sea. In such places, they are generally seen in

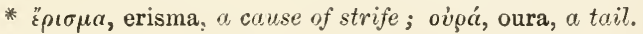


small societies of five or six individuals, and mostly apart from other races of water-birds. While swimming, their bodies are entirely hidden beneath the surface of the water, nothing but the head and neck being visible. 'Their form makes them rery expert in diving, when seeking for the molluscous animals and fishes which constitute their principal food. Their nest is a half-floating cradle, constructed of reeds and other water-plants.

The type of the race is-

The Ferruginous Spiny-tailed Duck (Erismatura ferruginea).

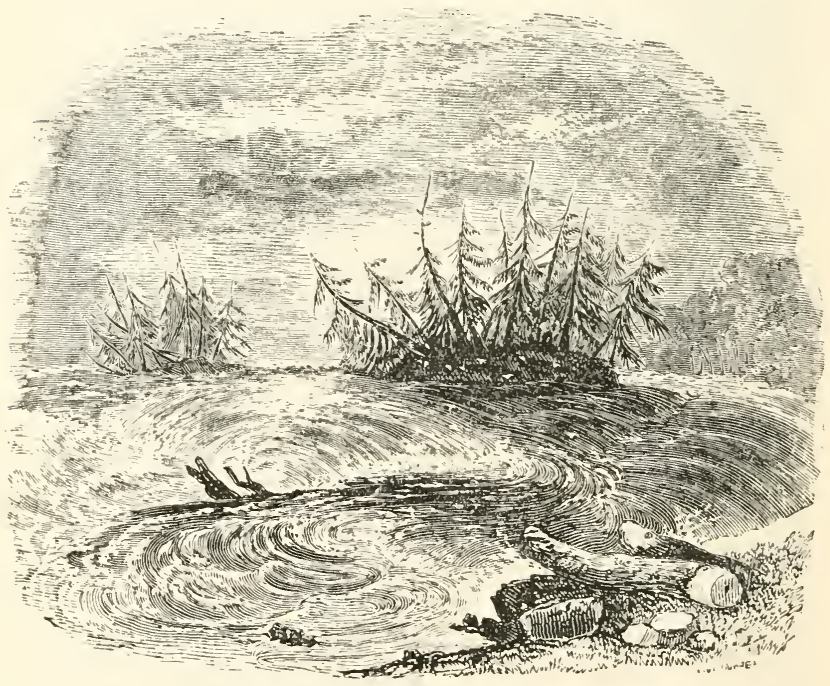




\section{SUB-FAMILY VIII.}

MERGIx.E.

The Mergansers.

GeN. Charac.-Bill straight, and much compressed on the sides, with the culmen elevated at the base and convex towards the tip, which is armed with a broad and much-hooked nail, the lateral margins of both the mandibles more or less serrated; the wings moderate and pointed; the tail short and rounded; the tarsi short, and the toes moderate, the outer as long as the middle, the three anterior ones united by a full web, and the hind toe mode. rate, elevated, and margined by a broad web.

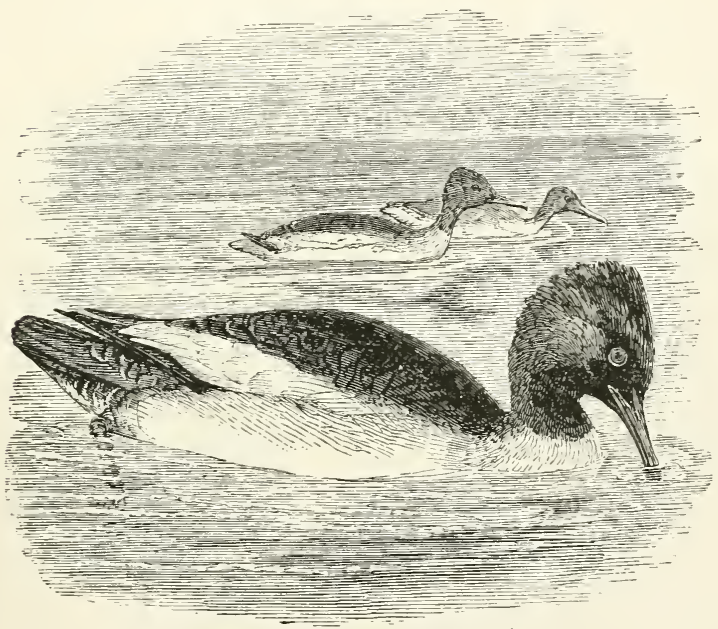

Fı, 199.-THE GOOSANDER.

(Mergus Mergunser.)

The members of this sub-family are distinguished by the narrowness of their bill, as compared with its length, and by the structure of its laminated edges, which assume the form of distinct conical teeth, pointing backwards. The food of the typical species consists principally of fishes, for securing which this form of the bill is admirably adapted. The 
Mergansers are eminently aquatic, and swim well, but from the weight and flattened form of their bodies appear deeply immersed in the water, the head, neck, and back only being visible. They are also excellent divers, moving, or rather flying beneath the surface with great rapidity, and to a considerable distance: it is during these submarine excursions that they capture their finny prey. Their flight is strong and swift, and they have great endurance of wing ; but from the shortness and backward position of their legs, are awkward upon land. They are natives of the coldest climates, and may be found during the summer or breeding season in very high latitudes. They build their nests on the margins of water, either concealed under a large stone, or placed under the cover of bushes. The nest is composed of grass and other vegetable materials, mixed, and lined with any kind of soft substances, and in it the female deposits from eight to twelve eggs.

The type of this sub-family,-

The Dun Diver, or Goosander (Mergus Merganser), is widely distributed throughout the Aretic regions, both of the Old and the New World. In Europe, during its southern migration, it visits France, Holland, and Germany, and is also a well-known winter visitant upon the coasts, lakes, and river's of the United States. During the summer the great body of these birds retire very far north for the purpose of reproduction, and at that time they are found in. Iceland and Greenland. In Asia, they visit Siberia and Kamtschatka; and in America, during the breeding season, they are spread through the northern districts of that vast continent. Their nest is there constructed, near the edge of the water, of a mass of grass, roots, and other materials, and lined with down. It is placed sometimes among stones, and sometimes in the long grass, or under the cover of bushes, and, when the locality affords them, in the stumps or hollows of decayed trees. The eggs are from twelve to fourteen in number, of a cream-yellow colour; their form is a long oval, both ends being equally obtuse. The Goosander, except when 
on the wing, is almost always seen upon the water, being mable to make much progress upon land in consequence of the backward position of its legs; its activity, however, in the former element makes ample amends for this deficiency. It rises with difficulty into the air, but when once on the wing its flight is swift, and can be sustained for a considerable time. The Goosander is a bird of wild lisposition, and very wary habits; from its dexterity and quickness in diving, it is not easily shot. The flesh, from the nature of its fool, is ill-flavoured and oily.

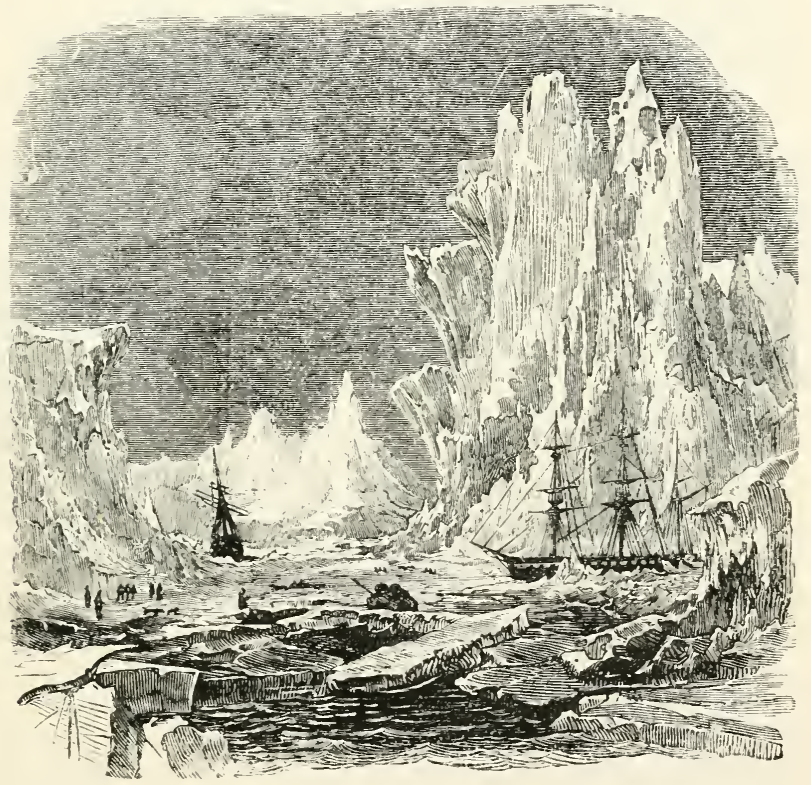




\section{FAMILY II.}

COLYMBIDE.

The Divers.

Gex, Charac,-Bill more or less long, mueh compressed, straight, and acute; the nostrils placed in a longitudinal groove, with the opening hasal, linear, or rounded; the wings moderate, with the first quill longest; the tail rery short; the tarsi short and much compressed; the toes long, and the three anterior ones more or less united together by a membrane, the hind toe short, and margined by a small membrane.

'The birds of this family display a fitness for diving' even more decided than is to be found either in the diving Ducks or in the Mergansers, having the characteristics with which such habits are connected carried out to a still greater degree of completeness. Their plumage is deep, close, silky, and extremely glossy. The bill is long and sharp, the wings, small, concave, and composed of stiff feathers, are used for the purpose of giving additional impetus to the body when diving. The legs are placed as far back as possible, the tarsus is flattened so as to cut the water, and the toes, either lobated or webbed, are so arranged as to fold up into a small compass when drawn towards the body, in order to give the back stroke. The tail is short or wanting, and the body flat; hence it appears to float deeply on the surface of the water. Necessarily embarrassed and awkward upon land, the Colymbida are alert and vigorous in their congenial element, from which they can seldom be forced to take wing, trusting rather to diving than to flight for safety; they rise, indeed, with difficulty, but having attained a due elevation, sweep along very rapidly, and are capable of a long-sustained flight. Their nest is always placed on the immediate margin of the water, amid the floating herbage that abounds in the localities they generally inhabit. These birds swim and dive with equal ease, and can remain submerged for a long period. This family includes the True Divers, the Grebes, and the Sun-Grebes. 
$S C B-F A M I L Y I$.

\section{Colymbina.*}

The True Divers.

Gex. Charac.-Bill long, straight, with the tip curred, and the sides compressed ; the nostrils basal, lateral, and placed in a groove, with the opening linear and perrious; the wings long and pointed; the tail very short; the tarsi short and much compressed; the toes long, the fore toes united together by an entire web, the hind toe short, and slightly margined by a membrane.

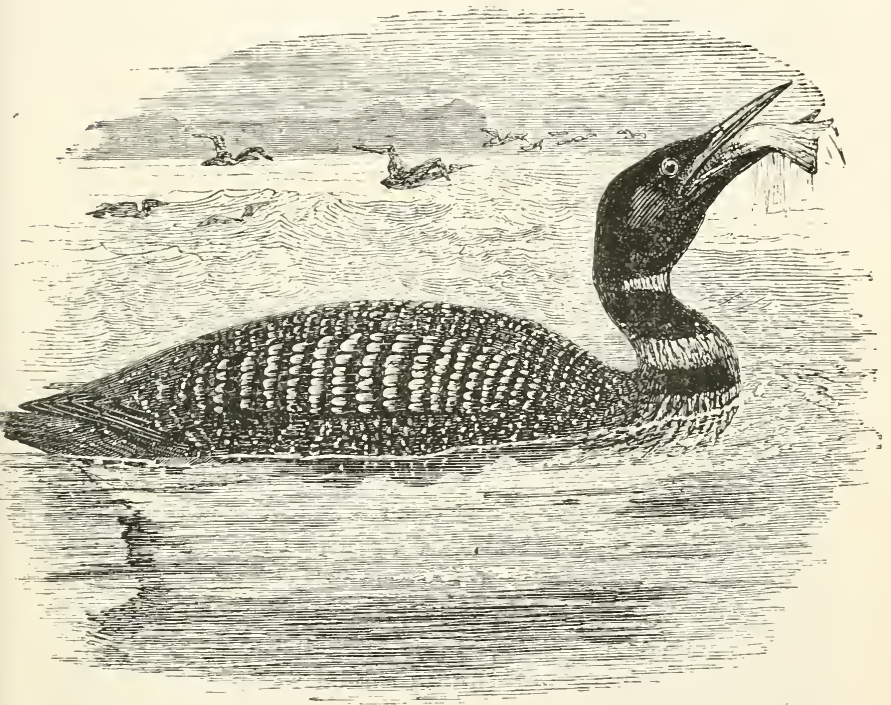

FIG. 200. - THE GREAT NORTHERN DIVER.

(Colymbus glacialix.)

These birds are found in the Arctic circle, but migrate to the more temperate climates during severe winters. They are observed on the sea-

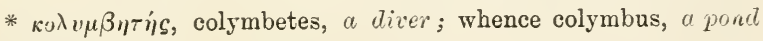
to swime in. 
coast, as also on lakes and ponds. 'They are usually met with in pairs, or in small parties, swimming about in scarch of ish and other aquatic animals, which constitute their food. Owing to the flatness of their bodies, they lie deep in the water, so that when resting on the surface little more than their neck is visible. They swim and dive with wonderful velocity, but they rarely fly, and then their flight is performed heavily and high in the air. 'The egrgs, which are two to three in number, are deposited on the bare ground, or in a nest composed of dry weeds; in either case they are placed near the water's edge.

'The type of this sub-family,-

The Northern Diver (Colymbus glacialis), is common on all the coasts of the North Sea, as well as on the inland lakes of high latitudes. Its principal food eonsists of fish ; and when inhaliting the ocean the different species of herring afford it an abundint supply. Its powers of swimming and diving are very remarkable, particularly the latter, which it is comstantly exercising, either in pursuit of prey or to escape olservation.

"To see them from some promontory, against which the air and the sea are setting full wind and tide, and driving before them myriads of herrings and other surface-fishes, is a glorious sight. They dash along the surface, they dart under it, they bounce up again, they bore through the advancing waves, and when the billow breaks in foam, and thunders over them, and the spectator naturally concludes that they are buried for ever in the deep, up they spring to the surface of the unbroken water further from the land, as though exulting in the tumults of the elements."-(Mudie.)

One of these birds will frequently make its way under water for a hundred or a hundred and fifty yards withont rising for respiration; and when it comes up to breathe, a moment's exposure of the head and bill is sufficient for the purpose. In swimming, its body is deeply immersed, owing to its weight and flatness, a position which allows this bird to dive with little apparent exertion, the mere depression of its head, and a slight propulsive effort with 
the feet, being sufficient to enable it to plunge into the sea. From the backward position of its legs, it camnot walk; its only mode of progression, therefore, when on land, is that of shoving itself forward by lying on its breast and striking the ground with its feet. The Northern Diver rarely flies, as it rises with difficulty from the surface of the water; but when once upon the wing its flight is swift, and frequently in a circle round those who intrude upon its haunts. Its cries have been compared to those of a man in distress, but it also utters occasionally a low hoarse croak. Its plumage is close, and the skin tough, on which account it is much used by the natives of northern countries in the manufacture of comfortable articles of clothing. The flesh is hard, and of a lank fishy flavour.

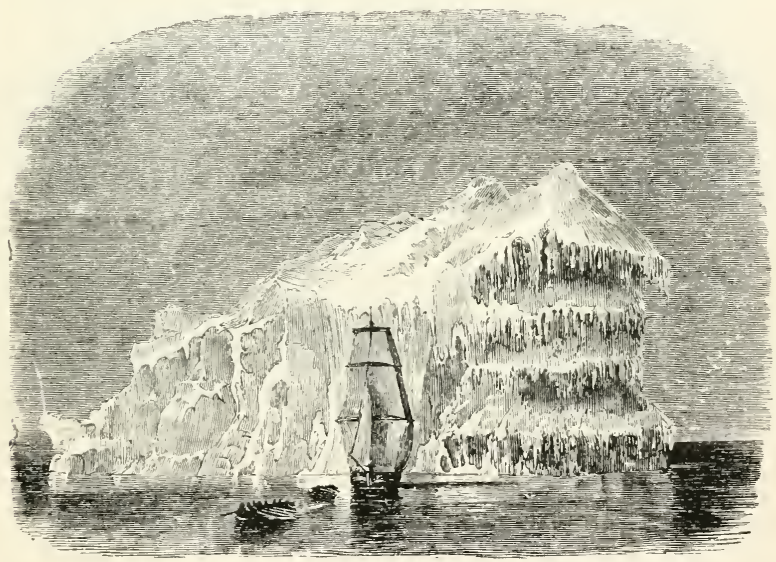


GEN. CuARac.-Bill long, straight, compressed on the sides, with the culmen alightly curved at the tip, which is acute and entire, the gonys ascending; the nostrils piereed in a groove, and oblong; the wings short, with the first quill the longest; the tail not apparent; the tarsi short and much compressed; the toes long, the outer longer than the others, the anterior ones broadly lobed on the sides, especially on the inner side; the claws short, very broad, and obtuse.

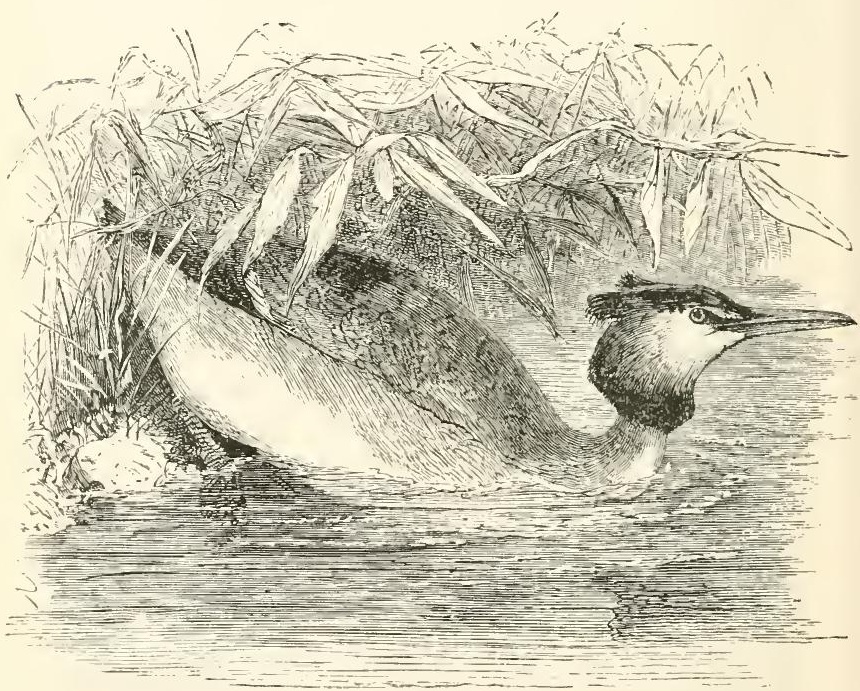

Fig. 211. -THE CRESTED GREBE.

(Podiceps (tristatus.)

T'he birds composing this sub-family are met with in most parts of the world. They are usually found in flocks near the sea-coast, or on the sides of lakes,

* Podex, the rump; pes, a foot; so called from the legs being placed near the hinder part of the body. 
fresh-water rivers, and marshes, but are rarely seen on the land, owing to the difficulty they have in walking. On the water, they swim and dive with the greatest facility, and are thus enabled to pursue fish at a great depth. If fearful of danger, they either hide among the reeds or dive beneath the Hoating water-plants, where, with only their bill above the surface, they lie concealed until the cause of their alarm is removed. At cartain seasons they migrate, proving that, although they seldom take wing, their flight can be sustained for a lengthened excursion. They live upon fish, insects, and occasionally water-plants. Their nest is composed of grass, lined with down : it is usually built amongst reeds and other aquatic vegetation, so that it sometimes seems to float on the surface of the water. The eggs are from three to four in number.

The type of this sub-family is-

The Crested Grebe (Podiceps cristatus), sometimes called the "Lonn." "The movements of this bird in the water are most graceful. In swimming it vies with the Swan, and it is a skilful diver. When on dry land its for'm is ungainly, but in its native element it might serve as the standard of perfection among water-bircts. The legs, compressed so as to present a sharp edge, cut the water with a minimum of resistance; the webbed feet are placed so far backwards that they fulfil at once the office of propellers and rudder. The body is conical in its shape, and covered with satiny plumage, which throws off water as perfectly as the fur of the otter. The long neck tapers to exceedingly narrow dimensions, and terminates in a small head produced into a slender beak. The conformation of the Greyhound is not better adapted for fleet running than that of the Grebe for rapid diving after the fishes that constitute its ordinary food; the Loon, however, will likewise feed on frogs, tadpoles, $\mathrm{Or}^{\circ}$ any small animals that come in its way. It frequents fiesh water during the summer months, but on the approach of winter resorts to the sea, not, it would seen. from any desire to vary its food, but simply to avoid being frozen up. The Loon is found in lakes throughout 
at great portion both of the Eastern and Western hemispheres, but not very far to the north. It rarely flies, except at the period of migration, when it passes swiftly through the air with neck and feet extended to their full length. It builds its nest amongst l'ushes and decaving reeds, but little above the level of the water, and lays four white egos, the male assisting his partner in the work of incubation. The young can dive and swim immediately that they are hatched; but if the mother. be suddenly alarmed while they are with her, she takes them under her wing and dives with them."-(Rev. ('. A. Johns.)

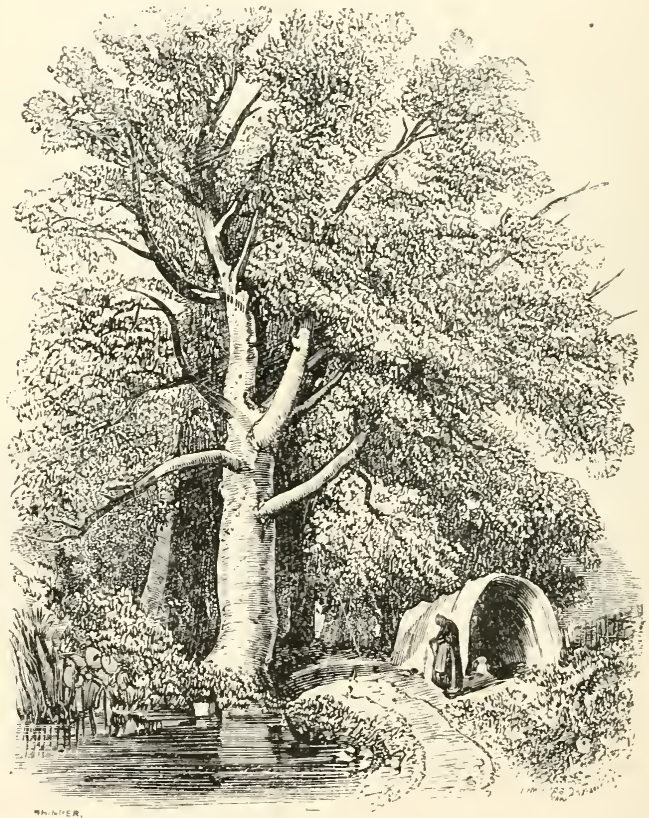




\title{
SU B-FAMILY III.
}

\author{
Heliorsine.*
}

The Sun-Grebes.

Ger. Charac. - Bill long, straight, and compressed, with the tip slightly eurred and emarginated, the gonys of the lower mandible short and advaneing upwards; the wings moderate and rounded; the tail long and much rounded; the tarsi short, and the toes margined with a membrane, which is more or less united to the middle one.

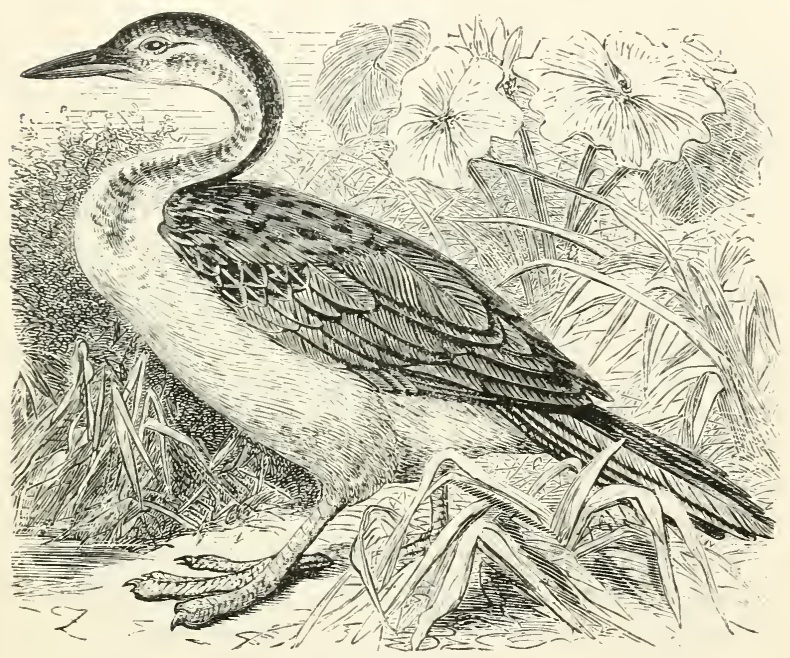

Fig. 202.-THE SENEGAL FIY-FOOT.

(Heliornis Senegalensis.)

These birds are chiefly seen on the sides of river's and creeks. In such places they search for small fish and insects, more especially flies, in catching. which they show great dexterity. They are very active, keeping their head and body continually in motion, and frequently expanding their tail and wings. The type of this sub-family is-

The Senegal Fin-foot (Heliornis Senegalensis).

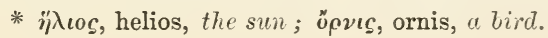




\section{FAMILY III.}

Alóide.

The Auks.

GEx. Charac.-Bill more or less long, generally compressed on the sides, and the culmen usually curred to the tip, which is sometimes hooked; the wings generally short, and more or less imperfectly formed; the tail short and graduated; the tarsi usually short and compressed; the toes entirely webbed, with the hind toe small or wanting.

The birds belonging to this family are distinguished by having only three palmated toes, and where a fourth or hind toe does exist, it is very small, without any web, and inclined forwards. The Alcida are distributed in most parts of the world, but most mumerously in high northern and southern latitudes. 'They are found upon the barren rocky shores of the Arctic and Antarctic lands and islands, often in Hocks consisting of vast numbers of individuals. 'They pass the greater part of their time in the sea, whence they obtain an abundant supply of food, which they procure by diving. In these birds, shortness of wing, and consequent deficiency in their powers of flight, are carried to the greatest extreme, the wings of the Penguins and other allied genera being so small and imperfectly developed as to be totally unfit for flying, and adapted to act merely as fins to aid their progress beneath the water. As in the Colymbidae, the legs of these birds are placed far backwards, but at scarcely so great an angle with the body. In consequence of this, they are enabled to sit in an upright attitude, resting equally on the foot and on the whole length of the tarsus. 'They are all birds of the ocean, never resorting to fresh water, as the Divers do. Many of the species that are able to $\mathrm{H}_{y}$, nestle on the rocks and precipices, where they lay a single ego of conical form, a shape which prevents it from rolling away, or moving except within a circle of the diameter of its own length, on the bare ledge of 
rock where it is deposited. Some burrow in the light sandy soils of the small islands they frequent, and the Penguins, and other species that have not any power of flight, incubate upon the shore, immediately above high-water mark. Their food consists entirely of fish and other marine animals.

This family comprehends the Auks proper, the Starakis, the Penguins, and the Guillemots.

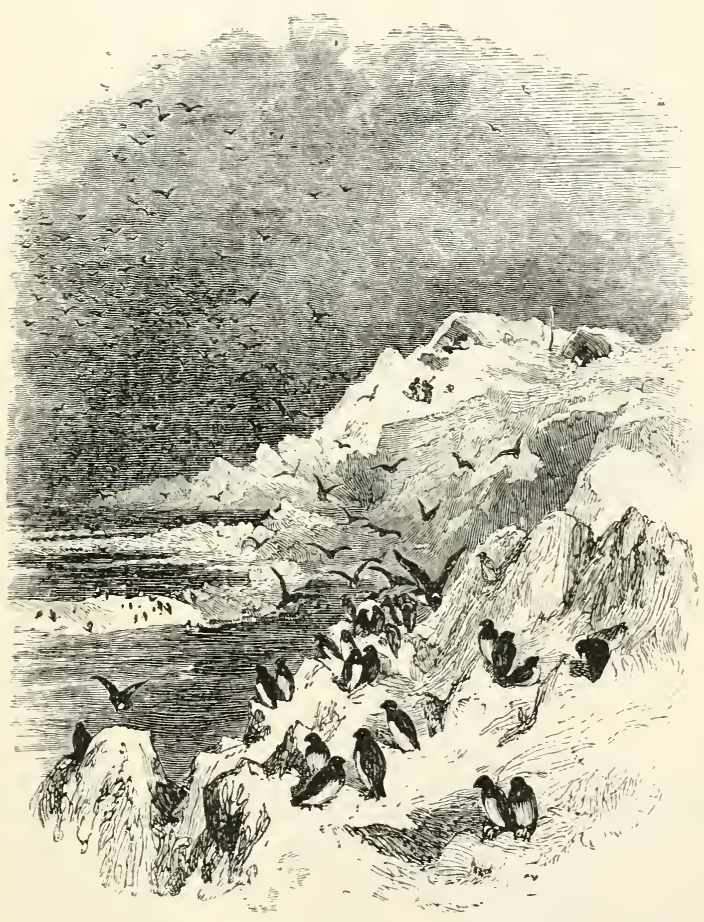


AlCINE.

The Aulis proper.

Grx. CuAac.-Bill more or less short, and much compressed on the sides, with the culmen and gonys keeled, the tip of the upper mandible acute and hooked; the nostrils linear; the wings more or less long and perfectly formed, with the first quill the longest; the tail short and graduated; the tarsi sbort and compressed; the toes entirely webbed, with the hind toe wanting.

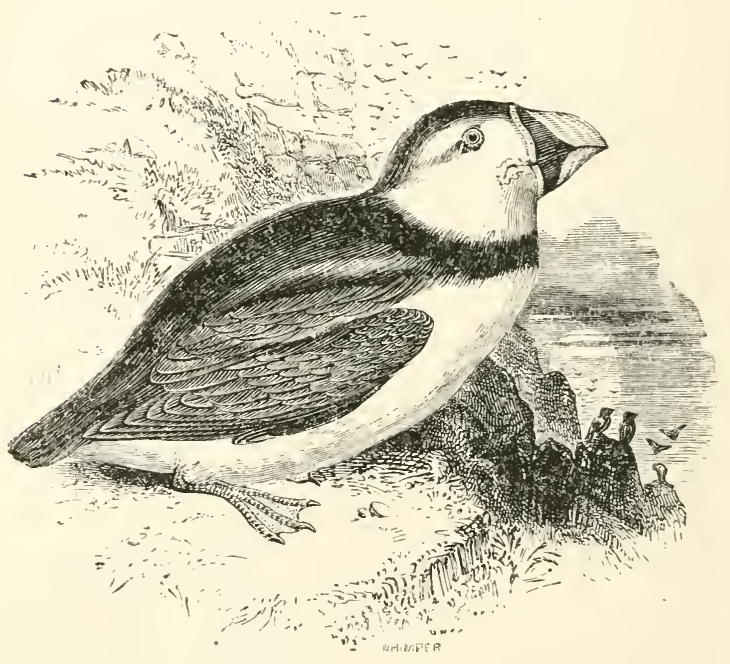

Fig. 203.-THE PUFFIN.

(Pnffinus arcticus.)

These birds frequent high northern latitudes, but at certain seasons visit the more temperate parts of Europe. They resort in great multitudes to barren rocks, on the ledges of which, or in a subterranean burrow, the female deposits a single egg. They live chiefly on the water, where they are very expert, swimming and diving with great rapidity. The shortness of their wings does not admit of much 
power of flight. They feed on various kinds of small fish, and whatever else they can procure near the surface of the sea.

The most familiar examples of this remarkable sub-family are-

The Puffins (Fratercola), well known on the northern coasts of our own island. On a first glance at a Puffin we cannot fail to be struck by the short and inelegant contour of its figure, and by the strange shape and brilliant colour of its beak, features which impart a singular aspect to the physiognomy of this inhabitant of the ocean, where, however, as if to belie its round and awkward appearance, it displays great agility, and an arrow-like quickness of motion. Its beak, deep, compressed, and pointed, with a sharp-ridged keel above and below, affords the heau ideal of an instrument for cutting through the water, a circumstance the more necessary when considered in connection with a form of body apjarently ill adapted for diving. The phumage, moreover, of these birds is thick, close, and smooth, so completely throwing off every particle of water as to render it impervious to wet.

The Puftin arrives on our coasts some time in April, but as it is not able to contend with storms, the time of its arrival is not certain. On its first appearance on our shore it is generally lean, but in a week or two becomes excessively fat, and begins to seek for a proper place to deposit its solitary egg in security.

These birds leare this country towards the end of August. When the time comes for them to depart, they assemble in immense multitudes on the rocks, from which they are supposed to fly for a considerable distance, and then to complete their migration by swimming on the sea. They usually fly very near the surface, and are frequently observed to dip their wings into the water, which seems to strengthen them in their flight.

Their diet consists principally of sprats and other small fishes; they retain the food intended for their young until partially digested, and then disgorge it into their mouths. Their bite is very severe, and they take such secure hold that the most common way of catching them is by introducing a stick into their holes, which 
they eagerly seize, and will suffer themselves to be drawn out with it rather than quit their hold.

As is the custom with most diving birds, the Puffin lays only one egg, and always deposits it in some deep burrow.

The appearance of an island frequented by these birds is thus graphically described by Audubon :- "On every crag or stone stood a Puftin, at the entrance of every hole another, and yet the sea was covered and the air filled by them. The burrows were all inhabited by young birds of different ages and sizes, and clouds of Puffins flew over us, each individual holding a small tish by the head. The burrows all communicated in various ways with each other, so that the whole island was perforated as if by a multitude of subterranean labyrinths, over which we could not rum without the risk of falling at almost every step. The voices of the young sounderl beneath our feet like voices fiom the grave, and the stench was extremely disagreeable. During the whole of our visit the birds never left the place, but constantly attended to their avocations. Here one would rise from beneath our feet; there, within a few yards, another would alight with a fish, and dive into its burrow, or feed the young that stood waiting at the entrance."

The typical species of this sub-family is-

The Arctic Fuffin, or Coulterneb (Puffinus arcticus). 


\section{$S U B-F A I I L Y I I$.}

\section{Phaleridin.e**}

\section{The Starakis.}

GEY. CHarac.-Bill short, broad at the base, with the sides gradually compressed, and the culmen curred to the tip, which is emarginated, the lower mandible grooved on the sides, and the gonys ascending; the nostrils lateral, and pierced in the bony covering of the broad nasal groove, with the opening linear; the wings moderate and pointed; the tail short and rounded; the tarsi short, compressed, and covered with small scales; the toes three, and all united together by an entire membrane; the claws moderate, compressed, and acute.

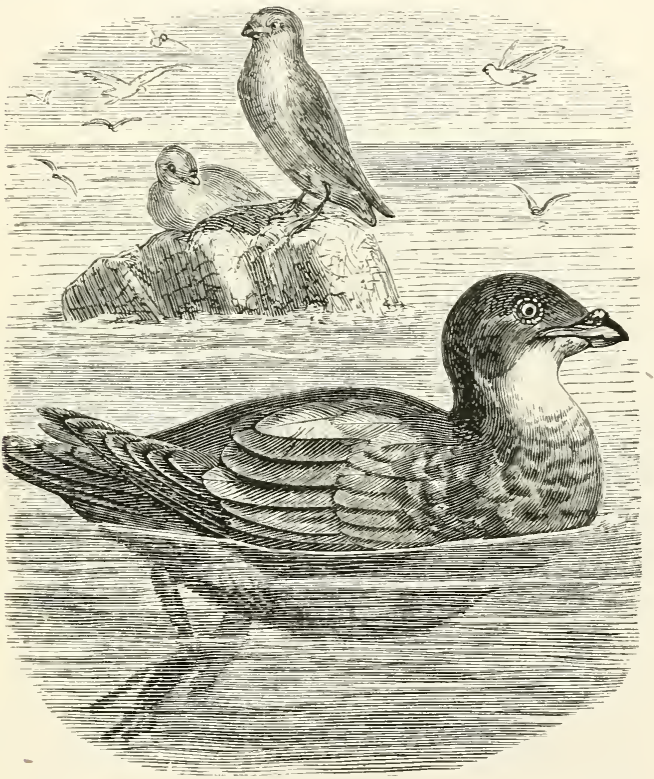

FIG. 204.-THE KNOTTY-BEAKED STARAKI.

(Phaleris nodirostris.)

The Starakis are found in the Arctic regions, and especially in the islands that lie between China and

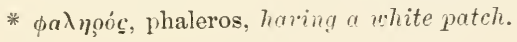

$$
\text { ? } \mathrm{A}: \dot{3}
$$


North America. They live in small flocks, swimming with ease and celerity while in quest of their food, which consists of crustacea, mollusca, and other marine animals. As the night approaches, they seek the shore, where, under the ledges of the rocks; or in burrows dug with their bill and feet, they retire to rest; and it is in such places that the female deposits her single egg.

'T'he type of this sub-family is-

The Knotty-billed Staraki (Plualeris nodirostrix).

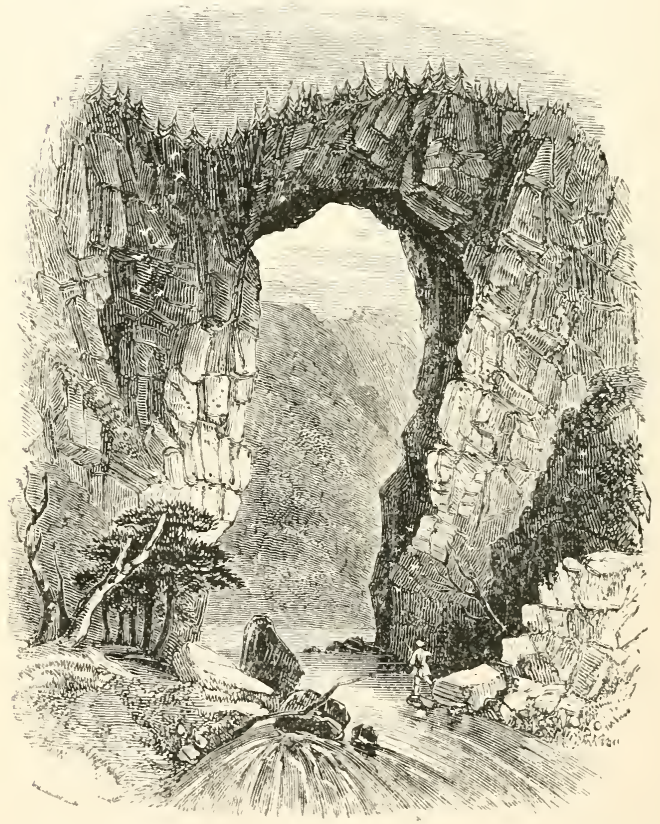


Gev. ChARAc.-Bill more or less long and straight, with the sides eompressed and grooved, the culmen ronnded and curved at the tip, which is acute; the nostrils placed in the lateral groove, and linear; the wings short, imperfect, being only eovered with scale-like plumes; the tail more or less short, and composed of narrow rigid feathers; the tarsi very short and depressed; the toes moderate and depressed, with the anterior toes united ly a web, the hind toe very small and united to the side of the tarsus.

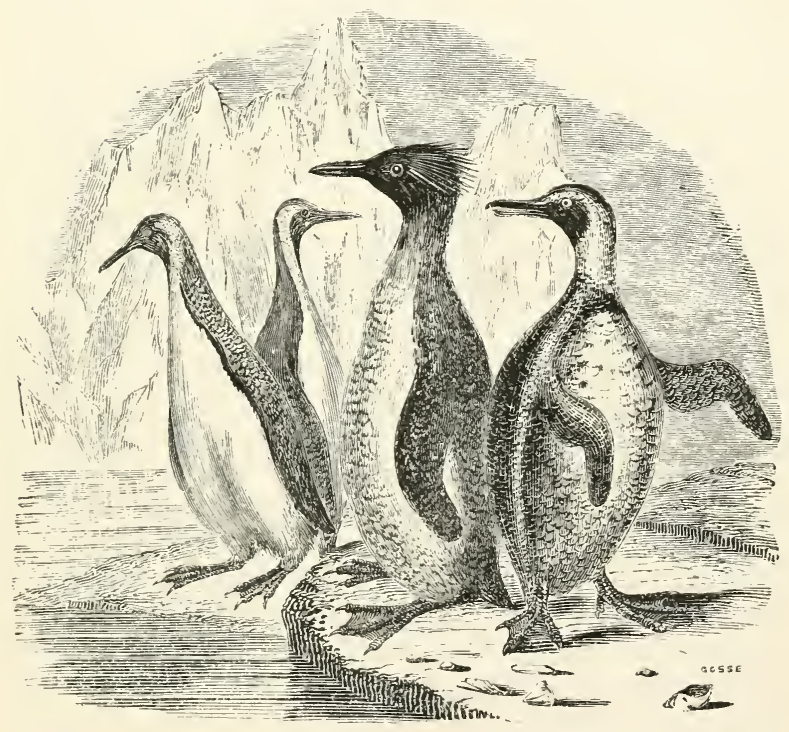

FIG. 205.-PENGLINS.

These birds are found on the rocky islands of the Southern Ocean, and the southern portions of * $\sigma \phi i v$, sphen, a wedge; so called from the shape of their bodies. 
South America and Africa; they are also frequently observed on the floating masses of ice that are scattered over that dreary region. Penguins are utterly incapable of flight; their paddle-like wings are covered with short rigid feathers resembling scales, disposed in regular order. The tarsi are placed so completely at the hinder end of the body, that, in resting, these birds naturally assume an upright attitude; the toes are webbed, and the tar'si very short and stout, so that they are essentially aquatic, seldom visiting the shore, except during the breeding season. From the weight of its body and the density of the plumage, the Penguin swims very deep in the water, the head, neck, and upper part of the back only being seen above the surface. Its powers of progression in its proper element are truly astonishing. It bounds through the sea like a porpoise, and uses its short fin-like wings to assist its progress: with these it stems the most turbulent waves with the greatest facility, and during the severest gale descends to the bottom, where it paddles about in search of crustaceans, small fish, and marine vegetables, upon which it feeds. A considerable portion of the year is employed by these birds in providing for' their young, in consequence of its being necessary that their progeny should acquire sufficient vigoul to resist the raging element on which they are destined to dwell, and which they most probably never leave, until by the impulse of nature they in their turn seek the land for the purpose of reproduction. Notwithstanding this care for the preservation of the brood, heavy gales of wind frequently destroy them in great numbers. From their incapacity for running, and their total inability to fly, the parent birds, when on land, are very easily captured; indeed, they offer no resistance, except a smart peck with the bill. The young, until nearly as large as the adult, are covered with a thick coating of long down, which, as they arrive at 
maturity, is replaced by short stiff feathers; these must be perfectly developed before the bird rentures upon the sea.

The type of this sub-family is-

The Patagonian or King Penguin (Aptenodytes Pennantii). These birds are very numerous in high southern latitudes. Mr. G. Bennet has particularly described a colony which covered an extent of thirty $\mathrm{Ol}^{\circ}$ forty acres, at the north end of Macquarie Island, in the South Pacific Ocean:-“"The number of Penguins collected together in this spot is immense, it would be almost impossible to guess at it with any near approach to truth, as during the whole of the day and night thirty or forty thousand of them are continually landing, and an equal number going to sea. They are arranged when on shore in as compact a manner, and in as regular ranks, as a regiment of soldiers, and are classed with the greatest order, the young birds being in one situation, the moulting birds in another, the sitting hens in a third, the clean birds in a fourth, \&c.; and so strictly do birds in a similar condition congregate, that, should a bird that is moulting intrude itself among those that are elean, it is immediately ejected from among them. The females hatch the eggs by keeping them close between their thighs, and if approached during the time of incubation, move away, carrying the eggs with them. At this time the male bird goes to sea to collect food for the female, which soon becomes very fat. After the young is hatched, both parents go to sea and bring home food for it, and it soon becomes so fat as to be scarcely able to walk, - the old birds getting very thin. They sit quite upright in their roosting-places, and walk in the erect position until they arrive at the beach, when they throw themselves on their breasts to encounter the very heavy sea which awaits then." 


\section{SUB-FA.IILY IV.}

\section{URIANINE.}

The Guillemots.

Gex. Charac.-Bill moderate, more or less strong, with the culmen eurved and the sides compressed to the tip, which is emarginated; the nostrils basal, and placed in a hroad groore, more or less elothed with plumes, with the opening exposed; the wings rather short and pointed; the tail short and rounded; the tarsi short, more or less compressed; the toes moderate, and the anterior ones united by a lroad web, the outer toe as long as the middle toe, the hind toe wanting; the claws short and eurved.

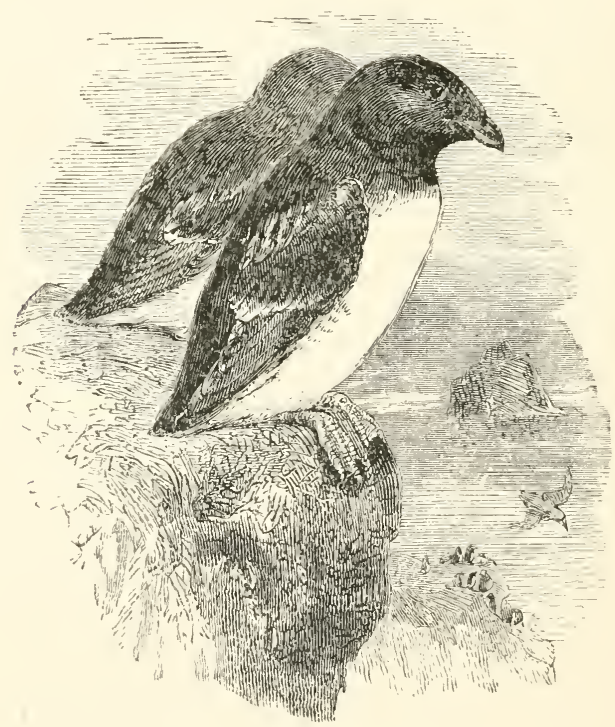

Fig. 206.-THE LitTLE AUK.

(Arctica alle.)

The Guillemots are found in the northern regions, from whence they migrate to more temperate latitudes during the winter.

The type of this sub-family is- 
The Little Auk, or Guillemot (Arctica alle). "This interesting little bird inhabits the countries extending northwards from our latitude to the regions of perpetual ice, occurring equally in the polar regions of both continents. In these high latitules the Guillemots congregate in almost innumerable flocks. Great quantities of them are destroyed by the crews of vessels, as well as by the Esquimaux, their flesh being considered both wholesome and delicate, and at the same time affording a beneficial change of diet to the mariner. They are said to be very tame, and easily captured, a circumstance readily accounted for, as the persons engaged in the whale fisheries, and the limited race of natives inhabiting the borders of the Arctic seas, are the only human beings by whom they are ever disturbed. Like the rest of its family, the Little Auk passes a great portion of time on the ocean, where it sports with great ease and fearless selfpossession, feeding upon small crustacea and fishes, diving for its prey with great celerity and adroitness."--(Gould, "Birds of Europe.") 


\section{FAMILY IV.}

Procellaride.

The Petrels.

Ges. Cuarac.-Bill more or less lengthened, straight, more or less eompressed and grooved, as if composed of several piees, with the tip strong, arehed, suddenly hooked and aeute, and the nostrils tubular and exposed.

'The birds of the Auk family are very scantily furnished with wings, and some of them are totally incapable of flight, but those to which we have now to advert possess large wings, and fly with great ease and rapidity.* Their body is tolerably short, supported upon moderately long legs, which are placed less backward than in many of the preceding groups, so that these birds walk with more grace than most of their allies. The anterior toes are well developed, and united by large webs, but the posterior toe is rudimentary or entirely wanting. The structure of the bill serves to distinguish them from the family of the Gulls, which they resemble in general form. The apical portion of both mandibles is distinct, separate from the basal part, and the upper surface of the base of the upper. mandible is usually occupied by a pair of tubes, generally united together, at the extremity of which are the openings of the nostrils. The nostrils are always of a tubular form. These birds are strictly oceanic in their habits, passing nearly their whole time in flying over the sea, and even apparently delighting in rough weather. Few of them ever visit the shore except for the purpose of breeding, when they deposit their eggs, and rear their young in holes or upon the ledges of the rocks. 'Their food consists of fishes and other marine creatures, together with fragments of animal matter that they find floating on the waves.

This family comprehends the Petrels proper and the Albatrosses.

* See "Animal Creation," p. 467. 


\section{$S U B-F A M I L Y I$.}

\section{Procellaris.e. \\ The Petrels proper.}

GeN. Charac. - Nostrils placed on the basal portion of the culmen, tubular, and generally opened in front.

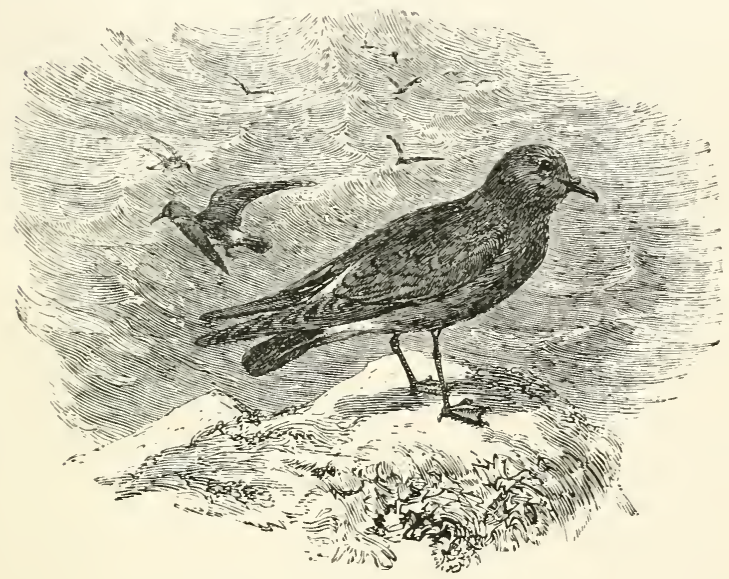

Fig. 207.-THE STORM PETREL.

(Procellaria pelagica.)

These birds live in the higher latitudes of both hemispheres during the summer, and, as the winter approaches, migrate in numerous flocks to the more temperate seas. Their flight is usually rapid and contiuuous, or performed in graceful curves near the surface of the ocean, where they seek fishes and other marine animals, on which they prey. It is indeed an interesting sight to observe these little birds in a gale, coursing over the waves, down the declivities, and up the ascents of the foaming surf, that threatens to burst over their heads; sweeping along the hollow troughs of the sea, as in a sheltered 
valley, and again mounting with the rising billow, occasionally dropping their feet and striking the water, and sometimes leaping with both legs parallel on the surface of the ronghest waves, for several yards at a time. When any greasy matter is thrown overboard from a ship, the Petrels instantly collect around it, facing to windward, with their long wings expanded and their webbed feet patting the water. In calm weather, they perform the same manoenvere by keeping their wings just so much in action as to prevent their feet from sinking below the surface. According to Buffon, it is from this singular habit that these ocean birds have obtained the name of "Petrel," in allusion to St. Peter, who also walked (on the water.

The type of this sub-family,-

The Storm Petrel (Procellaria pelagica), is the smallest, not only of its race, but of the whole order of web-footed birds, measuring less than six inches in length. It is of a sooty black colour, with the outer margins of the tertiary quills and the upper tail-covers white; the bill and feet are black. This bird is met with throughout the European seas.

The Storm Petrel makes its nest in a burrow, excavated to the depth of about a foot. It lays but a single egg, which is white and of small dimensions. The young resemble puffs of white down. The parent attends to its chick with great assiduity, feeding it with the oily fluid produced in great abundance in its crop. So large, indeed, is the amount of this oil, that in some parts of the world the natives make the Storm Petrel into a lamp, by the simple process of drawing a wick through its body. The oil soon rises into the wick, and bums freely. The Petrel only feeds its young by night, remaining on the wing during the dlay, and flying to vast distances from the land. Owing to this habit, and its custom of taking to the sea during the fiercest storms, it has long been an olject of dread to sailors, who fancy that the Petrels, or "Mother Carey's chickens," call up the storm around them. They also believe that the Petrel never goes on shore nor rests, and that it holds its egg under one wing, 
and hatches it while engaged in flight. This bird is essentially a storm-lover, for by the violence of the wind the substances upon which it feeds are brought to the surface, and can be snapped up before they sink again. Throughout the breeding season, the Petrel is indefatigable in search of food, and will follow ships for considerable distances, in hopes of obtaining some of the offal that is thrown over by the cook. During the night, it mostly remains with its offspring, and makes a curious grunting noise like the croaking of frogs. The ordinary cry is low, short, and something like the quacking of a young duck. By day, these birds are silent. The burrow in which the young Petrel is hatched is exceedingly odoriferous, the food on which they live having a very rancid and unsavoury smell, so that both the habitation and its inmates are abominably offensive to the nostrils. The young one is at first very helpless, and remains in its excavated home until several weeks old.

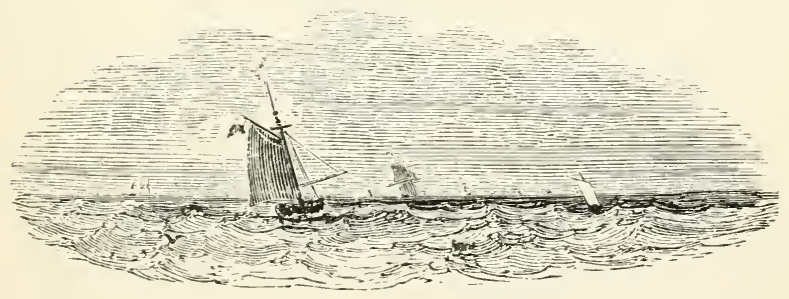




\section{SUB-FAMILY II.}

DiOMEDEIN.E.

The Albatrosses.

Gen, Charac.-Nostrils short, tubular, widest anteriorly, and placed near the base of the lateral groove.

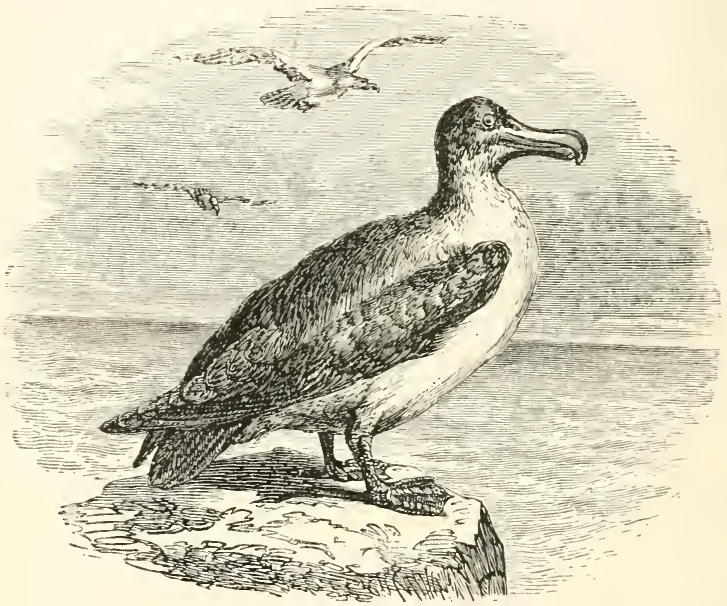

Fig. 208.-THE WANDERING ALBATROSS.

(Diomedea exulans.)

These, the largest of marine birds, are found throughout both hemispheres, but more especially in the neighbourhood of Cape Horn, the Cape of Good Hope, and throughout the Southern Ocean generally. They are seen sometimes at a great distance from land, skimming over the surface of the sea with great rapidity, or resting on the waves. During strong' gales and stormy weather, they soar into the higher region of the air. They feed most voraciously on fish, especially the flying-fishes, as also on mollusca and gelatinous animals. To such an extent do they cram themselves, that they are frequently unable to 
Hy; and in this state they are often attacked by Gulls and other sea-birds, who compel them to disgorge their food, that it may be shared by their feathered enemies. Their nests are built on the islands of the South Sea; they are composed of clay, mixed with regetable remains, are of a round form, and two or three feet high. These birds deposit only one very large egg: the parent is said to provide for her off'spring during the space of nine months.

\section{The type of the sub-family is-}

The Wandering Albatross (Diomedea exulans). The Wandering Albatross is by far the largest and most powerful species of its tribe, and from its great strength and ferocious disposition is held in terror by all the birds by which it is surrounded. It is most abundant between the 30th and 60th degrees of south latitude, and appears to be equally numerous in all parts of the Southern Ocean. It is confined to no particular locality, but would seem to be constantly engaged in making the circuit of the globe in that particular zone allotted by nature for its habitation. The open sea is, in fact, its natural range, and this it never leares except for the purpose of breeding, when it usually resorts to rocky islands the most difficult of access. "The powers of flight of the Wandering Albatross," says Mr. Gould, "are much greater than those of any other bird that has come under my observation. Although in calm or moderate weather it sometines rests on the surface of the water, it is almost constantly on the wing, and is equally at ease while sailing over the glassy sea during the stillest calm, or when sweeping with arrow-like swiftness before the most furious gale; and the way in which it just tops the raging billows and sweeps between the gulfy waves has a hundred times called forth my wonder and admiration." Although a vessel running before the wind frequently sails more than two hundred miles in the twenty-four hours, and that for days together, still the Albatross has not the slightest difficulty in keeping up with the ship, but also performs circles of many miles in extent, returning from these excursions to hunt up the wake of the vessel for any sulb- 
stances thrown overboard. Like other species of the genus, the Albatross is nocturnal as well as dimnal in its activity, and no bird takes so little repose ; it appears to be perpetually on the wing, scanning the surface of the oeean for mollusks, meduse, and the other marine animals that constitute its food. So frequently does the boldness of its alproach cost it its life, that hundreds are annually killed without the numbers being apparently in any degree lessened. It readily seizes a hook baited with fat of any kind; - if a boat be lowered, its attention is immediately attracted, and while flying round it is easily shot. Many exaggerated and marvellous accounts have been published respecting the weight and the dimensions of the bird, particularly as relates to the extent of its wings from tip to tip. Mr. Gould, after killing numerous examples of both sexes and of all ages, found the average weight of the Diomedea exulans to be $17 \mathrm{lb}$, and the extent of the wings from tip to tip ten feet and one inch; examples, however, have been met with weighing as much as $201 \mathrm{lb}$., the extent of whose outstretched wings measured twelve feet. The Wandering Albatross breeds in the rocky islands of the Southern Ocean, in the months of November and December. The grass-covered declivities of the lills, above the thickets of wood, are the spots selected for its nest, which consists of a mound of earth intermingled with grass and leaves matted together, eighteen inches in height and six feet in circumference at the base.

The following account of one of the breeding-places of this feathered monarch of the Southern Hemisphere is from the pen of Mr. Augustus Earle:- "Yesterday being a fine morning, accompanied by two of the men, I determined to ascend the mountain. As several parties had before gone up, they had formed a kind of path, at least; we endeavoured to trace the same way, but it required a great deal of nerve to attempt it ; the sides of the mountain are nearly perpendicular, but after ascending about 200 feet, it is there covered with wood, which renders the footing much more safe; but, in order to get to the wood, the road is so dangerous, that it almost makes me tremble to think of it; slippery grey rocks, and many of them unfortunately loose, so that when we took holi, they separated fiom the mass, and fell with a 
horrid rumbling noise ; here and there were a few patches of grass, the only thing we could depend upon to assist us in climbing, which must be clone with extreme caution, for the least slip or false step would dash one to atoms on the rocks below. By constantly looking upwards, and continuing to haul ourselves up by catching firm hold of the grass, after an hour's painful toil we gained the summit, where we found ourselves on an extended plain of sereral miles' expanse, which terminates in the peak composed of dark grey lava, bare, and frightful to behold. We proceeded towards it, the plain gradually rising; but the walk was most fatiguing, over strong, rank grass, and fern several feet high. A death-like stillness prevailed in those high regions. The prospect was altogether sublime, and filled the mind with awe. The huge Albatross here appeared to dread no interloper or enemy, for the young were on the ground completely uncovered, and the old ones were stalking around them. They lay but one egg upon the ground, where they make a kind of nest by scraping the earth around it. The young is entirely white, and covered with a woolly down, which is very beantiful. As we approached, they snapped their beaks with a very quick noise, - the only means of defence they seem to possess." 


\section{FAMULY Y.}

\section{Pelecanida.}

The Pelicuns.

Gex. Charac.-Bill more or less long, broad at the base, straight, and compressed to the tip, which is sometimes hooked; the nostrils linear, and sometimes scarcely risible; the wings long, and the first quill the longest ; the tarsi short and robust; the toes long, and all four connected together by a broad membrane; the fice and throat more or less naked, the latter sometimes furnished with a naked dilating skin, or pouch, from the base of the lower mandible.

The Pelecanidre are distinguished from the preceding families by the peculiar structure of their feet, which are furnished with four toes, all united by a continuous web, the hind toe being situated upon the imner part of the tarsus, and rather directed towards the front. The bill in the various genera is strongly formed, and generally longer than the head; in many the tip is bent downwards, and armed with a very strong hook; in others it is straight and sharp-pointed. In the latter case the tail is long and forked, and the legs very short, as in many of the Raptorial order. 'The feet are small, and the web connecting the toes so curtailed as to be inadequate for swimming. 'These birds live almost entirely in the air, and take their food upon the wing, swooping down upon the flying-fishes as they spring out of the sea, or harassing other aquatic birds, till they disgorge their prey, which is caught ere it reaches the surface of the water. In those genera that in their habits approach nearer to the typical Swimmers, we find another modification of form. Thus the Cormorants, well known for their aquatic powers, have the body long and flattened, and the wings, although equal to vigorous flight, much shorter than in the section last mentioned. Their legs also are placed near to the extremity of their body, and have not the same freedom of action; in consequence of which they are compelled both to sit and walk almost in a perpen- 
dicular position; such birds catch their prey underneath the water, being endowed with a power of diving little short of that of the typical Alcida. Yet strange to say, notwithstanding the webs on their feet, many of them perch with facility on trees; and in the Gannets the claw of the middle toe is serrated like that of the Heron.

To this family belong the Tropic Birds, the Darters, and the Pelicans properly so called.

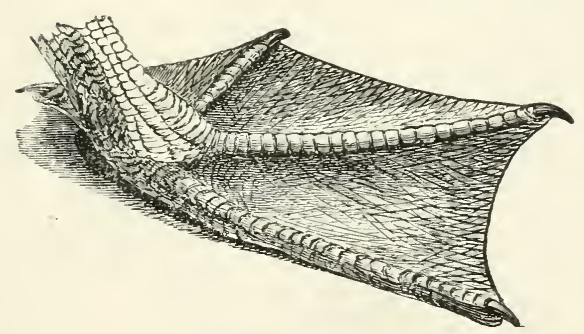

FOOT OF PELICAX. 


\section{Phä́tonisa.}

The Tropic Bircls.

Gix. Charac.-Bill as long as the head, and broad at the base, with the "ulmen elevated, keeled, eurved, and the sides much compressed to the tip, which is acute, the gonys long and ascending; the nostrils basal, linear, and exposed; the wings long and pointed; the tail moderate, graduated, with the two niddle feathers prolonged and linear; the tarsi short; the toes long, and all united by a membrane.

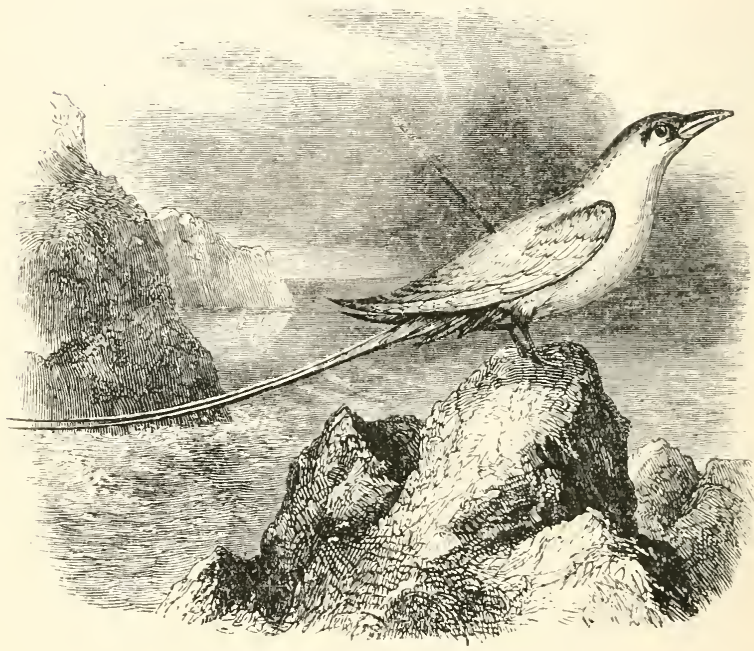

Fig. 209.-THE RED-TAILED TROPIC BIRD.

(Phaëton rubricuuda.)

These birds are only met with in the Tropical Seas, where they are frequently seen, at a great distance from land, flying with ontstretched pinions over the ocean, and seizing fishes and other marine animals that approach the surface, but more especially preying upon the flying-fish, as it bounds out of the sea. Notwithstanding the distance to 
which they roam, they are said by voyagers to return every night to roost upon dry land, and to breed upon the rocks of tropical shores. Some of them, as the Frigate-birds, resemble the Raptores in their habits, being endowed with a sight remarkably piercing, with an immense expanse and power of wing, and with the most determined audacity. 'They attack other birds nearly of their own size, forcing them to disgorge or relinquish the fish ther have caught. It is difficult to imagine a more iniposing sight than half a dozen of these aërial tyrants sailing in mid-air, and suddenly swooping down upon a shoal of fish that may have approached near the surface of the sea. At other times, during a storm, they will soar to such a height as to appear but as specks in the firmament; indeed, all their. powers of motion seem to be concentrated in their wings, for their feet are so short and imbecile that when upon the ground, they may be approached with perfect ease; but in their proper element their. speed is wonderful.

"The Frigate Pelican is possessed of a power of Hight superior, perhaps, to that of any other bird. The swiftest of our Hawks are obliged to pursue their victims at times for half a mile at the highest pitch of their speed before they can secure them; but the Frigate Pelican comes from on high with the velocity of a meteor, and on nearing the object of its pursuit, which its keen eye has spied while fishing at a distance, darts on either side to cut off all retreat, forcing it to drop or disgorge the fish which it has just caught. Yonder over the waves leaps the brilliant dolphin as he pursues the flyingfishes which he expects to seize the moment they drop into the water. The Frigate-bird who has marked them, closes his wings, dives towards them, and immediately ascending, holds one of the tiny things across its bill. Already fifty yards across the sea, he spies a porpoise in full chase, launches towards the spot, and, in passing, seizes the mullet

$$
\because \text { 1: } 2
$$


which had escaped from its dreaded foe; but now having caught a fish too large to be at once swallowed, he rises with it into the air, as if bound for the skies. 'Three or four of his own tribe have watched him, and observed his success. They shoot towards him on broadly extended pinions, mount upwards in wide circles, smoothly, yet as swiftly as himself. They are now all at the same height, and each, as it overtakes him, lashes him with its wings, and tugs at the prey. See! one has robbed him ; but before he can secure the contested fish, it drops. One of the other birds has caught it; but he is pursued by all. From bill to bill, and through the air rapidly falls the fish, until it drops quite dead on the water, and sinks into the deep."-(Audubon.)

The type of the race is-

The Red-tailed Tropic Bird (Phaëton rubricauda). Linneus has bestowed upon these birds the generic name of Phaëton, or Birds of the Sun, probably both from their soaring to great elevations under a tropical sun, and from the circumstance that they seldom or never quit the warm regions of the tropics, where, distinguished by their peculiar jerking flight, they are seen, during calm weather, hovering in mid-air, watching for prey ; or, when stronger breezes prevail, skimming gently over the surface of the ocean. They are amongst the most beautiful of all the oceanic birds, and excite the admiration of the mariner as the rays of a bright sun shine upon their chaste and satiny plumage. They are as gentle in manner as graceful in flight, and it is pleasing to watch their easy evolutions. When soaring to a great height, the action of their wings is slow, accompanied by a jerking motion as they rise and fall by starts, and at the same time utter their peculiar shrill notes.

"The Tropic Bird is the very reverse of the heavy, gigantic Albatross, and might well be called the fairy of the ocean; seen as it is in the genial latitudes of the warmest climates of the globe,-now a stationary speck, elevated as far as the eye can reach, contrasted with the dark blue of the sky, like a spangle in the heavens; then suddenly descending, like a falling star, and as suddenly 
checking its course to hover for a while over the topmost point of a vessel's masts, sometimes darting like a meteor, with its two long projecting tail-feathers streaming in the air, downwards on a shoal of flying-fish; and anon rising gracefully with its prize, again to soar aloft and take its rest above the clouds." - (Bishop Stanley's " History of Birds.")

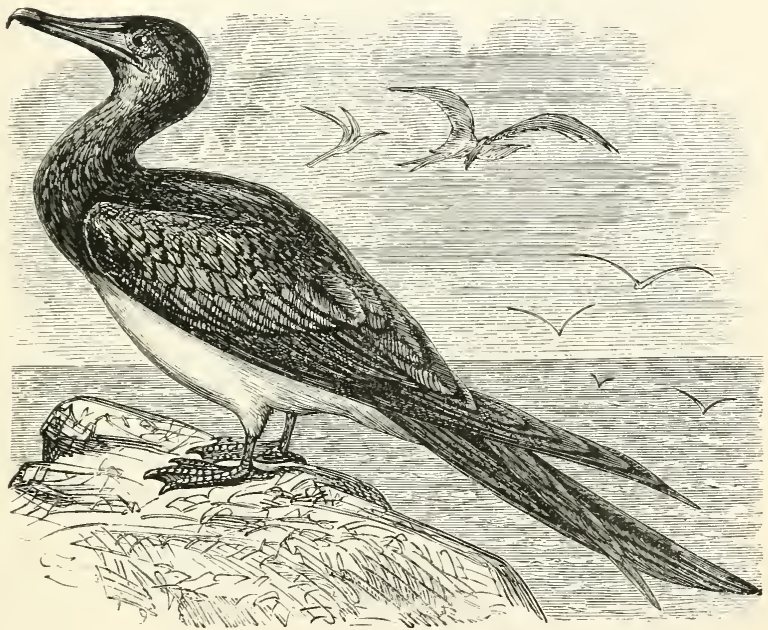

Fig. 210,-THE FRIGate-BIRD,

(Tachypetes Aquila) 


\section{$S U B-F A M I L Y$ II.}

Photeine.*

The Inarters.

Gex. Charac.-Bill lengthened, very slender and acute, with the lateral margins finely scrrated, and the gonys long and searcely ascending; the nostrils hasal, and covered by a shield; the wings long; the tail lengthened and widening towards the end; the tarsi short, very strong; the toeslong and mited by a hroad web; the claws short and curved.

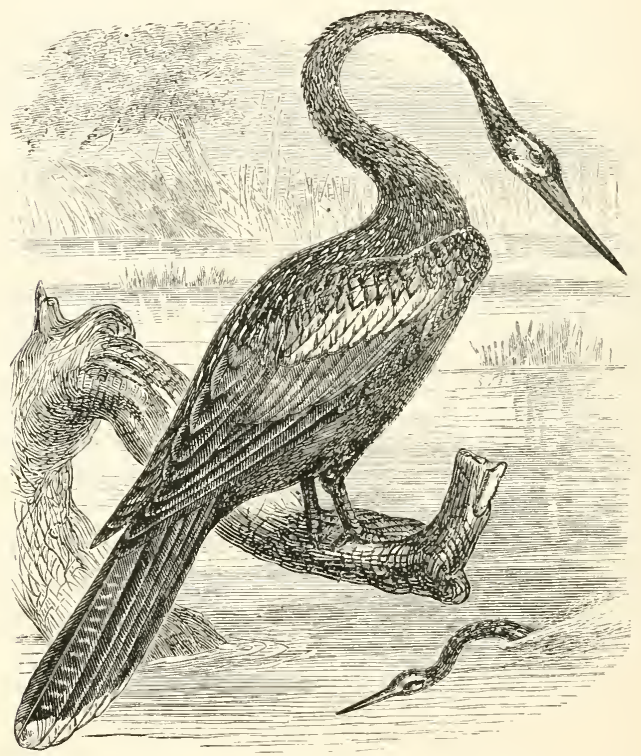

Fig. 211.-THE BLACK-BELLiED DaRTER.

(Plotus melanogaster.)

These birds are met with in the warmer parts of America, Asia, Africa, and also in Australia; they generally frequent rivers and lakes, on which they swim rather deep in the water. When at rest or watching for their food, which consists of fish, * $\pi \lambda \omega \dot{\omega} \eta \eta \mathrm{s}$, plotes, a swimmer. 
they mostly select a dead branch overhanging the stream, from which they dart on their prey. They are extremely shy and cautious. If alarmed while sitting by the river-side, they silently glide into the water with so little effort that they scarcely produce more agitation than would becaused by an eel, and reappear. at a distance, where, from the serpent-like appearance of their head and neck, they are easily mistaken for snakes, as these parts only usually appear above the surface. During the heat of the day they may be occasionally seen sailing very high in the air. Their nests are constructed of sticks, and placed on trees. The egges are from four to eight in number.

The species which has been best described is-

The Black-bellied Darter (Plotus melanogaster). The habitat of this singular bird, so far as we yet know, is confined to the colonies of Southern Africa and New South Wales, where it is thinly but generally dispersed in all situations favourable to its habits ; such as the upper parts of armlets of the sca, the river's of the interior, extensive water-holes, and deep lagoons. It usually takes up its abode in localities little frequented by man, seeks its prey in the water, dives with the greatest ease to the hottom of the deepest pools, and is as active in this element as can well be imagined. It ordinarily swims with a considerable portion of the body above the surface; but upon being disturbed immediately sinks it below the water, leaving the head and neck only to be seen, which from their form, ard the motion communicated to them by the action of swimming, present a close resemblance to those of a snake. Its food consists of fish, aquatic insects, newts, frogs, and other aquatic animals. After feerling, it perches on a snag of some fallen tree in the forest, nigh to its haunts, where it sits motionless for hours together. While thus perched, it is more easily approached and shot than on the water, where it is extremely watchful and circumspect. Dr. Livingstone says._- "Their chief time of feeding is by night; and as the sun declines, they may be seen flying from their roosting-places to the fishing-grounds. This is a most difficult bird to eatch when disabled. It is thoroughly 
expert in diving, and goes down so adroitly, and comes up in the most unlikely places, that the people, though most skilful in the management of the canoes, ean rarely secure them. The tail of the Darter is remarkably prolongerl, and capable of being bent so as to act both as a rudker in swimming and as a lever to lift the bird high enough out of the water to give scope for its wings, so that it can rise at will by means of this appendage." ("Nissionary Travels in South Africa.")

The typical species of the sub-family is-

The White-bellied Darter (Plotus Anhinga).

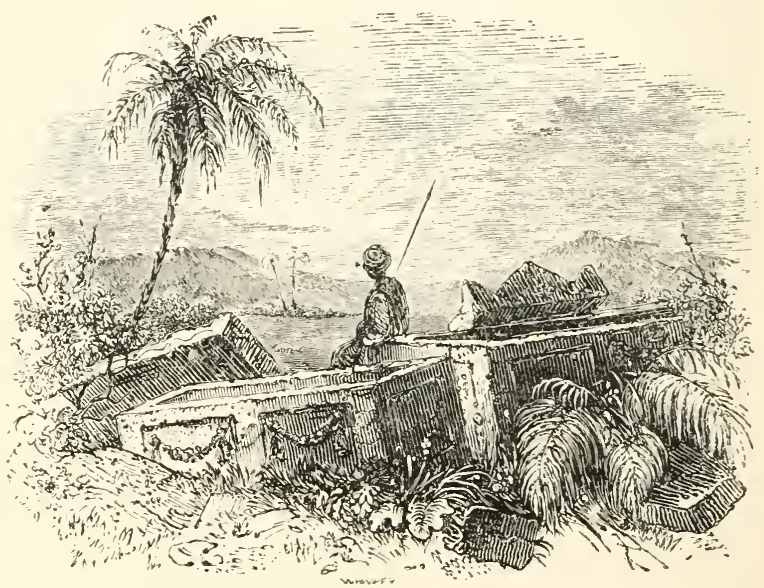




\section{$S U B-F A M I L Y$ III.}

\section{Pelecanine.}

\section{The Pelicans proper.}

Gen. Charac.-Bill lengthened, slender, depressed on the culmen, the sides much compressed, and the tip hooked and more or less compressed; the nostrils placed in the lateral grooves, and scarcely visible; the wings lengthened and pointed; the tail rather short, and generally wedge-shaped; the tarsi short and robust; the toes lengthened, with the outer one equalling the middle one, and all four united together by a membrane; the lower mandible and throat furnished beneath with a membranous pouch, more or less capable of extension.

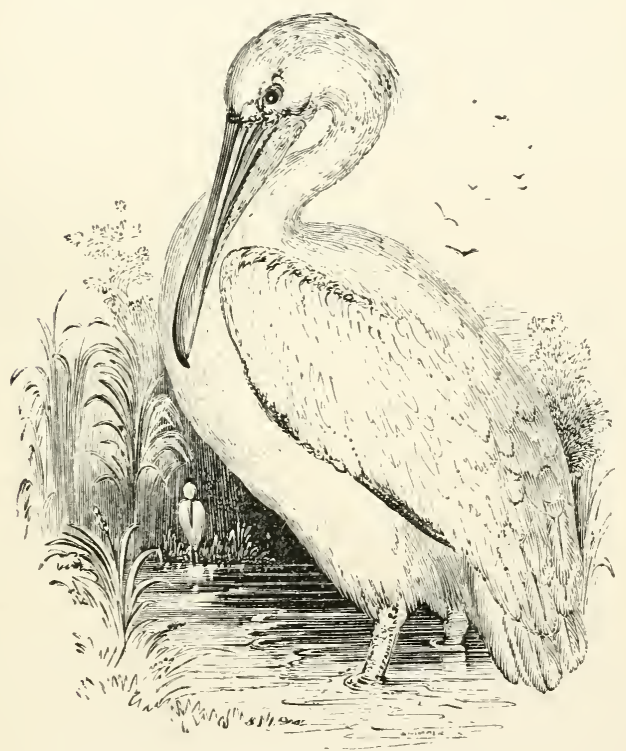

Fig. 212.-The White pelican.

(Pelecanus Onocrotalus.)

These large birds are very widely distributed over the world. In the northern parts of America they are found as far as $61^{\circ}$. They live in the vicinity of rivers or lakes, and on the sea-coast. In the 
morning and evening they are seen in small flocks of from six to fourteen individuals, engaged in fishing until their pouch is sufficiently filled. They then retire to some secluded retreat among the rocks and shoals, or doze on the surface of the water, while leisurely digesting their freshly-caught meal.

"It is a pleasant sight," says Mr. Gosse, "to see "Hock of Pelicans fishing. A dozen or more are Hying on heavy flagging wings, over the sea, the long neck doubled on the back, so that the beak seems to protrude from the breast. Suddenly a little ruffling of the water arrests their attention, and with wings half-closed down each plunges, with a resounding splash, and in an instant emerges to the surface with a fish. The beak is held aloft, a suap or two is made, the huge pouch is seen for a moment distended, then collapses as before, and heavily the bird rises to wing, and again beats over the surf with his fellows. It is worthy of observation that the Pelican invariably performs a summersault under the water; for, descending as he does, diagonally, not perpendicularly, the head emerges looking in the opposite direction to that in which it was looking before. When the morning 'appetite is sated, they sit calmly on the heaving surface, looking much like a miniature fleet. Towards evening they fly in long ranks to the trees near the shore."

Often the Pelicans skim over the surface of the sea or balance themselves in the air at a moderate elevation, and then pounce headlong on their prey. It has been remarked that they occasionally congregate in large flocks, and encircling a piece of water, beat the surface with their wings, until the affrighted fish are driven into a small space, and deprived of all means of escape. Their flight is generally low and heavy, but they are capable of rising to a considerable height. They deposit their eggs on rocks, sometimes in an excavation near the water, or on the banks of a cascade, generally choosing places which are difficult of access. 
The typical species, -

The White Pelican (Pelecanus Onocrotalus), is of about the size of a Swan; its plumage is white or slightly fleshcoloured, with the hook at the end of its beak of a cherryred. These birds are common throughout the warmer regions of the Old World, and equally, or perhaps more, numerous on the American continent. They inhabit marshy places, and live upon fish. Their habits are graphically described in the following sketch :-

"Ranged along the margins of the sand-bar," says Audubon, "in broken array, stand a hundred heavybodied Pelicans pluming themselves and awaiting the return of hunger. Should one chance to gape, all, as if by sympathy, in succession open their long and broad mandibles, yawning lazily and ludicrously. But when the red beanis of the setting sun tinge the tall tops of the forest trees, the birds rise clumsily on their short legs and heavily waddle to the water, and plunge into the stream. Lightly they float as they marshal themselves and extend their line; and now their broad paddle-like feet propel them onwards. In yonder nook the small fry are dancing on the quiet water. Thousands are there, and the very manner of their mirth, causing the waters to sparkle, invites their foes to advance. And now the Pelicans at once spread out their broad wings, press closely forward, with powerful strokes of their feet, drive the little fishes towards the shallow shore, and then, with their enormous pouches spread like so many bag-nets, scoop them out and derour them. These birds are altogether diurnal; when gorged, they retire to the shores of small islands in bays and rivers, or sit on logs floating in shallow water at a good distance from the beach, - in all which situations they lie or stand closely together. The White Pelicans appear almost inactive during the greater part of the day, fishing only after sunrise, and again an hour before sunset, though at times the whole flock will mount high in the air, and perform extended gyrations."

The Brown Pelican procures its food on the wing, and in a manner quite different to that of the White Pelican. "A flock will leave their resting-place, proceed over the waters in search of fish, and when a shoal is perceived, separate at once, when each from an elevation of from fifteen 
to twenty-five feet, plunges in an oblique and somewhat winding direction: spreading its wings, it stretches its lower mandible and pouch as it reaches the water, and suddenly scoops up the object of its pursuit,-immersing the head and neck, and sometimes the body, for an instant. It immediately swallows its prey, rises on wing, dashes on another fish, seizes and devours it; and thus continues, sometimes plunging eight or ten times in a few minutes, and always with unerring aim. When gorged, it rests on the water for a while; but if it has a brook, or a mate sitting on her eggs, it flies off at once towards them, no matter how heavily laden it may be. The generally-received idea that Pelicans keep fish or water in their pouch, to convey them to their young, is quite erroneous. The water which enter's the pouch when it is inmersed, is immediately forced out between the partially closed mandibles; and the fish, unless larger than those on which they usually feed, is instantly swallowed, to be afterwards disgorged for the use of the young either partially macelated or whole, according to the age and size of the latter. They, at times, follow the porpoise, "hen that animal is in pursuit of prey, and as the fishes rise from the deep water towards the surface, come in cunningly for their share,-falling upon the frightened shoal and seizing one or more, which they instantly gobble up."-(Audubon.)

The nest of the Pelican consists of a mass of giass, sedges, and other aquatic plants, and is generally placed quite close to the edge of the water. The eggs are two or three in number. During the process of incubation, the male is said to furnish his partner with food, and when the young are hatched, both parents are assiduous in attending upon them. In disgorging their prey for the nourishment of the young, the birds are clescribed as pressing the pouch against their breast, and it is probable that the notion prevalent among the ancients, that the Pelican in times of scarcity nourished her young with her own blood, must have originated in the gesture above mentioned,- - when the bright red tip of the bill, strongly contrasted with the white plumage of the breast, would have the appearance of being dipped in blood. 


\section{FAMILY VI.}

I.ARID.E.

The Gulls.

Gex. Charac.-Bill of various forms, more or less straight and compressed on the sides; the nostrils lateral, generally longitudinal, and sub-medial; the wings lengthened and pointed; the tail more or less long and of rarious forms; the tarsi generally moderate, strong, and covered in front with transverse scales; the toes moderate, with the anterior ones united by a full web, the hind toe usually short and elerated.

In this family, of which our Sea-gulls furnish well-known and characteristic examples, the wing's are well developed, and the birds possess considerable powers of thight. The bill is variable in its form, but generally rather elongated and compressed,-not furnished with a distinct tip, as in the Procellarida; while the nostrils form linear or oval slits in the sides of the upper mandible, without any trace of tubular structure. The feet, which are placed moderately forward, so as to enable the bird to walk with ease, are generally small; the three anterior toes are well united by a complete web, and the hinder toe is small, and raised above the level of the rest.

The Sea-gulls are very generally distributed, and numerous in most parts of the world, but are most abundant in the northern and southern latitudes. They fly well, and float very lightly and buoyantly over the surface of the waves, but do not swim much, and are incapable of diving. They are generally noisy, screaming birds, living together in considerable flocks. Their food consists chiefly of fishes, but they by no means confine themselves to this diet; indeed, Sea-Gulls feed upon all kinds of animal matter thrown up by the tide or discovered floating on the surface of the ocean; thus fulfilling the same duty on the shores of the sea as the Carrion Crow does in the interior of the comntry. No substance is too putrid to afford them a meal. 
'They may be seen in winter associating' with liooks and Crows, searehing for worms and insects, frequently at a great distance from the sea. 'The whole race is proverbially gluttonous, frequently taking so much food as not to be able to fly till they have disgorged part of their repast ; this, indeed, they will readily do when alarmed, and frequently when slightly wounded. The nest of the Gulls is formed of 'sea-weed, at the distance of a few feet from the water, and is mostly placed on a shelving rock.

This family includes the Gulls proper, the Skimmer's, and the Terns. 


\section{$S L^{\top} B-F^{\top} A M I L Y$ I.}

\section{L.ARINE.}

The Guils proper.

Ges. Charac. - Bill more or less lengthened, straight, compressed on the sides, with the eulmen straight at the base and curved to the tip, which is acute; the nostrils lateral, sub-medial, and oblong; the wings lengthened and pointed; the tail moderate and usually even; the tarsi moderate and strong; the toes moderate, the fore-toes united by a web, and the hind toc generally short and elevated.

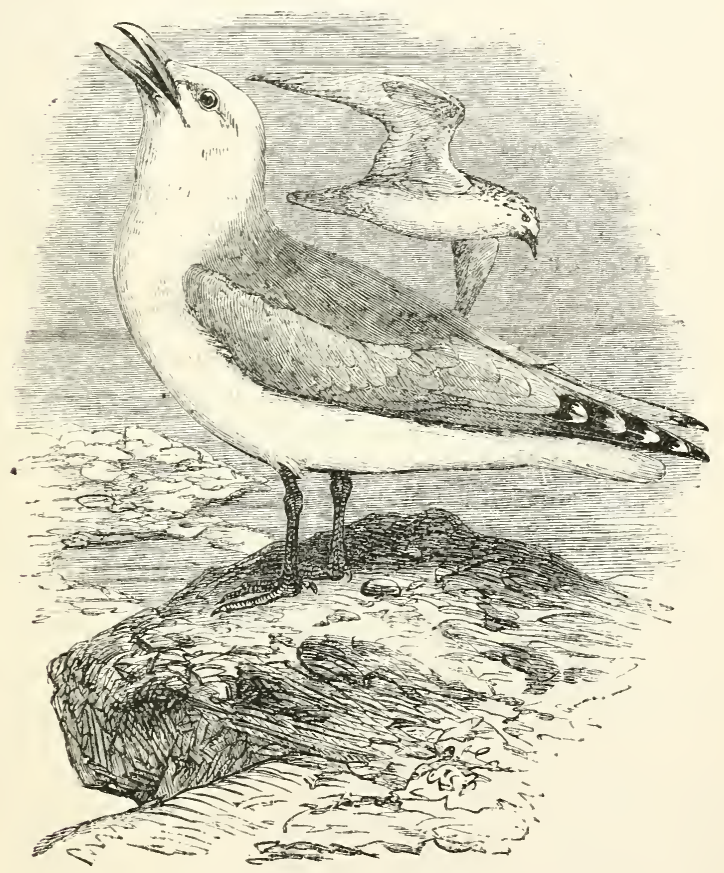

FIG. 213.-THE COMYON GULL.

(Larus canus.)

These birds are scattered over the seas of all countries throughout the world. Sometimes, during the 
spring and summer, they may be seen in flocks, in the marshes, on the borders of rivers, and on cultivated lands, where they seek for worms, insects, and larva. They return to the sea-coast on the approach of autumn and winter, subsisting principally on small fish and worms, which they obtain from the refuse left on the shore after the tide retires, and are especially fond of the spawn of crustaceous animals. 'The larger kinds attack the weaker species, darting' down upon them as soon as they have been fortunate enough to catch a fish, and causing them instantly to disgorge their prize. If the winter proves severe, the Gulls retire further south, until they find a more genial climate. Their flight is easy and buoyant, and when about to migrate, the flock ascends to a considerable height, and then moves off in a contimuous line to its destination. The nest is formed of dry coarse grass or sea-weeds, wherein are deposited three or four eggs.

\section{The type of this sub-family,-}

The Black-backed Gull (Larus marinus), is met with, but hy no means plentifully, upon our coasts, usually alone or in pairs, and rarely in a flock of more than eight or ten together. Like its congeners, it is of a very wary disposition, and must be taken by surprise, as it rarely admits of a near approach. It is of very voracious appetite, and preys upon all kinds of animal substances that may happen to be cast ashore. It also keeps close watch upon the lesser Gulls, whom it drives from any food they have discovered, appropriating the whole to itself; it will even sever and devour the fish from the hooks of the fishermen, if left dry by the ebbing of the tide. Its flight is slow, but light, without much exertion of its pinions, and, as in other species of the genus, always opposed to the wind. Its voice is a strong and hoarse cackle, that may be heard at a great distance when the bird is sailing in the air ; but this is more frequently repeated during the spring and breeding season than at any other times.

On the water, this Gull is extremely light, swimming with little exertion, gracefully rising and falling with the 
undulating waves of the ocean ; it is capable of sustaining a long and continued flight, and while constantly wandering over the surface of the water, or searching along the coast with every rising and receding tide, it seldom fails to find a plentiful suplly of materials for the gratification of its omnivorous appetite.

The Black-backed Gulls build their nests on inaccessible rocks, or sometimes in marshes near the sea, reserving the place selected entirely to themselves, and not even permitting birds of their own species to intrude upon their privacy; nevertheless, they are not always suffered to go ummolested, seeing that their eggs are regarder as dainties, being thought to resemble those of the Plover.

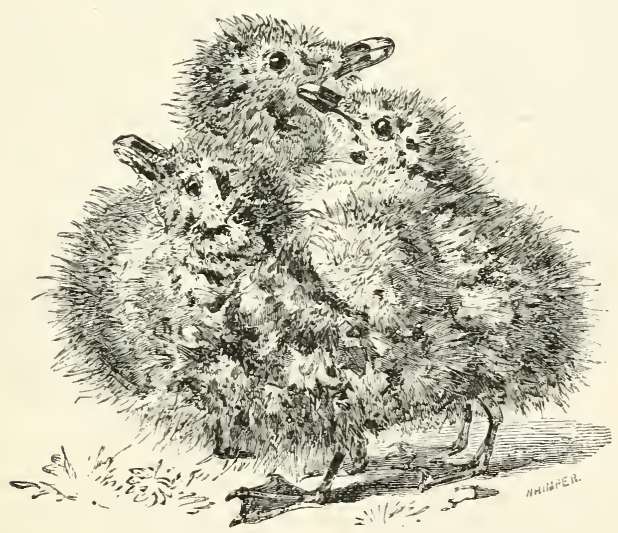

IOUNG GULLS COVERED WITH DOWN. 


\section{$S U B-F A M I L Y I I$.}

RHYNChOPSIN. **

The Skimmers.

GEs. Cinarac-Mandibles unequal, the upper one always shorter than the lower, which is only received in a narrow groove, their sides suddenly much compressed from the base; the wings lengthened, acute, and curved at the tip ; the tail moderate and forked; the tarsi rather longer than the middle toe, and covered with transverse scales; the toes moderate, and the anterior partly united by an indented web.

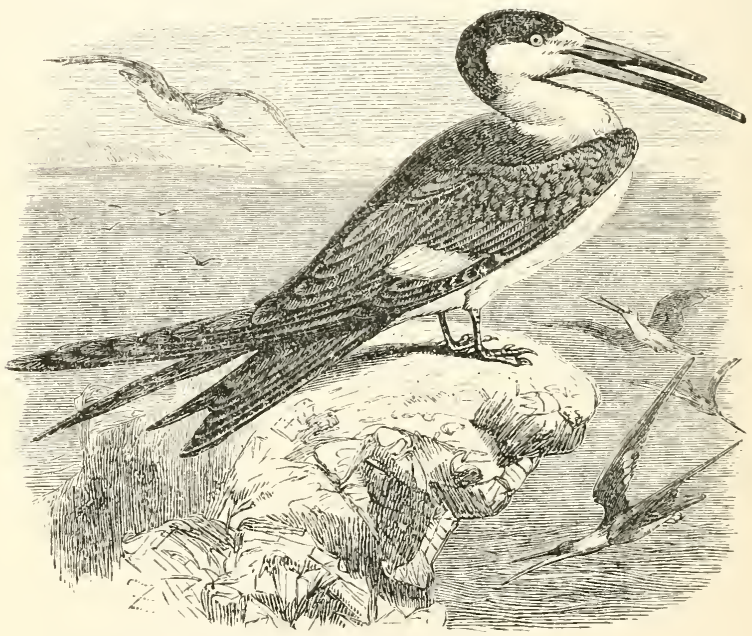

FIG. 214.-THE BLACK SKIMMER.

(Rhynchops nigru.)

The Skimmers differ from the true Gulls in the form of their bill, which is so remarkable as to distinguish them at once from all other birds. Their beak is elongated and compressed, so as almost to resemble the blades of a pair of scissors placed one

* $\dot{\rho} \dot{u} \gamma \chi 0 s$, rhynchos, a beak; ; $\ddot{\omega} \downarrow$, ops, the face; Beak-faced. 
above the other. The upper mandible is considerably shorter than the lower one, which consequently projects to some distance beyond it. The wings are long and pointed, indicating great power of flight, and the tail is forked. These birds are peculiar to the tropical parts of both hemispheres. 'They prefer' the sheltered inlets and estuaries of rivers, over the smooth water of which they fly, near the shores at the flood-tide, seeking for small fish and molluscons animals. These they obtain by skimming the surface of the prolific sea with their lower mandible, while the upper one is kept out of the water. Their Hight is swift and undulating. When on the ground, they walk very awkwardly, and though they possess webbed feet, they rarely swim or even float on the surface of the water. 'During the day, they collect in flocks on the isolated shoals left bare by the recess of the tide. When the breeding season comes, they visit the low sand-bars and dry flats of the coast, for the purpose of scratching out a slight hollow in the sands, wherein the female usually deposits three eggs. The female only sits on the nest during the night, or in wet and stormy weather. The young are scarcely distinguishable from the sand, on account of the similarity of their colour; and before they leave the nest may often be seen basking in the sun, and spreading out their wings upon the warm beach.

\section{The type of this sub-family,-}

The Black Skimmer (Rhynchops nigra), is an inhabitant of the coasts of America, from the Straits of Nagellan to the United States. It is about nineteen inches long, black above and white beneath, with a white band on each wing; the bill and legs are red. Supported by its long and pointed wings, which sometimes extend fully forty inches, the Skimmer darts swiftly over the surface of the ocean, dipping the extremity of its curious bill into the water as it moves along, for the purpose of capturing the small fishes and crustacea upon which it feeds. "This truly singular bird is the only species of its tribe hitherto 
discovered. Its favourite haunts are low sand-bars, raised above the reach of the summer tides, and also dry flat sands on the beach in front of the ocean. The remarkable conformation of the scissor-like bill has excited much surprise, and some writers, measuring the divine proportions of nature by their own contracted standards of conception, in the plenitude of their vanity have pronounced it to be 'a lame defective weapon.' Such ignorant presumption, or rather impiety, ought to hide its liead in the dust, on a more attentive examination of the peculiar construction of this singular beak, and the wisdom hy which it is so admirably adapted to the purposes and mode of existence for which it was intended. This bird is formed for skimming, while on the wing, the surface of the sea for its food, which consists of small fish, shimps, young fry, drc., whose usual haunts are near the shore, and towards the surface. That the lower mandible when dipped into the water may not retard the bird's progress, it is thinned and sharpened like the blade of a knife; the upper mandible, being at such times elevated above the water, is curtailed in its lengtl, as being less necessary, but tapering gradually to a point, that, on shutting, it may ofier less opposition. To prevent inconvenience from the rushing of the water, the mouth is confined to the mere opening of the gullet, which, indeed, prevents mastication from taking place there; but the stomach or gizzard, to which this business is solely allotted, is of unconmon bardness, strength, and muscularity, surpassing, in these respects, any bird with which I am acquainted. To all these is added a vast expansion of wing, to enable the Phynchops to sail with sufficient celerity while dipping in the water. The general proportion of our swiftest Hawks and Swallows is as one to two; but in the present case, as there is not only the resistance of the air, but also that of the water to overcome, a still greater volume of wing is given. The Black Skimmer measures nineteen inches in length, and upwards of forty-four in extent. In short, whoever has examined this curious apparatus, and observed the possessor, with his ample wings, long bending neck, and lower mandible occasionally dipped into and ploughing the surface, and the facility with which he procures his food, cannot but consider it a mere playful amusement, when compared with the dashing immersions of 
the Tern, the Gull, and Fish-hawk, who, to the superficial observer, appear so superiorly accommodated."-(Wilson.)

The Skimmer does not begin to lay till early in June, at which time these birds form themselves into small societies, fifteen or twenty pairs frequently breeding within a few yards of each other. The nest is a mere hollow formed in the sand, without other materials. The female lays three eggs, almost exactly oval, of clear white marked with large round spots of brownish-black, and intermixed with others, the colour of pale Indian ink.

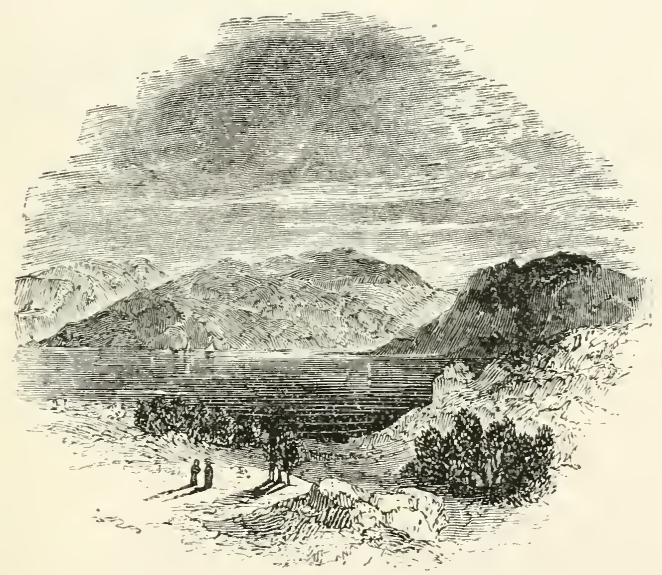




\section{$S C B-F A I I L Y I I I$.}

S'TERNIN.E.

The Terns.

GEx. ChaRAC.-Bill more or less lengthened, generally slender, straight, with the culmen sometimes curved at the tip, which is acute; the nostrils basal, lateral, ant linear; the wings very long and pointed; the tail long, and more or less forked; the tarsi usually short and slender; the toes of various lengths and more or less webbed, the hind toe long and slender.

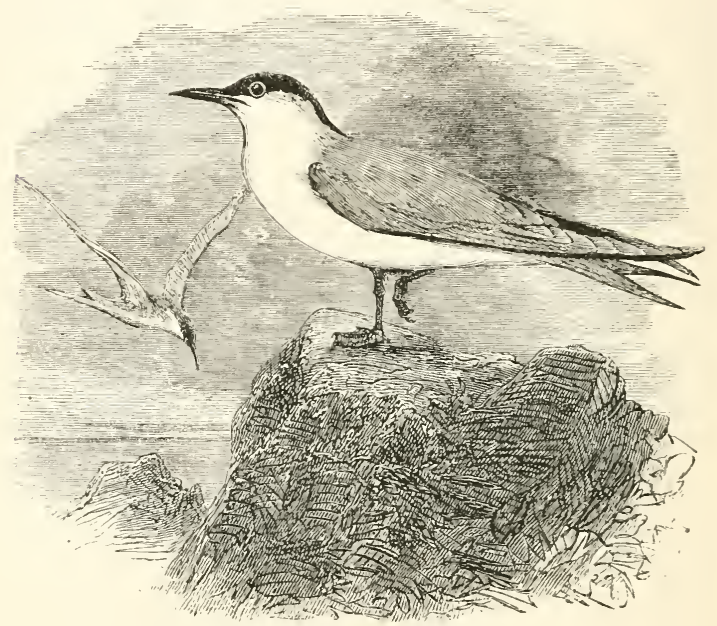

FiG. 215.-THE COMMON TERX.

(Sterna Hirundo.)

These birds are distributed thronghont both hemispheres, migrating in flocks from place to place, according to the season. They usually frequent the sea-coasts or salt-marshes, but are occasionally seen on the borders of inland lakes and rivers. They are continually on the wing, and their flight is lofty, of long continuance, and extended far from land. When seeking their food, they generally wheel round in large circles, or hover over their prey, and 
then suddenly dart straight upon it. At other times, they sweep the surface of the water, seizing with their bill any objects that may be drifting about on the sea. 'They float with buoyancy on the waves, but rarely, if ever, exercise their power of swimming. When seeking rest, they resort to the sandy beach, or they may be seen on shallow reefs, rocks, or even trees. Fishes form their ehief subsistence, though they also feed on various kinds of marine animals, or on any offal cast upon the shore. The larger species sometimes destroy the young' and eggs of other sea-birds. Their eggs are from two to four in number, and are usually deposited in a slight hollow on insulated rocks. The hatching of the egg's is mostly left to the influence of the sum, the parent only sitting on them at night and during cold weather; ret the young, when hatched, are most carefully fed, and protected from the attacks of other birds.

The Terns are distinguished from the Gulls by their long, straight, and pointed bills, small slender feet, very long wings, and forked tails; from the latter character, and incessant activity on the wing, they are frequently known as Sea Swallows.

The type of this race,-

The Common Tern (Sterna Hirundo), is smaller than any of the ordinary Gulls. It is more lively and active in its morements, and does not generally fly in circles, but "rambles" through the air, firequently diverging to the right or left, now skimming the surface of the sea, and anon sweeping aloft to a considerable elevation. Its mode of taking its prey is totally different from that of any of the Gulls. Very frequently a single Tern may be observed pursuing its course in a line with the breakers on a sandy shore, at the distance of from fifty to a humdred yards fiom the beach. Its beak is pointed downwards, and the bird is evidently on the look-out. Suddenly it descends perpendicularly into the water, making a perceptible splash, but scarcely disappearing. In an instant it has recorered the nse of its wings, and ascends again, 
swallowing some small fish, and continuing its eourse as before. Often, when the sea is calm, a cruising party of Terns comes in sight. Their course is less direct than in the instance last mentioned, as they seem to hunt after the fashion of spaniels. Suddenly one of the party arrests its flight, hovers for a moment, like a hawk, and descends as if shot, making a splash in the water. If unsuccessful, it rises at once; but if it has captured the object at which it aimed, it remains floating on the sea, till it has got rid of its victim by the summary process of swallowing it. Terns are by no means shy; they will frequently $\mathrm{fly}$ directly over a boat, uttering from time to time a short scream, which, though not melodious, is in strict keeping with the scene around, harmonizing well with the dashing of the billows and the music of the breeze.

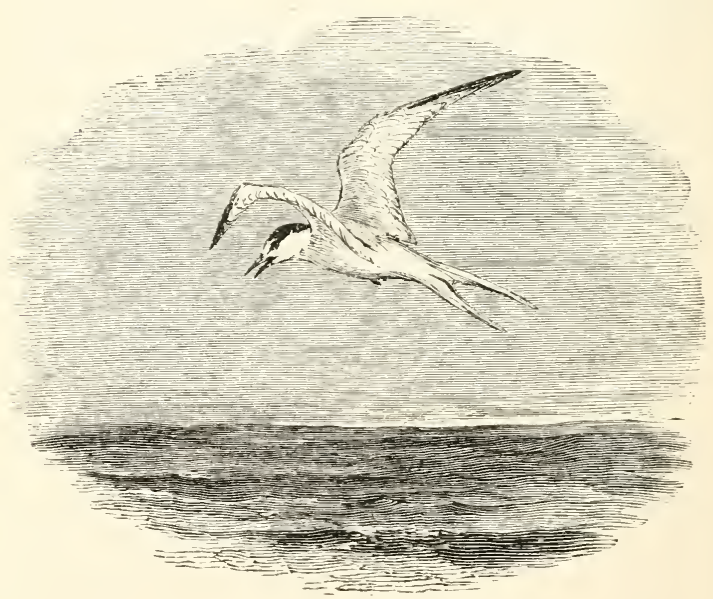


Such are the feathered tribes; thus widely are they spread through every region, whether to ormament the loveliness of Nature or fulfil, each in its separate sphere of usefulness, the will of Hin who sends them forth on their respective missions. Before the curtain falls on this grand spectacle, we may remark how very simple are the means employed to obtain such infinite results, such strange diversity of forms, of habits, and of instincts as adapt each race to its appointed place of residence. The works of GoD exhibit a perfection so divine, that as in Chemistry an atom more or less of any element will change throughout, the nature of the product, so by the slightest means, - an altered feather, or a sharpened claw, - His winged agents are equipped for every duty, and become the beauties and the safeguards of the world. 


\section{I A L Y TICA I I I I X.}

ORDER I.-ACCIPITRES.

SCB-ORDER I.-ACCIPITRES DIURNI.

Fim. I. Vulturide,-The Vultures - - - - porge 15

Gypaetina - The Bearded Vultures - - 17

Sarcoramphinæ - The Condors - - - $\quad$ - 19

Vulturine - - The Vultures proper - - $\quad$ - 22

Gypohieracine - The Eagle Vultuies - - $\quad 26$

Fam. II. FAlconide, -The Falcons - - - - $\quad 27$

Polyborinæ - The Caracaras - $\quad$ - $\quad$ - 29

Buteoninæ - The Buzzards - - - 31

Aquilinæ - . The Eagles - $\quad$ - $\quad$ - 33

Falconina - - The Falcons proper - - $\quad 43$

Milvinæ - - The Kites - - - $\quad 46$

Accipitrinæ - The Sparrow-hawks - - - 50

Circinæ - - The Harriers - - - 52

STB-ORDER II.-ACCIPITRES NOCTURNI.

Fam. I. Strigide.-The Owls - - . - - - 54

Surninæ - - The Hawk Owls - - $\quad 56$

Buboninæ - The Horned Owts - - $\quad 58$

Syrninæ - - The Owlets - - - - 61

Striginæ - - The Owls proper - - - 63

\section{() R D E R I I.-P A S E E R E S.}

TRIBE I.-FISSIROSTRES.

SUB-TRIBE I.-Fissirostres NocturNi.

Fim. I. Caprimulgide. -The Goatsuckers - - - 66

Steatorninæ - The Oit-birds - - - $\quad$ - 67

- Caprimulgina - The Goatsuckers proper - $\quad 69$

Podagrinæ - The Podagers - - - 74

SUB-TRIBE II.-Fissirostres DiURni.

Fam. I. Hirundinide.-The Swallows - - - $\quad-75$

Cypseline - The Swifts - - - 77

Hirundinina - The Swalloxs - - - - So 
TRIBE II.-TENUIROSTRES.

Fam. I. UpUpid - -The Hoopoes - - - - perfe 84

Upupinæ - - The Hoopoes proper - - - 85

Epimachinæ - The Plumed Birds - - $\quad 87$

Fam. II. Promeropide.-The Sun-birds - - - - s!)

Promeropinæ - The Sun-birds proper - - !2

Cœrebinæ - The Guit-guits - - - $\$ 5$

Fam. III. Trochilide.-The Humming-birds - - - 97

Grypinæ - - The Wedge-tailed Humming-bird: 1112

Trochilinæ - The Curved-billed Humming-birds 104

Mellisuginæ - The Straight-billedHuming-birrs 106

Fam. IV. Meliphagide.-The Honey-eaters - - - 109

Myzomelinæ - The Honey-creepers - - - 110

Meliphaginæ - The Honey-eaters proper - - 112

Melithreptinæ - The Honey-feeders - . - 114

Fam. V. Certhiade.-The Tree-creepers - - - - 116

Furnarinæ - The Oven-birds - - - 117

Synallaxinæ - The Sharp-tails - - - 11!

Dendrocolaptinæ The Tree-creepers moper - 121

Certhinæ - - The Creepers - - - - 123

Sittinæ - - The Nuthatches - - - 125

Orthonycinæ - The Molousas - - - $\quad$ - 127

Menurinæ - The Wrens - - . - 129

\section{TRIBE III.-DENTIROSTRES.}

Fam. I. Luscinide.-The Warblers _ - - $\quad$ - $\quad$ - 131

Malurinæ - - The Soft-tailed Warbleis - 132

- Luscininæ - The Warblers proper - - - 134

Erythacinæ - The Robins - - - - 138

Accentorinæ - The Accentors - - - -141

- Parinæ - - The Titmice - - $\quad$ - -143

- Motacillinæ - The Wagtails - - - - 146

Fam. II. TURDID E.-The Thrushes - - - - - 149

Formicarinæ - The Ant-Thrushes - - - 150

Turdinæ - - The Thrushes proper - - - 152

Timalinæ - The Babblers - - - -155

Oriolinæ - - The Oivoles - - - - -157

Pyenonctinæ - The Bulbuls - - - - 160

Fam. III. Muscicapide.-The Flycatchers - - - - $\quad$ - 162

Querulinæ - The Mourneis - - - - 163

Alectrurinæ - The Alectrures - - - - 165

Tyranminæ - The Tyrants - - - - -167

Tityrinæ - - The Becards - - - - 170

- Muscicapinæ - The Flycatchers proper - - 173

Vireoninæ- - The Greenlets - - . - 175 
Fam. IV. Ampelide.-The Chatterers - - - - page 177

Pachycephalinx - The Thick-heads - - - 178

Piprinæ - - The Manokins - - - - 180

Ampelinæ - - The Chattereis proper - 182

Campephaginis - The Criterpillar-eaters - $\quad 184$

Dierurine - - The Diongo Shitikes - - 186

Fam. V. LaniId E.-The Butcher-birds - - - 188

Laniine - - The Butcher-birds proper - $\quad 189$

Thamnophilinæ - The Bush Shrikes - . - 191

\section{TRIBE IV.-CONIRUSTRES.}

Fam. I. Corvide.-The Crows - $\quad$ - $\quad$ - $\quad$ - $\quad$ - $\quad$ - 194

Phonegaminæ - The Piping Croxs - - -196

Garrulinæ - - The Jays - - - - 198

Calleatine - - The Tiree Crows - - $\quad 200$

Corvinæ - - The Crows proper - - 202

Gymnoderinæ - The Fruit Ciows - - - 205

Pyrrhocoracinæ - The Choughs - - - $\quad 207$

Fam. II. Paradiseide.-The Birds of Paradise - _ - 209

Fam. III. Sturnidæ.—The Starlings - - - - $\quad$ - 212

Ptilorhynchinæ - The Glossy Stanlings - $\quad 213$

Graculinæ - . The Grakles - . - 217

Buphaginæ - The Ox-peckers - - -220

Sturnina - - The Stailings proper - -222

Quiscalinæ - The Boat-tails - - - - 224

- Icterinæ - - The Hang-nests - - -226

Agelainæ - - The Troop-birds - - $\quad 229$

Fam. IV. FringILlid E. -The Finches - - - - 232

Ploceinæ - . The Weavers - - $\quad$ - $\quad-234$

Coccothraustinæ- The Hawfinches - . - 239

Tanagrinæ - - The Tanagers - - - - 241

Fringillinæ- - The Finches proper - - - 243

Emberizina - The Buntings - - - 246

Alaudinæ - The Larlss - - - $\quad 249$

Pyrrhulinæ - The Bullfinches - - $\quad$ - 252

- Loxianæ - . The Crossbills - - - - 255

Phytotominæ - The Plant-cutters - - - 258

Fam. V. Colid æ.-The Colies - - - - - - $\quad 260$

Fam. VI. Musophagide.-The Plantain-eaters - - $\quad 263$

Musophaginæ - The Plantain-eaters proper - 264

Opisthocominæ - The Hoatzins - - - - 266

TRIBE V.-SYNDACTYLE.

Fam. I. CORACID E.-The Rollers - - - - - 268

Coraciasinæ - The Rolleis proper - - -269

Todinæ - - The Todies - - - - 271

Eurylaiminæ - The Boat-bills - - - - 274

Momotinæ - The Motmots - - - $\quad 276$ 
Fam. II. Meropide-The Bee-eaters - - - - page 279

Meropinæ - - The Bee-eaters proper - - 280

Fam. III. Trogonidæ.-The Trogons - $\quad$ - $\quad$ - $\quad$ - 282

Trogoninæ - The Trogons pioper - - - 283

Fam. IV. Alcedinid ж.-The Kingfishers - - - 28;

Bucconinæ - The Puff-birds - - - $\quad$ - 288

Halcyoninæ - The Crab-hunters - - - 290

Alcedininæ - The Kinafishers proper - $\quad-293$

Galbulinæ - - The Jacamass - - - 296

Fam. V. Bucerotide.-The Hornbills - - - - 298

\section{ORDER III. SCANSORES.}

Fam. I. Ramphastide.-The Toucans - - - 303

Fam. II. Psittacide.-The Parrots - - - - $\quad$ - 306

Pezoporinæ - The Ground Parots - - 308

Arainæ - - The Macaws - - - 310

Lorinæ - - The Lories - - - $\quad 312$

Psittacinæ - - The True Parrots - - 314

Cacatuina - - The Cockatoos - - - 316

Fam. III. PICID e.-The Woodpeckers - - - - - 318

Capitoninæ - The Barbets - - $\quad$ - $\quad$ - 320

Picumninæ - The Piculets - - - $\quad 322$

- Picinæ - - The True Hoodpeckers - - 324

Gecininæ - The Green Woodpeckers - $\quad 326$

Melanerpinæ - The Black Woodpeckers - 328

Colaptinæ - - The Ground Woodpeckers - - 330

Yuncinæ - - The Wrynecks - - - 332

Fam. IV. CUCUlide.-The Cuckoos - - - - - 335

Indicatorinæ - The Indicators, or Homey-ynides 336

Saurotherinæ - The Rain Cnckoos - - - 338

Coccyzinæ - - The Ground Cuckons - - 340

Crotophagine - The Anis, or Tick-eaters - $\quad 343$

Cuculinæ - - The Cuckoos propes - - - 345

()PDER IV.-GALLIN A.

SEC'TION I.-GALLINE (properly so called).

Fam. I. Cracide.-The Curassows - - . - - 351

Penelopinæ - The Guans - $\quad$ - $\quad$ - 352

Cracinæ - - The Curassows proper - 354

Fam. II. Megapodide,-The Megapodes - - - - 356

Talegallinæ - The Talegallas - - - 357

Megapodina - The Mound-birls - $\quad$ - 359 
Fam. III. Phasianide.-The Pheasants - - - page 361

Pavonina - - The l'eacocks - - - - 362

Phasianine - The Tive Pheasants - . - 364

Gallinæ - - The Jungle-fouls - - - 367

Meleagrine - The Tuikeys - - - - 369

Lophophorine - The Monauls - - - $\quad 372$

Fam. IV. Tetraonide.-The Grouse - _ _ - - 374

Perdicina - - The Portividges - - - 375

Francolininæ - The Francolins _. - - 377

T'urnicine - - The Bush Quaits - . - 380

- Odontophorina - The Anerican l'artideses - - 38?

Tetraoninæ - The Giouse proper - - - 384

Pteroclinæ - - The Sand Grouse - - 387

Fam. V. Chionidide,-The Sheath-bills - - - - 389

Thinocorine - The Shore Larks - - 390

Chionidinæ - The Sheath-bills proper - - 392

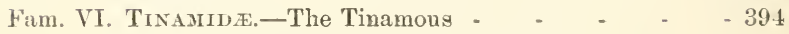

SECTION II.-COLUMBE.

Fam. I. Columbidæ,-The Pigeons - - - - $\quad 396$

Treroninæ - - The Tree Pigeons - - 399

Columbinæ - The Pigeons proper - - - 401

Gourina - - The Ground Pigeons - - 404

Diduneuline - The Tooth-billed Pigeons - - 406

Didinæ - - The Dodos - - - 408

\section{ORDER V.-CURSORES.}

Fan. I. Struthionide,-The Ostriches - - - - 412

Struthionina - The True Ostriches - - - 413

Otidina - - The Bustarls - - $\quad$ - 419

Apteryginæ - The Kivis - - - 421

\section{ORDER VI.-GRALLATORE.}

Fam. I. ChARAdRIIDE,-The Plovers - - - - 426

Edicnemine - The Thick-knees - - - 427

Cursorinæ - - The Coursers - - - - 429

Glariolinæ - . The Pratincoles - - 431

- Charadriine . The Tine Plovers - - - 433

Hrmatopodinæ - The Oyster-catchers - - - 435

Cincline - - The Tumstones - - - 438

Fam. II, ARDeide.-The Herons - - - - 440

Psophina - - The Trumpeters - - - 441

- Gruinæ - . The Cianes - - . - 444

- Ardeinæ - - The Herons proper - - - 448

Ciconina -. - The Storks - - - 451

Tantaline - The Ibises - - - 454 
Fam. III. Scolopacide.-The Snipes .

- page 457

-Limosinæ - . The Godwits - - - 459

Totanina - . The Longshanks - - - 462

Recurvirostrinæ. The diocets - - - - 465

Tringinæ - - The Sandpipers - - - 467

Scolopacinæ - The Snipes proper - - - 470

- Phalaropodinæ - The Phalaropes - - $\quad 473$

Fam. IV. Palamedeide.-The Screamers - - - - 476

Parrinæ - . The Jacanas - . - - 177

Palamedeinw - The Screamers proper - 479

Fam. V. RatiLid Æ.-The Rails - - - - - - 481

Rallinæ - . The Rails proper - - - 483

Gallinulinæ - The Gallinules, of Moortens - 485

\section{ORDER VII.-PALMIPEDES.}

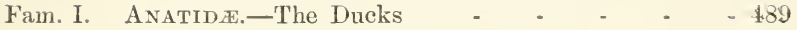

Phonicopterinæ. The Flamingoes _ _ - 491

Plectropterinæ - The Spu-vinged Geese - - 494

Anserinæ - - The True Geese - - - 496

Cygninæ - - The Swans - - - - 499

- Anatinæ - - The River Dicks - - 503

Fuligulinæ - The Sea Ducks - - - - 506

Erismaturinæ - The Spiny-tailed, Ducks - 507

Merginæ - . The Mergansers - $\quad$ - $\quad 569$

Fam. II. Colymbide.-The Divers - $\quad$ - $\quad$ - $\quad$ - 512

Colymbinæ - The True Divers - - 513

- Podicepinæ - The Giebes - - - - 516

Heliorninæ - The sun-Grebes - - 519

Fam. III. ALCID ж.-The Auks - . - - - - - 520

Alcinæ - . The Auks proper - - 522

Phaleridinæ - The Starakis - - - - 525

Spheniscinæ - The Penquins - - - - 527

Urianinæ - . The Guillemots - - - 530

Fam. IV. Procellaride.-The Petrels - - - - 532

- Procellarinæ - The Petrels proper - - 533

Diomedeinæ - The Albatrosses - - 536

Fam. V. Pelecanide. -The Pelicans - . - 540

Phaëtoninæ - The Tropic Birds - - 542

Ploteinæ - - The Darter's - - - $\quad 546$

Pelecaninæ - The Pelicans proper - . - - 549

Fam. VI. Laride.-The Gulls - - - - - - 553

Larinæ - - The Gulls proper - - 555

Rhynchopsinæ - The Skimmers - - - 558

Sterninæ - - The Terns - - . - 562 


\section{MLPIIAETICAL INDEX.}

Accentorina, $1+1$.

Accentors, 141.

Accipitres, 13.

Diurni, 14.

Noeturni, 54 .

Accipitrinæ, 56 .

Agelainæ, 229 .

Alaudinæ, 249.

Albatrosses, 536 .

Alcedinida, 287.

Alcedininx, 293.

Alcida, 520.

Alcinæ, 522.

Alectrures, 165.

Alectrurinæ, 165.

Ampelida, 177.

Ampelinæ, 182.

Anatidx, 489 .

Anatinæ, 503.

Anis, or Tick-eaters, 343.

Anserinæ, 496.

Apteryginæe, 421.

Aquilinæ, 33.

Arainæ, 310.

Ardeida, 440.

Ardeina, 448.

Auks, 520. proper, 522 .

Avocets, 465.

Babblers, 155.

Becards, 171.

Bee-eaters, 279. proper, 280.

Birds of Paradise, 209.

Boat-bills, 274.

Boat-tails, 224.

Buboninæ, 58.

Bucconinæ, 288.

Bucerotida, 298.

Bulbuls, 160.

Bullfinches, 252.

Buntings, 246.

Buphaginæ, 220.
Bush Shrikes, 191.

Quails, 380.

Butcher-birds, 188. proper, 189.

Buteoninæ, 31 .

Buzzards, 31.

Cacatuinre, 316.

Calleatinæ, 200.

Campephaginæ, 181.

Capitoninæ, 320.

Caprimulgidæ, 66.

Caracaras, 29.

Caterpillar-eaters, 181.

Certhiadæ, 116.

Certhinæ, 123.

Charadriida, 426 .

Charadriinæ, 436.

Chatterers, 177.

proper, 182.

Chionididae, 389.

Chionidinæ, 392.

Choughs, 207.

Ciconinæ, 451.

Cinclinæ, 438.

Circina, 52.

Coccothraustina, 239.

Coccyzinze, 340.

Cockatoos, 316.

Corebinæ, 95.

Colaptina, 330.

Colidæe, 260.

Colies, 260.

Columbe, 396.

Columbidæe, 396 .

Columbinæ, 401.

Colymbidx, 512.

Colymbinæ, 513.

Condors, 19.

Conirostres, 193.

Coraciacinæe, 269.

Coracidæ, 268.

Corvida, 194.

Corvinæ, 202. 
Coursers, 429.

Crab-hunters, 290 .

Cracida, 351.

Cracinæ, 354 .

Cranes, 444.

Creepers, 123.

Crossbills, 255.

Crotophagina, 343.

Crows, 194.

Fruit, 205.

Piping, 196.

proper, 202.

Tree, 200.

Cuckoos, 335.

Ground, $3 \pm 0$.

proper, 345 .

Rain, 338.

Cuculidæ, 335.

Cuculinæ, 345.

Curassows, 351.

proper, 354 .

Cursores, 412.

Cursorinæ, 429.

Cygninæ, 499.

Cypselinæ, 77.

Darters, 546 .

Dendrocolaptiræe, 121.

Dentirostres, 131.

Dicrurinæ, 186.

Didinæ, 408.

Didunculinæ, 406 .

Diomedeinæ, 536.

Divers, 512.

true, 513.

Dodos, 408.

Drongo Shrikes, 186.

Ducks, 489.

River, 503.

Sea, 506.

Spiny-tailed, 507.

Eagles, 33.

Emberizinæ, 246.

Epimachinæ, 87.

Erismaturinæ, 507.

Erythacinze, 138.

Eurylaiminæ, 274.

Falconidæ, 27.

Falconinæ, 43.

Falcons, 27.

proper, 43 .
Finches, 232.

proper, 243.

Fissirostres, 66.

Diurni, 75.

Nocturni, 66.

Flamingoes, 491.

Flycatchers, 162.

proper, 173.

Formicarinæ, 150.

Francolininæ, 377.

Francolins, 377.

Fringillidæ, 232.

Fringillina, 243.

Fuligulinæ, 506.

Furnarinæ, 117.

Galbulinæ, 296.

Gallinæ, 348, 367.

Gallinules, or Moorhens, 485.

Gallinulinæ, 485.

Garrulinæ, 198.

Gecininæ, 326.

Geese, true, 496.

Glariolinæ, 431.

Goatsuckers, 66. proper, 69.

Godwits, 459.

Gourinæ, 404.

Graculinæ, 217.

Grakles, 217.

Grallatores, 424.

Grebes, 516. Sun, 519.

Greenlets, 175.

Grouse, 374. proper, 384 . Sand, 387.

Gruinæ, 444.

Grypinæ, 102.

Guans, 352.

Guillemots, 530.

Guit-guits, 95.

Gulls, 553. proper, 55.5.

Gymnoderinæ, 205.

Gypaetinæ, 17.

Gypohieracinæ, 26.

Halcyoninæ, 290.

Hang-nests, 226.

Harriers, 52.

Hawfinch€s, 239. 
Hawks, Sparrow, 50.

Heliorninie, 519.

Hematopodinæ, 435.

Herons, 440. proper, 448.

Hirundinida, 75.

Hirundininæe, 80 .

Hoatzins, 266.

Honey-creepers, 110.

Honey-eaters, 109. proper, 112.

Honey-feeders, 11.

Honey-guides, 336.

Hoopoes, 81. proper, 85 .

Hornbills, 298.

Humming-birds, 97. Curved-billed, 104. Straight-billed, 106. Wedge-tailed, 10.2 .

Ibises, 454 .

Icterinæ, 226.

Indicatorinæ, 336 .

Indicators, 336.

Jacamars, 296.

Jacanas, 477.

Jays, 198.

Jungle-fowls, 367 .

Kingfisher, 287.

Kites, 46, proper, 293.

Kivis, 421.

Laniidæ, 188.

Larks. 249. Shore. 390.

Laridæ, 553.

Larinæ, 555.

Limosinæ, 459.

Longshanks, 462.

Lophophorina, 372.

Lories, 312.

Lorinæ, 312.

Loxianæ, 255.

Luscinidæ, 131.

Luscininæ, 134.

Macaws, 310 .

Malurinæ, 132.
Manakins, 180.

Megapodes, 356 .

Megapodidæ, 356.

Megapodinæ, 359.

Melanerpinæ, $32 \mathrm{~S}$.

Meleagrinæ, 369.

Meliphagidæ, 109.

Meliphaginæ, 112.

Melithreptina, $11 \%$.

Mellisuginæ, 112.

Menurinæ, 129.

Merganser's, 509.

Mergina, 509.

Meropidæ, 279.

Meropinæ, 280.

Milvina, 46.

Mohouas, 127.

Momotina, 276.

Monauls, 372 .

Moorhens, 485.

Motacillinæ, 146.

Notmots, 276.

Mlound-birds, 359 .

Mourners, 163.

Muscicapidæ, 162.

Muscicapinæ, 173.

Musophagidæ, 263.

Musophaginæ, 264.

Myzomelinæ, 110.

Nuthatches, 125.

Odontophorinæ, 382.

Edicneminæ, 427.

Oil-birds, 67.

Opisthocominæ, 266.

Orioles, 157.

Oriolinæ, 157.

Orthonycinæ, 127.

Ostriches, 412 . true, 413.

Otidinæ, 419.

Oven-birds, 117.

Owlets, 61 .

Owls, 54 .

Hawk, 56 .

Horned, 58. proper, 63.

Ox-peckers, 220.

Oyster-catchers, 435.

Pachycephalinæ, 178.

Palanedeidæ, 476 . 
Palamedeinæ, 479.

Palmipedes, $4 \mathrm{~S} 8$.

Paradiseidæ, 209.

Parinæ, 143.

Parrine, 477.

Parrots, 306.

Ground, 308.

true, 314 .

Partridges, 375.

American, 382.

Passeres, 65 .

Pavoninæ, 362.

Peacocks, 362.

Pelecanidæ, 540 .

Pelecaninæ, 549 .

Pelicans, 540. proper, 549 .

Penelopinæ, 352.

Penguins, 527.

Perdicinæ, 375.

Petrels, 532.

proper, 533.

Pezoporinæ, 308.

Phaetoninæ, 542.

Phalaropes, 473.

Phalaropodinæ, 473.

Phaleridinæ, 525.

Phasianidæ, 361.

Phasianinæ, 364.

Pheasants, 361 . true, 364.

Phonegaminæ, 196.

Phøenicopterinæ, 491.

Phytolominæ, 258.

Picidæ, 318.

Picinæ, 324.

Piculets, 322.

Picumninæ, 322.

Pigeons, 396.

Ground, 404.

proper, 401.

Tooth-billed, 406 .

Tree, 399 .

Piprinæ, 180.

Plantain-eaters, 263. proper, 264.

Plant-cutters, 258.

Plectropterinæ, 494.

Ploceinæ, 234.

Ploteinæ, 546.

Plovers, 426.

true, 433 .
Plumed Birds, 87.

Podagers, 74.

Podagrinæ, 74.

Podicepinæ, 516.

Polyborinæ, 29.

Pratincoles, 431.

Procellaridæ, 532.

Procellarinæ, 533.

Promeropidæ, 89.

Promeropinæ, 92.

Psittacidæ, 306.

Psittacinæ, 314.

Psophinæ, 441.

Pteroclinæ, 387.

Ptilorhynchinæ, 213.

Puff-birds, 288.

Pycnonotinæ, 160.

Pyrrhocoracinæ, 207.

Pyrrhulinæ, 252.

Quails, Bush, 380.

Querulinæ, 163.

Quiscalinæ, 224.

Rails, 481. proper, 483.

Rallidæ, 481.

Rallinæ, 483.

Ramphastidæ, 303.

Recurvirostrinæ, 465.

Rhynchopsinæ, 558.

Robins, 138.

Rollers, 268.

proper, 269.

Sandpipers, 467.

Sarcoramphinæ, 19 .

Saurotherinæ, 338.

Scansores, 302.

Scolopacidæ, 457 .

Scolopacinæ, 470.

Screamers, 476 .

proper, 479 .

Sharp-tails, 119.

Sheath-bills, 389 .

proper, 392.

Shore Larks, 390.

Shrikes, Drongo, 186. Bush, 191.

Sittinæ, 125.

Skimmers, 558.

Snipes, 457 .

proper, 470. 
Spheniscinæ, 527.

Starakis, 525.

Starlings, 212. glossy, 213. proper, 222.

Spur-winged Geese, 194.

Steatorina, 67 .

Sternina, 562.

Storks, 451.

Strigidæ, 54.

Striginæe, 63.

Struthionidæ, 412.

Struthioninæ, 413.

Sturnidæ, 212.

Sturninæ, 222.

Sun-birds, 89 . proper, 92 .

Swallows, 80.

Swans, 499.

Swifts, 77.

Synallaxinæe, 119.

Syndactylæ, 268.

Syrninæ, 61 .

Talegallas, 357.

Talegallinæ, 357 .

Tanagers, 241.

Tanagrinæ, 241.

Tantalinæ, 454.

Tenuirostres, 84 .

Terns, 562.

Tetraonidæ, 374 .

Tetraoninæ, 384.

'Thamnophilinæ, 191.

Thick-heads, 178.

Thick-knees, 427.

Thinocorinæ, 390.

Thrushes, 149.

Ant, 150. proper, 152 .

Tick-eaters, 343 .

T'imalinæ, 155.

Tinamidæ, 394.

Tinamous, 394.

Titmice, 143.

Tityrinæ, 170.

Todies, 271.

Todinæ, 271.
Totaninæ, 462.

Toucans, 303.

Tree-creepers, 116. proper, 121.

Treroninæ, 399.

Tringinæ, 467.

Trochilidæ, 97.

Trochilinæ, 104.

Trogonidæ, 282.

Trogoninæ, 283.

Trogons, 282. proper, 283.

Troop-birds, 229.

Tropic-birds, 542.

Trumpeters, 441.

Turdidæe, 149.

Turdinæ, 152.

Turkeys, 369.

Turnicinæ, 380.

Turnstones, 438.

Tyrannine, 167.

Tyrants, 167.

Upupidæ, 84.

Upupinæ, 85.

Urianinæ, 530 .

Vireoninæ, 175.

Vultures, Bearded, 17. Eagle, 26. proper, 22.

Vulturidæ, 15.

Vulturinæ, 22.

Wagtails, 146.

Warblers, 131. proper, 134.

Soft-tailed, 132.

Weavers, 234.

Woodpeckers, 318 .

Black, 328.

Green, 326.

Ground, 330 . true, 324 .

Wrens, 129.

Wrynecks, 332.

Yuncinæ, 332. 






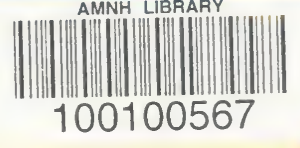

$$
\begin{aligned}
& \text { s } 1 \\
& * x
\end{aligned}
$$

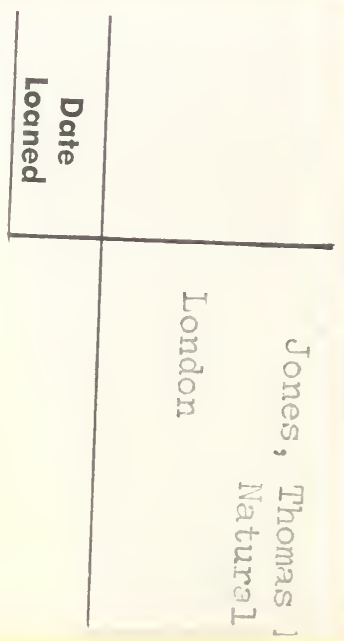




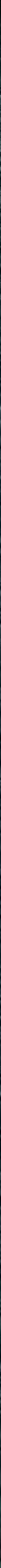

